
The Journal of Public Space

ISSN 2206-9658

2020 | Vol. 5 n. 3

https://www.journalpublicspace.org

\section{EDITORIAL TEAM}

\section{Founder, Editor in Chief}

Luisa Bravo, City Space Architecture, Italy

\section{Scientific Board}

Davisi Boontharm, Meiji University, Japan

Simone Brott, Queensland University of Technology, Australia

Julie-Anne Carroll, Queensland University of Technology, Australia

Margaret Crawford, University of California Berkeley, United States of America

Philip Crowther, Queensland University of Technology, Australia

Simone Garagnani, University of Bologna, Italy

Pietro Garau, Sapienza University of Rome, Italy

Carl Grodach, Monash University, Australia

Jeff Hou, University of Washington, United States of America

Chye Kiang Heng, National University of Singapore, Singapore

Maurice Harteveld, Delft University of Technology, Netherlands

Fiona Hillary, RMIT University, Australia

Aseem Inam, Cardiff University, United Kingdom

Setha Low, The Graduate Center, City University of New York, United States of America Miquel Marti, Universitat Politècnica de Catalunya, Spain

Alessandro Melis, University of Portsmouth, United Kingdom

Darko Radović, Keio University, Japan

Estanislau Roca, Universitat Politècnica de Catalunya, Spain

Joaquin Sabate, Universitat Politècnica de Catalunya, Spain

Robert Saliba, American University of Beirut, Lebanon

Ellen Marie Sæthre-McGuirk, Nord University, Norway

Martin Zebracki, University of Leeds, United Kingdom

\section{Strategic Advisory Board}

Cecilia Andersson, UN-Habitat Global Public Space Programme, Kenya

Tigran Haas, KTH Royal Institute of Technology, Sweden

Maggie McCormick, RMIT University, Australia

Michael Mehaffy, KTH Royal Institute of Technology, Sweden

Laura Petrella, UN-Habitat Global Public Space Programme, Kenya

Hendrik Tieben, Chinese University of Hong Kong, Hong Kong

\section{Advisory Board for Research into Action}

Ethan Kent, PplacemakingX , United States of America

Gregor Mews, Urban Synergies Group, Australia

Luis Alfonso Saltos Espinoza, Observatorio Ciudadano por el Derecho a la Ciudad y

Espacios Públicos de Guayaquil, Ecuador 


\section{Section Editors}

Beitske Boonstra, Erasmus University Rotterdam, Netherlands

Luke Hespanhol, University of Sydney, Australia

Fiona Hillary, RMIT University, Australia

Jeroen Laven, Placemaking Europe, Netherlands

Maggie McCormick, RMIT University, Australia

Ellen Marie Sæthre-McGuirk, Nord University, Norway

\section{Assistant Editor}

Zoë Atkinson Fiennes (Vol. 2 n. 3, 2017 / Vol. 4 n. I, 2019 / Vol. 4 n. 2, 2019)

\section{Journal Manager}

Luisa Bravo, City Space Architecture, Italy

\section{Correspondents and Peer Reviewers}

Europe and Middle East

Gem Barton, Brighton University, United Kingdom

Michael Barke, University of Northumbria at Newcastle, United Kingdom

Simon Bell, Estonian University of Life Sciences, Estonia

Pedro Ressano Garcia, Universidade Lusófona, Portugal

Henning Eichinger, Reutlingen University, Germany

Konstantinos loannidis, Aristotle University of Thessaloniki, Greece

Marjut Kirjakka, Aalto University, Finland

Yoav Lerman, Tel Aviv University, Israel

Nicola Marzot, TU Delft, Netherlands

Fabiano Micocci, University of Thessaly, Greece

Vitor Oliveira, University of Porto, Portugal

Lakshmi Priya Rajendran, Anglia Ruskin University, United Kingdom

Yodan Rofe, Ben-Gurion University of the Negev, Israel

Massimo Santanicchia, Iceland Academy of the Arts, Iceland

Goran Vodicka, University of Sheffield, United Kingdom

Katharine Willis, Plymouth University, United Kingdom

Parisa Ziaesaeidi, Erfan Institute of Higher Education, Iran

America

Camilo Vladimir de Lima Amaral, Universidade Federal de Goias, Brazil

Roberto Andrés, Universidade Federal de Minas Gerais, Brazil

Deland Chan, Stanford University, United States of America

Dave Colangelo, Portland State University, United States of America

Amir Gohar, University of California Berkeley, United States of America

Thomas Fowler, California Polytechnic State University, United States of America

Maria Goula, Cornell University, United States of America

Adrian Gras-Velazquez, Swarthmore College, United States of America

Matthew D. Lamb, Pennsylvania State University, United States of America

Marieta Maciel, Universitade Federal de Minas Gerais, Brazil

Leonardo Parra, Universidad de Los Andes, Colombia

Renato Rego, Universidade Estadual de Maringá - UEM, Brazil 
Asia

Pak Damrongsak, Thammasat University, Thailand

Nga Nguyen, Vietnam National University Ho Chi Minh City, Vietnam

Bing Wang, Beijing University of Civil Engineering and Architecture, China

Zhen Xu, Nanjing Forestry University, China

\section{Africa}

Sahar Attia, Cairo University, Egypt

Izak van Zyl, Cape Peninsula University of Technology, South Africa

\section{Australia and New Zealand}

Christopher Brisbin, University of South Australia, Australia

Liz Brogden, Queensland University of Technology, Australia

Martin Bryant, University of Technology Sydney, Australia

Glenda Caldwell, Queensland University of Technology, Australia

Philippa Carnemolla, University of Technology Sydney, Australia

Debra Cushing, Queensland University of Technology, Australia

Emilio Garcia, University of Auckland, New Zealand

Morten Gjerde, Victoria University of Wellington, New Zealand

Kai Gu, University of Auckland, New Zealand

Daniel O'Hare, Bond University, Australia

Anoma Kumarasuriyar, Queensland University of Technology, Australia

Manfredo Manfredini, University of Auckland, New Zealand

Michael Marriott, Queensland University of Technology, Australia

Ari Mattes, University of Notre Dame, Australia

Linda Matthews, University of Technology Sydney, Australia

John Mongard, The Designbank, Australia

Milica Muminović, University of Canberra, Australia

Kaan Ozgun, University of Queensland, Australia

Mark Pennings, Queensland University of Technology, Australia

Gavin Perin, University of Technology Sydney, Australia

Helena Piha, Queensland University of Technology, Australia

Dorina Pojani, University of Queensland, Australia

Paul Sanders, Queensland University of Technology, Australia

Leigh Shutter, Griffith University, Australia

Thomas Sigler, University of Queensland, Australia

Claudia Justino Taborda, Queensland University of Technology, Australia

Mark Taylor, University of Newcastle, Australia

Margaret Ward, Griffith University, Australia

Yannis Zavoleas, University of Newcastle, Australia 


\section{FOCUS AND SCOPE}

The Journal of Public Space is the first, international, interdisciplinary, academic, open access journal entirely dedicated to public space.

Established on a well-consolidated global network of scholars and professionals, The Journal of Public Space is committed to expand current scholarship by offering a global perspective and providing the opportunity for unheard countries to speak up and to discuss neglected as well as emerging topics that are usually sidelined in mainstream knowledge.

The Journal of Public Space is addressing social sciences and humanities as a major field, and is interested also in attracting scholars from several disciplines. It will perform as a scholarly journal but also as an interdisciplinary platform of discussion and exchange by scholars, professionals, organizations, artists, activists and citizens, whose activities are related to public space.

The Journal of Public Space will be enriched by hosting papers on design projects, art performances and social practices, fostering civic engagement and non-expert knowledge.

\section{TOPICS}

Authors are welcome to submit original research articles dealing with themes relating to the vision of the journal, which may include, but are not confined to:

SPACE
Architecture
Urban Planning
Urban Design
Urban Morphology
Urban Resilience
Landscape architecture
Interior design
Interactive and visual design
Art
City transformation
Infrastructure
Environment
Ecology
Climate change

SOCIETY
Gender
Human scale
People
Everyday life
Social engagement
Health and safety
Perception and senses
Human rights
Social justice
Education
Heritage
History
Culture
Geography
Anthropology
Ethnography
Community empowerment
Migrations
Conflicts
Inclusion/Exclusion
Informality
Sub and fringe cultures

SYSTEMS

Economy

Political power

Governance

Law and regulations

Public policies

Private sector/interest

Developing countries

Management and

maintenance

Digital/Virtual world

Technology

Media

Third sector

Decision-making process 


\section{POLICIES}

\section{Peer Review Process}

A double blind peer review process, based on a distinguished board of editors and editorial advisors, ensures the quality and high standards of research papers. Each paper is assessed by two reviewers and any identifying information in relation to the author is removed during the review process. Reviewers follow an evaluation framework and recommendation guidelines to ensure objectivity and fairness.

Submitted articles should not have been previously published. If publication or dissemination through presentation has occurred, then the article should acknowledge this and pay due credit to the original source.

\section{Publication Ethics Statement}

The Journal of Public Space aligns itself with the Committee on Publication Ethics (COPE) best practice guidelines for dealing with ethical issues in journal publishing.

$$
\begin{array}{|l|l|l|l|l}
\mathbf{C} & \mathbf{O} & \mathbf{P} & \mathbf{E} & \text { commitiee on publication ethics hes://publicationethics.org/ }
\end{array}
$$

\section{Open Access Policy}

The Journal of Public Space is licensed under a Creative Commons AttributionNonCommercial 4.0 International License. It provides immediate open access to its content on the principle that making research freely available to the public supports a greater global exchange of knowledge.

(c) (i) (s) https://creativecommons.org/licenses/by-nc/4.0/

\section{CONTACT}

\section{Publisher}

City Space Architecture non-profit cultural association

Via Paolo Giovanni Martini 26/d

40134 Bologna, ITALY

jps@cityspacearchitecture.org

www.cityspacearchitecture.org

\section{Partner}

UN Habitat - United Nations

Human Settlements Program

Nairobi, KENYA

www.unhabitat.org

\section{in cooperation with}

KTH Royal Institute of Technology

Centre for the Future of Places

Stockholm, Sweden

https://www.kth.se/en

https://www.cfp.abe.kth.se/

RMIT University

Melbourne, Australia

https://www.rmit.edu.au/

The Chinese University of Hong Kong

School of Architecture

Hong Kong SAR

http://www.arch.cuhk.edu.hk/ 
The Journal of Public Space | 2020, Vol. 5 n. 3 | Editorial Team and Policies

\section{Call for papers}

The Journal of Public Space welcomes full papers for 2022 issues, to be published in April, August and December.

Submissions will be ongoing throughout the year.

Submission can be made:

- using the OJS platform by registering online. If you are already a registered author you can log in using your username and password;

- by sending an email to the Editor in Chief Luisa Bravo at this email address:

submission@journalpublicspace.org

Before submitting, please read:

- the Focus and Scope of the journal

- the Author Guidelines

Full papers should be between 5.000 and 8.000 words.

https://www.journalpublicspace.orgl 
The Journal of Public Space

ISSN 2206-9658

2020 | Vol. 5 n. 3

https://www.journalpublicspace.org

\title{
2020: A Year without Public Space under the COVID-I9 Pandemic
}

\author{
Editors \\ Luisa Bravo, Hendrik Tieben
}

Vol. 5 n. 3 | 2020

SPECIAL ISSUE 
Cover image: A mural by Anne Siems, titled 'Beauty + Terror', on a boarded building in Seattle's Capitol Hill neighbourhood. Picture by Catherine Anstett (2020).

\section{DISCLAIMER}

The designations employed and the presentation of the material in this journal do not imply the expression of any opinion whatsoever on the part of the Secretariat of the United Nations concerning the legal status of any country, territory, city or area or of its authorities, or concerning the delimitation of its frontiers or boundaries, or regarding its economic system or degree of development. The analysis, conclusions and recommendations of this publication do not necessarily reflect the views of the United Nations Human Settlements Programme. Reference in this journal of any specific commercial products, brand names, processes, or services, or the use of any trade, firm, or corporation name does not constitute endorsement, recommendation, or favouring by UN-Habitat or its officers, nor does such reference constitute an endorsement of UN-Habitat. 


\section{TABLE OF CONTENTS}

\section{EDITORIAL}

2020: A Year without Public Space under the COVID-I9 Pandemic

Luisa Bravo, Hendrik Tieben

\section{SPACE}

Public Space and COVID-19: Contraction, Expansion, and Adaptation

Vikas Mehta

Opportunity in the Time of COVID-19. Lessons Learned

to Improve Public Space

Miquel Marti, Lara Espindola

What Still Matters in a City. The COVID-I9 Pandemic Offers a "Teachable

Moment" Illustrating that Public Spaces Must Simultaneously Connect us, and

Protect us too

Michael West Mehaffy, Tigran Haas, Peter Elmlund

Neighbourhood Streets as Public Space. Covid-I 9 Public Life

in Kimisange, Rwanda

Josephine Mwongeli Malonza

Domestication Will Shape Future Public Spaces. A Report from Rotterdam Maurice Harteveld

Reframing Public Spaces: from Recreational Amenity to Civic Good in Resilient

Cities. COVID-19 Offers an Opportunity to Re-evaluate Neighbourhood Spaces to Ensure they are Available to All

Kevin Fan Hsu

Agoraphobia: New York City Public Space in the Time of COVID-19 Miodrag Mitrasinovic

Observations on Access and Use of Public Space during COVID-19

in Hong Kong and Taipei

Ying-Fen Chen, Yu Sze Cheung, Hendrik Tieben

Not all Lockdowns are Created Equal. Indian Migrant Crisis

in Times of COVID-19

Stany Babu 
The Journal of Public Space

ISSN 2206-9658

2020 | Vol. 5 n. 3

https://www.journalpublicspace.org

Missed Pauses and Everyday Interactions for Migrant Indian Women during

COVID-19 Times

SriPallavi Nadimpalli

\section{SOCIETY}

When Digital Public Spaces Matter. Role of Neighbourhood Platforms

in Times of COVID-19

Franziska Schreiber

Youth Access to Public Space during COVID-19 Pandemic in Hanoi, Vietnam.

A descriptive study

Phạm Quỳnh Hương, Phan Song Thuong, Luong Thuy Duong, Nguyen

Xuan An

Recovering the Urban Past for Equitable Present and Future Social Recovery lan Morley

Shifting the Threshold of Public Space in UK, Algeria and Mexico during the

COVID- I 9 Pandemic

Barbora Melis, Jose Antonio Lara Hernandez, Yazid Mohammed Khemri,

Alessandro Melis

Observations on Death and Life of Public Space in Australia during

the COVID-19 Pandemic

Gregor Helmut Mews, Milica Muminovic

Porch Placemaking. How In-between Spaces Work During and After

the COVID-19 Pandemic

$183-190$

Koichiro Tamura

\section{SYSTEMS}

Exploring the Impact of COVID-19 Lock-down on Public Spaces through a Systems Modelling Approach

Nicholas Stevens, Silvia Tavares

Affirmatively Reading Post-consumerism. Distributed Participatory Creativity and Creative Destruction of the Malled Metropolitan Centres of Auckland, New Zealand, during COVID-19 Lockdown

Manfredo Manfredini 
The Journal of Public Space

ISSN 2206-9658

2020 | Vol. 5 n. 3

https://www.journalpublicspace.org

\section{VIEWPOINT}

Public Spaces as an Invaluable Resource for Delivering Healthy and More

Equitable Cities and Communities

Jose Chong, Sohel Rana, Mark Ojal

Urban Questions in the Times of Coronavirus

Darko Radović, Davisi Boontharm, Pieter Klomp, Antonella Bruzzese,

Stephen Cairns, Alenka Fikfak, Pieter Klomp, Kengo Kuma, Beatriz

Maturana, Ana Medina, Eiji Oguma, David Sim, Sidh Sintusingha, Saline

Verhoeven

Thoughts on Public Space and Flourishing during COVID-19

Setha Low

Artists in the Streets: Seattle Murals in the Time of COVID-19

Catherine Anstett 
The Journal of Public Space

ISSN 2206-9658

2020 | Vol. 5 n. 3

https://www.journalpublicspace.org

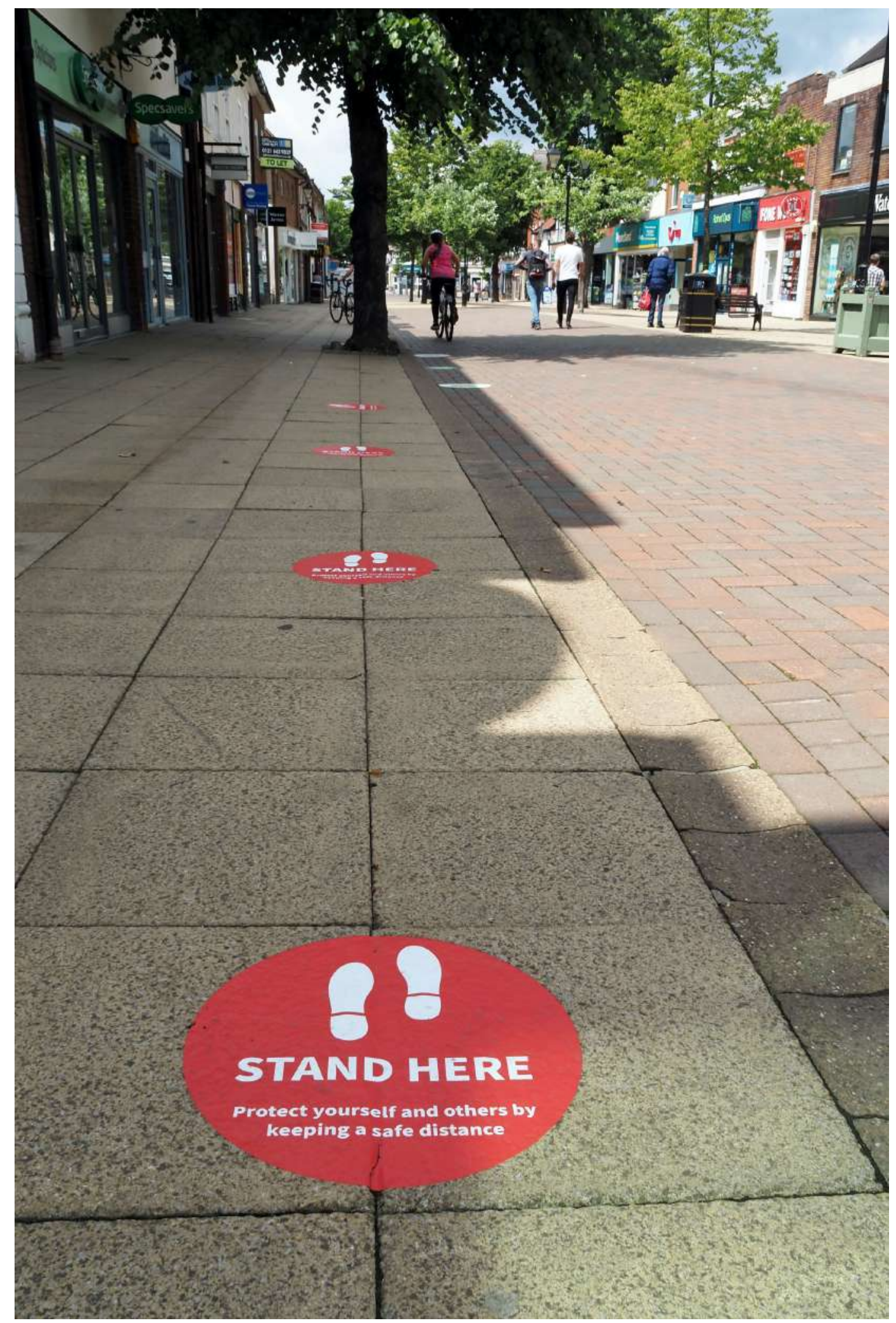

Solihull, United Kingdom. Photo by Julie-Ann Gylaitis on Unsplash 


\title{
EDITORIAL
}

\section{0: A Year without Public Space under the Covid-I 9 Pandemic}

\author{
Luisa Bravo \\ City Space Architecture, Italy \\ luisa.bravo@cityspacearchitecture.org \\ Hendrik Tieben \\ The Chinese University of Hong Kong, School of Architecture, Hong Kong SAR \\ hktieben@cuhk.edu.hk
}

On 8-I 3 February 2020 City Space Architecture, the publisher of The Journal of Public Space, participated in the 10th World Urban Forum in Abu Dhabi as an exhibitor, and in collaboration with 16 global institutions' promoted the exhibition 'PUBLIC SPACE IS VITAL FOR AN EQUITABLE URBAN FUTURE'. On April 7, while about $40 \%$ of global population was under coronavirus lockdown, City Space Architecture and the School of Architecture at The Chinese University of Hong Kong jointly announced the online initiative '2020: A Year without Public Space under the COVID-19 Pandemic' through The Journal of Public Space ${ }^{2}$ : after one month of consultation, by email and through online meetings, with academic scholars and colleagues from different geographical locations, we, public space scholars and activists, felt the urgency to build social and health resilience by establishing an open environment for discussion and learning, while taking advantage of technology and virtual platforms that many could access for free.

Throughout 2020, social distance dictated by COVID-I 9 health emergency severely affected everyone's access to public space and with it creating a range of impacts on different levels. The world-wide lockdown destabilized the global economy and challenged country leaders, while at the human level the pandemic generated isolation and loneliness, with a significant rise of helplessness and fear, deeply impacting on the most vulnerable groups. In many countries, people were asked to stay home and rearrange daily routines and work activities in indoor domestic spaces, looking at the world from behind a window. Outdoor physical activities were no longer allowed.

Many governments seemed to lack proper strategies to manage the risk of massive contagion. People died alone in hospitals, numbers were increasingly and scarily high. In the

\footnotetext{
I The Chinese University of Hong Kong, Healthbridge Foundation of Canada, Block by Block, Project for Public Spaces, University of Auckland, Columbia University, Federal University Rio de Janeiro, Auckland City Council, KTH Centre for the Future of Places, IHC Global, Consortium for Sustainable Urbanization, Sustasis Foundation, Global Utmaning, Public Space Research Group (PSRG), Ukrainian City and Regional Planning Research Center, General Assembly of Partners (GAP) Older Persons. Read a report here: http://www.cityspacearchitecture.org/?e=53

${ }^{2}$ Full announcement of the online initiative:

https://www.journalpublicspace.org/index.php/jps/navigationMenu/view/covid-19-program
} 
Global South, the poor living in informal settlements had scarce access to water, washing hands and maintaining proper hygiene was dangerously impossible.

Some of the key questions during the long, stressful lockdown emerge: how can we face this unprecedented emergency and get prepared to its consequences, with specific regard to health disparity? Will public space restrictions stay in place after the recovery period? Should we just aim to return to a pre-COVID status quo, or for a 'better normal'? And more generally, what will be the future of public space?

As the pandemic was moving across different continents and urban conditions, through our online initiative we exchanged experiences of care, solidarity, entrepreneurship, academic perspectives, artistic interpretations and creative practices of human resilience, engaging more than 100 speakers during 20 webinars from May to September 2020, and more than 2700 registered attendees from over 80 countries, including representatives from UNHabitat. The key idea of the initiative was to include diverse speakers from different parts of the world and disciplines to discuss their experiences. Thus, at the beginning, a Call for Speakers and Call for Advisors on Public Space ${ }^{3}$ was launched, leading to the establishment of a global community now affiliated with City Space Architecture.

The initiative culminated in a two-day online symposium under the same name ${ }^{4}$ in November 2020, organised in cooperation with Worldwide Universities Network (WUN) and with the support of major Universities and international institutions, and hosted by The Chinese University of Hong Kong.

This special issue of The Journal of Public Space has been a core component of this initiative since the beginning. A Call for Papers was made in April 2020 at the launch of the webinar series. Eventually from 35 submissions, 20 research papers and commentaries were selected to provide insights from different locations on six continents. In addition, UN-Habitat, as key supporter of the initiative, contributed a viewpoint which puts forward key recommendations on planning of public spaces for healthy communities with particular views on the Global South.

Most of the contributions are tentative in nature, as they were produced in the first phase of the COVID-I9 pandemic. This preliminary status was accepted since the initiative aimed to kick-off an ever-growing joint learning process based on international exchange in view of the evolving and deadly global crisis. Some of the contributions became stepping stones for more substantial research projects, with opportunity to relate local research to a wider horizon provided by the exchange activities of the initiative. This special issue encapsulates key learnings globally from the early stage of the pandemic, which stand relevant to this day when we face squarely the same issues as we step into gradually and navigate the postCOVID era.

This journal issue starts with V. Mehta's observations that the "elimination of events and programming and the cordoning off of standardized equipment has left public space in an unembellished state of bareness." According to Metha, citizens faced with this situation took over other types of urban spaces, such as neighbourhood streets, in a self-driven and creative process of expansion and adaptation. The use of such neighbourhood streets was also observed by J. Mwongeli Malonza in Kimisange, Rwanda, as well as G. Mews and M.

\footnotetext{
${ }^{3}$ Call for Advisors: http://www.cityspacearchitecture.org/?p=call-for-advisors-on-public-space

${ }^{4}$ Website of the symposium '2020: A Year without Public Space. Reflection \& Outlook':

https://www.publicspace-covid 19.com/
} 
Muminovic, who describe how families and children in Australia adapted and transformed such spaces with their own creativity.

Furthermore, S. Low highlights the importance of public space for social connection and hence the potentials risks if we fail to appreciate such during the social distancing period. $P$. Huong, P. Thuong, L. Duong and N. An from Vietnam investigate with their survey the attitudes toward pandemic control and access to public spaces among local youth in Hanoi in the early phase of the pandemic. A key phenomenon during the COVID-I 9 pandemic has been the increased use of digital platforms as a way to compensate for the restricted use of physical spaces. Thus, F. Schreiber focuses on the enhanced role of digital neighbourhood platforms during the COVID-19 pandemic in Germany. Another study on the changing use of social media is provided by M. Manfredini, who focuses social activities in Auckland's vast sub-urban malls during the pandemic.

The question how the new public space adaptations will continue and expand on city-level after the pandemic is addressed in M. Harteveld's text by referring to examples from Rotterdam and the Netherlands in general. Similarly, K.F. Hsu addresses how in Singapore, changes made during the pandemic, could inform the future planning of neighbourhoods and ensure their availability to all while J. Chong, S. Rana and M. Ojal from UN-Habitat identify pathways of how public and green spaces could contribute toward the futureproofing cities and communities with particular view on the situation in the Global South. The severe issue of health disparity is discussed in several contributions. The texts by $M$. Mitrasinovic on New York, and Y.F. Chan, S. Cheung and H. Tieben on Hong Kong and Taipei explore how the earlier existing social-spatial polarizations increased health risks for urban poor and migrant populations during the pandemic. The text on Hong Kong and Taipei, however, also demonstrates how these cities were able to draw essential lessons from the earlier SARS epidemic which allowed them to significantly reduce the number of infections and fatalities. I. Morely likewise offers a historical perspective, and reviews how British cities, in response to the health crises of the $19^{\text {th }}$ century, developed their systems of green spaces. These historical examples bring valuable lessons to creating a more equitable urban recovery after the current crisis. Health disparity and access to public space under the pandemic is also discussed in the two papers on India: S. Babu describes the ordeal of millions of migrant workers forced to drift across different parts of the country, while S.P. Nadimpalli focuses particularly on the example of female migrants in Hyderabad during the pandemic.

The role of specific spatial situations is investigated in three other contributions. $M$.

Mehaffy, T. Haas, and P. Elmlund postulate how specific urban forms and spaces in European and American cities affect the spread of infections and use of public space under the pandemic. B. Melis, J. Antonio, L. Hernandez, Y.M. Khemri and A. Melis analyse in a comparative study shifting spatial thresholds in Algerian, Mexican and British cities. A similar perspective on thresholds, or "in-between spaces", is offered by K. Tamura. He explores "Porch Placemaking", through which porches allow residents to engage safely with neighbors during the pandemic. N. Stevens and S. Tavares explore similar ideas within suburban conditions, by studying public spaces under lockdown in Queensland, Australia, using a systems approach and positing new activities and functions for these spaces in the postpandemic era.

D. Radović and D. Boontharm responded to the call for papers by organizing a round table with eleven other participants from different parts of the world on May I, 2020, jointly 
searching for the most relevant questions regarding the crisis of public space in the times of Coronavirus.

The journal issue ends with the contribution of photographer $\mathrm{C}$. Anstett, who produced also the cover image. With her photos, Anstett captures an artists' initiative in Seattle, in which bordered-up windows of closed-down shops were painted to bring together and uplift the community in a time of crisis and isolation.

The COVID-19 pandemic has made clear the fundamental role of public space in our cities, not just for social life but also in regards of the functioning of the entire economic and urban system. The long confinement has seriously affected the way we use, live and understand our common urban spaces and the way we relate to each other as human beings. We now live in the so-called I,5-meter society, where health and safety are considered as priorities in order to prevent urban shocks, and social and ecological resilience is the unavoidable challenge for urban leaders.

In the 'next normal', the shared civic space will no longer be as we know it. After decades of inspiring academic discussions and urban theories, opposed to relentless slowness of decision-makers, the COVID-19 pandemic has accelerated the process leading to a necessary positive change: it is time to develop a new thinking and a new approach to urban complexity built around public space, spreading awareness on the importance of public space culture in building resilience, and changing the mindset of new generations of global citizens towards a more comprehensive understanding of our cities and societies.

\section{Acknowledgment}

We would like to thank all the speakers, who accepted our invitation and made this initiative so successful, and all the Universities and institutions that generously supported our work, by sharing information across their networks and through social media.

A special thanks to Ying-Fen Chen and Stephanie Cheung, from The Chinese University of Hong Kong, who managed the Zoom events and produced the recordings (available on the YouTube channel of City Space Architecture) and the summaries (published on the website of The Journal of Public Space -> COVID-19 initiative).

Finally, we would like to thank all the registered attendees, 2700+ from over 80 countries, that actively participated in the global discussion on public space during the COVID- 19 pandemic, interacting with us with great enthusiasm.

To cite this article:

Bravo, L., Tieben, H. (2020). 2020: A Year without Public Space under the COVID-I9 Pandemic. The Journal of Public Space, 5(3), I-I4, DOI 10.3289I/jps.v5i3.1425 


\section{0: A Year without Public Space under the COVID-I 9 Pandemic}

Online initiative jointly developed by City Space Architecture and the School of Architecture at The Chinese University of Hong Kong, andf disseminated through The Journal of Public Space

Co-funded by the RGC Fund Project: "Built Environment and Planning for Healthy Cities", School of Architecture, The Chinese University of Hong Kong Curators: Luisa Bravo and Hendrik Tieben https://www.journalpublicspace.org/index.php/jps/navigationMenu/view/covid-19-program

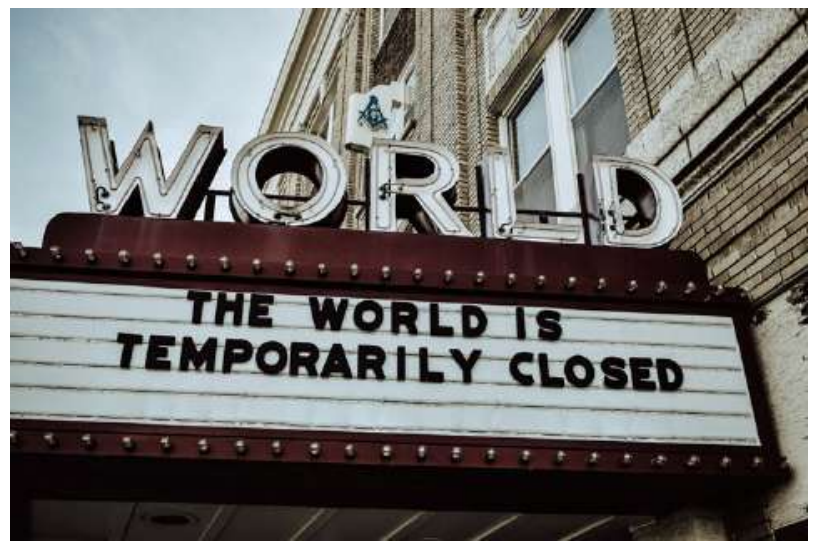

Series I (May 2020)

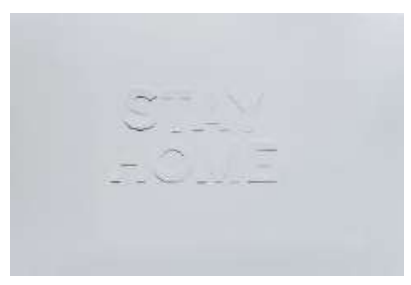

\#I / Reframing the Role of Public Space during and after the COVID-19 Pandemic

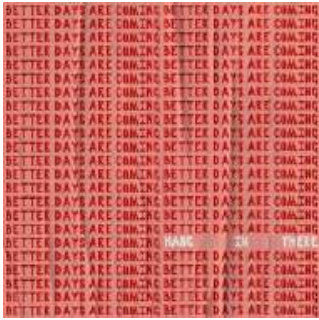

\#2 / Innovative Approaches and Creative Practices in Response to the COVID-19 Pandemic

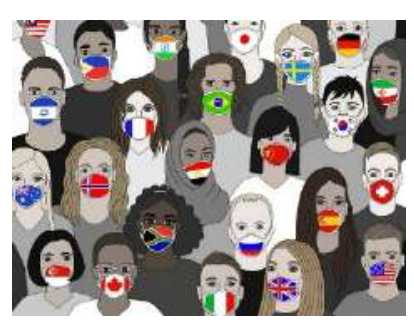

\#3 / Health Disparity and Public Space in High Density Environments

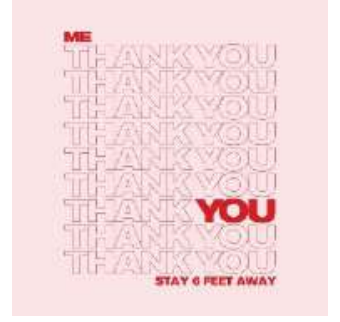

\#4 / Expert Group Discussion with the Audience

\section{Series 2 (June 2020)}

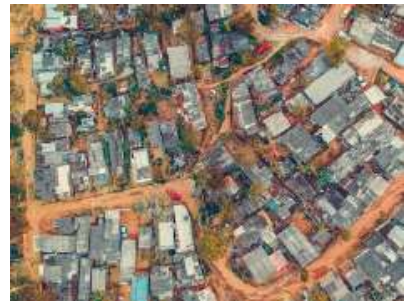

\#I / COVID-19 Challenges and Responses in Informal Settlements

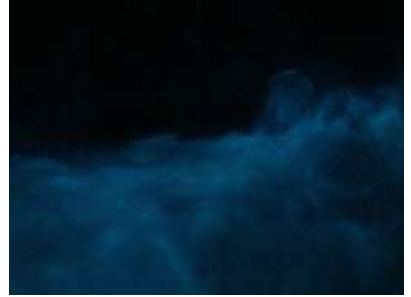

\#2 / Speculative Cities: thinking forward. Exploring speculative practices and how they relate to and/or change public space in the current and post COVID19 conditions

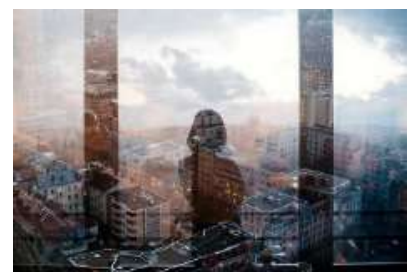

\#3 / Creating accessible and inclusive public spaces with/for resilient communities

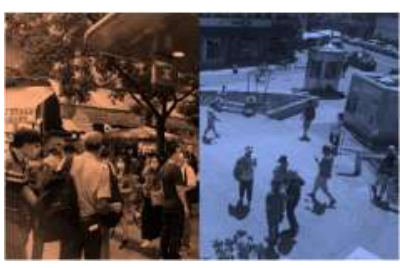

\#4 / Global Design Studio in the Age of Pandemics 


\section{Series 3 (July 2020)}

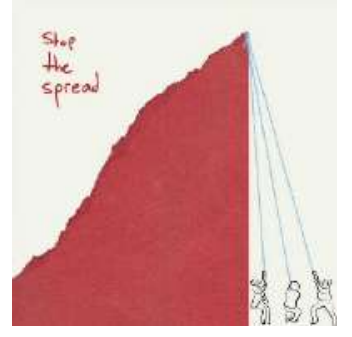

\# I / Towards Healthy Cities in the Age of Pandemics

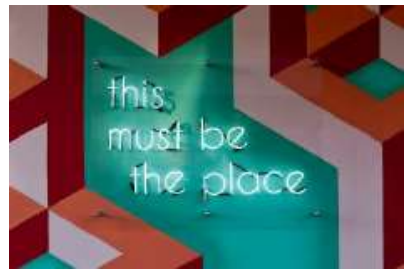

\#2 / Innovative Approaches and Creative Practices in

Response to the COVID-19 Pandemic

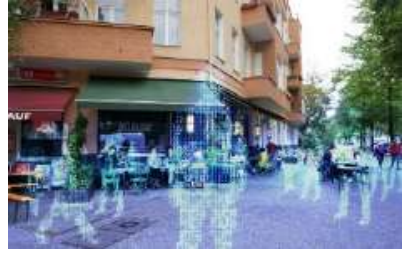

\#3 / Rethinking public spaces. Exploring the interplay of the analogue and virtual realm and its effects on public and social life in cities

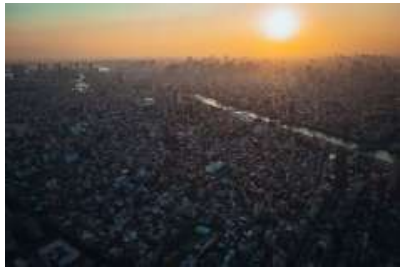

\#4 / Future Safe and Sustainable Urbanization. Expert Group Discussion with the Audience

\section{Series 4 (August 2020)}

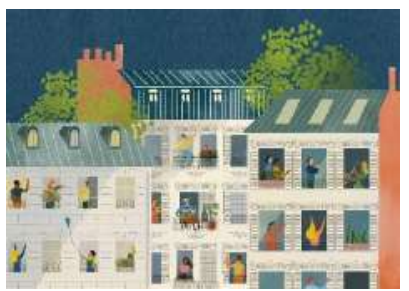

\#I / The Impact of the Pandemic to Street Life, Urban Culture and Beyond

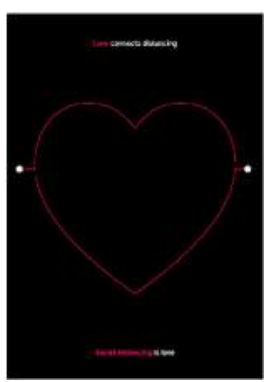

\#2 / Innovative

Approaches and Creative Practices in Response to the COVID-19 Pandemic

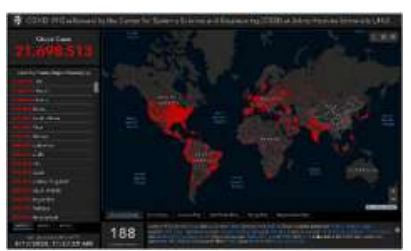

\#3 / Cities Learning from Pandemics

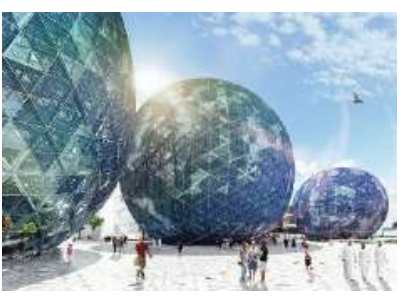

\#4 / The Role of Renewable Energy in post COVID-19 Public Spaces

Series 5 (September 2020)

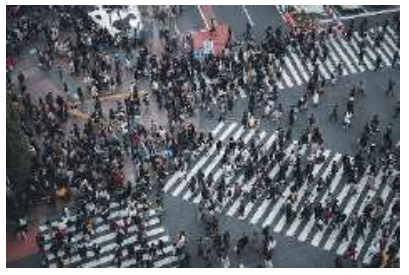

\#I / Tactical urbanism as a crisis response and as mobiliser for systemic change

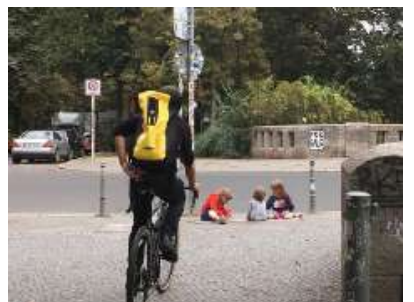

\#2 / Right to the city for children: from value driven discourse to transformative actions

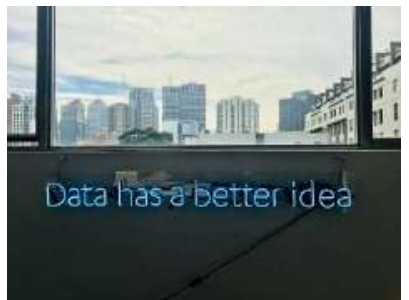

\#3 / Parks, Piazzas \&

Pandemics: Promoting Safe

Access to Public Places with

Data Analytics

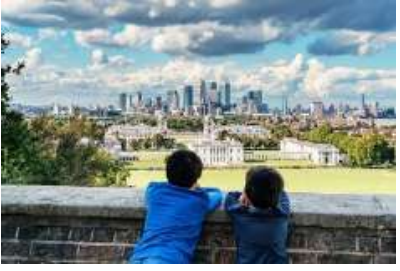

\#4 / Our Future Cities: public space initiatives, innovative policies and creative actions to recover during and after the pandemic

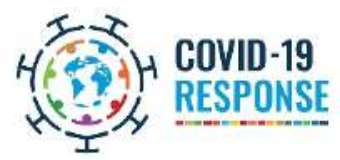




\section{Series I (May 2020)}

\#I / Reframing the Role of Public Space during and after the COVID-19 Pandemic

Jeff Hou, Urban Commons Lab, University of Washington, USA

- Setha Low, Public Space Research Group, Center for Human Environments at the Graduate Center of City University of New York, USA

- Luis Alfonso Saltos Espinoza, Observatorio Ciudadano por el Derecho a la Ciudad y Espacios Públicos de Guayaquil, Ecuador

- Mona Helmy, Department of Architecture, Faculty of Engineering, The British University in Egypt (BUE), Egypt

\#2 / Innovative Approaches and Creative Practices in Response to the COVID-I9 Pandemic

- Jay Wahl, Kimmel Center for The Performing Arts, Philadelphia, USA Yena Young, Plastique Fantastique, Germany

- Manfredo Manfredini, The University of Auckland, New Zealand

- Andrea Baldini, Nanjing University, Nanjing, China

- Kirsten Meredith Hanna, Auckland University of Technology, New Zealand

- Franco Manai, The University of Auckland, New Zealand

\#3 / Health Disparity and Public Space in High Density Environments

- Gregor H. Mews, Queensland University of Technology / Urban Synergies Group, Brisbane, Australia

- Miodrag Mitrasinovic, The New School, New York, USA

- Mindy Fullilove, The New School, New York, USA

- Mahak Agrawal, The Spatial Perspectives, India

- Fan Ning, Health in Action, Hong Kong

- Jens Aerts, ISOCARP Urban Health Community of Practice / BUUR, New York, USA

\#4 / Expert Group Discussion with the Audience

- Lance Jay Brown, Consortium for Sustainable Urbanization, New York, USA

- Miquel Marti Casanovas, Escuela Técnica Superior de Arquitectura, Universitat Politècnica de Catalunya, Barcelona, Spain

- Sharmila Jagadisan, School of Architecture, Vellore Institute of Technology, Tamil Nadu, India

\section{Series 2 (June 2020)}

\#I / COVID-19 Challenges and Responses in Informal Settlements

- Gregor H. Mews, Queensland University of Technology / Urban Synergies Group, Brisbane, Australia

- Rasmus Bering, Dreamtown, Copenhagen, Denmark

- KT Suresh, Senior National Lead, Urban \& Labour, Action Aid India

- Josephine Mwongeli Malonza, University of Rwanda, Kigali, Rwanda

- Tatenda Churu and Casper Chigama, House of Art Association, Harare, Zimbabwe

\#2 / Speculative Cities: thinking forward. Exploring speculative practices and how they relate to and/or change public space in the current and post COVID-19 conditions

- Fiona Hillary, Program Manager, RMIT University, Master of Arts (Art in Public Space), School of Art, Australia

- Maggie McCormick, Adjunct Professor, RMIT University, School of Art, Australia / Honorary Professor, Reutlingen University, Germany 
- Katrina Simon, Associate Dean, Landscape Architecture, RMIT University, School of Architecture and Urban Design, Australia

- Davisi Boontharm, Professor in Architecture and Urban Design, I-AUD Meiji University, Japan

- Mark Jacques, Professor of Architecture (Urbanism), Industry Fellow, Architecture and Urban Design, RMIT University, Australia

- Sarah Fayad, Researcher and Teaching Assistant, Graduate School of Design, Harvard University, USA

- Emily Sexton, Artistic Director of Arts House, Melbourne,Australia

- Andrei Nikolai Pamintuan, Creative Director, Pineapple Lab, Philippines

- Sophie Jerram, Letting Space and Urban Dream Brokerage in response to post earthquake conditions, New Zealand

\section{\#3 / Creating accessible and inclusive public spaces with/for resilient communities}

- Hannes Juhlin Lagrelius, World Blind Union, Toronto, Canada

- Katherine Kline, GAP General Assembly of Partners Older Persons, New York, USA

- Shu-Ti Chiou, Health \& Sustainable Development Foundation, School of Medicine, Yang-Ming University, Taiwan

- Nelson Saule Junior, Global Platform for the Right to the City, Polis Institute of Studies, Training and Assistance in Social Policies, São Paulo, Brazil

- Silvia Tavares and Nicholas Stevens, University of the Sunshine Coast, Queensland, Australia

- Wael Sinno, UN-Habitat Lebanon, Beirut, Lebanon

- Alessandro Melis, Cluster for Sustainable Cities, University of Portsmouth, United Kingdom / Curator of the Italian Pavilion 'Resilient Communities', I7th Venice Architecture Biennale (202I)

\section{\#4 / Global Design Studio in the Age of Pandemics}

- Miodrag Mitrasinovic, Parsons The New School, New York, USA

- Terri Tan,The Chinese University of Hong Kong, Hong Kong \& Sian Singh, Unitec Institute of Technology, New Zealand

- Stephanie Cheung, iDiscover, Hong Kong

- Georgeen Theodore, Interboro Partners, New Jersey Institute of Technology, USA

- Setha Low, Public Space Research Group, The Graduate Center, City University of New York, USA

- Ali Madanipour, Global Urban Research Unit (GURU), Newcastle University, United Kingdom

- Manfredo Manfredini, University of Auckland, New Zealand

- Annabel Pretty, Unitec Institute of Technology, New Zealand

\section{Series 3 (July 2020)}

\#I / Towards Healthy Cities in the Age of Pandemics

- Manfredo Manfredini, University of Auckland, School of Architecture and Planning, New Zealand

- Kevin Lau, Chinese University of Hong Kong, Hong Kong

- Leigh Wilson, University of Sydney, Australia

- Lee Beattie, University of Auckland, New Zealand

- Kim Dirks, University of Auckland, New Zealand

\#2 / Innovative Approaches and Creative Practices in Response to the COVID-19 Pandemic

- Martin Zebracki, School of Geography, University of Leeds, United Kingdom

- Susan Moffat, Global Urban Humanities Initiative, University of California Berkeley, United States

- Luke Hespanhol, School of Architecture, Design and Planning, University of Sydney, Australia 
- Linda Di Pietro, Indisciplinarte, Italy / affiliated to IN SITU - European Platform for Artistic Creation in Public Space

- Giulia Gualtieri and Viviana Cordero, Huasipichanga, Ecuador / The Netherlands

- Floor van Ditzhuyzen and Bas Sala, We Love Public Space Festival, The Netherlands

\#3 / Rethinking public spaces. Exploring the interplay of the analogue and virtual realm and its effects on public and social life in cities

- Astrid Ley, Department of International Urbanism, University of Stuttgart, Germany

- Carlos Smaniotto Costa, CeiED Interdisciplinary Research Centre for Education and Development, Universidade Lusófona, Lisbon, Portugal

- Franziska Turber, Foresight Consultant, Z_Punkt, Germany

- Federico Bastiani, Social Street, Bologna, Italy

- Franziska Schreiber, Department of International Urbanism, University of Stuttgart, Germany

- Tat Lam, The Chinese University of Hong Kong, School of Architecture, Hong Kong / Founder, CEO, Shanzhai City

- Jessica Cheung, The Chinese University of Hong Kong, School of Architecture, Hong Kong I Shanzhai City

- Melissa Permezel, UN-Habitat, Innovation Unit

\#4 / Future Safe and Sustainable Urbanization. Expert Group Discussion with the Audience

- Charles R. Wolfe, Seeing Better Cities Group, London, United Kingdom

- Dhanya Rajagopal, Design Trust for Public Space, New York, United States

- Gregory Scruggs, Seattle, United States

- Yasser Khalil, Ajman Municipality, Ajman, United Arab Emirates

- Furaha G. Abwe, Urban Planning for Community Change, Arusha, Tanzania

\section{Series 4 (August 2020)}

\#I / The Impact of the Pandemic to Street Life, Urban Culture and Beyond

- Maurice Harteveld, Delft University of Technology, Urban Design | Public Space, The Netherlands

- Angeliki Anagnostou, Delft University of Technology, The Netherlands

- Fabiano Micocci and Vaso Trova, University of Thessaly, Department of Architecture, Greece

- Edna Peza, Université de Paris, France

- Vikas Mehta, University of Cincinnati, United States

\#2 / Innovative Approaches and Creative Practices in Response to the COVID-19 Pandemic

- David McGillivray, Strategic Hub for Culture and Creativity, University of the West of Scotland / FESTSPACE, United Kingdom

- Ali A. Alraouf, Hamad Bin Khalifa University, Qatar / ISOCARP - International Society of City and Regional Planners

- Clarissa Lim, Malaysian Institute of Art / Hubs for Good program from the British Council, Malaysia

- Laura Sobral, Instituto A Cidade Precisa de Você [The City Needs You Institute], Brazil

- Magdalena Rembeza, Gdańsk University of Technology (GUT), Poland

\#3 / Cities Learning from Pandemics

- lan Morley, The Chinese University of Hong Kong, Hong Kong

- Ana Medina, Universidad de Las Américas, Ecuador

- Ayanda Roji, City of Johannesburg's Parks and Zoo Agency, South Africa

- Jason Luger, Northumbria University, United Kingdom 
- Cecilia Andersson, UN-Habitat, Manager of the Global Public Space Programme

\#4 / The Role of Renewable Energy in post COVID-19 Public Spaces

- Agatino Rizzo, Lulea University of Technology, Sweden

- Alessandra Scognamiglio, ENEA (Italian National Agency for New Technologies, Energy and Sustainable Economic Development), Italy

- Björn Ekelund, Luleå University of Technology, Sweden

- Daniele Santucci, Climateflux, Germany

- Robert Ferry and Elizabeth Monoian, Land Art Generator, United States

- Taichi Kuma, Kengo Kuma and Associates, Japan

- Jorge Toledo García, Ecosistema Urbano, Spain

- Vincent Kitio, UN-Habitat, Chief of the Urban Energy Unit

\section{Series 5 (September 2020)}

\#I / Tactical urbanism as a crisis response and as mobiliser for systemic change

- Graeme Hanssen, Human Power Initiative, Yasar University, Turkey

- J. Antonio Lara-Hernandez, Institute of Mobility and Urban Territorial Development in Yucatan, Urban Resilience Research, Mexico

- Rossella Ferorelli, Municipality of Milan / SMALL - Soft Metropolitan Architecture \& Landscape Lab, Italy

- Boopsie Maran, Places for Good, New Zealand

- Pritika Akhil Kumar, Co:Lab, India

- Paula López Barba, Imagina Madrid, Spain

\#2 / Right to the city for children: from value driven discourse to transformative actions

- Gregor Mews, Urban Synergies Group / Queensland University of Technology, Australia

- Tim Gill, independent researcher, United Kingdom

- Robyn Monro-Miller, International Play Association on Right to Play (UN-Convention of the Rights of the Child), United Kingdom

- Paul Tranter, School of Science, University of South Wales in Canberra, Australia

- Joshua Lam, Hong Kong Public Space Initiative, Hong Kong

- Benjamin Shirtcliff, lowa State University, United States

\#3 / Parks, Piazzas \& Pandemics: Promoting Safe Access to Public Places with Data Analytics

- Kevin Fan Hsu, Centre for Liveable Cities, Singapore

- Zhongwen Huang, Urban Redevelopment Authority (URA) Digital Planning Lab, Singapore

- Chong Lee Tan, National Parks Board (NParks), Singapore

- Damiano Cerrone, Demos Helsinki, Finland

- Jo-Ting Huang-Lachmann, Climate Service Center Germany (GERICS), INNOVA project, Germany

- David Grahame Shane, Columbia University GSAPP (Graduate School of Arch, Planning and Preservation), United States

\#4 / Our Future Cities: public space initiatives, innovative policies and creative actions to recover during and after the pandemic

- Husam Al Waer, University of Dundee, School of Social Sciences, Scotland

- Sabine Knierbein, TU Vienna, Interdisciplinary Centre for Urban Culture and Public Space, Austria

- Rashiq Fataar, Our Future Cities, South Africa 
- Frank D'hondt, Secretary General, ISOCARP, The Netherlands

Supporting Universities and institutions (alphabetical order):

A Cidade Precisa de Você, Brazil

- Centre for Liveable Cities, Singapore

- Centre for the Future of Places, KTH Royal Institute of Technology, Sweden

- Cluster for Sustainable Cities, University of Portsmouth, United Kingdom

- co+labo radović, Architecture and Urban Design Laboratory, Keio University, Japan

- College of Design, Architecture, Art, and Planning, \& Orville Simpson Center for Urban Futures, University of Cincinnati, USA

- Consortium for Sustainable Urbanization, USA

- Department of Architecture, Faculty of Engineering, The British University in Egypt (BUE), Egypt

- Department of Architecture, University of Thessaly, Greece

- Department of International Urbanism, University of Stuttgart, Germany

- ETSAB Escola Tècnica Superior d'Arquitectura de Barcelona, Universitat Politècnica de Catalunya (UPC), Spain

- I-AUD, Meiji University, Japan

- IN SITU - European Platform for Artistic Creation in Public Space

- Integrated Urbanism \& Sustainable Design (IUSD), Cairo Lab, Ain Shams University, Egypt

- $\quad$ Lulea University of Technology, Sweden

- Observatorio Ciudadano por el Derecho a la Ciudad y Espacios Públicos de Guayaquil, Ecuador

- Public Space Research Group, Center for Human Environments at the Graduate Center of City University of New York, USA

- QUT Design Lab, Queensland University of Technology, Australia

- $\quad$ Research LAB for Urban Settlements and Landscapes, Graduate Institute of Building and Planning, National Taiwan University, Taiwan

- $\quad$ RMIT University, School of Art, CAST - Contemporary Art and Social Transformation Research Group, Australia

- Urban @ Parsons, The New School, USA

- Urban Commons Lab, University of Washington, USA

- Urban Design | Public Space, Department of Urbanism, Delft University of Technology (TU Delft), The Netherlands

- Urban Relational Informatics Lab, The University of Auckland, New Zealand

- Urban Synergies Group, Australia

and

- UN-Habitat, Global Public Space Programme

- UN-Habitat, Urban Energy Unit

- UN-Habitat, Innovation Unit

\section{Readings}

UN-Habitat (2020), UN-Habitat launches COVID-I 9 Response Plan and Campaign targeting the world's most vulnerable communities, Press release (April 23, 2020) - https://unhabitat.org/unhabitat-launches-covid-19-response-plan-and-campaign-targeting-the-world\%E2\%80\%99s-mostvulnerable- 0

UN-Habitat (2020), UN-Habitat COVID-I 9 Response Plan - https://unhabitat.org/un-habitat-covid19-response-plan 
Final Online Symposium > November 6-7, $2020>$ https:/www.publicspace-covid I9.com/

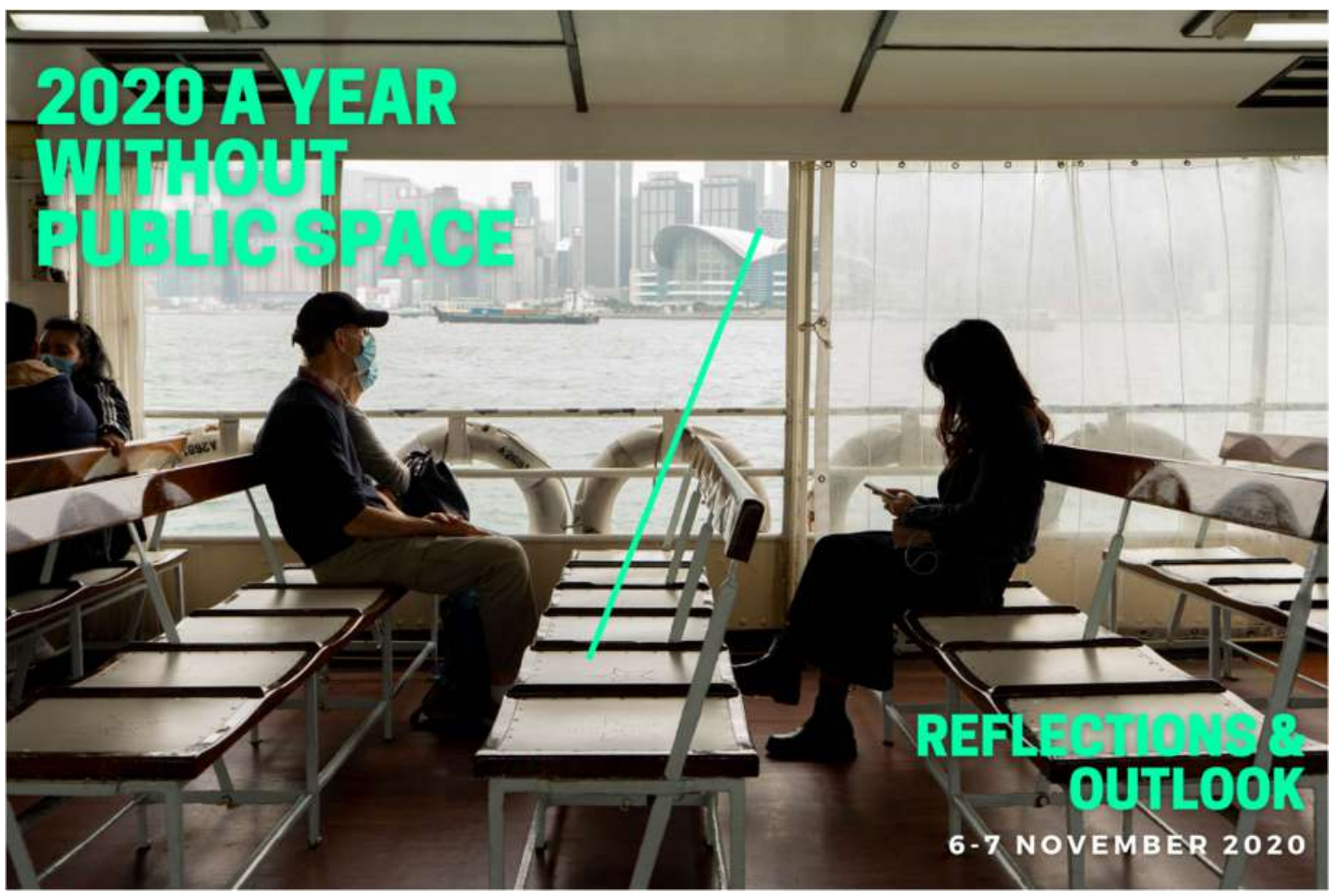

\section{DAY 1 | 6 NOVEMBER}

Opening Remarks | 9AM

Hendrik Tieben, Associate Director, School of Architecture, Chinese University of Hong Kong (CUHK) CY Chiu, Dean, Faculty of Social Sciences, CUHK Tung Fung, Director, Institute of Future Cities, CUHK

\section{Reframing the Role of Public Space in the Age of} Pandemics | 9:15AM

Diane Joy Brand, Dean, Faculty of Creative Arts and Industries, University of Auckland, New Zealand Setha Low, Director, Public Space Research Group, Graduate Center of City University of New York, USA Mahak Agrawal, Founder, The Spatial Perspectives, India Moderated by Miodrag Mitrasinovic (Parsons School of Design)

\section{Emergence of Digital Public Space: Harnessing the} Power of Data | 11AM

Tat Lam, Chief Executive Officer, Shanzhai City, Hong Kong Timothy Jachna, Dean, College of Design, Architecture, Art, and Planning, University of Cincinnati, USA

Manfredo Manfredini, Associate Professor, School of Architecture and Planning, University of Auckland, New Zealand

Moderated by Jeroen Van Ameijde (CUHK)

*All times shown are GMT +8
Cities and Health - Governmental and Institutional Roles in Building Resilient Communities | 1:45PM Mee Kam Ng, Associate Director, Institute of Future Cities, CUHK

Min Jay Kang, Associate Professor, Graduate Institute of Building and Planning, National Taiwan University (NTU), Taiwan

Riduan Ngesan, Senior Placemaking Executive, Think City, Malaysia

Moderated by Corrin Chan (Hong Kong Institute of Architects)

Innovative Approaches and Creative Practices | 5:15PM

Maggie McCormick, Fiona Hillary, Contemporary Art and Social Transformation (CAST), RMIT University, Australia Floor van Ditzhuyzen, Architect, Researcher and City Guide, Public Space Detective, The Netherlands Katelijn Verstraete, East Asia Arts Director, British Council Moderated by Luisa Bravo (City Space Architecture)

\section{Campus as Public Space in the Age of Pandemics |} 8PM

Peter Lennie, Executive Director, Worldwide Universities Network

Raymond Chan, University Dean of Students, CUHK José Escamilla, Director, TecLabs, Tecnológico de Monterrey University, Mexico Moderated by Hendrik Tieben (CUHK) 


\section{DAY 2 | 7 NOVEMBER}

Cities and Health - Role of Research and Design in Creating Sustainable and Healthy Cities | 9AM

Lee Beattie, School of Architecture \& Planning, University of Auckland, New Zealand

Kevin Lau, Research Assistant Professor, Institute of Future Cities, CUHK

Jason Gilliland, Director, Human Environments Analysis Laboratory, Canada

Moderated by Kai Gu (University of Auckland)

Cities and Health - Creating Healthy Neighborhoods | 10:45AM

Leigh Wilson, Faculty of Medicine and Health, University of Sydney, Australia

Kim Dirks, Faculty of Engineering, University of Auckland, New Zealand

Albert Lee, Director of Centre for Health Education and Health Promotion, CUHK

Moderated by Kevin Hsu (Centre for Liveable Cities, Singapore)

*All times shown are $G M T+8$
Cities and Health - Combating Health Disparities in High Density and Informal Communities | 1:15PM lean Woo, Director, Jockey Club Institute of Aging, CUHK KT Suresh, National Lead Policy \& Campaigns (Urban \& Labour), Action Aid India

Wael Sinno, Area Coordinator, UN-Habitat, Lebanon Moderated by Gregor H Mews (Urban Synergies Group/ QUT)

Roundtable Discussion and Closing Remarks: 2020 Reflection and Outlook After A Year Without Public Space |3PM

lim Walker, Founder, Walk 21 Foundation, UK

Jose Chong, Global Public Space Programme, UN-Habitat Luisa Bravo, Founder, City Space Architecture, Italy Maurice Harteveld, Assistant Professor, Urban Design, Delft University of Technology, The Netherlands Moderated by Hendrik Tieben (CUHK)

Virtual Hong Kong Public Space Tour led by Walk in Hong Kong | 4:45PM

\section{ORGANISERS \& PARTNERS}

\section{(2) $4 x+x+\frac{1}{40}$ \\ 19: School of Architecture

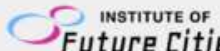

\section{WON}

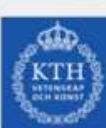<smiles>C1=C[C@H]2C[C]12</smiles>

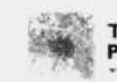

osrg CUT

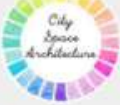

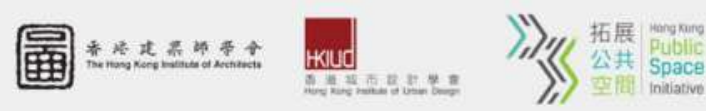
r.n...

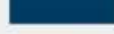
D RMIT

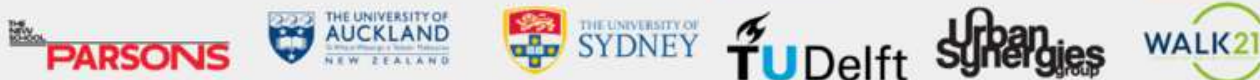

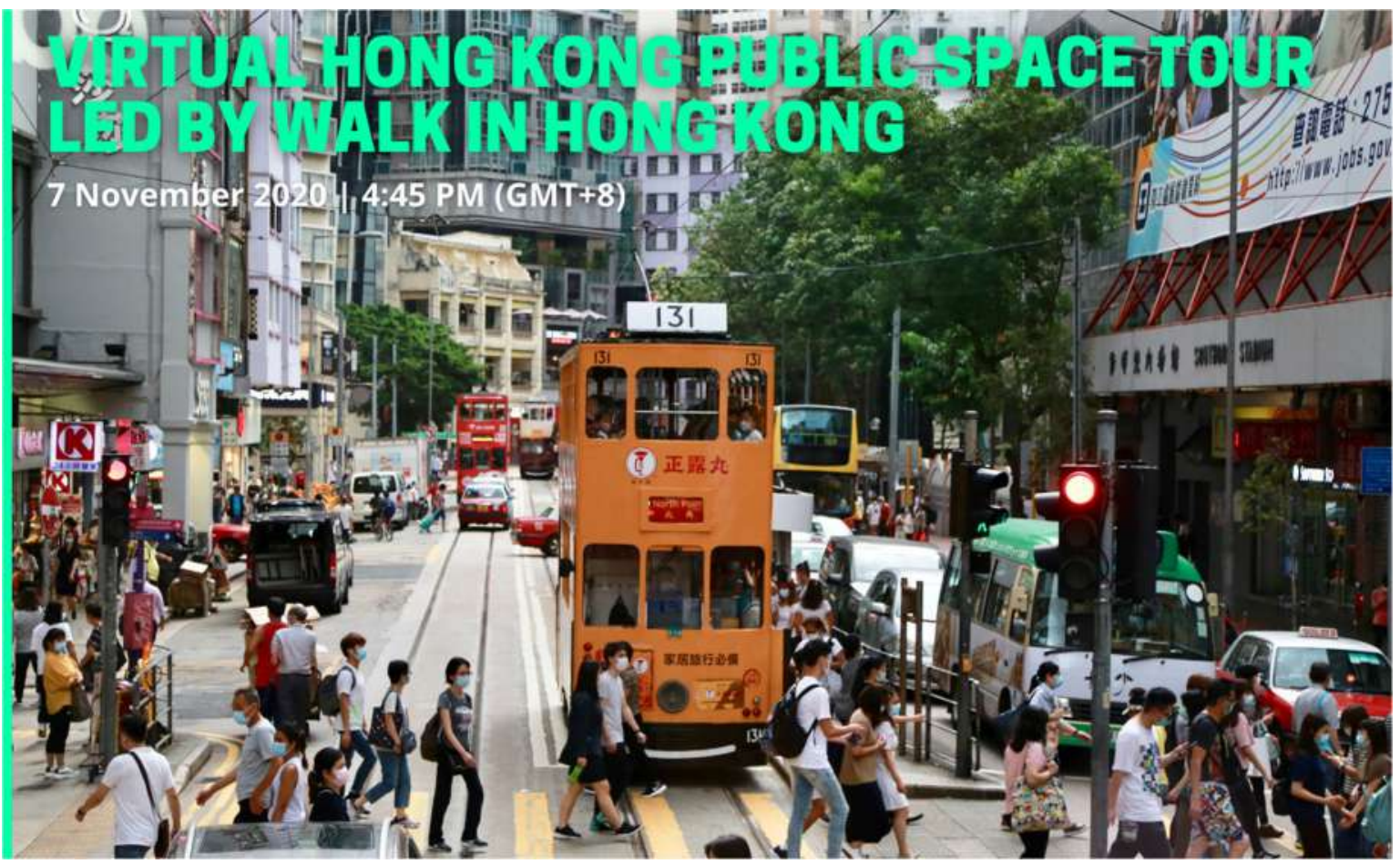




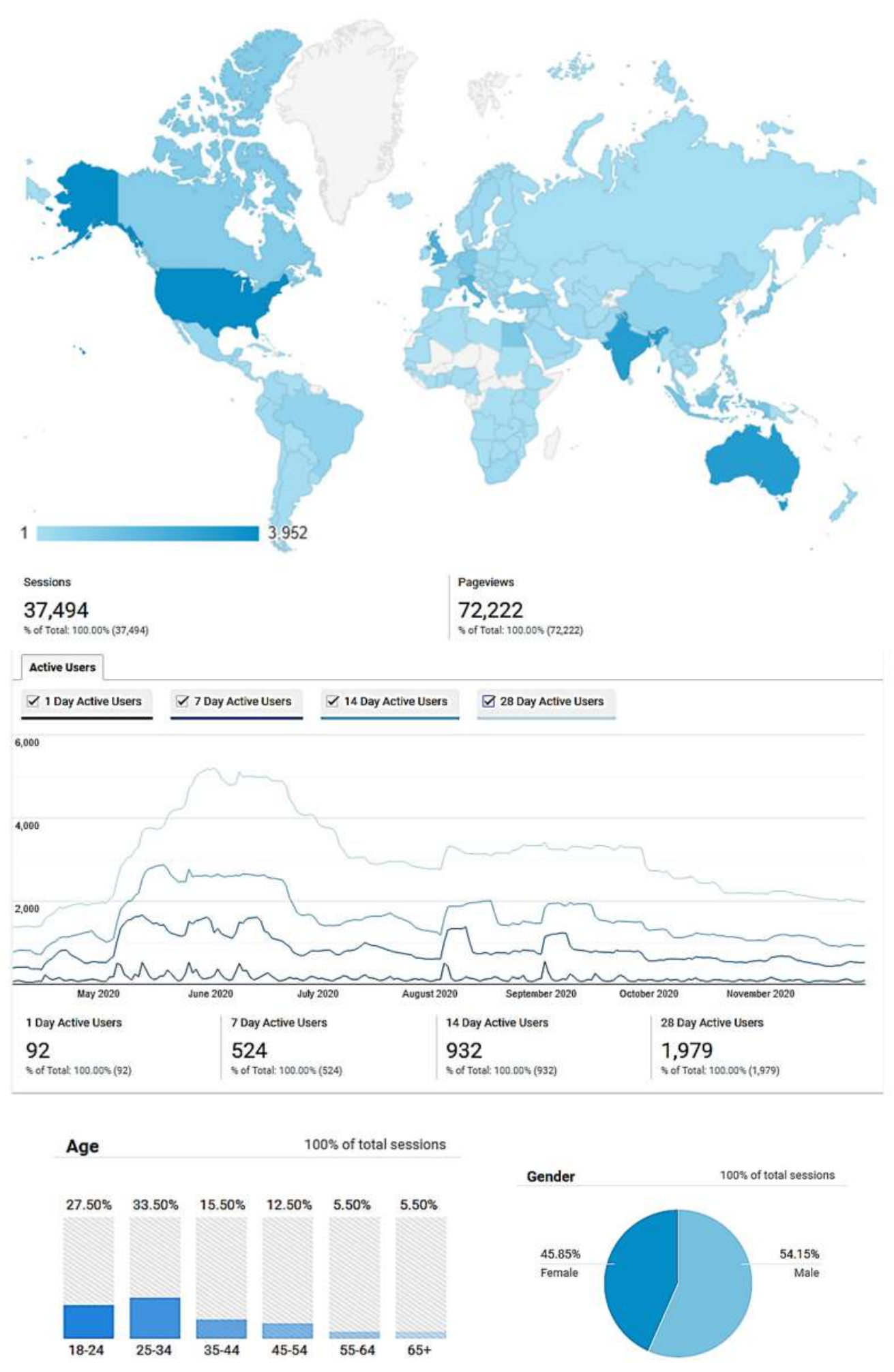

Figure I. Global impact of the online initiative '2020: A Year without Public Space under the COVID-I9 Pandemic. Data retrieved from Google Analytics for the account The Journal of Public Space,

in the period 7 April 2020 (day of the public announcement of the initiative) - 30 November 2020. 


\title{
Public Space and COVID- I 9: Contraction, Expansion, and Adaptation
}

\author{
Vikas Mehta \\ University of Cincinnati, United States of America \\ vikas.mehta@uc.edu
}

\begin{abstract}
COVID-I 9 has hit cities hard. With the closure of places of work and learning, third places, places of leisure and consumption, and more, the pandemic has diminished our territories and contracted public space and public life. But a keen observation reveals a more nuanced picture. In many neighbourhoods, an interesting phenomenon of reclaiming much neighbourhood space for public use is evident. The repurposing of residential streets, sidewalks, parking lots, and other modest public spaces in neighbourhoods shows an expansion of public space and sociability. This expansion is also that of agency. The elimination of events and programming and the cordoning off of standardized equipment has left public space in an unembellished state of bareness. Space is available for citizens to make public. This pandemic has revealed our desire for publicness of the everyday, our ingenuity to use spaces for public life, and what is possible in our cities and in our public spaces.
\end{abstract}

Keywords: public space, neighbourhood, agency, adaptation, COVID-19 pandemic

To cite this article:

Mehta, V. (2020). Public Space and COVID-19: Contraction, Expansion, and Adaptation, The Journal of Public Space, 5(3), I5-22, DOI 10.3289I/jps.v5i3.I360

This article has been double blind peer reviewed and accepted for publication in The Journal of Public Space. (c) (1) This work is licensed under a Creative Commons Attribution - Non Commercial 4.0 International License https://creativecommons.org/licenses/by-nc/4.0/ 
We have been asked to keep a social distance, not bring people (aside from the family or ones we reside with) into our personal space. We have to operate from our homes and stay largely within our neighbourhoods. For most, this has meant that we cannot share space with close friends and even some of our families. COVID-19 has taken away our access to much of public life and sociability, whether it is in our third places, workplaces, mundane spaces of mobility, learning places, or places of leisure and consumption. Coffeeshops, cafes, bookshops, restaurants, barbershops and salons are shuttered; most offices, other than essential, are shut; schools and universities are locked; retail stores, malls, theme parks, sports arenas and other places of leisure and play are closed. For many in the urban cores, the pandemic has essentially brought everyday life to a halt - commuting in public transit is hazardous, public spaces that are open are crowded, and even walking to get some fresh air doesn't permit a safe distance. The most obvious perception, in these times of the pandemic, is the shrinking of territory - a contraction of public space and public life. While this is generally true, the specific realities on the ground are more nuanced. Observing the lives of people who live outside of the hyper intense urban areas - the centre city and the urban core-reveals an interesting phenomenon of reclaiming of much neighbourhood space for public use.

\section{Contraction, expansion, or adaptation?}

Even though the majority of US population lives in cities, a vast number of these urbanites reside in mid- to low-density neighbourhoods from the charming historic streetcar suburbs to the non-descript exurban neighbourhoods. The lived experience in these neighbourhoods is quite different even with the same constraints. Residents feel the same limitations on their lives but for those who have to stay home, the space of the neighbourhood - what sociologists call parochial space (different from public space) - provides a support system that, at least in part, delivers an alternative. In many of these neighbourhoods can be evidenced a remarkable range of repurposing of space on residential streets. With little use of the vehicle, driveways have become gathering places; pedestrian space is no longer limited to the meagre sidewalk and the pavement is a space to walk, bike, have conversations and active play; street junctions, cul-de-sacs, and parking lots are places for happy hour; the linear typology of the street is now easily morphed into gathering space - a path to place (Figure I). Different people have adapted to the situation differently. Although centre city neighbourhoods face many challenges due to limited space, street use for play, gathering, and socializing is not uncommon (Figure 2). In the terms introduced by Osmond (1957, cited in Hall, 1966), the streets have transformed from sociofugal to sociopetal spaces. Mitchell $(2003,35)$ reminds us that "a space is made public when, so as to fulfil a pressing need, one group takes space and through its actions makes it public." In the absence of unlimited urban territory, neighbourhood residents have taken the space within reach and are using it to make it public. This adaptation is an expansion of public space. 

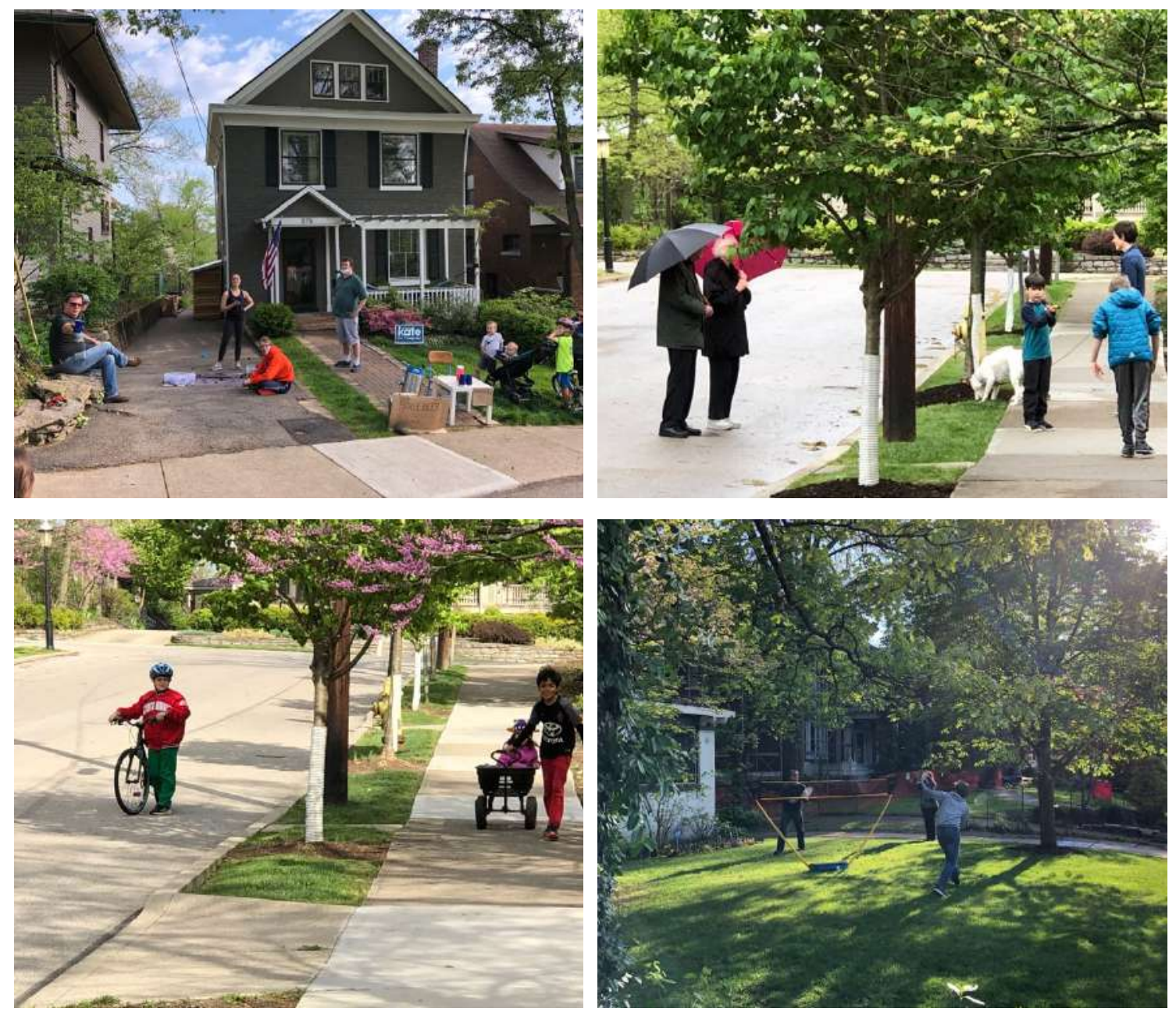

Figure I. Public (and some private) spaces in streetcar neighbourhoods, such as Clifton in Cincinnati, Ohio, are used for gathering, socialization, walking, biking, active play, and many other means of public life. Source: all photographs by author.
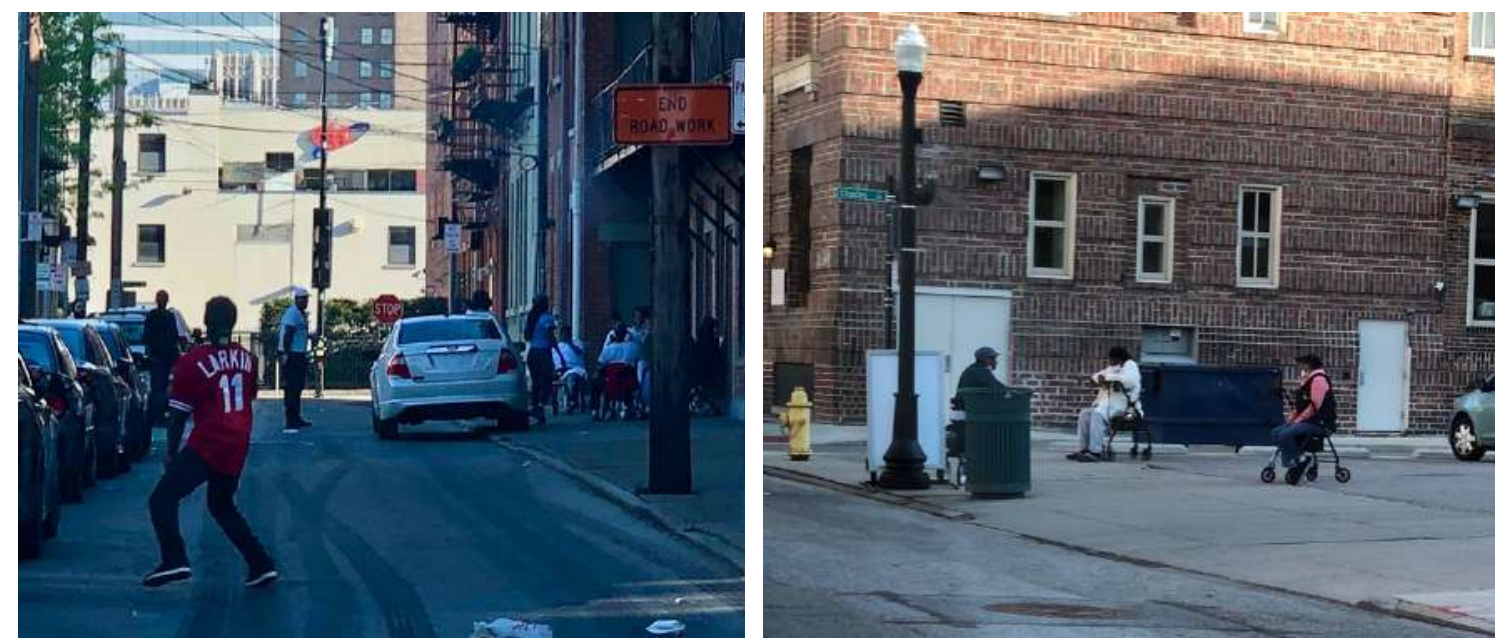

Figure 2. Even though centre city neighbourhoods, such as Over-The-Rhine in Cincinnati, Ohio, have limited space, street use for play, gathering, and socializing is not uncommon now.

Source: all photographs by author. 


\section{Expansion of agency}

The expansion of public space has another important dimension to it. This expansion is also that of agency. With the stay-at-home and social distancing orders, we are staying away from the hyper-designed, themed, and programmed private, quasi-public, and public spaces - shopping streets, shopping malls, theme parks, sports arenas and more. Even in our city parks and other urban open public spaces, there are no active events, and all programming is suspended, there are few directions to follow, and standardized equipment is out of bounds - the bareness of public space is made visible (Figure 3).
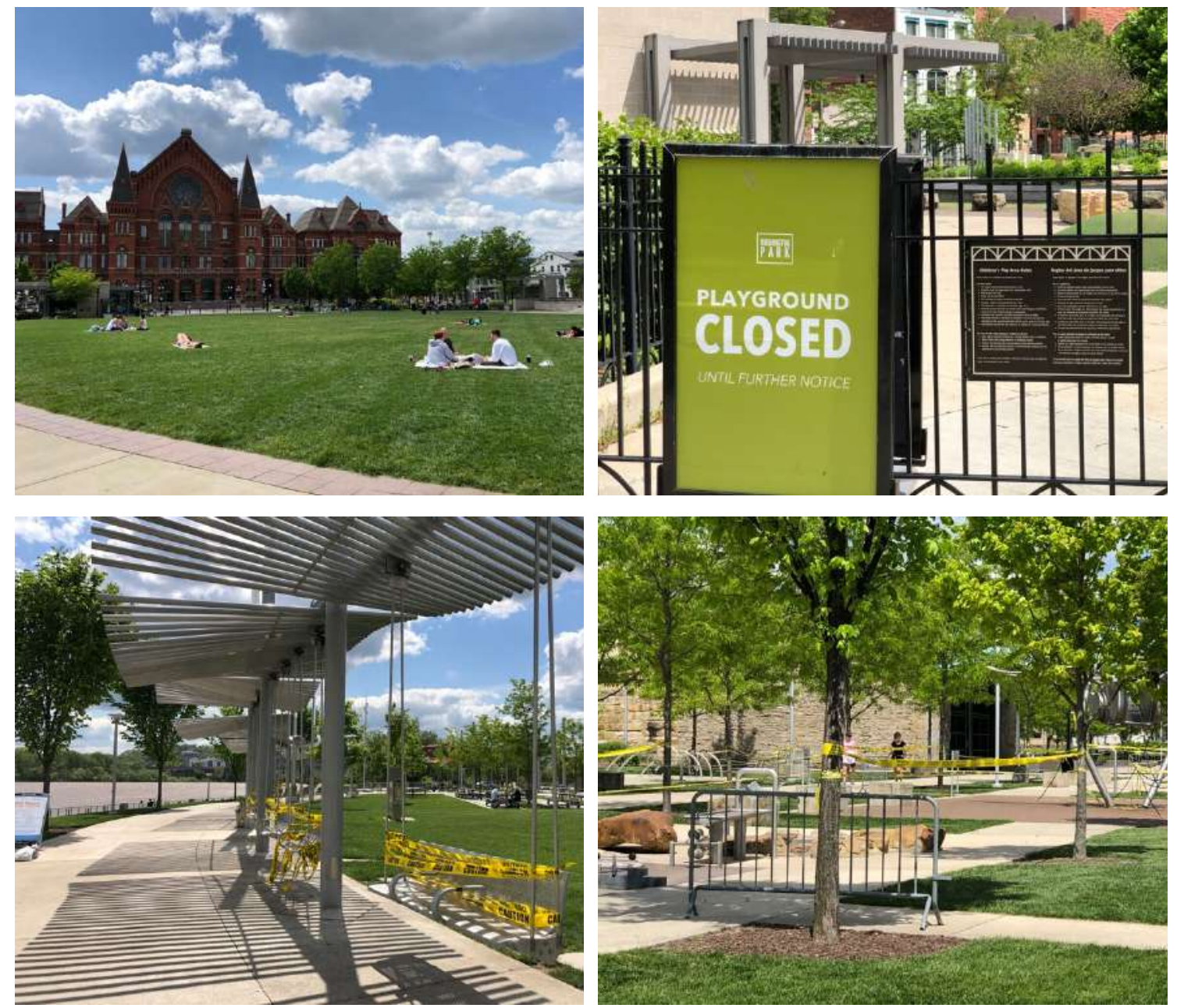

Figure 3. The bareness of urban open public space in major city parks is visible, such as in Washington Park and Smale Riverfront Park in Cincinnati, Ohio. Events and programming are suspended, and standardized equipment is out of bounds. Source: all photographs by author.

This transformed public space may not be unmanaged, but it is certainly unguided. What is left over is a raw and unembellished state of space. For this short period, the grip of capital on public space has been loosened and space is left on its own for citizens to make public. Agency has been transferred to the people. This available public space presents itself as a near-blank canvas for people to interpret and use space as desired, 
within culturally acceptable norms. The adaptation and agency are visible in the occupancy of space (Figure 4). Children's use of space is exemplar. With play equipment sealed, swings removed, water turned off in city parks, and the six-feet social distancing barrier in place, children are finding ways to invent play equipment, create play opportunities in the spaces available. On neighbourhood streets, with automobile traffic reduced, biking has provided an ideal combination of physical distance and freedom to move; street pavement has become a place for soccer; and sidewalk chalk is become a regular art activity (Figure 5). Children's territory has widened as they are able to actively use street pavements along with sidewalks, neighbourhood parking lots, driveways and more. But the perception of territory is not only spatial, but it is also temporal. With more eyes on the street, children are spending time out at various times of the day and for much longer than usual.
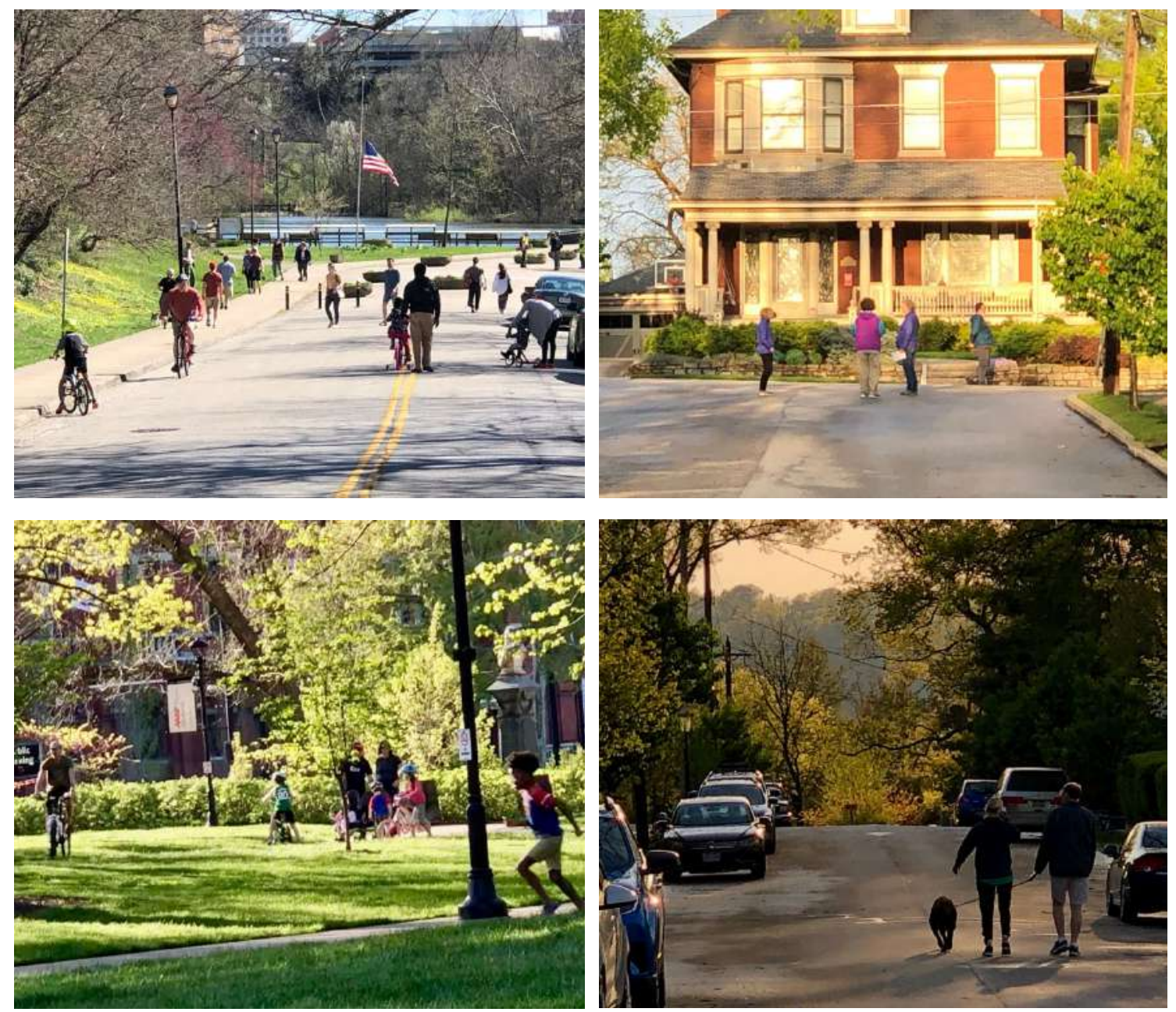

Figure 4. Agency has been transferred to the people. This available public space presents itself as a nearblank canvas for people to interpret and use space as desired, within culturally acceptable norms. The adaptation and agency are visible in the occupancy of space, such as in examples above of Burnet Woods, Washington Park and streets in Clifton in Cincinnati, Ohio.

Source: all photographs by author. 

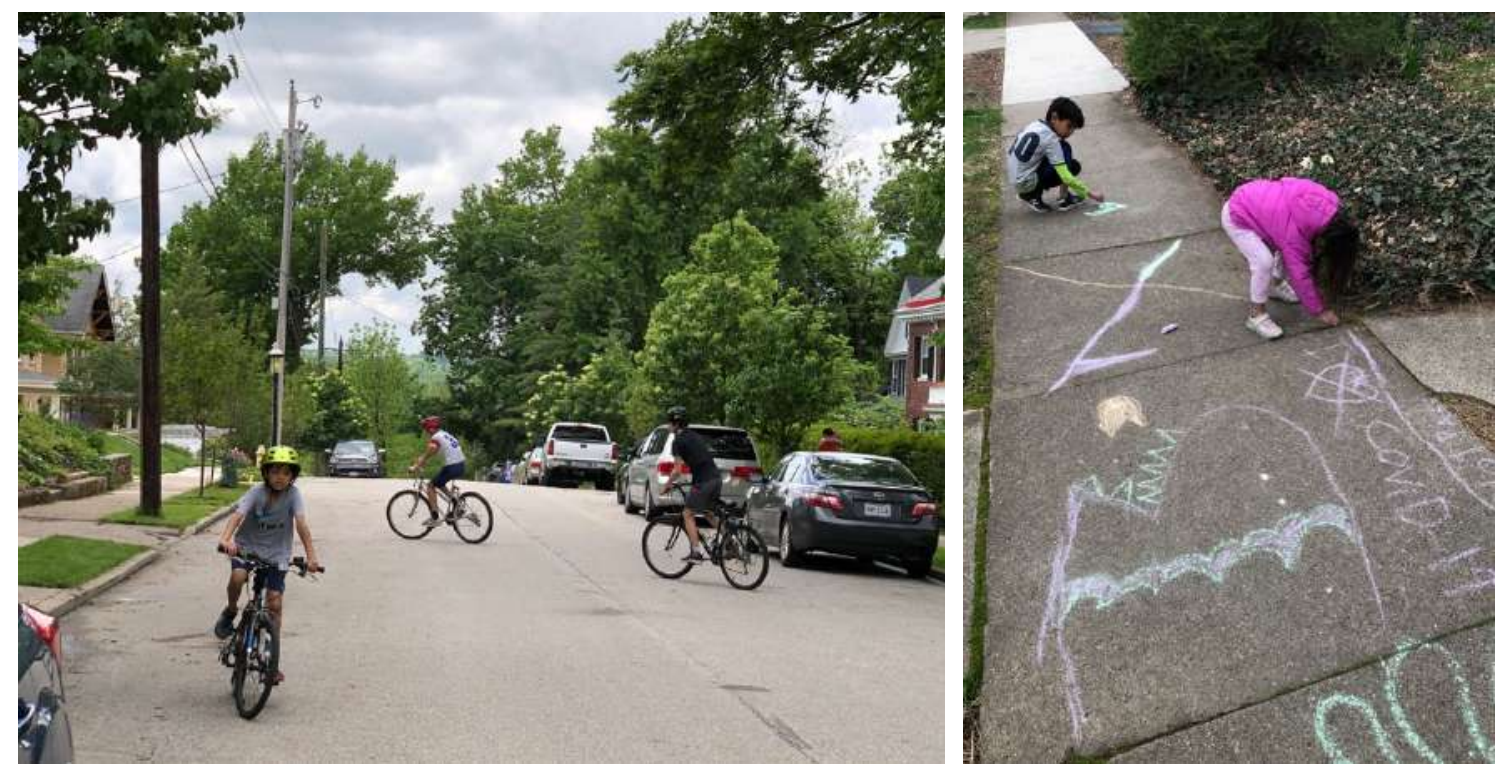

Figure 5. With reduced automobile traffic, neighbourhood streets are ideal for biking, sports, and even sidewalk chalk. Source: all photographs by author.

\section{The typological switch}

Taking a broader citywide view shows a typological switch in the occupancy of public space and several other spaces of public life. With several quasi-public and public spaces closed, partially closed, or inaccessible, many are embracing the more open-ended and loose public spaces such as neighbourhood streets, natural urban parks, trails, and woods (Figure 6). Neighbourhood residents have become aware of the value of local streets and sidewalks as these have become the most used public spaces for family walks, children's play, exercise, or just for getting out to get some fresh air. Going out with the family means going to the everyday neighbourhood public spaces instead of shopping malls or theme parks. Although our current situation may seem dismal, we must not ignore the value of this adaptation of space where we have to been forced to shed the dependency on consumption in using public space.

\section{Hope for future}

As public space scholars know, and examples from around the world in times of the pandemic have shown, there is not one public. The many publics have an equally varying set of needs, varying resilience, and varying ways to enact resilience. It is evident that not everyone can partake in this new expanded public space. The social disparities are stark. The stay-at-home situation can be mitigated by those who have access to their own private open space or nearby public spaces such as sidewalks, streets, parks, and woods. But stay-at-home orders can be insufferable for residents who live in neighbourhoods with housing that has little private open space, a limited access to public space due to inadequate public spaces, or unsafe conditions due to crime or traffic, or poor condition of public spaces. For some, this time has translated into finding the (forced) time to enjoy being outdoors while for others it has meant suffering through a lockdown or taking serious risks. 

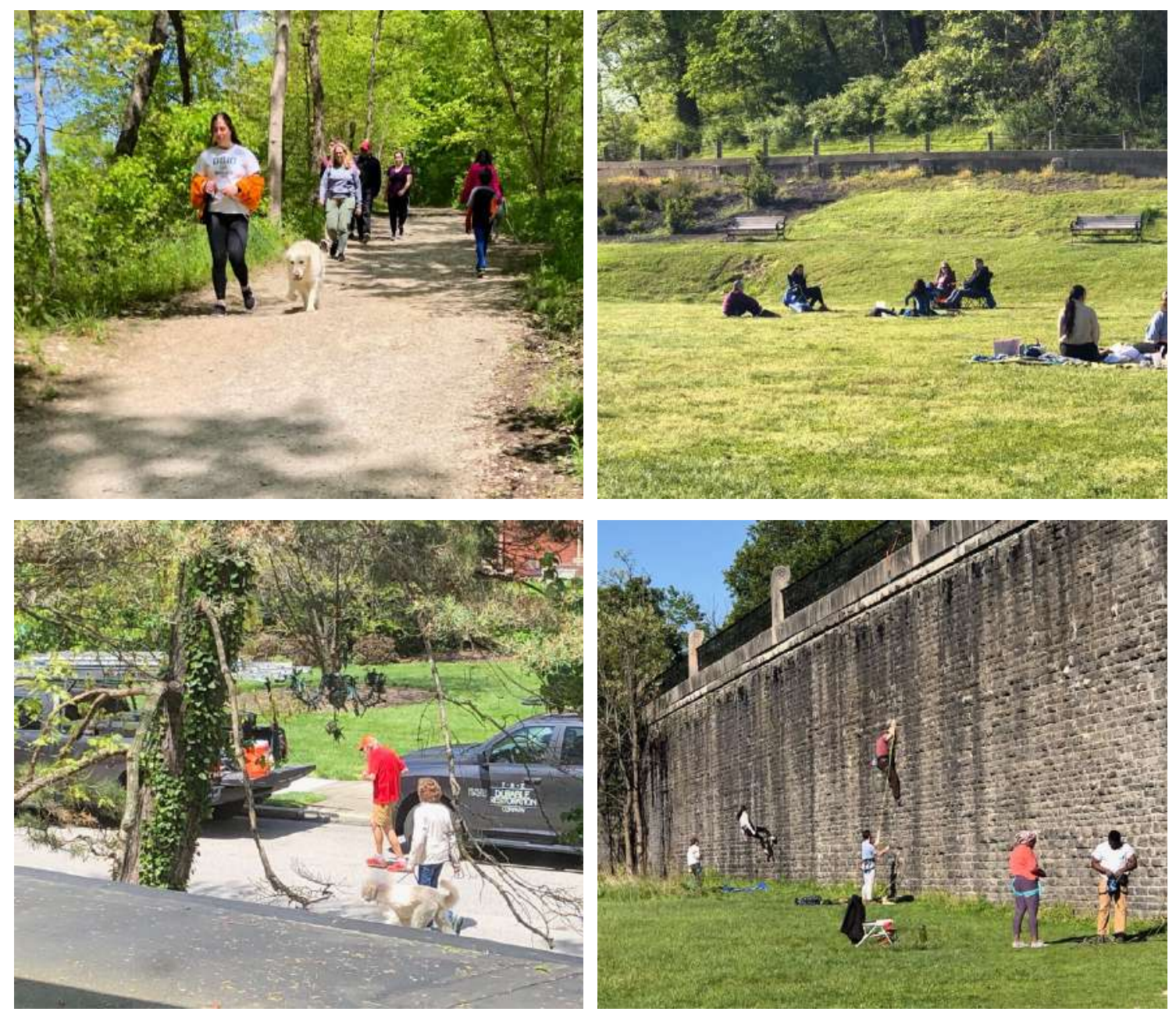

Figure 6. Many are using the more open-ended and loose public spaces including neighbourhood streets, natural urban parks, trails, and woods, such as Sharon Woods, Eden Park and Clifton in Cincinnati, Ohio. Source: all photographs by author.

The pandemic has taken many lives, caused devastation to economies that has brought so many families at the brink of economic collapse. This is not a time to romanticize the current situation. We do not want to stop going to work, we do not want to lose our third places, we want our services to be available again, our places of learning to open, we want access to spaces of leisure and consumption, and more. Yet, there are lessons to take away from the changed circumstances and heeding to these lessons may prepare us better for the future. Public space serves the many political, social, and economic purposes. In the current scenario, there are two long-range benefits of public space to public health. The everyday physical activity provides benefits that are crucial to public health, particularly in countries where obesity is a major problem. Not only does being outdoors lower the risk of coronavirus transmission, being active also translates into reduction of other life-threatening diseases. More importantly, the expanded use of neighbourhood public space leading to social interactions provides socio-psychological benefits helping alleviate social isolation that researchers have found to cause 
depression and impact early mortality (Holt-Lunstad, Smith, Baker, Harris, \& Stephenson, 2015; Leigh-Hunt et al., 2017).

This pandemic has shown that we desire publicness of the everyday - socializing, conversations and other interactions with our neighbours and others, and we have the spaces and the ingenuity to use these spaces for public life. A vast amount of public space in cities is, in fact, parochial space - residential streets, neighbourhood parks, play areas, community gardens, community centres, and numerous non-private spaces in neighbourhoods. These spaces may not be the foremost public spaces to enact political action, but these are valuable spaces that form the social glue in our societies and help us live healthier. What we would hope is that through the current processes of contraction and expansion we are able to adapt and generate an augmented public space.

\section{References}

Hall, E. T. (1966). The Hidden Dimension. New York: Doubleday.

Holt-Lunstad, J., Smith, T., Baker, M., Harris, T. \& Stephenson, D. (2015). Loneliness and Social Isolation as Risk Factors for Mortality: A Meta-Analytic Review. Perspective on Psychological Science, I0(2), 227-37.

Leigh-Hunt, N., Bagguley, D., Bash, K., Turner, V., Turnbull, S., Valtorta, N., \& Caan, W. (2017). An overview of systematic reviews on the public health consequences of social isolation and loneliness. Public Health, I52, I57-I7I.

Mitchell, D. (2003). The Right to the City: Social Justice and the Fight for Public Space. New York: Guilford Press.

Osmond, H. (1957). Function as the Basis of Psychiatric Ward Design. Mental Hospitals, 23-29. 


\title{
Opportunity in the Time of COVID-I9. Learning Lessons to Improve Public Spaces
}

\author{
Miquel Martí, Lara Espindola \\ Universitat Politècnica de Catalunya, Spain \\ miquel.marti@upc.edu | laraespindola@gmail.com
}

\begin{abstract}
To face the COVIDI9 pandemic, cities have taken short term actions. Streets have been closed to traffic during weekends to enable temporary playgrounds or car lanes have been transformed into bike lanes or used to enlarge sidewalks following tactical urbanism practices. Time has appeared as a main factor in the management of public space (defining timeslots to exit to the street or trying to avoid peak hours in public transportation by extending the starting and ending working times). Technologies have been key, enabling online work, virtual gatherings and creative activities, as well as developing applications for better tracing the disease or enforcing the lockdown regulations. But what will be the lasting effects of these measures in the long-term transformations of cities?

This commentary was written in May 2020, in the middle of a total lockdown in Barcelona. It is based on the events, reflections and public opinion reactions at this precise moment in this particular place. It argues that the urban adaptations to the COVIDI 9 could be an opportunity to adjust, strengthen and accelerate some ongoing urban strategies: the transition towards a more sustainable mobility and a greener city; the development of neighbourhood life; the application of technologies in urban planning and management, community-based initiatives and everyday public space experiences.
\end{abstract}

Keywords: COVID 19, urban mobility, neighbourhood, urban health, digital space

To cite this article:

Marti, M., Espindola, L. (2020). Opportunity in the Time of COVIDI9. Learning lessons to improve public spaces, The Journal of Public Space, 5(3), 23-30, DOI I0.3289I/jps.v5i3.I373

This article has been double blind peer reviewed and accepted for publication in The Journal of Public Space.

(i) \$) This work is licensed under a Creative Commons Attribution - Non Commercial 4.0 International License https://creativecommons.org/licenses/by-nc/4.0/ 


\section{Introduction}

During these days of lockdown due to the COVIDI9 pandemic we have seen all around the world shocking images of empty public spaces. We can only conceive as temporary such pictures, and with the starting of scaling measures, streets are recovering immediately part of their life. Public space is the soul of most cities and a city without some kind of lively public spaces would be nonsense. Meanwhile, animals have occupied our streets, recalling us that either our cities recover a synergic relation with nature or the future of the planet could be a post human one (Weisman, 2007).

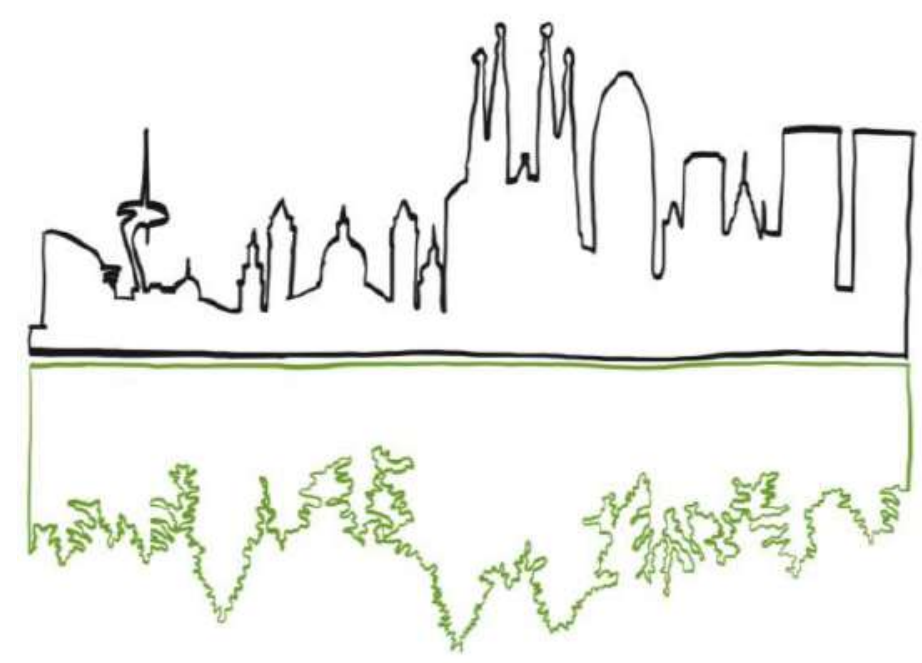

Figure I. City and nature: searching for synergies.

Source: by the authors, inspired in the cover image of the book The World without Us

The point is not if the post-COVID city will be a completely different one (which is not likely), but if in the mid-term (when a vaccine will be available) we will tend to live as we did before (which would be a pity). As many thinkers are stating these weeks (Noam Chomsky, Naomi Klein, Slavoj Zizek), the impact of the pandemic should be an opportunity to strengthen some changes that societies were already facing (Žižek, 2020).

From the particular perspective of public space, we think about three issues on which the COVIDI9 is having an impact that would be important to drive positively: the changes on the urban mobility and the redesign of the street network; the debate about density, complexity, proximity and the availability of open spaces under social distance conditions; the increasing role of information and communication technologies in planning, managing and experiencing cities.

\section{Impacts on urban mobility and the redesign of the street network}

Under the effects of the pandemic, the modes of transportation that we use to move around the city have changed. We have two opposite effects. On one hand, the capacity of public transit is diminishing because we can't travel so close ones to the others. One the other hand, online working has been spread and consolidated. Keeping some forms 
of online work once the lockdown will be finished could be a lasting effect of the crisis. This may be useful not only to reduce the number of commuters, but to make more flexible the working schedules (starting and ending times) in order to avoid the peak hours, when public transportation can be overwhelmed (Guerrero \& Muñoz, 2020). Public transit should be reinforced by upgrading the network of reserved lanes, increasing the frequencies and providing more public funding to compensate the reduction of incomes from users' tickets. Nevertheless, the weight of public transportation in the modal choice of citizens is expected to decrease. In those circumstances, are cities facing a rise in the use of private cars?
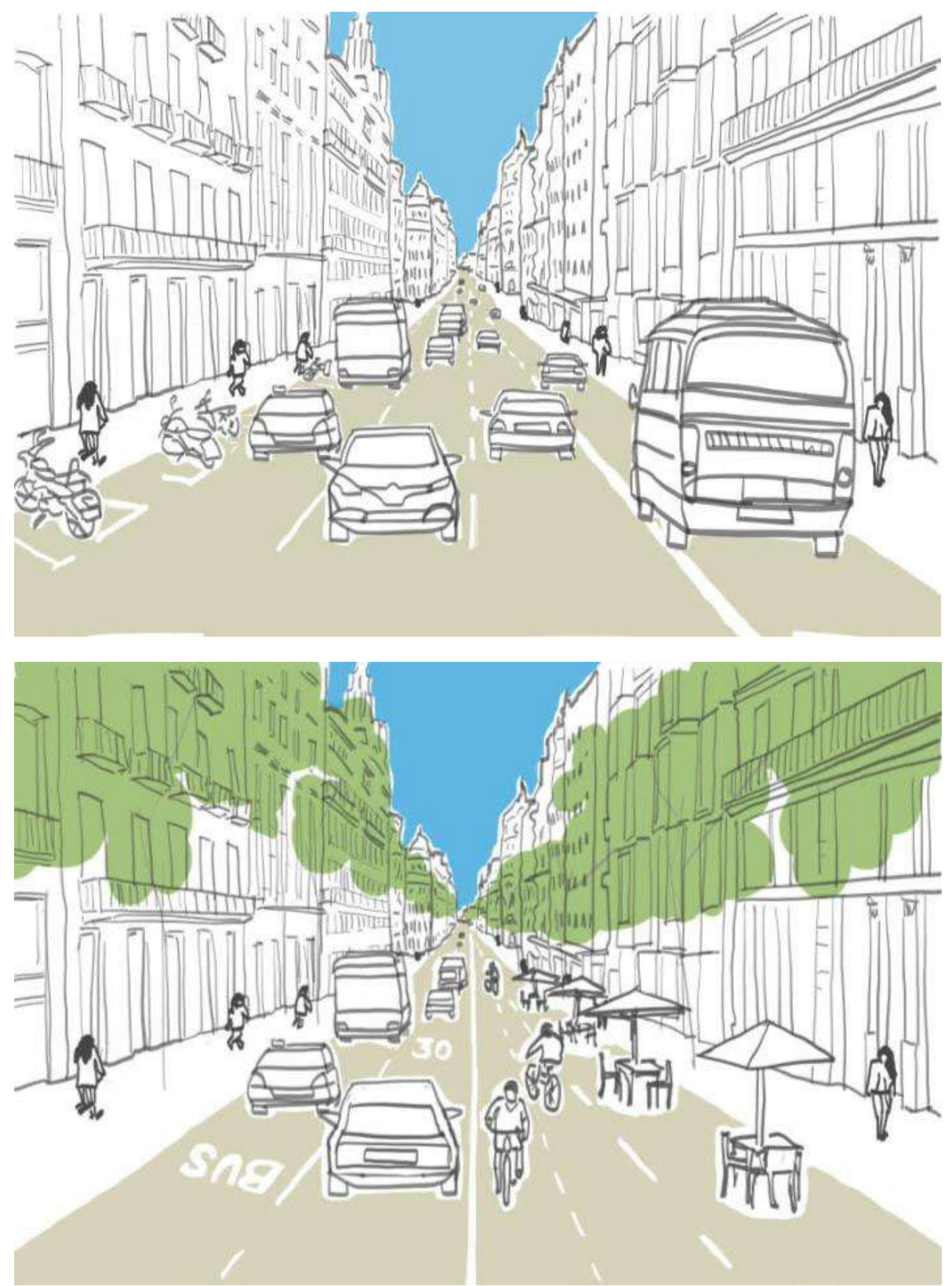

Figure 3. Imagine the redesign of streets in Barcelona. Source: by the authors 
A city like Barcelona (as many other European cities), it is deep into a process of reducing the presence of cars in the streets in favour of other uses (civic, green or sustainable mobility modes) under the model of superblocks and peaceful routes. Walking is already an important way of moving in the central city (about $35 \%$ of journeys) but less than $4 \%$ of citizens ride bikes for their everyday movements (eSMARTCITY, 2020). The possibility of shifting the reductions in the use of the public transportation towards cycling is an alternative considered in many metropolis [from the tempoRERvélo (Compagnon \& Corby, 2020) in Paris, where about $650 \mathrm{~km}$ of longdistance bike lanes are going to be implemented in two months, to Bogota, where bike lanes are doubling the network of Transmillenium BRT. In Barcelona, the adaptation to the effects of the pandemic appears as an opportunity to improve the infrastructure for cycling and substantially increase the use of bikes for mid-distance journeys (up to I5 $\mathrm{km}$ ). In that sense, some measures previously considered could be accelerated: the development of a network of safe bike lanes not only urban but also interurban; services of shared bicycles of several sorts adapted to the needs of different users; a bike parking system related to intermodal hubs (like traditional train or metro stations or new access points to shared vehicles located in former gas stations, parkings or car dealers); an integrated ticket system making easy to combine different transportation modes (seamless intermodality); the development of applications for planning, booking and paying mobility services including bikes (mobility as a service).

If cities maintain the aim of limiting and reducing the presence of cars, the debate about how to redesign the public space is highlighted. In circumstances of social distance to avoid contagion, we need wider sidewalks and larger bike lanes, but also more room for recreative uses (like bar terraces and children playgrounds, smaller and separated), without forgetting the urgent need to make our cities greener. The street space is limited and therefore extremely valuable (particularly in Mediterranean cities), but it can be better shared between these different uses (Pérez Mendoza, 2020). The actions of tactical urbanism (Martí Casanovas, 2020) implemented these weeks (rapid, low cost, reversible interventions like ground painting or using mobile urban furniture) constitute an interesting laboratory to explore and test permanent changes in the transformation of our streets in order to build more peaceful cities: cleaner and less polluted, human centred and easily inclusive, slower and enabling new urban experiences.

\section{Should be our cities less dense? Decompressed density, complexity and proximity.}

A second issue that the pandemic has underlined are crowded public spaces. The concentration of people in public places respond to different phenomena: mass tourism, collective events (like sport matches or concerts) or the simple fact that many cities are quite dense. While the big social events should wait for some kind of collective immunity to be fully restarted, tourism is a sector that can undergo significant long term changes. To launch alternatives to mass tourism could be an opportunity. Ecotourism, based on the experiences of nature and the values of rural territories, appears as a source of local development for some interior areas. At the same time, online work could also enhance the move of some citizen to the countryside (López Letón, 2020). Both dynamics would contribute to achieve more balanced urban development between 
big metropolis and a network of distributed medium cities supporting less populated regions.

But from the urban point of view, a key question is about density. In order to avoid infectious diseases, our cities should become less dense? Probably not. In the XIX century, urban features were clearly a cause for the appearance and spreading of infectious diseases. The combination of high density with a lack of sanitary conditions in the water supply and sewage infrastructures, poor habitability of the dwellings and lack of public spaces explained the link between city and infections. Such conditions don't exist anymore, at least in the European city of the XXI century. In this context, nowadays the main concerns of public health related to the urban environment are respiratory and heart illnesses due to air pollution and a sedentary life (Higueras \& Pozo Menéndez, 2020). Therefore, a mobility model based on the use of car contributes directly to an unhealthy urban environment. A shift towards sustainable mobility (clean, efficiently intermodal, favourable to active modes of transportation like walking and cycling) is key to promote urban health. And density appears as one of the conditions to enhance a sustainable mobility. In one century, density evolved from being associated to infections to be a factor of public health.

Besides, a reasonable mid-high density ( 25.000 inhabitants/sqkm) is a crucial factor for an overall sustainable city. It makes possible to provide many services (from public transportation to energy) in an efficient way (with fewer costs) (Kamiya, 2020). Density is also a necessary condition for having a rich intense neighbourhood life. The combination of density with complexity (related to the diversity of uses) makes possible neighbourhoods full of proximity services. In such areas, residents can find whatever they need in their everyday life reducing the need of mobility. It's the principle that what matters in a metropolis is a high accessibility to the services it offers with a minimum mobility. The concept of self-sufficient neighbourhoods or the city of 15 minutes walking turn around these same ideas. The efforts to increase the diversity of uses in urban areas (combining housing, commercial activities, other services, and also more and more economic activities from a clean industrial sector) are at the core of the agenda of many cities.

However, mid-high density standards require a good system of public green spaces to be balanced [a "decompressed density", as referred by Salvador Rueda (Rueda, 2018)]. A good system implies not only enough outdoor spaces, but also a diversity of typologies (intended for different recreation uses) and a right distribution on the whole city. During the pandemic, when the use of public space needs some social distance, we wonder how we could better manage or increase it. Temporary regulations are implemented: timeslots for being outdoors related to ages or activities, or changing the use of some places during some time (for instance, a street closed to traffic that becomes a playground for some hours or an expecting plot transformed into a temporary square). Time appears as a rising factor in the governance of the city. In turn, to increase public space in dense consolidated metropolis is not easy. The lockdown period has seen the recovery of rooftops life in Mediterranean cities. It's a way to be explored, as it can strengthen some current trends: the importance of small community places, acting as transitions between private dwellings and fully public spaces; the naturalization of cities, with the greening of façades and rooftops; the memory of rich cultural and historical roots, because in the past, the rooftops were much more lively. 


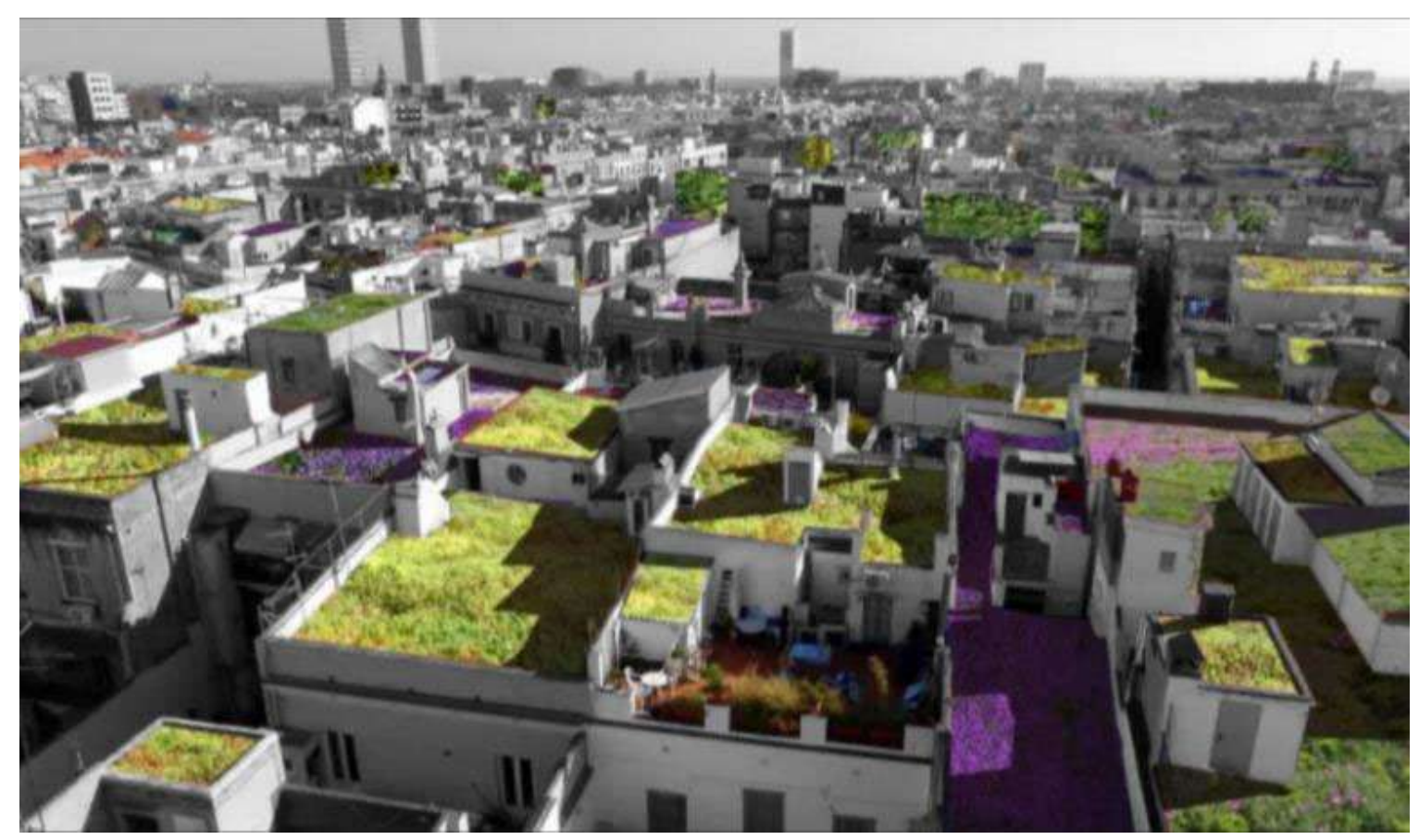

Figure 3. Proposal of green and community rooftops in the Raval neighbourhood of Barcelona Source: by the authors, based on an image of Barcelona Municipality. www.barcelona.cat/barcelonasostenible

Eventually, we could also change our habits and use more the big open metropolitan spaces [not only seafronts, but also mountains, rivers or agrarian parks that surround Barcelona (Batlle, 20I4)]. The dynamization of these rural spaces and their connection with the network of urban public places (through civic green corridors and permeable city edges enabling transition) is a main challenge for cities that could be enhanced by the impact of the pandemic.

\section{The increasing role of technologies: community initiatives and real time planning}

The last issue to be considered are the possible changes in the relation between public space and technology. The public sphere always shows two faces: the physical public space (streets, squares, parks) and the virtual public space (public opinion, social media, social networks). In the information and communication era, the online social space become progressively important (the last decades showing that this process doesn't undermine the vitality of the physical public space). The pandemic can accelerate this trend in several ways. On one hand, the rise of online interactions offers new opportunities and means to develop cooperative initiatives to build together [as Richard Sennet (Sennett, 2012) would put it] bottom up collective projects. On the other hand, our urban life will be more and more helped by technological applications. 


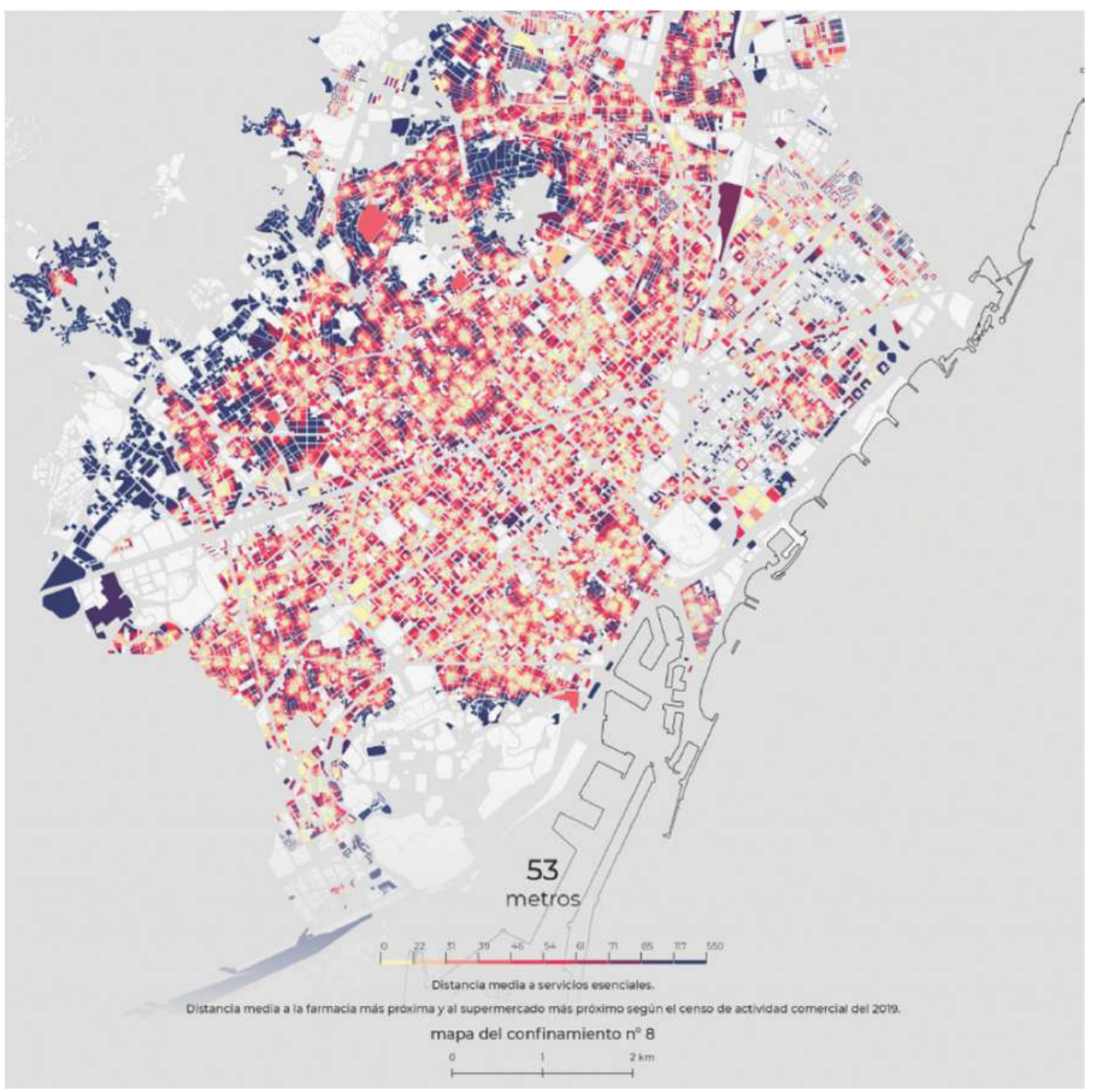

Figure 4. Neighbourhood proximity services in Barcelona: urban planning based on data analysis Source: http://www.300000kms.net/_arxiv/habitar.pdf

The analysis on real time of big amounts of data about how we move and use the city is increasingly present in urban governance. For instance, it will provide decision-making tools for more flexible urban planning and develop applications for intelligent traffic and public space management (synchronising traffic lights to adjust priorities between the flows of pedestrians, bikes and public transport or to control and limit the capacity of public space to avoid excessive crowds). To have access to these advantages of technologies implies that a lot of information on our personal life will be exposed, in the hands of public administrations or private corporations. A coercive use of this data by governments or a profit use by companies could involve a loss of freedom and privacy. But as Saskia Sassen (Sassen \& Sennet, 2020) states, such dangers should propel us to find efficient mechanisms to control the use of data, but never renounce to the great benefits of treating them properly. 
Sum up, in the field of urbanism and in relation with public space, the COVIDI9 pandemic is an opportunity to learn positive lessons in order to strengthen ongoing processes like the redesign of more green, calm, inclusive, healthy street spaces, the reconciliation with nature of our urban habits and lively neighbourhood environments and the use of new technologies for the construction and management of a city in which citizens can be fully engaged.

\section{References}

Batlle, E. (20/4). La matriu ecològica metropolitana i les diverses escales de les infraestructures verdes. Quaderns PDU Metropolità, Issue 3, pp. 6-25.

Compagnon, S. \& Corby, S. (2020). L'lle-de-France va investir 300 millions d'euros pour la réalisation du RER vélo. Le Parisien, 2104.

eSMARTCITY (2020). La ciudad de Barcelona transforma su movilidad urbana para adaptarse a la salida progresiva del confinamiento. Movilidad Urbana, 2904.

Guerrero, D. \& Muñoz, O. (2020). La desescalada amenaza con colapsar Barcelona. La Vanguardia, 0305.

Higueras, E. \& Pozo Menéndez, E. (2020). Urbanismo y salud: ¿Son las ciudades europeas resilientes a las pandemias?. The Conversation, 2304.

Kamiya, M. (2020). Densidad urbana, conceptos y políticas. El Comercio, 2404.

López Letón, S., 2020. El éxodo inmobiliario que viene tras el virus: de la ciudad al campo. El País, 0205.

Martí Casanovas, M. (2020). "Hay que ganar espacio para el uso de peatones y bicis durante la desescalada" [Interview] (28 04 2020).

Pérez Mendoza, S. (2020). José María Ezquiaga: "La ciudad pos-COVID será la ciudad posautomóvil". elDiario.es, 0605.

Rueda, S., 2018. Carta para la planificación ecosistémica de las ciudades y metrópolis, Barcelona: s.n. Sassen, S. \& Sennet, R. (2020). Desafios ante un futuro incierto [Interview] (20 04 2020).

Sennett, R., 2012. Together: The Rituals, Pleasures and Politics of Cooperation. New Haven, CT: Yale University Press.

Weisman, A. (2007). The World Without Us. New York: Thomas Dunne Books/St. Martin's Press.

Žižek, S., 2020. Pandemic!: COVID-I 9 Shakes the World. New York and London: OR Books. 


\title{
What Still Matters in a City. The COVID-I 9 Pandemic Offers a "Teachable Moment" Illustrating that Public Spaces Must Simultaneously Connect us, and Protect us too
}

Michael Mehaffy

Ax:son Johnson Foundation, Sweden

michael.mehaffy@gmail.com

Tigran Haas

KTH Royal Institute of Technology, Centre for the Future of Places, Sweden

tigran@kth.se

Peter Elmlund

Ax:son Johnson Foundation, Sweden

peter.elmlund@gmail.com

\begin{abstract}
Various commentators have sought to assess the long-term impact of the COVID-19 pandemic on urban form and public space, with predictions ranging from "the end of urban density," to a new impetus for auto-encapsulated sprawl, to exacerbation of the effects of urban inequality, to an explosion of digital surveillance, to a return to relative normalcy with new protective strategies. Here we tease out a more basic lesson about public space: that it is far from one amorphous thing, but it has both connective and protective characteristics. Its structure has a profound impact upon the life of the city and the health and well-being of its residents. Furthermore, it is up to us, as practitioners at the interface of science and policy, to chart the very real choices emerging for a better generation of public space and urban form.
\end{abstract}

Keywords: COVID-19, pandemic, public space, sociable distancing, place network

To cite this article:

Mehaffy, M., Haas, T., Elmlund, P. (2020). What Still Matters in a City. The COVID-I 9 Pandemic Offers a "Teachable Moment" Illustrating that Public Spaces Must Simultaneously Connect us, and Protect us too, The Journal of Public Space, 5(3), 3I-38, DOI I0.3289I/jps.v5i3.1378

This article has been double blind peer reviewed and accepted for publication in The Journal of Public Space. 


\section{Introduction}

Since their beginnings, cities and towns have been shaped by pandemics as well as other stressors (war, fire, weather and so on). What has happened to the human race beginning in late 2019 is certainly historic, but hardly exceptional - except perhaps in the memories of those alive today. It follows that the impacts of this pandemic are likely to be significant but not novel, historically speaking. In fact, this episode may only heighten the urban challenges and choices we have already faced. At its best, it may prompt us to tease out factors that we left much too vague and ill-considered before.

In the literature of urbanism, planning and urban policy, the pandemic has brought out a number of intriguing assessments of long-term impacts, as a survey of the early literature reveals. Perhaps most notable is a re-assessment of the benefits of urban density and population size, previously described as key aspects of urban sustainability (Desai, 2020) but now identified as key corollaries of high transmission rates (Rocklöv and Sjödin, 2020, Stier, Berman and Bettencourt, 2020). Others foresee a renewed phase of low-density, cardependent sprawl (Kotkin, 2020) while still others note the continued negative and inequitable impacts of sprawl (Litman, 2020) and the further exacerbation of economic and other urban inequalities (Bonaccorsi et al, 2020). Others see an acceleration of big data and Smart city technology, with its associated implications for data privacy and surveillance (Inn, 2020). Still others see a resumption of megacity high-rise business as usual following relatively modest retrofitting (Acuto, 2020).

Here, rather than try to prognosticate - mindful of Yogi Berra's advice that "it's difficult to make predictions, especially about the future" - we ask a more basic question about this episode as a "teachable moment." What does the pandemic reveal about the nature of cities, and especially, the nature of their public spaces? What does it reveal about our choices ahead, and their potential impacts?

Following are our conclusions:

I. It is not density in the abstract, but the patterns of density that matter most for both contact and safety. Different urban forms at the same density can have very different connective and protective properties. The famous diagram below, by the UK's Urban Task Force, shows three very different urban forms with exactly the same density, 75 units to the hectare ( 30 units to the acre). We added the red lines to show that the connective properties are also radically different in the three examples. In the "tower in the park" model to the upper left, there are "choke points" in lifts/elevators, lobbies and entrances, that force people into close contact. In the rowhouse form in the middle, the points of connection are much more diffuse, although there are still ample public spaces that provide contact as desired while maintaining social distancing. In the perimeter block model to the lower right, a series of smaller lifts/elevators and a greater number of entries also provides a greater range of connectivity while affording social distancing.

2. It is perfectly possible to achieve safe social distancing within many different kinds of public spaces. In addition to the overall urban form, other structural features of both buildings and public spaces can provide for social distancing while also allowing social contact - what we call "sociable distancing." The key requirements are connective structures that provide partial enclosure and separation while also providing partial connectivity and contact, controllable by the users. History is full of examples of these "connective spaces," which serve to connect public spaces more effectively to private ones. They include stoops, balconies, porches and other "lowly" urban elements whose importance as protective connectors should finally be recognized. 


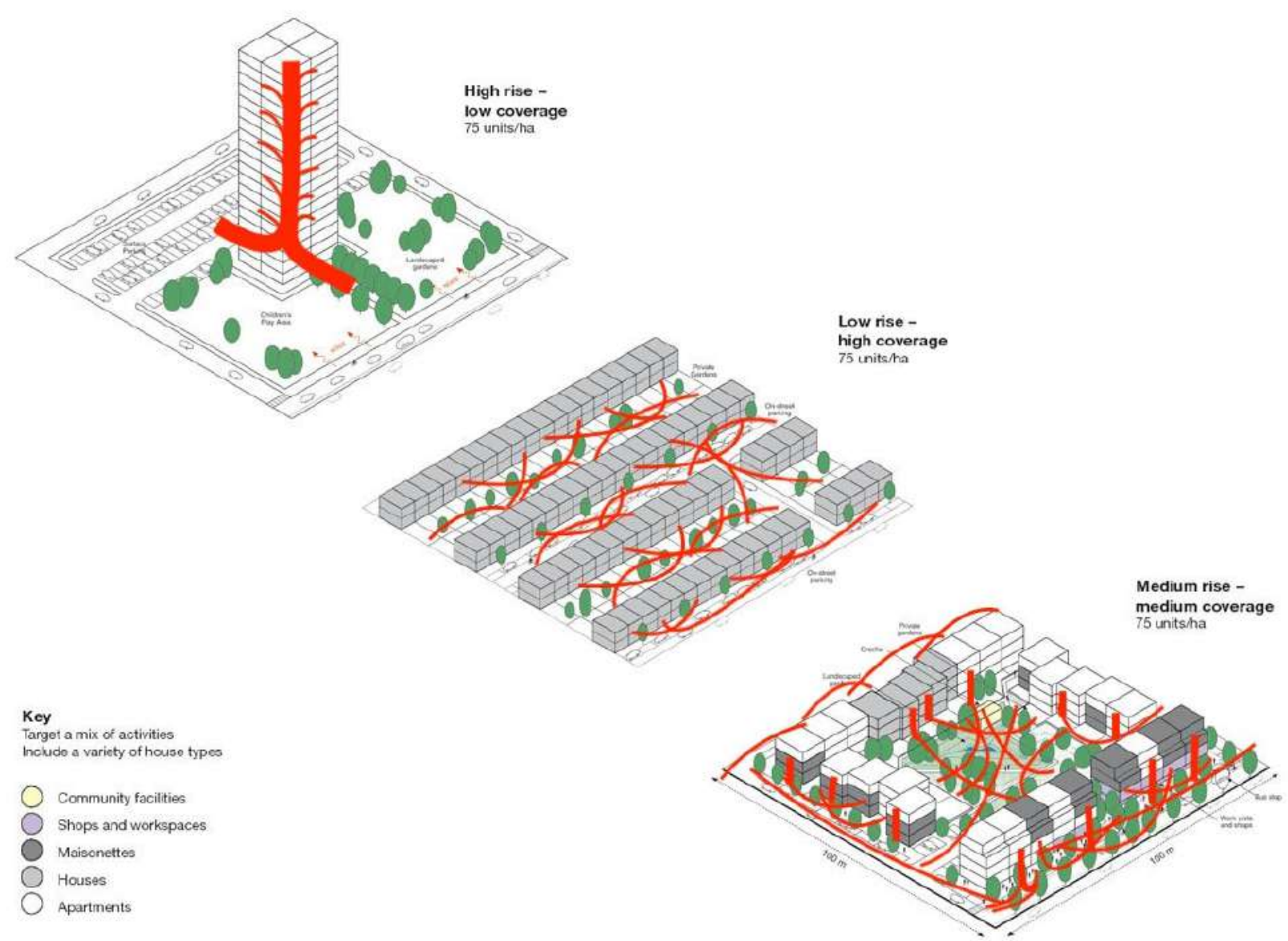

Figure I. Illustration from the UK Urban Task Force (1999) demonstrating that the same density can take very different urban forms (illustration modified by the authors).

3. What matters in public space is not only its capacity to connect us to one another within it, but also to afford controlled protection, and to connect us to other private spaces and the greater protections they afford. As our work has demonstrated, public spaces have an essential room-like structure of partial enclosure and partial openness, providing controlled connectivity to their occupants (Mehaffy, Elmlund and Haas, 2019). Furthermore, they are embedded within a web-network of more private room-like spaces, including literal rooms. The porch in the example above, together with the sidewalk, the landing, and the adjoining private living room, are all part of this system or "place network." Such structures can be observed in abundance in thriving streets and urban spaces, including the example of the London streetscape shown below.

4. This capacity of public spaces to protect as well as to connect means that these spaces are not static, but evolving and transforming in response to user needs and choices. Different populations will of course have different needs for protection and contact (e.g. the elderly, children, people in environments they perceive as dangerous) and the best urban spaces afford them a measure of choice and control - either in selecting from a suitable range of protective or connective spaces, or in actually rearranging the spaces (moving chairs, occupying tables, putting out boundary-marking devices such as picnic blankets, etc.). (Mehaffy, Elmlund and Haas, 2019) 


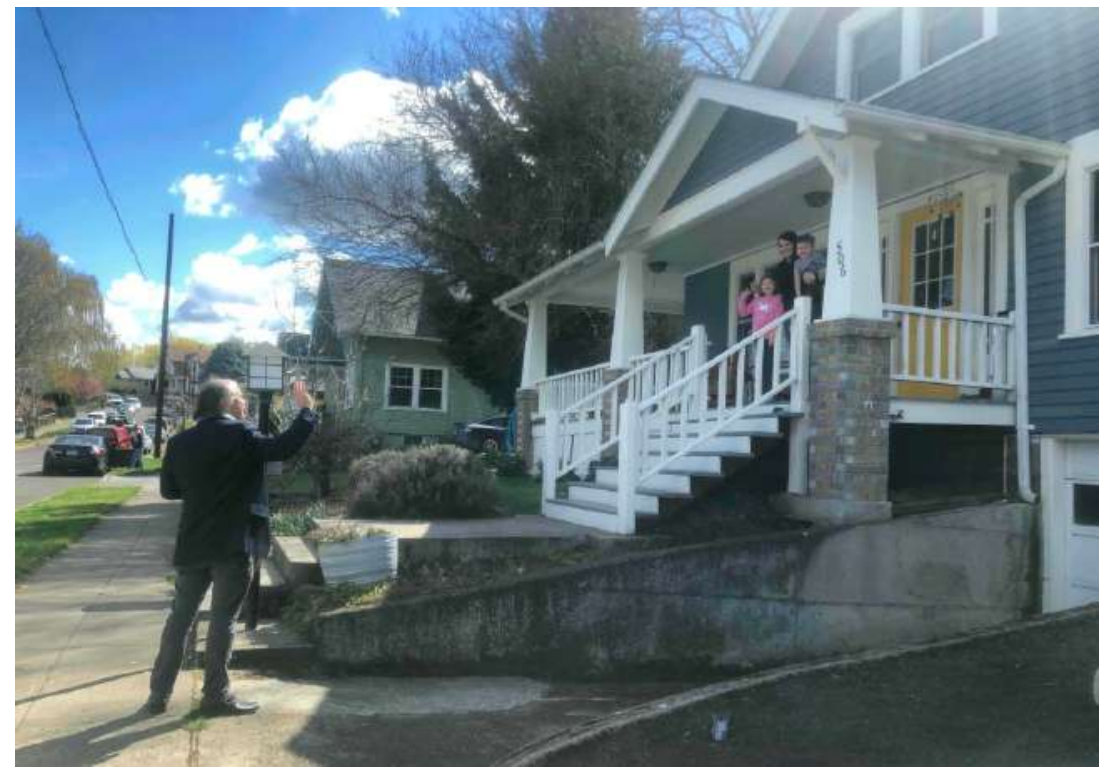

Figure 2. One of the authors in a "sociable distancing" visit with his daughter and grandchildren. Photo: The authors.

5. In addition to fully public spaces, the "third places" to which they connect are also critically important for urban vitality - and the impact of their absence is painfully evident during the COVID-19 pandemic. Third places, described notably by Ray Oldenburg (2002), include more enclosed public spaces, like dog parks and community gardens, and also more private spaces that offer public accommodations, like cafés and restaurants. However, as Oldenburg makes clear, to function optimally, any "third place" must be free or relatively inexpensive to enter, it must be easily accessible from home or work on a daily basis, and, less tangibly, it must be perceived as welcoming to all. As Oldenburg and others have pointed out, such third places are crucial to a community for a number of reasons. They are firstly distinctive informal gathering places, secondly, they make the citizen feel at home, thirdly they nourish relationships and a diversity of human contact, fourthly they help create a sense of place and community, and finally, they invoke a sense of civic pride. There is additional evidence that third places are important locales for the formation of social "weak ties" and the generation of social capital (Jeffres et al., 2009). They may also be important sides of so-called "knowledge spillovers" and the generation of city innovation and economic development (Roche, 2019).

At a deeper level, public and private spaces are not simply the physical structures that are conceived and arranged by planners and designers, but the places that people identify, and that are, to a large degree, socially produced and modified. A number of writers have described this more tacit aspect of place networks, including Edward Soja (1996) and Henri Lefevbre (1974) in their description of open-ended, undefinable, fluid, and endlessly complex "thirdspace" (Soja's term). Perhaps more relevant for our discussion is Bruno Latour's "actor-network theory" (1996) in which people, their spaces, their institutions, and their conceptions, all interact within a system, in which the physical, the social and the psychological must be seen as part of one transforming structure. 


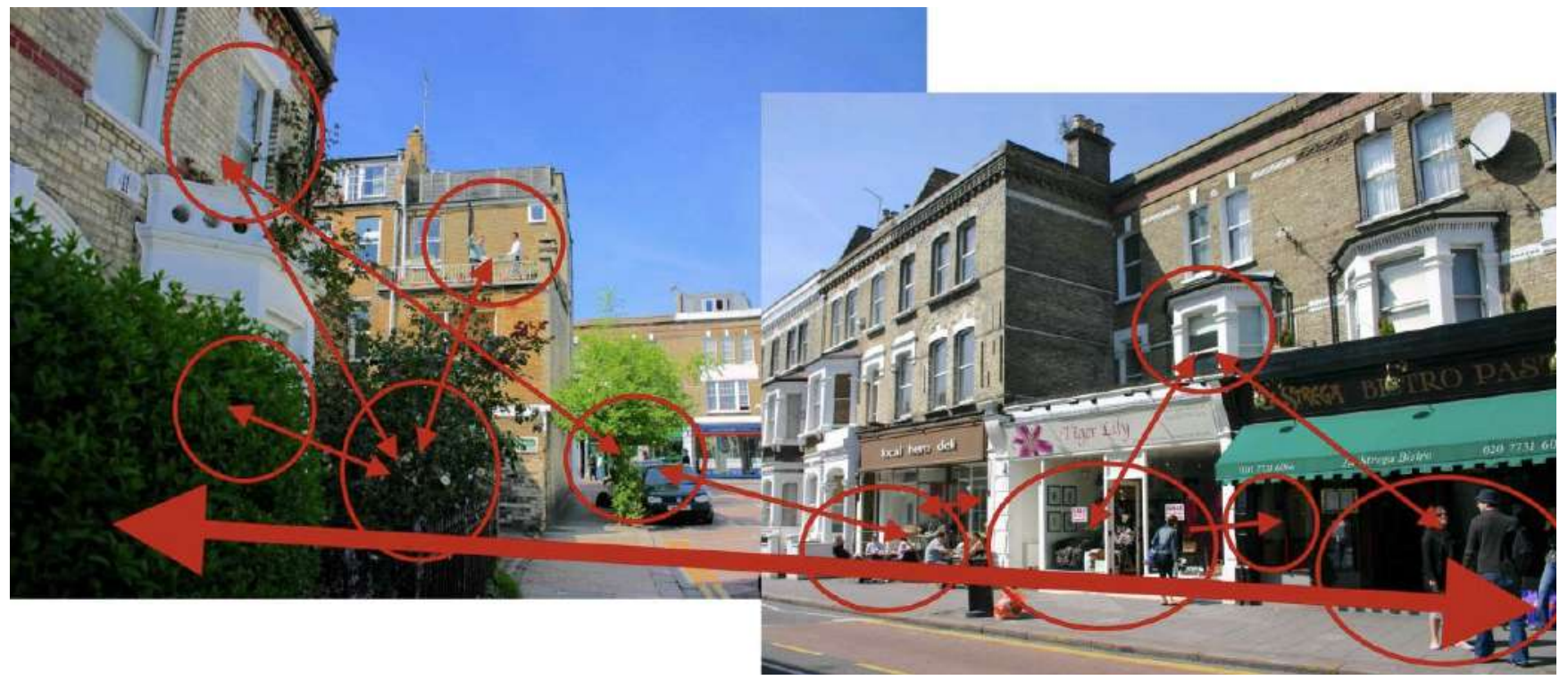

Figure 3. Composite photo of a fairly ordinary London street nearby where one of the authors happened to live. A close examination of its "place networks" reveals a dizzying system of room-like spaces, from the most private actual rooms (bedrooms etc.) to the most public room-like spaces leading to the street (sidewalk café groups, etc.) and many different kinds of indoor and outdoor spaces in between. Photo: the authors.

\section{Rooms in a building...}

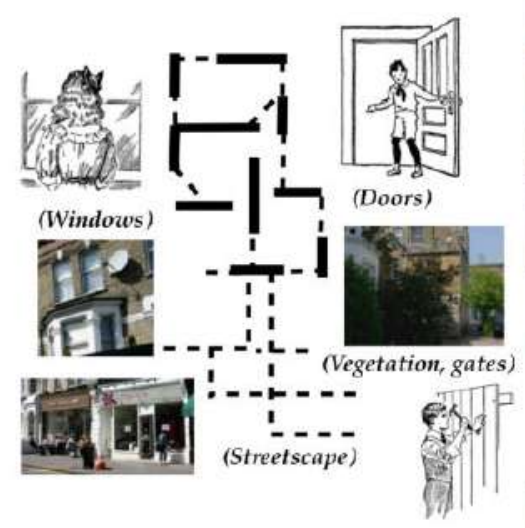

\section{"Rooms" outside a building...}
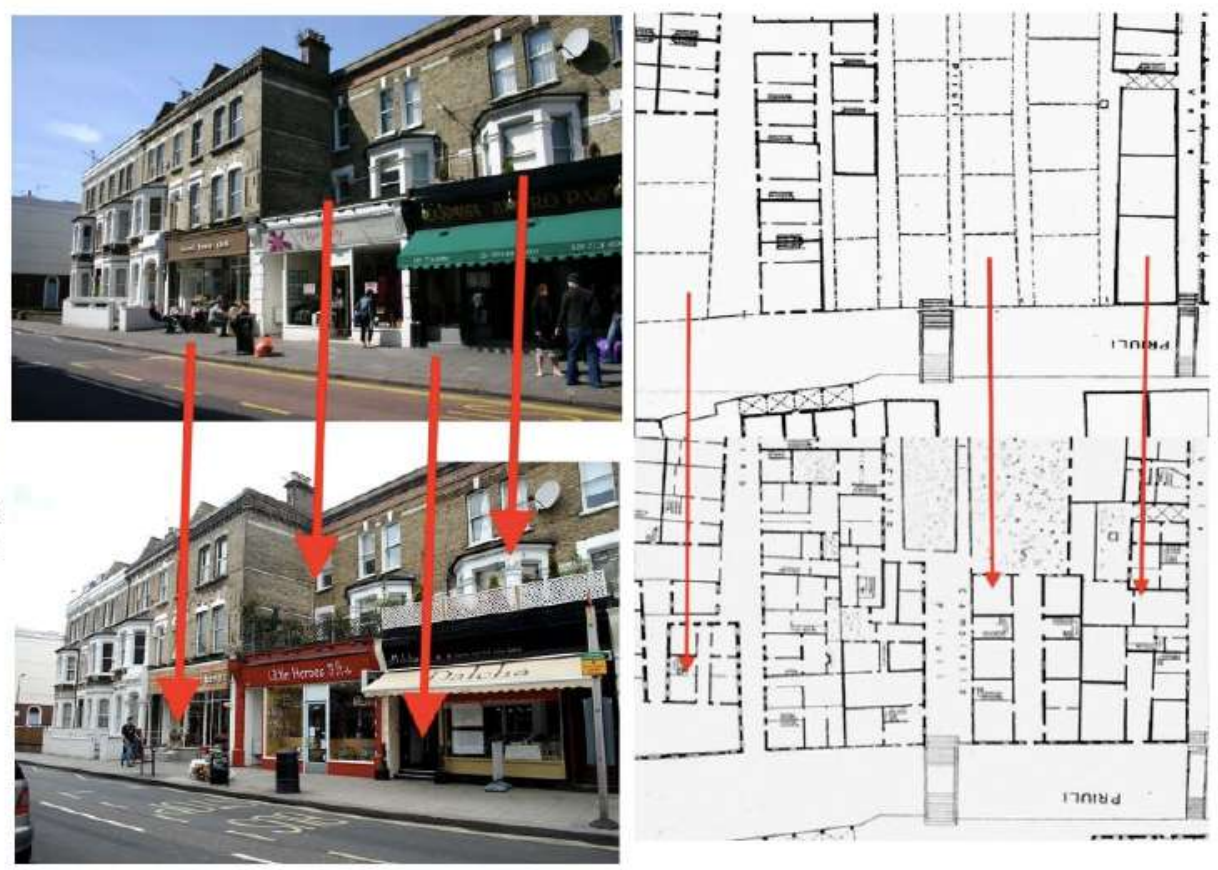

Figure 4. We are constantly co-producing and transforming our room-like public as well as private spaces, our "place networks," over many scales of time. We open windows, close doors, remodel spaces, and make longer-scale transformations, like the changes over five years in London (centre) and over a century in Venice (right).

In all of these examples, what matters is that people are interacting with their public and private spaces, modifying them, transforming them, making them more or less connective, and more or less protective. The mental aspects define and constrain the physical, but 
the reverse is also true. Moreover, this transformation goes on at the scale of hours or days (open a door, close a window, set out a picnic blanket) or years or centuries (remodel a home, build new buildings, transform a city) - as the illustration below demonstrates.

6. When it comes to urban space and density, something like a "Goldilocks principle" applies. Too many of the discussions of urban density seem to only assume either extreme high density in the cores, or extreme low density at the edges. The best examples from history demonstrate that there is a distribution of sizes and densities of spaces, buildings, neighbourhoods and cities, forming "polycentric" regions. This is true even in smaller areas, like informal settlements - which, at their best, also self-organize into patterns of public and private spaces, with a complex pattern of density gradients (Mehaffy, Elmlund and Haas, 2019). While density as an isolated attribute can certainly be beneficial, it does not follow that very high densities are only beneficial - or in the wake of the COVID-I9 pandemic, only harmful. As we have seen, the real question is how density can be achieved selectively to meet particular goals, within particular structures of connectivity. We need to do a better job teasing out the actual working dynamics behind "density" and other simplistic abstractions. Of course, we also need to recognise that it is not only density that matters, but the pattern of uses and activities, and their mixed distribution (Mehaffy, 2015)

7. The pandemic has highlighted a number of severe weaknesses in our current urban condition. We have witnessed the extreme degree to which our systems have poor resilience, and far from optimum conditions of equity and sustainability. Instead of the features of "ecological resilience" needed - redundancy and diversity, a mix of finegrained scales, inter-connected web-network structures, and the capacity for selforganization - our systems, including our systems of settlement, are characterized by the "engineered resilience" of long, narrow supply chains, large, "too big to fail" systems, hierarchical, "tree-like" structures, and "top-down," command-and-control approaches (Mehaffy and Salingaros, 2017). Instead of an optimum mix of equitable opportunity and access, too many cities and regions continue with pockets of deprivation and poverty, placing a drag on the viability and sustainability of their entire regions (Bettencourt, 20/3). Instead of the natural capacity of urbanism to achieve high quality of life with low resource consumption (characterised by walkability, compactness, optimal distribution of destinations, efficient transport, etc.) we are overly dependent on unsustainably high resource consumption urban systems that utilize automobiles, segregated functions, lowdensity sprawl, tree-like organization, and other characteristics of a "depletion economy" - very far from what is needed for a sustainable "repletion economy" (Mehaffy and Salingaros, 2017; Mehaffy, 20I2).

8. There is a corollary for social resilience. As the work of Klinenberg (200I) and others have shown, residents depend upon a web-network of relationships to cope with stressful events. Crucially, these web-networks are formed and maintained within public spaces, and the adjoining private and group spaces to which they connect. As Klinenberg observed in his famous study of the Chicago heat wave of 1995, the key difference in higher survival rates for some residents "turned out to be the sidewalks, stores, restaurants, and community organizations that bring people into contact with friends and neighbours" (Klinenberg, 20I3).

9. Medical science has provided a very helpful lens on our urban professions. As with medical science, the first requirement is to have a clear picture of the nature of the challenge before us - a point famously made by Jane Jacobs in her last chapter of The 
Death and Life of great American Cities (196I). Also, as with medical science, there is a necessarily iterative relationship between the research science and the practice. With a useful model of cities supplied by the science - analogous perhaps to the germ theory of infections - we can recognize the structural changes needed to promote health and wellbeing, following the evidence, and using an iterative, self-correcting, learning process.

Moreover, at its best this process learns from recent experience as well as the accumulated experience of centuries. It is capable of moving past pseudo-scientific nonsense and failed ideas, into a more responsive application of useful ideas about our environmental challenges.

\section{Conclusion}

We see that public spaces are far from amorphous realms where people mix haphazardly. Rather, like private rooms, they also have a clearly articulated structure of boundaries and controlled gateways, albeit one that is in constant transformation, and continuously shaped by social and psychological forces as much as physical ones. Nor do public spaces constitute a wholly separate realm from more private spaces, except in pathological forms of urbanism. In the best and most vital streets and neighbourhoods, public and private spaces form a complex web-network of intricate spatial relationships, with their boundaries and openings forming membrane-like structures, whose connectivity is modulated by users and by other complex forces.

In this sense, public spaces are of the essence of cities, and healthy public spaces are of the essence of healthy cities. We can intervene in this web-like structure to make them more equitable, more accessible to all, more optimal, more ecological, and more vital. But we can only do so having first understood their tissue-like qualities, and the ways we can, like a good surgeon, operate on this "tissue" to enhance health and cause minimal further damage. In particular, we must understand at the outset that enclosure and seclusion are not by themselves the enemies of connectivity and openness, but on the contrary, their necessary close partners. It is only when one or the other aspect of urban space goes wholly out of balance - when we create fortifications, privatizations and gated communities at one extreme, or nebulous, swoopy "no man's lands" at the other - that we set up our cities for decline, for the squandering of resources, for growing pollution and emissions, for growing human misery, and for ultimate catastrophe.

On the other hand, as Jacobs also pointed out, cities do contain within them the seeds of their own regeneration - if we apply the knowledge and skills necessary to promote their diversity and health. The COVID-19 pandemic has done us an inadvertent favour by throwing this situation into high relief, if we will look. Our choice is stark: we can continue to let the revealed pathologies of our cities fester out of control - or we can commit to putting the lessons of this historical moment to work for us.

\section{References}

Acuto, M. (2020). COVID- 19: Lessons for an Urban (izing) World. One Earth 2(4) 2020, pp. 317 319. Accessed at https://www.sciencedirect.com/science/article/pii/S259033222030I55X

Bettencourt, L. M. A. (20I3). The kind of problem a city is. Santa Fe Working Paper 20I3-03-008. Santa Fe: Santa Fe Institute. Available on the Web at https://sfi-edu.s3.amazonaws.com/sfiedu/production/uploads/sfi-com/dev/uploads/filer/fa/f6/faf6I4I 8-fc4f-42d5-8c28-dfI I 97a390| I8/I303-008.pdf. 
Bonaccorsi, G., Pierri, F., Cinelli, M., Porcelli, F., Galeazzi, A., Flori, A., and Pammolli, F. (2020). Evidence of economic segregation from mobility lockdown during COVID-I9 epidemic. Working paper, Politecnico di Milano. Accessed at https://arxiv.org/pdf/2004.05455.pdf.

Desai, D. (2020). Urban Densities and the Covid-19 Pandemic: Upending the Sustainability Myth of Global Megacities. ORF Occasional Paper, 244(4). Accessed at https://www.orfonline.org/wpcontent/uploads/2020/05/ORF_OccasionalPaper_244_PandemicUrbanDensities.pdf

Inn, T. L. (2020). Smart city technologies take on COVID- I9. Penang Institute Issues (working paper). Accessed at https://penanginstitute.org/wpcontent/uploads/2020/03/27_03_2020_TLI_download.pdf

Jacobs, J. The Death and Life of Great American Cities. New York: Random House.

Jeffres, L. W., Bracken, C. C., Jian, G., \& Casey, M. F. (2009). The impact of third places on community quality of life. Applied Research in Quality of Life, 4(4), 333. Accessed at https://engagedscholarship.csuohio.edu/cgi/viewcontent.cgi?article=10 I \& context=clcom facpub

Klinenberg, E. (200I). Dying alone: The social production of urban isolation. Ethnography, 2(4), pp. $50 \mathrm{I}-53 \mathrm{I}$.

Klinenberg, E. (2013. Adaptation: How can cities be climate-proofed? The New Yorker, January 7 2013. Accessed at https://www.newyorker.com/magazine/2013/0 //07/adaptation-eric-klinenberg

Kotkin, J. (2020). "Angelenos like their single-family sprawl. The coronavirus proves them right." Los Angeles Times, April 26, 2020. Accessed at https://www.latimes.com/opinion/story/2020-0426/coronavirus-cities-density-los-angeles-transit

Lefevbre, H. (1974). The Production of Space. Oxford: Blackwell.

Litman, T. (2020). Pandemic-Resilient Community Planning. Victoria: Victoria Transport Policy Institute. Accessed at https://www.vtpi.org/PRCP.pdf

Mehaffy, M. (20I2). The real reason cities can be so much greener than other places. CityLab (February 22, 2012). Accessed at https://www.citylab.com/life/2012/02/real-reason-cities-can-beso-much-greener-other-places/I293/

Mehaffy, M. (20I5). Urban form and greenhouse gas emissions: Findings, strategies, and design decision support technologies. Delft: Delft University of Technology.

Mehaffy, M., Elmlund, P. and Haas, T. (2019). Public spaces and private conflicts in the New Urban Agenda. WIT Transactions on Ecology and the Environment, 238, pp. 87-96. Accessed at https://www.witpress.com/Secure/elibrary/papers/SCI9/SCI9008FUI.pdf

Mehaffy, M. and Salingaros, N. (2017). Design for a Living Planet: Science, Settlement, and the Human Future. Portland: Sustasis Press.

Roche, M. P. (20/9). Taking Innovation to the Streets: Microgeography, Physical Structure and Innovation. Review of Economics and Statistics, I-47.

Rocklöv, J., \& Sjödin, H. (2020). High population densities catalyse the spread of COVID-19. Journal of Travel Medicine, 27(3), taaa038. Accessed at https://academic.oup.com/jtm/article/27/3/taaa038/58077/9? casa token=70 lyBeWLUAAAAA:NISMCbZI6d52lyheRKssHDsdeVZvowyYzVmTGR_v4KH5IVvPFdMEFmEQK2B Loc7Zb6Swzw7eM-pF

Soja, E. (1996). Thirdspace: journeys to Los Angeles and other real and imagined places. Cambridge, Mass: Blackwell.

Stier, A., Berman, M., \& Bettencourt, L. (2020). COVID-I9 attack rate increases with city size. Mansueto Institute for Urban Innovation Research Paper. Accessed at https://arxiv.org/pdf/2003.10376.pdf

Urban Task Force (1999). Towards an Urban Renaissance. London: Routledge. 


\title{
Neighbourhood Streets as Public Space. COVID-I 9 Public Life in Kimisange, Rwanda
}

\author{
Josephine Mwongeli Malonza \\ University of Rwanda, Rwanda \\ josemwongeli@yahoo.com
}

\begin{abstract}
Since the World Health Organisation (WHO) declared the Covid-19 a global pandemic in March 2020, countries have had to swiftly adopt lockdowns and social distancing measures in order to prevent worse public health outcomes that are likely to influence the relationship between urban society and space. Whereas the economic impact of the pandemic is obvious, its influence on public life remains uncertain, and yet the pandemic has drastically changed our relationship with our streets, public spaces and public facilities. A longer-term concern lies in understanding the risk that living the new normal could have on our future perception and use of public space. Using activity mapping on a neighbourhood street in Kigali, Rwanda, this paper explores the relationship between public space and quality of life before and during Covid-I 9 lockdown. The research found that neighbourhood streets are increasingly becoming popular for recreational activities, and hence more valuable to users. This positive sensory experience, at a time when the pandemic preys on public life in urban areas, shines new light on the notion of street as public space.
\end{abstract}

Keywords: COVID-19, neighbourhood street, public space, quality of life, Rwanda

To cite this article:

Malonza, J. M. (2020). Neighbourhood Streets as Public Space. COVID-I 9 Public Life in

Kimisange, Rwanda, The Journal of Public Space, 5(3), 39-52, DOI I0.3289I/jps.v5i3.I367

This article has been double blind peer reviewed and accepted for publication in The Journal of Public Space.

(i) \$) This work is licensed under a Creative Commons Attribution - Non Commercial 4.0

International License https://creativecommons.org/licenses/by-nc/4.0/ 


\section{Introduction}

Public space is an integral part of our cultural, social and economic heritage, making it a stage for interaction, socialization and representation of society and culture (Carmona, Heath, Oc, and Tiesdell, 20I0; UN-Habitat, 20I5). Intuitively, public space plays an 'interactive role' in society; it catalyses a relation between the intangible (people's activity) and the tangible (physical space). In the recent decades, the way citizens relate to the public dominion has deeply changed towards more and more bottom-up, pop-up and temporary interventions taking place in the public realms (Caldwell and Guaralda, 2016). The New Urban Agenda (NUA) adapted in 2016 during the third habitat meeting in Quito emphasizes on the need for a shared vision towards a better and more sustainable future, and speaks directly to and brings forth the fundamental values of public space in the way its various principals relate to its flexibility and quality. NUA envisions a process through which public space increasingly embraces multifunctionality, inclusivity, social interaction and participation (Garau et al. 20I5). However, this progress has become prone to global disasters and shockwaves like the one that came with the Covid-19 pandemic, disrupting the public realm in most parts of the globe. In this perspective, the pandemic is said to be drastically changing our relationship with our streets, public spaces and public facilities (UN-Habitat 2020). WHO's declaration of the Covid-19 as a pandemic, and the response by many countries to impose significant restrictions on the size, purpose and location of gatherings in public space and other health measures is likely to have a tremendous influence on the relationship between urban society and space. In order to slow down the transmission of Covid-19, people have been encouraged to stay home unless when seeking essential services, observe physical distancing and wear masks when in public (WHO 2020a). Lockdowns and/or cessation of movements have been enforced in many cities. Physical distancing rules were introduced, and it is said in the better part of 2020, half of the worlds' population stayed at home to help prevent the spread of the pandemic (Sandford, 2020). Clearly, before a cure or vaccine could be found, the physical space has become the mechanism to fight the pandemic. It is against this backdrop that an understanding of how the pandemic is influencing public life and hence use of public space, is sought. Certainly, these rapid measures have a tremendous influence on the relationship between urban society and urban space. It has remained unclear if the impacts of COVID-19 on public space will be as profound as they are in other aspects of our life (Corbera et al. 2020) and this is expected to take several years to ascertain due to the immediacy of the pandemic. This allows us to keep pursuing the existing urban development trajectile, while carrying more optimism to the fundamental changes the pandemic is likely to bring to our future urban practices and values.

Rwanda recorded her first case of Covid-19 on 14 ${ }^{\text {th }}$ March 2020 and rapid contact tracing as well as preventive measures such as social distancing, hand-washing and/or sanitizing stations were placed in bus stops and major shopping centres and markets. On $20^{\text {th }}$ March 2020, a national lockdown was put in place and only movement for essential services was permitted, until $30^{\text {th }}$ April when the lock down measures were readjusted to allowing movement but with strict use of masks in public and a curfew from $2000 \mathrm{~h}$ to $0500 \mathrm{~h}$ was instituted. A second national lockdown was put in place on $18^{\text {th }}$ to $31^{\text {st }}$ May and a later lockdown of Kigali city from $3^{\text {rd }}$ to $22^{\text {nd }}$ February 2021 with a curfew of $1900 \mathrm{~h}$ to $0400 \mathrm{~h}$ in place (GOR, 2020). Similar to other government policies in the country, the public health responses to Covid- 19 have been robust and adhered to 
by citizens.

Despite the interruption by the Covid-19 pandemic, Rwanda remains keen on localizing Sustainable Development and has made commendable efforts in this path (Government of Rwanda 2015; Bhowmick, 2019). As the nation's Vision 2020 (Government of Rwanda 2012) comes to an end, a transitional strategy, referred to as the National Strategy for Transformation (NST I), has been put in place to propel Rwanda to urban prosperity and sustainability (Government of Rwanda, 2019a). Whereas the growth and development of a city ought to be accompanied by the provision of adequate public space that serves as a place for social interaction, to date, there is no series of public spaces for Rwandan cities (Gubic and Oana, 2020). Surprisingly, an historical look confirms that public space was deeply rooted in the Rwandan traditional setting, whereby the everyday life of society revolved around public space (Malonza, 2018). Filling this gap calls for a combination of both the top-down institutional policy frameworks as well as bottom-up 'home grown solutions' through public involvement. The expectation that these efforts could result in positive outcomes remains valid since public space and related processes are ever evolving with time, bringing in new variety, complexity and richness that was rarely experienced in the past (Bravo and Guaralda, 2016).

In August 2015, Kigali celebrated the implementation of a car free zone for exclusive use by pedestrians (Malonza and Rukwaro, 2017), being the first ever formally recognized public space in Kigali's central business district (CBD). This initiative had been inspired by the 2013 Kigali city master plan, that emphasized on a green transport theme, aiming to achieve higher quality of life and climate resilience. With respect to outdoor activities, Kigali city conducts two car-free days each month, aimed at promoting physical activities such as fitness, jogging and outdoor games on urban roads temporary closed for vehicles (Gubic and Baloi 2020), which leads to healthy lifestyles. While gyms and stadia remained closed during the lockdowns, homes and neighbourhood streets became the only hope for recreational activities. With respect to community projects, Rwanda conducts a national monthly communal cleaning event referred to as umuganda, which leads to social interaction between people while at the same time creating something beautiful and meaningful to them. With lock downs, social life benefits keep diminishing and it is feared people may lose the sting of having to meet friends in public space. These conceptualisations and innovative use of urban space in pre-Covid-19 Rwanda, confirm that outdoor space can be seen as a productive landscape for health and social development (Armstrong, 2000).

Although there has been a growing evidence on the adaptation of public space to climate change and natural disasters (Silva and Costa, 20I8), Public space adaptability to pandemics has not been widely studied, until it became of paramount importance in the Covid-I 9 era. Existing studies tend to focus on the overall subject of public space, with the aim to measure proportions and recommend means to increase their quantity and qualities. The influence of these attributes during a pandemic and the transformational impact of the 'lockdown' measures remains unexplored. The purpose of this paper is therefore to identify the extend to which the Covid-19 pandemic influenced use of public space, and a further exploration of how the new ideas and measures can be integrated into practice. The results could serve as evidence for future design and policymaking to facilitate safer and healthier access to public space, during pandemic and beyond. The analysis of user activities before and during lockdown is examined using 
activity mapping. The following sections describe the theoretical underpinnings, research methods and analysis of the relationships between users and activities in a neighbourhood street as public space, and their differences before and during Covid- 19 lockdowns.

\section{Literature review}

\section{I. Humans and urban space}

Humans are social by nature, and our everyday life is constructed around the way we interact with others and with spaces around us. It takes human presence in urban space for social interaction to happen, which is furthermore a key ingredient to health and wellbeing, and a top priority for humanity in times of pandemic and hardships.

According to Kevin Lynch, no factor of city is experienced automatically, unless it is known in relation with its environment and hierarchy of events which cause its occurrence and existence and they are experiences of memories (Lynch, 1960). The notion that cities belong to and are about people engages the understanding that the social dimension of space; people's presence in space and their activities carries more weight than the physical dimension of space itself. In this perspective, urban environments are beyond a collection of buildings separated by streets or parks but an "art of relationship" (Tibbalds, 1992; Cullen, 1975).

According to Gehl (1987), as illustrated in Figure I, the environment-human relationship can be categorized into three; A) Necessary activities are mandatory, leave participants with no choice and hence have to happen regardless of the status of the outdoor environment for instance going to school or shopping. B) Optional activities, which take place if time and place (good setting and weather) allow for instance recreational walks or playing. C) Social activities, which depend on the presence of others in public space to happen for instance participating in group sports or organized social activities (Gehl, I987; Mehta, 20I4). It is concluded that a good outdoor environment makes a space more usable and desirable.

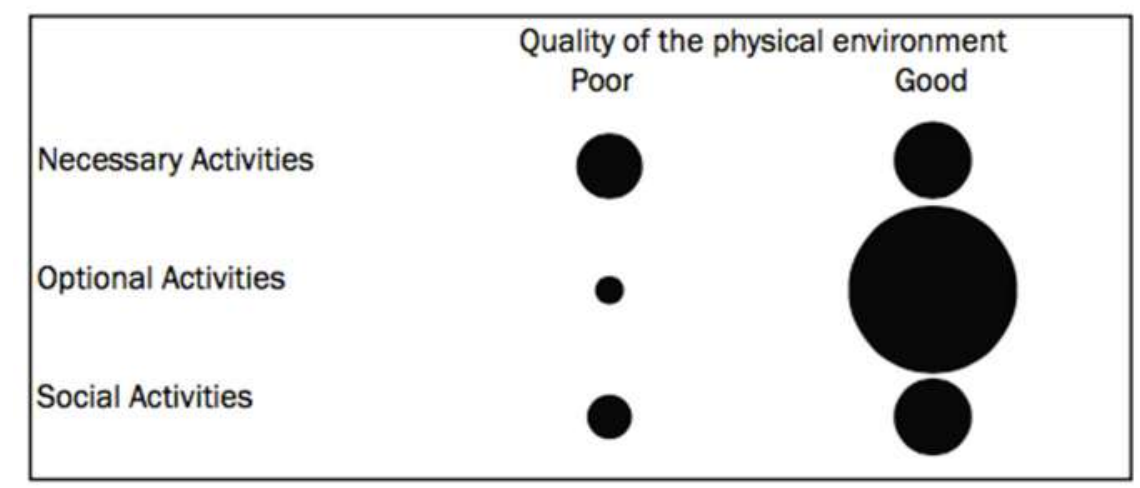

Figure I. The relationship between quality of physical environment and public life. Source: Gehl (1987)

Carmona (2019) has further argued that quality urban public spaces are also safe, comfortable, and relaxing, with safety induced by public surveillance that people provide 
as well as the balance between pedestrians and traffic (Carmona, 2019). This in itself makes public space a multi-functional space, whose flexibility; stability and adaptability is largely determined by users and events.

Interestingly, De Meulder and Heynen (2003), conceptualized the role of public space using three analogies; space as neutral, receptor and reflector of socio-economic processes, space as a possible tool in the launch of certain social processes and space as a scene in which social processes occur. They argue that when space is viewed as neutral, receptor and reflector of socio-economic processes, the focus shifts from it being 'a determinant experienced', to it being the 'influence exerted'. Further, space is seen as a possible 'tool' in the launch of certain social processes, while additionally becoming the 'scene' in which these social processes occur. Their study captures both the actions and interactions between the 'scene and the play', as would be applicable in the spatial organization of most neighborhoods and cities in the world (De Meulder and Heynen, 2003).

\subsection{Public Space and Quality of life}

Quality of life is seen as the outcome of the interaction of human and urban environment (Das, 2008) and is believed to be the driver of a city's prosperity and sustainability, by promoting urban commons and public good for all (UN-Habitat 2015). During pandemics such as the Covid-19 pandemic, the relationship between human and environmental health becomes more paramount. In response to this, the $\mathrm{WHO}$ and UN-Habitat released a Sourcebook (2020), 'Integrating Health in Urban and Territorial Planning', which is designed to guide decision makers from the public health, urban and territorial planning sectors including planners, city managers, health professionals and others towards developing sustainable and healthy cities planned and built with health at the core (UN-HABITAT and WHO, 2020)

Therefore, satisfaction with urban environments remains a key indicator of quality of life as public space remains an integral part of urban environments. Since public space serves as a meeting place that is open and freely available for all, it has every potential to increase the quality of life in terms of social interaction, creating attractive environments, encouraging participation of activities in public space and ensuring the safety of users.

Access to outdoor activities directly impacts on people's ability to live longer and healthier (Thompson, 2008; Van den Berg, et al., 2010). People living near green spaces seem to enjoy higher levels of recreation as they spent more time doing physical activities than others and people with access to green spaces enjoy healthy transport, reduction of stress and better weight management (Björk, et al 2008; Nelson and Hansen 2017). A line of trees on a street can go a long way in improving the perceived safety of the same and encouraging drivers to keep low speeds. (Dumbaugh and Gattis, 2005). It is no wonder that public playgrounds near vegetation are used more frequently and experienced as better than other playgrounds.

\subsection{Links of public space to health and wellbeing}

Research has reported the association between contact with public spaces and health benefits both at the individual and population level (Lee and Maheswaran 20I I; Kondo et al., 2018). The underlying health benefits of public spaces are largely grouped into three tracks: the provision of opportunities for physical activities, the recovery from 
stress and fatigue, and the facilitation of social contacts and cohesion.

Indeed, Public Space provides residents with the opportunities to have a direct contact with the natural environment, and hence offering them with positive restorative effects on their health and wellbeing, while at the same time providing a buffer against stressful life events (van den Berg et al. 2010). Nutsford, Pearson and Kingham (20II) have argued that the benefits of green space on mental health and wellbeing may also arise from participation in activities occurring in these spaces, such as social interaction or physical, leading to alleviation of stress and anxiety and improved mood and attention (Nutsford, Pearson and Kingham 20I3)

The appreciation of any public space in an urban area is obvious since it is hard to find considering the pressure of rapid urbanization in cities. Where access to open space in the countryside is unlimited, in cities, it becomes particularly important (Maas et al. 2006). This means that the ability of urban residents to access any available 'public space' as well as any attributes leading to both an increase in activities, users and hence frequency is equally significant, especially during a pandemic.

In this perspective, the covid-19 impact on public space remains a catalyst in reexploring the meaning and value of public space. On one hand, restricting people's access to public space is seen to reduce spread, while on the other, people's access to public space, especially parks and green areas, may help in reducing Covid-1 9 related stress (Freeman and Eykelbosh, 2020)

\section{Research Methods}

\section{I. The Research area}

Kigali city is rapidly urbanizing and the spatial expansion of the city has largely been influenced by its hilly topography separated by wetland valleys the hilltops. Whereas the formal/planned neighbourhood tend to occupy the habitable hilltops and slops, the informal/unplanned neighbourhoods tend to occupy the lower slopes close to wetland valleys(Baffoe et al. 2020). Since the 2013 Kigali city Masterplan and environmental policies (REMA, 2017) do not permit settlements at slopes above $35 \%$ and/or inside wetland valleys, most human settlements are found on the gentle slopes (Uwimbabazi and Lawrence, 20I I).

The research area is in Kicukiro district, one of the three districts composing Kigali city. The case study area is part of the KK $33 \mathrm{Av}$, an avenue located in between two neighbourhoods; Kimisange and Kigarama as illustrated in Figure 2. Kimisange neighbourhood is composed of three upper middle income housing estates constructed after 2010. They include; Mountain View, Kyberion and Comfort homes, whereas Kigarama neighbourhood is a mixed-income neighbourhood constructed before 2000. The two neighbourhoods host approximately 200 households and there is no formal public space in existence. The construction of a cultural village by the Rwanda Development Board (RDB) is underway at the top of mount Rebero, about two kilometres South East of the study area. The entire neighbourhood has been mapped as the future for middle and high income residents in Kigali city (Baffoe et al. 2020). The area is characterized by pretty new streets, tarmacked in 2019 and attractive walkways laced with flower gardens. Efforts put in by government in partnership with residents to light the streets further help improve the image and safety of the neighbourhood. The juxtaposition of the two neighbourhoods and the research area offers them prime 
opportunity as users of the space, be it active or passive recreation. Before Covid-19, residents could organize group sports inside school playgrounds, community Centres, or undeveloped plots, especially during the weekends. Areas such as GS Kimisange school, association mwana ukundwa community centre and undeveloped plot on KK 776 street would gather groups of about 60 people on Saturdays after umuganda or Sunday mornings.

The forest reserve adjacent to the study area is also increasingly used for recreational activities, specifically because its natural and steep slope (approximately 45 degrees) is good for cardio exercises.

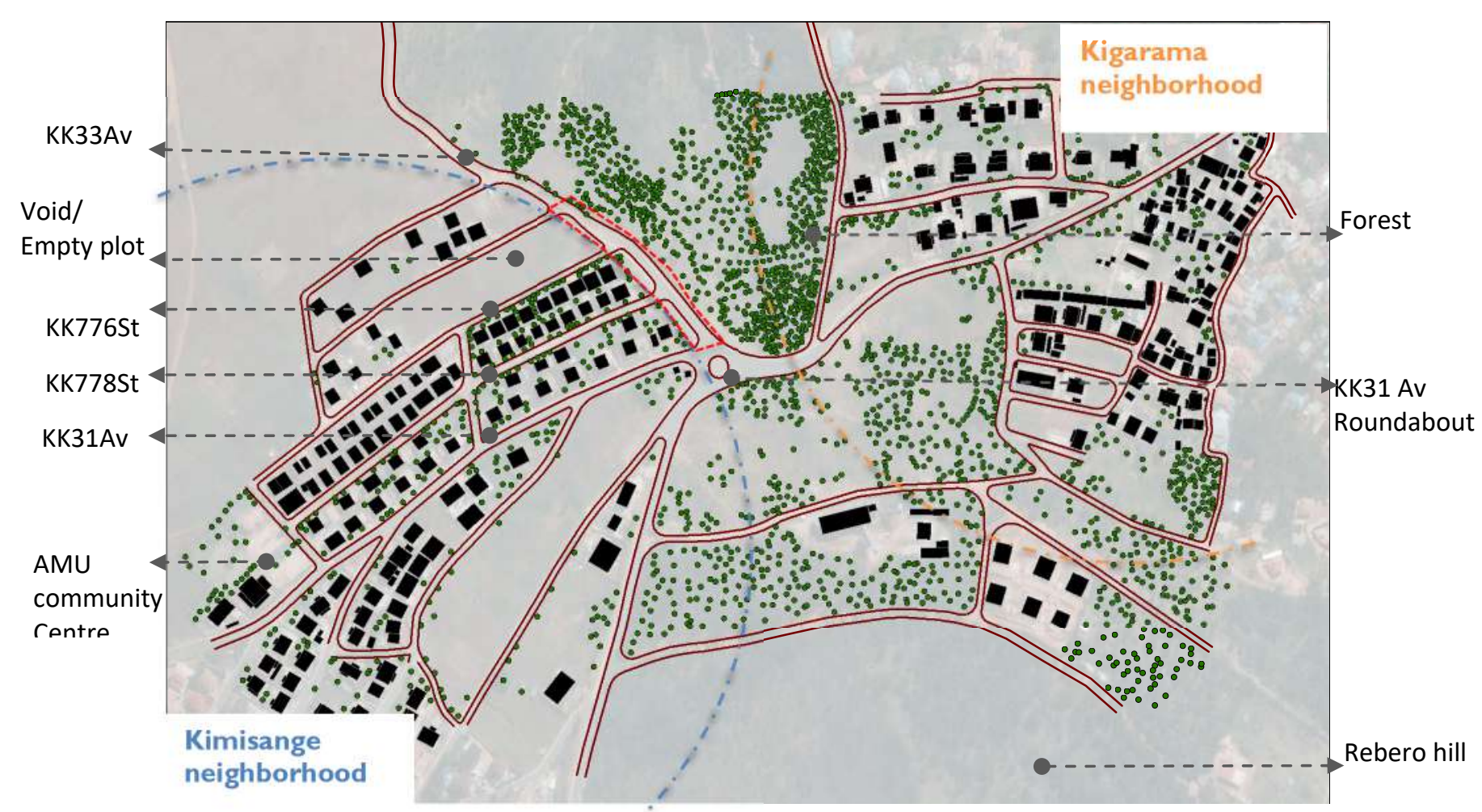

Figure 2. Research area. Source: Google earth modified by Author

The area, due to its location on the slopes of mount Rebero, is also popular for views and $180^{\circ}$ vista of Kigali city and perhaps the best view point for Mount Kigali, being the tallest mountain in Kigali at about 1,800 meters above sea level, as illustrated in Figure $3 c$, which is also a source of fresh breeze to this area. In between the two neighbourhoods is a forest reserve adjacent to the KK33Av, giving it a serene environment. The low traffic volume and steep sloped streets make them attractive for sporting activities as illustrated in Figure $3 \mathrm{a}, \mathrm{b}$. In line with this, the recent use of the KK3I Av roundabout as the end point of 'Tour du Rwanda' international cycling competition event in February 2020 placed the site on the national and global scene, and introduced a new attraction to the event attendees. People travel from other neighbourhoods in Kigali and park their cars in either of the three estates' streets to take the thrill of climbing down and up the streets and the forest. 

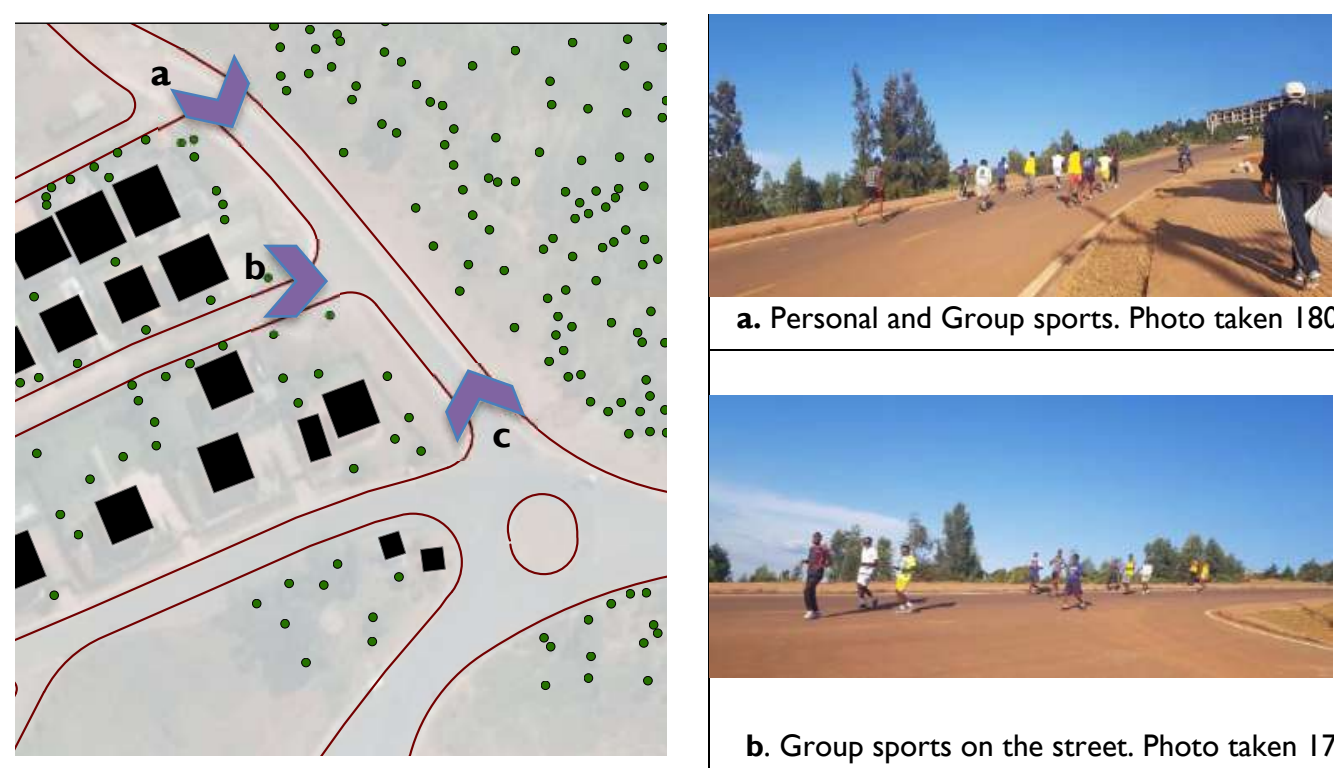

a. Personal and Group sports. Photo taken I800h

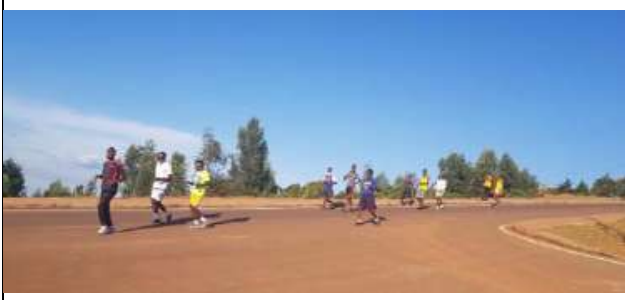

b. Group sports on the street. Photo taken I730h

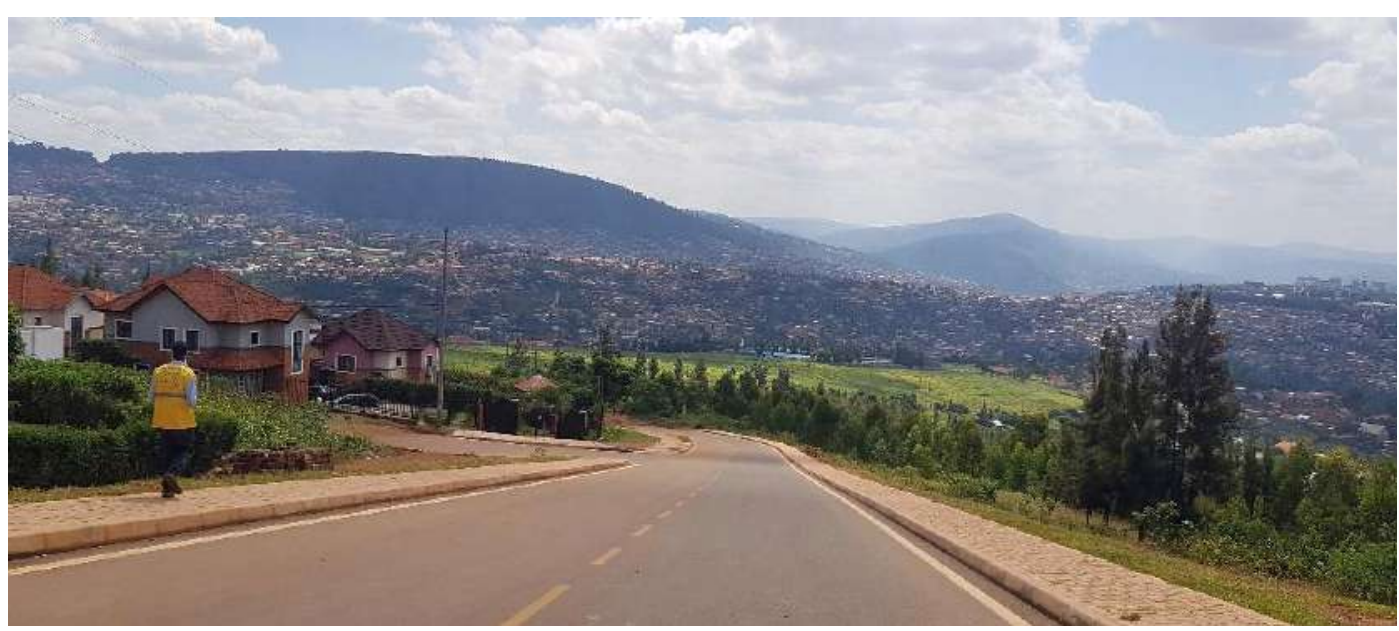

c. Street features, slope, view and vista. Photo taken $1200 \mathrm{~h}$

Figure 3. A zoom into the study street. Source: Author

\subsection{Data Collection and analysis}

Through field observation, the empirical evidence is extracted from activities that took place before Covid-19 and those that are taking place currently. Patterns of use are explored in four tracks; length of stay, preferred visit time, frequency of recent use and type of activities. Mapping is done by marking individuals' activity points, considering their types, number of users, users' age and how they use the space related to the physical features of the street. Activity mapping and analysis reveals the nature and frequency of activities as well as the most and least sub-areas used. It is therefore possible to relate the empirical evidence to theoretical underpinnings in order to arrive at a critical discussion about how public space and quality of life interrelate. 


\section{Results and Discussion}

4.I. Understanding the changing quality of public life in Kimisange

The results in Table I present the case street as a significant hotspot for recreational activities during the Covid- 19 period during both weekdays (a, b) and weekends (c, d). Although linear in configuration and relatively small in size, the area does qualify to be public space since it is characterized by consistent social interaction between people and can be freely and easily accessed by everyone regardless of age, gender and income. This is a first important criterion for a public space to be capable of taking care of the public needs of all its users.

Table I. Activity mapping before and during Covid-19. Source: Author

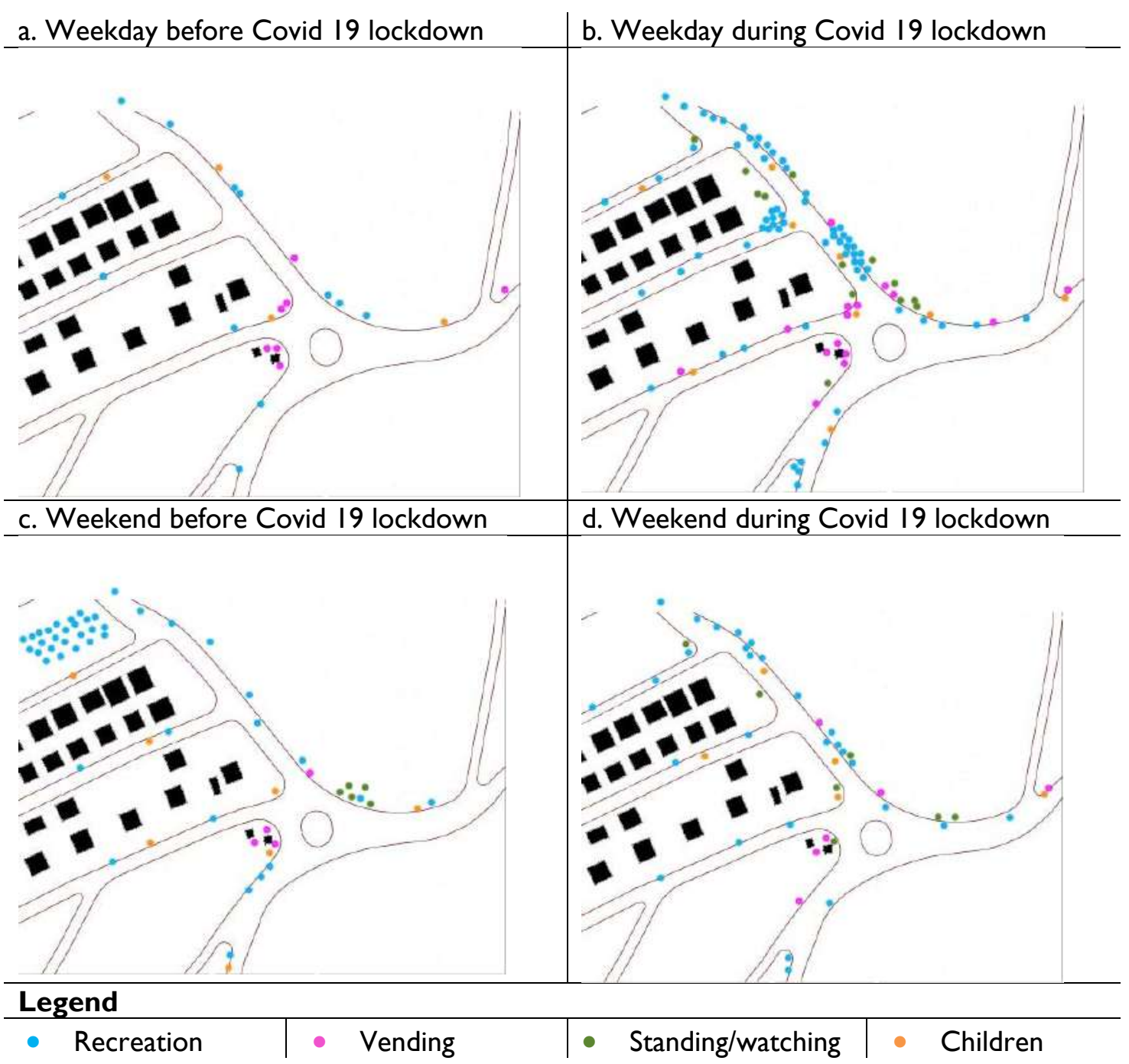

The patterns of use during weekdays and weekends are significantly varied during and before the pandemic. Most people preferred to use the street more freely, and not limiting their activities to sidewalks on the urban void otherwise used for group sports in the weekends before the lockdown.

The absence of one huge group doing sports at the urban void, shows adherence to 
government's recommendations to keep social distancing, and users seem to innovatively use the available space for their recreation while at the same time respecting the health protocol in place. Less people used the street in weekends than weekdays, unlike before lockdown. This change of frequency in itself highlights a changing pattern of use of urban space; whereby before lockdown, weekdays would be dedicated to work or errands outside home but during a lockdown, people are more available at home/within neighbourhoods while at the same time with the need to do recreational activities outside the home at every available opportunity.

Results in Table 2 indicate that more people used the street for recreational activities, be it personal or group activities, during the pandemic than before. More mixed groups, of different ages used the street during than before the pandemic, hence the higher effective area used. These findings may seem to relate/contradict the government's recommendation that residents minimize trips outside home and avoid group sports, informed by health research findings that travels outside home and behaviours in public space may lead to a potential risk of infection.

Table 2. Analysis of human, urban space and behaviour on the street before and during the pandemic. Source: Author

\begin{tabular}{|c|c|c|c|c|c|c|}
\hline & $\begin{array}{l}\text { Personal } \\
\text { activities }\end{array}$ & $\begin{array}{l}\text { Group } \\
\text { activities }\end{array}$ & $\begin{array}{l}\text { Different } \\
\text { ages }\end{array}$ & Mixed use & $\begin{array}{l}\text { Effective } \\
\text { area used }\end{array}$ & $\begin{array}{l}\text { Street } \\
\text { features }\end{array}$ \\
\hline \multicolumn{7}{|c|}{ Before Covid-19 } \\
\hline \multicolumn{7}{|c|}{ During Covid-19 } \\
\hline Legend & Low & & & & & igh \\
\hline
\end{tabular}

The results show that there is still significant evidence of the wide set of benefits derived from public space. This leaves no chance to undervalue any public space in our cities, including those at the neighbourhood scale. Comparing the street before and during Covid-19, there are more group recreational activities, as the street is able to absorb activities that used to happen in gymnasiums and playgrounds that remain closed. The vibrant street further attracts children who either watch or join in the sporting activities, and more vendors of telecommunication services. Before Covid-19, more people from outside the neighbourhood would come to enjoy the vista, but during Covid-19, more people from outside come to do sports in groups. Whereas activities (mainly walking) used to happen mainly only along the sidewalks, the effective area of the street used has grown threefold as active and passive activities are happening right inside the street; and requirements for distancing mean the sidewalk is inadequate. Unlike before, the proportions between use of space during weekday and weekends 
have shifted significantly. Clearly, even with no improvement on its physical features in the past five months, outdoor space has become more desirable, as people need a break from staying indoors and at home to catch more fresh air.

At a time when the pandemic is taking a toll on public life, it is interesting to see the way users are innovating outdoor space and transforming an area initially provided for vehicular traffic into a recreational area for pedestrian activity. The natural 'gym' requires no equipment and all are welcome.

Therefore, to sustain high quality of life benefits from public space, it is important to emphasize on 'sociability' qualities that can help promote vibrant public life in neighbourhood streets as public space. Recreational activities happening on the street, coupled by the fact that group sports dominate the area, improve sociability of the street immensely. This interaction attracts many more people from the neighbourhood and beyond, and the growing presence of children in the street justify just how fascinating the space has become.

With caution on matters of health and safety, it is also true that popular and group activities such as sports are likely to make physical distancing rules hard to follow especially when excitement and senses are at the peak. There has also been concern on the increased footprint for recreation, now covering $70 \%$ of the street and feared risks of road accidents especially with drivers not so familiar with the pop-up use of space. Nonetheless, it is conversations like this that drive the search for a paradigm shift in post-Covid planning, and are likely to form a firm base for tactical urbanism through which we can ensure that the future is well informed by the current empirical evidence, especially the perception and use of neighbourhood streets as public space.

\subsection{Resisting normalization of social distancing}

Most Covid- 19 related restrictions are obviously too many because there is evidence on how badly the pandemic has hit other regions and there had not been any news of vaccines or confirmed cure for the same when the study was conducted in 2020 . The Covid-19 period is therefore, assumedly a time to unlearn the social life and public space as we used to know it, and learn new ways of work and study. Populations are quickly adopting to new norms such as e-learning and virtual meetings, which are making the digital space more prominent than ever in people's lives, but does it dilute the human desire for social cohesion? There is need to guard against a common tendency for temporary measures to become more permanent.

This study has confirmed that when time and conditions allow neighbourhood residents to interact with newcomers to the street, the relationship grows gradually and increasingly residents get recruited to some of the group sporting activities. More and more residents are now actively involved in sports, both from within the neighbourhood and visitors. Even though the study area is not designed for sports, it remains attractive for sports and the people's positive perception goes a long way to improving the social utility of the area, which may render the environmental comfort to be not so strong a criterion for a successful public space as theory had depicted (Gehl, 20II).

\section{Conclusion}

To sum up, the early findings from the observation of activities in the case study street 
confirm that the increasing presence of people in the street for recreational activities has and continues to influence conceptualization of the street as public space. Rather than see public space as something permanently fixed to a particular locality and inked into a static city map, the study has instead introduced a new sense that public space actually moves and evolves as shaped by peoples' activities

Therefore, it becomes increasingly acceptable that public space, is to be seen as places where people willingly visit, do activities they enjoy, and spend more time with each other. In this perspective, if we were to unpack what it takes to catalyse a high quality of life in cities and neighbourhoods, then the answer might not be far from the form of our streets.

Considering the Covid-19 impact on public life and the increased need for outdoor activities, the study has showed that sociability in public space has every potential to rebrand neighbourhood streets into successful public spaces. Indeed, public life is based on people's need of being with others and this social need gets even more valuable in difficult times. Regardless of the physical features remaining the same, the daily and repetitive patterns of use during the lockdown enhance both necessary activities and social activities, improving quality of life on the street even though the pandemic was feared to negatively impact on people's appreciation of any public space outside home. This way, features like steep topography, that would otherwise be seen as impediments of social activities, become an opportunity by enhancing both the active recreational activities as well as passive activities of standing and watching.

Whereas the street is traditionally known as a conduit of movement from point $A$ to $B$, the current use seems to have transformed its meaning to a fascinating part of the neighbourhood's social life. The street is no longer just for cars but also for people, no longer just for adults but also for children and recreation is no longer just a weekend activity, but also for weekdays and enjoyed in the presence of other people. This further reinforces the notion of street as public space.

More importantly, it could be argued that this contextual manifestation, especially in times when the pandemic preys on public life globally, offers hope that when the crisis comes to an end, public spaces could bounce back stronger as a catalyst for public life and public health. Although over the last 12 months, people have had to adopt to new social behaviour, keeping social distances and staying home, the emotional connections to other people and public space seem not to have been lost. As we look forward to the lessons Covid-19 will have taught us with respect to perceiving, using and designing cities and neighbourhoods, possibilities to move our mindsets in new directions and rethink the intersection between pandemic and urban life favourably. Public space has to remain central in the Covid-19 debate and beyond, given the diversity of innovations around its use, which further informs future planning and design.

\section{References}

Appleyard, B., Cox, L. (2006). At Home in The Zone: Creating livable streets in the U.S., Planning. Vol. 72, no. 9, pp. 30-35.

Baffoe, G., Malonza, J., Manirakiza,V., Mugabe, L. (2020). 'Understanding the Concept of Neighbourhood in Kigali City, Rwanda', Sustainability 12(4). 10.3390/su I 204 I 555 
Bhowmick, S. (2019, May 17). Toward the SDGs: The Rwanda story. Observer Research Foundation. Available at https://www.orfonline.org/research/toward-the-sdgs-the-rwandastory-50935 (Accessed: I 5 July 2020)

Björk, J., Albin, M., Grahn, P., Jacobsson, H., Ardö, J., Wadbro, J., Östergren, P-O. and Skärbäck, E. (2008). Recreational values of the natural environment in relation to neighbourhood satisfaction, physical activity, obesity and wellbeing. Journal of Epidemiology and Community Health, 62(4), e2.

Bravo, L. (2013). Open Spaces, Public Spaces, Publics, Open-minded Places. Ricerche e progetti per il territorio, la città e l'architettura. Special Issue No I/20I3

Bravo, L., Guaralda, M. (2016). 'An open access forum for the discussion and advancement of research about public space', The Journal of Public Space, I(I), pl-4.

Caldwell, G. A., \& Guaralda, M. (2016). Blurring the physical boundaries of the city: Media architecture and urban informatics for community engagement. In G. A. Caldwell, C. H. Smith, E. M. Clift \& G. Cairns (Eds.), Digital Futures and the City of Today New Technologies and Physical Spaces (pp. 235-250). Bristol, UK: Intellect.

Carmona, M., Heath, T., Oc, T., \& Tiesdell, S. (2010). Public Places Urban Spaces: The Dimensions of Urban Design. New York: Taylor \& Francis Ltd.

Carmona, M. (2019). 'Principles for public space design, planning to do better', Urban Design International, 24(I), p47-59.

Corbera, E., Anguelovski, I., Honey-Rosés, J., Ruiz-Mallén, I. (2020). 'Academia in the time of COVID-1 9: Developing an ethics of care', Planning Theory \& Practice, I-9. doi: I0.1080/| 4649357.2020 .175789 |

Das, D. (2008). Urban Quality of Life: A Case Study of Guwahati, Springer Science+Business Media B.V., Social Indicators Research, 88, pp. 297-310.

Freeman, S., Eykelbosh, A. (2020). COVID-I 9 and outdoor safety: Considerations for use of outdoor recreational spaces. National Collaborating Centre Environmental Health. 2020.

Available online: https://www.researchgate.net/publication/34072I289 COVID-

19 and outdoor safety Considerations for use of outdoor recreational spaces Prep ared by/link/5e9a24a8299bf /3079a24c5c/download (Accessed: 16 July 2020)

Garau, P., L. Lancerin, and M. Sepe. (20I5). The Charter of Public Space. Trento: LiST

Gehl, J. (2010). Cities for People. Washington DC: Island Press

Gehl, J. (20II). "Life Between Buildings: Using Public Space" Translate by Jo Koch. Library of Congress Cataloguing in Publication Data. Washington, DC: Island Press.

Government of Rwanda. (2020). Office of the Prime Minister official twitter handle. Available at https://twitter.com/PrimatureRwanda/status (Accessed: 2 July 2020)

Government of Rwanda. (2012). Rwanda Vision 2020 revised 20I2. Available at http://www.minecofin.gov.rw/fileadmin/templates/documents/NDPR/Vision_2020.pdf (Accessed: 12 July 2020)

Government of Rwanda. (20I5). National Urbanisation Policy. Available at https://www.bpmis.gov.rw/asset_uplds/files/National\%20Urbanization\%20Policy.pdf (Accessed 20 June 2020)

Government of Rwanda. (2019a). 2019 Rwanda Voluntary National Review (VNR) Report. Available at https://sustainabledevelopment.un.org/content/documents/23432Rwanda_VNR_Documen $\mathrm{t}$ _ Final.pdf (Accessed: 25 May 2020)

Gubic, I. and Baloi, O. (2020). 'Public open space initiatives for healthier cities in Rwanda', Journal of Public Space, 5(2), pp. I29-I46.

Joye, Y., Willems, K., Brengman, M. and Wolf, K. (20I0). 'The effects of urban retail greenery on consumer experience: Reviewing the evidence from a restorative perspective', Urban Forestry \& Urban Greening, 9(I), pp. 57-64. 
Kondo, M. C., Fluehr, J., M., McKeon, T. \& Branas, C. C. (2018). 'Urban green space and its impact on human health', International journal of environmental research and public health, I5(3), p. 445

Lee, A. and Maheswaran, R. (20II). 'The health benefits of urban green spaces: a review of the evidence', Journal of Public Health. 20I I;33(2), P2 I 2-222

Maas, J., Verheij, R., Groenewegen, P., (2006). 'Green space, urbanity, and health: how strong is the relation?', Journal of Epidemiol Community Health, 60(7), P587-592

Malonza, J. and Rukwaro, R. (2017). 'Rethinking urban public space in the rapidly urbanizing East African region; case of car free zone, Kigali', Africa Habitat Review. ISSN25 I 9-785 I, I I ( I), pII07-II 24.

Malonza, J., Rukwaro, R., Anyamba, T. (2018). 'Mapping socio-cultural influences in contemporary urban public open space: The case of Biryogo, Kigali city', International Journal of Creative Research and Studies ISSN-0249-4655, 2(9), p59-77

Mehta, V. (20I4). 'Evaluating public space', Journal of Urban design, I9(I), p53-88.

Nutsford, D., Pearson, A., Kingham, S. (2013). 'An ecological study investigating the association between access to urban green space and mental health', Public Health. 2013;127(II), pl005-I0II.

Project for Public Spaces (2017a). Street as places- Using streets to rebuild communities. Available at: https://www.pps.org/product/streets-as-places- using-streets-to-rebuild communities (Accessed I 2 July 2020).

Project for Public Spaces (2017b). Qualities of a Great Street. Available at: https://www.pps.org/reference/qualitiesofagreatstreet (Accessed I 9 July 2020)

REMA. (2017). State of Environment and Outlook Report: Achieving Sustainable Urbanisation.

Sandford, A. (2020). Coronavirus: Half of humanity now on lockdown as 90 countries call for confinement. Available at: https://www.euronews.com/2020/04/02/coronavirus-in-europespain-s-death-toll-hits-10-000-after-record-950-new-deaths-in-24-hou (Accessed: 16 July 2020).

Silva, M. M. and Costa, J. P. (2018). 'Urban floods and climate change adaptation: The potential of public space design when accommodating natural processes', Water, I0(2), pl 80.

Thompson, I. (2004). Ecology, community and delight: Sources of values in landscape architecture. London: Taylor \& Francis.

UN-Habitat (2020) UN-Habitat Guidance on COVID-I 9 and Public Space. UNHabitat, Nairobi.

UN-Habitat and World Health Organization. (2020). Integrating health in urban and territorial planning: a sourcebook. World Health Organization.

UN-Habitat. (2015). Global public space toolkit: From global principles to local policies and practice.

UN-Habitat, Nairobi. ISBN: 978-92-I-I32656-7.

UN-Habitat (2013) Streets as Public Spaces and Drivers of Urban Sustainability. UNHabitat, Nairobi

Uwimbabazi, P. and Lawrence, R. (20II). 'Compelling Factors of Urbanization and Rural-Urban Migration in Rwanda', Rwanda Journal, Series B, 22(I), p9-26.van den Berg, A., van Winsum-Westra, M., de Vries, S. and van Dillen, S. (2010). 'Allotment gardening and health: a comparative survey among allotment gardeners and their neighbors without an allotment', Environmental Health, 9(74).

van den Berg. A., Maas, J., Verheij, R. and Groenewegen, P. (2010). 'Green space as a buffer between stressful life events and health', Social Science \& Medicine. 2010;70(8), pl2031210.

WHO, (2020a). Coronavirus disease (COVID-19) advice for the public.

Available at https://www.who.int/emergencies/diseases/novel-coronavirus-2019/advice-forpublic (Accessed 19 May 2020).

WHO, (2020b). Rwanda hastens safety measures against novel coronavirus. Available at https://www.afro.who.int/news/rwanda-hastens-safety-measures-against-novel-coronavirus (Accessed 5 May 2020). 


\title{
Domestication Will Shape Future Public Spaces A Report from Rotterdam
}

\author{
Maurice Harteveld \\ Delft University of Technology, Netherlands \\ M.G.A.D.Harteveld@tudelft.nl
}

\begin{abstract}
This commentary aims to provide a window on the future by studying actions, taken to control the spreading of the corona virus, while obviously affecting public space over a year. What has been the effects on public space directly linked to these actions during the pandemic; what values play a role, and what can we expect for the future? We have seen how immediate responses induced by the COVID-19 crisis influences traveling, gathering, and public live in general. Now, it is time to look further. Having a base-point in Rotterdam and taking The Netherlands as an example, the commentary argues that some shifts in using, appropriating and experiencing public space will remain. Yet, mainly those not just being immediate responses to sudden societal change, rather those which are embedded in long-term change.*
\end{abstract}

Keywords: domestication, COVID-19, Rotterdam

* This articles includes research and statistics updated to March 202I.

To cite this article:

Harteveld, M. (2020). Domestication Will Shape Future Public Spaces. A Report from Rotterdam, The Journal of Public Space, 5(3), 53-66, DOI I0.3289I/jps.v5i3.I379

This article has been double blind peer reviewed and accepted for publication in The Journal of Public Space. (i) $\$$ This work is licensed under a Creative Commons Attribution - Non Commercial 4.0 International License https://creativecommons.org/licenses/by-nc/4.0/ 


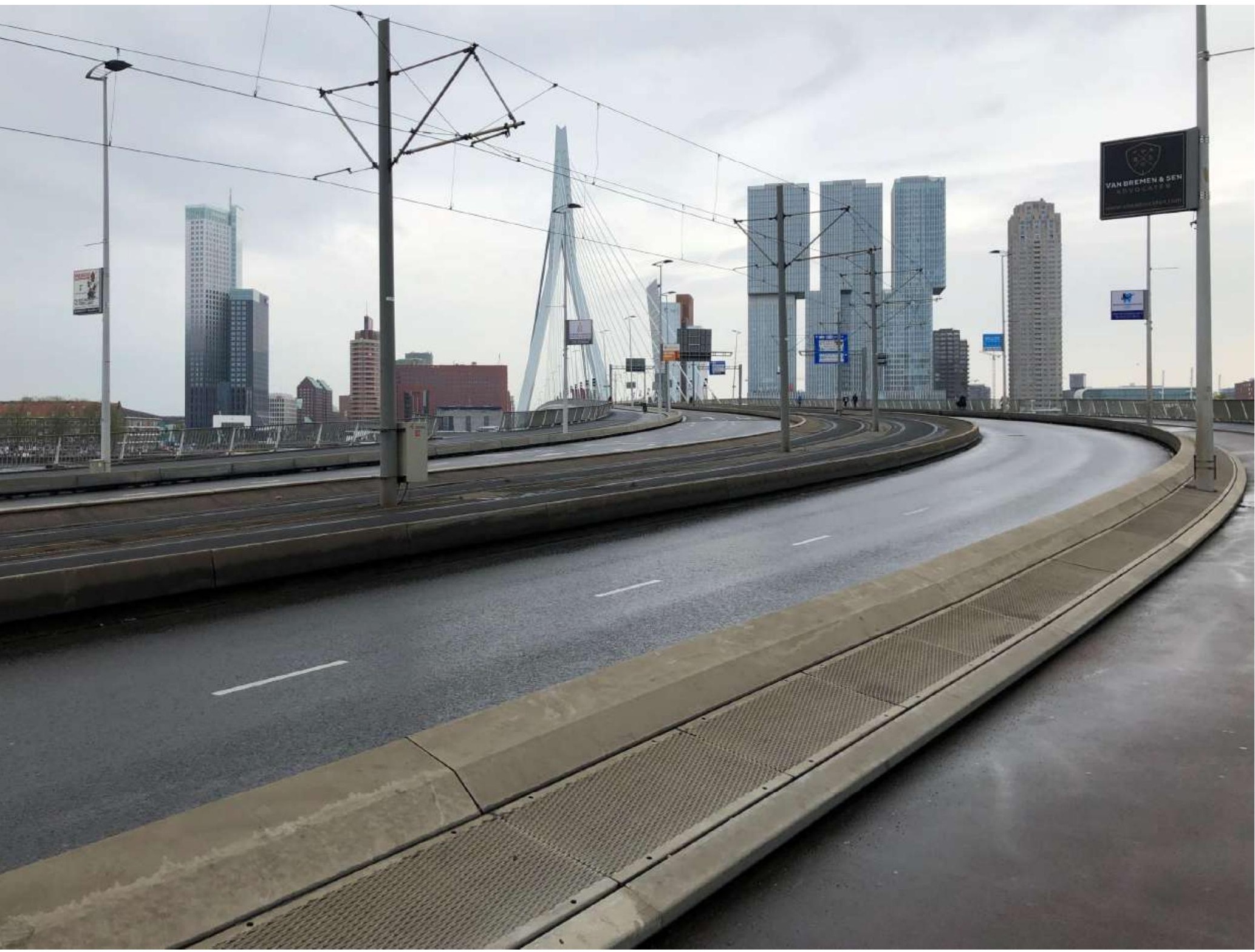

Figure I. Desolated Rotterdam, March 2020 (image by the author).

"In my daily work environment, at Delft University of Technology, almost all on-campus activities have been cancelled since Friday 13th of March 2020. De facto, the university buildings have been closed at that date, and academic life stayed alive online up to today! Small-scale education has been prioritised in specific periods and time-slots with respect to emergency ordinances and law. Occasionally I have met a colleague and graduate. Lectures and research meetings remain remote work. So, I have been on campus only $I \%$ of my working hours over a period of more than a year. As such, I am joining that part of society which is working from home because we can, and because we are asked to do so. The coronavirus influenced my work, profession, and discipline." 


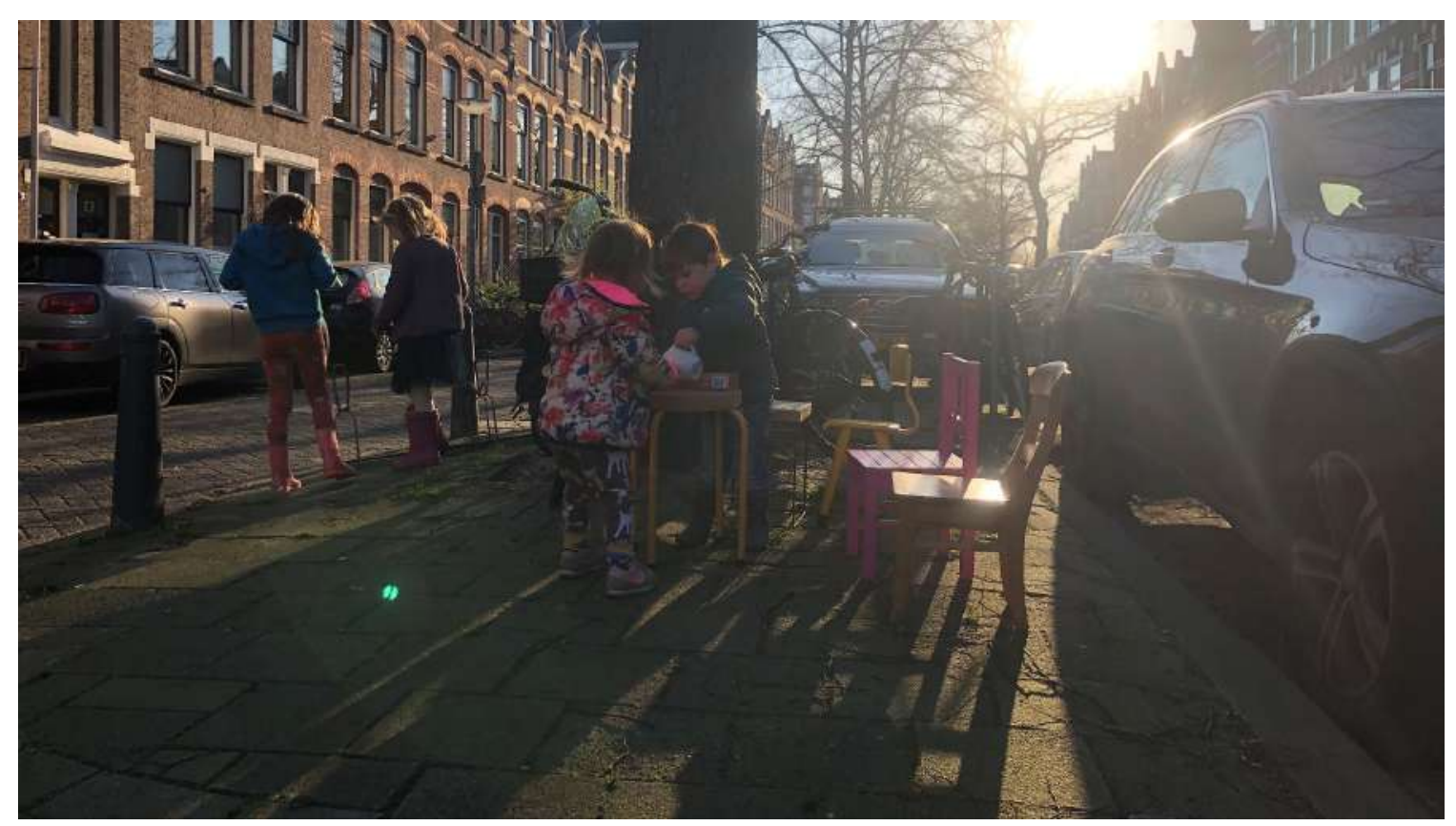

Figure 2. Domesticated Public Space, March 2020 (image by the author).

\section{COVID- 19: public measurements and effects in the public space}

The uninterrupted Dutch governmental calls upon people throughout the Netherlands to work from home as much as possible, or spread working hours, is illustrative for action effecting public space. Requests to avoid large group settings and public transport if not essential is adds to the impact on public space. Mirroring the initiation of farreaching containment measures taken in countries confronted with SARS-CoV-2 and the ongoing pandemic of COVID-19 in earlier stages, large meetings and events have even been cancelled throughout the country by ordinances. People do gather though, and go out, but not often crowding happens at large scale. Some moments, the police takes action. Sometimes access roads to parks or beaches have been controlled as acupuncture-like responses. Still, no enforced state of isolation, barricades, or nationwide control on movement. The size of outdoor meetings can only be within a range of four to two people, not from the same household, with an observable restricted I.5 metres between them. This rule is enforced only occasionally, when larger groups seem to provoke. A warning is more often applied. Public gatherings within interior public spaces have been restricted stronger than outdoors. Public buildings, like schools, childcare facilities, hotels, retail, restaurants, and cafes have been closed twice when reported hospitalised people have been at the high points.

Government urges people to limit visits to vulnerable people, with explicit restrictions to retirement and nursing homes. Furthermore, people with symptoms resembling a cold, having a cough, sore throat or fever are strongly requested to stay at home. (Government 2020, March 5; updated frequently) Effectively, people stayed home or close to home and seek alternatives for gathering. Generally, these effects seemed as desired. 


\section{Dynamic social values and acculturated global response landing in space}

The social consequences of such sets of measures are undoubtedly significant. They are worldwide. Health is a moral value which is shared globally. Consequently, public life has changed. This has been visible particularly in the Netherlands, because the Dutch are able to continue their lives in public uninterruptedly despite all. Police may monitor by air and by land, there is and has been no full lock-down. Without placing 17 million inhabitants and their foreign guests in quarantine, people share urgency for orders in still controllable situations. The Dutch government may have used power to delay the spread of the virus by all agreed legal means, but it exercises power foremost by calling upon social responsibility. Action is distributed. It's almost as if it echoes the Enlightened Dutch philosopher Baruch Spinoza: "obedience has no place in a social order where sovereignty is in the hands of everyone and laws are enacted by common consent". (see Harteveld 2019: 132) Dutch value 'free assembly' and 'connectivity'. The message going along with the first governmental actions contrasts for instance the French, which started with the presidential announcement that the government has taken firm action to curb the spread of the virus: "Nous sommes en guerre, en guerre sanitaire." (Macron 2020, 16 March) Such dissimilarities show how different countries are taking familiar measures reducing the spreading of the virus through different ways of acting. Socio-political consensus may differ, times of making decisions may, but foremost local cultures do. Contrasting authoritarian action, in the Netherlands, 'free will' somehow continues to be valued next to 'health'. People have been engaged to keep 'physical distancing', 'social abstinence', and 'public isolation' upon their own estimation. "So that our nursing homes, home care services, hospitals and, above all, our intensive care units don't become overwhelmed.", as Mark Rutte, the liberal Prime Minister of the Netherlands, emphasised on the immediate goal of the government in his first public address on the situation: reducing health risks by raising awareness to case fatality rates. At the same time, the long-term goal has been to build up herd immunity in a controlled manner, while waiting for a vaccine to be developed. "The reality is that coronavirus is here in our midst, and for the time being it is here to stay." (Rutte 2020, 16 March) Acceptance, as a person's assent to the reality, seems to come along for most people to mediate between values. Social values have been dynamic under pressure of moral believe to control health.

"When I look outside my window, I see a different world. That is to say, ...not fully unfamiliar. Full-grown lime trees dominate. In front of my house a free-assessable community garden demarcates a common place, surrounded by century-old urban building blocks. Neighbours gather outside. Kids play. In difference to say 2019, they do so more often, remaining on distance in a peaceful uncertainty every day. In addition, other locals keep enjoying the place. Different individuals and micro-groups are sitting down to meet, relax, read, eat, talk. Age, lifestyle, cultural background... many differences, mostly locals. In March, birds sang louder than ever. Tranquillity was periodically disturbed when pelotons of mostly male cyclists raced by. Public responsibility had not reached everybody! A police helicopter circled low above the space. Many more would follow. Once an animated group of vicenarians were sitting (too) close while enjoying a drink and making selfies. Another disruption? New hip place to be? Over spring, I've seen teenagers secretly kissing, as well as a frequent visiting elderly enjoying the sun during quiet hours with a mouth mask on. During summer, frequently my vogue neighbour of age shared dinner with her 'younger' friends. After they left in the Ramadan evenings, a guy in jellabiya met his casual friends to talk. At those days also the outdoor terrace of the next-door restaurant with 
tables on distance was always 'full'. When autumn started, more shared scooters appear. Eating take-out became the new norm at the place. Rain often prevented people to stay or take a stroll. In recent winter, neighbours went ice skating, teenagers-built snowmen, and parents pull their kids go to school on a sledge. This public space appeared to be a 'pars pro toto' for what was happening apparently throughout the country."
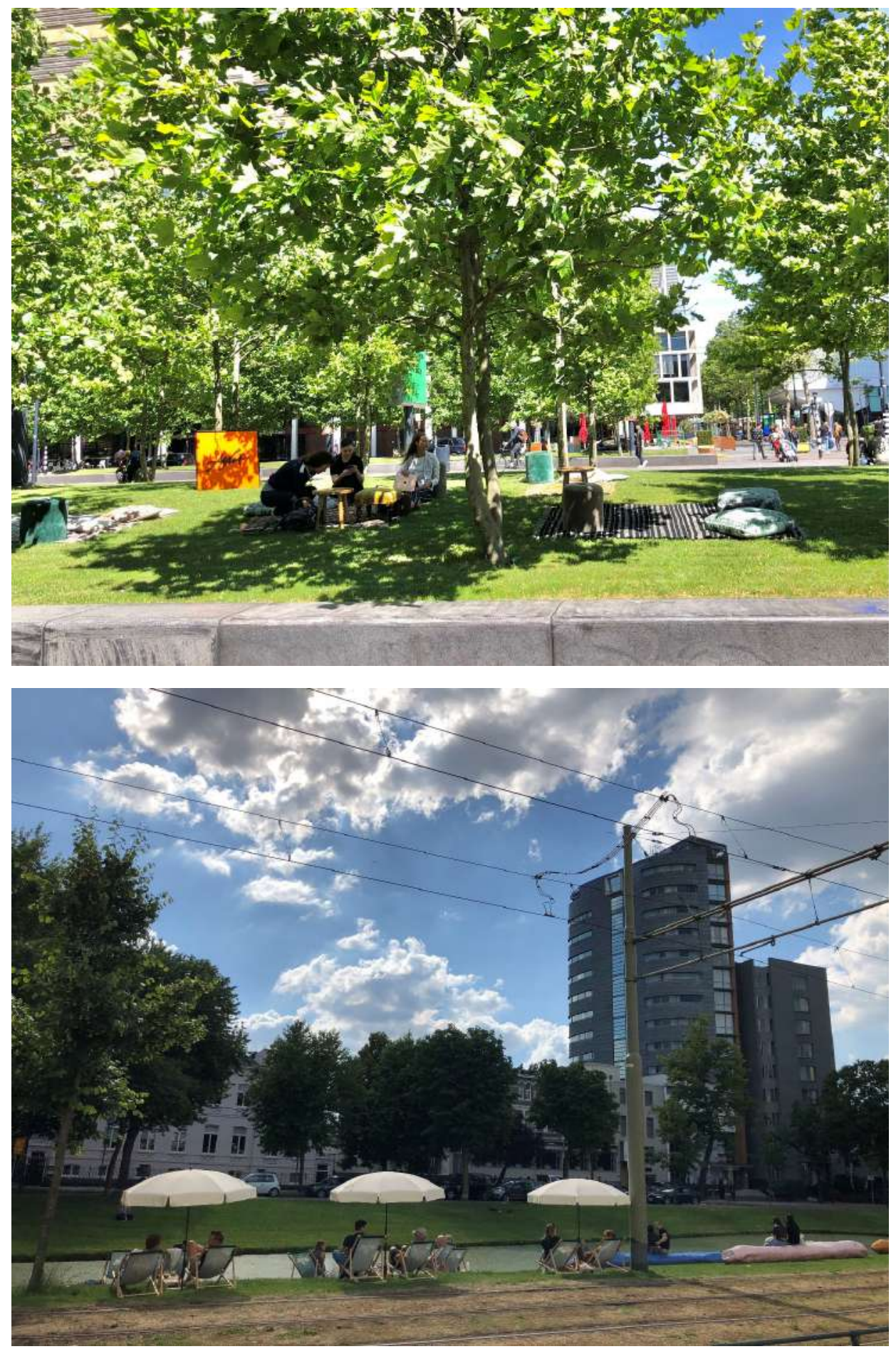

Figure 3. Urban living rooms, June 2020 (images by the author). 


\section{Behavioural Change in the Public Spaces}

Outdoors, the overall effect was manifest! Change in behaviour was observed immediately in the first weekend under the new conditions. People collaboratively shared in action. The public spaces were abandoned in March. Less people moved, there was hardly any traffic. Empty highways and alienated arterial roads! Sirens of ambulances and the sounds coppers of medical air rescue, increasing on daily base and only gradually diminishing after months, 'reminded us again that public life primary is affected by the health crisis. Immediate action introduced opposite effects at certain places too: The first kind came in the second weekend after the first public address. Weather was remarkably sunny. Quite some Dutch people flocked out naively. It was crowded in forests, parks and on the beaches. Keeping distance wasn't always possible anymore. The Dutch government quickly alerted citizens though their cell broadcast alarm system. The emergency notification read: “Keep your distance to others". (NL-Alert 2020, March 22) Since alarm bells rang, mass recreation largely stayed out. An additional public warning came: if crowding would appear again in these large public spaces, they would be closed. Prime Minister suggested: “...if there is no other option, choose a quiet place in your own neighbourhood: that small park that you normally skip, or the bench along the water." (Rutte 2020, 3 April) No need to effectuate closure. People sought alternatives and found these in hide-away public spaces already. In the following weekend, this generated a second kind of naive opposite effect. Neighbourhood places were found by outsiders, as friends were invited here. People also started running and cycling 'en masse', as sports facilities closed. There was significantly more traffic measured throughout the local urban fabric. (Bos and Rusman / De Voogt and Bolle 2020, 4 April) The national government also observer the pressure on these public spaces. Reacting on local crowding, the Prime Minister emphasised that major social dilemmas arose, which literally concern "the distribution of scarce space". Informed by medical advisors of the cabinet, he added an earlier forecast: "We will have to search together for the new normal in the one-and-a-half-meter society, a society that will be different in that respect from the way we were used to recently." (Rutte 2020, 7 and I5 April) The forecast echoed international prognoses. Although required distances might differ from state to state, depending culture and socio-spatial possibilities, the mantra became that the virus would stay thus physical distancing would determine our public lives, hence our public spaces. For a while a new comprising social value seemed to emerge: 'distancy'. It suited the short-term purpose. Yet, against the backcloth of this emergent apparent valuable property, undesired or at least unsought effects to this may have been more important signifiers for change: social values like 'togetherness' and 'commonness' translate in 'enjoying' leisurely green spaces in and around the city, and 'sharing' space near the house.

\section{Value Conflicts catalysing the (re-) Discovery of Local Life}

In the Netherlands, the level of basic rules, prevention measurements, and enforcing compliance were motivated by the stressed capacity of intensive care and grimly

\footnotetext{
' In 2020, nearly 22.5 thousand flights for police and trauma teams took off and landing in Rotterdam. (Schiedam-24 2021, I February)
} 
increasing death rates particularly during the first twelve weeks. ${ }^{2}$ People had not been tested at large scale nor consecutively at the time. Numbers turned to normal end of May. The majority of the population seemed healthy still/again. (RIVM 2020, May 2I; CBS 2020, May I5; and 202I, February 8) Easing of coronavirus restrictions started. Smaller group gatherings indoors/outdoors were accepted and, steadily controlled, all kinds of public buildings were allowed to open-up again, if only users take precautions following physical distancing rules and hygiene advices. It motivated large groups to visit beaches and parks again. Distance was pressured again. (Bouma 2020, May 22) People seemed not to be able to abolish crowding completely, or at least not endlessly. They embraced the popular new-found customs to go to the green areas. In addition, they complemented this with being outdoors in the neighbourhood. People actively (re)discovered the direct living environment. Since the COVID-19 crisis, numerous local initiatives have been set up. "People crave socialising", as a national Dutch newspaper observed; "This summer, areas in various cities will be made car-free to turn them into 'holiday streets' and 'living streets'." Citizen initiatives boomed. The sudden social revival in the residential area might be more than a temporary side-effect of the pandemic? "Corona forces many to look closer to home, and then it becomes more apparent what is missing there." (Van Noort 2020, 19 June) After this period without much restrictions, much less corona-deaths, ${ }^{3}$ and the introduction of intensive testing, nonetheless the second wave did start. Death rates peaked in October. Most long-term care recipients. ${ }^{4}$ (CBS 202I, February 8, RIVM 202I, March 13) Along with this news, people took a walk around the block even more often, or took the car to expand horizons. The city changed further despite release actions. Even inner-cities turned to the hustle and bustle for leisurely walks. Window-shopping was one of the alternative recreational forms that remained, next to experiencing green for example. Shops were open though and took into account public health measures and distance. Yet, walkers, not so much buyers, were dominating the shopping streets. The advance of this got an extra push in the first period. Webshops, including rising online versions of local stores and for example virtual fitting, provided alternatives. People found other ways to shop. (Leijten and Saris 2020, 27 April; Kamerman / Van den Dool and Wassens 2020, 26 October) Given the new peak, public life became under governmental control again, and in steps toward Christmas stricter measures were announced: "We all remember the news footage back in the spring. Empty motorways, empty trains and buses, empty offices and classrooms, empty shopping streets. That is the situation we have to return to", as the public address underlined. Coronavirus infection numbers grew: "The Netherlands is shutting down". Only shops selling basic necessities would stay open: supermarkets, shops selling food, including weekly markets, and chemists, dry cleaners, opticians and home care shops. In difference to March, all other stores were forced to close. Five weeks later, in $202 \mathrm{I}$, also the night-time curfew applied throughout the country. The increase of positive test results was made crucial in underpinning decisionmaking, as became distribution and infectivity models. (Rutte 2020, I4 December, and 2021, 23 February) The message had become stronger and governmental action

\footnotetext{
${ }^{2}$ In that period, 5,775 reported deaths confirmed to be caused by the coronavirus, with estimates being nearly double based on excess mortality. Ten thousand people seemed to have passed away.

${ }^{3}$ In the following four months: 690 confirmed corona-deaths.

${ }^{4}$ in October alone: 2,005 extra deaths. The second wave peaked lower, but lasted longer. Based on municipal reports, a total of 16,046 people died of COVID-19 in the Netherlands until March I3, 202 I.
} 
stricter, but the envisioned effect stayed out. Dutch cities did never return to be desolated anymore. Public life continued and evolved under the new condition.

"Saturday, I3th of March, $202 \mathrm{I}$. We are year later. Still on-distance online almost every day. I do observe a different world. It's not unfamiliar, but from a different angle. Outside my house, neighbours have remained the dominant user group: The local public. Birds sing less loud. They may be used to the reduced noise levels in the city. Citizens' initiatives may be small but manifest. Some garden benches are added to the sidewalk of my street. Street are being cleaned and plants watered by the people living around. Acceptance, little disobedience. Only one time, most recently, when a group sat around campfire after curfew, police on bikes intervened. Having less rules in perspective again, clusters do emerge more frequent than before though. Sunny weather is a stimulus, also during chilly days. I also go to urban forests, green parks and the beaches now. I see people everywhere. New are the trendy people with a coffee-to-go in Het Park of Rotterdam, and the urbanites - gold jacket and charcoal skinny jeans - with hot chocolate and take-away waffles in the woods of Kralingse Bos. One can't avoid the increase of outdoor athletes along the river Maas, and for example scooter girls and guys with a classic urban vibe and music in Zuiderpark. All such places are popular. Yet, different places, different groups. Regardless of closed shops, even the inner-city reveals a specific public. As I concluded last year; the city is our common house."

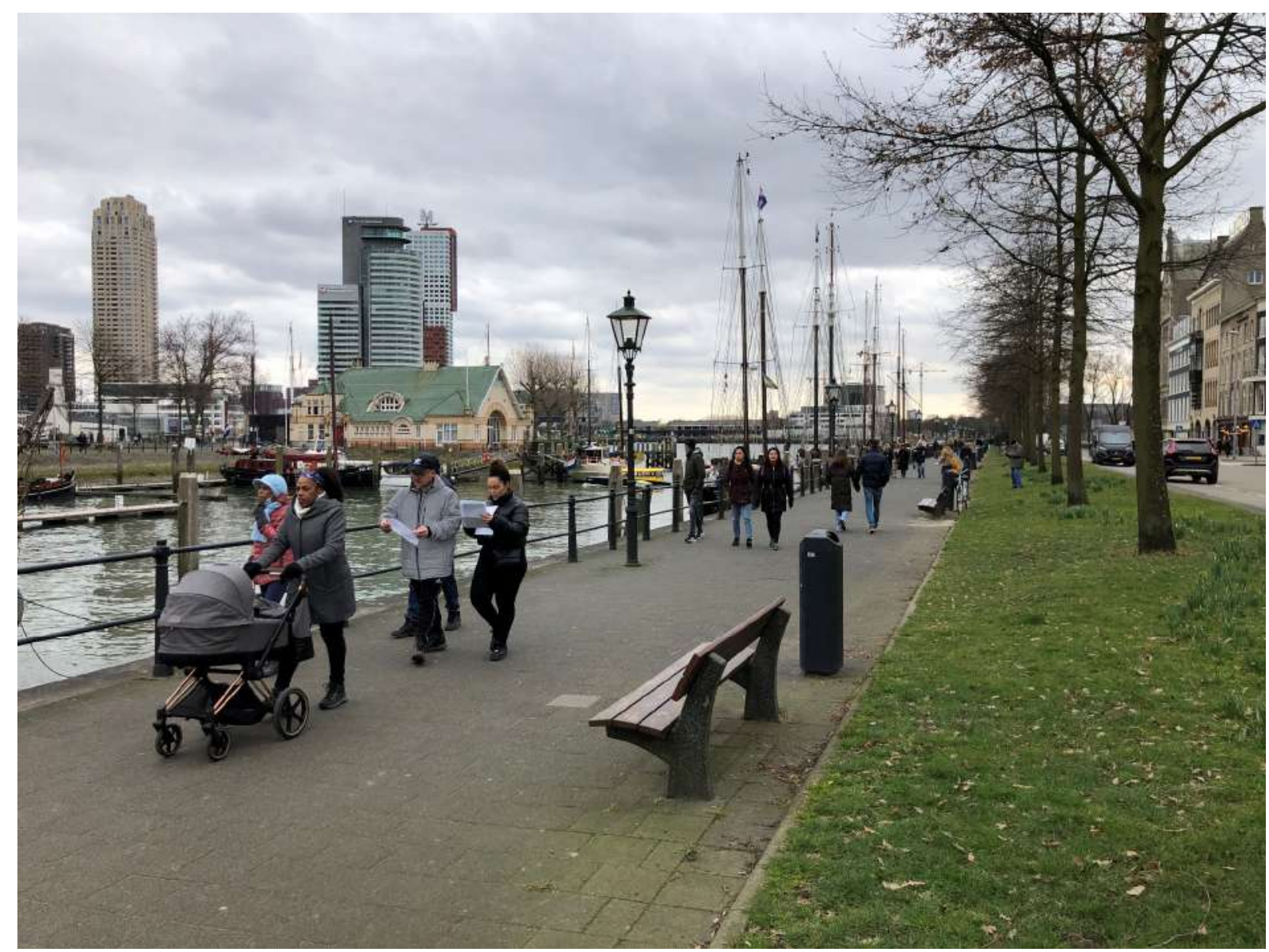

Figure 4. Different places, different people, March 202I (image by the author). 


\section{Living Together on the Long Term}

Recently, death rates has dropped becoming lower than normal. (CBS 202I, March 5) The development of a safe and effective vaccine for the highly communicable respiratory virus has always been an important epidemic control measure fitting the long-term goal. Interrupting chains of transmission nationwide remain simply the most effective action in this, until immunity has reached. (WHO 2020, 16-24 February) Vaccines have arrived and vaccination programmes are in process. The human coronaviruses is not disappearing overnight, but what about its impact on public spaces? What will stay in the future? All kind of scenarios have emerged over the past year. Futures embedded with full attention for urban hygiene and health follow prime moral value during the pandemic in its indisputably relevance around the world. There are also futures which are formed by trans-national calls to design for ongoing physical distancing, following the perspectives of virologist and epidemiologist. For sure, designers are able to alter the arrangement of public furniture in order to cater gatherings while withholding physical closeness, or to expand sidewalks, to parcel public space, and alike. Nonetheless, these solutions give short-term answers, valid until the virus is under control. Public life is evolving in a different direction though. Instead of physically distancing society, more likely, an opposite challenge will inform the design of public space on the long term. Not distancing but nearness seem to shape future public spaces. Localisation, social contraction, compression and convergence will balanced out globalisation, expansion, dispersion and divergence, even when human travel revives world-wide. The strong shift towards the house, as seen over the recent year, stays longer. People share public spaces in the neighbourhoods. More than ever! Different people, different places... Public spaces are not used by all people at once, nor by people as a whole: they never have been. The city is formalising our municipal autonomy in an anti-egoistic manner. The public interest is safeguarded. Health remains at stake. At the same time, public spaces are not only owned by governments representing the people. Not everything is controlled. Other actors and actions play a role too: Municipally-owned space is appropriated by all kinds of locals. Neighbourhood public spaces form the majority of public spaces. They are known by specific groups. (sec. Harteveld 2019: I38) In 2020, the public spaces close to home have come into scope explicitly, as did alternatives to temporary closed leisure, shopping, and entertainment spaces. People use, appropriate and experience their local environment, more than they did. Public space evolved into living rooms by/of/for people even further. The value of 'living together' is not changed. The quality of being together as a community is. This determines the future for the public space.

\section{Towards Designing Public Spaces for Domestication}

Of course not everybody is sticking to the house, and not always. Nowadays, no less than 3 million people, qualifying as crucial workers, are working anyhow on-site in The Netherlands. ${ }^{5}$ They have to move no matter what. (CBS 2020, 27 July) Also, we can state that others increasingly are travelling again since the first shock. Moving is inherent

\footnotetext{
${ }^{5}$ Here the term 'key occupations' applies: staff working in vital processes, care, social support, police, firefighters, crisis managers can't stay at home, like those taking care of fuel, waste, goods, information, and e.g. operating public transportation.
} 
to participating in life. Mobility is re-establishing despite stronger governmental measurements. Still, most important, comparing mobility patterns reveals that distance travel radically dropped over the year. (Google Analytics 2020, 29 March and 20 October; CBS 2021, 12 March) Hence, people stay local more than they did in 2019 and before. Strong ongoing economic and communication trends are pulling this shift for decades already. These determine the future of public space. From one standpoint, remote work and shopping are allowing certain people to stay home. (e.g. Baran and Greenberger 1967, Encel 1975, Salomon 1985, et seq.) In 2020, (partial) telecommuting just became very visible. ${ }^{6}$ So much as it became most prevalent among employees with certain occupations, like ICT professionals, managers, creatives, linguistics, teachers, administrators, and legal servants working. ${ }^{7}$ (CBS 2020, 6 April / 12 August, and 2021, 16 February) In 2020 too, online shopping and ordering clearly boosted, as prior to this, the rise has been already apparent. Over the recent decade, the number of physical stores has fallen consequently. People visit physical shops less. ${ }^{8}$ (CBS 2020, 4 August and 2019, 18 December; De Graaff 2004, Plaut and Shach-Pinsly 2019). From another standpoint, emerging economic and social distance to work and amenities keep people local. Travel costs and economic opportunities as well as travel time and communication barriers may keep people home, whereas increasing unemployment rates have always pushed the homeward shift. (e.g. Klaassen and Drewe 1973 et seq.) In 2020, significant groups have become financial victims of the coronavirus outbreak in the Netherlands. People have reduced workflow in the first two months and over time unemployment numbers have grown modestly, expected to grow more. Economic conditions remained fragile on the long term. ' (Jongen, Ebregt, Scheer, and von Gaudecker 2020, May; Adema, Yvonne, Wiljan van den Berge, and Alice Zulkarnain 2020, Augustus; and CPB 2020, November, and CBS 202I, I 8 February) Here, the offering of jobs and services in the vicinity of the house counts. Embedding last year's homeward shift in such pull and push factors, the strong estimate is that local, green and recreational public spaces effectively become more important in daily life anyhow. This may be supported by a third view point, one of the people themselves. When people are using and experiencing their direct living environment more, colliding a lack of alternatives, being more at home and/or having more free time, their general perspectives on public space change. We continue to exercise, stroll, sun, meet, or simply to be together - no matter of obeying physical distance. The expected increasing presence of locals at the neighbourhood scale supports an ongoing 'domestication of public space'. In this process, people accustom public spaces in the vicinity of their houses to make them fit for their changing lives related to being more at home. People are appropriating public space increasingly. Again, for over a decade, so-called proactive citizens aimed at the public interest, acting in the public domain, and so-called placemakers emerge. (e.g. Dekker, De Hart, and Faulk 2007, CROW, and Project for Public Spaces 2008). In 2020, new groups of people have become aware of the public

\footnotetext{
${ }^{6}$ During the first wave: 9 million people worked at home.

${ }^{7}$ Compared to statistics from before the outbreak: nearly twice as much ICT professionals worked home, exceeding $40 \%$ total. Also, a third of e.g. managers, creatives, linguistics, teachers, administrators did.

${ }^{8}$ Compared to a decade ago: II\% less shops and stores. In 2020: online sales increased by $3.9 \%$ in QI and $5.9 \%$ in $\mathrm{Q} 2$.

${ }^{9}$ In the first two months, about $13 \%$ of the working population reduced workflow and few became unemployed. Over 2020 , up to $3.6 \%$ of the labour population eventually did. For 2021 , the estimate is $6 \%$.
} 
spaces nearby. They take action together and recreate their shared public space. This does come with adjustments in public space and occasionally conflicts, like neighbour quarrels. (Sevil 2020, 27 September) It confirms that these people conceive public space as our valuable immediate living environment, and, within communities, they appropriate it progressively. Where possible bend it to their free will.

Ultimately, public space nearby becomes important. The urban space becomes an extension of the living room, even the urban living room itself. And, 'domestication' turns into a social value. The related shifts in using, appropriating and experiencing public space generate a wide variety of design assignments for the public space and the urban fabric. A strong call to design for all, including the equal provision of public space at local levels emerges. Different people, different places, thus different designs! This brings us closer together, ... once again! Something which ought to be familiar to public space.

\section{References}

Adema, Yvonne, Wiljan van den Berge, and Alice Zulkarnain (2020, August) Langdurige Effecten van de Coronacrisis voor de Arbeidsmarkt, CPB Coronapublicatie. Den Haag: Centraal Planbureau

Baran, Paul, and Martin Greenberger (1967, April) "Urban Node in the Information Network", P3562, Santa Monica: RAND Corporation, invited paper as presented at 1967 IEEE International Convention Record, March 20-23, Session 4, 'The City of Tomorrow', Monday 9:30 A.M. - 12:00 Noon, New York.

Bos, Kim and Floor Rusman (2020, 4 April) "Social Distancing. Corona: Garantie op Groot Social Ongemak", NRC Weekend, Zaterdag 4 \& Zondag 5 April, 2020, pp. 2-3

Bouma, Katja (2020, 22 May) "Raportage: Drukte in Amsterdam. Naar Buiten, Ja. Wat moet je Anders?” De Volkskrant, Vrijdag 22 Mei 2020, pp.2-3

CBS (2019, I8 December) In Tien Jaar Tijd Ruim II Procent Minder Winkels, I 8-I 2-2019 00:00, https://www.cbs.nl/nl-nl/nieuws/2019/5 I/in-tien-jaar-tijd-ruim- I I-procent-minder-winkels, retrieved 20 November 2020

CBS (2020, 6 April) Thuiswerkers per Beroep, 2019, 6-4-2020 12:00, as published at https://www.cbs.nl/nl-nl/maatwerk/2020/I5/thuiswerkers-per-beroep-2019, retrieved 2 March 2020

CBS (2020, I5 May) Nearly 9 Thousand More Deaths in First 9 Weeks of COVID-19, 15-5-2020 15:01, as published at https://www.cbs.nl/en-gb/news/2020/20/nearly-9-thousand-moredeaths-in-first-9-weeks-of-covid-19, retrieved 20 May 2020

CBS (2020, 22 May) Deaths registered Weekly, by Sex and Age. Changed on: 22 May 2020, published at https://opendata.cbs.nl/statline/\#/CBS/en/dataset/70895ENG/table?ts=I590076257433

CBS (2020, 27 July) Hoeveel Mensen werken er in Cruciale Beroepen? (incl. Bijlage Revisieberoepen Tabell en Tabel2, 27/7/2020), as published at https://www.cbs.nl/nlnl/faq/corona/economie/hoeveel-mensen-werken-er-in-cruciale-beroepen-, retrieved I March 2020

CBS (2020, 4 August) Coronacrisis jaagt Online Winkelen aan in het Tweede Kwartaal, 4-8-2020 00:00, as published at https://www.cbs.nl/nl-nl/nieuws/2020/32/coronacrisis-jaagt-onlinewinkelen-aan-in-het-tweede-kwartaal, retrieved 20 November 2020 
CBS (2020, 12 August) ICT Workers at Home most often during Coronavirus Crisis, I2-8-2020 15:00, as published at https://www.cbs.nl/en-gb/news/2020/33/ict-workers-at-home-mostoften-during-coronavirus-crisis, retrieved 20 November 2020

CBS (202I, 8 February) Nearly 13 thousand COVID-1 9 Deaths up to November 2020, 8-2-202I 15:00, as published at https://www.cbs.nl/en-gb/news/2021/05/nearly-13-thousand-covid-19deaths-up-to-november-2020, retrieved I March 2020

CBS (202I, I6 February) Werkzame Beroepsbevolking; Thuiswerken, I6-2-202I 02:00, as published at https://www.cbs.nl/nl-nl/cijfers/detail/83258NED?q=thuiswerkers, retrieved 3 March 2020

CBS (202I, I8 February) Werkloosheid gedaald naar 3,6 Procent, I8-2-202I 06:30, as published at https://www.cbs.nl/nl-nl/nieuws/2021/07/werkloosheid-gedaald-naar-3-6-procent, retrieved I March 2020

CBS (202I, 5 March) Mortality in Week 8 lower than expected, 5-3-202। 15:00, as published at https://www.cbs.nl/en-gb/news/2021/09/mortality-in-week-8-lower-than-expected, retrieved I March 2020

CBS (202I, 26 February) Detailhandel; Omzetontwikkeling, Index 2015=100. Gewijzigd op: 26 februari 2021 , as published at https://opendata.cbs.nl/\#/CBS/nl/dataset/83868NED/table?ts=|615823425053, retrieved I March 2020

CBS (202 I, 12 March) Mobiliteit in Coronatijd, I2-3-202 I 10:04, as published at https://www.cbs.nl/nl-nl/visualisaties/welvaart-in-coronatijd/mobiliteit, retrieved I 3 March 2020

CPB (2020, November) Novemberraming: Economische Vooruitzichten 202 I, CPB Raming. Den Haag: Centraal Planbureau, retrieved from https://www.cpb.nl/raming-november-2020vooruitzicht-202I

CROW, and Project for Public Spaces (2008) Succesvolle Openbare Ruimtes: Praktijkvoorbeelden en Principes. (Publicatie 273). Ede: CROW, 2008

De Graaff, Thomas (2004). On the Substitution and Complementarity between Telework and Travel: A Review and Application. (paper presented at the NECTAR workshop 'Communication, Labour Markets and Urban Systems' organized at the University of Alicante). Amsterdam: Vrije Universiteit Amsterdam, retrieved from http://degree.ubvu.vu.nl/repec/vua/wpaper/pdf/200400I6.pdf

De Voogt, Sam, and Joram Bolle (2020, 4 April) "Vaker de Weg op. Buitensport. De Rondjes zijn niet meer te tellen", NRC Weekend, Zaterdag 4 \& Zondag 5 April, 2020, PP. E2I-E23

Dekker, Paul, Joep de Hart, and Laila Faulk (2007) Toekomstverkenning Vrijwillige Inzet 2015. Den Haag: Sociaal en Cultureel Planbureau 
Encel, S (1975, October) "Social Aspects of Communication", invited paper, IEEE Transactions on Communications, Vol. COM-23, No. 10, October 1975, pp. 1012-1018

Google Analytics (2020, 29 March) COVID-19 Community Mobility Reports on The Netherlands, available at https://google.com/covid I/mobility

Google Analytics (2020, 20 October) COVID-1 9 Community Mobility Reports on The Netherlands, available at https://google.com/covid I9/mobility

Government (2020, 5 March) Dutch Measures against Coronavirus. online since March 5th, 2020, and frequently updated: https://www.government.nl/topics/coronavirus-covid-I9/tacklingnew-coronavirus-in-the-netherlands

Harteveld, Maurice (2019) "Reviewing Premises on Public Spaces in Democratic, Inclusive, Agential Cities, Illustrated by Amsterdam", The Journal of Public Space, 4(2), pp. I23- I 44.

Jongen, Egbert, Jos Ebregt, Bas Scheer, and Hans-Martin von Gaudecker (2020, May) Arbeidsmarkt: Sterke Daling Gewerkte Uren. CPB Coronapublicatie. Den Haag: Centraal Planbureau.

Kamerman, Sheila (2020, 26 October) "Winkelen in Coronatijd: 'We nemen het er nog even van", NRC Handelsblad, Maandag 26 Oktober 2020, pp. 6-7.

Klaassen, Leo Hendrik, and Paul Drewe (1973) Migration Policy in Europe : A Comparative Study. Farnborough: Saxon House / Lexington: Lexington Books.

NL-Alert (2020, 22 March) Noodmelding NL-Alert 22-03-2020 I I :29 "Volg Instructies Rijksoverheid op: houd I,5 Meter Afstand! Bent u Ziek of Verkouden? Blijf Thuis. Bescherm Uzelf en de Mensen om u heen. Samen tegen Corona. Keep your Distance to Others."

NRC (2020, 2I May) "Drukte op Hemelvaartsdag", as published online only at https://www.nrc.nl/nieuws/2020/05/21/drukte-op-hemelvaartsdag-a4000432

Macron, Emmanuel (2020, 16 March) Adresse aux Français du Président de la République Emmanuel Macron, 16 Mars 2020. Paris: Élysée

Plaut, Pnina O. and Dalit Shach-Pinsly (2019) Digital Social Networks and Travel Behaviour in Urban Environments. London and New York: Routledge

RIVM (2020, May 21) COVID- 19: Current Information, as published at https://www.rivm.nl/en/novel-coronavirus-covid-19/current-information-about-novelcoronavirus-covid-19, retrieved 2I May 2020

RIVM (202I, March I3) "COVID-19_Aantallen_Gemeente_Cumulatief.csv" (this file contains the cumulative numbers of positively tested persons and the number of hospital admissions per reporting date, and the number of deaths per death date, per municipality in The Netherlands), daily updated and published at: https://data.rivm.nl/covid-I9/COVID19 aantallen_gemeente_cumulatief.csv, retrieved 21 May 2020

Rutte, Mark (2020, 16 March) Television Address by Prime Minister Mark Rutte of the Netherlands, as translated at https://www.government.nl/documents/speeches/2020/03/16/televisionaddress-by-prime-minister-mark-rutte-of-the-netherlands, retrieved 20 May 2020. 
Rutte, Mark (2020, 3 April) Letterlijke Tekst Persconferentie na Ministerraad 3 april 2020. Mediatekst |03-04-2020. retrieved 20 May 2020 at https://www.rijksoverheid.nl/documenten/mediateksten/2020/04/03/letterlijke-tekstpersconferentie-na-ministerraad-3-april-2020

Rutte, Mark (2020, 7 April) Letterlijke Tekst Persconferentie Minister-President Rutte en minister De Jonge na afloop van crisisberaad cabinet. Mediatekst | 07-04-2020, retrieved 20 May 2020 at https://www.rijksoverheid.nl/documenten/mediateksten/2020/04/07/letterlijke-tekstpersconferentie-minister-president-rutte-en-minister-de-jonge-na-afloop-van-crisisberaadkabinet

Rutte, Mark (2020, 7 April) Letterlijke Tekst Persconferentie Minister-President Rutte en minister De Jonge na afloop van crisisberaad cabinet. Mediatekst | 15-04-2020, retrieved 20 May 2020 at https://www.rijksoverheid.nl/documenten/mediateksten/2020/04/I5/letterlijke-tekstpersconferentie-minister-president-rutte-en-minister-de-jonge-na-afloop-van-crisisberaadkabinet

Rutte, Mark (2020, I4 December) Television address by Prime Minister Mark Rutte of the Netherlands, as translated at https://www.government.nl/documents/speeches/2020/I2/ /4/television-address-by-primeminister-mark-rutte-of-the-netherlands, retrieved I March 202I.

Rutte, Mark (202I, 23 February) Letterlijke tekst persconferentie minister-president Rutte en minister De Jonge, Mediatekst | 23-02-202I, retrieved 2 March 202 I at https://www.rijksoverheid.nl/documenten/mediateksten/2021/02/23/letterlijke-tekstpersconferentie-minister-president-rutte-en-minister-de-jonge-23-februari-202I

Schiedam-24 (202I, I February) Bijna Zeventig Procent minder Verkeer op Vliegveld Rotterdam, 01 02-202I, retrieved I March 202I at https://schiedam24.nl/nl/nieuws/nieuws/bijna-zeventigprocent-minder-verkeer-op-vliegveld-rotterdam/1645I

Sevil, Malika (2020, 27 September) "Achtergrond: In Coronatijd ergeren Buren zich Helemaal Groen en Geel”, Het Parool, Zaterdag, 26 September 2020, pp. I, and 6

Salomon, Ilan (1985, September) "Telecommunications and Travel: Substitution or Modified Mobility?” Journal of Transport Economics and Policy, Sep., 1985, Vol. 19, No. 3, pp. 219235

Van den Dool Pim, and Rik Wassens (2020, 26 October) "In De Tweede Golf Gaan We Weer Wat Vaker Even Een Blokje Om”, NRC Handelsblad, Maandag 26 Oktober 2020, pp. 6

Van Noort, Wouter (2020, 19 June) "Hé wat Leuk, De Buren! Hoe in Coronatijd Mensen hun Eigen Wijk Ontdekken”, NRC Cultuur: Leven. De Buurt bloeit op. A section of NRC Handelsblad, Maandag 22 Juni 2020.

WHO (2020, 16-24 February) Report of the WHO-China Joint Mission on Coronavirus Disease 2019 (COVID-19). Geneva: World Health Organization (WHO). 


\title{
Reframing Public Spaces: from Recreational Amenity to Civic Good in Resilient Cities. COVID-19 Offers an Opportunity to Re-evaluate Neighbourhood Spaces to Ensure they are Available to All
}

\author{
Kevin Fan Hsu \\ Centre for Liveable Cities, Singapore \\ kevin_hsu_from.TP@mnd.gov.sg
}

\begin{abstract}
Cities emerging from the pandemic increasingly recognize that public spaces are a critical element of resilience, not merely recreational amenities. Future public spaces must be designed to accommodate more diverse and distanced activities, and may even change function entirely during public health emergencies. The need for informal public spaces has also become apparent, and cities can benefit from identifying them as resources and integrating them into land-use plans. Parks, sidewalks and cycling paths can be justified as investments in resilience and survivability and quickly expanded. Their provision must be viewed through the lens of social and spatial equity: in many cities, not every person or community has convenient access to these critical public goods. Planners must go beyond metrics on the mere availability or density of public spaces, and delve deeper to assess the quality of spaces, and the ability of different demographic groups to reach them.

Historic neighbourhoods that developed organically offer useful inspiration when designing for equitable access and daily convenience, and can also accommodate the dispersal of jobs away from central business districts. Efforts to develop decentralised, "complete" neighbourhoods can be a boon for adaptive reuse, public space provision, and greater variety of work settings, while public areas of civic buildings can be re-imagined as nodes of collaboration in a knowledge-based economy. Beyond building infrastructure, maintaining lively and welcoming public spaces requires empathy, respect for the commons, and care for fellow human beings. Physical spaces in a city can only be fully and genuinely "public" if they are safe, and open to everyone, regardless of age, language, identity, sexual orientation or ability. As cities undertake revitalization efforts following the pandemic, they must strive to ensure such places are available to all.
\end{abstract}

Keywords: resilience, urban planning, equity, public space, post-pandemic design

To cite this article:

Hsu, K. F. (2020). Reframing Public Spaces: from Recreational Amenity to Civic Good in Resilient Cities. COVID-19 Offers an Opportunity to Re-evaluate Neighbourhood Spaces to Ensure they are Available to All, The Journal of Public Space, 5(3), 67-82, DOI I0.3289I/jps.v5i3.1416

This article has been double blind peer reviewed and accepted for publication in The Journal of Public Space.

This work is licensed under a Creative Commons Attribution - Non Commercial 4.0 International License https://creativecommons.org/licenses/by-nc/4.0/ 
With repeated lockdowns forcing the populace to sequester indoors, the global COVID-I9 pandemic has provoked a host of questions about public space. Around the world, governments are re-examining land use policies, as they contend with the social challenges and disparities revealed — and amplified - by orders to stay home for extended periods.' As cities emerge from the pandemic to explore a "new normal," they will inevitably adjust their visions of the urban future. This article offers observations on the value, planning and function of public spaces during and after the pandemic, drawing inspiration from several international examples, including the densely settled city-state of Singapore.

\section{"Public space" is a critical element of resilience, rather than an optional recreational amenity}

Planners have long extolled the salubrious effects of light, air, and open space, specified in zoning ordinances and planning norms. Early thinking around parks considered them recreational spaces (Bassett, 1938; Mason, 2006), offering benefits such as leisure, commemorative value, and areas for games and sports (Taylor, 2009). As cities, particularly in North America and Europe, developed more sophisticated understandings of parks and public spaces, a much wider array of values were ascribed to them, including social, economic and environmental goods, civic identity, and the promotion of physical health and mental well-being (Design Council UK, 2003; Peiser and Shwann, 1993; Maas et al., 2009; Henderson, 2012; Sturm and Cohen, 2014; Larson et. Al, 2016; Lennon et al., 2017).

In Singapore, efforts to develop parks and enhance greenery after independence in 1965 were intended to raise "the morale of the people and [give] them pride in their surroundings," (Lee, 2000) and act as a "social leveller" across different socio-economic groups (Er, 20l8). A pioneering generation of leaders combined urban density with greenery to give rise to today's liveable context. From the early idea of a "Garden City," (National Library Board, 2020) to more recent calls to grow into a "City in Nature," (Khoo, 2017; National Parks Board, 2020) the island city-state has consistently set aside land, planted trees and shrubs, and explored new ways to introduce vertical and rooftop greenery into the urban landscape (Rowe and Lee, 2019; Centre for Liveable Cities and National Park Board, 2015). The Singapore Botanical Gardens, which supplied expertise and materiel for greening initiatives during the 1970s, was even inscribed on the UNESCO World Heritage list in 2015 (UNESCO, 20I5).

However, there are still cities in many parts of the world today where a significant portion of the population does not have access to parks and open spaces. The COVID19 pandemic heightens the urgency of ensuring such basic amenities are available to all. With people tethered to their homes for weeks or months, access to recreational space close by is more important than ever. Parks with sufficient area to permit movement and exercise are a public good with implications for system-level health. As cities strive to become resilient, they must look beyond disaster response and protections against sea-level rise, to recognize that public space provision is an essential good. Resilience indices can be updated to reflect households' access to public space, 
given stressors such as global pandemic. Safe public spaces in cities are not merely a factor that boosts liveability, but a critical feature that ensures survivability.

\section{Public spaces are not only for socialising; they are also places of transit, distance, and solitude}

The mental image of the social urban park is likely to transform, as plazas, central greens, and public squares evolve from focal points for mass gatherings, demonstrations, and inter-personal exchange, into places for separation and dispersal Johnson, 2002; Lee, 2009; Parkinson, 2012; Gul et al., 20I4; Hammond, 2019; Kwok and Chan, 2020). Humans are social creatures, so William Whyte's seminal observation about New York's public spaces -"what attracts people most, it would appear, is other people" (Whyte, 1980) -remains valid. At the same time, parks will have to serve multiple functions - not only as places for people to "mix, relax and meet in the city,"(Low et al., 2005) but also as places that can accommodate diverse, safely-distanced activities. In more extreme cases, parks may even be converted to temporary field hospitals, quarantine centres, or dormitories during a health emergency.

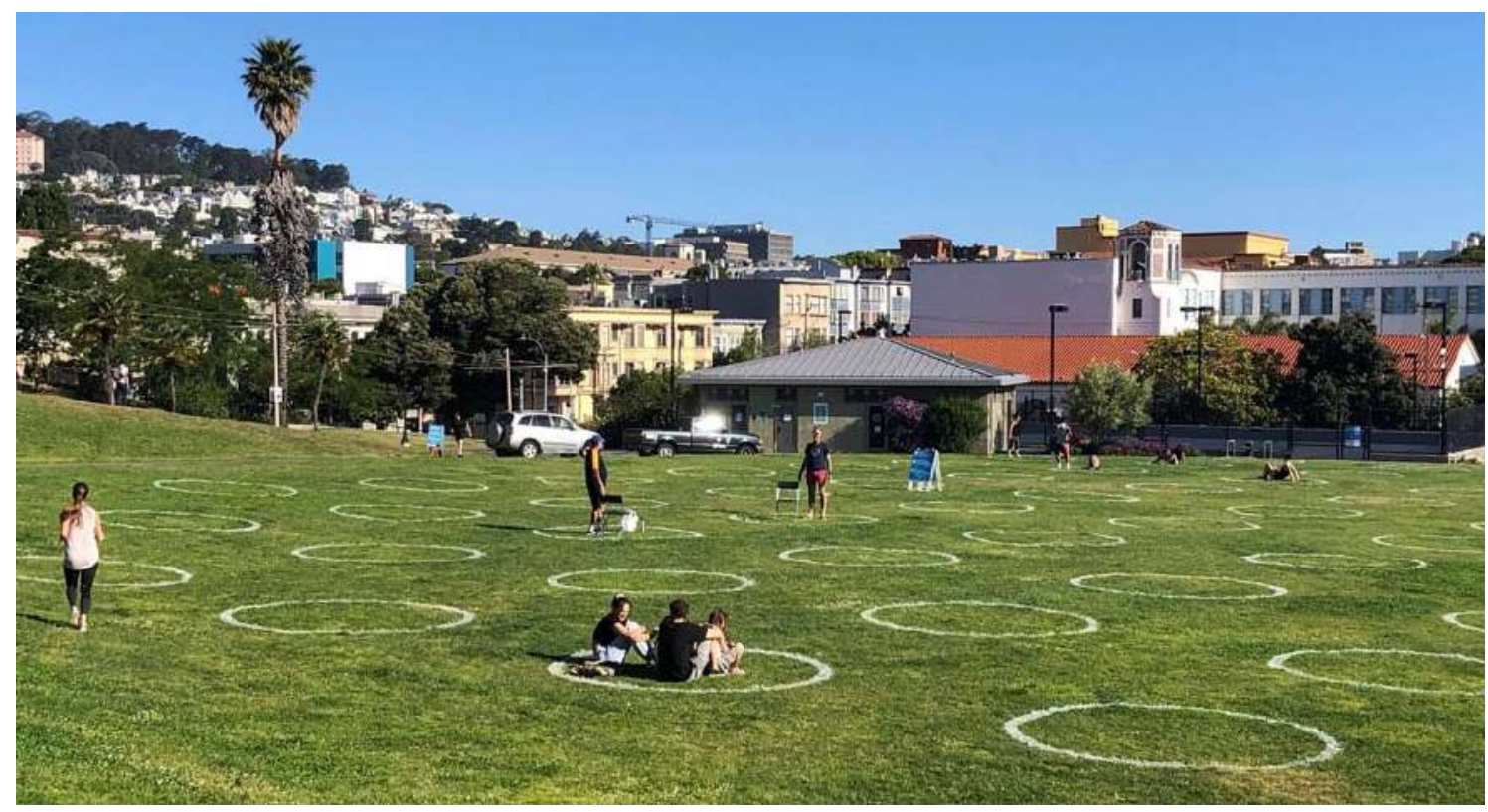

Figure I. "Human parking spaces” in Mission Dolores Park in San Francisco, May 2020. Photo by Natasha Chu.

Future architects and urban planners will wrestle with balancing the role of parks as places for physical distancing vs. sites of community-building that strengthen social bonds (Peters et al., 2009). Discussion of the dichotomous nature of parks-passive or active, regulated or unregulated, competitive or non-competitive-may well resurface (Harnik, 20I2). When seeking planning inspiration, designers can draw from other cultural traditions that view public space as spiritual retreat, source of solitude, or refuge (Thralls, 2018; Hammitt, 2002; Beatley, 2017; Goto, 2003). 
The value of informal spaces becomes apparent when these spaces disappear With the partial shutdown of many businesses, a city's informal gathering places-sites not necessarily marked as parks on a land-use document (Rupprecht and Byrne, 2014; Lutzoni, 2016) — have also been deeply impacted. In Singapore, for example, residents frequently gather in the local coffee shop or kopitiam, in hawker centres that serve meals, and in ground-floor "void decks" of public housing flats. Due to the pandemic, many of these places were closed, eliminating their normal civic function (Butler, 2016). Singapore has also designated a network of green corridors, utilising land alongside drainage canals and road reserves to link parks, nature areas, and other open spaces. This Park Connector Network (PCN) allows people to exercise, cycle and commute. While some informal social spaces were closed, the $\mathrm{PCN}$ remained open and consequently witnessed greater numbers of users than before.

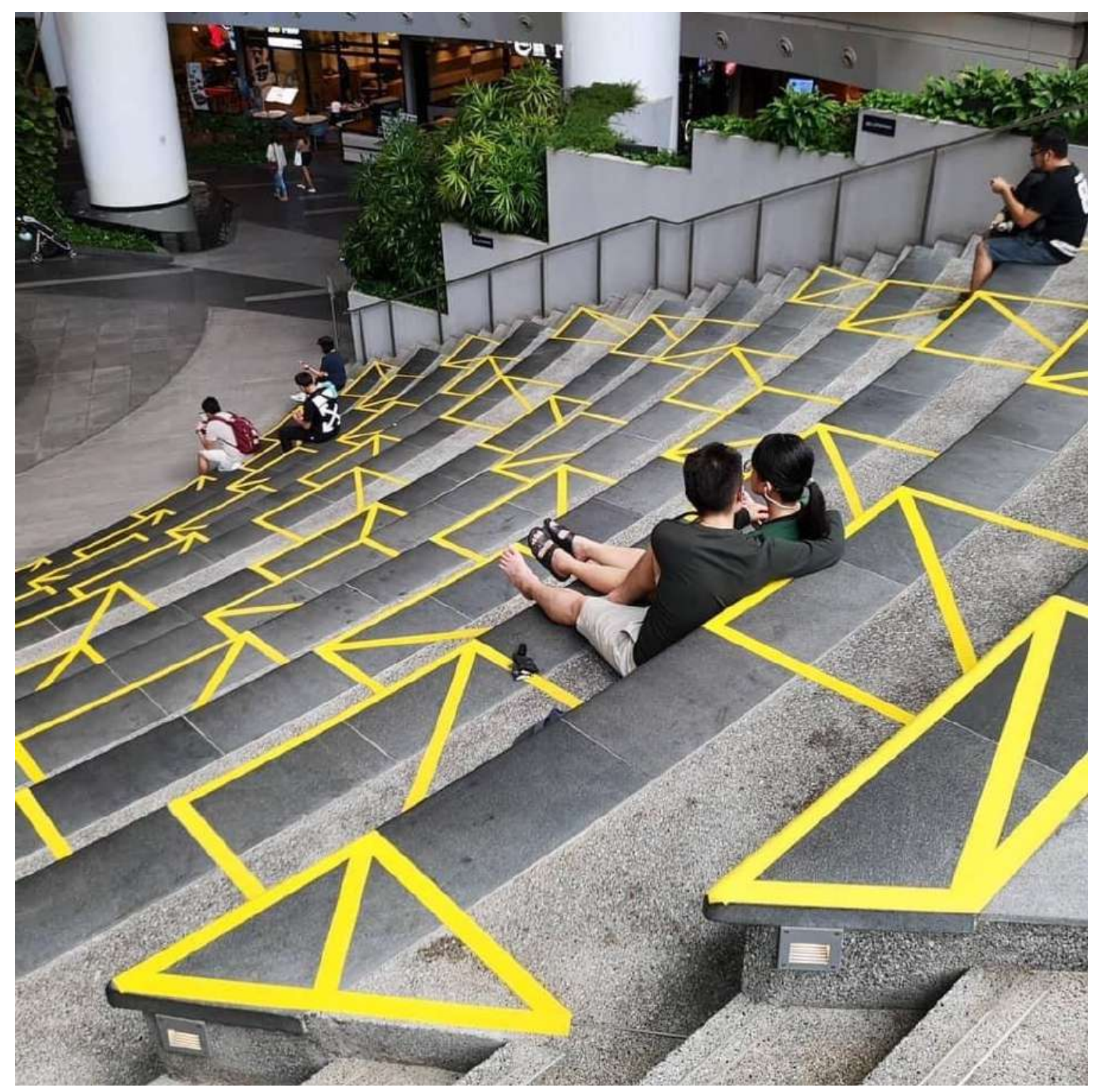

Figure 2. Seating has been carefully marked in public areas to promote safe distancing in Singapore. Photo by Emeric Lau. 


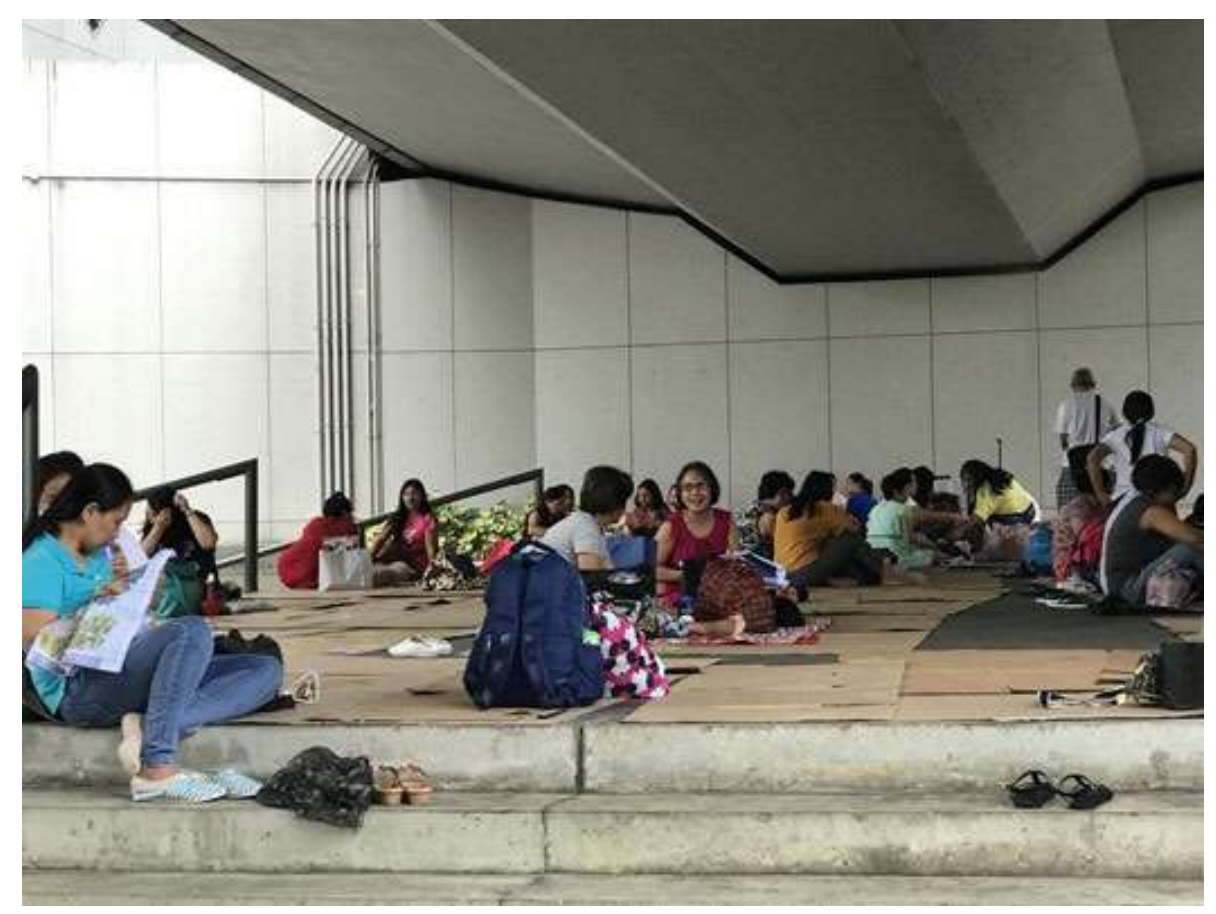

Figure 3. Unofficial public spaces accommodate many activities,

such as pre-pandemic weekend social gatherings in Hong Kong. Photo by Kevin Hsu.

As cities look to the future, planners can strive to identify informal spaces, inventory them as municipal and national assets, and include them in the city's land use plans.

Observing and engaging with the public in the places where they spend their daily lives would allow planners to better understand citizens' values and preferences. As the old adage goes, "We measure what we care about." Land use planning benefits from placing informal public spaces into dialogue with typologies of parks, park connectors, and greenery. Traditional parks are still needed, but informal spaces bring social value to households that should not be underestimated (Teo, 1997).

Assessing, responding to, and incorporating public sentiment about public spaces can also be strengthened (Hee and Ooi, 2003; Hee, 20I7). The National Parks Board has begun more extensive citizen consultation for the design of upcoming park facilities (The Straits Times, 2020), and the non-profit organization Participate in Design incorporates walking tours, mobile stations for community input, and other engagement strategies in its work on public amenities with town councils. The incoming generation of Singapore's national leaders has suggested such efforts at co-creation are desirable (Prime Minister's Office, 2019). After the pandemic, government planners will have the opportunity to reacquaint themselves with the value of what Ray Oldenburg calls "third places," or "informal public gathering places" outside of home and work that form "the heart of a community's social vitality," (Oldenburg, 2002; Oldenburg, 1999) and continue expanding the role of public input.

Even without the pandemic, the need for genuinely public spaces pervades many cities in Asia. Observing the situation in Thailand, Malaysia, and other nearby countries, Douglass et al. consider shopping malls in Southeast Asia as "privately owned spaces 
seeking to maximise consumption while limiting all other forms of lifeworld expression" (Douglass et al., 2008; Pomeroy, 20I I). Setha Low has warned about the privatisation of public space in New York and elsewhere, captured by developers and retailers that prey on consumer spending (Low, 2008).

However, alternatives to consumption-based malls have experienced a rise in popularity and may command greater priority in future land-use planning. Hong Kong's malls operated through the pandemic, yet the city has witnessed many more people visiting "country parks" where they can safely distance, rather than typical retail haunts. Their preference for natural landscapes proves the point of Hong Kong's urban researchers and activists (Liber Research), who have consistently resisted proposals to open up cherished nature areas to real estate development (Agence-France Presse, 2018). Cities would do well to ask themselves: do they really need another shopping mall? Or are there public alternatives, such as parks, hiking trails and accessible waterfronts, that would better serve residents in good times and bad?

\section{Cities can accelerate the creation of cycling paths and sidewalks by conceiving of them as alternative public spaces that contribute to resilience, not just enablers of transportation}

The pandemic has clarified the need for expanding public spaces, which are no longer solely about leisure, but also justified in terms of safety and survivability. The recalculation of cost-benefit analyses to include resilience considerations can break the logjam on long-awaited projects such as walking trails, cycling paths, and even sidewalks. In many Southeast Asian cities, sidewalks - taken for granted in the West-do not exist. Pedestrians walk in the road, braving the rush of buses, cars, and motorbikes. While Singapore does have an extensive network of sidewalks, planners often think of them in functional terms-running parallel to stormwater drains, thoroughfares for households to reach bus stops and MRT stations - not as goods in and of themselves.

Yet by widening and upgrading sidewalks, cities can provide more space for human beings to safely enjoy the outdoors. By 2018, the Land Transport Authority had upgraded 200 kilometres of walkways by erecting shelters to protect pedestrians from rain and sun (Land Transport Authority, 2018). Are there further ways to make city pathways pleasurable amenities? Could streets become world-famous destinations, such as the Champs-Elysees in Paris or Las Ramblas in Barcelona?

Incidentally, if sidewalks are reframed as recreational spaces that permit safe yet enjoyable distancing, then keeping them clear and accessible to residents of all ages and physical abilities would become a priority. The popularity of Singapore's Park Connector Network during the pandemic also speaks to the need for accelerating their expansion and ensuring full connectivity, both for enabling non-vehicle mode share, but also as resilient public goods. 


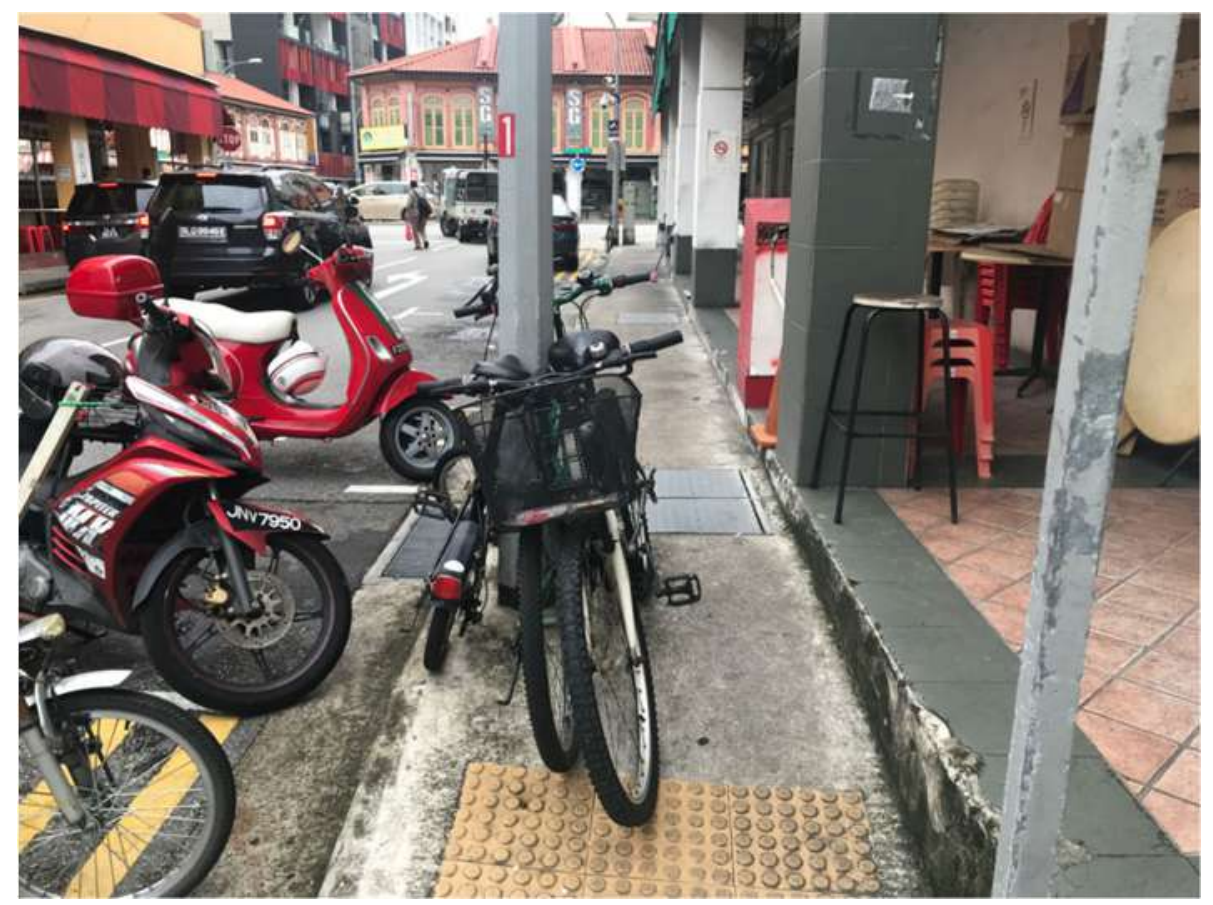

Figure 4. Keeping sidewalks accessible for pedestrians of all physical abilities, including along this lane in Geylang, Singapore, will be increasingly important. Photo by Kevin Hsu.

\section{Spatial equity and socio-economic inequality have come into stark relief, and cities must address these disparities}

A city's neighbourhoods are marked by distinct physical, cultural, and demographic characteristics. Building features that improve quality of life under a pandemic, such as balconies or common walkways, may grace some neighbourhoods but not others. They are also differentiated by residents' ability to access public spaces, whether local, regional or national-level sites. Districts where residents can step outside and easily reach a major park are greatly favoured under a pandemic; places farther from such amenities, and without local substitutes, are at a severe disadvantage.

Studies in the United States have found that access to greenery, community recreation facilities, amenities and programs may differ by income or race (McKenzie et al., 2013; Nexbitt et al., 2019). The availability of ostensibly public resources is unequal, and cannot be taken for granted-a phenomenon even more acutely felt in the current crisis. A possible inspiration lies in historic Savannah, Georgia, which offers the meticulous presence of public squares in each ward, within easy walking distance for residents.

Another dimension requiring scrutiny is the use of "privately-owned, public open spaces" as places for the public to rest and recreate (SPUR, 20I3; Reeves et al., 2020). The concept was popularised in cities such as New York and San Francisco, where developers opened up certain portions of the building in exchange for city incentives. However, some community members have lodged complaints of gate-keeping and intentional inaccessibility of POPOS. 
When the economy shuts in a pandemic, building owners may also choose to close their doors to the public. Rooftop and indoor POPOS could very well be restricted, depriving downtown residents of supposedly public spaces (Hsu, 2018). To resolve this dilemma, cities may need to implement regulatory fixes or engage in negotiations with property managers.

Ultimately, traditional ideas of "accessibility" are due for a rethink, emphasizing quality, not merely presence. There are vast differences among a tiny pocket park, a "privatelyowned, publicly-accessible" open space that can be chained shut by a company, and a large public commons that actually supports physical activity.

To promote spatial equity, and ensure fair and optimal distribution of services and amenities, planners can regularly measure equal/unequal access across the city's neighbourhoods, taking into account demographic factors such as income, race and ethnicity, native language, physical ability, gender and age, to ensure that all populations are appropriately served by the prevailing planning regime-and to identify areas for improvement.

\section{Many urban agglomerations grew out of towns and villages, now amalgamated into metro areas. Older patterns of living, exemplified by historic districts, may enjoy a renaissance}

The pandemic has revealed the disadvantage of residential-only estates, whereas neighbourhoods that contain a full family of amenities-sometimes called "complete communities" or "complete neighbourhoods"- -are getting a second look (City of Portland, 2012; University of Delaware, 2013; Price, 20I8). For example, real estate developers in China regularly build isolated housing projects, which sometimes have a few shops at the margins, but mostly lack the range of services required for everyday life. In contrast, historic neighbourhoods that developed organically over time, such as Laoximen in Shanghai or Dashilar in Beijing, are much likelier to feature a broad set of community-serving establishments.

In Singapore, a number of national-level cultural, entertainment, and leisure destinations are located in or near the downtown core.' Well-loved regional parks are spread out more widely, serving nearby residents, but also attracting users from across the island. Local offerings are diffused across neighbourhoods. Under normal circumstances, residential areas are linked to major attractions by a heavily utilised public transportation system, and the idea of a " 45 -minute city" bound together by trips via bus and rail has been touted as a goal (Singapore Ministry of Transport, 2019) but this concept is challenged during a pandemic, when residents are less willing to take public transit to far-away locations. Options close to home gain added importance (Ministry of Environment and Water Resources, 20I5), yet at present, local amenities do not fully substitute for regional and national-level attractions in terms of quality, level of service, and size.

In a post-COVID world, cities' planning norms are likely to re-prioritise local options, rather than assuming residents will freely travel to national and regional destinations. A

\footnotetext{
I The Singapore Urban Redevelopment Authority's (URA) Digital Planning Lab has developed some useful experimental analyses looking at the availability, accessibility, and diversity of various amenities.
} 
more decentralised model of integrated, full-service neighbourhoods might feature community facilities, a generous selection of dining options, ample offices for workers, places of worship, and greater availability of recreational options and diverse, locallyaccessed public spaces that permit distancing - all to serve distinct human needs. The Mayor of Paris, Anne Hidalgo, has floated the concept of a "fifteen-minute city" where housing, work, provisions, healthcare, education, and leisure should all be accessible to households on foot or by bicycle, without having to use cars or mass transit (Bloomberg, 2020).

One can look to existing developments built by the Housing \& Development Board (HDB) in Singapore as an example, with vibrant town centres and distributed neighbourhood centres offering a wide range of amenities within walking distance of all residents. New residential estates such as Punggol, Bidadari and Tengah are also incorporating neighbourhood centres and expanding parks and cycling paths for residents to enjoy (Housing and Development Board, 2020; Land Transport Authority, 2020). Finally, walkability and distance play some role in the fluid conception of neighbourhood identity and can enhance sense of place (Ewing and Handy, 2009; Zukin, 20 I2; Arup, 2016; Zavattro, 2019). Post-pandemic planning can take advantage of older forms that connect design, amenities, and local identity. Looking ahead, more people may seek out the "kampong" or "village" feel, and pandemic measures that restricted citizens to their neighbourhoods may end up strengthening attachment to place-or increase the desire to live in such places.

\section{Jobs can thrive in decentralised or historic neighbourhoods, but cities and employers must be open to re-imagining workplaces and facilities}

Employment opportunities may migrate outside the Central Business Districttraditionally congested in daytime, but empty at night - shifting the location and physical backdrop of workplaces. Working from home has proven feasible, and is likely to remain popular. Individual entrepreneurs, creative professionals, and employees of small firms looking to stay closer to home can utilize co-working spaces or start-up garages dispersed across a city's neighbourhoods. When remote teams from larger companies choose to gather for collaborative sessions, flexible meeting spaces spread out among regional nodes could be a convenient option. New businesses serving the immediate community could also arise, reducing the need to travel to the city centre and closing the distance between live-work-play.

To accommodate these shifts, planning paradigms would need to evolve, to allow a greater variety of dynamic and mixed land uses. Neighbourhood niches would be filled over time by diverse companies well-suited to that community. Adaptive reuse projects could also end up substituting for premium office space downtown: according to surveys by the National Trust for Historic Preservation in the United States, millennials value social spaces, authenticity, and cultural heritage (National Trust for Historic Preservation, 2017). They would likely appreciate the opportunity to live and work in revitalized, historic neighbourhoods.

Public libraries in Singapore are instructive: today, they function not only as storehouses of reading material, but also as informal workplaces, where freelancers engage in creative projects and conduct business meetings. As the strictures of permanent employment relax due to shifting hiring patterns and generational preferences, freelance 
work is likely to grow (The Straits Times, 2020). Could similar public spaces allow freelance knowledge workers a place to congregate? In the National Library, the existing seating plans already accommodate the I-metre of physical distancing required by the government, allowing them to continue operations in the early phase of COVID-I9. When pondering the future of public spaces, aside from more parks, cities can also consider building covered, air-conditioned spaces with Wi-Fi connectivity and outlets.

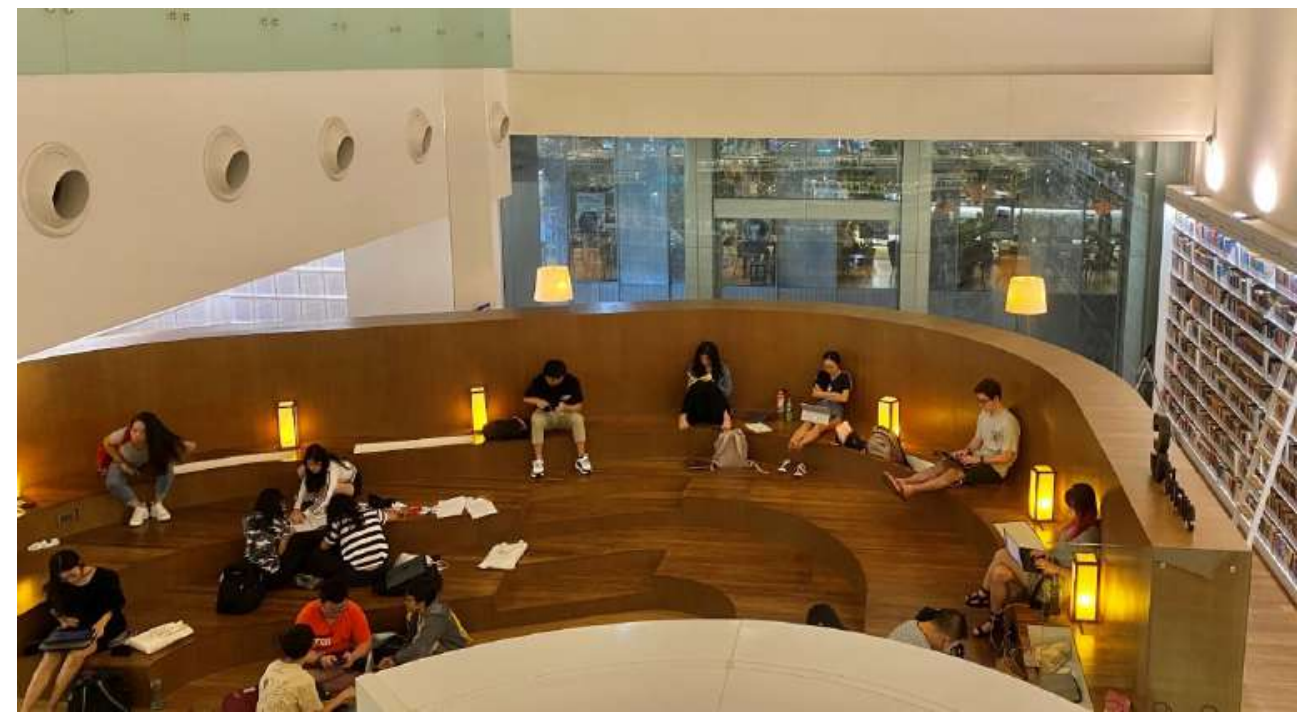

Figure 5. Libraries serve as community gathering places, and even as workplaces for enterprising freelances. Library@Orchard in Singapore. Photo by Kevin Hsu.

The common areas of libraries, museums and other civic buildings could be valued as centres of economic productivity, not written off as crowd-pleasing - but not incomegenerating-social welfare amenities. As an added bonus, people working closer to home could facilitate more frequent interaction among neighbours and strengthen community bonds.

\section{Street closures and placemaking measures that return streets and parking spaces to pedestrians could proliferate after the pandemic}

As of May 2020, more than 50 cities worldwide-including Boston, Cologne,

Philadelphia, London, Vancouver, and Washington D.C.- had closed at least one street or lane to motor vehicles, for some duration of the pandemic, to allow residents more space to exercise at a safe distance from others (Hsu, 2020). Cities have been able to take advantage of the low-traffic period to test out road closures and to complete bike infrastructure, without incurring significant economic impacts.

Even before the pandemic, the Urban Redevelopment Authority of Singapore closed certain streets to vehicle traffic during festivals and celebrations, creating walk-only zones as part of its "place management" strategy. Such place-making approaches could inform immediate and long-term responses to post-pandemic planning, as COVID-19 case counts taper off and cities aim to restore economic vitality by increasing visitor foot traffic. 
Installing more "parklets" to replace roadside parking spaces with public seating-a concept born in San Francisco that mushroomed into a global movement-and converting more roads into outdoor café seating could encourage patrons to return to retail areas (The Guardian, 2016; The Washington Post, 2020). Giving streets back to the people during the pandemic may have initially been motivated by public health, but these efforts may be maintained if they turn out to be economically useful, and sufficiently enjoyable to the public (Hass-Klau, 1993; Lung, 2002).

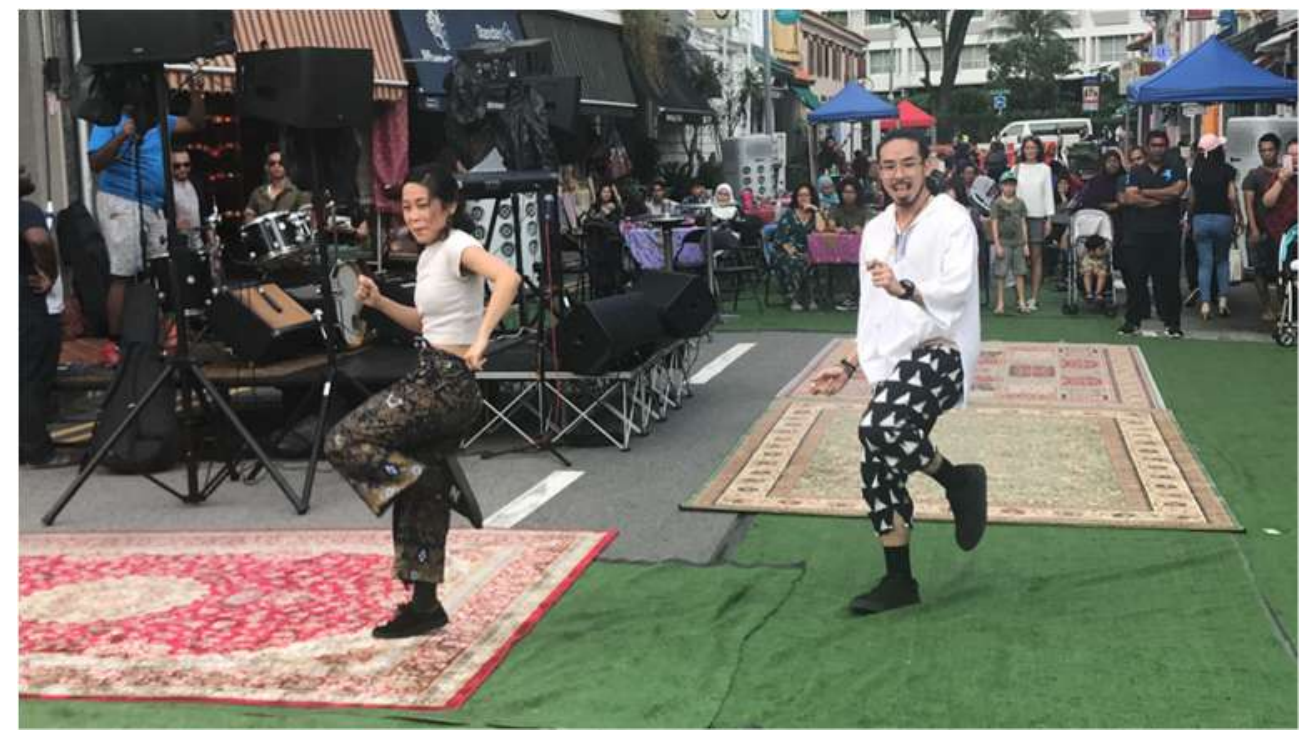

Figure 6. Streets in the Kampong Glam historic district of Singapore were closed to vehicle traffic, and the URA Place Management Department arranged for rugs, seating, live music, and performances during a community event in November 2018. Photo by Kevin Hsu.

\section{Functioning public spaces require empathy, collective responsibility, and mutual respect}

The pandemic renews the debate about what makes for public space. Beyond the provision of physical infrastructure, cities must re-examine the people, activities, and norms that define these spaces. Public perceptions - and citizen behaviour in response to those perceptions - are crucial ingredients that allow spaces to succeed, or to collapse into dysfunction (Center for Active Design, 2018). Ultimately, public space exists where there is public spiritedness. In such places, people feel a sense of welcome; they are able to safely traverse, engage in activities of their choosing, and co-exist alongside others.

Civic pride and empathy for others are key ingredients in a public space ethos. People inculcated with appropriate habits and pro-social mindsets are less likely to litter or vandalise, and to contribute to making spaces safe for all-including minorities and the elderly. Under COVID-19, mask-wearing has emerged as a sign of public spiritedness. In places like Taiwan, Vietnam and Hong Kong, where there has been high compliance with mask-wearing, life remains closer to normal, even with prevention measures. In contrast, intense partisan combat over masks in the United States-interpreted by some groups as an infringement on constitutional rights, but as a reasonable and 
obvious public health policy by most others - has made a return to public activity far more difficult.

Following the pandemic, one hopes members of the public venturing outdoors will feel not only great relief from confinement, but also a resurgent sense of ownership and pride over public spaces. Ideally, they would cherish these spaces, seeing the commons as a place all citizens have the responsibility to maintain —and the opportunity to curate.

\section{Ensuring public spaces for all}

As cities emerge from the pandemic, the lessons learned about our public spaces can positively influence the future management and planning of cities. Cities must now consider public spaces a critical element of resilience, not only recreational amenities. These public spaces must accommodate more diverse (and distanced) activities, and be prepared to alter their function in public health emergencies.

Informal public spaces, sidewalks, and cycling paths are excellent public goods that cities can quickly expand. With some imagination, these can transcend mere mobility to enhance quality of life and survivability. However, all of these amenities must be viewed through a lens of social and spatial equity: not every resident has easy access to the same public goods. A more nuanced stock-taking of the range, quality, and availability of public spaces will help in this effort.

Fortunately, traditional neighbourhoods that developed organically over time offer design inspirations to promote equitable access and daily convenience, and can accommodate the dispersal of jobs. The possible rise of decentralised, "complete" neighbourhoods may turn out to be a boon for local public spaces, with civic buildings re-imagined as nodes of collaboration and knowledge-based economic activity. In taking a reference from placemaking, cities that prioritise streets for pedestrians and cyclists can help attract foot traffic and restore economic vitality, though these measures must be balanced with public health concerns over crowding. Ultimately, maintaining lively and welcoming public spaces requires empathy, respect for the commons, and care for others, manifested in health-promoting behaviours such as wearing masks.

Physical spaces in a city can only be fully and genuinely "public" if they are open to allregardless of age, language, sexual orientation, cultural identity, or ability. Achieving this aspiration post-pandemic requires making spaces safe, secure, and broadly accessible. At the same time, cities will lift restrictions and restore creative freedoms to rejuvenate public places. Striking the right balance between these priorities requires citizens and government to partner for the common good.

Under normal conditions, city residents and planners may overlook and undervalue public spaces. The global pandemic has given humanity a long moment of pause, reminding governments and publics of the fundamental need for social connection and association. Humans need civic places where we co-exist with others, and where we feel a sense of connection to the larger community. In the process of rebuilding and recovery, cities must strive to ensure such places are available to all.

\section{Acknowledgment}

The author wishes to thank Michael Koh for his encouragement and feedback on this article. 


\section{References}

Agence France-Presse (2018) 'Wild Hong Kong: Fans of Country Parks Oppose Concreting of Trails, Taking Land for Homes', South China Morning Post, 6 January [online]. Available at: https://www.scmp.com/lifestyle/travel-leisure/article/2 I 270 I8/wild-hong-kong-fans-countryparks-oppose-concreting-trails (Accessed May 2020).

Arup (2016) Cities Alive: Toward a Walking World [online]. London: Arup. Available at: https://www.arup.com/perspectives/publications/research/section/cities-alive-towards-awalking-world (Accessed June 2020).

Bassett, E. M. (1938). 'The Master Plan' in LeGates, R and Stout, F. (1998) (eds.) Early Urban Planning: 1870-1940. New York: Routledge.

Beatley, T. (2017) Handbook of Biophilic City Planning \& Design. Washington, DC: Island Press.

Butler, S. and Diaz, C. (2016) "Third Places" as Community Builders [online]. Available at: https://www.brookings.edu/blog/up-front/2016/09/14/third-places-as-community-builders (Accessed: May 2020).

Center for Active Design (20I8). The Assembly Civic Engagement Survey [online]. Available at: https://centerforactivedesign.org/assembly-civic-engagement-survey (Accessed June 2020).

Centre for Liveable Cities and National Parks Board, Singapore. (2015) Biodiversity: Nature Conservation in the Greening of Singapore [online]. Available at: https://www.clc.gov.sg/docs/default-source/urban-systems-studies/uss-biodiversity.pdf (Accessed: May 2020).

City of Portland. (2012) The Portland Plan [online]. Portland: City of Portland. Available at: https://www.portlandonline.com/portlandplan/index.cfm?c=58776 (Accessed May 2020).

Design Council UK. (2003). The Value of Public Space: How High Quality Parks and Public Spaces Create Economic, Social and Environmental Value [online]. London: Bartlett School of Planning. Available from: CABE Space (Accessed May 2020).

Douglass, M., et al. (2008) 'The Livability of Mega-Urban Regions in Southeast Asia' in Jones, G. and Douglass, M (eds.) Mega-Urban Regions in Pacific Asia: Urban Dynamics in a Global Era. Singapore: NUS Press, pp. 284-319.

Er, K. (20I8) Growing a Biophilic City in a Garden [online]. Available at: https://www.csc.gov.sg/articles/growing-a-biophilic-city-in-a-garden\#notes (Accessed: May 2020).

Ewing, R and Handy S. (2009) 'Measuring the Unmeasurable: Urban Design Qualities Related to Walkability', Journal of Urban Design, I4(I), Pp. 65-84.

Goto, S. (2003) The Japanese Garden: Gateway to the Human Spirit. New York: P. Lang.

Gul, M., Dee, J., and Ozdemir, C. (2014) 'Istanbul's Taksim Square and Gezi Park: the Place of Protest and the Ideology of Place', Journal of Architecture and Urbanism, 38(I), pp. 63-72.

Hammitt, W.E. (2002) 'Urban Forests and Parks as Privacy Refuges', Journal of Arboriculture, 28(I), PP. $19-26$.

Hammond, T. (2019) 'The Politics of Perspective: Subjects, Exhibits, and Spectacle in Taksim Square, Istanbul', Urban Geography, 40(7), pp. 1039-54.

Harnik, P. (20I2) Urban Green: Innovative Parks for Resurgent Cities. Washington, DC: Island Press.

Hass-Klau, C. (1993) 'Impact of Pedestrianization and Traffic Calming on Retailing A Review of the Evidence from Germany and the UK', Transport Policy, I (I), pp. 2 I-3I.

Heat, H.S. (2019) DPM Heng Swee Keat at the "Building Our Future Singapore Together" Dialogue. Prime Minister's Office, Singapore [online]. Available at: https://www.pmo.gov.sg/Newsroom/DPM-Heng-Swee-Keat-Building-Our-Future-SingaporeTogether-Dialogue (Accessed May 2020).

Hee, L. and Ooi, G.L. (2003) 'The Politics of Public Space Planning in Singapore', Planning Perspectives, I8(I), PP. 79-103.

Hee, L. (2017) Constructing Singapore Public Space. Singapore: Springer.

Henderson, J. (2012) 'Urban parks and green spaces in Singapore', Managing Leisure, I8(3), Pp. $213-23$. 
Housing and Development Board, Singapore. (2020) Neighbourhood Centres [online]. Available at: https://www.hdb.gov.sg/residential/living-in-an-hdb-flat/my-neighbourhood/neighbourhoodcentres (Accessed June 2020).

Hsu, K. F. (2018) Urban Gems of San Francisco: Privately-owned Public Open Spaces (POPOS) [online]. Available at: https://www.youtube.com/watch? $v=J M U 2 w c N h S f Q$ (Accessed May 2020).

Hsu, K. F. (2020) 'Uniting Health, Mobility and Urban Resilience: Verified City Actions to Create Public Space for Walking and Biking During the Pandemic', Working Paper.

Johnson, N. (2002) 'Mapping Monuments: The Shaping of Public Space and Cultural Identities', Visual Communication, I (3) [online]. Available at: https://doi.org/I0.I I 77//477035720200I00302 (Accessed: May 2020).

Kang, J.C. (2020) 'Inequality Has Been Laid Bare by the Outbreak. Now What?' The New York Times, 20 May, Available at: https://www.nytimes.com/interactive/2020/05/20/magazine/covidquarantine-inequality.html (Accessed May 2020).

Khoo, T.C. (2017) Singapore: The First City in Nature? [online]. Available at: https://www.clc.gov.sg/research-publications/publications/digital-library/view/singapore-thefirst-city-in-nature (Accessed: May 2020).

Kwok C. and Chan N.K. (2020) 'The Making of Contentious Political Space: The Transformation of Hong Kong's Victoria Park', Space and Culture [online]. Available at: I0.1 177//20633 I2209/2160 (Accessed: May 2020).

Land Transport Authority, Singapore. (2020) Factsheet: Islandwide Cycling Network (ICN) Programme to Improve Safety and Connectivity for all Path Users [online]. Available at: https://www.lta.gov.sg/content//tagov/en/newsroom/2020/3/news-releases/islandwide-cyclingnetwork--icn--programme-to-improve-safety-and.html (Accessed June 2020).

Land Transport Authority, Singapore. (2018) 'LTA Completes $200 \mathrm{~km}$ of Sheltered Walkways Under Walk2Ride Programme', 2 September [online]. Available at: https://www.lta.gov.sg/content/ltagov/en/newsroom/2018/9/2/factsheet-lta-completes-200kmof-sheltered-walkways-under-walk2ride-programme.html (Accessed May 2020).

Laris, Michael. (2020) 'Cities are Closing Streets to Make Way for Restaurants and Pedestrians', The Washington Post, 25 May [online]. Available at: https://www.washingtonpost.com/local/trafficandcommuting/cities-are-closing-streets-tomake-way-for-restaurants-and-pedestrians/2020/05/25/Iflaf634-9b73-I l ea-ad098da7ec214672_story.html (Accessed May 2020).

Larson et. al. (2016) 'Public Parks and Wellbeing in Urban Areas of the United States', PLOS One, I I (4) [online]. Available at: https://doi.org/I0.137//journal.pone.01532II (Accessed: May 2020).

Lee, K.Y. (2000) From Third World to First: The Singapore Story-1965-2000. Singapore: Times Editions.

Lee, N. (2009) 'How is a political public space made? - The birth of Tiananmen Square and the May Fourth Movement', Political Geography, 28(I), Pp. 32-43.

Lennon, M., Douglas, and O., Scott, M. (2017) 'Urban Green Space for Health and Well-Being: Developing an 'Affordances' Framework for Planning and Design', Journal of Urban Design, 22(I) [online]. Available at: 10.1080/I3574809.2017. I336058 (Accessed: May 2020).

Liber Research. (2018) Genuine Options for Future Land Development: Research and Public Consultation 未來土地發展真實選項：好誠實研究及公眾諮詢 [online]. Available at: https://liberresearch.com/research-category/land-supply/ (Accessed: May 2020).

Low, S. (2008) 'The Erosion of Public Space and the Public Realm: Paranoia, Surveillance and Privatization in New York City', City \& Society, I8(I), pp. 43-9.

Low, S., Taplin, D. and Scheld, S. (2005) Rethinking Urban Parks: Public Space and Cultural Diversity. Austin: University of Texas Press.

Lund, H. (2002) 'Pedestrian Environments and Sense of Community', Journal of Planning Education and Research, $2 \mathrm{I}(3)$, PP. 30I-I2. 
Lutzoni, L. (2016) 'In-Formalised Urban Space Design: Rethinking the Relationship Between Formal and Informal', City Territ Archit, 3(20) [online]. Available at: https://doi.org/I0.1 186/s40410-016-0046-9 (Accessed: May 2020).

Maas J. et al. (2009) 'Morbidity Is Related to a Green Living Environment', Journal of Epidemiology \& Community Health, 63 (I2) [online]. Available at: 10.I I36/jech.2008.079038 (Accessed: May 2020).

Mason, R. (2006) 'Theoretical and Practical Arguments for Values-Centered Preservation', CRM: The Journal of Heritage Stewardship, 3(2), pp. 21-49.

McKenzie, T.L., et al. (2013) 'Neighbourhood Income Matters: Disparities in Community Recreation Facilities, Amenities, and Programs', Journal of Park and Recreation Administration, 3I (4), pp. I2-22.

Ministry of Environment and Water Resources. (2015) Our Home, Our Environment, Our Future. Sustainable Singapore Blueprint [online]. Singapore: Ministry of Environment and Water Resources. Available from: https://smartnet.niua.org/sites/default/files/resources/Sustainable\%20Singapore\%20Blueprint\% 2020I5.pdf (Accessed May 2020).

Ministry of Transport, Singapore. (2019) Government accepts Land Transport Master Plan 2040 Advisory Panel's Recommendations [online]. Government of Singapore. Available at: https://www.mot.gov.sg/news-centre/news/detail/government-accepts-land-transport-masterplan-2040-advisory-panel-s-recommendations (Accessed May 2020).

National Library Board, Singapore (2020) "Garden City" vision is introduced I I th May 1967 [online]. Available at: http://eresources.nlb.gov.sg/history/events/a7fac49f-9c96-4030-8709cel60c58d I5c (Accessed: May 2020).

National Parks Board, Singapore. (2020) City in Nature [online]. Available at: https://www.nparks.gov.sg/about-us/city-in-nature (Accessed: May 2020).

National Trust for Historic Preservation, United States and Edge Research. (2017) Millennials and Historic Preservation: A Deep Dive Into Attitudes and Values Results from an Online Survey of Millennials [online]. Washington, DC: National Trust. Available at: https://nthpsavingplaces.s3.amazonaws.com/2017/06/27/09/02/25/407/Millennial\%20Research\%20Report.p df (Accessed June 2020).

Nexbitt, L., et al. (2019) 'Who Has Access to Urban Vegetation? A Spatial Analysis of Distributional Green Equity in 10 US Cities', Landscape and Urban Planning, I8I (Jan), Pp. 5I79.

Oldenburg, R. (1999) The Great Good Place: Cafes, Coffee Shops, Bookstores, Bars, Hair Salons, and Other Hangouts at the Heart of a Community. Lebanon: De Capo Press.

Oldenburg, R. (2002) Celebrating the Third Place. Lebanon: De Capo Press. O'Sullivan, F. (2020). 'Paris Mayor Pledges a Greener 15 Minute City', Bloomberg, 18 February [online]. Available at: https://www.bloomberg.com/news/articles/2020-02-I8/paris-mayorpledges-a-greener-I 5-minute-city (Accessed May 2020).

Parkinson, J. (20I2) Democracy and Public Space: The Physical Sites of Democratic Performance. Oxford: Oxford University Press.

Peiser, R. and Schwann, G. (1993) 'The Private Value of Public Open Space Within Subdivisions', Journal of Architectural and Planning Research, I0(2), Pp. 9I- 104.

Peters, K., Elands, B., and Buijis, A. (20I0) 'Social Interactions in Urban Parks: Stimulating Social Cohesion?', Urban Forestry \& Urban Greening, 9(2), pp. 93-100.

Pilkington, E. (2020) 'Black Americans dying of Covid-19 at three times the rate of white people,' The Guardian, 20 May. Available at: https:/www.theguardian.com/world/2020/may/20/blackamericans-death-rate-covid-19-coronavirus (Accessed: May 2020).

Pomeroy, J. (20II) 'Defining Singapore Public Space: From Sanitization to Corporatization', Journal of Urban Design, 16 (3), Pp. 38I-396. 
Price, A (2018). We Need Complete Neighborhoods [online]. Strong Towns. Available at: https://www.strongtowns.org/journal/2018/2/6/complete-neighborhoods (Accessed June 2020).

Project for Public Spaces (2009) 10 Benefits of Creating Good Public Spaces [online]. Available at: https://www.pps.org/article/l Obenefits (Accessed: May 2020)

Reeves, B., et al. (2020) The Best Privately-Owned Public Open Spaces in SF [online]. Curbed San Francisco. Available at: https://sf.curbed.com/maps/sf-parks-private-popos-public-ownedspaces-downtown (Accessed May 2020).

Rowe, P. and Hee, L. (2019) A City in Blue and Green: The Singapore Story. Singapore: Springer.

Rupprecht, C.D.D. and Byrne, J.A. (20I4) 'Informal Urban Greenspace: A Typology and Trilingual Systematic Review of Its Role for Urban Residents and Trends in the Literature', Urban Forestry \& Urban Greening, I3(4), pp. 597-6 I I.

Seow, J. (2020) 'More Singapore Residents Working as Freelancers', The Straits Times, 3I January [online]. Available at: https://www.straitstimes.com/singapore/manpower/more-residentsworking-as-freelancers (Accessed May 2020).

SPUR. (2013) A Guide to San Francisco's Privately-Owned Public Open Spaces: Secrets of San Francisco [online]. San Francisco: SPUR. Available at:

https://www.spur.org/sites/default/files/migrated/anchors/popos-guide.pdf (Accessed May 2020).

Sturm, R. and Cohen, D. (20I4) 'Proximity to Urban Parks and Mental Health', J Ment Health Policy Econ, I7(I), pp. 19-24.

Taylor, D. E. (2009) The Environment and the People in American Cities, 1600s-1900s: Disorder, Inequality, and Social Change. Durham: Duke University Press.

Teo, P. (1997) 'Space to Grow Old In: The Availability of Public Spaces for Elderly Persons in Singapore', Urban Studies, 34(3), pp. 419-39.

Teo, G. (2019) "'45-minute city, 20-minute towns": Advisory panel outlines vision for Land Transport Master Plan 2040', Channel News Asia, 12 January [online]. Available at: https://www.channelnewsasia.com/news/singapore/45-minute-city-20-minute-towns-landtransport-master-plan-2040-I I I I 4494 (Accessed May 2020).

Thorpe, A. (2016) 'A Day for Turning Parking Spaces Into Pop-up Parks', The Guardian, I5 September [online]. Available at: https://www.theguardian.com/artanddesign/2016/sep/15/aday-for-turning-parking-spaces-into-pop-up-parks (Accessed May 2020).

Thralls, C. (2018) 'Urban Parks as Sacred Places: Pilgrimage, Solitude, and Access to Nature', Studies in Spirituality, 28, pp. 21 I-3I.

UNESCO. (2015) Singapore Botanic Gardens [online]. Available at: https://whc.unesco.org/en/list/l 483 (Accessed: May 2020).

University of Delaware. (2013) Complete Communities Toolbox [online]. Available at: https://www.completecommunitiesde.org (Accessed June 2020).

Valentino-DeVries, J., Lu, D., Dance, G.J.X. (2020) 'Location Data Says It All: Staying at Home During Coronavirus Is a Luxury,' The New York Times, 3 April, Available at: https://www.nytimes.com/interactive/2020/04/03/us/coronavirus-stay-home-rich-poor.html (Accessed May 2020).

Whyte, W.H. (1980) The Social Life of Small Urban Spaces. 200 I reprint. New York: Project for Public Spaces.

Yan, G. (2020) 'Public Engagement for Pasir Panjang Park Kicks Off Park Co-creation Programme', 18 January [online]. Available at: https://www.straitstimes.com/singapore/environment/publicengagement-for-pasir-panjang-park-kicks-off-park-co-creation-programme (Accessed: May 2020).

Zavattaro, S. (2019) Place Brand Formation and Local Identities. London: Routledge.

Zukin, S. (2012) 'The Social Production of Urban Cultural Heritage: Identity and Ecosystem on an Amsterdam Shopping Street', City, Culture and Society, 3(4), pp. 28I-29I. 


\title{
Agoraphobia: New York City Public Space in the Time of COVID-I 9
}

\author{
Miodrag Mitrašinović \\ Parsons School of Design, The New School \\ mitrasim@newschool.edu
}

\begin{abstract}
This paper explores how the first two waves of the Covid-19 pandemic (February May 2020) in New York City had magnified extreme polarization between two different visions of public space: one clearly represented by the Hudson Yards Plaza in Manhattan, and the other epitomized by the Corona Plaza in Queens. It argues that the phenomenon of agoraphobia, the fear of others, translates into the fear of public space and by extension the fear of democracy driven by deep anxieties surrounding the definition of "the social." This is clearly exemplified by Hudson Yards, which closed its doors to the public in May and approached early bankruptcy. On the other hand, Corona Plaza is still a vibrant public space providing vital social and community services. The Plaza was co-produced by the local communities, city agencies, the non-profit sector and public-private partnership, and it provides a resilient model for the production of public space in NYC. The paper argues that the process of producing an infrastructure of inclusion in Corona, which had preceded the construction of Corona Plaza and was strengthen through it, has enabled the Plaza to strive even during the Covid-19 pandemic.
\end{abstract}

Keywords: New York City, Corona Plaza, infrastructures of inclusion

To cite this article:

Mitrašinović, M. (2020). Agoraphobia: New York City Public Space in the Time of COVID-19. The Journal of Public Space, 5(3), 83-90, DOI 10.3289I/jps.v5i3.I36I

This article has been double blind peer reviewed and accepted for publication in The Journal of Public Space.

(i) $\$$ This work is licensed under a Creative Commons Attribution - Non Commercial 4.0 International License https://creativecommons.org/licenses/by-nc/4.0/ 
When the second wave of infections and hospitalizations hit New York City (NYC) in early May, it became evident that nearly sixty percent of new infections came from homes in low-income neighbourhoods, in overcrowded living situations, from northcentral Queens, southeast Brooklyn, and the Bronx. New York State Governor Andrew Cuomo was seemingly surprised to hear the news and said, "When you look at the racial breakdown of who is getting hospitalized, you'll see it is disproportionately minorities. Disproportionately African American and Latino. It always seems that the poorest people pay the highest price. Why is that?" asked Cuomo (NBC 2020). "Let's actually get research and data that can inform us as to why are we having more people in minority communities, more people in certain neighbourhoods, why do they have higher rates of infection," Cuomo said (NYI 2020).

The real question, however, is not 'why that is'-since research on the above is abundant and conclusions are clear-but 'what do we do about it?' And, importantly for this special volume of the Journal of Public Space, what does public space have to do with it?

In early May 2020, four billion people around the world are under lockdown orders due to the COVID- 19 pandemic. Most of the open and public spaces in our cities are deserted. But not all of them. Tracking cell phone location-data in NYC found that the movement of individuals in the top ten percent of the income bracket has come to a standstill, particularly after mid-March when forty percent of them left the city (Quealy 2020); whereas that of the bottom ten percent has increased (Valentino-DeVries et al 2020). Most of the "essential employees"-food-industry workers, police, firefighters, first responders, healthcare workers, delivery, security and maintenance personnel-are in the bottom ten percent and thus must continue to commute despite the risks.

Although overall ridership in NYC's public transportation system has plummeted by ninety percent compared to 2019, subway lines which connect low-income and immigrant neighbourhoods in the outer boroughs with places of employment remain crowded in peak hours. Along Subway Line 7 in Queens, the neighbourhoods of Elmhurst and Corona have been hit the hardest. As recent reports clearly show (Parrott and Moe 2020), many African American and Latino "essential employees" and their families who reside there have been disproportionally impacted by the pandemic. In recent years, the public space imagery symbolic of NYC has been that of the High Line and Hudson Yards. To most New Yorkers, these public spaces—both strongly supported and enabled by Governor Cuomo's administration-represent the Bloomberg-model of urban growth and governance (Brash 20II), and the corresponding radical polarization that has characterized urban development in NYC since 2001 .

Eight miles east of Hudson Yards, at the 103rd Street/Corona Plaza subway stop, along the "International Express" Line 7 (Tonnelat and Kornblum 20I7), one finds a very different model of public space. A quick look at the differences in demographics reveal a stark contrast: eighty four percent of Hudson Yards' residents are US citizens, and nearly seventy percent are US born, and their average annual income is US\$I6IK. Corona's average income is US\$45K, more than sixty percent of its (documented) residents are foreign born, and over twenty percent of them have become naturalized US citizens since 1990 (US Census 2019). Severe overcrowding, public health problems, limited sources of healthy food, outsized rent burdens, as well as a significant number of uninsured residents, make Corona a very fragile urban district. 


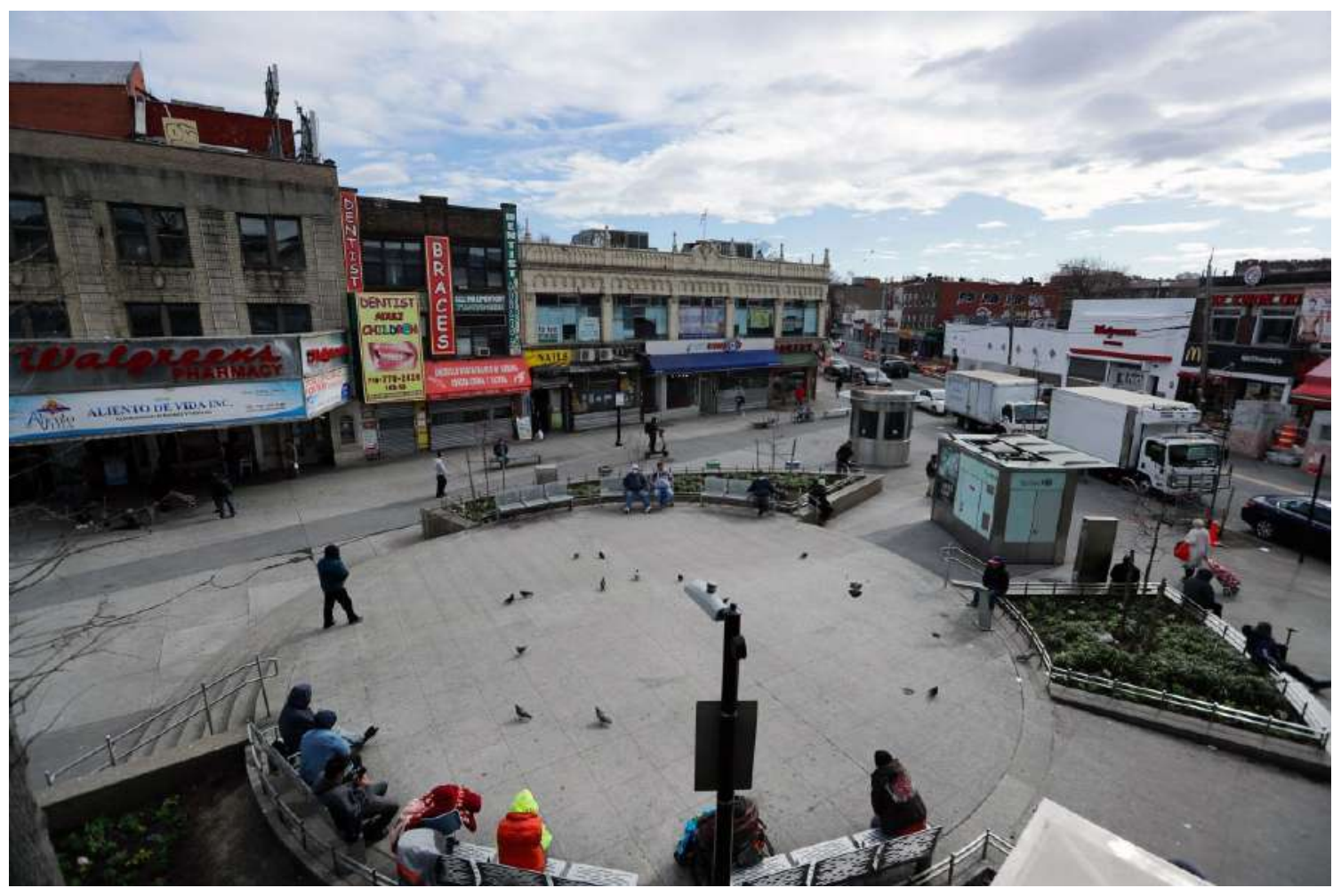

Figure I. Corona Plaza, Queens, April 2020. Photo Credit: Associated Press.

At the same time, the cultural vibrancy and variety of Corona has been well documented: its unique history as well as its cultural, ethnic and racial diversity. Corona Plaza' was developed starting in 2012 on the site of a local thoroughfare and a parking lot adjacent to the 103rd Street Station; a place where developers' trucks picked up daily laborers and food trucks and street vendors lined up along Roosevelt Avenue (Queens Museum of Art 2009). It was developed through the NYC Department of Transportation Plaza Program, through which they have transformed underused spaces adjacent to transportation stops and hubs into vibrant public spaces (NYC DOT 2020).

The program aims to ensure that all New Yorkers-particularly communities of colour and working-class neighbourhoods - live within a 10-minute walking radius from a quality public space. DOT's competitive application process prioritizes neighbourhoods that lack open space, and partners with local organizations and community groups which commit to operate, maintain and manage newly formed pedestrian plazas. In the case of Corona Plaza, the Queens Museum, Queens Economic Development Corporation (EDC), local community organizations, civil society associations, as well as local businesses came together to create a public space where diverse immigrant communities come together.

\footnotetext{
' Data and information used below is derived from public sources, media coverage, author's conversations with various protagonists, as well as from Mogilevich et al 2016.
} 
Agoraphobia: New York City Public Space in the Time of COVID-19

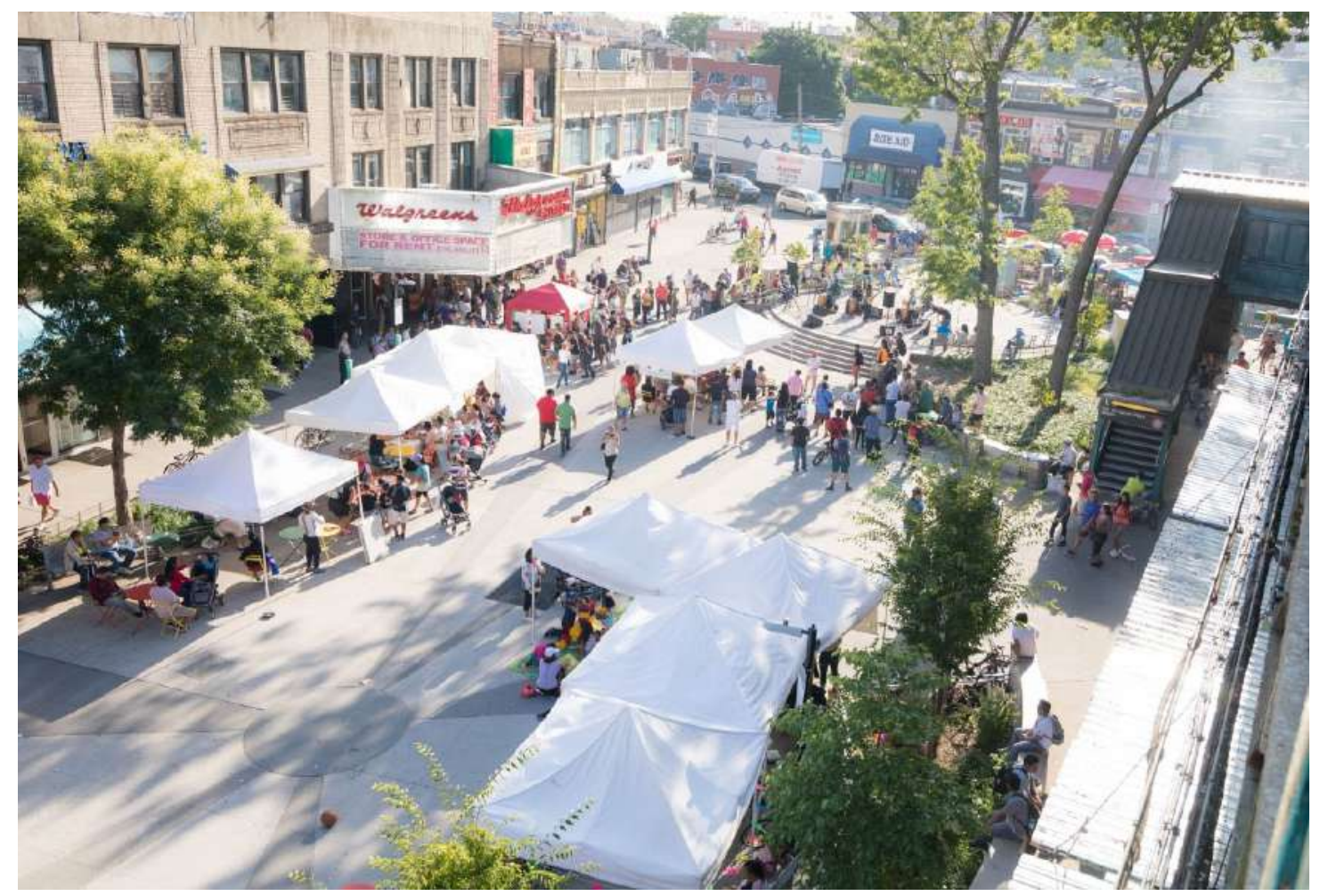

Figure 2. Corona Plaza, Queens, June 2019.

The Corónate festival. Photo Credit: Martin Bolivar and the Queens Museum.

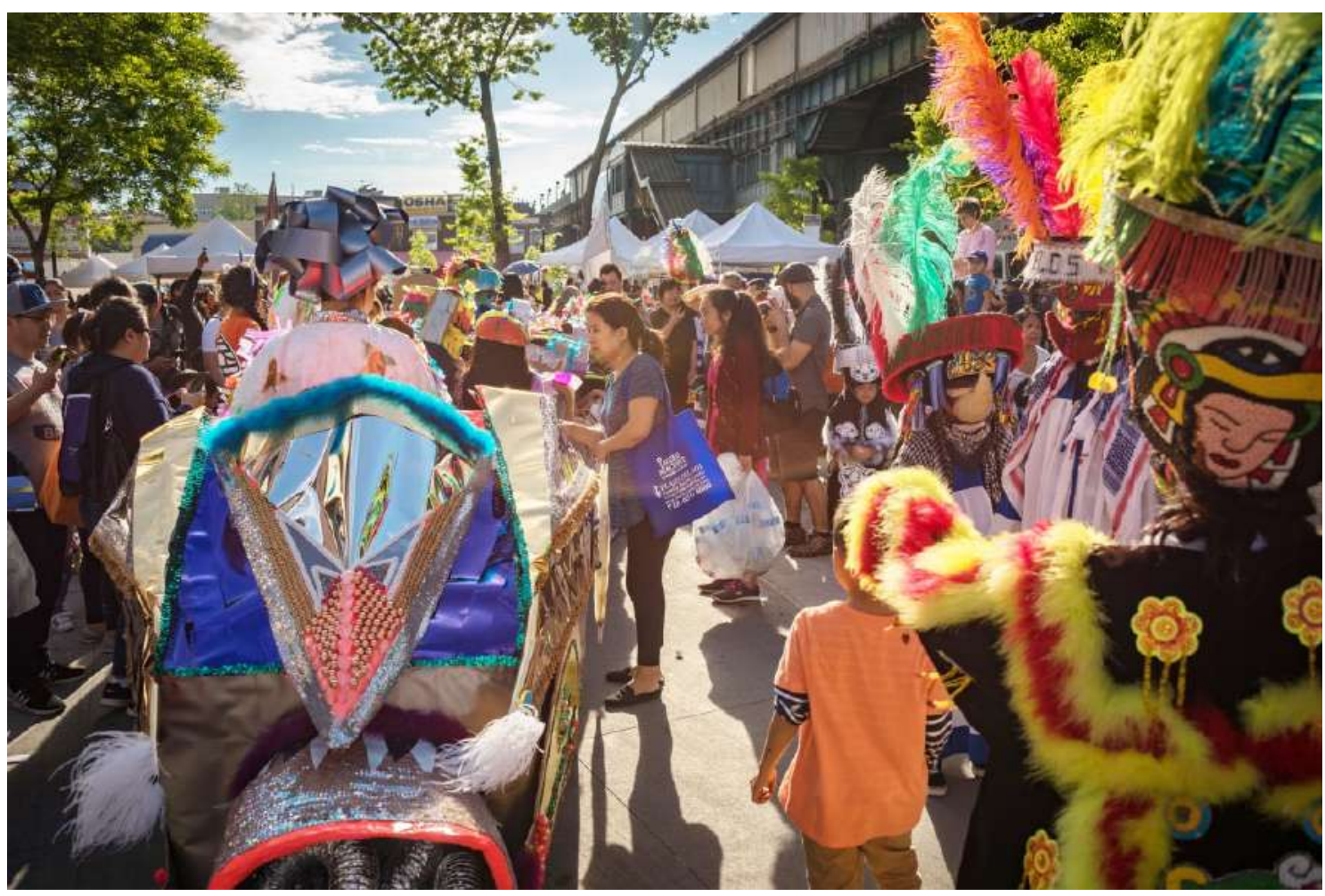

Figure 3. Corona Plaza, Queens, June 2019.

The Corónate festival. Photo Credit: Martin Bolivar and the Queens Museum.

86 | The Journal of Public Space, 5(3), 2020 | ISSN 2206-9658

City Space Architecture / UN-Habitat 
In neighbourhoods like Corona, a central plaza plays the key role as a catalyst for engaging residents in community development, a platform for developing and presenting local cultural producers, a site where community-based organizations could offer and promote social services, and a stimulus to promote health and wellbeing in immigrant communities surrounding the plaza (Mogilevich et al 2016).

As Alexandra García, Queens Museum's Community Organizer and the Corona Plaza Programs Coordinator suggested in 2012, "a dignified public space for immigrants gives more than it takes and offers opportunities of engagement and entertainment that inspire people as creators and participants rather than recipients of services or consumers" (Mogilevich et al 2016: 39). In 2018, after a comprehensive participatory process, Corona Plaza opened in its current configuration with year-long programming of cultural events. During March, April and May 2020 (at the time of this writing), Hudson Yards remains deserted, a ghostly monument to corporate greed and unethical governance, where urban and architectural forms follow finance, surveillance and data harvesting. Corona Plaza, on the other hand, remains active: less busy than usual, and without public events, but still pulsating with each passing of the 7 train. A thriving place only a few months ago, today caution, fear, lack of trust and carefully choreographed movements are evident. Altered food trucks sell personal protective equipment, fruit vendors wear masks and rubber gloves, while neighbours encounter each other with cautious affection.

And yet the paradox of the coronavirus-ravaged New York City is that nearly eighty five percent of all the hospitalized individuals are people who were neither working nor commuting - half being African American and Latino (Higgins-Dunn and Breuninger 2020). They were infected at home by family members who are either essential workers or have to maintain public presence in order to economically sustain family. In Corona, nearly one quarter of housing units are severely overcrowded with multiple generations living together ${ }^{2}$. When in an overcrowded neighbourhood people depend on access to public space in order to provide for their family, and when their families cannot attend public spaces due to the imposed restrictions, there is no feasible way to avoid subsequent infections in their homes.

In her 1996 book Evictions: Art and Spatial Politics, Rosalyn Deutsche titles the last chapter "Agoraphobia" (Deutsche 1996). Agoraphobia is an anxiety disorder induced by the panic fear of open spaces, public transit, parks or streets; basically, a fear of encountering others. As a result, agoraphobic individuals stay at home for extended periods of time and organize their entire lives away from others. In NYC today, even those who never suffered from agoraphobia find themselves avoiding others through panic manoeuvres in public spaces. Nearly sixty percent of low-income, working-class New Yorkers reported that at least one member of their family suffers from anxieties related to COVID-19 (Hester Street Collaborative et al 2020). The "other" is nearly everyone out there, a fact exacerbated by the erosion of trust across social and geographic scales.

\footnotetext{
${ }^{2}$ The NYC Department of Housing Preservation and Development defines a crowded apartment as one in which there's more than one person per room and a severely crowded apartment as one with more than I.5 people per room. Corona, Queens is one the most severely crowded neighbourhoods in NYC, with nearly twenty five percent of all residents living in severely overcrowded conditions. See: Hester Street Collaborative et al 2020.
} 
For Deutsche, agoraphobia translates into the fear of democracy. Namely, the fear of others, and by extension the fear of public space, is driven by deep anxieties surrounding the definition of "the social." Relentless escalation in degrees of inequality has already polarized the urban territory of NYC, and there is no doubt that the ongoing pandemic has intensified this situation. Agoraphobia, no longer just an individual anxiety but also the basis for a political ideology, has forced much of the narrowing down of the spaces of possibility-spaces where we should struggle to define who we want to be as individuals and as a society, what kind of city we want to live in, and how we want to live together. That's why Hudson Yards and Corona Plaza represent such a surreal contrast, and such conflicting political visions of urban life.

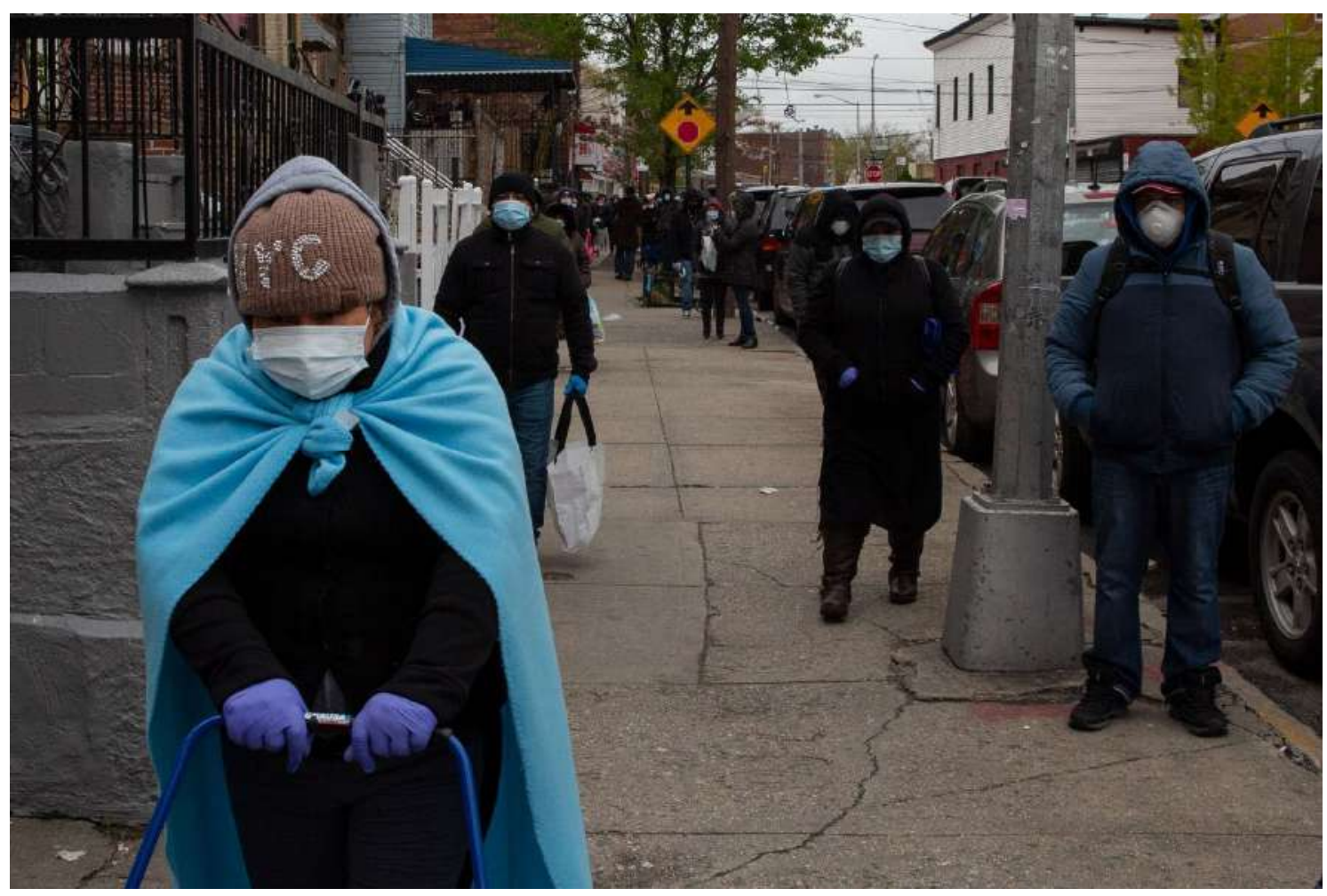

Figure 4: Corona, Queens, April 2020. People waiting for food in front of a community soup kitchen at a local church. Photo Credit: Ben Fractenberg@THE CITY.

How can public space post-COVID-19 be re-imagined as a catalyst for identifying the new meanings of the social, while simultaneously "putting it at risk?" (Lefort, as quoted in Deutsche 1996: 273; Lefort 1986). The only way will be to reject the agoraphobic bourgeois idea that public space is organized on the basis of a stable social consensus and argue that it ought to be configured on the basis of sustaining the search for the genealogies, trajectories and intersections of the struggles and conflicts that make urban life possible. In order to do just that we need democratically constituted public spaces. First, we must rebuild the trust.

What does Corona Plaza offer as a model for the post-COVID-19 conceptions of public space? May 2020 report Excluded in the Epicenter (Hester Street Collaborative et al 2020 ) indicates that during the pandemic, over sixty five percent of low-income, 
working-class New Yorkers have been supported by, and have received valuable information, financial support and critical community-based services from communitybased organizations. In Corona, community organizations not only support residents in time of crisis, but enable differentiated, multiple publics to come together in Corona Plaza, transcend the limitations of isolated communal spaces, and produce a true public space. What they create in the process is what I have elsewhere called "infrastructures of inclusion" (Mitrašinović 2016). Infrastructures are commonly thought of as systems, facilities, services, relations, networks and relationships, as well as the necessary interdependencies, which all cumulatively make a society sustain itself. Infrastructures of inclusion are the types of social-spatial-material infrastructures communities and civic groups build (Simone 2004) to catalyse and sustain processes of transformation-of themselves, their communities and their societies-towards more diverse, democratic, just and inclusive cities, based on the principle of "just distribution justly arrived at" (Harvey 1973: 84). Infrastructure is never only an ensemble of material things; its true character is always relational. In this context, the diverse communities and civic groups in Corona have for a long time been engaged in the praxis of infrastructuring (Manzini 2015) of generating novel configurative possibilities by catalysing processes of solidarity, cooperation, mutual aid, leadership and trust. They have been involved in a collective, collaborative and creative process of configuring new ways of becoming public by cocreating a unique public space.

\section{References}

Brash, J. (20II) Bloomberg's New York: Class and Governance in the Luxury City. University of Georgia Press.

Deutsche, R. (1996) Evictions: Art and Spatial Politics. MIT Press.

Harvey, D. (1973) Social Justice and the City. Johns Hopkins University Press.

Hester Street Collaborative, Make The Road New York, and Center for Popular Democracy (2020) Excluded in the Epicenter: Impacts of the Covid Crisis on Working-Class Immigrant, Black, and Brown New Yorkers. Hester Street. Available at: https://hesterstreet.org/wpcontent/uploads/2020/05/Excluded-in- the-Epicenter_final-compressed.pdf. Last accessed on 14 May 2020.

Higgins-Dunn, N. and Breuninger. K. (2020) "Cuomo Says it's 'Shocking' Most New Coronavirus Hospitalizations are People Who Had Been Staying Home,” CNBC News, 6 May 2020.

Available at: https://www.cnbc.com/2020/05/06/ny-gov-cuomo-says-its-shocking-most-newcoronavirus-hospitalizations-are-people-staying-home.html. Last accessed on 14 May 2020.

Lefort, C. (1986) The Political Forms of Modern Society: Bureaucracy, Democracy, Totalitarianism. MIT Press.

Manzini, E. (2015) Design, when Everybody Designs: An Introduction to Design for Social Innovation. MIT Press.

Mitrašinović, M. (2016) Concurrent Urbanities: Designing Infrastructures of Inclusion. Routledge.

Mogilevich, V. et al. (2016) Corona Plaza Es Para Todos: Making a Dignified Public Space for Immigrants. Queens Museum.

NBC (2020) "Who Are the New COVID- 9 Hospitalizations in New York? The Breakdown Is Worrisome," NBC 4 news, 6 May 2020. Available at: https://www.nbcnewyork.com/news/coronavirus/who-is-getting-hospitalized-for-covid-19-innew-york- here-is-the-breakdown/2405077l. Last accessed on 14 May 2020. 
NYI (2020) “Minorities Are Being Disproportionately Hurt by Covid-9 in New York City," NYI News, 8 April 2020. Available at: https://spectrumlocalnews.com/nys/centralny/politics/2020/04/08/minorities-are-being-disproportionately-hurt-by-covid-19-in-ny. Last accessed on 14 May 2020.

NYC DOT (2020) New York City Department of Transportation, Pedestrian Plaza Program Guidelines. Available at: https://wwwl.nyc.gov/html/dot/html/pedestrians/nyc-plazaprogram.shtml. Last accessed on I4 May 2020.

Parrott, J.A. and Moe, L. (2020) The New Strain of Inequality: The Economic Impact of Covid- 9 In New York City. Center for New York City Affairs, The New School. Available at: http://www.centernyc.org/reports-briefs/2020/4/I5/ http://www.centernyc.org/reportsbriefs/2020/4/I 5/the-new-strain-of-inequality-the-economic-impact-of-covid-19-in-new-yorkcity. Last accessed on 14 May 2020.

Quealy, K. (2020) "The Richest Neighborhoods Emptied Out Most as Coronavirus Hit New York City,” New York Times, 16 May 2020. Available at: https://www.nytimes.com/interactive/2020/05/I5/upshot/who-left-new-york-coronavirus.html.

Queens Museum of Art (2009) "Reflections from Naila Rosario, QMA's Community Organizer 2006-09," 9 November 2009. Available at: https:/queensmuseum.org/2009/I I/reflectionsfrom-naila-rosario-qmas-community-organizer-2006-09. Last accessed on I4 May 2020.

Simone, A.M. (2004) "People as Infrastructure: Intersecting Fragments in Johannesburg," Public Culture, 16(3): 407-429.

Tonnelat, S. and Kornblum, W. (2017) International Express: New Yorkers on the 7 Train. Columbia University Press.

US Census (2019) United States Census Bureau, New York City data. Available at: https://www.census.gov/quickfacts/fact/table/newyorkcitynewyork/PST0452I8. Last accessed on I4 May 2020.

Valentino-DeVries, J. et al (2020) "Location Data Says It All: Staying at Home During Coronavirus Is a Luxury,” New York Times, 14 May 2020. Available at: https:/www.nytimes.com/interactive/2020/04/03/us/coronavirus-stay-home-rich-poor.html. Last accessed on 14 May 2020. 


\title{
Observations on Access and Use of Public Space during COVID-I 9 in Hong Kong and Taipei
}

\author{
Ying-Fen Chen, Yu Sze Cheung, Hendrik Tieben \\ The Chinese University of Hong Kong, School of Architecture, Hong Kong SAR \\ aei.aurora@gmail.com | syscheung@cuhk.edu.hk | hktieben@cuhk.edu.hk
}

\begin{abstract}
This paper compares the conditions and related responses during the COVID-I9 pandemic in Hong Kong and Taipei, two cities which were among the first to be affected by the pandemic after the virus was first discovered in Mainland China. The cases of both cities offer interesting observations due to their earlier experiences with the SARS epidemic, which led to their prompt reaction, and helped to avoid general lockdowns and to keep most public spaces open. Public space, in the later discussion of worldwide pandemic, has been recognized as a crucial urban facility to mediate people's outdoor activities and secure health and wellbeing issues. The more detailed comparison, however, identifies specific issues particularly in Hong Kong, where, despite the generally low number of infections and fatalities, the severe pre-existing socio-spatial inequalities were further exacerbated and affected vulnerable groups, such as domestic workers, elderly and urban poor. At this early stage, the paper aims to identify which policies have helped most, and which challenges would need to be addressed to improve people's health and wellbeing and prepare better for future crises, particularly in the aspect of public space. The study of these two highly urbanized and densely populated cities is also relevant for the current debate about the relationship between urban density and pandemics, as both cities demonstrate that through decisive actions and civic responsibility, infection numbers could be kept comparably low.
\end{abstract}

Keywords: Hong Kong, Taipei, public space, health and wellbeing, COVID-19 pandemic

To cite this article:

Chen, Y. F., Cheung, Y. S., Tieben, H. (2020). Observations on Access and Use of Public Space during COVID-19 in Hong Kong and Taipei, The Journal of Public Space, 5(3), 9I-I04, DOI I0.3289I/jps.v5i3.I38I

This article has been double blind peer reviewed and accepted for publication in The Journal of Public Space. 
COVID- 19 took the world by surprise in 2020, as of 20 July, there are over 14.34 million cases confirmed worldwide, with 603,69l deaths (World Health Organization, 2020). What also took the world by surprise is the low number of confirmed cases and deaths in Hong Kong ( 1,886 cases and 12 deaths) (Centre for Health Protection, 2020) and Taiwan (455 cases and 7 deaths) (Taiwan Centers for Disease Control, 2020a)', two places with close proximity and ties with Mainland China, where the first cases of COVID-19 were identified in late 2019. Both places swiftly contained the pandemic, flattened the curve and transmission rate. Many accounts the success to experiences and learnings from SARS, as both governments swiftly responded to the crisis with wellcoordinated mechanisms, leading to stringent travel and quarantine controls, extensive contract tracing and testing, physical distancing measures supported by a collaborative response by the civil society. Larger community outbreaks have been prevented so far, and thus, in contrast to many other places, both Hong Kong and Taipei did not go through a de facto lockdown. While school teaching went online in Hong Kong, in Taipei it was still conducted face-to-face, businesses were encouraged to allow workfrom-home practices, and citizens were recommended to wear masks in public spaces and keep appropriate physical distance, yet most restaurants and businesses remained open, and, in contrast to many other cities worldwide, access to public spaces was not drastically affected. This is even more remarkable considering the high urban density of both cities and the related difficulties for physical distancing.

This article, written during the ongoing pandemic, shares observations of the use of public space in these two cities, trying to pinpoint issues that have emerged. These issues reflect how the city's urban environment as well as specific policies affect the population's health. Although the two cities launched similar policies of epidemic control in the beginning, subsequent policies regarding public spaces-as specific locations with both the risk of community outbreak and the opportunity of keeping people physically and mentally healthy-were established based on the urban spatial differences and similarities in Hong Kong and Taipei (urban density, condition of public spaces, major urban issues, etc.). The comparison of these policies should be understood to further improve pandemic preparedness and overall well-being of the population.

\section{Developing Epidemic Prevention Strategies from the 2003 SARS Experience Both Hong Kong and Taipei were seriously hit by the Severe Acute Respiratory Syndrome (SARS) in 2003, which also was first identified in Mainland China, causing a deep fear in the population of the disease. These experiences transformed the cities' public health systems, and more importantly, people's mindset and values. In Hong Kong, a new Infectious Disease Centre was built, and the Centre for Health Protection (CHP) was established under the Department of Health in 2004. Likewise, to develop a thorough prevention system, a novel governmental sector, the National Health Command Centre (NHCC) was established in Taipei in 2004 (Taiwan Centres for Disease Control, 2018). These two centres played an important role in the response to the COVID-19 pandemic by coordinating the efforts of academics, health practitioners}

\footnotetext{
I Taiwan is considered by Mainland China and UN as a province of China, which statement is either debating or disagreeing in other contexts around the world.
} 
and the government, and hosting daily media conferences to report on the latest COVID-19 updates. In addition, microbiologists and scientists published important findings during and after SARS and became international key opinion leaders people listened to this time. The general public gained essential hygiene knowledge and acted readily as another pandemic hit Hong Kong and Taipei again after 17 years.

Such experiences meant prompt response in the current health crisis for both cities. The Hong Kong government's first step was to exercise tracking and quarantine control from the start of COVID-19. Preparedness and response plan was launched as early as 4 January 2020 when Hong Kong had no confirmed case yet. On the same day, "serious response level" was also launched, a steering committee was formed to coordinate response work. ${ }^{2}$ In Taipei, the government also leveled up in the beginning of January. The Centres for Disease Control and Prevention (CDC) under NHCC was in charge of coordinating prevention strategies and considered border control as a top priority (The Reporter, 2020). ${ }^{3}$ By 25 March, all non-Hong Kong residents were not allowed to enter Hong Kong, similar restrictions were implemented in Taipei.

On the community level, wearing masks was the first reaction of people in Hong Kong and Taipei, causing panic buying and mask shortages. To ensure citizens all have access to masks, CDC in Taipei established a series of mask policies as the first action of epidemic prevention. Since 24 January, export of medical masks was banned for one month and was extended afterwards. The government controlled the mask production lines and market by regulating prices and distribution approaches, assuring that hospitals and clinics could get enough masks for medical uses, while guaranteeing citizens a certain number of masks every week (Chen and Hau, 2020). As the National Health Insurance $(\mathrm{NHI})$ provides every citizen with a social insurance plan, every citizen has a complete medical record since 1995. Based on this system, the government could regulate the masks distribution and purchase. In addition to citizens registered with $\mathrm{NHI}$, the government designed various approaches for non-citizens such as migrant workers and other foreigners to enable them to buy masks (National Health Insurance Administration, 2020). ${ }^{4}$ These responses created trust in the government's handling of the crisis in Taipei (Zheng Wei, 2020) ${ }^{5}$. In addition to the government's policy of masks control, individual technicians created several online maps based on the mask storage

\footnotetext{
${ }^{2}$ On 25 January, a ban of direct flights and high-speed rail to and from Wuhan was issued, and to counter the second wave of infections, a ban was issued on 25 March and all non-Hong Kong residents coming from overseas countries or territories arriving at the airport were not allowed to enter the city, makeshift virus test centres were set up. Since then, home quarantine entries were tracked via the newly invented wristbands and mobile app. All close contacts of confirmed cases were tracked and sent to testing, and if necessary, quarantines.

${ }^{3}$ The government began requiring citizens arriving from Hubei Province submitting travel reports at the customs and beginning to track the people under quarantine by electronic monitoring system on 28 January. Later on 2 February, citizens from Mainland China were banned from entering; 8 February, all kinds of transportation to Mainland China were suspended; and ultimately on 18 March, all non-citizens were banned from entering Taiwan while citizens traveling back were required quarantine for 14 days.

${ }^{4}$ From 9th April onward, Citizens living overseas, were allowed to receive a certain number of masks from relatives in Taipei.

${ }^{5}$ The press launched an opinion poll about the people's satisfaction of the government's reaction to COVID-19 specifically in the aspect of mask policy, which showed that around 70\% residents were standing for this policy.
} 
estimating system published by the government to help people purchase masks from available pharmacies efficiently (Shiroma, 2020).

In Hong Kong, the situation at the arrival of the pandemic was different as the territory had just experienced over seven months of political unrest (Lam, Sum and Ng, 2019).

Before this political backdrop, parts of Hong Kong's population criticized the government for the lack in the provision of hygienic items such as masks and disinfectant hand wash in the first months of the crisis, as well as the strongly increased prices of these essential items. Even for medical staff, it had been difficult to get adequate protective items, so that their union had to pressure the government to increase supply (Rizzo and Hersher, 2020). After two infection waves had passed, on 5 May, the Hong Kong government announced that all residents could apply for free reusable CuMask+ ${ }^{\mathrm{TM}}$, a commissioned project initiated by the Innovation \& Technology Bureau. The masks were distributed to citizens by online registration, stormed concerns over privacy and queries over the effectiveness of the mask due to inconvenient and impractical procedures for cleaning (Ho, 2020; Zhang, 2020).

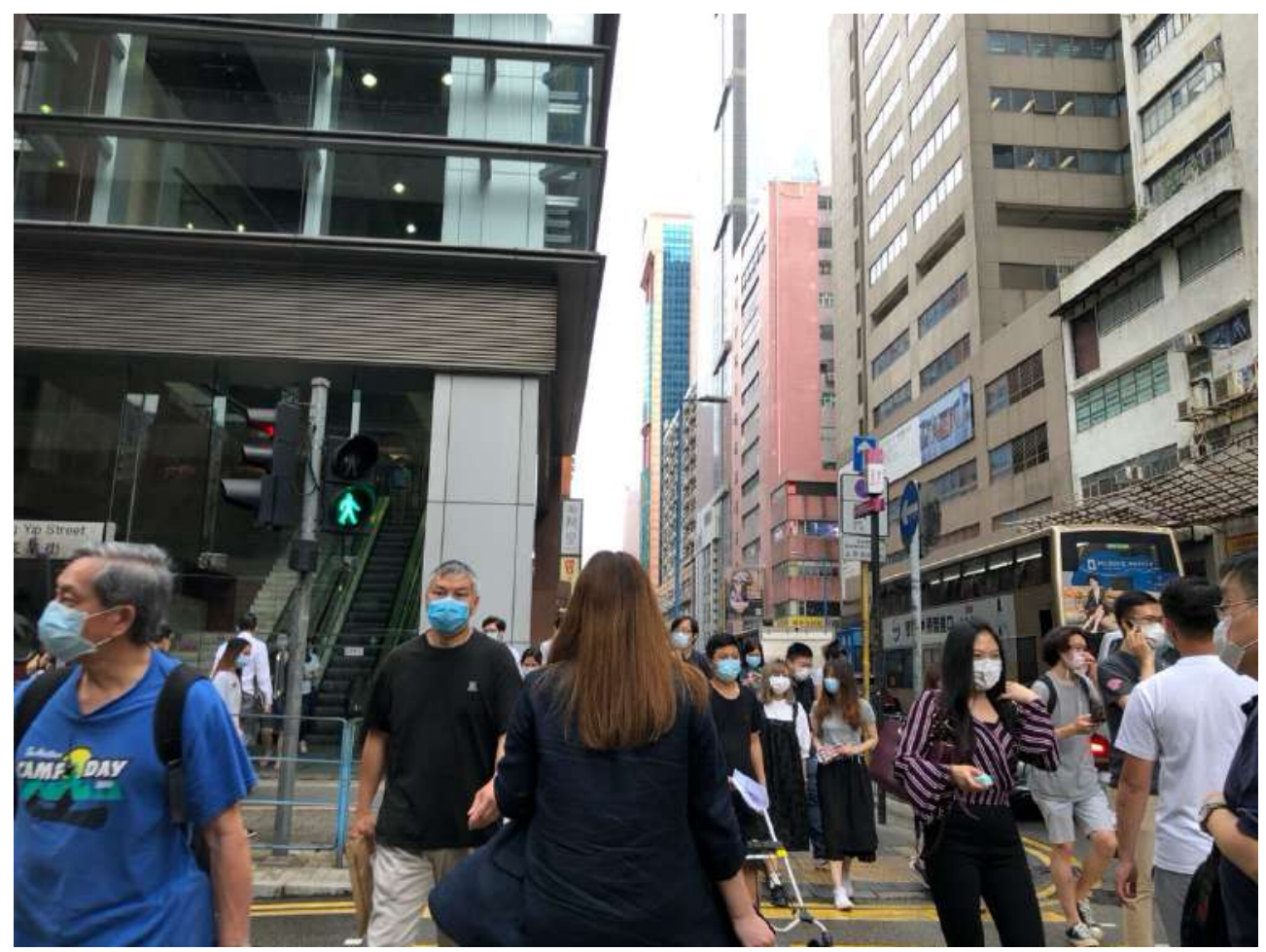

Figure I. Street crossing in Kwun Tong, Hong Kong (May 2020).

\section{Approaches on Regulating Large-Scale Activities and Physical Distancing}

Despite the above difficulties in provision of protective gear in the first months, the overall swift actions in both cities prevented (up to the point of writing) wider community outbreaks. Thus, Hong Kong and Taipei did not experience lockdown or shelter-in-place regulation as many other cities worldwide. In Taipei no large-scale bans or enforced closures of public or private commercial spaces were issued. The government suggested citizens to wear masks in hospitals and crowded indoor spaces, 
such as department stores, theatres, museums, campus buildings, during the first wave of infection (Taiwan Centres for Disease Control, 2020b). Also, the highly frequented mass-transit systems in both cities remained open. After the second wave hit Taipei in mid-March, with the return of overseas citizens from more affected areas, citizens were required to wear masks on public transportation and most indoor public spaces (Strong, 2020). After the second wave of infections in Hong Kong in late March, more stringent physical distancing restrictions were imposed to reduce the chance of larger community outbreaks ${ }^{6}$. The Hong Kong government also announced the closure of bars, beauty parlours, clubhouses, nightclubs, as well as premises for karaoke, mahjong tin-kau and massage, and premises selling liquor. In addition, it imposed a ban for gatherings with more than four people in public spaces. Public facilities such as libraries, study rooms, museums, playgrounds, sports centres, and alike in Hong Kong were closed for most of the time, while public services such as child-care centres and day-care centres for elderly were also affected. These bans and closures have gradually been lifted and relaxed since 9 May. Due to a third wave of infections in Mid-July, tighter restrictions were implemented again, in addition to all types of premises' closure, and for two days restaurants had to cease dine-in services. Also, a mandatory mask-wearing policy was imposed in all public indoor and outdoor spaces, and group gatherings were limited to two persons.

Citizens in Hong Kong and Taipei largely complied with physical distancing measures implemented and suggested by the governments. Over $95 \%$ of Hongkongers wore masks (Zheng, 2020), avoided social gatherings and meetings, worked from home, and stayed at home even before the compulsory physical distancing rules kicked in. Essential practices such as washing hands, washrooms hygiene, improving toilet pipes all helped, according to Dr Ho Pak-Leung, Head of University of Hong Kong's Centre for Infection. The discussions of physical distancing and lock-down also emerged in the organization of large-scale religious activities which traditionally are celebrated in the first months of the year. Outside of Taipei, many traditional festivals were affected, such as the Mazu Festival and Pilgrimage. During the rituals, devotees traditionally gather and follow the gods in a large parade, some of these rituals have become large-scale festivals attracting believers and tourists. In February, due to the fear of COVID-19, the organization of these festivals became the centre of debates in the news and social media. Some temple managers considered the high amount of already-made expenses and expected the rituals would potentially bring power over the virus. However, the public believed that cancelling this year's festivals would be the only way to avoid a community outbreak. Eventually, the government abstained from emergency orders to cancel the festivals, but temple managers ultimately took the advice from the CDC and cancelled the event under public pressure. Meanwhile in Hong Kong, all large-scale events and religious activities were cancelled to comply with the government's physical distancing measures.

\footnotetext{
${ }^{6}$ Made by the Chief Executive in Council under section 8 of the Prevention and Control of Disease Ordinance (Cap.599) (Or Cap. 599).

${ }^{7}$ Premises include amusement game centres, bathhouses, fitness centres, places of amusement, places of public entertainment, party rooms, clubs or nightclubs, karaoke establishments, mahjong-tin kau premises, beauty parlours, massage establishments, sports premises and swimming pools.
} 
These examples present the key aspect of the success in both cities: The governments imposed responsive and stringent regulations, while informed residents followed widely the regulations as they appealed to their own sense of civic responsibility (Shan, 2020).

\section{People's Use of Public Space under the Pandemic}

While these measures in both cities could be seen as an overall success, certain challenges are observed below and will be further studied in follow-up papers to improve preparedness for future pandemics. These challenges are linked to three factors: (I) the general lack of sufficient and appropriate public and private space, particularly in view of the extreme urban density of Hong Kong; (2) the social polarization and health disparity exacerbated by the pandemic; and (3) the insufficient and uneven access to health provisions (e.g. health insurances, testing, and masks) as well as access to internet.

Both cities are very densely populated: with Hong Kong having an average density of 6,940 people per sq. $\mathrm{km}$, with the densest district reaching 61,560 people per sq. $\mathrm{km}$ in 2019 (Census and Statistics Department HKSAR, 2020); while Taipei has an overall density of 9,918 people per sq. $\mathrm{km}$, the most densely populated district reached 27,418 people per sq. km in 2016 (Taipei City Government, 2017). Residents in Taipei enjoy 5.7 sq. $\mathrm{m}$ of open space (including green space) per person in 2018 (Public Works Department Taipei City Government, 2019). Hong Kong's Planning Department Guideline requires 2 sq. $\mathrm{m}$ of open space per person, in the poorer and highly dense districts the open space amount per person is much lower in reality (Chow, 20I8), a stark contrast with the standard of World Health Organization at 9 sq. $\mathrm{m}$ per person. According to a recent report, open space in Hong Kong is also highly unequally distributed (Lai, 2017). This is particularly critical in Hong Kong as average living space per person is only 170 sq. $\mathrm{ft}(\sim 15.8$ sq. $\mathrm{m})(\mathrm{Ng}, 20 \mathrm{I})$, even worse, 209,700 people live in subdivided units with a median living space of $57 \mathrm{sq} . \mathrm{ft}(\sim 5.3 \mathrm{sq} . \mathrm{m})$ per person (Census and Statistics Department HKSAR, 2018).

These crammed living conditions made neighbourhood public spaces essential breathing spaces before COVID-19, and even more so during the pandemic when many other public facilities and school premises were closed. Even though these public spaces are not ideal, people needed them to exercise and get fresh air especially during the pandemic. Yet, the distribution of public spaces in the dense urban areas in Hong Kong is mostly scattered and individual spaces can only be reached via crowded streets with narrow sidewalks. The implementation of mandatory mask-wearing in public space further exacerbated the issue of accessibility. Particularly in the poor neighbourhoods in early days of the outbreak, residents could not afford masks and sanitizers as the prices spiked up. Hong Kong's large country parks and greeneries, which take up three quarters of the territory, became a significant refuge with parts of the population flocking to these green spaces during weekends and public holidays. However, vulnerable groups might not be able to reach these country parks because of various difficulties, such as long working hours, expensive transportation costs, lack of information, physical disabilities, etc.

In Taipei, planning initiatives had started to create and connect large public space networks along the waterfronts as well as within the urban areas; and streets in older districts often have no separations between pedestrians and cars, allowing people to extend their activities into the car-lanes if needed. Large investments into a continuous 
system of riverside parks created a large public space infrastructure, which include wetland areas with bicycle lanes and spaces for a high diversity of outdoor sports and activities. These riverside areas were separated from the urban space by dikes to prevent Taipei from flood disaster before the 1980s. However, as traditional ideas of flood prevention changed, these spaces between the city and the river were redesigned to public parks during normal days and retarding basins during typhoon season (Yau, 200I). As community outbreaks were avoided and masks made available for all income groups, this system that supposed to create the city's resilience to flood disaster was heavily used during the pandemic and provided alternative transport-options and spaces for physical exercise and mental relief. Moreover, to develop a sustainable and green urban environment as well as reinforcing residents' physical and mental health, Taipei City Government established a bicycle-sharing system "YouBike" in 2012 (YouBike Co., 2020). From January to March 2020, the bikes were borrowed 200,000 times more than the same period in 2019, with a significant decrease of people taking public transportation like buses and MRT as they were considered high-risk spaces for virus transmission (Tsai, 2020).

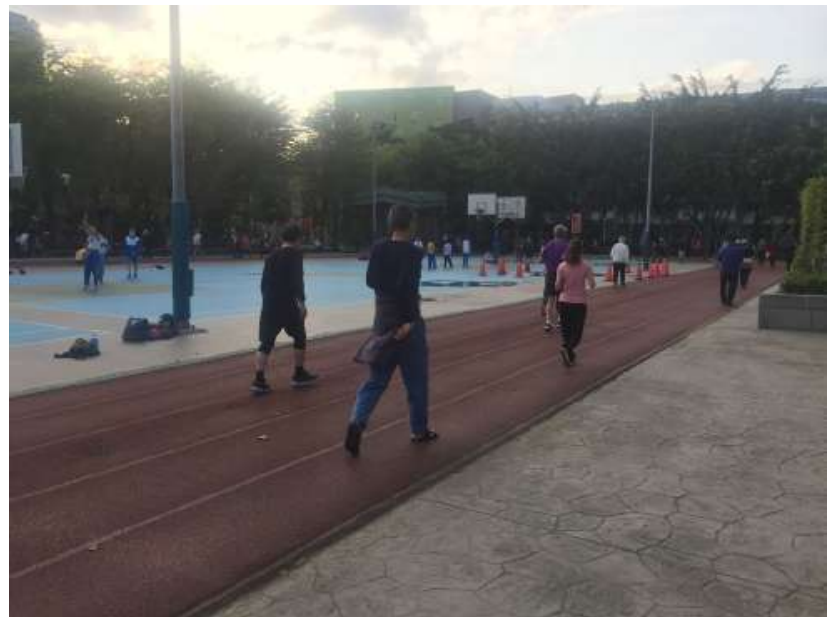

Figure 2. Most of Taipei's public spaces remained open throughout the pandemic for residents to exercise and relax (photo April 2020).

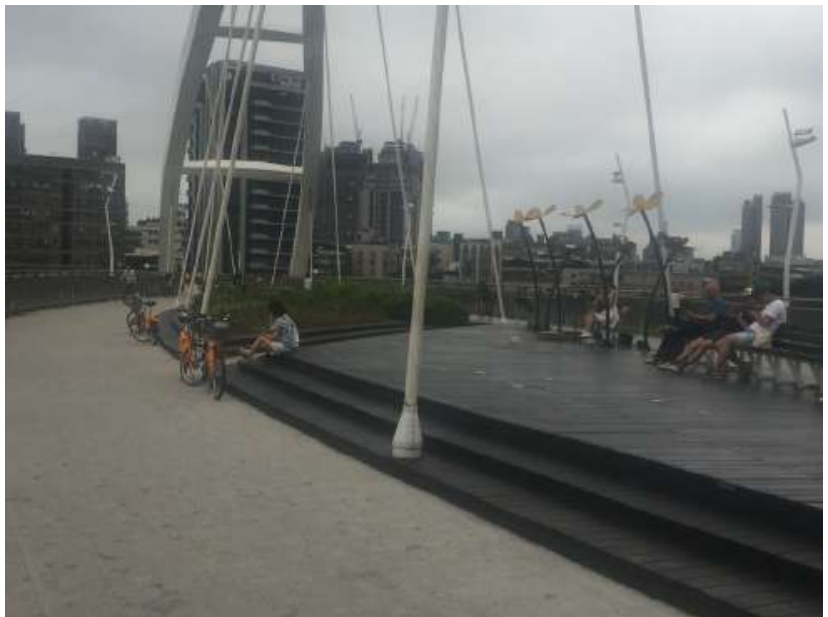

Figure 3. The bike lanes and share bike system in Taipei became even more popular during the pandemic. New public spaces such as pedestrian and cycle bridges became favourite places for people to rest (photo May 2020).

The Google Mobility Report also shed light on and confirmed observations on how citizens responded to physical distancing guidelines and alluded to remarkable differences between the two cities. Hong Kong citizens' movement significantly dropped (35\% in retail \& recreation, $37 \%$ in public transport, $30 \%$ in workplace, and $26 \%$ in parks), and a 19\% increase in residential areas (Google, 2020a), whereas in Taiwan ${ }^{8}$ there actually was a $6 \%$ increase in the movements to parks, and only a slight drop of $2 \%$ in retail \& recreation (Google, 2020b) (as of 21 July 2020). Except preventive steps like testing body temperature, cleaning hands with $75 \%$ methanol, and wearing masks as suggested by the government and initiated by citizens before getting into indoor (semi-

\footnotetext{
${ }^{8}$ See the first footnote for more clarification.
} 
)public spaces like restaurants, stores, museums, movie theatres, governmental buildings, people's behaviours in open-air public spaces in Taipei seemed not to change significantly during the pandemic. More people spent time on outdoor activities with the belief to stay healthy during the pandemic, as shown in the Google Mobility Report. This suggested a general sentiment of the population in Taipei to consider open-air public space as less risky for COVID-19 transmission, it also attributed to the general trust in the government's recommendations on where and when to wear masks. In addition, because the CDC provided information (anonymously) about confirmed infection cases and the places which infected persons had visited during their I4-days COVID-19 incubation period, people would avoid, if possible, such places until the end of the 14days period (Taiwan News, 2020). Due to the CDC's strategy to close places for a short period of time only after the rare cases of confirmed infections, people's daily activities in public open space did not significantly change in Taipei under COVID- 19.

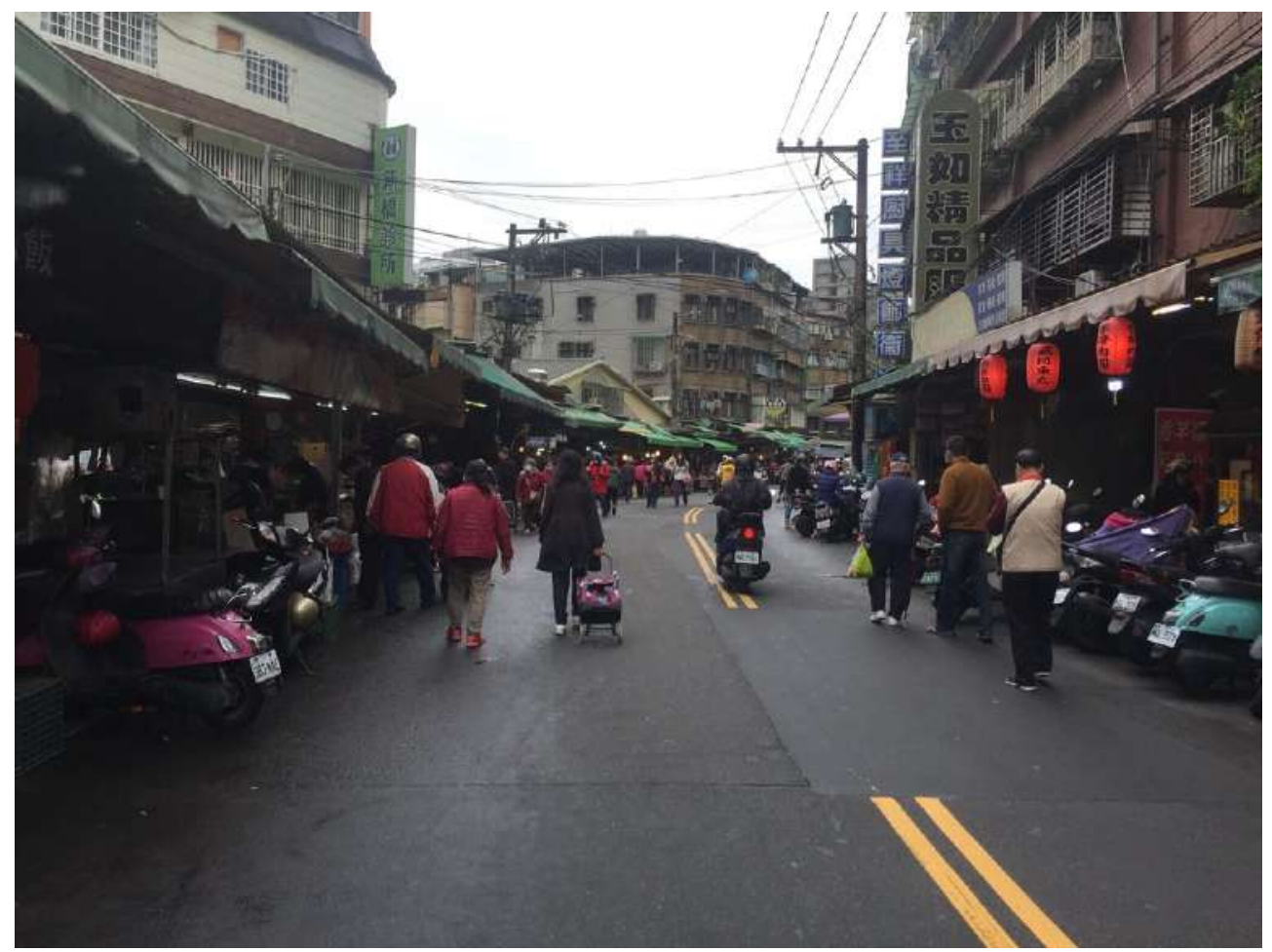

Figure 4. While restaurants remained open in Taipei, many residents bought ingredients in the markets and cooked at home. As smaller streets in the older districts have often no rigid separations between pedestrians and vehicles, people took over the streets, while vehicles adopted (April 2020)

Despite the similar behaviour and usage of public space in Taipei, significant differences can be identified regarding health disparity and access to public space between the cities, particularly affecting vulnerable groups in Hong Kong. Over the last years, Hong Kong's Gini coefficient increased to 53.9 (Central Intelligence Agency, 2016), one of the highest in Asia and indicating severe social inequality. I.3 million of Hong Kong's 7.45 I million inhabitants live in poverty (2018). In contrast, The Gini coefficient reaches only 33.6 (Central Intelligence Agency, 20I4), indicating a far more balanced society of 
Taipei. As mentioned above, in Taipei, all citizens and documented residents are protected by the $\mathrm{NHI}$, guaranteeing access to public and private medical services at highly subsidized rates. Hong Kong has a volunteer health insurance scheme, and all identity card holders are entitled to subsidized services only in public hospitals. During the current health crisis, Hong Kong's vulnerable groups like elderly, lowincome families, subdivided units' residents, homeless, migrant workers, and newly unemployed are more severely affected. Many tried to stay home if possible, to reduce the infection risk, and had no access to masks or reused masks for many days. This, in addition to long working hours, affected their access to public space and country parks (which are normally at the periphery of the city and would incur transportation time and costs as mentioned), which have proven generally to be positively correlated to one's well-being. Moreover, in Hong Kong's highly dense living environment, staying at home could be highly stressful. According to Professor Paul Yip Siu-fai, director of the University of Hong Kong's Centre for Suicide Research and Prevention, "Many people in Hong Kong live in small homes, and the stay-home advice as well as the suspension of public services have entrenched inequality in the city." (Ting, 2020).

The Sunday gatherings of Hong Kong's 400,000 domestic workers in public streets and spaces, parks, promenades as well as footbridges were common scenes in Hong Kong before the pandemic. The "four-people ban", recently limited to two, meant that most of the domestic workers had to stay at "home" on their only day-off. As they generally live with their employers, staying at "home" on their day-off blurred the line between work and rest. Cases had been reported in which domestic workers were not allowed to leave the house on their weekly day-off, forced to continue working, or were asked to resign if they would go out. In fact, according to a survey conducted by Asian Migrants Coordinating Body in March, 2020 with over I, I 27 workers, 20\% were not "given their weekly rest day or got less than what they should get this past month", $25 \%$ who stayed at home on their day-off were asked to work.

Meanwhile in Taipei, the government decided to ban specific large-scale activities in certain public spaces after related cases were confirmed. For example, when a migrant caregiver tested positive for COVID-19 on 26 February (Everington, 2020), the government began banning people's gatherings in the Taipei Main Station Lobby, usually a highly frequented gathering place for migrant workers (Huang, 2020). Such regulations caused citizen protests, and the station lobby was redesigned while the epidemic has been controlled to welcome the public and a wide range of activities.

The restricted opening hours of third spaces such as restaurants and privately-owned public spaces also affected the vulnerable parts of the population in Hong Kong. Some 448 homeless who slept regularly at McDonalds, also known as McRefugees, had to go back onto the streets as the chain had to close their outlets at 6pm for two weeks in late March. The closing of public facilities such as showers at sport centres also affected homeless who had relied on them. (Low, 2020) When the third wave hit and all restaurants had to close temporarily their dining spaces, this group, in addition to bluecollar workers, faced extreme difficulties finding safe spaces to stay and eat respectively. 
Observations on Access and Use of Public Space during COVID-19 in Hong Kong and Taipei

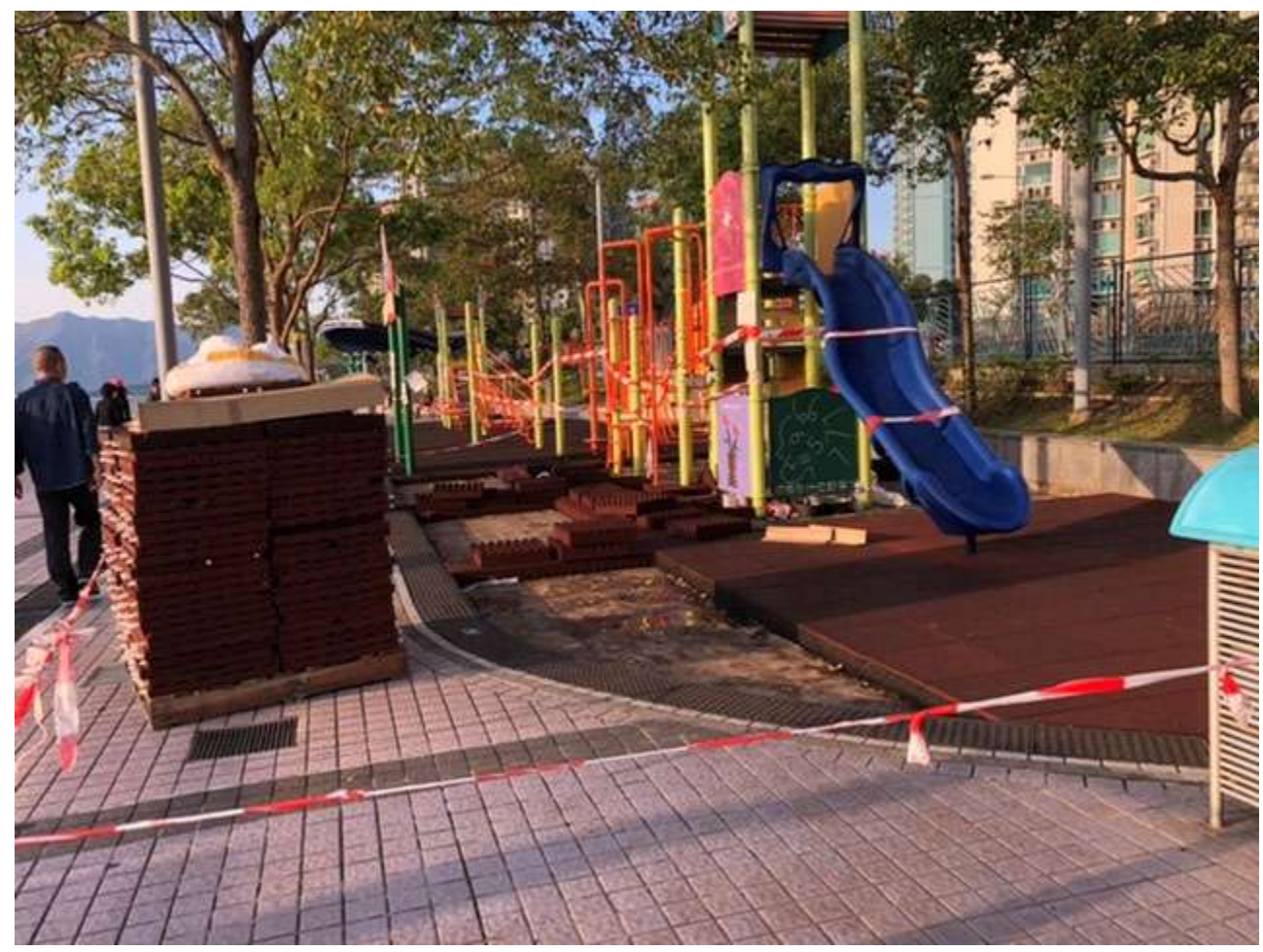

Figure 5. Closed playground at the waterfront in Ma On Shan, Hong Kong (April 2020).

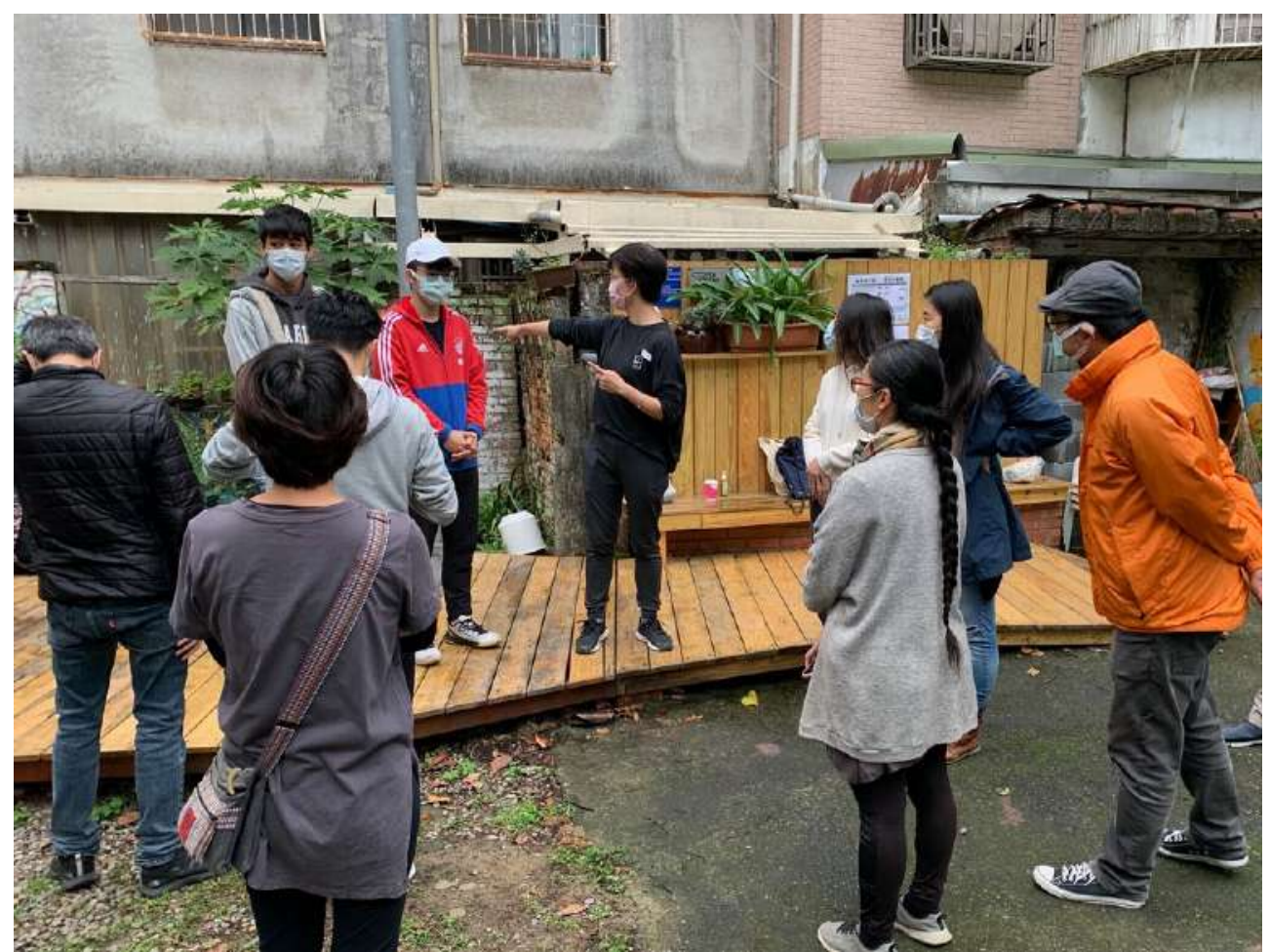

Figure 6. Community gardening events in Taipei continued under the pandemic, however, in early April, due to the second infection wave, participants were asked to wear masks and provide contact details in case of infection cases (photo April 2020). 


\section{Takeaways and Preliminary Considerations for Future Pandemic Preparedness}

Hong Kong and Taipei showed how swift responses by the governments and civil societies helped to avoid de facto lockdowns and community outbreaks, and to keep numbers of infections and deaths low. Their example also demonstrates that high urban density does not necessarily lead to higher infection numbers. Yet, the current pandemic also revealed underlying social challenges, if not well addressed, could undermine cities' pandemic preparedness and resilience. Public space is inevitably constructing crucial parts of urban life for health and recreation purposes. During a pandemic they have two key roles: (I) they may be spaces which incur risks of infection, but (2) they also provide key access to amenities, commercial spaces and jobs, as well as physical exercise and relaxation.

In Hong Kong the link between epidemics and public space goes far back in time, with the first public park Blake Gardens created in 1905 in the aftermath of the bubonic plague (Chu, 20I5). Streets and sidewalks in its hyperdense urban districts are narrow and cramped, and occupied by clutters of economic activities, making it nearly impossible to maintain physical distance. Since the early 2000s there have been initiatives of civic society groups such as Walk DVRC to increase spaces for pedestrians and non-motorized transport. During this pandemic, such initiatives were proposed and partly already implemented in many American and European cities (Koop, 2020; Cabinet Office UK Government, 2020; Bliss, 2020). The experience of COVID-19 would offer a prime opportunity to implement such schemes, especially in Hong Kong's most dense low-income districts. However, such actions are not yet taken.

In Taipei, the significant increase in the use of shared bikes, reduced use in vehicles and public transport systems, and the organic use of the riverside parks might be interpreted as how existing sustainable transportation alternatives and human-centric public space designs helped the population react in the moment of crisis, and therefore improve the city's resilience. This would be a crucial point for post-COVID urban designs, and important to be further investigated.

As in other places, existing socio-spatial problems were further pronounced by the pandemic leading particularly in Hong Kong to precarious conditions, which were not reflected in the low numbers of COVID-19 infections and fatalities. The increasing wealth-gap, evident in the city's staggering high Gini coefficient, increased the pressure to find appropriate housing and open space. Most dramatic is the situation for people living in the city's subdivided units, with no place for physical distancing and mental relief. This paper has been a first comparative study of the usage and policies of public space of both cities during the pandemic, further in-depth studies are planned to follow.

Questions which should be further explored are: (I) What affected most people's access to public spaces during the pandemic? (2) Which were the most problematic spatial conditions and how did they affect different vulnerable groups? (3) What kind of spaces were important to provide relief from mental stress and allow physical activities? (4) And, how could initiatives, such as the widening of sidewalks and closure of vehicular lanes, be implemented to provide more inner-city public spaces for citizens. 


\section{Acknowledgement}

This paper was submitted in July 2020 and thus represents information collected up to this date. The paper is part of a larger ongoing research project of the authors supported by a RGC Development Fund provided by the Chinese University of Hong Kong and a Worldwide Universities Network Fund.

\section{References}

Asian Migrants Coordinating Body (AMCB) (2020) 'Results of Online Survey on the Situation of Migrant Domestic Workers during COVID-19 outbreak'. 16 March [online]. Available at: https://www.facebook.com/groups/amcb.hk/permalink/277600/845845740/ (Accessed: 17 May 2020).

Bliss, Laura (2020) 'Mapping How Cities Are Reclaiming Street Space'. Citylab, 3 April [online]. Available at https://www.citylab.com/transportation/2020/04/coronavirus-city-street-publictransit-bike-lanes-covid-19/609190/ (Accessed: 17 May 2020).

Cabinet Office UK Government. (2020) 'Our plan to rebuild: The UK Government's COVID-19 recovery strategy'. 12 May [online]. Available at: https://www.gov.uk/government/publications/our-plan-to-rebuild-the-uk-governments-covid19-recovery-strategy/our-plan-to-rebuild-the-uk-governments-covid-19-recovery-strategy (Accessed: 17 May 2020).

Central Intelligence Agency. 'The World Factbook'. [online] Available at: https://www.cia.gov/library/publications/the-world-factbook/rankorder/2I72rank.html (Accessed: 17 May 2020).

Centre for Health Protection (2020) 'Latest Situation of Coronavirus Disease (COVID-19) in Hong Kong' [online]. Available at: https://chp-dashboard.geodata.gov.hk/covid-I9/en.html (Accessed: 17 May 2020).

Census and Statistics Department, HKSAR (2018) 'Thematic Report: Persons Living in Subdivided Units' [online]. Available at: https://www.statistics.gov.hk/pub/BII201022016XXXXB0100.pdf (Accessed: 17 May 2020).

Census and Statistics Department, HKSAR (2020) 'Table E489: Land area, mid-year population and population density by District Council district' II March, [online]. Available at: https://www.censtatd.gov.hk/hkstat/sub/spl50.jsp?.productCode=D5320I89 (Accessed: 17 May 2020).

Chen, Wei-ting \& Hau, Elizabeth (2020) 'Taiwan's Ban on Mask Exports to be Extended until the end of June'. Focus Taiwan CNA English News, I 3 April [online]. Available at: https://focustaiwan.tw/society/202004I300I7 (Accessed: 17 May 2020).

Chu, Judy (20I5) 'HKG/ Legacy of Plague I: Blake Garden'. Faculty of Architecture, The University of Hong Kong, 16 December [online]. Available at: https://fac.arch.hku.hk/asian-cities-research/hkglegacy-of-plague-i-blake-garden/ (Accessed: 17 May 2020).

Everington, Keoni (2020) 'Indonesian Infected with Coronavirus Traveled Extensively on Taipei MRT, TRA'. Taiwan News, 27 February [online]. Available at: https://www.taiwannews.com.tw/en/news/3882260 (Accessed: 17 May 2020).

Google (2020a) 'COVID-I 9 Community Mobility Report, Hong Kong'. 2 I Julyl [online]. Available at: https://www.gstatic.com/covid I9/mobility/2020-04-17 HK_Mobility Report_en.pdf (Accessed: 28 July 2020).

Google (2020b) 'COVID-19 Community Mobility Report, Taiwan. 2I July [online]. Available at: https://www.gstatic.com/covid 19/mobility/2020-04-17_TW_Mobility_Report_en.pdf (Accessed: 28 July 2020).

Ho, Kelly (2020) 'Coronavirus: Hong Kong Gov't Reveals Producers of Giveaway Masks, as Applicants Raise Privacy Concerns'. Hong Kong Free Press, 7 May [online]. Available at: 
https://hongkongfp.com/2020/05/07/coronavirus-hong-kong-govt-reveals-producers-ofgiveaway-masks-as-applicants-raise-privacy-concerns/ (Accessed: 17 May 2020).

Huang, Tzu-ti (2020) 'Sitting on Floor of Taipei Main Station Lobby Banned due to Coronavirus'. Taiwan News, 29 February [online]. Available at: https://www.taiwannews.com.tw/en/news/3883174 (Accessed: 17 May 2020).

Koop, Fermin (2020) 'After Lockdown, Milan Wants to Transform the Way People Move Around the City' 2 I April [online]. Available at: https://www.zmescience.com/science/milan-afterlockdown-movement-citizens-922352/ (Accessed: 17 My 2020).

Lai, Carine (2017) 'Unopened Space: Mapping Equitable Availability of Open Space in Hong Kong' Hong Kong: Civic Exchange [Report]. Available at: http://civic-exchange.org/report/unopenedspace-mapping-equitable-availability-of-open-space-in-hong-kong/ (accessed I7 July 20I8).

Lam, Jeffie, and Sum, Lok-kei and Ng, Kang-chung (2019) 'Hong Kong Elections: Pro-Democracy Camp Wins 17 Out of 18 Districts While City Leader Says She Will Reflect on the Result.' South China Morning Post, 25 November [online]. Available at: https://www.scmp.com/news/hong-kong/politics/article/3039151/hong-kong-elections-tsunamidisaffection-washes-over-city (Accessed: 18 May 2020).

Low, Zoe (2020) 'Coronavirus: Lockdown of Public Showers Leaves Hong Kong's Homeless Struggling to Stay Clean Amid Covid-19 Pandemic'. South China Morning Post, 18 March [online]. Available at: http://scmp.com/news/hong-kong/society/article/30756/4/coronavirus-lockdownpublic-showers-leaves-hong-kongs (Accessed: 17 May 2020).

Low, Zoe and Chan, Ho-him (2020) 'Coronavirus: Hong Kong's homeless 'McRefugees' Scramble for Places to Stay as McDonald's Axes Dine-In Services in Evening to Help Fight Pandemic'. South China Morning Post, 25 March [online]. Available at: https://www.scmp.com/news/hongkong/health-environment/article/3076804/coronavirus-hong-kongs-homeless-mcrefugees (Accessed: 17 May 2020).

$\mathrm{Ng}$, Naomi (2018) 'Hong Kong's Small Flats “To Get Even Smaller”, Hitting Quality of Life'. South China Morning Post, 17 April [online]. Available at: https://www.scmp.com/news/hongkong/economy/article/2142165/hong-kongs-small-flats-get-even-smaller-hitting-quality-life (Accessed: 17 May 2020).

National Health Insurance Administration (2020) ‘Name-Based Mask Distribution System’. 7 April [online]. Available at:

https://www.nhi.gov.tw/english/Content_List.aspx?n=022B9D97EF66C076 (Accessed: 17 May 2020).

Public Works Department, Taipei City Government (2019) 'Statistics'. 30 August [online]. Available at: https://english.pwd.gov.taipei/cp.aspx?n=A2DC33C92E50FDBD\&s=B3BED3C3BCIE09I0 (Accessed: 17 May 2020).

Rizzo, Meredith and Hersher, Rebecca. (2020) 'It's Not Easy For Anyone: Coronavirus Disrupts Life And Work In Hong Kong.' NPR News, I 3 February [online]. Available at: https://www.npr.org/sections/goatsandsoda/2020/02/I3/8055I I 970/it-s-not-easy-for-anyonecoronavirus-disrupts-life-and-work-in-hong-kong (Accessed: 18 May 2020).

Shan, Shelley (2020) 'Virus Outbreak: Dajia Matsu Pilgrimage is postponed.' Taipei Times, 28 February [online]. Available at: https://www.taipeitimes.com/News/front/archives/2020/02/28/2003731748 (Accessed: 17 May 2020).

Shiroma Silvia (2020) 'Coronavirus: How map hacks and buttocks helped Taiwan fight Covid-19'. BBC News, 7 June [online]. Available at: https://www.bbc.com/news/technology-52883838 (Accessed: 8 March 2021).

Strong, Mathew (2020) 'Wearing a Face Mask to Become Compulsory on the Taipei MRT from April 4'. Taiwan News, 3 April [online]. Available at: https://www.taiwannews.com.tw/en/news/390970I (Accessed: 17 May 2020). 
Taipei City Government (2017) 'Demographic Overview'. I3 December [online] Available at: https://english.gov.taipei/cp.aspx?n=C619997124A6D293 (Accessed: 17 May 2020).

Taiwan Centers for Disease Control (2014) 'SARS (Severe Acute Respiratory Syndrome)' 24 November [online]. Available at: https://www.cdc.gov.tw/En/Category/ListContent/bg0g_VU_Ysrgkes_KRUDgQ?uaid=uID6dR GtmP4Q5YAIGmSKIw (Accessed: 17 May 2020).

Taiwan Centers for Disease Control (2018) 'NHCC: Origin'. 31 January [online]. Available at: https://www.cdc.gov.tw/En/Category/MPage/gL7-bARtHyNdrDq882p/9Q (Accessed: 17 May 2020).

Taiwan Centers for Disease Control (2020a) 'COVID-19 (SARS-CoV-2 Infection)' [online]. Available at: https://sites.google.com/cdc.gov.tw/2019-ncov/taiwan?authuser=0 (Accessed: 17 May 2020).

Taiwan Centers for Disease Control (2020b) 'Name-Based Rationing System for Purchases of Masks to be Launched on February 6; Public to Buy Masks with Their NHI Cards'. 4 February [online]. Available at:

https://www.cdc.gov.tw/En/Bulletin/Detail/ZlJrlunqRjM49LIBn8p6eA?typeid=I58 (Accessed: 17 May 2020).

Taiwan News (2020) 'Taipei, New Taipei, and Keelung Cleared of Coronavirus Risks'. Taiwan News, 14 February [online]. Available at: https://www.taiwannews.com.tw/en/news/3876227 (Accessed: 17 May 2020).

The Reporter (2020) 【不斷更新】武漢肺炎大事記：從全球到台灣, 疫情如何發展？ [online]. Available at: https://www.twreporter.org/a/2019-ncov-epidemic (Accessed: 17 May 2020).

Ting, Victor (2020) 'Coronavirus: Suicide Experts Warn of Pandemic's Impact on Mental Health, with Hong Kong's Jobless, Poor and Elderly Most at Risk'. South China Morning Post, 26 April [online]. Available at: https://www.scmp.com/news/hong-kong/healthenvironment/article/3081582/coronavirus-suicide-experts-warn-pandemics-impact (Accessed: 17 May 2020).

World Health Organization (2020) 'WHO Coronavirus Disease (COVID-I9) Dashboard' [online]. Available at: https://covid I9.who.int/ (Accessed: 17 May 2020).

Yau, Yat-Man (200I) 'The Study of the Process of Water Development and the Land Use Along the Riverside of Taipei Areas [大台北地區水利開發的歷程與河岸地利用的研究]' Geographical Research [師大地理研究報告], 35.

YouBike Co. (2020) 'What is YouBike' [online]. Available at: https://taipei.youbike.com.tw/about/youbike?5cc296a4083e7b59672d2d52 (Accessed: 17 May 2020).

Zhang, Karen (2020) 'Coronavirus: Free Masks from Hong Kong Government Appear for Sale Online'. South China Morning Post, 12 May [online]. Available at: https://www.scmp.com/news/hong-kong/health-environment/article/3084076/coronavirus-freemasks-hong-kong-government (Accessed: 17 May 2020).

Tsai Ya-hua [蔡雅樺] (2020) 疫情帶動YouBike、共享運具使用增加。Liberty Times Net, 24 April [online]. Available at: https://news.Itn.com.tw/news/life/paper/1365632 (Accessed: 17 May 2020).

Zheng Wei [鄭煒] (2020) 民調：近七成民眾 力挺購買口罩實名制。《經濟日報》，II February [online]. Available at: https://money.udn.com/money/story/5658/4337455 (Accessed: 17 May 2020).

Zheng Ming [鄭銘] (2020) 世衛贊香港防疫 何栢良：是港人自救防疫。Sound of Hope, 5 March [online]. Available at: https://www.soundofhope.org/post/350722?lang=b5 (Accessed: 17 May 2020).

I 04 | The Journal of Public Space, 5(3), 2020 | ISSN 2206-9658

City Space Architecture / UN-Habitat 


\title{
Not all Lockdowns are Created Equal. Indian Migrant Crisis in Times of COVID-I 9
}

\author{
Stany Babu \\ University of Bahrain, Bahrain \\ sbabu@uob.edu.bh
}

\begin{abstract}
The COVID- 19 pandemic in India laid visible the stark disparity and unequal distribution of resources in the Indian society. With the imposition of one of the harshest lockdowns in the world, the migrant workers in the country (both interstate and intrastate) have taken the cruel brunt of this pandemic. These internal migrant workers were left in the urban economic centres (cities) with no proper housing, jobs (most of them being employed in informal sectors) and any form of income generation. This led to a mass exodus of migrant workers from urban centres to their rural homes in the hope that they may not go hungry and will have a roof over their heads. The global crisis brought to the forefront that the pandemic is being experienced differently by different economic strands of the Indian society. By severing the public transportation (buses and trains), to mitigate the risk of spread of the virus across districts and states, the migrant workers were denied the only means of affordable movement. This paper will chronicle the many obstacles and hardships that were faced by the migrants when public transportation was denied, on their long journey 'home', without any certainty of reaching their villages alive.
\end{abstract}

Keywords: migrants, India, public transportation, lockdown, pandemic

To cite this article:

Babu, S. (2020). Not all Lockdowns are Created Equal. Indian Migrant Crisis in Times of COVID19, The Journal of Public Space, 5(3), I05-I I4, DOI 10.3289 I/jps.v5i3.I370

This article has been double blind peer reviewed and accepted for publication in The Journal of Public Space. (c) (5) This work is licensed under a Creative Commons Attribution - Non Commercial 4.0 International License https://creativecommons.org/licenses/by-nc/4.0/ 
"I tried catching a bus or truck yesterday, but there is no transport available on the road, so I decided to walk. It's better to be home than to be here in the city without food and water." - Surendra Pandey, a 28 year old labourer along his $110 \mathrm{~km}$ (68 mile) walk home

(Sharma \& Khanna, 2020)

On 24th of March 2020 the Prime Minister of India Narendra Modi through his 8PM national address declared that the country will be going into a nationwide lockdown, within four hours, for a period of 21 days. Lockdown I.0, as it is now being called, was the first in a series of lockdowns. While this announcement impacted all sections of the society, the crisis was acutely felt by the internal migrant workers whose jobs were informal and contractual (Jan Sahas, 2020, P 6). Soon after the lockdown was declared, the country saw the middleclass man hurrying to supermarkets to stock up on essential goods, while the migrant workers were contemplating a harsher reality on how to survive in a city that had now become a death trap with no proper access to social security, food, housing or income. India has welfare measures for those beyond the poverty lines, but they are not accessible to migrant workers since welfare services are available only in their places of births (Chatterjee, 2020). With strict movement restrictions and public transportation (interstate and intrastate trains and buses) coming to a standstill, the migrant workers were left stranded in a foreign space with no means of getting back to the relative safety of their rural homes. This led to a mass exodus of migrant workers on foot, the only means of transportation available to them. As stated in a letter by 20 senior judges of the Supreme Court of India to the Chief Justice of India, the lockdown and its repercussions felt by the migrant workers led to one of the 'biggest humanitarian crisis in Independent India' (SWAN, 2020, p.I I).

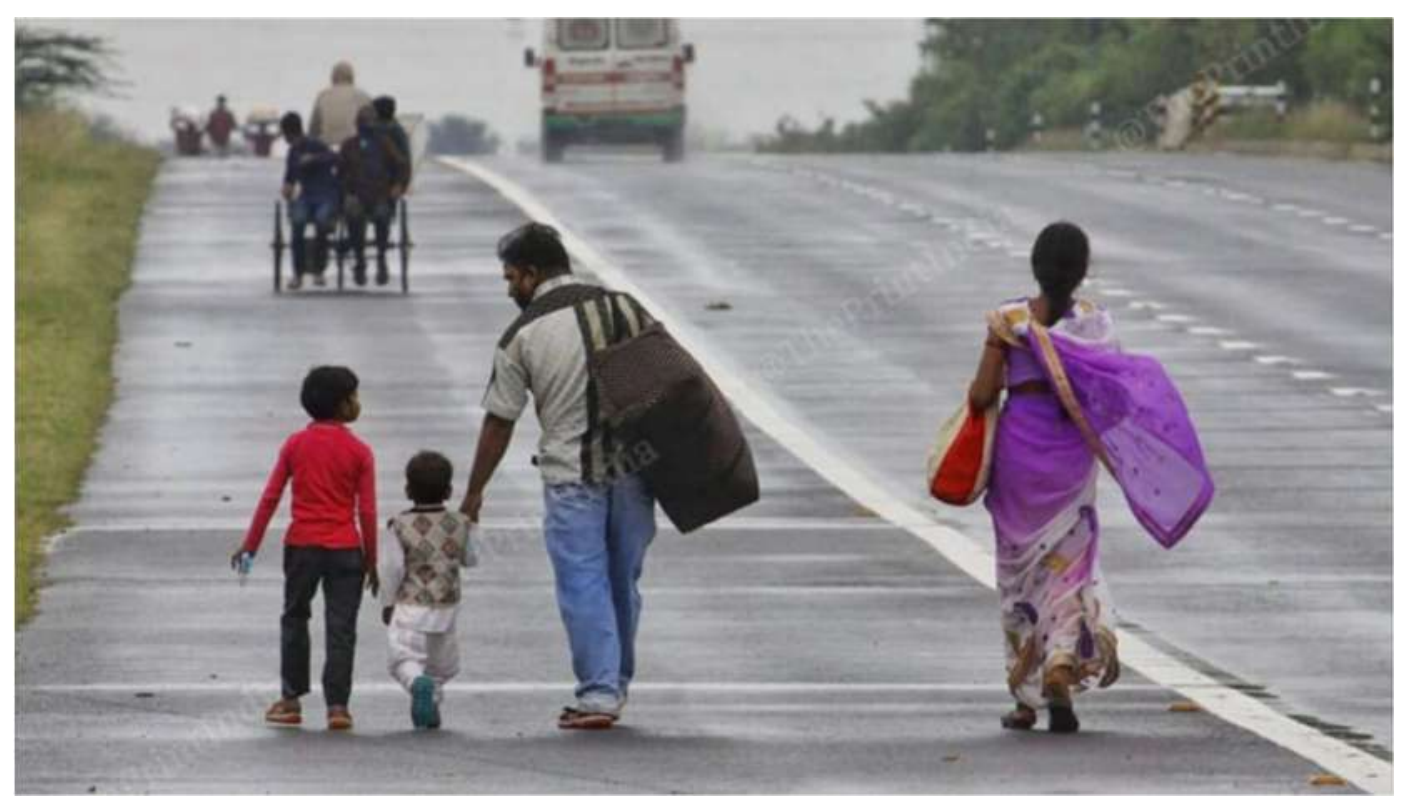

Figure I. Migrant workers trudging along a highway to the Delhi-Ghaziabad border. Photo: Suraj Singh Bisht | ThePrint

The migrant workers in Indian urban centres are the invisible backbone of the economy. They constitute 37\% of the Indian population (Singh, 2020) out of which 65 million are 
interstate migrants (Dharker, 2020) as per the 201 I census. They account for ' $50 \%$ of the national income and constitute a large part of the human capital base of the country' (Ratho \& Bhowmick, 2020). Niti Aayog, the policy think-tank of the Indian Government in their 'Strategy for New India @ 75' stated that 85\% of all workers are employed in the informal sector (Niti Aayog, 2018). 'Faced with social and political anti-migrant attitudes on one hand, and precarious employment opportunities on the other, they live in a state of chronic crisis. 'Rural 'homes' of memories and belonging do not sustain their livelihoods, while cities fail to give them economic security and a sense of belonging' (Kumar \& Das, 2020). According to the World Bank, 'the lockdown in India has impacted the livelihoods of a large proportion of the country's nearly 40 million internal migrants. Around 50,000-60,000 moved from urban centres to rural areas of origin in the span of a few days' (World Bank, 2020, P 2). Public transportation at affordable rates are the only means of movement for the migrant workers who have travelled across the length and width of India to different cities for employment. By curtailing this movement and in the face of an economic shutdown that had rendered them jobless and homeless. the Indian government pushed the migrant workers to a point of desperation.

For the internal migrant workers risk of starvation in the Indian cities was more acute than the virus itself. According to a report titled 'Voices of the Invisible citizens' conducted by the NGO Jan Sahas,

The mass reverse exodus proves that if unable to work, then there is nothing left for a migrant in a city. This shows how in cities, migrants are being reduced merely to their labour power, not considered equal citizens by either the civil society or the state, and thereby denied any social community to fall back on. It is also symptomatic of the exclusion of the migrant population from all social safety mechanisms.

(Jan Sahas, 2020, p. 28)

The day after the announcement of a national lockdown, Mumbai, Chennai, Kolkata and other cities which had drawn the migrants with the economic benefits, saw a mass exodus of more than half a million migrants, the scale of which has not been seen since Indian partition. Migrant workers started walking, cycling and hitchhiking home covering hundreds of kilometres, in some cases covering a distance from the South Indian city of Chennai in Tamil Nadu to a village in the North Eastern state of West Bengal. This was an unprecedented situation that the government had not taken into consideration before calling for a short notice lockdown. There were no proper planning or policies available or introduced to tackle this sudden crisis. This flight of migrants gained international attention as we saw families with young children trekking across highways with little to no food or rest. Many migrants were stopped at their state borders as they had closed interstate movement to curb the spread of the virus. These workers who had walked for kilometres were asked to go back to a place with no job and limited rations. Even when they did reach their rural 'homes' they brought with them the fear of virus spread which led to inhumane acts such as spraying the returning workers with disinfectants causing outrage across and outside the country. A stark contrast was drawn showcasing the citizens shuttled back from foreign countries through free flights to their 'home' country, while migrant citizens within the country were left to their own devices on surviving the pandemic. While the rich and middle 
class were lamenting the inconvenience of being cooped up within their homes, the ground situation for the migrants was one of survival. Many started crowding near railway stations, which had halted all trains, and in desperation even hid inside essential goods trucks. 'Workers state that while they are aware of the dangerous implications of their actions in the event of a lockdown, they are forced to make a choice between their safety and hunger. Based on reports from media articles, labourers were stranded on borders with no water or food' (Jan Sahas, 2020, p. 19).

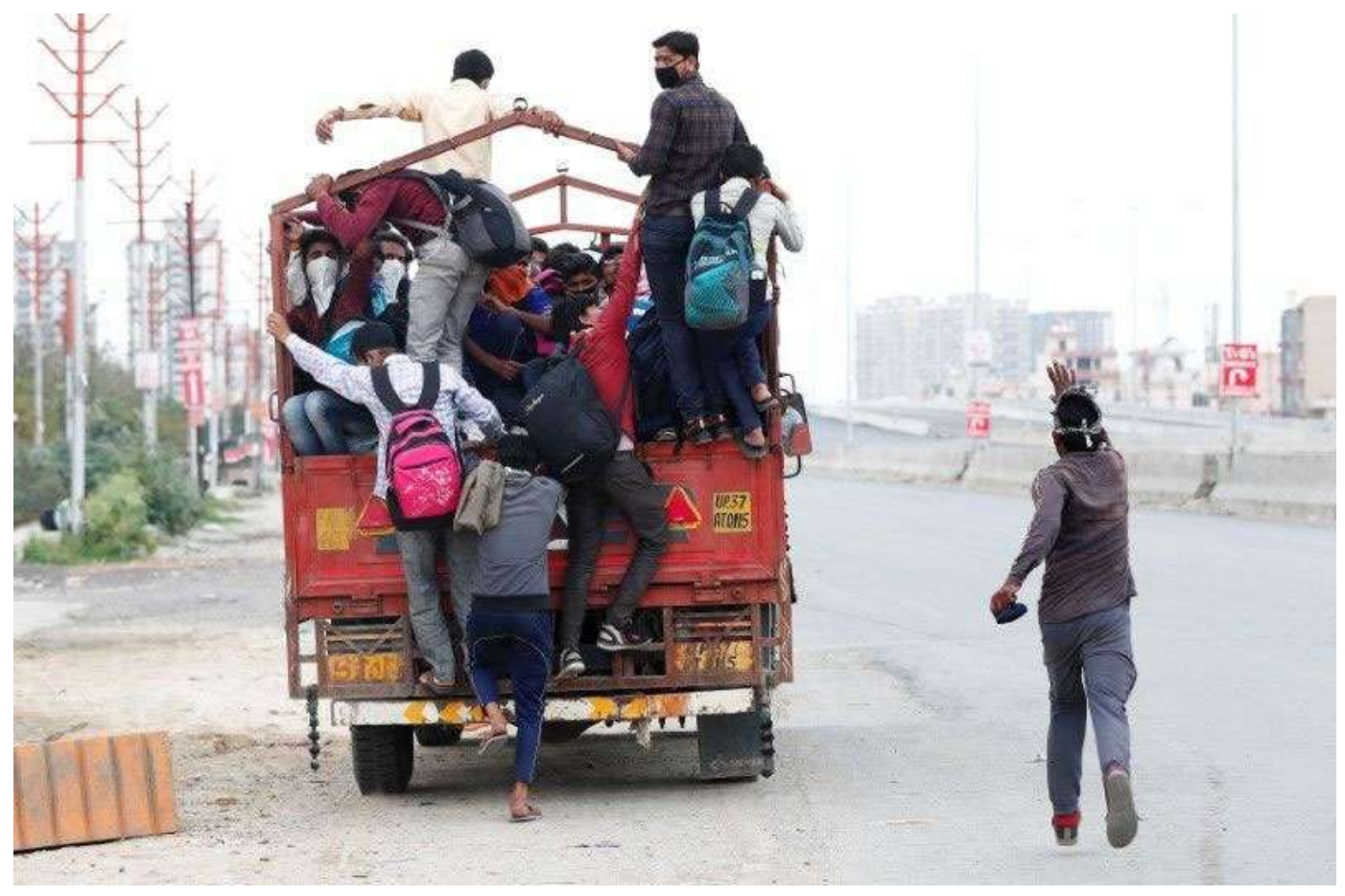

Figure 2. Migrant workers try to board a truck while another runs behind Photo: Adnan Abidi | REUTERS

Witnessing the catastrophe that was being unfolded in the country, the Union Home Ministry urged the state governments to provide immediate relief such as food and shelter to their migrant workers with the help of civil society and to curtail their movement across states. Civil society organisations and state authorities started delivering food to the fleeing migrants and those stranded within the cities and extended welfare schemes such as community kitchens. States like Kerala started labelling migrant workers as guests to mitigate the stigma and to make the workers feel safer in their host city. Kerala alone accounted for $69 \%$ of the overall shelters in the country during the period according to the report handed over to the Supreme court of India by the Union Government (Ramani, 2020). But according to Jan Sahas, '62 percent of workers did not have any information about emergency welfare measures provided by the government and 37 percent did not know how to access the existing schemes' (Jan Sahas, 2020, p. 3).

The scale of the crisis was evident in Uttar Pradesh and the National Capital Region (NCR) in North India. With the increasing risk for the population and faced with heavy criticism, the government of Delhi and state government of Uttar Pradesh started 
providing buses to transport the fleeing migrants. But the ratio of buses to migrants were insufficient. This decision saw thousands of migrants queuing, maintaining little to no physical distancing, and desperately trying to access the few buses to travel back to their homes. The Union Home ministry later in an affidavit to the Supreme court of India claimed news about the buses were fake media reports, contrary to the tweets by Chief Minister of Uttar Pradesh and Delhi's Deputy Chief minister and Transport minister, when criticism was drawn regarding the handling of the bus provision (Singh \& Anand, 2020). Protests were witnessed across India by migrant workers demanding public transportation to chart them back to their villages. In Mumbai protests broke out when migrant workers gathered near Bandra Railway station after fake news was reported about possible trains.

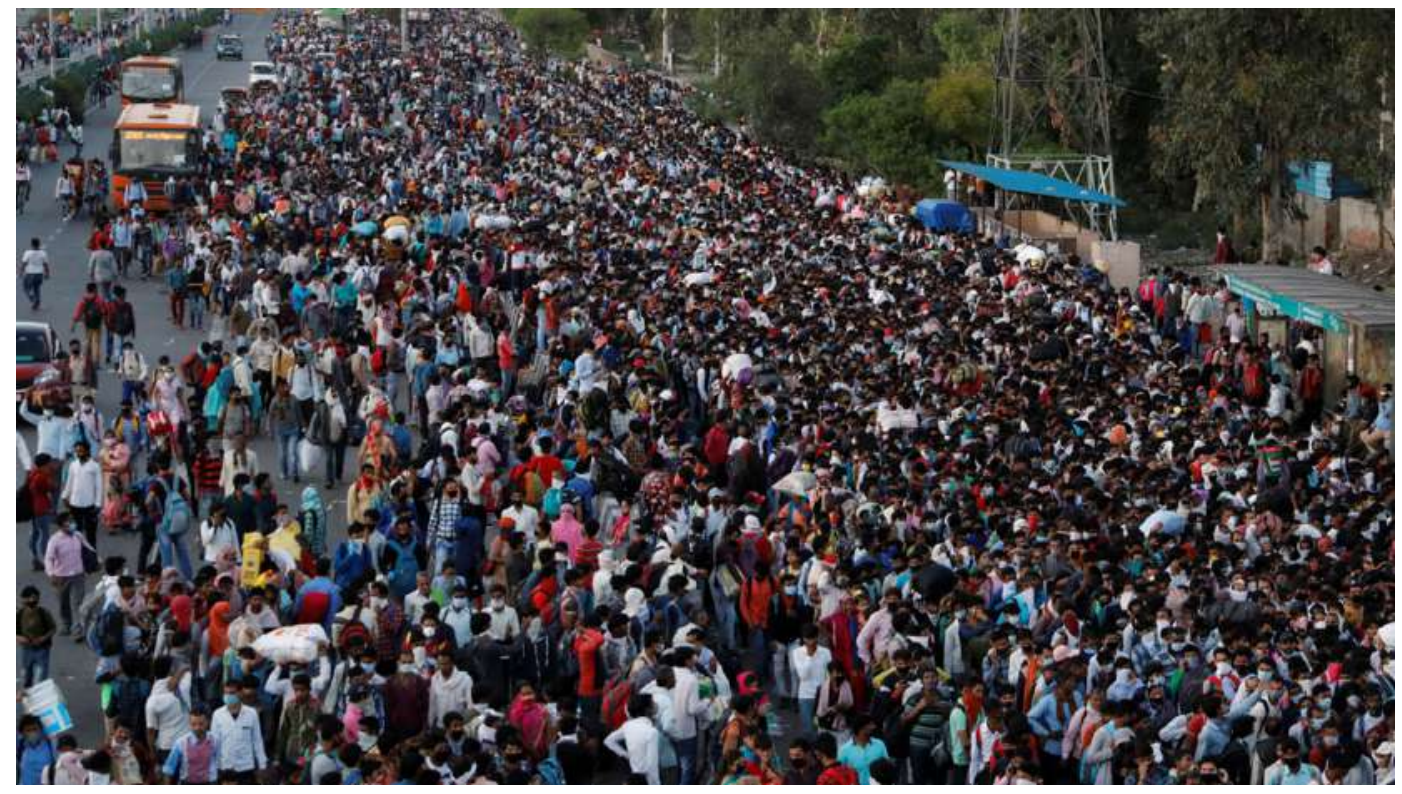

Figure 3. Migrants queue to access the buses made available to shuttle them back home, in Ghaziabad. Photo: Anushree Fadnavis | REUTERS

Highways and railway tracks became their guide lanes on their journey by foot towards home. This mode of movement posed high risk of accidents and safety issues. This crisis led to deaths beyond the figures we see of those who died due to the virus. These numbers should also be included in the total death count since they lay bare a systematic failure from the state when addressing the pandemic. One of the accidents that caught the attention of the entire country, due to the scale of its tragedy, is the death of 16 migrant workers from a group of twenty who were run over by a goods train when resting assuming all trains have stopped functioning, while they were following the rail tracks back to their villages.

The severity of the issue and with national and international criticism towards the Central government's handling of the lockdown, special trains called Shramik trains were arranged for the fleeing migrant workers from May $\mathrm{I}^{\text {st }}$ with partial easing of lockdown. This decision saw joyous migrants queuing with police supervision and adequate precautions being undertaken before entering the train such as sanitising, 
thermal screening and quarantine facilities when reaching their villages. But many migrants were still stranded with no information regarding these trains.

Table I: Deaths due to Lockdown (last updated on 04/07/2020) - Conservative figure

Source: Data compiled by Thejesh G.N., Kanika Sharma and Aman;

https://thejeshgn.com/projects/covid I9-india/non-virus-deaths/

\begin{tabular}{l|c}
\hline Reason & N. of deaths \\
\hline Exhaustion (walking, standing in queues) & 47 \\
\hline Starvation and financial distress & 216 \\
\hline Police brutality or state violence & 12 \\
\hline $\begin{array}{l}\text { Lack of medical care and attention to vulnerable groups (elderly or } \\
\text { patients) }\end{array}$ & 77 \\
\hline Death by crimes associated with lockdown (not communal) & 18 \\
\hline Accidents due to walking or during migration & 209 \\
\hline Alcohol withdrawal-related deaths and suicides & 49 \\
\hline $\begin{array}{l}\text { Suicides due to fear of infection, loneliness, and lack of freedom of } \\
\text { movement }\end{array}$ & 133 \\
\hline Death by Shramik Trains & 96 \\
\hline Deaths in quarantine centres & 49 \\
\hline Unclassified (unable to categorize, need more details) & 65 \\
\hline
\end{tabular}

The government and local authorities faced severe backlash when it came to attention that the migrant workers, who were already cash deprived, were being asked to pay for their tickets, at times at higher prices. The backlash from opposition, activists and citizens across India against the insensitive decision compelled the government to declare that the government will cover workers' travel expense. Karnataka High Court directed the state government to cover the cost of travel of migrant workers and the Supreme Court of India issued a delayed order on May $28^{\text {th }}$ stating that the migrants shouldn't be made to pay for their tickets (SWAN, 2020, PII-I2). But as reports emerged, many workers still had to pay for their tickets despite the government assurance (ibid, P 20). Within the period of 4 months a total of 462 I Shramik trains were operated carrying around 6,319,000 migrants to their home states. An estimated 97 people died while travelling on these trains due to pre-existing medical conditions as informed by the Minister of Railways Piyush Goyal. But according to a zonal officer in the railways, "Heat, exhaustion and thirst are among the primary issues faced by the passengers on board these trains' (SWAN, 2020, PI5). Several reports emerged about the deplorable conditions on these trains with passengers being given limited provision of food and water (Ameen, 2020). Another factor that was not taken into consideration was the lack of transportation and other adequate provisions to reach the railway stations in the main cities to access the Shramik trains. Many migrant workers who had registered via government portal and police stations for the Shramik trains were incapable of reaching the trains on time because of the distance they had to travel to the main city to access these trains. Similarly, the means of transportation to travel 
back to their villages and towns once they have reached their home state was not considered. These legs of the journey were again taken under precarious conditions by the migrant workers (ibid, pp. 29-50).

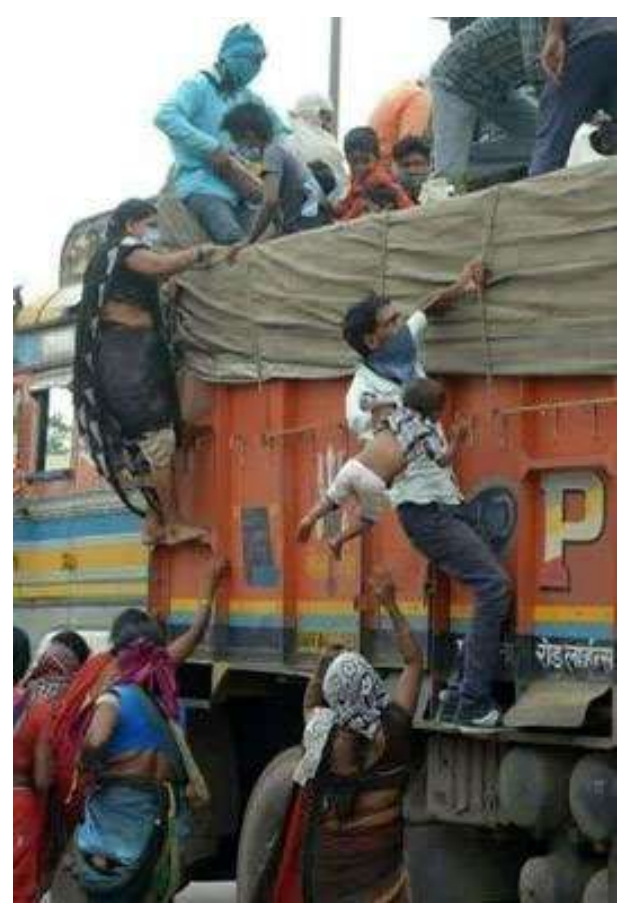

Figure 4: Stranded migrants in Raipur hitching rides on trucks calling it their 'only option' to avoid the long walk home Photo: NDTV

The migrant workers' crisis has now become a glaring failure of the Indian state apparatus. This crisis has shed light into the apathy with which they were treated in the national discourse. 'The extensive media coverage of the mass movement of migrants, media reports along with concerns by activists and public has ensured that the centre and state move towards direct action now in addressing this issue' (Jan Sahas, 2020, P 25). On 14th May 2020, the government took the first step in allocating a sum of Rs 1000 crore for care of migrant workers from the Prime Minister's Citizen Assistance and Relief in Emergency Situations Fund (PM-CARES). This amount was allotted to the different states to be used for accommodation, food, medical and transportation assistance. But as academic and activist Yogendra Yadav highlights, there is little to no proper policy addressing the migrant workers and mention of their circumstances is usually absent in the Prime minister's addresses to the nation. Despite the measures announced during this period such as low cost rental accommodation for returning migrant workers, National food security act, One Nation One ration (to make the food rations available for all citizens in every city and village in India) and the National Rural Employment Guarantee Act (NREGA), the immediate need of the migrants, that of free public transport, was not addressed (Narayan, 2020). State governments of Uttar Pradesh, Madhya Pradesh and some other states have started to roll back labour protection laws as a means to boost investors and businesses, putting the migrant workers in an even more precarious position. This decision is being met with criticism as repealing labour laws is seen as violation of fundamental human rights and would 
allow for slave like working conditions. As stated in the Stranded Workers Action Network (SWAN) report titled 'To leave or not to leave'.

'Given the array of shocks and risks that the working poor, and women in particular, are exposed to, the need for a comprehensive evaluation and implementation of social protection measures made by the erstwhile National Commission for the Enterprises in the Unorganised Sector (NCEUS) is critical. The International Covenant on Economic, Social and Cultural Rights (ICESCR), 1966, is an international human rights treaty in which India is a signatory. Anchoring on human dignity, ICESCR lays out the need for certain fundamental rights and freedoms for everybody. It is, therefore, high time that we reconfigure our society and strengthen our laws based on these principles instead of the proposed dilution of labour laws.'

(Swan, 2020, p. 52)

In Karnataka the state government attempted to halt shramik trains from operating on behalf of real estate and industry leaders who required the migrant labour force. The decision was revoked due to wide scale opposition. The government during the parliament session in September denied having data regarding the migrant deaths and loss of livelihood incurred by the migrant workers due to the lockdown imposed, as they didn't collect the data (Saha, 2020). This is once again a systematic erasure of the value of a migrant worker's life, who we claim are the backbone of the country. This situation urges us to make the states and the central government accountable and to protect migrant workers in the long-term planning of cities. Our structure is not capable of handling the mass reverse exodus, with people moving back to rural areas with poor employment rates. There maybe two ways we can try addressing the situation. One is to make the city equipped and safe as quickly as possible with dedicated central and state government policies set to mitigate the crisis, , up to date data regarding migration and safety nets to accommodate and protect the migrant workers. A structural realignment and reforms are required to make 'Cities for All' by strengthening and challenging the local levels of administration (Agarwala and Vaidya, 2020). Or, this might be our opportunity to rethink the development of rural areas, to take on a radical restructuring of their economy to make them self-sufficient. Whichever the answer is, this pandemic has shown migration without adequate social security is a humanitarian crisis that needs to be addressed at a national level and should pave the means to protect the migrant workers now and in any future natural disasters. 


\section{References}

Agarwal, K. (2020) 'Not Just the Aurangabad Accident, 383 People Have Died Due to the Punitive Lockdown', The Wire, I0th May. Available at: https://thewire.in/rights/migrant-workers-noncoronavirus-lockdown-deaths

Agarwala, P. \& Vaidya, H., (2020) 'Can COVID-1 9 fill the void of City Governance for Urban Transformation?', UN India, 7th May. Available at: Can COVID-19 Fill the Void of City Governance for Urban Transformation? - UN India

Ameen, F. (2020) 'No food and water aboard Shramik special trains ', The Telegraph India, 23rd May. Available at: Coronavirus: No food and water aboard Shramik Special trains - Telegraph India

Anand, J. \& Singh, V. (2020) 'Corononavirus lockdowm| Union Home Ministry blames 'fake news' for migrant workers gathering at bus stations', The Hindu, 06th June. Available at: Coronavirus lockdown | Union Home Ministry blames 'fake news' for migrant workers gathering at bus stations - The Hindu

Biswas, S. (2020) 'Coronavirus: India's pandemic lockdown turns into a human tragedy', BBC, 30th April. Available at: https://www.bbc.com/news/world-asia-india-52086274

Chatterjee, P. (2020) 'The Pandemic Exposes India's Apathy Toward Migrant Workers', The Atlantic, 12th April. Available at: https://www.theatlantic.com/ideas/archive/2020/04/the-pandemicexposes-indias-two-worlds/609838/

Dharker, A. (2020) 'COVID-I 9 has made migrant workers' plight, state apathy visible', The Indian Express, 25th May. Available at: Covid-19 has made migrant workers' plight, state apathy visible | The Indian Express

Gettleman, J., Raj, S. \& Kumar, H. (2020) 'As India Reopens, Deadly Accidents Break Out', The New York Times, 8th May. Available at: https://www.nytimes.com/2020/05/08/world/asia/indialeak-train-reopen.html

Jan Sahas. (2020) 'Voices of the Invisible Citizens', Jan Sahas, New Delhi, April. Available at: https://ruralindiaonline.org/library/resource/voices-of-the-invisible-citizens/

Kumar, N. \& Das, R. (2020) 'Noida's migrant worker exodus is more about their notions of 'home' than coronavirus: Study', The Print, I st April. Available at : https://theprint.in/opinion/noidasmigrant-worker-exodus-more-notions-of-home/392290/

Kumar, N. \& Das, R. (2020) 'Chronic crisis: Migrant workers and India's COVID - 19 lockdown', LSE South Asia Centre, 8th April. Available at: https://blogs.Ise.ac.uk/southasia/2020/04/08/chronic-crisis-migrant-workers-and-indias-covid19-lockdown/ 
Not all Lockdowns are Created Equal

Narayan, S. (2020) 'The invisible ghosts who walk will haunt India for years to come', The Wire, 19th May. Available at: The Invisible Ghosts Who Walk Will Haunt India for Years to Come (thewire.in)

Niti Aayog (2018) 'Strategy for New India @ 75', Niti Aayog, New Delhi, November

Padmanabhan, C. (2020) 'Will Migrants' Lockdown Experiences Become the Debris of History That Reaches the Sky?', The Wire, I I th May. Available at: https://thewire.in/rights/india-lockdownmigrants-deaths

Ramani, S. (2020) 'Coronavirus package | Will migrant workers benefit from the Centre's measures? ', The Hindu, 17th May. Available at: Coronavirus package | Will migrant workers benefit from the Centre's measures? - The Hindu

Ratho, A. \& Bhowmick, S. (2020) 'East to West: India's migrant crisis looms large during COVID-19', Observer Research Foundation, I0th April. Available at: https://www.orfonline.org/expert-speak/east-west-india-migrant-crisis-looms-large-duringcovid I $9-64880 /$

Saha, P. (2020) 'No data on deaths, job losses among migrant workers during lockdown:government', India Today, 14th September. Available at: No data on deaths, job losses among migrant workers during lockdown: Government - India News (indiatoday.in)

Sharma, S. \& Khanna, S. (2020) 'India's migrant workers face long walk home amid coronavirus lockdown', Reuters, $26^{\text {th }}$ March. Available at: India's migrant workers face long walk home amid coronavirus lockdown | Reuters

Singh, S. (2020) 'Explained: Indian migrants, across India', The Indian Express, 6th April. Available at: Explained: Indian migrants, across India | Explained News, The Indian Express

SWAN. (2020) 'To leave or not to leave? Lockdown, Migrant Workers and their journey home', Stranded Workers Action Network(SWAN), $5^{\text {th June. Available at: To leave or not to leave }}$ - SWAN 2020 (strandedworkers.in)

Tanvi, N,S. (2020) 'The face of exploitation', The Hindu, I I th May. Available at: The face of exploitation - The Hindu

World Bank (2020) 'COVID-1 9 Crisis Through a Migration Lens', Migration and Development Brief 32, April

I I 4 | The Journal of Public Space, 5(3), 2020 | ISSN 2206-9658

City Space Architecture / UN-Habitat 


\title{
Missed Pauses and Everyday Interactions for Migrant Indian women during Covid- 19 Times
}

\author{
SriPallavi Nadimpalli \\ University of Melbourne, Australia \\ snadimpalli@student.unimelb.edu.au
}

\begin{abstract}
The time-space activities for women largely emerge from the relational needs and demands of others in their lives. Davies (2003) explains that as women take on multiple roles in both public and private spheres, they often have limited time for a pause. Drawing from Snow and Brissett (1986), Davies explains that these pauses are moments of relaxation, re-energising or reflection, which are essential for an individual's wellbeing. Findings from 20 interviews conducted with migrant women in Hyderabad, India, showed that these pauses were necessary and integral to their everyday spatial routines at home and work. In addition to giving respite from daily chores at home, pauses helped establish social connections and form an attachment with a new place as migrants. This paper reflects on how these pauses can be impacted during COVID-19 times, especially when migrant women continue to experience an increased share of responsibilities at home due to patriarchal expectations and limited movement outdoors due to the lockdown restrictions in India.
\end{abstract}

Keywords: migrant women, Indian, pauses, everyday interactions, COVID-19

To cite this article:

Nadimpalli, A. (2020). Missed Pauses and Everyday Interactions for Migrant Indian Women during Covid-19 Times, The Journal of Public Space, 5(3), II5-I20, DOI 10.3289I/jps.v5i3.I295

This article has been double blind peer reviewed and accepted for publication in The Journal of Public Space. 
Within the time-geography approach, originally developed by Torsten Hägerstrand, all individual activities take place in time and space, which form the basic constraints or enabling factors that affect freedom of action and movement. Feminist researchers, however, have argued that, unlike men, women's freedom of choice to use their time and space is gendered and is "substantially influenced by the interlocking of the public and private spheres and by women's structural position in these spheres" (Davies 2003, p.135). Most women have complex daily patterns owing to multiple roles and overlapping responsibilities that combine caregiving, domestic chores in addition to paid work, which impacts their everyday access and use of space (Law 1999; Davies 2003; Whitzman 2013).

Feminist researchers have primarily attributed this differential access to space and everyday mobility to the traditional divide between public and private spaces, which translates into expected behavioural norms based on gender (for example, see Rose 1993; Phadke et al. 20 I I). Patriarchy and societal expectations sometimes require women to demonstrate purpose and legitimacy while using public spaces, which are traditionally understood as masculine. Law (1999) explains that embodied skills conditioned by social practices also impact mobility choices available and elected by women. This further impacts on women's access to economic and social resources (Law 1999; Whitzman 2013). While these are some of the predominant factors that influence the everyday movements of women, other factors could emerge based on the context and how different identities are recognised and positioned within them. In this paper, I draw on the work of Karen Davies (2003), who forefronts the rationality of care in understanding the time-space activities for women in both public and private spheres. Unlike the linear conceptualisation of time, proposed by Hägerstrand's timegeography, women's activities often consist of multiple activities occurring simultaneously with overlapping temporalities with limited scope for a pause (Davies 2003). Here, pauses are defined as "moments at work or home when the usual flow of work is halted for a period" (Davies 2003, p. 140). Drawing from Snow and Brissett ( 1986$)$, Davies explains that pauses are not necessarily a period of inactivity but can be moments of relaxation and re-energising or reflection, which are essential for an individual's well-being.

In this paper, I examine the narratives of 20 migrant women interviewed in Hyderabad, India to understand the nature and significance of these pauses in their lives. Migrant women often experience multiple barriers to integration (including social, cultural and structural) in their receiving cities. The research findings suggest that pauses have not only granted respite from everyday chores but it also helped the migrant women build a connection with their new home through their routine practices. This paper reflects on these findings to understand how pauses can be altered in COVID-I 9 times and impact the everyday life of migrant women.

\section{The context}

A total of 20 interviews were conducted in Hyderabad, India, during early 2018. These interviews were a part of a doctoral thesis examining spaces of belonging for migrant Indian women as internal migrants in India and as international migrants to Australia. This paper only focuses on some of the key findings from the Hyderabad case. While the interviews were conducted before the pandemic, the findings are relevant and 
important for understanding the differential impact of COVID-19 on particular social groups, especially those who are marginalised.

Hyderabad is the joint capital of the state of Telangana and Andhra Pradesh, with a population of 7.67 million (Census of India $20 \mathrm{II}$ ). The migrant women interviewed were residents of Gagillapur, which is a peri-urban area in the north-west of the city. Gagillapur has primarily attracted rural migrants (both inter- and intra-state) due to its established industrial area, which offers employment opportunities. Also, the area is rapidly urbanising due to the expanding city limits.

Almost all the participants interviewed were married with children, and their ages ranged between $25-65$ years. Most of them attended school and received some basic education, except for three uneducated participants. However, there was only one participant who graduated high school and had a diploma. The predominant reason for their migration was stated as marriage or job opportunities (primarily for the spouse). Other reasons included escaping hardships, like drought or family feuds in the hometown, or migration with parents during childhood. No independent migrations were stated.

Most women in Gagillapur identified managing home, undertaking domestic chores and caring for their family as their primary responsibility. Seven participants were also simultaneously engaged in small home-based businesses (like tailoring) or entrepreneurial activities (like operating a mini-grocery store or a food stall or cart) with their spouses. One other participant worked as a community resource person with an NGO.

\section{Everyday Movements}

The participants were asked to describe different spaces that were part of their routine activities to understand their importance in their daily lives. Most frequently recurring time-space routines were core activities related to I) work, 2) purchasing necessities (like groceries, vegetables, government subsidised rations), 3) caregiving activities (like domestic chores or care-related trips, like chaperoning children to schools) or 4) trips to places of worship. Social interactions, as part of restorative activities, also recurred at varying frequencies in multiple locations to accommodate both casual and meaningful interactions. Other restorative trips included travel for leisure, religion or visiting family and relatives both within and beyond Hyderabad.

Core activities, however, occurred in combination with social interactions and rarely as an isolated, separate event. For example, women often completed their essential purchases or daily chores in small groups (where possible) to socialise simultaneously. The rationality of care appeared to be an integral part of their lives due to the gender normative expectations both within the public and private spheres. For most women, trips outdoors were also limited to purchasing necessities and care-related activities. Also, as most of the women interviewed did not drive, they preferred tasks that could be completed independently (or in small groups) and within short walking distances from home. Overall, as the migrant women prioritised their needs of their families before theirs, there was limited scope for pauses in their time-space routines. 

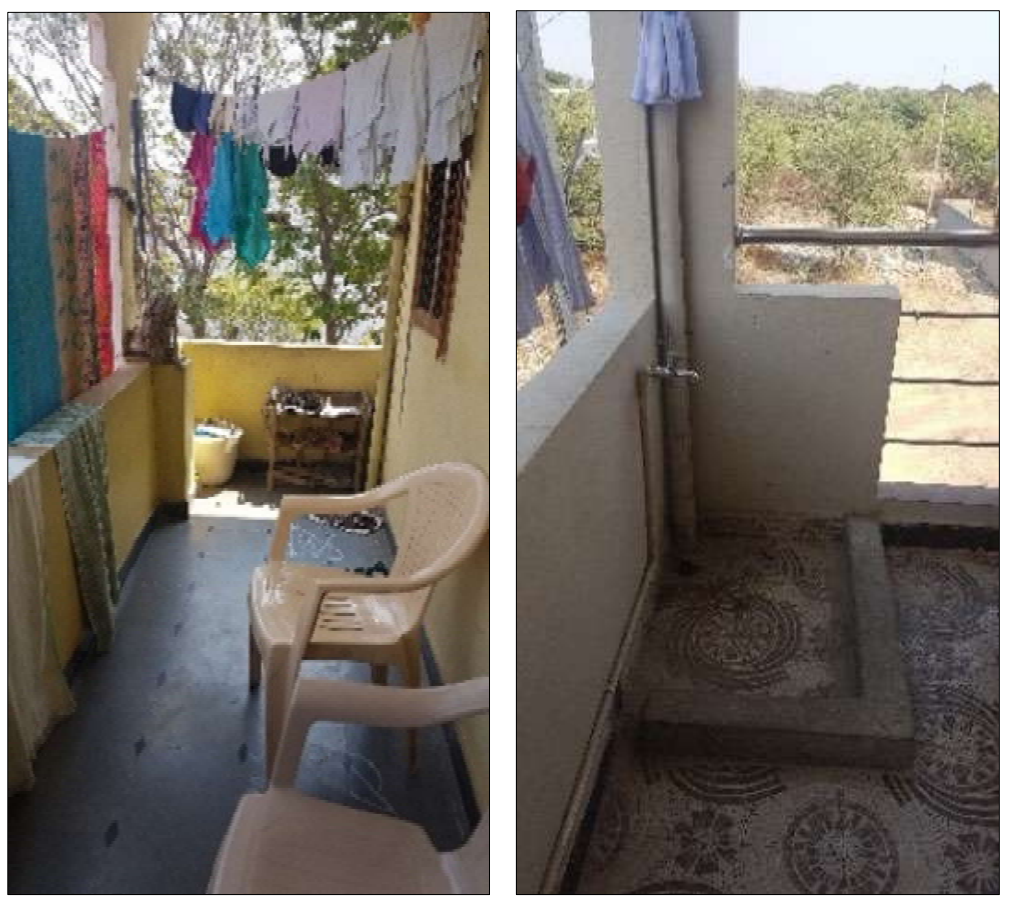

Figure I. Corridor spaces in a multi-tenant building. Left: outdoor seating, right: laundry or meat cleaning corners (Picture by the author)

\section{Pauses}

Home and its vicinity (like the doorstep and front porch) served as an important social space when the migrant women got together in small groups during mid-day. These interactions were accommodated during a brief period, in-between morning and evening chores when their children and spouse were away. One participant explained that catching up at the doorstep was convenient as "everyone can get resume their work", even if they take a quick break from their busy routines.

Similarly, the women utilised corridor spaces within multi-tenant apartments during this "free" time to co-ordinate their daily chores, like washing clothes or doing prep-work for cooking and socialise (see Figure I). These pauses made mundane tasks pleasurable by making them a collective activity.

Some of the participants also stated that as their children got older, they could pursue other interests. These pauses expanded and transformed into time and space for homebased businesses for at least two participants, who worked as professional tailors from their living rooms. Some women chose to utilise this time to pursue other hobbies and interests.

In the public sphere too, most core-activities were co-ordinated between friends and neighbours. For example, some participants chaperoned their young children to school every day and sometimes delivered lunchboxes in the afternoon. These short walks were also utilised for socialising between mothers. Tuan (1979) explains that established paths and routes part of a routinised activity, form a habit field which often require minimal decision making to navigate. These habit fields aid in developing an affective bond with a place. For migrant women, it was particularly important to build multiple habit fields in their new environment, to build familiarity. Some other habit 
fields were weekly walking trips to an informal vegetable market, which was organised every Wednesday in Gagillapur (See Figure II). In addition to purchasing vegetables and knick-knacks, the market presented opportunities for socialising and eating at the food stalls with other women.

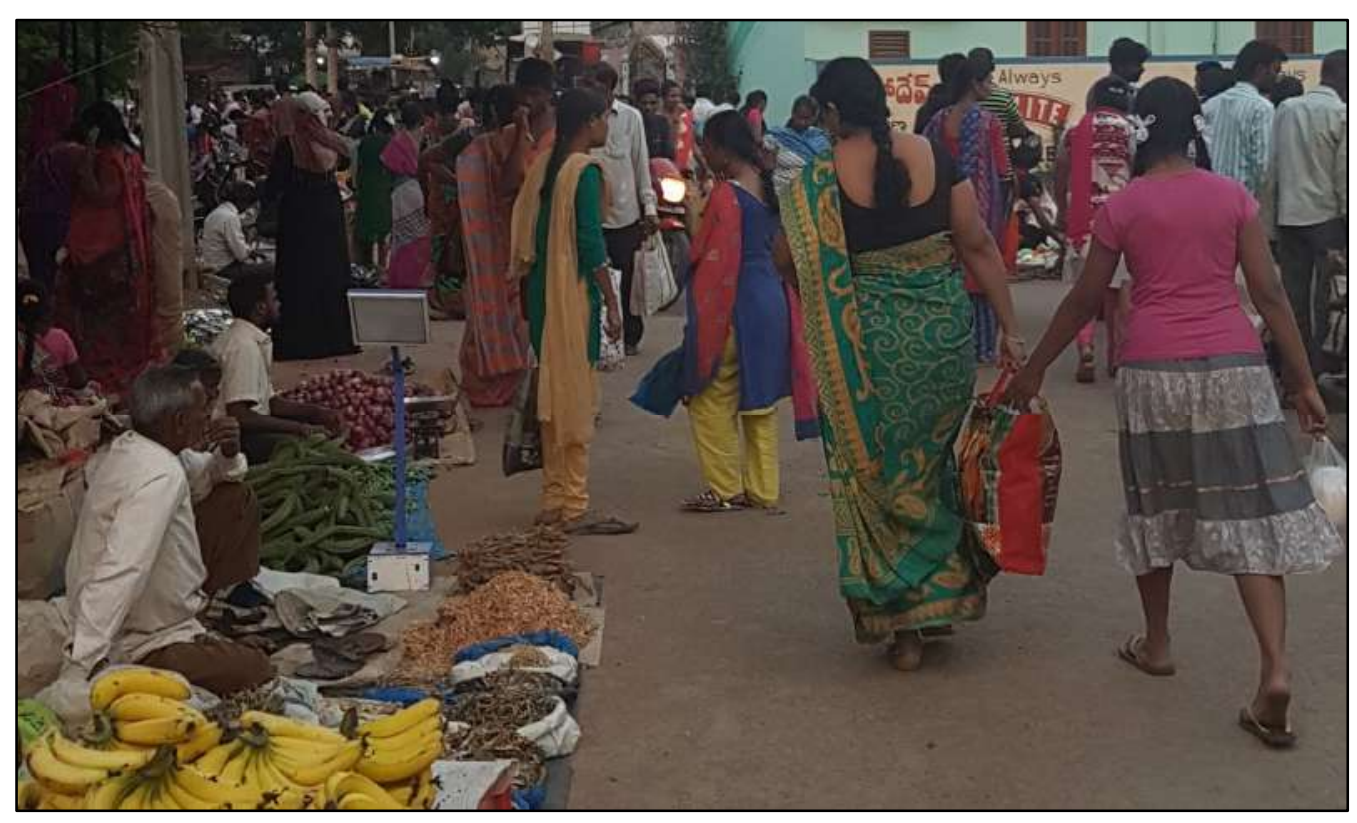

Figure 2. Wednesday Vegetable Market, Gagillapur (Picture by the author)

Social and cultural connections influence place belonging and are an integral part of any individual's life (Antonsich 2010). However, in India, due to the vast language and cultural differences within the country, migrants often experience social isolation while being identified as an outsider. These factors impact the migrant's sense of belonging in their new homes. Social interactions integrated as pauses in-between core activities, therefore, helped the women develop place-belonging by identifying other groups with similar interests in their neighbourhood and by establishing habit fields through their collective spatial use.

\section{Missed pauses in the times of a pandemic}

In response to the pandemic, on March $24^{\text {th }}, 2020$, the Indian government issued a nationwide lockdown for a 21 -day period, which was subsequently extended multiple times until May. These restrictions were subsequently eased in phases based on the change in the pandemic situation across the country. As part of the initial restrictions, all international and domestic movement ceased, public gatherings were banned, and a curfew on non-essential movement was enforced between $7 \mathrm{pm}$ and $7 \mathrm{am}$. The movement of autorickshaws, taxis and buses were also stopped in Hyderabad due to stringent rules.

The lockdown restrictions have impacted the time-spaces routines of every individual, especially the poor and marginalised people in the informal sector in India, who have lost income and housing. Further, due to mobility restrictions, several migrant workers were stranded, displaced and also unable to return home. 
In Gagillapur, most of the participants were financially dependent on their spouses who worked in the factories or service sector jobs. Due to the lockdown, several individuals would have either lost their jobs or suffered reduced working hours due to staggered shifts, resulting in financial distress at the household level. Further, with the closure of schools, most women were likely to experience an increase in responsibilities as caregivers when families were confined to their homes. Seeking entry into formal or informal employment to mitigate financial stress would also be difficult for the participants due to their busy schedules, limited educational qualifications in addition to restricted mobility and limited jobs in turbulent times. The increased stress over health, possible loss of jobs (or reduced income), lack of security within the household, coupled with mobility restrictions, could have possibly increased the likelihood of domestic violence occurrence in the private sphere.

For the migrant women in Gagillapur, missed pauses could translate into lost opportunities for relaxation, social interactions and time for self with increased stress and vulnerabilities at home, while they continue to fulfil gender norms as primary caregivers and experience restrictions from structures of power operating in both public and private spheres.

Citing Snow and Brissett (1986, p.I), pauses "are an essential element of the social rhythm that demonstrates degrees of personal and community well-being and vitality". However, in the pandemic, the migrant women in Gagillapur were likely to experience dislocation in their rhythms, which is detrimental to their sense of belonging as migrants as well as women.

\section{References}

Antonsich, M. (2010) 'Searching for Belonging - An Analytical Framework', Geography Compass, 4(6), 644-659, available: http://dx.doi.org/I0.1III/j.1749-8198.2009.003 I7.x.

Census of India (20II) CensusInfo India Dashboard, available: https://censusindia.gov.in/20I Icommon/censusdata201I.html [accessed February 2019].

Davies, K. (2003) 'Responsibility and Daily Life: Reflections over timespace' in May, J. and Thrift, N., eds., Timespace: geographies of temporality Routledge, I33-I48.

Law, R. (1999) 'Beyond 'women and transport': towards new geographies of gender and daily mobility', Progress in Human Geography, 23(4), 567-588.

Phadke, S., Khan, S. and Ranade, S. (201I) Why loiter?: Women and risk on Mumbai streets, Penguin Books India.

Rose, G. (1993) 'Women and Everyday Spaces' in Feminism and geography : the limits of geographical knowledge Polity Press, 17-40.

Snow, R.P. and Brissett, D. (1986) 'PAUSES: EXPLORATIONS IN SOCIAL RHYTHM', Symbolic Interaction, 9(I), I- I8, available: http://dx.doi.org/I0.I525/si.I 986.9.I.I.

Tuan, Y.-F. (1979) 'Space and place: humanistic perspective' in Gale, S. and Olsson, G., eds., Philosophy in Geography.Theory and Decision Library (An International Series in the Philosophy and Methodology of the Social and Behavioral Sciences) Springer, 387-427.

Whitzman, C. (2013) 'Women's safety and everyday mobility' in Whitzman, C., Legacy, C., Andrew, C., Klodawsky, F., Shaw, M., Viswanath, K., ed., Building inclusive cities women's safety and the right to the city, Routledge, 35-52. 


\title{
When Digital Public Spaces Matter. Role of Neighbourhood Platforms in Times of COVID- 19
}

\author{
Franziska Schreiber \\ University of Stuttgart, Department of International Urbanism, Germany \\ franziska.schreiber@si.uni-stuttgart.de
}

\begin{abstract}
Research on community resilience has highlighted the critical role of analogue public spaces for social interaction and community support. However, neighbourhoods are increasingly "hybrid spaces" where face-to-face and virtual interaction blend. Based on the case of Germany, this paper argues that hyperlocal social networks such as digital neighbourhood platforms have taken on a prominent role during the COVID-19 pandemic, as they fulfil functions traditionally associated with analogue public space and provide a useful crisis management tool. They allow communities to share information, establish social contacts, and organize flexible help, which increases their capacity to cope with and adapt to the effects of the pandemic. Yet not everybody has equal access to these digital public spaces and they bear the risk of reinforcing existing social inequalities. In the future, they need to be planned, designed, and managed just as carefully as their physical counterparts to be socially inclusive and serve the common good.
\end{abstract}

Keywords: hyperlocal social networks, social cohesion, digital public space, community resilience, COVID-19

To cite this article:

Schreiber, F. (2020). When Digital Public Spaces Matter. Role of Neighbourhood Platforms in Times of COVID-19, The Journal of Public Space, 5(3), I2I-I30, DOI I0.3289I/jps.v5i3.I368

This article has been double blind peer reviewed and accepted for publication in The Journal of Public Space. (c) (i) (5) This work is licensed under a Creative Commons Attribution - Non Commercial 4.0 International License https://creativecommons.org/licenses/by-nc/4.0/ 
In 2020, COVID-19 put the world firmly in crisis and literally on hold. In many countries, public life came to a complete standstill: Public institutions such as schools, nurseries, and universities were closed; restaurants and stores shut down; and the use of sports and recreational facilities were prohibited to slow the spread of the virus. In this situation, the immediate neighbourhood became the primary space for action and social interaction as well as the scene of remarkable solidarity and neighbourly help (Schnur, 2020). Virtually overnight, people hung lists in their hallway to organize shopping assistance for neighbours who belonged to a high-risk group; they bought vouchers to support nearby shops or offered to take care of children of "essential workers". This support seems exceptional, but it's actually not. In times of crisis neighbourly aid has always been the norm rather than the exception.

What seems new, however, is the way in which civic engagement and social life in neighbourhoods is being organized and practiced, and with what flexibility and speed. One wonders if and how the growing role of social media and digital communication over the last decade transforms and affects neighbourhood organization in such times of crisis. Nowadays, neighbourhoods increasingly equal "hybrid spaces" (Meine, 2017), where face-to-face and virtual interaction blend: Online-initiated relations require analogue encounters to last, while neighbours who first met analogue now also use messenger services for communication and organisational purposes (Becker, Göppert, Schnur, \& Schreiber, p. 206). In particular, hyperlocal social networks such as digital neighbourhood platforms and local Facebook groups have recently become an important site for social interaction, public debate, and civic engagement and fulfil the functions traditionally associated with public spaces. They allow communities to share (local) information, ask for advice or offer help, connect with others, and encourage identification and a sense of belonging (Schreiber \& Göppert, 2018).

In times of stress and shocks, it is typically the analogue public space that provides a critical infrastructure for communities to establish social contact and organize support, and thereby helps strengthening community resilience (Ley, 2019, p. 168). However, if such space is avoided (or even forbidden to use), digital social networks may constitute alternative spaces that contribute to community-building and crisis management and help make neighbourhoods more resilient. Based on earlier research I have done between $2016-2018$ on various digital neighbourhood platforms in Germany and their contribution to community building, social cohesion and civic engagement (Schreiber \& Göppert, 2018) I seek to propose some first conclusions on their role and meaning in times of crisis. I will do so by focusing on the case of nebenan.de, the largest hyperlocal network in Germany.

\section{The rise of digital networking between neighbours}

Digital neighbourhood platforms are a rather new phenomenon, yet they already show considerable success - even before the COVID-19 pandemic started. Over the past couple of years, hyperlocal social networks such as nextdoor.com (available in different countries), neighbourly.co.nz (New Zealand) or nebenan.de (Germany) emerged around the world. They greatly differ in terms of size, target group and funding structure, but share the same intention of connecting neighbours both online and offline to overcome the widely felt anonymity in larger cities and to ease the exchange of local information and services (Schreiber \& Göppert, 2018). Within the last decade, user numbers on 
such platforms have skyrocketed and challenge the prevailing assumption that many people - especially city dwellers - do not attach great importance to their neighbourhood (Becker et al, 2018).

The world's biggest hyperlocal network nextdoor.com was released in $20 \mathrm{II}$ and is now active in 260,000 neighbourhoods across II countries and has more than 10 million members in the U.S. alone (Kelly, 2020). During the COVID-19 pandemic, such platforms gained further relevance and prominence - both from civil society and policymakers. As soon as the coronavirus outbreak took off, their usage grew rapidly. Nextdoor.com has seen an increase in user activity of up to $80 \%$, especially in severely affected areas such as Seattle and New York City (ibid.). Yet, little is known about the activities that are being organized, by whom, for whom, and with what effect on communities. A closer look at Germany's largest hyperlocal network nebenan.de as an example for the role of such platforms during COVID-19 will help shed some light on this.

\section{The case of nebenan.de: From sharing to solidarity?}

Nebenan.de launched in 2015 and to date counts more than I,6 million users. It operates as a social business and generates its revenues from voluntary contributions and cooperation with local businesses and city authorities, who pay fees for so-called business or organisational profiles. For private persons, the platform is free of charge. As a registered neighbour, various functions are available including an overview of local businesses, events, and existing neighbourhood groups, a digital marketplace as well as a private chat function and a prominent field for community interaction. What distinguishes nebenan.de from traditional social media is its hyperlocal scope, its 'hybrid' aim of connecting people both digitally and in the analogue realm as well as the higher level of familiarity among users. On the platform, only verified neighbours can become part of the digital community and are required to use their correct name and a photo showing themselves. Moreover, neighbours can only see and communicate with those living in their immediate proximity and in neighbouring areas. These features make interaction much more personal and lower the threshold to get in touch.

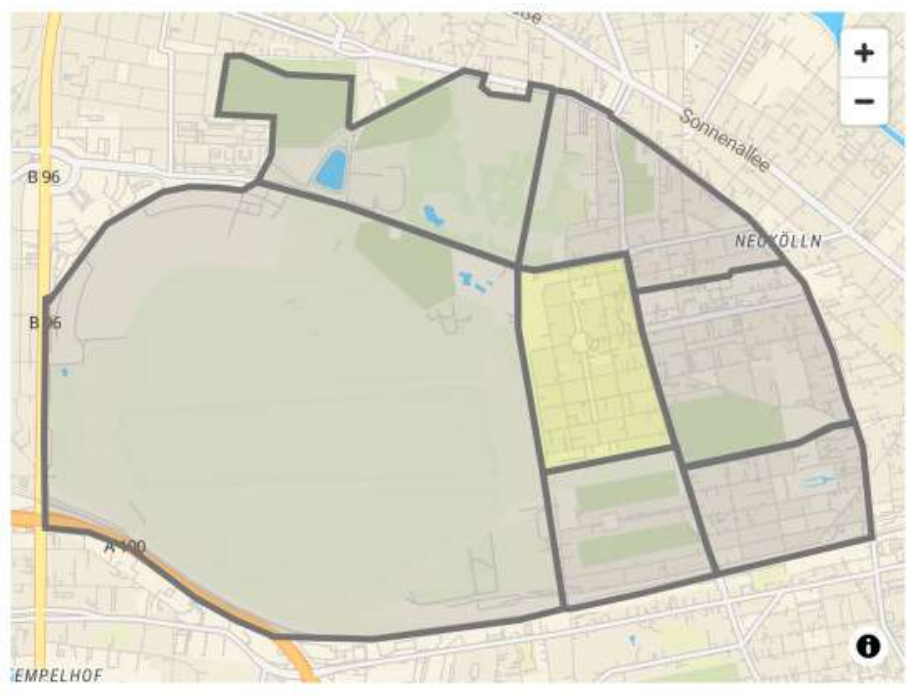

Direkte Nachbarn: 2166 Mit Umgebung: 5592
Figure. I. Screenshot of a digital neighbourhood on nebenan.de and the surrounding areas visible to the registered user. The neighbourhood "Schillerkiez" counts 2166 users whereas the larger area counts 5595 users. (Source: Franziska Schreiber) 
In addition, nebenan.de doesn't apply any algorithms to filter or prioritise content, which leaves the decision up to communities what they consider important and underlines its strict data security policy where no personal data are passed on to third parties (Vollmann, 2018). The combination of the hyperlocal focus and the higher data security of nebenan.de compared to other social media was found to be a major reason for many to revert to the platform in past years.

During the pandemic, user numbers and activities increased significantly on the hyperlocal social network - similarly to other platforms such as nexdoor.com. According to nebenan.de's own data, the number of daily new registrations quadrupled between mid-March 2020 and end-April 2020 and nationwide membership jumped from I,4 million to I,6 million users. In addition, weekly activities of neighbours on the platform increased by $30 \%$.

Yet, it is not only the number of users and activities that are changing, but also the content. In the past, nebenan.de was mainly used in the sense of a sharing economy as well as for community purposes and building new relationships. Neighbours made use of the platform to post classified advertisement and to share and swap things such as drilling machines, rollerblades, kitchen utensils, and many more. The platform also served them to crowdsource and exchange hyperlocal information (e.g., on nearby doctors, good restaurants or recommendable nurseries), and to offer and ask for help related to computer issues, watering flowers or pet sitting. Moreover, neighbours harnessed the digital means to organize community events and to identify and form groups with like-minded people in their immediate proximity. Such neighbourhood groups ranged from people who like to play board games; to cat or dog lovers; to those interested in sustainability issues and keen to initiate projects (Schreiber \& Göppert, 2018).

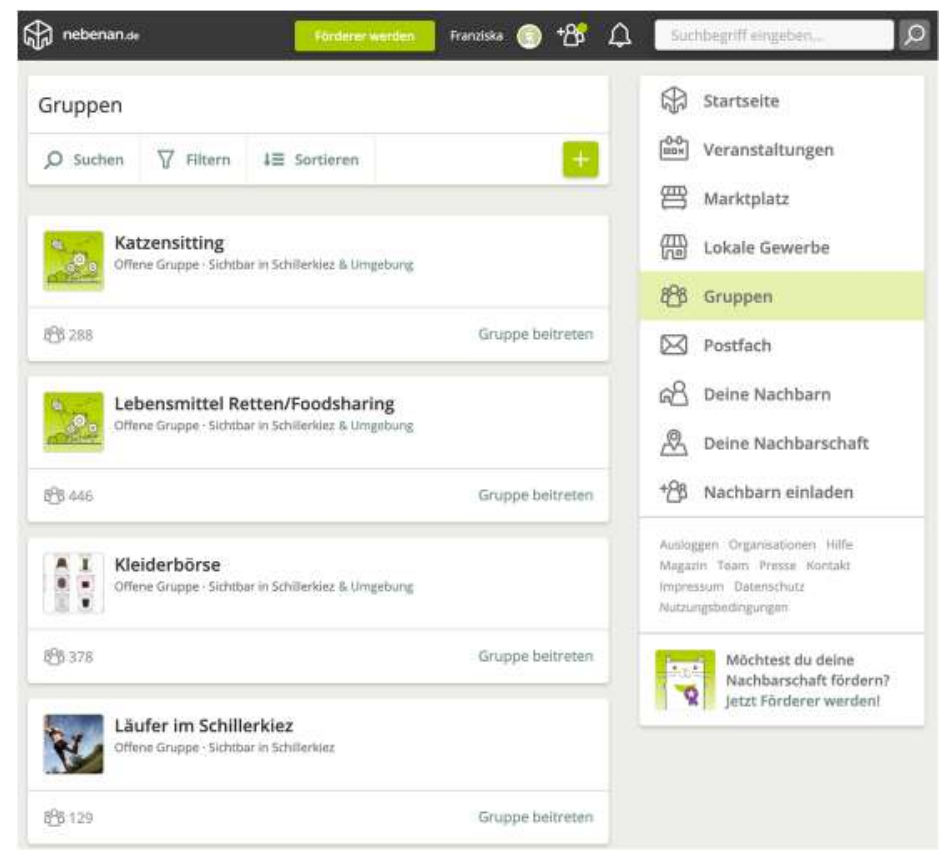

Figure. 2. Screenshot of groups available in a selected digital neighbourhood on nebenan.de. On the right, the functions on the platform are listed including home, events, market place, local businesses, groups, inbox, your neighbours, your neighbourhood and invite neighbours (from the top). On the left, the available groups are shown including cat sitting, food sharing, cloth swapping and a runner's group (from the top). (Source: Franziska Schreiber) 
With the beginning of the pandemic though, the focus changed towards crisis management. All of a sudden, three particular social groups and their needs became the focus of attention and a new set of support activities evolved aimed at helping them in coping with the effects of the coronavirus. Help was offered and organised for vulnerable neighbours (e.g., elderly or those who belong to the high-risk group), for "essential workers" such as doctors, caregivers or cashiers, and families with young children. For vulnerable neighbours, assistance was provided for grocery shopping or walking the dog to protect them from infection, and phone calls were made to counteract social isolation and loneliness. Various solidarity actions were organized for "essential workers" including balcony singing, cooking food or doing the laundry. As soon as schools and day-care-centres closed, help was extended to families and support provided relating to childcare and learning activities (Spiewak, 2020; own observations).

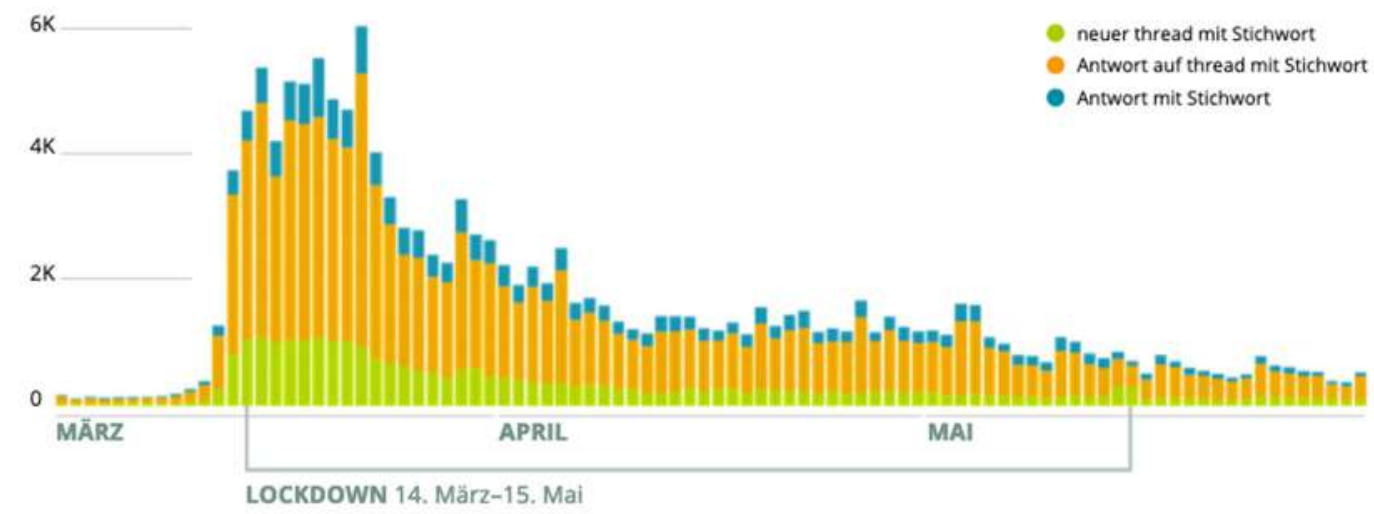

Graph.I. Posts and replies with keywords Corona, Covid, Quarantine from I March to 30 May 2020. Green refers to posts with keywords, orange refers to responses to posts with keyword and blue indicates responses with keywords (Source: nebenan.de)

To reach neighbours in need who were not part of the digital platform, notes were hung in hallways and outside of buildings to inform about possible support. Moreover, nebenan.de quickly expanded its activities by setting up a dedicated Coronavirus help page and hotline to increase its reach beyond the digital community. Between midMarch to the end of July 2020, a total of over 7,600 requests for help were received via the hotline and $85 \%$ of them have been successfully mediated. More than 12.400 neighbours offered their help through this channel, often several neighbours responded to one request for help (nebenan.de, 2020). The platform also started cooperating with various local authorities providing them with the opportunity to directly contact their citizens through the hyperlocal social network to pass on specific Corona-related information (Spiewak, 2020).

We can only speculate whether and how these activities will change further during and after COVID-19. However, previous research on the relationship between digital platforms and civic engagement suggests that most support structures are only occasional and of short duration (Becker et al, 2018). User numbers, in turn, are likely to remain high for the time being thanks to the platform's increased popularity and its engagement during the crisis. What becomes obvious, in turn, is that those, who use 
the platform benefit from crucial support structures and relevant knowledge, which increases their capacity to cope with and adapt to the effects of the pandemic. However, this raises critical questions regarding the accessibility of such platforms and their effects on communities in times of crisis and beyond.

\section{Who benefits and who doesn't?}

No empirical studies have yet been published on the use and implications of such platforms during the COVID-19 pandemic, but we can draw on earlier research analysing their user structures and how they shape public and social life (Schreiber \& Göppert, 2018). In a recent study of four different neighbourhoods in Germany we found that digital platforms expand the local social network of people and increase both their bonding and bridging social capital (Becker et al, 2018). Nearly all users interviewed either met new friends and/or established loose contacts to people of the same and other milieus. The reason is that hyperlocal social networks facilitate neighbourly contact by creating occasions (e.g., lending a drilling machine) and lowering the inhibition threshold of reaching out to others. In this way, they serve as a sort of "introduction service" (Wellman \& Hampton, 1999, p. 652), especially for newcomers to the neighbourhood and those with limited local social capital (Schreiber \& Göppert, 2018). Short encounters through swapping or sharing items or support services convey a sense of mutual helpfulness and local connection that people in larger cities often miss. Such encounters paired with real profile pictures can increase the "public familiarity" (Blokland \& Nast, 20I4) and strengthen a sense of belonging and trust in the neighbourhood. Moreover, hyperlocal social networks ease the crowdsourcing of local knowledge and information and support civic engagement by making existing opportunities visible (Becker et al, 2018, pp. 207-208).

Yet, not all social and age groups use and thus benefit from these platforms equally. It is especially adults between the age of 25 and 70 who use hyperlocal social networks, whereas younger people and senior citizens (above $75+$ ) are hardly reached. The average age with over 40 , however, is significantly higher than that of the average users of social media, which can be explained by the crucial role of the local area for the everyday life of older people (Schreiber \& Göppert, 2018). Young people, in turn, are usually integrated into a dense social network through school and leisure activities and are consequently less dependent on such platforms. Moreover, studies show that they typically revert to other types of social media (MPFS, 2017). In terms of the social status of the users, research suggests that members of the middle class with a high level of education and a modern orientation are overrepresented on digital neighbourhood platforms. This seems to be independent of migration background. However, people with migration background were hardly found on these platforms and seem to be insufficiently addressed by the monolingual offers (Schreiber \& Göppert, 20 I8). Initial research also reveals that digital neighbourhood groups are largely formed among people with similar attitudes and social status. In this way, hyperlocal social networks can support mechanisms of social exclusion by intensifying social relations among 'similar' neighbours, whereas people labelled as 'others' according to ethnic and social boundaries are excluded (Becker et al, 2018).

Transferring these results to the context of the pandemic means that with all the euphoria around digital neighbourhood platforms, certain groups and potentially entire 
areas are left out of the neighbourly support networks, both analogue and digital, and end up potentially being doubly disadvantaged (Kurtenbach, 2020). Especially for neighbours of a lower social status and with limited social capital, who might be less able to organise themselves during the COIVD-I 9 crisis, the limited neighbourly support can become an additional disadvantaging factor. Considering the increasing segregation in "affluent" and "poor" neighbourhoods in many cities around the world, this might even be argued for entire neighbourhoods, particularly those that are poverty-stricken (ibid.). Although hyperlocal social networks were found to be used in different types of neighbourhoods in terms of their demographic structure and socioeconomic profile (Schreiber, Becker, Göppert, \& Schnur, 2017), there is still a risk that they may enhance inequality both at individual and neighbourhood scale in the long run. Accordingly, the implications of digital neighbourhood platforms are ambivalent. On the one hand, such platforms can enhance social cohesion and contribute to community resilience, on the other hand, they may reinforce existing social and socio-spatial inequalities and leave those behind, who might need neighbourly support and additional resources the most.

During the pandemic, nebenan.de has tried to expand its reach and diversify addressees by setting up a phone hotline for people less familiar with digital tools. Their requests are sorted by postcode and fed into the respective local neighbourhood network allowing people in the immediate environment to directly contact those needing support (Meinel, 2020). By the end of April more than 6,000 people had used the hotline, mostly elderly or relatives organising assistance for family members - especially concerning shopping assistance and pet care. It is too early to say to what extent this hotline has helped to address the digital divide, but it is certainly a step in the right direction. That it helped closing the social gap is, in turn, rather unlikely.

\section{What can we learn for post-Corona times? Imagining possible futures.}

The COVID-19 pandemic clearly demonstrates the importance of the immediate environment both for crisis management and for social and public life in general, making "“" proximity" the central imperative of the city of the future" (Schneidewind et al, 2020, p.4). Many neighbourhoods in Germany have proven highly resilient in times of COVID19. Community support was organized quickly and flexibly adjusted to the ever-changing situation. This paper shows that hyperlocal social networks played an important role in this. However, we have also seen their limitations in terms of accessibility and inclusivity. Considering that an increasing part of public and social life will likely take place virtually in the future, on digital public spaces such as these platforms, it will be critical to learn from this experience and draw appropriate conclusions. This offers various entry points for both practice and research and to engage with possible futures of these platforms.

- Strengthening recognition as local crisis management tool

The rise in the number of users and activities on hyperlocal social networks during the COVID-19 pandemic offers the potential for harnessing them as dedicated crisis management tool going forward. An increased number of users is now connected and trained in organizing civic engagement and social life in a speedy and flexible manner, should another crisis (of any kind) arise. Integrating these platforms into the "official" crisis management strategies and infrastructures both at local and national level 
promises great benefits. In this context, initial experience in the collaboration between local authorities and platforms such as nebenan.de during the coronavirus crisis should be drawn on and expanded.

- Taking a hybrid approach to the future design of public spaces

Digital neighbourhood platforms have facilitated new social relations and neighbourly support structures, which might persist beyond the pandemic if sufficiently cultivated and supported. However, online-initiated social relations require analogue encounters to last and quality public spaces in the local area where neighbours can meet and mingle and actively engage and shape their environment. Strengthening neighbourhoods thus necessitates taking a hybrid approach to future public space design by thinking both the digital and analogue realm closer together. In addition to investing in well-equipped and modern community centres, this could be ensured through a stronger presence of existing local initiatives and institutions on these platforms to make their often hidden offers visible (Becker et al, 2018). Another pathway could be to create a physical pendant to hyperlocal social networks as done by the initiative Lulu dans ma rue in Paris combining a digital platform with a physical kiosk.

- Harnessing the possibilities of neighbourhood platforms for planning practice Hyperlocal social networks offer important insights into the local needs and sensitivities of citizens and ease communication between neighbours and local authorities as shown during the pandemic (Schreiber \& Göppert, 2018; Spiewak, 2020). Considering the future design of public spaces, utilising such platforms can offer new perspectives for planning practice to engage with citizens and to gain insights into their needs. Here, we can learn from a parallel discourse within planning practice where the potential of 'urban acupuncture' as a new planning approach using digital social networks to involve citizens in hyperlocal placemaking is being explored and shows promising results (Houghton, Foth, \& Miller, 20I5). Further research is, however, needed to understand how to best harness the affordances of such platforms for planners and communities in the future.

- Increasing the inclusivity of digital public spaces

As hyperlocal social networks increasingly fulfil the functions traditionally associated with analogue public spaces, it becomes ever more important to plan, design and manage them just as carefully as their physical counterparts in order to be socially inclusive and to ensure that they serve the common good and not merely private interests. This might involve raising awareness of the availability of such platforms, building digital competencies, ensuring multilingualism and redesigning user interfaces.

Particular attention and support should be given to social groups and types of neighbourhoods, which are not yet embedded in the digital neighbourly support network. To support this, more research is needed on why certain social groups use such hyperlocal social networks, why others don't, and how to make them more accessible in order to counteract social inequalities. This also includes exploring the effects of the hotline set up by nebenan.de during the crisis as supporting element and how it helped close the digital divide.

- Ensuring sustainable financing, provision, and maintenance in the long run The most frequently used platforms such as nebenan.de and nextdoor.com, which assume fundamental (public space) functions for more and more people, are operated commercially and compete around user number. Whether the business model of nebenan.de is viable remains to be seen. However, many other platforms have already 
vanished due to high competition. This raises questions regarding data protection, sustainable financing, provision, and maintenance of such digital infrastructure in the long run, as well as the role and responsibility of the public sector in this regard (Becker et al, 2018, p.210). This necessitates a discussion on potential publicly owned platforms, public-private partnerships as well as open-source platforms as a public good. The variety of these potential roles of hyperlocal social networks for crisis management, public space design and collaborative planning opens up new perspectives for research and practice to build upon to make cities and neighbourhoods more resilient and inclusive going forward.

\section{References}

Becker, A., Göppert, H., Schnur, O., \& Schreiber, F. (20I8). Die digitale Renaissance der Nachbarschaft. Soziale Medien als Instrument postmoderner Nachbarschaftsbildung. Forum Wohnen und Stadtentwicklung, 4, 206-2I.

Blokland, T., \& Nast, J. (2014). From Public Familiarity to Comfort Zone: The Relevance of Absent Ties for Belonging in Berlin's Mixed Neighbourhoods: Belonging in Berlin's Mixed Neighbourhoods. International Journal of Urban and Regional Research, 38(4), I I 42-I I 59.

Houghton, K., Foth, M., \& Miller, E. (20I5). Urban Acupuncture: Hybrid Social and Technological Practices for Hyperlocal Placemaking. Journal of Urban Technology, 22(3), 319.

Kelly, S. M. (2020, May 18). Neighborhood social network Nextdoor is both a lifeline and a hub of anxiety. CNN Business. Retrieved from https://edition.cnn.com/2020/03/18/tech/nextdoorcoronavirus/index.html.

Kurtenbach, S. (2020, April 28). Nachbarschaftshilfe als Zeichen gesellschaftlichen Zusammenhalts. Vielfalt leben - Gesellschaft gestalten. Retrieved from https://blog.vielfaltleben.de/blogger/sebastian-kurtenbach/.

Ley, A. (2019). Community Resilience and Placemaking through Translocal Networking: Learning from Thailand and the Philippines. The Journal of Public Space, 4(2), I65- I 78.

Medienpädagogischer Forschungsverbund Südwest (MPFS.) 20I7. JIM 20 I 7. Jugend, Information, (Multi-) Media. Basisstudie zum Medienumgang 12- bis 19-Jähriger in Deutschland. Stuttgart. Retrieved from https://www.mpfs.de/fileadmin/files/Studien/IIM/2017/JIM_2017.pdf.

Meine, J. (2017). Hybride Sozialräume durch digitale Netzwerkstrukturen im Stadtquartier. In T., Hagemann (Ed.). Forschung und Entwicklung in der Sozialwirtschaft: Band II. Gestaltung des Sozial- und Gesundheitswesens im Zeitalter von Digitalisierung und technischer Assistenz: Veröffentlichung zum zehnjährigen Bestehen der FH der Diakonie (I st ed.). Baden-Baden: Nomos. 
Meinel, H. (2020, May 4). Coronahilfe von nebenan - Das bewirkt die Hotline für Nachbarschaftshilfe. Nebenan Magazin. Retrieved from https://magazin.nebenan.de/artikel/coronahilfe-von-nebenan-das-bewirkt-die-hotline-fuernachbarschaftshilfe.

Nebenan.de (2020). nebenan.de und die Corona-Pandemie. Mit starken Nachbarschaften durch die Krise (Zwischenbericht September 2020). Nebenan.de Retrieved from https://magazin.nebenan.de/assets/downloads/nebenan_corona_report_2020.pdf.

Schneidewind, U., Baedeker, C., Bierwirth, A., Caplan, A., \& Haake, H. (2020). „Näher“„Öffentlicher" - „Agiler“: Eckpfeiler einer resilienten,,Post-Corona-Stadt (Zukunftsimpuls Nr. 14).

Schnur, O. (2020). Kiez und Corona. Nachbarschaft im Krisen-Modus - ein Kommentar. vhw werkSTADT, 40, I-8.

Schreiber, F., \& Göppert, H. (20I8). Wandel von Nachbarschaft in Zeiten digitaler Vernetzung. Vhw-Schriftenreihe, 9, I-44.

Schreiber, F, Becker, A., Göppert, H., \& Schnur, O. (2017). Digital vernetzt und lokal verbunden? Nachbarschaftsplattformen als Potenzial für sozialen Zusammenhalt und Engagement - ein Werkstattbericht. Forum Wohnen und Stadtentwicklung, 4, 2 I I-2 I6.

Spiewak, M. (2020, March I5). In der Krise gewinnt Nachbarschaft neue Bedeutung. ZEIT Online. Retrieved from https://www.zeit.de/gesellschaft/2020-03/nachbarschaftshilfe-nebenan-decoronavirus-sozialleben-ina-remmers.

Vollmann, M. (2018, February 28). Hyperlocal Neighbourhood Networks: Building Social Capital and Empowering Local Urban Communities. Urbanet. Retrieved from https://www.urbanet.info/hyperlocal-neighbourhood-networks/.

Wellman, B., \& Hampton, K. (1999). Living networked on and offline. Contemporary Sociology, 28(6), 648-654. 


\title{
Youth Access to Public Space during COVID- 9 Pandemic in Hanoi, Vietnam. A Descriptive Study
}

Pham Quynh Huong

Center Research for Migration, Environment, and Social Development (CMESD), Vietnam phamquynhhuong2@gmail.com

\section{Phan Song Thuong, Luong Thuy Duong}

Vietnam Academy of Social and Sciences, Institute of Regional Sustainable Development, Vietnam thuongthuong266@gmail.com | duongjuly@gmail.com

Nguyen Xuan An

The Vietnam National Institute of Educational Sciences, Vietnam

nguyenxuanan89@gmail.com

\begin{abstract}
Vietnam is considered to overcome COVID-19 pandemic rather successfully by applying strict measures to prevent transmission, including quarantine and social distancing. It has created impacts on youth access to public space. This is a case study on young people in Hanoi, Vietnam based on the combination of an online survey with 325 respondents and 15 in-depth interviews. The study focuses on reviewing the relations between knowledge of COVID- 19 with attitudes toward pandemic control and access to public spaces among youth in order to learn about factors that may influence social distancing and their accessibility to public space.
\end{abstract}

Keywords: hyperlocal social networks, social cohesion, digital public space, community resilience, COVID-I 9

* This article includes research and statistics updated to March 202I.

To cite this article:

Hương, P., Thuong, P., Duong, L., An, N. (2020). Youth Access to Public Space during COVID-19 Pandemic in Hanoi, Vietnam. A Descriptive Study, The Journal of Public Space, 5(3), I3 I-I46, DOI 10.3289I/jps.v5i3.1369

This article has been double blind peer reviewed and accepted for publication in The Journal of Public Space. (c) (5) This work is licensed under a Creative Commons Attribution - Non Commercial 4.0 International License https://creativecommons.org/licenses/by-nc/4.0/ 


\section{Background}

Vietnam is located in Southeast Asia with 96 million populations and shares the northern border with China, which had the first COVID-19 outbreak in the world. Up until 03/202I, Vietnam had suffered from the third phase of the Covid-19 pandemic. By March 6th 202I, there had been 2510 positive cases to SARS-COV-2 reported in Vietnam, including 542 cases being treated, 1920 recovered cases, and 35 deaths.

The first wave of Covid-1 9 pandemic - Study period

Our research was conducted in April 2020 when the first phase of COVID-19 occurred with complicated developments, leading to a 15-nationwide social distancing. By April 24th 2020, Vietnam had reported 270 positive cases, including 45 cases being treated, 225 recovered cases (accounting for 83.3\%), and no deaths ( $\mathrm{MOH}, 2020)$. Among the infected, females account for more than men (54.8\% compared to $45.2 \%)$, with age ranging mainly from 20 to 50 years old. The source of infection is mainly from abroad. Community spreads accounted for only 35.76\% (Vietnam-5F, 2020).

The first wave of Covid-1 9 pandemic and Vietnam's response

During the research process, The Ministry of Health $(\mathrm{MOH})$ divided the pandemic progress in Vietnam into three phases which is briefly described in the paragraphs below.

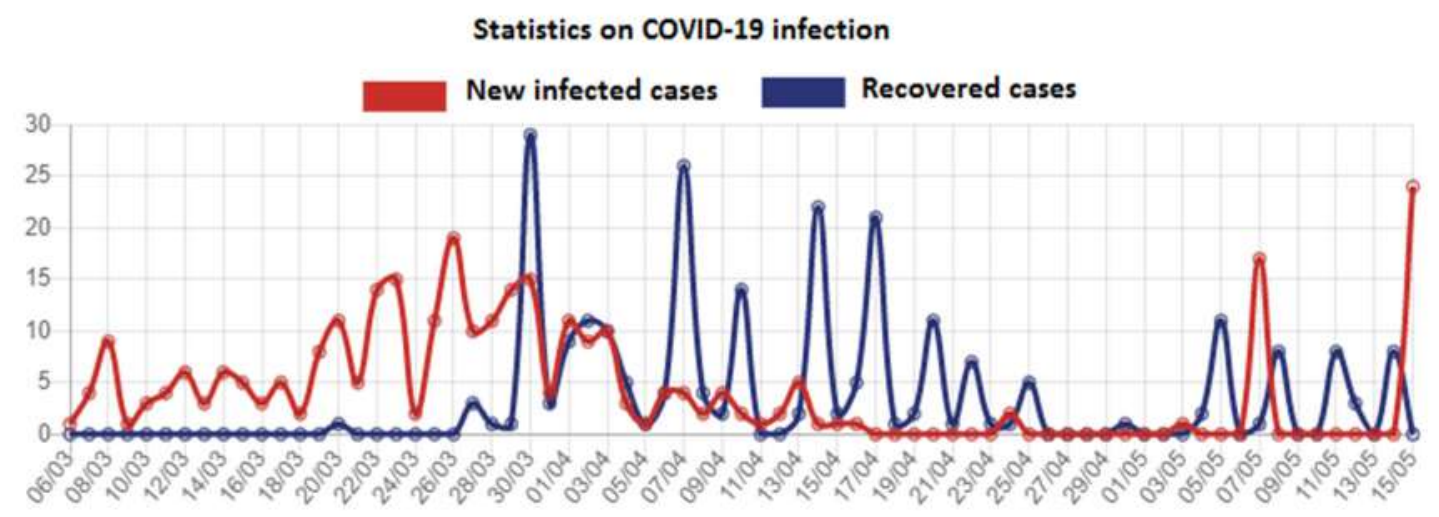

Figure I. Statistics on Covid-19 infection from March I6th 2020 to May I5th 2020.

(Source: MOH, 2020)

Phase I

The first COVID- 19 case was reported in $23^{\text {rd }}$ January 2020. In this phase, 16 persons were infected, treated and already recovered. The infection sources were from people travelling from Wuhan and other countries. There was no transmission case to the community (Le Hiep, 2020). In China, the pandemic hotspot, COVID- 19 started to spread out significantly. The pandemic was transmitted quickly to neighbouring countries (VNA 2020).

As long as the first case in Vietnam was confirm, the government has applied the most stringent preventive measures to minimize contagion. After the country declared COVID-19 as a nationwide epidemic (on February, $I^{\text {st }} 2020$ ), actions were immediately taken. Body temperature control was done to all passengers from China and all 
suspected cases were quarantined. Students throughout the country were not allowed to go to school, and thus, had to stay at home. The whole Son Loi infection commune was confined $(\mathrm{MOH}, 2020)$.

\section{Phase 2}

From $6^{\text {th }}$ March, infection cases mainly came from Vietnamese people travelling back from Europe and the United States. The first cases of community infection were also confirmed. There were two epidemic clusters in Hanoi and Binh Thuan Province. As on $19^{\text {th }}$ March Vietnam had 85 cases, of which 69 on treatment and no death. On March, II $^{\text {st }}$ 2020, WHO officially declared COVID-19 as a global pandemic (VNA, 2020). On $17^{\text {th }}$ March, Vietnam temporarily suspended visa grants for entry foreigners. Vietnam Airlines ceased all incoming international flights. From $2 I^{\text {st }}$ March, Vietnam stopped visa grants for all foreigners. All people from abroad entering Vietnam were sent to concentrated quarantine camp in 14 days. Two epidemic clusters were isolated. From 28 March, all crowded-gathering activities were shut down $(\mathrm{MOH}, 2020)$.

\section{Phase 3}

On 20 March, there were some infection cases in community that could not identified infection sources. There were two big epidemic outbreaks at Bach Mai Hospital in Hanoi and Buddha Bar in Ho Chi Minh City. Within a month, the infection cases increased rapidly, but so did the recovered ones. After two weeks of social distancing along with other preventive measures, Vietnam had no new case. After social distancing was relaxed, from $7^{\text {th }}$ May there appeared new cases from abroad (VNA, 2020).

Strongest preventive actions were taken such as limiting gatherings, cluster lockdown, social distancing, and compulsory I4-day quarantine after entry into Vietnam $(\mathrm{MOH}$, 2020; VGP, 2020).

In Vietnam to ease the control and communication, the Ministry of Health encodes the coronavirus infected and suspected people as follows: F0 as a Coronavirus infected person, $\mathrm{FI}$ as a person who has direct contact with F0 had conversation in 15 minutes or more, in a distance of less than 2 metres; who was in the same hotel or on the same flight as the F0. Similarly, F2 is someone who has been in direct contact with FI.

\section{Study objectives and methodologies}

The subject of this study is to research behavioural changes among Hanoi youth in access to public spaces and adaptation to social distancing. This study focuses on reviewing the relations between knowledge of COVID- 19 with attitudes towards pandemic control and access to public spaces. The study also learns about factors that may influence social distancing, including those that encourage access to public space and those that have impacts on the understanding of pandemic-caused risks.

The case study was carried out via an online survey and in-depth interview. An online survey was conducted with a short questionnaire of 12 questions. Face-to-face in-depth interviews with young people living in Hanoi were done by sociologists. The study was carried out during social distancing time in Hanoi (April $20^{\text {th }}$ ) to its end (on May $10^{\text {th }}$ ). There was total of 325 online respondents and 15 in-depth interviews taken. The table I below illustrates characteristics including gender, age, and education of participants of the online survey. Participants consists of more females than males. Most of them are under 30 years old, and graduate education. 
Youth Access to Public Space during COVID-19 Pandemic in Hanoi, Vietnam

Table I. Demographic about online respondents

\begin{tabular}{|c|c|c|}
\hline & Frequency & Percentage \\
\hline \multicolumn{3}{|l|}{ Gender } \\
\hline Male & $|5|$ & 46.5 \\
\hline Female & 174 & 53.5 \\
\hline \multicolumn{3}{|l|}{ Age } \\
\hline Under 20 & 99 & 30.5 \\
\hline From 20 to 30 & 161 & 49.5 \\
\hline Above 30 & 65 & 20.0 \\
\hline \multicolumn{3}{|l|}{ Education } \\
\hline High school & 22 & 6.8 \\
\hline $\begin{array}{l}\text { Undergraduate, } \\
\text { Graduate }\end{array}$ & 303 & 93.2 \\
\hline
\end{tabular}

\section{Study findings}

\section{Knowledge of young people about COVID-19}

During COVID- 19 time, "social quarantine" and "social distancing" were two measures successfully applied to improve efficiency in pandemic control in Vietnam. Most respondents had an explicit distinction between these two terms. According to their understanding, social distancing meant limiting contact with people within a short distance while social quarantine meant staying at home. The interests in learning about social quarantine and distancing were seen vividly when the social distancing order was implemented throughout the nation. Specifically, the sudden increase in number of searches for these two keywords on Google/Google Trends is a clear evidence for the people's concern.

Social quarantine was considered necessary, especially at the pandemic peak in Vietnam (the first half of April 2020) while social distancing was more suitable for the after-peak period. Social quarantine and distancing were essential even though they caused negative impacts on the economy and people's lives.

"Social distancing and quarantine are highly necessary because if the pandemic outbreak, it would cause severe consequences and the number of deaths would grow in an unpredictable manner."

(Female, 22 years old) 


\section{Youth attitudes toward COVID- 19 and access to public space}

2.I. The attitude of young people towards COVID-19 epidemic

- Worry about the disease and the spread of the disease.

Many people felt worried about the pandemic outbreak when the $17^{\text {th }}$ case was reported in $7^{\text {th }}$ March 2020. She was the first person found positive for coronavirus on a crowded flight. As a result, all passengers and aircrews on this flight were at risk of being infected, which forced them to be isolated from other people. This created a mass effect in society. People rushed to shops to get supplies.

"Right when the I $7^{\text {th }}$ patient appeared, I felt that the disease was so dangerous and very close to me. No one knows who she/he had contact with, with or without pathogens. Transmission risk is high."

(Male, 29 years old).

Most of respondents in in-depth interviews were afraid of the increased outbreak of the disease, because at the time this research was conducted, the vaccine for this disease was still being studied while the situation in European countries was very complicated.

"Coronavirus is really scary because of its danger and its contagion speed. Moreover, there have not been vaccines for it. In Vietnam, however, there were many people who have been cured but there are also many who tested positive for coronavirus again (twice or 3 times) and struggle to recover completely". (Male, 22 years old, student)

"Before the I 7th patient, I was not afraid because I thought it was just a common flu epidemic. However, when the 17th patient was detected and the disease broke out in Europe were the most worrisome."

(Male, 23 years old, tour guide)

Young people in the research are those whose jobs were in regular contact with other people or working outside, such as doctors, nurses, or tour guides. They are much more afraid of the danger and the spread of COVID-I9.

"As a trainee at Bach Mai Hospital, I regularly use food and drink services at Truong Sinh (I-2 times / day) [Truong Sinh is a service facility in the hospital, and an outbreak] so there is a possibility that I am F2 or F3. However, as soon as it was confirmed that the I7th patient was positive, we were instructed to limit our visits to the clinic and to eat in the room. Until the case of a nurse at the infectious transmission department was positive, we were tested and isolated at home". (Female, 22 years old, student)

"I am at risk of infection because I work as a tour guide and have a lot of contact with foreigners. There are days when I feel tired, so I also worry about being infected."

(Male, 23 years old, tour guide) 
- $\quad$ Believe in the measures to prevent COVID-19 from government Besides, there were others with fewer worries as they believed in pandemic preventive measures by the Government and communities.

"The pandemic is not so worrying if we place our trust in the government disease prevention and control activities and we have senses in pandemic control according to instructions by the Ministry of Health."

(Female, 21 years old).

"The disease has spread and there were people who died because of it so it is right to feel afraid. But we shouldn't be worried much. We have measures to prevent it and if people are conscious, it can be prevented. It depends on humans to let the epidemic spread much or not. If there is one person who is unconscious like without social distancing and social quarantine, the virus will spread from I to I00 people and much more."

(Female, 19 years old, student)

"In my opinion, on a I0-point scale, my fear level of epidemic is only at 5 because I see that Vietnam has been very proactive. Shown through the cases of the I7th patient or the outbreak in Bach Mai hospital, the intervention of the media or the social confusion of people are the reason for this proactiveness. If we are conscious and have good perception in self protection, self-isolation and social distancing as directed by the Prime Minister, there is no need to worry uncontrollably."

(Female, 22 years old, student)

2.2. The psychological effects that young people experience when implementing social distancing and social quarantine.

In the context of the rising epidemic and isolation measures applied, fear and anxiety have become common. At the same time, the social distancing and implemented limits have created tremendous pressure on people, including young people. Many people have experienced different psychological stages from imbalance to adaptation. The general feelings among youth were uneasiness and discomfort when they had to stay at home and limit physical contact with colleges and friends. Youths with high outdoor activity habits felt more difficult when staying inside their homes.

"I felt sad, bored and there was nothing left for me to do because I used to work outdoors. At home, sometimes I felt stressed and stifling." (Male, 23 years old).

"When I practiced social distancing and stayed at home, at first, I feel frustrated and bored. It is boring because I had to repeat everything day by day."

(Female, 21 years old, students)

"There was a bit of a break due to not interacting with friends, not having entertainment activities and doing sports."

(Male, 19 years old, student) 
"I think that, when I was at home for 2 weeks for social quarantine, I was very uncomfortable because my house is small. I do not have enough space to exercise on my own.

Being in the room too much and using the internet for entertainment for too long also made me feel uncomfortable and tired in the morning which made it difficult to sleep at night."

(Female, 22 years old, student)

\subsection{The importance of public space to the young folks.}

Research about Public space in the Hanoi area of Doan The Trung and colleagues (2018) reported that teenagers and young adults actively came to public spaces and considered these being their regular activities. Spaces namely sidewalks, parks, gardens or walking streets were popular locations where the youngsters often visit during the weekends or their free time. Apart from this, serving the needs of improving health or playing sports such as football yards and other spaces were also preferred by young people.

Young people desire for quarantine to end of the quarantine also reflects their anxiety and dissatisfaction as well as the importance of public space. Social quarantine and social distancing have urged young people to temporarily give up their habit of accessing public spaces. As a result, when people were asked about their willing after social quarantine and social distancing, many commented that they would return to public spaces as a routine. The table below illustrates the most impressive memory of youth in Hanoi about public spaces (Table 2). These places would be their first places they would like to visit right after the quarantine end. During the social quarantine, most youngsters missed going to the locations for communication and urban services $(47,4 \%)$, followed by lovely hubs of Hanoi $(35,9 \%)$ and public spaces with Hanoi's identity. This means that public spaces are not just the areas daily activities, but rather reflect the lifestyle of city's residents, their strong connection to the city and carry the identity of the capital.

Table 2. Most impressive memory about public space. Source: Survey 2020.

\begin{tabular}{l|l} 
Most impressive memory about public space & $\begin{array}{l}\text { \% within the total } \\
\text { surveyed people }\end{array}$ \\
\hline Place for communication and urban services & 47.4 \\
\hline Lovely hubs of Hanoi & 35.9 \\
\hline Public space with Hanoi's identity & 37.8 \\
\hline Places for study and work & 8.3 \\
\hline Exercises, sports, culture & 5.8 \\
\hline Relating to Covid-19 & 6.4
\end{tabular}

Many people had a strong attachment to public spaces. Most of them prioritized public spaces as the foremost location to come after the quarantine (Table 3) with public space including areas with services $(31,52 \%)$ school, hospitals and public constructions $(20,61 \%)$ as well as official public spaces (19,39\%). 
Youth Access to Public Space during COVID-19 Pandemic in Hanoi, Vietnam

Table 3. Places that are looked forward to being visited after the quarantine. Source: Survey 2020.

\begin{tabular}{l|l} 
Places that are looked forward to being visited after the quarantine & Percentage (\%) \\
\hline Official public spaces & 19.39 \\
\hline Areas with service (cafes, restaurants, vendors) & 31.52 \\
\hline Unconstructed spaces & 25.45 \\
\hline Schools, hospitals and public constructions & 20.61 \\
\hline Stay at home & 3.03
\end{tabular}

Many people hoped that by the end of the quarantine, they could return to public spaces and experienced their activities here like before (Figure 2). Young people still wished to access public spaces for social activities (60.6\%) and entertainment (29.7\%). Thus, accessing public space was an essential need and an ongoing expectation of many.

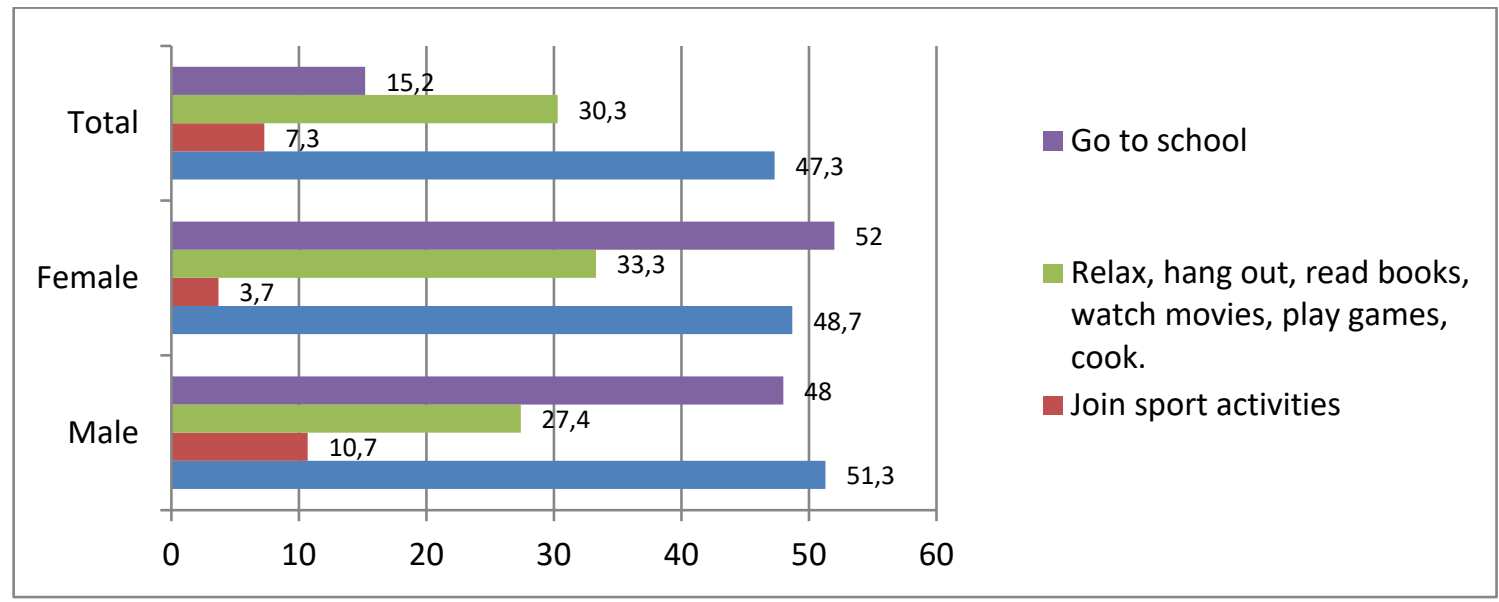

Figure 2. Wished activities in public spaces of young people after the quarantine. Sources: Survey 2020

When social distancing was compulsory, everyone missed public spaces with many activities. Right in social distancing time, people missed and had more understanding of the value of public spaces.

"I love the feeling of being with friends and chatting while drinking tea or eating meals at familiar sidewalk restaurants" (Female, 22 years old). "I miss Football yards, gyms for sport activities, and cafes to communicate with others that are basic activities in daily life."

(Male, 24 years old).

To many people, public spaces are their favourite places where they can relax and enjoy the moment with their friends and families. 
"I prefer enjoying my favorite drink in a tranquil cafe alone, which makes me focus on my work and spares me a comfortable space. Driving around West Lake with my friends is also a good choice since the sight and the atmosphere here ease my mood.

(Female, 22 years old).

"I love to have a cup of coffee or tea after having breakfast, or gossip with my close friends about our quarantine and difficulties".

(Male, 23 years old)

Many people, with various intentions, have looked forward to the end of the quarantine so that they can be back to public spaces.

"I will go to West Lake first to breathe the air because West Lake is a very airy and comfortable place that is easy to relieve pressure and bring comfort to me." (Female, 21 years old). "I would go to the restaurants first since my appetite has obsessed and discomforted me during the quarantine. I want to return to my daily routine via my hobbies as soon as possible"

(Male, 23 years old).

\section{Behavioural changes among young people in COVID- 9 social distancing}

\section{I. Accessing and using public spaces before Covid-19 pandemic}

Public spaces are perceived differently among respondents. In this research it might include parks, big squares, services space, cafeteria or other useful spaces like grounds, empty spaces, flyovers, sidewalks, temples, pagodas, etc.

Public spaces were utmost necessary and closely attached to the life of Hanoi youth. Before the pandemic, Hanoi young people used to visit public spaces. The very frequent and frequent levels were respectively $31.7 \%$ and $39.1 \%$ (Figure 3 ).

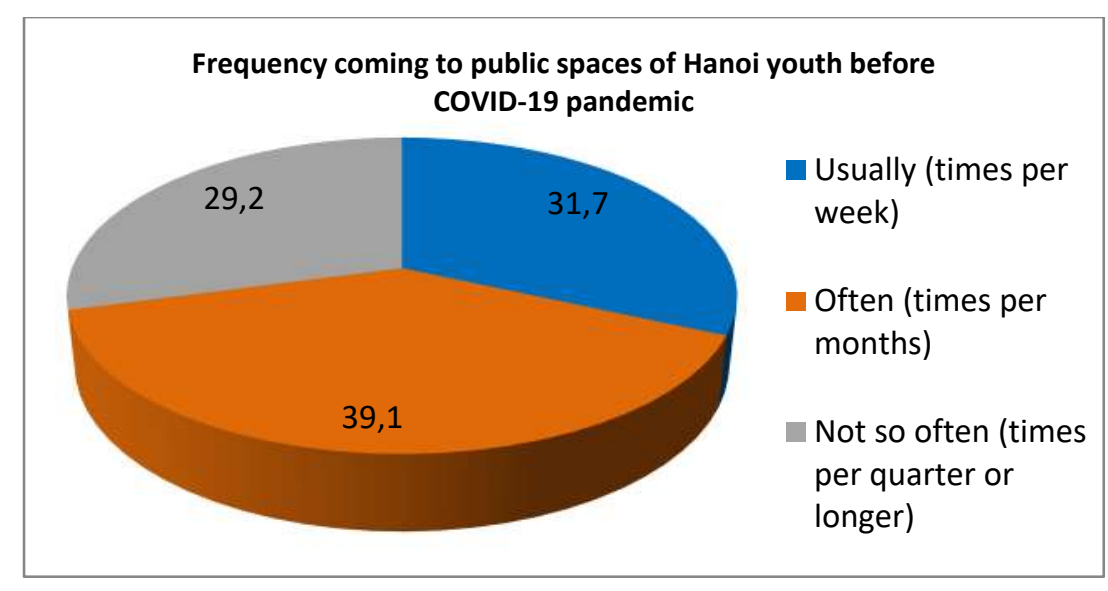

Figure 3. Frequency coming to public space of Hanoi youth before Covid-19 pandemic Source: Survey 2020

Their main needs when accessing public spaces included entertainment, relaxation (79.4\%), meeting, eating and sharing information with others $(52.0 \%)$, having chats with lovers, friends, and relatives (50.8\%) (Figure 4). 
Youth Access to Public Space during COVID-19 Pandemic in Hanoi, Vietnam

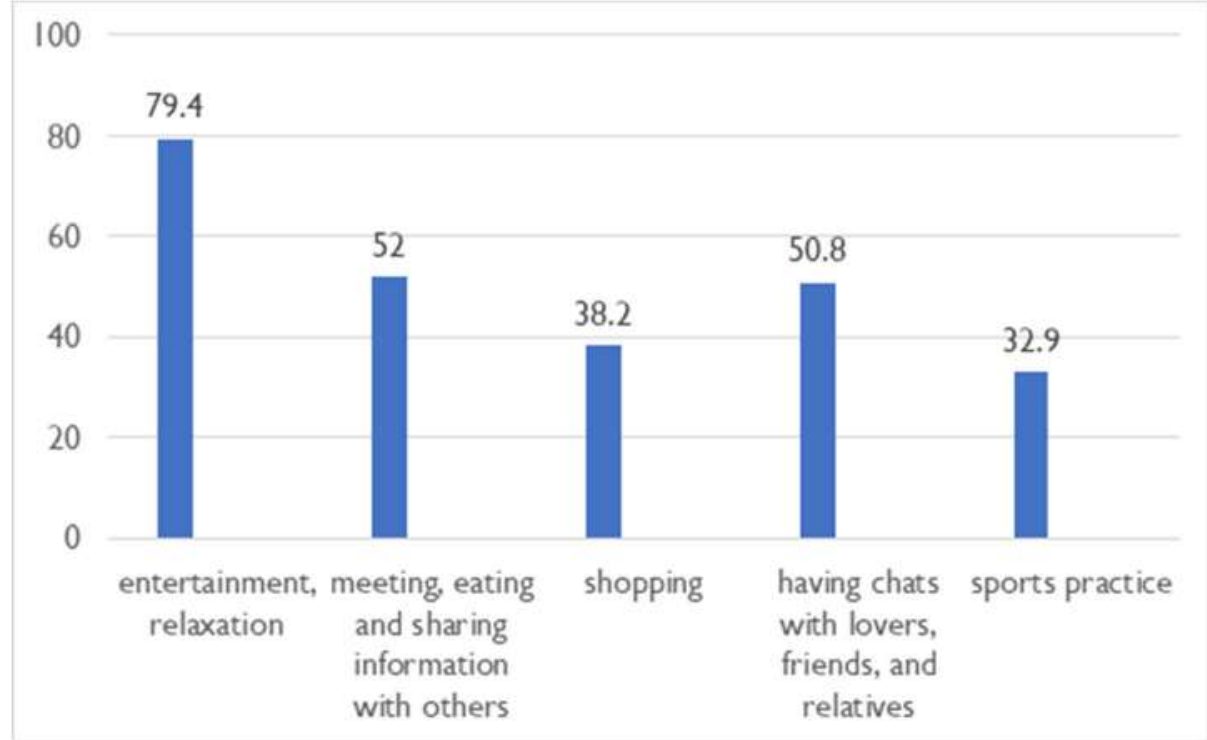

Figure 4. Activities at public spaces by Hanoi Youths before Covid-19 pandemic. Source: Survey 2020

Public spaces were places for young people to have social activities with friends, coworkers and neighbours (83.2\%), or with family members (48.8\%) (Table 4). Women were often with their relatives and friends ( $60.5 \%$ and $53.0 \%$ respectively), while most respondents visiting public space alone were men $(81,8 \%)$. These results depict the importance of public space to Hanoi's young population (Table 4 and Figure 5). Public spaces are where they spend their time chatting and relaxing with their friends, families and colleagues.

Table 4. With whom Hanoi youth go to public spaces. Source: Survey 2020

\begin{tabular}{l|c|c|c} 
Person/ people to access to public space with & \% of total & \multicolumn{2}{|c}{ \% within gender } \\
\cline { 3 - 4 } & & Male & Female \\
\hline Families and relations & 48.8 & 39.5 & 60.5 \\
\hline Friends, colleagues, neighbours & 83.2 & 47.0 & 53.0 \\
\hline Alone & 3.4 & 81.8 & 18.2
\end{tabular}

3.2. Adaptation activities in the time of social distancing

During the social distancing period, people were put under psychological pressure, especially those who were used to hanging out at public spaces. Concurrently, there were also changes in their daily lives and behaviours to adapt with the new situation. 


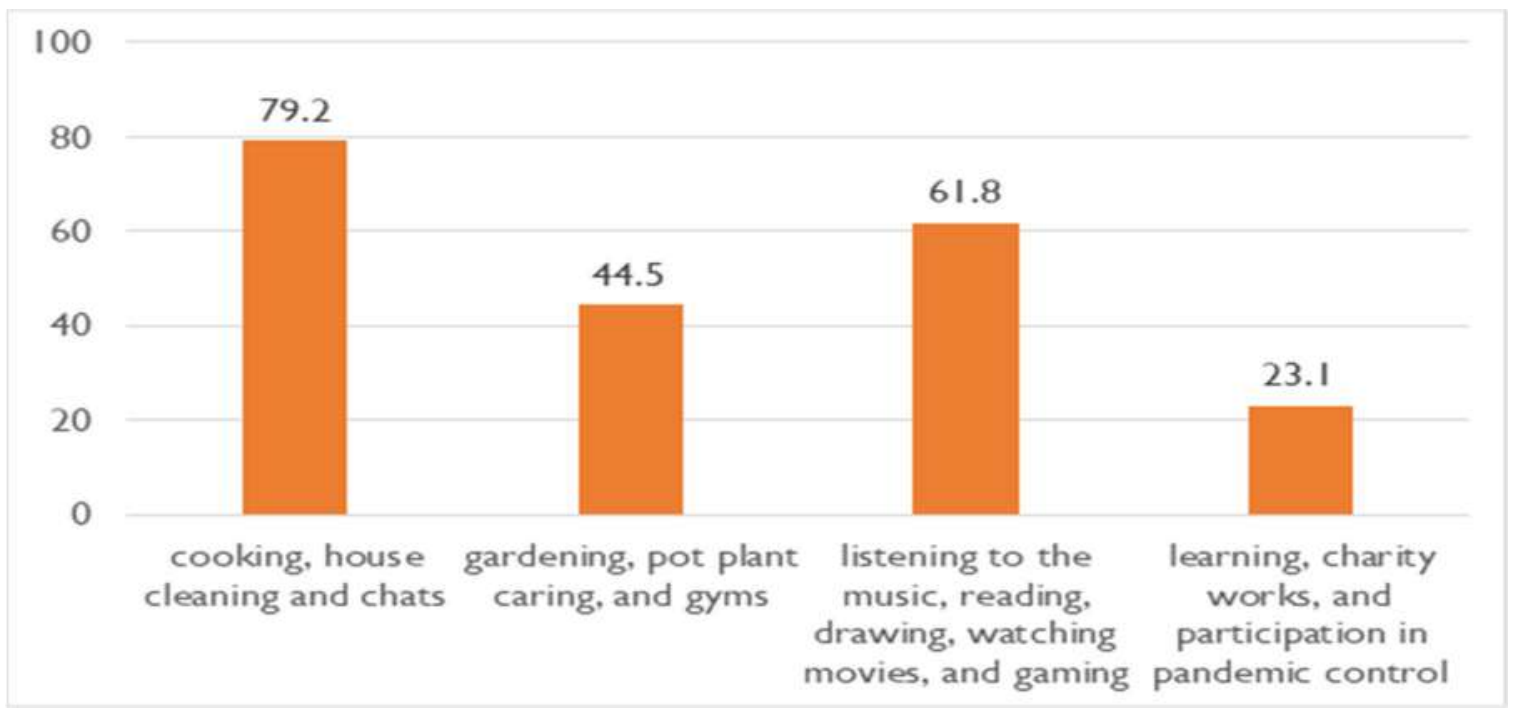

Figure 5. Adaptation activities of Hanoi youth in the time of social distancing. Source: Survey 2020

According to the online survey, during the social distancing period, people's behaviors changed to adapt (Figure 5). They spent most of their time interacting with family members via activities like cooking, house cleaning and chats (79.2\%). They also had more time for personal entertainment activities like listening to music, reading, drawing, watching movies, and gaming (6I.8\%); physical activities like gardening, pot plant caring, and exercising (44.5\%). About one fourth (1/4) took active social actions like learning, doing charity works, and participating in pandemic control (23.1\%). A very interesting fact is that more female youngsters took their time cooking and chatting with family members than males (Table 5), while men participated in sport activities and other entertainments more than women did.

Table 5. Activities during social distancing. Source: Survey 2020

\begin{tabular}{|c|c|c|c|}
\hline \multirow[t]{2}{*}{ Activities } & \multirow[t]{2}{*}{$\%$ of total } & \multicolumn{2}{|c|}{$\%$ within gender } \\
\hline & & Male & Female \\
\hline Cook, tidy, chat with family members & 43.8 & 56.2 & 79,2 \\
\hline Garden, exercise, play sport & 53.2 & 46.8 & 44,5 \\
\hline Listen to music, read books, draw, watch movies, play games & 58.9 & 41.1 & 61,8 \\
\hline Study and volunteer, support activities preventing Covid-19 & 52.5 & 47.5 & 23,1 \\
\hline
\end{tabular}

While many people struggled to stay at home most of the time, others found solutions. After a period of implementing social distancing and social quarantine, some young people in the survey found a way to adapt to not going out, participating less in community activities and using public spaces. Feelings of boredom and frustration have 
also gradually been replaced by increased feelings of comfort with indoor activities or activities in quiet spaces.

"In order to replace the activities in public spaces which I cannot do, I take time to do what I love like cooking for the family, watching movies, and playing games. In the past, I had more face-to-face talks with friends, now I have less chat with them. Sometimes, I text them to kill time." (Female, 22 years old).

"In the first days, I felt bored and uncomfortable but after that I found comfort. I had more time to study, take care of myself, listen to my inner-self, be moderate and take a suitable diet and physical activities" (Female, 22 years old).

Many found positive aspects of staying at home.

"During social distancing, my family always had reunion meals. Before, I was occupied and had less time to talk with others. During social distancing period, my family members play together. I even have more time to take care for my parents and myself."

(Female, 21 years old).

"I just have a little bit of frustration due to not hanging out with my friends, and not having entertainment outside. I have more favourite activities at home now. I listen to music and watch

films alone. Sometimes, I watch movies with my younger brother, but I mainly watch alone. I also do exercises to maintain my activeness."

(Male, 19 years old, student)

During social distancing period, people's behavioural changes were reflected by taking more moderate living and better care for themselves and their families. Here after are some examples of these behavioural changes:

"I do more physical activities and pay more attention to personal hygiene. Staying at home is also interesting because there is more time to care for my home, play with cuisine and enjoy life."

(Male, 29 years old).

In addition, social distancing changed ways of communication with relatives and friends, working methods, and online learning. Online communication advanced during the COVID-I9 pandemic. "Physical visits to friends are limited so I text and use Facetime instead.

However, such changes in communication are less comfortable, natural and emotional than face-to-face interactions."

(Female, 21 years old).

\section{Discussion \& Conclusion}

- Public space accessing before the COVID-19 pandemic

There are diverse forms of public spaces in Vietnam as a whole and in Hanoi specifically. Hanoi has parks ranging from small to large scales, but sidewalks are noticeable as the most popular kind of public space in this city. Many daily activities of Hanoi residents 
occur there, especially in the area near the city centre. Cafes and street vendors abound alongside the pavements which are students' favourite places. The most frequent activities here include walking, sitting, chatting, relaxing, eating and drinking. (Sanders et al., 2015; Nguyen Quang Minh et al., 2019).

Activities in public spaces are quite various. While there are soft activities namely gossiping, watching other people, studying, doing exercises, and playing sports. Some people prefer more lively ones such as skating, hip-hop and flash-mob dancing (Geertman et al., 2016; Tran, 2015; Pham et al. 2019). Most people come to public spaces for physical and exciting activities. To be more specific, just one third of the total did soft activities, whilst respondents visiting public space for other purposes occupied only a small part (I3\%) (Geertman et al., 20I6). Interests of young people also vary from one to another. Some youngsters are keen on private and tranquil public space with a good light system. There are some that dislike crowded places or public space with many guards. Meanwhile others prefer lively and bustling public spaces. In addition, young people choose public spaces to perform impressive shows or experience new activities that have not been accepted by the authority (Geertman, 2015; Tran, 20I5). The diversity of public spaces together with various activities here have created a unique identity of urban areas which is a part of Vietnamese citizens and the young population's lifestyle.

- Negative impact on mental health and daily lives

The quarantine has a negative impact on many people's mental health and daily lives, especially young adults and teenagers who are used to participating in social activities in public space. Beside concerns about the pandemic, residents also have to suffer from confined, stifling feelings when they stay at home and are not able to be involved in daily habits involving social interactions namely shopping with their friends or families, going for a walk or playing sports. This result is similar to ones of other research. Covid-19 pandemic is responsible for an increase in anxiety and stress of people all over the world (WHO, 2020). According to a study on the impact of the pandemic on every aspect of the society, the pandemic affected the mental health of many social groups, regardless of their classes. To be more specific, their behaviours show signs of frustration, distress and worry more regularly. The more time they spend at home, the more pressure and depression they are put under (Elgimati and colleagues, 2020). A research at the start of 2020 which surveyed students who had to stay at home recorded a high anxiety level among these young people (Wang \& Zhao H, 2020). Another research conducted in February 2020 which aimed at the impact of the COVID pandemic on Chinese citizens reported that most Chinese do not suffer from anxiety or depression (Yenan, 2020). It is also believed that youngsters are negatively affected more easily than their seniors, while women are often more anxious than men. Highly-educated people are notably proved to be more depressed that those who have lower education, and people working in specialized fields are at higher risk of suffering from anxiety and depression than laborers or service workers. As shown from these results, groups of young people who receive higher education are more vulnerable to mental health impacts of COVID-19. Due to this, respondents who are young adults and teenagers of the surveys are looking forward to the end of the social quarantine and the social distancing when they can return to their routines in public spaces. Besides, many people also hope to meet and communicate with their friends again. 
- Positive attitudes towards pandemic prevention.

Despite suffering from mental problems due to the COVID-19, in-home quarantine, and being limited from accessing public space, teenagers and young adults complied the quarantine request with a positive attitude. This can be attributed to several attempts of the government. According to the research of Nguyen T.T.P. (2020) in April 2020, in the circumstance when Vietnam had weak preventive strategies, the state had to consider efficient solutions to "flatten the bend" of the total positive cases. This means that the role of the government in instructing and announcing explicit and public information together with the involvement of social media play a significant part in reinforcing citizens' trust in the government's policies, therefore changing citizens' behaviours regarding pandemic prevention (wear mask, wash their hands, keep distance, health declare). This can explain the faith of young people in this research as well as why they adapt with modifications in behaviours after they were prohibited from accessing public space during the quarantine.

- Social distancing has made many people change their attitudes and behaviours. In Vietnam, several new trends have appeared, especially among young family to reduce stress during the social quarantine. Online groups namely "Hate kitchen, not addicted to home", or "Love kitchen, addicted to house" with up to about tens of thousands of participants are notably a trending phenomenon. These are places where Internet users share their funny moments of cooking, tidying, or feeling relaxed when they do household chores. Besides that, several indoor sports activities are done with the encouragement of gyms and medical staff who upload their exercise instructions on the Internet ${ }^{2}$. It is not to mention voluntary attempts during the COVID-I 9 period. Many groups have actively supported doctors, families meeting difficulties due to the pandemic ${ }^{3}$, which is considered as an initiative of citizens and young people to balance the COVID-19 life.

Young people participating in this research has adapted several changes in order to deal with the quarantine and distancing due to COVID-19. In the social distancing period, there have been many activities to enhance communication among family members and enable them to have more time for personal activities. Many at-home activities have been created to help people maintain their sense of balance. However, being unable to access public space, many people gain a better understanding of the value of public space in their daily life. Public space remains the top expected destination to visit of everyone after the pandemic ends.

\footnotetext{
' https://laodong.vn/chuyen-nha-minh/suc-hut-cua-hoi-ghet-bep-khong-nghien-nha-dang-gay-bao-mang-xahoi-798498.Ido

${ }^{2}$ https://hellobacsi.com/benh-truyen-nhiem/coronavirus/tap-luyen-the-duc-tai-nha-trong-mua-dich-covid$19 / \#$ gref

${ }^{3}$ http://bvydhue.com.vn/cl01/t/01-917/nhung-tam-long-thien-nguyen-trong-mua-dich-covid-19.html
} 


\section{Acknowledgment}

Our special thanks go to the Project of Transformative Youth Spaces (TRYSPACES) for creating conditions and support for the ideas and activities of the study group. We highly appreciate the ideas suggested by City Space Architecture. We would like to thank Ms. Truong Thi Ly and Ms. Do Thi Ngan for their taking part in conducting indepth interviews.

\section{References}

Doan The Trung, Ta Quynh Hoa, Nguyen Quang Minh, Tran Minh Trung, Nguyen Manh Tri, Chu Ngoc Huyen, Pham Tien Hau (2018) 'Summary report of the public spaces observational survey phase I'. Report of NUCE Team for TRYSPACES Hanoi.

Elgimati, Y., Alrasheed, A. and Mohamed Bashir, A. (2020) 'Effect of a COVID-I9 on Social, Psychological, Economic and Health Conditions in Libya', Journal of Applied Science, Engineering, Technology, and Education. Takalar, Indonesia, 3(2), pp. 160-170. doi: 10.35877/454RI.ascil 36.

Geertman, S. (2015) 'Youth - friendly public space in Hanoi', VIUP Journal of Construction and Planning', No. 74, pp. 35-37.

Geertman Stephanie, Danielle Labbé, Julie-Anne Boudreau, Olivier Jacques (2016) 'YouthDriven Tactics of Public Space Appropriation in Hanoi: The Case of Skateboarding and Parkour', Pacific Affairs, Vol. 89 (3), pp:59I- 6II.

Le Hiep (2020) 'The overview of 3 phases of Covid-19 epidemic in Vietnam', https://thanhnien.vn/thoi-su/toan-canh-3-giai-doan-dich-covid- I9-tai-viet-nam-1207707.html.

Ministry of Health (MOH) (2020) 'Coronavirus Disease (COVID-19) Outbreak in Vietnam', Ministry of Health, https://ncov.moh.gov.vn/.

Nguyen Q.M. et al. (2020) 'Identifying and Assessing the Attractiveness of Public Spaces for the Youth as a Key Factor to Help Establish Social Sustainability-Case Studies from Hanoi' In: Reddy J., Wang C., Luong V., Le A. (eds) ICSCEA 2019. Lecture Notes in Civil Engineering, Vol 80, Springer, Singapore, https://doi.org/I0.1007/978-98|-I5-5I44-4 I2.

Nguyen T.T.P., Nguyen L.H., Le H.T., Vu G.T., Hoang M.T., Nguyen D.N., Le X.T.T., Tran B.X., Nguyen T.T., Pham Q. T., Ta N.T.K., Nguyen Q.T., Latkin C.A., Ho R.C.M. and Ho C.S.H. (2020) 'Perceptions and Attitudes Toward COVID-19-Related National Response Measures of Vietnamese: Implications for Pandemic Prevention and Control', Front. Public Health 8:589053. doi: 10.3389/fpubh.2020.589053. 
Youth Access to Public Space during COVID-19 Pandemic in Hanoi, Vietnam

Pham, T. T. H., Labbé, D., Lachapelle, U., Pelletier, E.(2019) 'Perception of obstacle to park access and park use amongst youth in Hanoi - How cultural and local context matters', Landscape and Urban Planning, No. 189, pp. I56-165.

Sanders, P., Zuiggest, M., Geurs. K.(2015) 'Liveable streets in Hanoi - A principal component analysis', Habitat International, No. 49, pp. 547-558.

Tran, T. H. G.(20I5) 'Old villages and new streets - Stories about public space: Public space system in Trung Hoa - Nhan Chinh new town', Journal of Construction, No. 74, pp. 52-53.

Vietnam News Agency (VNA) (2020) 'The fight against COVID-19 in Vietnam: 100 days of review', Vietnam News Agency <https://www.vietnamplus.vn/cuoc-chien-chong-dich-covid I9-taiviet-nam-100-ngay-nhin-lai/638|40.vnp.

Vietnam-5F Data Team (2020) 'Covid-19 pandemic in Vietnam', https://datastudio.google.com/s/s7-」 5zilzA.

VGP News (2020) 'Infographics: 100-days battle against Covid-19 outbreak', http://news.chinhphu.vn/Home/Infographics-100day-battle-against-Covid 19outbreak/20205/39970.vgp.

Wang $\mathrm{C}$ and Zhao H (2020) 'The Impact of COVID-19 on Anxiety in Chinese University Students', Front. Psychol. I I:I I68. doi: 10.3389/fpsyg.2020.0II68

WHO (2020) 'Coronavirus Disease (COVID-19) Advice For The Public' https://www.who.int/emergencies/diseases/novel-coronavirus-2019/advice-for-public

Yenan Wang, Yu Di, Junjie Ye \& Wenbin Wei (2020) 'Study on the public psychological states and its related factors during the outbreak of coronavirus disease 2019 (COVID-19) in some regions of China', Psychology, Health \& Medicine, Vol 26 (I), Pp. 13 - 22, DOI: I0.1080/I3548506.2020.17468 I 7 . 


\title{
Rethinking Past Green Space Manufacture to Boost Equitable Future Urban Recovery
}

\author{
lan Morley
}

The Chinese University of Hong Kong, Department of History, Hong Kong SAR

ianmorley@cuhk.edu.hk

\begin{abstract}
A multitude of determinants influence the urban planning process. Yet, in the presentday context of an ongoing pandemic causing infirmity and death in thousands of towns and cities, how can examples of urban planning from history, namely ones that sought to boost public health, (re)shape the current planning paradigm? Is there a need in the light of the global impact of Covid- I 9 to (re)evaluate the value of past planning models and so, in accordance, rethink present-day urban density management and public space creation? In consequence, this paper puts forward an overview of how urban planning and public health have historically interlinked, albeit with reference to $19^{\text {th }}$ century Britain and the establishment of public parks. Used communally by assorted social groups such green spaces were considered to be crucial for physical and mental health. Significantly too, these open areas are still a fundamental element of the $21^{\text {st }}$ century British cityscape and, arguably, as part of the present and future social recovery from Covid-19, will play a vital role in public life and well-being.
\end{abstract}

Keywords: city planning, public health, public space, parks, Britain

To cite this article:

Morley, I. (2020). Rethinking Past Green Space Manufacture to Boost Equitable Future Urban Recovery, The Journal of Public Space, 5(3), I47-I58, DOI 10.3289I/jps.v5i3.1283

This article has been double blind peer reviewed and accepted for publication in The Journal of Public Space. 


\section{Introduction}

There is no shortage of data on the evolution of urban environments in past and contemporary eras. Descriptions, analyses, and explanations of their development have been provided by countless authors heralding from a variety of scholarly fields: consequently, a wide-ranging general international commentary on cities and their built fabrics now exists. However, in this intellectual setting it is often understated that public health and urban planning have interwoven existences. To be blunt, the history of cities is the history of disease and, likewise, the history of disease is the history of cities. Moreover, the importance of the relationship between urban planning and public health is frequently downplayed. For instance, as a tool of the state modern city planning emerged during the $19^{\text {th }}$ century to help tackle human health and environmental pollution issues apparent within fast-growing industrial settlements in Europe and North America (Lopez, 2018). Green space creation was vital to the emergent urban design and health management process.

The opening sentence of Edmund Bacon's influential text Design of Cities (1967) states that a city's environmental form reflects the nature of the civilisation to which it belongs. In comprehending how the character of the urban environment reveals the disposition of society at large Bacon emphasizes the role/significance of architectural mass and space. In view of his standpoint, and with reference as well to empiricism derived from humankind's past city planning experiences, thus, whoever engages in the laying of buildings, roads, and public spaces should possess cognizance of how their actions can potentially forge high quality, people-friendly built environments but, in contrast, know that when planning is applied defectively low quality, alienating, and dreary urban fabrics will result. (Carmona et al, 2003: vii) Command of planning's impacts upon people, particularly their quality of life, inevitably garners extra magnitude when severe social disruption, e.g. a pandemic, occurs.

\section{Covid-19 and the contemporary green space challenge}

Critical urban studies have shown that whilst in recent decades the worldwide tendencies of rapid urbanisation and globalisation have improved the lives of millions of people, the negative side effects of these trends have become all the more obvious. Of note too, the transpiring of the Covid-19 pandemic since 2019 has intensified such predicaments. Given this situation and taking into consideration the contagion's severity, its wide geographical diffusion, and the fact that the vast majority of its victims are urban dwellers, fresh debate has been prompted as to how the configuration of built environments can affect citizens' well-being. Governments, civil groups, academics, architects, and planning practitioners have therefore elicited new discussion as to how, as an example, public space is planned, accessed, and used.

Notwithstanding it being universally recognised that the existence of urban green space positively contributes to citizens' health and contentment (Shoari et al, 2020), and in conjunction a correlation is known to exist between the absence of green space and increased health issues (Barton and Rogerson, 2017), the Covid-19 pandemic has exposed four elemental issues: physical and mental health impediments allied with contemporary urban living are rising; urban-based health care systems run the risk of breaking down when large numbers of people concurrently suffer from infectious illness; city planning systems have in recent decades failed to comprehensively address 
the paucity of green space within many urban communities; and, in association with the prior point, the standards approach to urban green space planning is malfunctioning in many parts of the world.

Prior to the onset of the Covid-19 pandemic a multitude of local, national, and international commitments to enhance the establishment of green urban spaces existed. For example, UN-Habitat (2018: 4) has advised that 15-20\% of urban land should be dedicated to open public space and the World Health Organisation (WHO, 20I7) devised a globally-applicable green space accessibility index: it recommends that individuals should have access to an open area (of minimum 0.5-hectare area) within 300 metres distance from their place of being. In spite of such advocacies the gravity of the Covid- I9 pandemic has reawakened the public, governments, civil bodies, and urban designers to the ambient risk of urban living as well as the challenge of accomplishing liveable city goals. As an upshot, debates on city planning and well-being have broadened. Evidently, earlier studies on these and related topics have accrued fresh value. By way of illustration, the research of Russo and Cirella (2018) in suggesting that urban places should have at least $9 \mathrm{~m}^{2}$ of green space per capita has renewed urgency as to the need to lay out more open spaces but, in doing so, has accentuated the need to assure that such plots deliver optimal benefits to persons from all social sectors. Furthermore, as previously indicated, the standards approach which has been used in recent years to attain global consistency and certainty in urban green space planning has been shown to be, in many countries, ineffective: land development pressures arising from high rates of urbanisation have meant numerous governments are failing to attain green space provision standards. As a result, innovative approaches to space availability and management are being sought so that urban development can be better directed towards the sustainability framework. In this regard it is worthwhile to ask whether history can supply models to guide future urban management and, so, the post-Covid social recovery process?

\section{The $19^{\text {th }}$ century and urban planning's turning point}

Urbanists have emphasised that the character of the built fabric is influenced by a range of determinants, e.g. the natural world, locational factors, and human-made matters that include culture, aesthetics, the economy, law, and technology. Within grand narratives of historical city evolution scholars such as Peter Hall (1998) have underscored that the rudiments of urban planning are a repetitive feature of civilisations through time. But, within such accounts, evidence is provided to demonstrate that by the early- $19^{\text {th }}$ century urban planning theory and practice acquired new dimensions and perspectives. In Britain concern for public health left an indelible mark upon the design and management of towns and cities.

As to why the $19^{\text {th }}$ century is widely acknowledged as being a turning point in the planning of urban places one must not overlook the social, economic, and environmental effects triggered by the industrial revolution (which commenced in England during the late-1700s). In the view of Lewis Mumford (196I: 458) the 1800s bore witness to the supremacy of three urban features: the factory; the railway; and, the slum. This author though, in the frame of this paper, wishes to highlight the importance of another feature: the municipal park. The development of public parks, to summarise, provided new sources of fresh air, new sites for citizens to engage in a variety of leisure 
activities as well as to engage with nature, and new means to diffuse existent social tensions. Composed as meeting grounds for all groups in urban society the social role of parks was reflected in the activities permitted within them, and via their planting, buildings, and monuments (Conway, 1991: 4).

Whilst cities prior to industrialisation had been "the mainspring of cultural innovation and repositories of everything that is worth while" (Cherry, 1974: 6), the rapid influx of persons from the countryside brought new pressures, tensions, and challenges to urban life and administration (Luckin, 2008: 210). Given this, from about 1830, to thwart the new scale of urban problems in Britain there was increased intervention in, and management of, community affairs. But then again, and considering the historical situation analytically, what did urban planning comprise of? What regulations were introduced as part of its practice? Under what conditions were planning decisions made? Irrespective of modern city planning being developed as an outcome of the British political elites' realisation that the administrative set-up developed in earlier times to safeguard urban environments was impotent under the dynamics of industrialisation, the application of new rules and procedures to regulate the design of houses and residential districts was profoundly swayed by the expansion of medical knowledge with regard to three separate, but connected, matters: overcrowding; insanitary living conditions; and, the widespread presence of infection. Such was the occurrence of contagious illness that by the 1840s the city dwellers' average life expectancy was less than 27 years. Hence the British came to view the industrial city through a binary lens: one view allowed them to observe it as a place of progress, viz. as the engine initiating the growth of national wealth and power; the other standpoint centred upon concern, even alarm, as to its hazardous environmental condition. Contemporary accounts make clear, Britain's industrial revolution rendered a heavy price for the labouring population. With slum dwellers described as "worse off than wild animals" (Fraser and Maver, 1996: 352) it became noticeable as the early- $19^{\text {th }}$ century unfolded that a distinct spatial distribution of disease and mortality existed. (Dennis, 1984: 18) Not only was life expectancy in cities considerably less than what it was for those residing in rural places, it also varied greatly between districts within cities.

In seeking to offset the public health breakdown bureaucrat Edwin Chadwick composed the ground-breaking Report on the Sanitary Condition of the Labouring Population of Great Britain (1842) - it was the first social reform report to coalesce statistical data with descriptive evidence so as to highlight urban life expectancy variations caused by class and place of residence (UK Parliament, 202I) - and important laws were authorised: in 1847 the first national decree dedicated to granting local authorities power to acquire land for the purpose of establishing and maintaining parks was passed; and, in 1848 the first national public health law was sanctioned. It, said Hamlin (1998: 246), supplied new rhetoric and ideology to social reform arguments. Szreter (2004: 215) commented that the decree presented a distinct way of dealing with the aligned problems of health, security, and environmental deterioration: the fashioning of light, air, and space within the industrial built fabric.

To overcome the problems evident within their cities elected municipal governments acquired powers in order to, amongst other things, construct new environmental infrastructure. As Conway (1991: 6) explained, administrative accretion aided local councils to surmount the worst excesses of early-1800s urban growth whilst, in concurrence, it permitted them opportunity to augment civic pride. In basic terms, the 
expanding of the legislative framework granted local governments enriched capacity to directly tackle the effects of industrialisation and urbanisation, and parks in this context "were important to the development of town planning and to the loosening of the texture of the urban environment." Despite, by 1901, 27 settlements in England having an urban environmental density in excess of 25 people per acre (Cherry, 1974: I2-I3), a number of administrative and cultural yardsticks had been formed: the British realised that local governments were best suited to dealing with the challenge of fast urban growth and the accompanying decline in living standards; access to greenery was considered essential to wholesome urban life; and, parks had capacity to cater for various social functions. Such was the British mindfulness of the value of 'green lungs' that by the early-1900s more than one dozen national laws and countless local improvement acts had been passed re environmental betterment/green space creation, and municipalities by that time ventured to provide ten acres of open space for recreational usage per I,000 local inhabitants (Myles Wright, 1948: 224-5).

\section{From adversity we progress}

In the fields of Urban History and Planning History much discourse has centred upon why public health notions affected the British effort to manage urban development during the $19^{\text {th }}$ century. Much debate has focused upon the agents that contributed to the process of forging the new planning frame, these principally being:

- Citizens' concern about deteriorating urban conditions. Public sentiment compelled local and national governments to respond to unacceptable environmental matters, e.g. increasing urban densification which, notably, was linked to worsening sanitation and the prevalence of contagious illness (Cherry, 1988: 45);

- Civil servants, doctors, and epidemiologists, persons who in the early-1800s believed that disease was caused by miasma, i.e. 'bad air' derived from putrefying material. Such individuals, by means of their graphic accounts of urban life, instigated two advances: they supplied proof of the spatial dichotomy within industrial places, it being the contrast of rich and poor, low and high density living, clean and unclean streets, healthy and unhealthy persons (Rodgers, 1989: 2); and, in tendering facts pertaining to urban conditions their data acted as a crude indicator of industrial-age material progress as well as placed attention on unforeseen problems linked to rapid urban growth, e.g. avoidable ill-health and mortality (Morley, 2007: 64-5);

- Cholera. In spite of the proliferation of numerous infectious illnesses the arrival of a new disease, cholera, sparked unprecedented fear. As Britain's 'shock disease' its presence recalled the medieval plagues, and as the sanitary reformer's 'best friend' it incited municipalities to form their own Boards of Health, it provoked the medical community to venture further into slum districts in an attempt to comprehend disease behaviour, and it fortified the need to introduce new environmental directives so that freer movement of air in and about buildings could be generated. (Mumford, 2018: 18). This desire for fresh air and open space buttressed the quest to establish municipal parks; 
- Lack of access to open space useable for leisure purposes. Whilst within the pre-industrial city several types of easily accessible open areas existed, e.g. the market place, church yards, town square, and common land at the urban fringe, owing to the greatly enlarged territorial size of cities and their devouring of open sites for building purposes, by the early-1800s public space for recreation was much less reachable. Awareness of this actuality led to three notable developments.

First, just one year after the passing of the Reform Act which instituted the British system of democracy, the 1833 Report of the Select Committee on Public Walks provided a foundational survey of open space available for public use within the major urban centres. Second, in exposing the need for more open areas the document roused businessmen and landowners to donate money and land so that public parks could be established, and it stimulated councils to compose environmental improvement bills, set up open access debates, and then pass rulings so that green space creation and management could become a basic component of local governance. Third, the report had pertinence to ongoing discourse on social improvement. Given that reformers, moralists, and others had from the 1820 s observed that urbanisation diminished opportunities for fresh air and exercise (Chadwick, I842), and in promoting 'rational recreation' so that the mind and body could be refreshed, they perceived parks as being able to supply much needed physical and psychological benefits. Additionally, parks were observed to reinforce family unity. They granted, said Conway (1991: 35), "opportunities for the recreation of all family members and so would have a positive role to play in enhancing family togetherness." Yet, in proffering a précis of the historical British situation it must be recognised that the pursuit of municipal park-building was just one strand in the national search for urban space creation. It is worth noting that parliamentary Select Committees repeatedly remarked upon the absence of open land within working class districts, and they advocated expanding earlier housing laws so that greater volumes of open land could be formed in built-up areas. Plus, in London towards the end of the 1800 s, The Commons Preservation Society lobbied for the sparing of greenery at the urban fringe from building encroachment. Similarly, bodies such as the Metropolitan Public Garden, Boulevard and Playground Association (by the 1880s) endorsed the need for communal recreational space within inner districts.

From 1833 to 1885 , in England alone, more than 180 public parks were laid out. They ranged from 0.25 acres to over 400 acres in spatial extent. Sanctioned by the passing of local and national laws the worth of public green space to health, virtue, and happiness was universally recognised by the end of the $19^{\text {th }}$ century. The value of such open areas as a critical infrastructure to upholding well-being has not waned since: in 2017 a National Health Service report reiterated the usefulness of green space to strengthening community happiness and the prevention of common health issues.

\section{The worth of green space for all}

Thanks to public health and urban planning empiricism it is accepted that liveable cities facilitate comfort, relaxation, discovery, as well as passive and active engagement with the environment. (Carmona et al, 2003: 165). It is realised as well, first, that to simply have green space is not enough to necessarily guarantee a high quality of urban life: for 
health benefits to transpire attention must be put upon spatial quality, accessibility, and management. Second, we recognise that planners and policy-makers today face conflicting demands in justifying public service provision. This discord, warn civil groups, threatens the existence of many green public spaces. In Britain, Fields in Trust (202I) has cautioned that whilst presently approximately 33 square metres of green area is provided per capita there is strong evidence to suggest that in the coming years total green space provision will decline and hundreds of thousands of urban dwellers will lose access to parks within a short walking distance from their place of residence. Fields in Trust contest that in order to protect green space as community assets legal protection in perpetuity must be issued. Without doing so, and citing its Revaluing Parks and Green Spaces project, the organisation estimates that the value of physical health and mental well-being provided by green areas - $£ 34 b n$ per annum - will dramatically reduce. In an attempt to comprehend the tangible profits generated by the existence of green spaces a number of factors necessitate focus. To start with, peoples' proximity to open space is of enormous importance: if green areas are not accessible then few persons can enjoy the benefits of using them (Ahmadpoor and Shahab, 202I). For this reason, when movement restrictions are imposed upon the public/they are barred from voyaging beyond their locality, poor planning interventions from earlier times as to where public spaces are sited means there is little or no opportunity for most people in a municipality to use and enjoy them. As the Covid-19 pandemic has laid bare, whilst the scarcity of green space is a matter of serious concern in numerous cities so too are the matters of public space distribution and the means by which neighbourhood planning has formerly been undertaken (Wargent and Talen, 202I: 89). That's why from the 1850s in cities like London, Manchester, and Liverpool care was given to siting parks. In these cities parks were purposefully scattered throughout the built fabric so that labouring populations could walk to them without difficulty. In Liverpool landscaped spaces were sited in proximity to the urban periphery so that a green ring could be formed, and they were additionally utilised as spatial wedges between inner districts. (Cherry, 1988: 47) This strategy not only made public spaces easy-to-reach but had the knock-on effect of ensuring councillors were hugely popular at times of local elections. Notably as well, lessons from 1800 s Britain show that parks do not necessarily have to be large in size. What is though paramount is that they are reachable without too much hindrance and are perceived as safe to use. Usability, particularly during disruptive social times when people have restricted access to friends, family, facilities, and services beyond their local neighbourhood's bounds, means green spaces become meeting points and activity centres so that physical and mental well-being can be upheld. Simply put, challenging social times explicitly validate the usefulness of green space inclusion in neighbourhood planning.

Aside from the issue of ease of access the quality of an open area influences the public's willingness to use it. Where parks are well maintained - green space upkeep obliges financial investment (Wargent and Talen, 202I: 89) - and are free from crime or social nuisances they become effective at providing physical and mental benefits to different groups of people, especially those most vulnerable to social disruption, i.e. children, the elderly, those with disabilities, and ethnic minorities. (Khan, 2020) Public perceptions of green space security, state Sugiyama et al (2008), greatly determines their usability whilst at times of social crisis, when peoples' anxiety level is high, good park maintenance helps alleviate citizens' stress. In contrast, Ahmadpoor and Shahab (202I: 
5I-2) remark that when a park "is littered and all of its commodities are poorly maintained, it is much less effective at delivering the positives associated with green space." When people have limited opportunities for socialising/social support poorlykept public spaces indeed contribute to anxiety, and they diminish community morale.

\section{Conclusion}

All in all, it is assumed because of urban planning's advancement through time that its application nowadays will assure security, inclusivity, resilience, and sustainability. Certainly, as the example of $19^{\text {th }}$ century Britain testifies, an interface can exist between an urban planning system, contagious disease management, and space making/use. But, the value of grasping planning's history extends far beyond merely appreciating such a fact. The history of planning permits us to better understand our present-day surroundings' form and the processes - environmental, cultural, political, legal, etc. that brought it into being. It supplies us with other valuable lessons too. Hensely et al (2020: 82-3) in taking up the 3ls framework - ideas, institutions, and interests emphasise that it becomes possible to unravel the symbiosis between public health and urban planning, their shifting collaboration through time, and why public health now has limited influence within urban planning systems in many countries.

The knowledge harvested from studying cities and their past planning processes expands our comprehension of how design ideas, urban management practice, policy making, and cultural practice reciprocally enrich. It advises us that epidemics have distinct socio-morphological imprints. Accordingly, urban history enlightens us that the experience of contagion will vary between different social and racial groups within the city although, in turn, this circumstance can be mitigated by green public space manufacture and usability facilitating community resilience. History reveals as well that the social, economic, and environmental fractures, tensions, and injustices exposed and aggravated by pandemics will not dissipate once a public health crisis ends: such matters might afterwards become less noticeable but they will not vanish. In addition, the contemporary conundrum of providing enough communal open land for rapidly growing metropolitan populations remains. Of equally serious challenge will be the continuing need to (re)direct urban governments with their respective approaches to planning, designing, and managing green space towards the goals of the 2030 Agenda for Sustainable Development. This procedure, assert Feltynowski and Kronenberg (2020), will be critical in guiding equitable environmental strategy not just within the largest metropolises but smaller-sized urban settlements too on account of parks, since the onset of the Covid crisis, having been crucial to millions of peoples' daily well-being. The role of parks will undoubtedly be important in societies' future revival.

Nancy Kwak (2018: 53-4) remarked that urban historians "explain change over time in space for different actors", and that as urban space is "considered not as fact but rather as physical form constructed in complex ways", they bestow alternate lenses to grasping the evolutions in the relationship between built form, its design, and its use. More so, to paraphrase David Lowenthal (1993), because I800s Britain was a civilisation that embraced innovation whilst concomitantly witnessing its environmental and cultural landscapes change so dramatically, it affords us a case study of how urban problems were, by means of the establishment of new accessible public spaces, directly confronted. This issue should not be underestimated because, explains Ewen (2016), by 
drawing upon urban histories it is possible for planners today to advocate local solutions to health and environmental problems. As the effects of Covid-1 9 plainly demonstrate, globally normative urban planning exercises do not always work as well in the real world as they do on paper. Therefore, is a return to local planning solutions with distinct nuances applicable to all social groups in cosmopolitan urban society, now required? In rebuffing a globalised normative approach to planning is there is fresh capacity to erode the present-day disconnect between public health and urban planning, and to set up new pathways of connection? Whilst we may believe that clean water, walkable communities, and green public spaces are universal products of the historical collaboration between public health and urban planning, as UN-Habitat and the WHO's statistics clearly show, unsafe drinking water, poor sanitation, inadequate housing, inadequate green space provision alongside the unequitable distribution of open areas are a daily fact of life still for hundreds of millions of urban dwellers. So, to conclude, does our planning mentality require change? Should we move away from viewing the city as a whole to rather seeing it as a socio-spatial mosaic (as the British did in the I800s)? Will this permit within the planning system public space interventions to become more evenly distributed? And, with these questions in mind, how can we ensure public health is a more prominent determinant within the planning of towns and cities? After all, it is not good enough to be members of a global civilisation where health only becomes part of the public and planning conversation once a critical problem, i.e. a pandemic, arises.

\section{References}

Ahmadpoor N. and Shahab S. (202I). Realising the Value of Green Space: A Planners' Perspective on the Covid-1 9 Pandemic. Town Planning Review, 92(I), 49-56. DOI: https://doi.org// 0.3828/tpr.2020.37

Bacon E.N. (1967). The Design of Cities. New York: Penguin Books.

Barton J. and Rogerson M. (2017). The Importance of Greenspace for Mental Health. BJPsych International I4(4), 79-8I.

Carmona M, Heath T, Oc T, and Tiesdell S. (2003). Public Places, Urban Space. The Dimensions of Urban Design. Amsterdam: Elsevier.

Chadwick E. (I842). Report on the Sanitary Conditions of the Labouring Population of Great Britain. London: HMSO.

Cherry G. (1974). The Evolution of British Town Planning. Leighton Buzzard: Leonard Hill Books.

Cherry G. (1988). Cities and Plans. The Shaping of Urban Britain in the $19^{\text {th }}$ and $20^{\text {th }}$ Centuries. London: Edward Arnold.

Conway H. (1991). People's Parks. The Design and Development of Victorian Parks in Britain. Cambridge: Cambridge University Press.

Dennis R. (1984). English Industrial Cities of the Nineteenth Century: A Social Geography. Cambridge: Cambridge University Press.

Ewen S. (2016). What is Urban History? Cambridge: Polity Press. 
Feltynowski M. and Kronenberg J. (2020) Urban Green Spaces - An Underestimated Resource in Third-Tier Towns in Poland Land 9(45), I-19. DOI: 10.3390/land9 I 10453.

Fields in Trust. (202I). Retrieved from http://www.fieldsintrust.org/News/latest-greenspace-index-highlights-importance-of-parks-and-green-spaces (accessed February 18 202I).

Fraser H and Maver I. (1996). The Social Problems of the City. In Fraser H and Maver I (Eds.). Glasgow Volume 2: 1830 to 1912. Manchester: Manchester University Press.

Hall P. (1998). Cities in Civilization. Culture, Innovation, and Urban Order. London: Weidenfeld and Nicolson.

Hamlin C. (1998). Public Health and Social Justice in the age of Chadwick. Cambridge: Cambridge University Press.

Hensley M, Mateo-Babiano D, Minnery J, and Pojani D. (2020). How Diverging Interests in Public Health and Urban Planning can lead to less Healthy Cities. Journal of Planning History, 19(2), 7I-89. DOI: I0.II77/I5385I321987359I.

Khan O. (2020) Coronavirus Exposes how Riddled Britain is with Racial Equality in The Guardian, April 20 2020. Retrieved from https:/www.theguardian.com/commentisfree/2020/apr/20/coronavirus-racialinequality-uk-housing-employment-health-bame-covid- 19 (accessed February 26 2020).

Kwak N. (2018). Understanding 'Urban' from the Disciplinary Viewpoint of History. In lossifova D, Doll C, and Gasparatos A (Eds.) Defining the Urban. Interdisciplinary and Professional Perspectives. London: Routledge. 
lan Morley

Lopez R. (2018). Public Health and Urban Planning: Intertwined Histories. In Hein C (Ed.) The Routledge Handbook od Planning History. London: Routledge.

Lowenthal D. (1993). The Past is a Foreign Country. Cambridge: Cambridge University Press.

Luckin B. (2008). Pollution in the City in Daunton M. The Cambridge Urban History of Britain. Cambridge: Cambridge University Press.

Morley I. (2007). City Chaos, Contagion, Chadwick and Social Justice. Yale Journal of Biology and Medicine 80 (2), 6I-7I.

Mumford E. (2018). Designing the Modern City. Urbanism Since 1850. New Haven: Yale University Press.

Mumford L. (196I). The City in History. New York: Harcourt, Inc.

Myles Wright H. (1948). The Planner's Notebook. London: The Architectural Press.

National Health Service. (2017). Healthy New Towns Programme. https://www.england.nhs.uk/ourwork/innovation/healthy-new-towns (accessed February 19 202I).

Russo A. and Cirella G.T. (2018). Modern Compact Cities: How much Greenery do we need? International Journal of Environmental Research and Public Health I5(I0), 2I80-95. DOI: 10.3390/ijerphI5102180.

Shoari N., Ezzati M., Baumgartner J., Malacarne D., and Fecht D. (2020). Accessibility and Allocation of Public Parks and Gardens in England and Wales: A Covid-1 9 Social Distancing Perspective. PLoS One I5(I0), e024I I02. DOI: 10.137I/journal.pone.024II 02. 
Szreter S. (2004). Health, Economy, State and Society in Modern Britain: The Long-Run Perspective. Hygeia International: An Interdisciplinary Journal for the History of Public Health 4(I), 205-27.

Sugiyama T., Leslie E., Giles-Corti B. and Owen N. (2008). Associations of Neighbourhood Greenness with Physical and Mental Health: Do Walking, Social Coherence, and Local Social Interaction Explain the Relations? Journal of Epidemiology \& Community Health 62, e9

UK Parliament. (202I). I842 Sanitary Report. Retrieved from https://www.parliament.uk/about/living-heritage/transformingsociety/livinglearning/coll9-health I/health-02//842-sanitary-reportleeds/\#: :text=In\%20July\%201842\%2C\%20the\%20most,Chadwick\%20(I800\%2DI890) (Accessed February 20 202I).

UN Habitat. (20I8). SGD Indicator II.7I Training Module: Public Space. Nairobi: United Nations Human Settlement Programme (UN-Habitat).

UN Habitat. Public Space. Retrieved from: https://unhabitat.org/topic/public-space (Accessed: May 12 2020).

Wargent M. and Talen E. (2021) Rethinking Neighbourhoods. Town Planning Review 92(I), 89-96. DOI: https://doi.org/I0.3828/tpr.2020.43

World Health Organisation. (2017). Urban Green Space Interventions and Health: A Review of Impacts and Effectiveness. Retrieved from http://www.euro.who.int/data/assets/pdf file/0010/337690/FULL-REPORT-forLLP/pdf?ua=I (Accessed February 22 202I). 


\title{
Shifting the Threshold of Public Space in UK, Algeria and Mexico during the Covid-I9 Pandemic
}

\author{
Barbora Melis \\ University of Portsmouth, United Kingdom \\ barbora.melis@port.ac.uk \\ Jose Antonio Lara Hernandez \\ Universidad Marista de Merida, Mexico \\ joselarah@p.marista.edu.mx \\ Yazid Mohammed Khemri, Alessandro Melis
University of Portsmouth, United Kingdom
yazid.khemri@port.ac.uk | alessandro.melis@port.ac.uk
}

\begin{abstract}
Through its worldwide impact, the on-going Covid-19 pandemic has fundamentally affected the way people live and experience the built environment in every country. Starting to spread in late January 2020 in Europe and in the Mediterranean Region, the threat of viral infection with the Coronavirus led to several phases of lockdowns from mid-March on until now. The limited accessibility and the safety measures during this last year have challenged dramatically the perception and the use of public space thresholds between private, semi-private and public conditions, creating new forms of temporary appropriation. The consequential paradigms of household isolation and social distancing have also contributed to the augmentation of the public space, now swinging between digital and analogue possibilities. In opposition to the former wide range of possibilities of space uses in everyday life, being subject to restricted spatial conditions under the current situation leads to new challenges on a cognitive level: the resulting change in the perception of proximity and distance, indoor and outdoor, private and public, implies an expanded use of both spaces introducing many opportunities of colonisation of private, public and semi-public appropriation creating new forms (and sometimes also old ones) of resilience. Algiers, Portsmouth and San Francisco de Campeche have been selected as case studies to observe how the lockdown was organised from the same time on in different places with distinct political approaches and public control measures, and the impact this had on the community and the use of public space in the three cities.
\end{abstract}

Keywords: public space, temporary appropriation, community, resilience, pandemic

To cite this article:

Melis, B., Lara Hernandez, J. A., Khemri, Y. and Melis, A.. (2020). Shifting the Threshold of Public Space in UK, Algeria and Mexico during the Covid-I 9 Pandemic, The Journal of Public Space, 5(3), I59-I72, DOI 10.3289|/jps.v5i3.1387

This article has been double blind peer reviewed and accepted for publication in The Journal of Public Space.

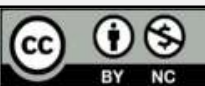
This work is licensed under a Creative Commons Attribution - Non Commercial 4.0 International License https://creativecommons.org/licenses/by-nc/4.0/ 


\section{Background of the research}

The current Coronavirus pandemic has affected the lives of everyone and signifcantly impacted the urban public space around the world undermining the conventional flow of outdoor public space activities in all countries affected by Covid-19.

As the United Nations states (2020), public spaces are key in reducing stress levels, improving mental health and wellbeing, contributing to children's development, and establishing temporary facilities. As a consequence of the lockdown measures, the "normality" of our urban lives got suspended. The latter represents the loss of access to the wider public realm and has revealed the uneven distribution of accessibility of public urban space related to a loss of social life, reduced levels of outdoor activities and a lack of informal social support networks, particularly for more vulnerable or disadvantaged people (Varna \& Oswell, 202I). However, as a result of the emerging pandemic reality, this has also given the opportunity to local communities to re-invent and re-define new spatial models in the form of temporary appropriation (TA) for comunication and interaction with people in their local environments adhering to social distancing and contributing to a more resilient model of the society. This paper is a first attempt to explore unconventional uses of public space due to the pandemic including a more flexible use of the liminal adoption of spaces between public and private, creating new forms of connection with people whilst respecting social distancing. Among these, TA is conceptualised as a form of colonisation beyond the expectation of the planning determinsm in the urban realm, emerging as a resilient response of community to crisis (Melis, Lara-Hernandez, \& Thompson, 2020). In this text, and according to the UN definition, resilience is intended as the ability of community exposed to a crisis, such as the pandemic, to resist, absorb, accommodate to and recover from its effects in a timely and efficient manner (UNISDR \& WMO, 20I2).

Spreading worldwide, Covid-19 was declared a pandemic by the World Health Organization on the II th March, 2020 (World Health Organisation, 2020a) and people worldwide were forced to remain confined to narrow ranges, within close proximity of where they lived. For instance, the severe lockdown modalities and the control of public spaces by institutions and law enforcement agencies in the Medieterranean region, especially in Italy and Spain, contrast with the laissez-faire orientation of Northern countries, like the UK and Sweden (Edwards, 2020).

UK, Algeria and Mexico are considered, here, as paradigmatic examples of contextual differences leading to a variety of community responses in terms of TA of private, semiprivate and public spaces. Utilising a participant overt observation mapping as defined by Groat and Wang (2013) in their book Architectural Research Methods in all three places, during the period March-May 2020, it has been observed that the conditions of lockdown and the response of the communities are variables of the climatic, cultural and political context.

In the section that follows, we will focus on the concept of public space and the TA in order to better understand, through categorisation of activities, its potential use as a methdology enabling the measurement of community resilience. Within the aforementioned countries, Southsea (Portsmouth, UK), El Houma (Algiers) and San Francisco de Campeche (Mexico) have been selected to carry on observations oriented to the measurement of resilience of communities through TA activities providing a new framework of community-based resilience in the times of the pandemic. These different observations of interventions in politically and culturally diverse places prove that a new 
reimagining of our public space is possible and led by the local community challenging planners and urban designers to capture this zeitgeist (Varna \& Oswell, 202I), and to involve and develop it further in the planning process of our future cities.

\section{The resilience of the public space through temporary appropriation}

Given the complexity of the concept, implying multiscale methodologies, it is not the purpose of this section nor our intention to exhaustively review such extensive literature. Rather, the aim is to acknowledge the concept within the theoretical framework which advocates that public spaces are areas of urban settlements where sociability occurs. The construction of urbanity (Lofland, 1998; Madanipour, 1998), allows accessibility to a wide range of activities and uses, involving different kinds of people and groups (Kärrholm, 2007). Authors such as Zukin (1987), Avritzer (2002) and Graham and Aurigi ( 1997 ) have highlighted also the political dimension of public space, arguing that, in democratic countries, the public spaces are crucial to fuel and maintain the democracy. The space where this conflict is more evident is in the public space, which serves as the locus of collective expressions for those who are deprived of institutional settings to disagree (Roy \& Alsayyad, 2004). Salcedo-Hansen (2002) argues that the public space is always under control and the exercise of power and, at the same time, there will always be resistance against that control. Scholars like Low (2000) and Mouffe (2007) consider that the access to public spaces where people can exercise freedom of speech and aggregation to a diverse social group sharing interest is a precondition for democracy. We agree with Jackson (2003) when she states that the social capital starts at the scale of the neighbourhood and most commonly in public spaces. McBride ( 2005, p. 102) supports this argument stating that "When we lose public space, we lose democracy". Lack of public space, or its TA, has, therefore, a series of negative effects such as loss of urban identity (Bolio Arceo, 2012), the risk of increasing levels of mental illness among the population (Evans, 2003; Jackson, 2003) or even alienation (Martínez, 20I4). The current lockdown due to Covid- I 9 has exacerbated the aforementioned negative impacts (World Health Organisation, 2020). The resilience of a public space, intended as the capacity of a system to adapt to change, is proportional to the possibility of TA. It follows that, in times of lockdown, the response in terms of community resilience is particularly dependent on the possibility of allowing forms of TA (Melis et al. , 2020).

Lara-Hernandez and Melis (2018) described the concept of TA in which the bond between people and places is enhanced. When the diversity of TA of public spaces is increased, the social sustainability is augmented, increasing community resilience, and strengthening socio-urban buffer areas in the city (Melis et al., 2020). The activities that fall within this measure of public space resilience fall into three categories: economy, leisure, and sacralisation. These are the activities which we will consider in the emerging forms of TA during lockdown, in relationship to the selected case studies, Southsea, El Houma and San Francisco de Campeche.

Having explained the concept of TA, now we will move to elucidate each of the three case studies. 


\section{Resilience of the community through temporary appropriation of semiprivate and private space: the case of Southsea, UK}

The United Kingdom was one of the last European countries to respond with appropriate measures to the spread of Covid-19 in late January 2020, which led to a partial lockdown from mid-March entering in a national lockdown on the $23^{\text {rd }}$ March, 2020 (GOV.UK, 2020).

The lockdown challenged dramatically the perception of public space thresholds between private, semi-private and public conditions and accentuating its importance for a vibrant community. "A nearby patch of green has become more precious than the trendiest address, streetscapes have revealed their naked selves without the activities that usually animate them" (Wehner, 2020). Enlarging the private space of the ground floors of buildings and connecting it to the public realm by creating semi-public spaces through TA has proven to be a successful strategy in creating a new sense of community and neighbour support and exchange.

Southsea, a cohesive neighbourhood of Portsmouth, the most densely populated city in the UK, with 5,100/ sqkm inhabitants (World Population Review, 2020), seems an ideal case study to represent extreme lockdown conditions in the UK. The main observation has regarded the resilience of outdoor spaces of the town house, which constitutes the basic unit of the urban fabric, here and everywhere in the UK. Its front yard, as a semiprivate zone, has become a social and physical buffer allowing activities previously assigned exclusively to public space.

The versatility of this space type, during the pandemic, as an opportunity to welcome the very diverse culture of the city, due to a large international university, corroborated a certain attitude towards laissez-faire, as well. According to the TA categories, the following activities have been detected: a) trade including the delivery of online purchases and exchange or sale of second-hand objects and plants; b) leisure including exercise and relax; c) social activities including neighbour barbeques in residential parking lots and celebrations like "Clap-for-Carers" on Thursday evenings, as well as concerts and visiting (see Figure I).

Among the TAs of both the front yards, walkways and the streets, the celebration of Veterans Day on May 8th, consistent with the reccomendations of the British Government, which seemed to be rarely perceived as prescriptions by the citizens, well rapresented the British motto "Keep Calm And Carry On".

Deriving from the poster produced by the British Government in 1939 in preparation for World War II, particularly felt here in the city of the Royal Navy and the D-Day boarding, this attitude has been revitalised as a sort of flag during the Covid-19 emergency.

One hour of outside-activity in green urban areas was widely supported and encouraged, and, when not possible in public space, the backyards have been used as a compensation by households. Also, the centrality of parks in the British way of living, as a symbol of urban cultural inclusiveness, has not been neglected during the lockdown, thanks to limited access restrictions with a nearly imperceptible controlling presence (see Figure 2). Road closure at Southsea seafront encouraged walking, biking and other outdoor activities, improving mobility and safety in this area.

A limitation of these observations, when compared with those shown by the media in the cities of the Midlands or the north of England, is that Portsmouth is one of the English cities with the greatest solar radiation. In addition to the extraordinary 
compactness of the residential fabric, such an enviable climatic condition has allowed spatial opportunities, which, despite the Victorian flavour of the architecture, and albeit occasionally, recall common uses of public space in the Mediterranean region (as in the case of El Houma, described below).

Beyond the constraints, which with the advent of vaccinations, at the time of writing, should fade away, a positive aspect of the public space issue in the south of the United Kingdom in times of pandemic is its transformative, plastic and of diversity potential, which we hope will remain a heritage of the communities also for the future.
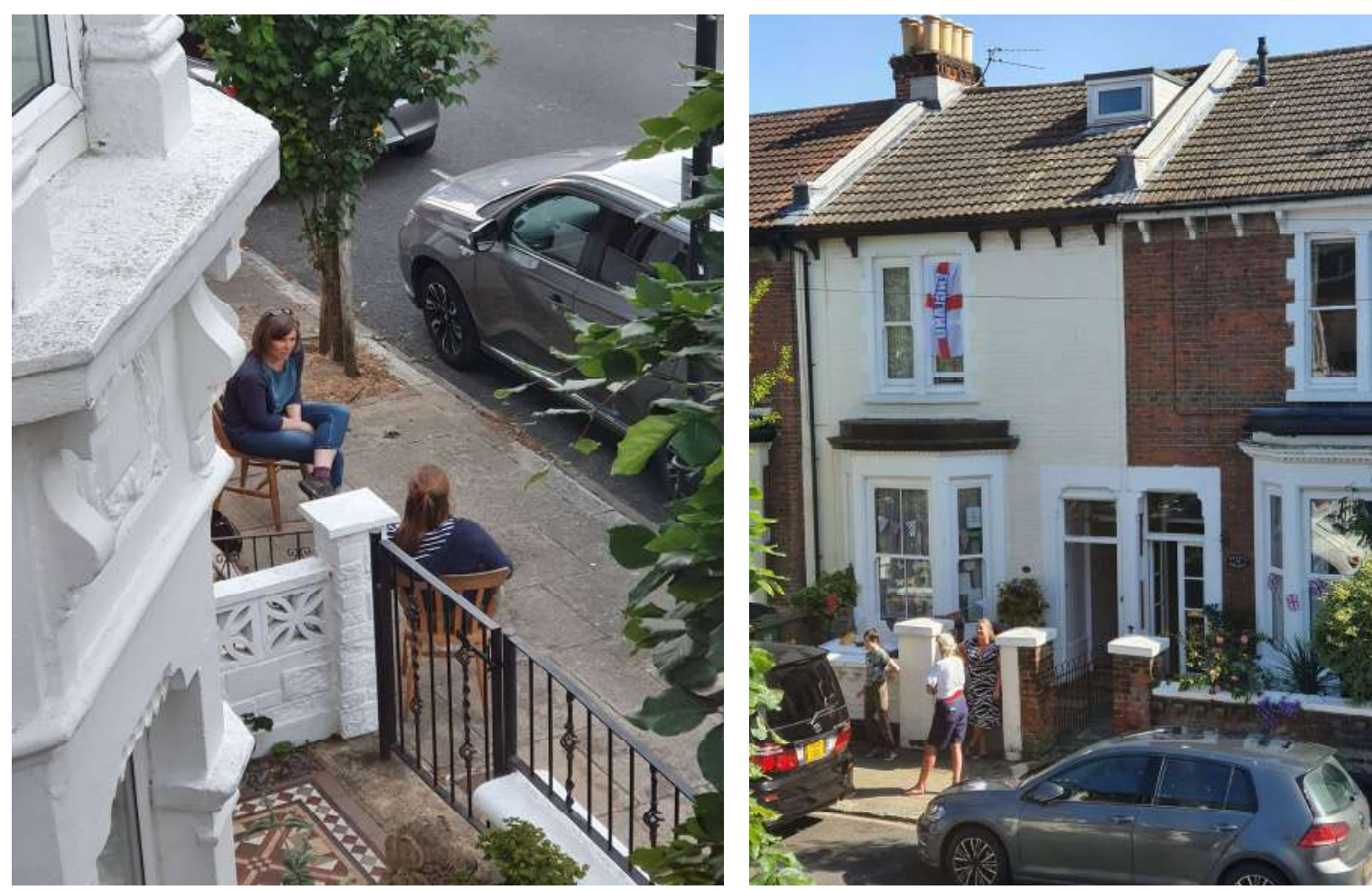

Figure I: Neighbours socially distanced chat and neighbours celebrating Veterans Day in May 2020 in Southsea. Source: B. Melis.

\section{The resilience of communities and the temporary appropriation of public space: The case of El Houma}

Given the strategic position that Algeria occupies as a Mediterranean country, and having a busy schedule of flights to and from Europe, the country witnessed the spread of the pandamic in February. Following the surge of Covid-19 infection in Europe, the country rushed into closing its borders and imposing a strict lockdown protocol all over the country. In addition to closing the borders, this protocol, in addition to other measures, precisely suspended all informal markets and restricted people from leaving their houses and gathering in public spaces, something which Algerians are accustomed to do.

Socialising in Algiers' public spaces is pivotal in the lifestyle of Algerians, which forms the main basis of the concept of El Houma. The El Houma is a term specific to North Africa and is used to refer to a neighbourhood where frequent social use of space takes 
place, engendering an organic urban life (Khemri et al., 2020). It is a socio-spatial product, defined by the intensity of social interactions and is formed of intricate social relations between residents (Dris, 2005; Grangaud, 2009). El Houma represents local social life of people in a neighbourhood, and the practices that happen in El Houma engender social dynamics, which, in turn, promote social cohesion, sense of community and strong feelings of trust and solidarity among neighbours (Khemri \& Melis, 202I). These spatial dynamics are the main drivers into raising awareness among residents to consider fighting disruptions as their collective duty and inspire local resilience strategies within the neighbourhood.

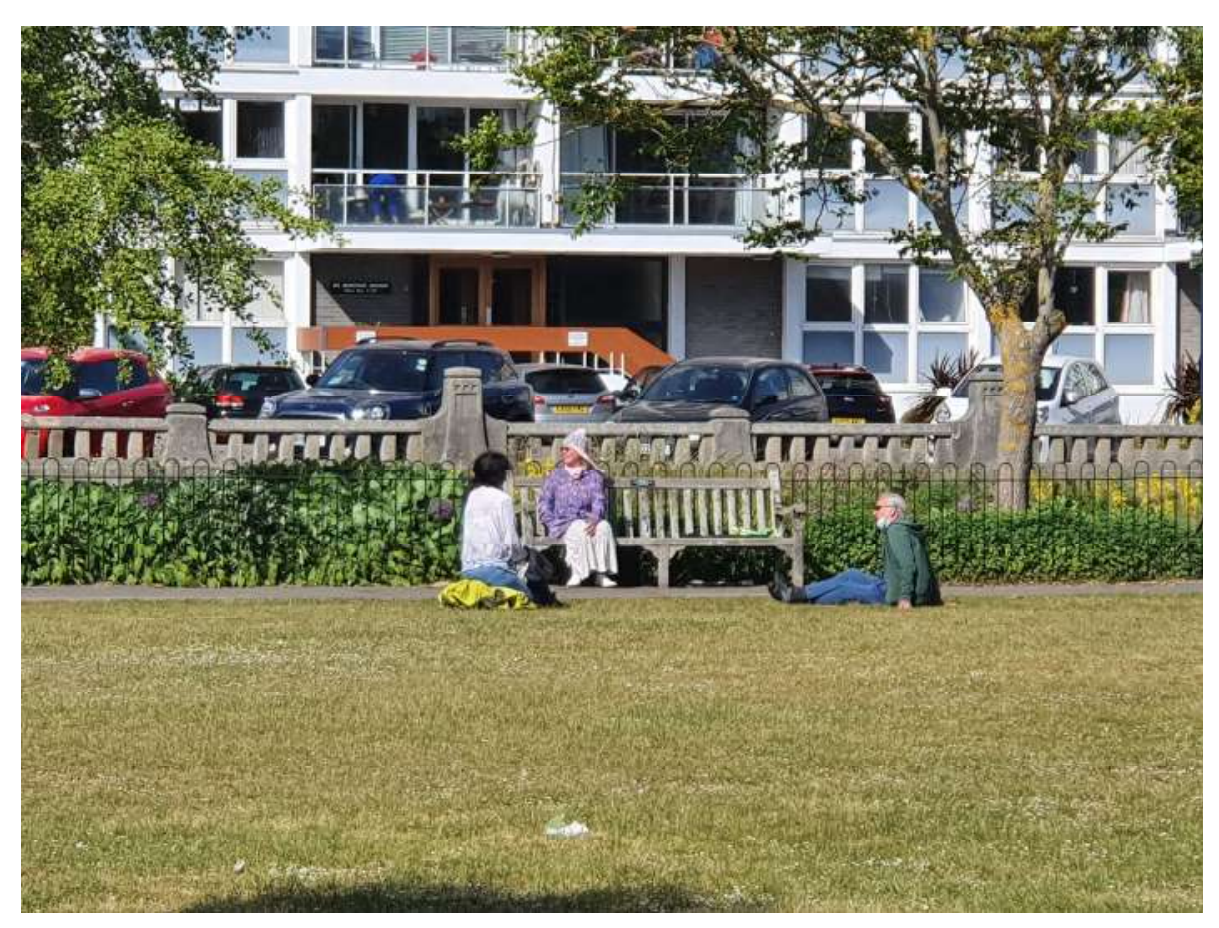

Figure 2: People chatting socially distanced in a public park in Southsea. Source: B. Melis.

El Houma, as any other resilient urban system, is formed of a combination of tangible (built environment) and intangible (culture, social life and lifestyle) aspects. People would consider their area of living as El Houma only when the built environment allows frequent and enduring social use of space, while performing various activities such as chatting, resting, reading, playing card games or sports activities, eating and drinking, and informal street vending (Khemri \& Melis, 202I).

A series of observation taking place in Algiers' El Houma, as a case study here, showed a strong sense of belonging among residents, which allows various forms of urban spaces uses such as the occupation of public spaces of El Houma to celebrate weddings, whereas the lack of resources and money to afford renting a hall is considered a disruption that people within El Houma collaborate to overcome. For instance, members of El Houma ferquently collaborate to organise a wedding, set the tables in the public space and occupy the dance floor during the ceremony (see Figure 3). The strong sense of community and sense belonging within El Houma grant its members the right to use the space freely to perform their socio-cultural life and deem all activities appropriate. Similar to occupying a public space to organise a wedding 
ceremony, people would use it to play football, marble games or any other leisure activities, and, when a member of El Houma dies, neighbours would occupy the public space to organise the funeral, by gathering next to the deceased's house to show support and solidarity. Another important activity that contributes to urban life, and, thus, El Houma, is informal commerce activity, whereas a lot of people rely on street vending as their source of income, others equally benefit from this activity, as it is perceived affordable to all social classes.

Before the pandemic and the enforcement of the lockdown, these activities took place in various expressions of the urban landscape, in the narrow streets or the wall fountains of the Casbah (the Algerian medieval medina), or in the arcades, planted boulevards and public spaces of the city. However, unlike the UK, the Algerian government imposed strict lockdown and curfew on the country, like most countries around the world did, which restricted people from going out and socialising in urban areas.

Public spaces under the threat of Covid- 19 lowered significantly the degree of sociability between people, making spaces lifeless and sending signs of unsafety, something, which neighbourhoods that embody El Houma have never undergone.

Nonetheless, some people had to improvise to continue practising their daily life outdoor. Even though it was illegal to go outside, some people used roof terraces of buildings and narrow streets to spend time outside. Small public spaces in residential areas were transformed into a mosque to perform prayer on the day of Eid al-Fitr, which is a religious holiday celebrated by Muslims worldwide at the end of Ramadan. This activity is usually performed indoors; however, at the time mosques were closed because of Covid-19, so people gathered in a public space to perform prayer, while observing social distancing (see Figure 4).

Due to different climatic, cultural and political contexts, an opposite spatial logic of TA to that observed in England prevails in El Houma. Before and during the pandemic emergency, the community frequently gather in the shade of the public interstitial space between the buildings, with several spatial practices.
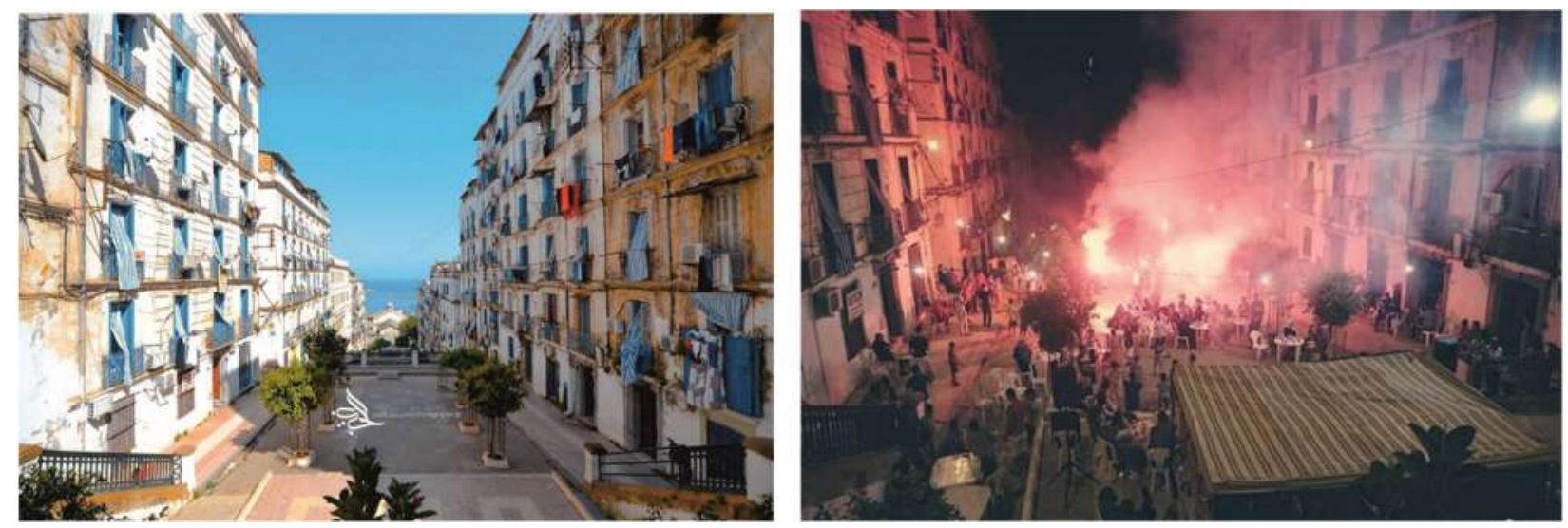

Figure 3: The impact of Covid- I 9 can cancel the possibility of having various activities in public spaces of El Houma, such as celebrating weddings. Source: Boucetta. 


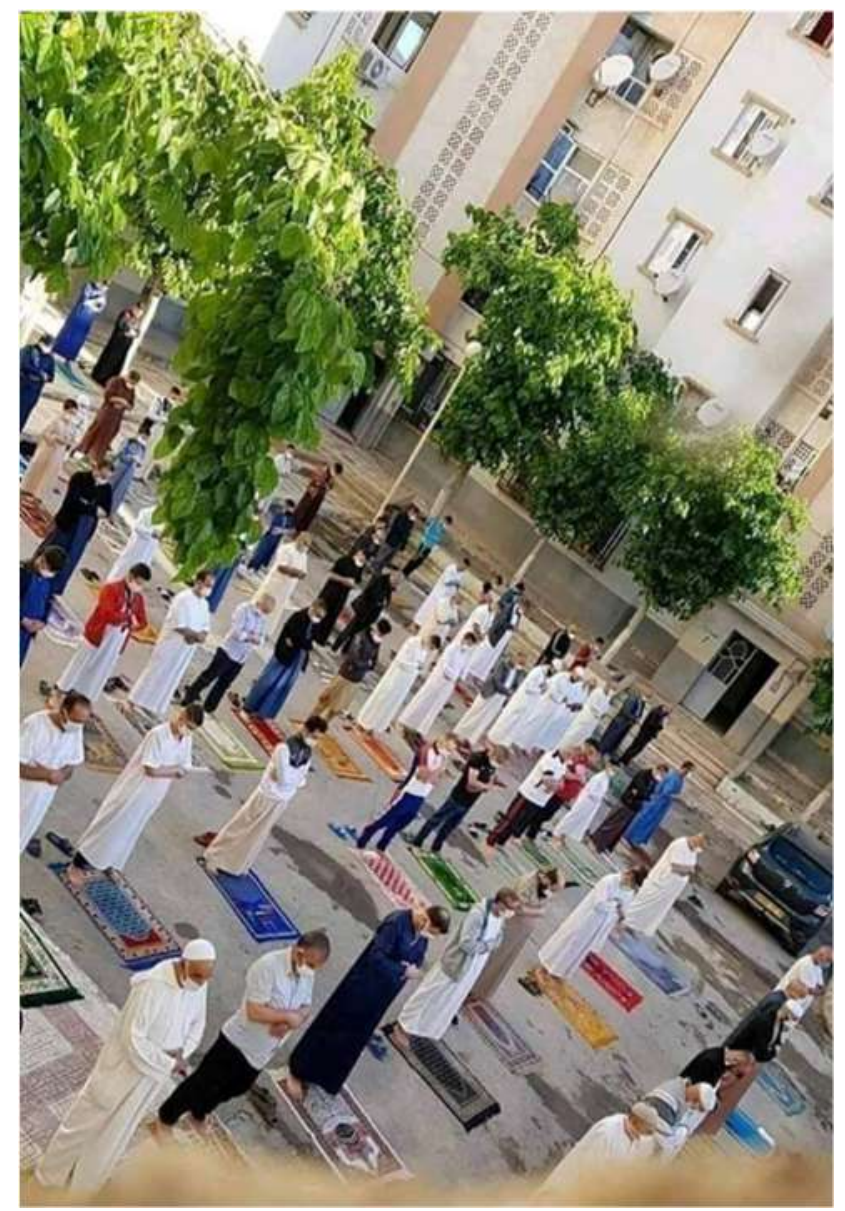

Figure 4: Public space is used to perform prayer on Eid Al-Fitr in 2020.

Source: Ziari, 2020 retrieved from: https://www.annasronline.com/index.php/2014-08-I7-|3-22-10/20 I408-27-| 8-45-22/I51028-2020-05-26-10-33-I4

\section{The resilience of communities and the temporary appropriation of public space: The case of San Francisco de Campeche}

During last year, 2020, the pandemic was very challenging for communities worldwide. The lockdowns were a common measure to avoid the spreading of the disease, starting from Asia, then Europe and lastly in America. Such measures severely disturbed the life in cities, starting from disruption of supply chains till protests and social movements, including conspiracy theories. For instance, in February 2020, the Mexican government reported that 12 million formal jobs were lost within two months of lockdown due to the pandemic (Redacción, 2020).

Each city as a socio-ecological system, depending on their resiliency capacity, has the ability to auto regulate itself and overcome disturbances (Holling, 1973; Yamagata \& Maruyama, 2016). TA of public spaces as described by Lara-Hernandez and Melis (2018) plays a significant role towards increasing resilience. To illustrate the latter, we will take the case of San Francisco de Campeche presented last August by Lara-Hernandez (2020): A Year without Public Space under the Covid- 19 Pandemic Series organised by City, Space and Architecture. 
San Francisco de Campeche is the city capital of the state of Campeche (Mexico), having approximately a quarter of a million inhabitants located in the Yucatan peninsula in Mexico. Despite that the state of Campeche was one of the less affected in terms of Covid-19 infections within Mexico, starting from May 2020, due to lockdown restrictions, access to the central market and public transportation was very limited (Figure 5). Thus, making it extremely hard for people living outside walking distance from the central market to get their daily goods.
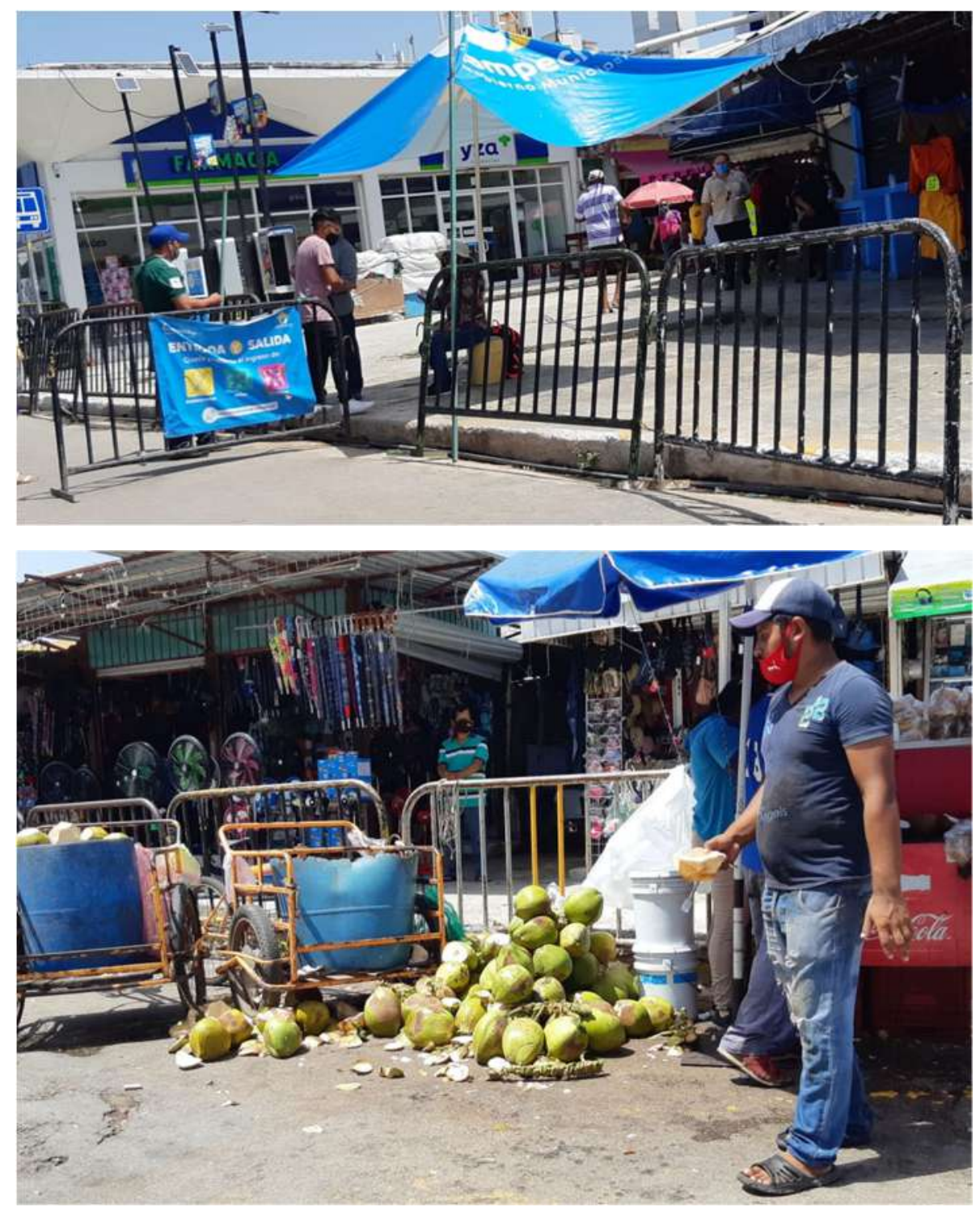

Figure 5: Fence around central market in San Francisco de Campeche. Source: J.A. Lara-Hernandez, 2020.

Nevertheless, such circumstances propitiate the emergence of several street vendors in different areas of the city, each of them offering different type of products, reflecting a wide diversity of design configuration (see 
Figure 6). In terms of design, the street vendors configured their vending stands following design principles illustrated by Lara-Hernandez (20I3) to create the so called "space of contact", a term introduced by Choay (200I). Such design principles include i) the availability of shade, ii) a view opening degree ranging from 70 to I 20 degrees, iii) available seating places and lastly iv) the possibility to see and be seen by others.
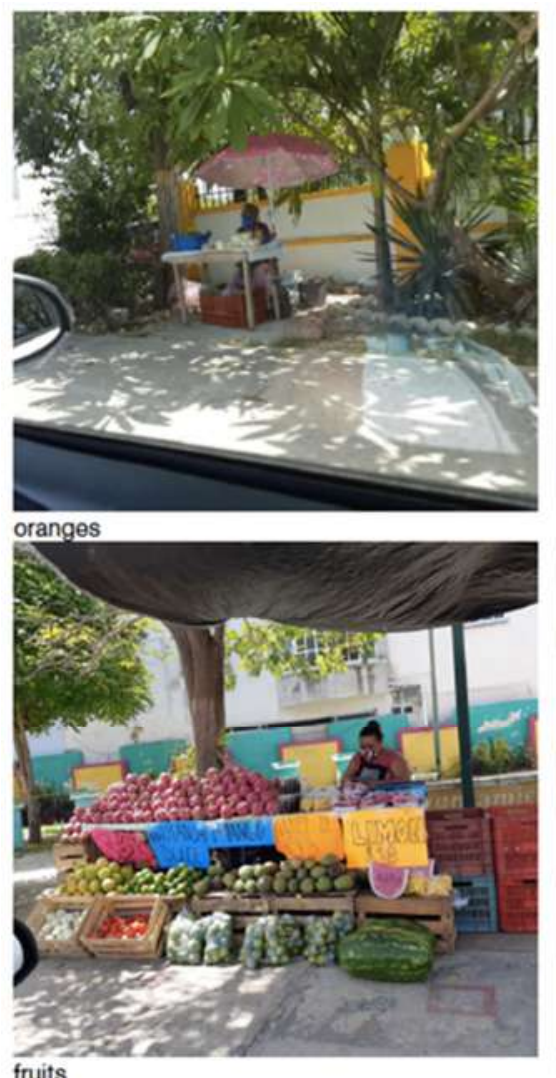

fruits
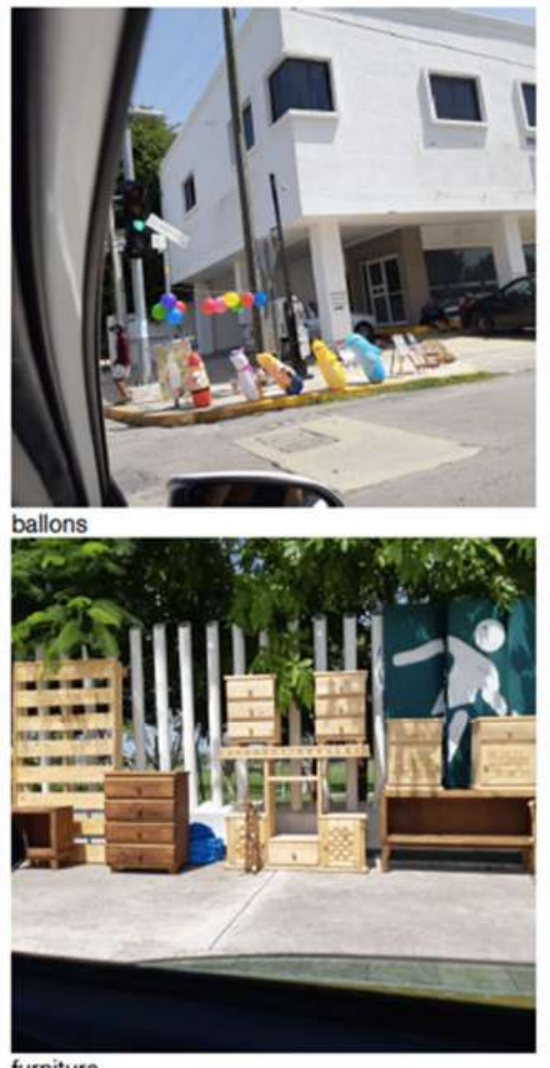

furniture
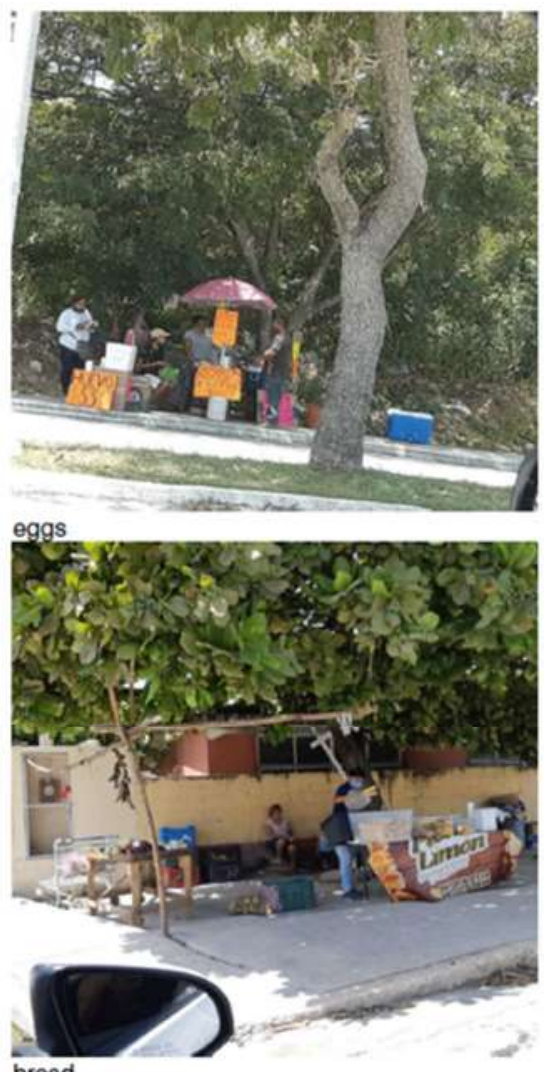

bread

Figure 6: Street vendors temporary appropriating the public space. Source: Photographed by J.A. LaraHernandez, 2020.

In terms of planning, the TA emerging in the area was mapped through the street vendors (see Figure 7). What is interesting about the data in Figure 6 is that there is a clear pattern of the location of vending stands. Each black dot represents a street vendor and the dashed line in circle around it shows a radius of $200 \mathrm{~m}$ walking distance. Thus, to some extent, the emerging TA of the street vendors supplied the immediate needs of people who could not go to their usual shopping to the central market. Looking at the city as a socio-ecological system this is a clear example of an unplanned resilience strategy to halt the negative effects of the lockdown, minimising the risk of Covid-19 contagion. Additionally, the latter is a clear example of what Melis, LaraHernandez, and Foerster (2020) described as an architectural exaptation at the level of public space, which increases the level of resiliency of a place. 

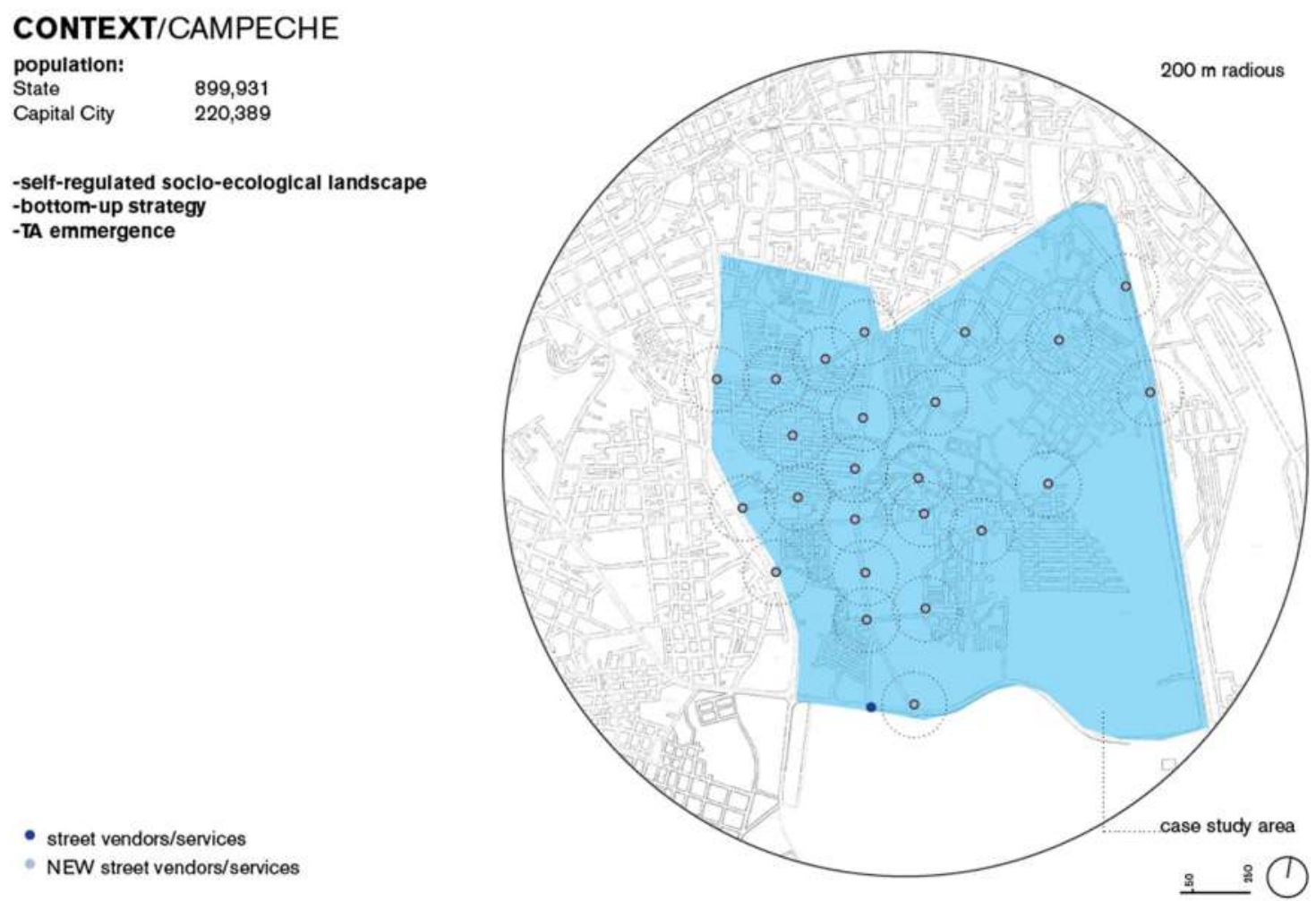

Figure 7: Street vendors map. Source: Lara-Hernandez, 2020.

\section{Discussion and Conclusion}

The Covid-I 9 pandemic lockdown evolved in a new context of urbanity, giving a new meaning to both public and semi-public space. But how do we ensure that we get the public space we want and need, whether that is green space that helps us stay healthy, or the shared space that makes our cities feel vibrant and alive?

As expected, the conventional resilience strategy has been less effective during the lockdown period, when social distancing was required. In opposition to the wide range of possibilities in everyday life, the current situation, being subject to restricted spatial conditions, has led to new challenges, on a cognitive level.

From the comparison, it emerges that some differences in the use of public and semipublic space in different countries, in times of pandemics, manifest themselves in a different balance of the categories of activities that represent TA. In Algiers, the activities of mutual support of the families of the community prevail (even though strongly depending on the spatial dimension and feature of the built environment: Medina vs Modern), in Mexico, the urgency corresponds to a greater presence of basic commercial activities, while, in England, the barriers between public and private spaces are thinning, which, in some ways, make the use of the street more similar to that of the Medina.

However, in the English case, some forms of appropriation of public space take on a symbolic and identity value in support of national institutions, such as the NHS. It is as if, in this case, the lack of social cohesion based on extended family models, was compensated by a strong sense of belonging to the national community. 
Certainly, the case of Southsea/Portsmouth is particular, given that it is a city proud of its political past as the centre of military actions (Normandy landings) for the liberation of democratic Europe from Nazi-fascist tyranny. Therefore, the push to occupy public space is probably felt as a demonstration of support for the national government (or, in this case, an emanation of it (NHS).

During lockdown in Southsea, new individual or family uses of private space have included public functions previously designated to exclusively public space in open urban areas. In Algiers, instead, forms of occupation of the public space prevailed for group activities and private individuals, which were then ratified by the sense of solidarity which characterizes the sense of community of El Houma. While, in the first case, unconventional uses of private space have also been identified, compared to prepandemic normalcy, in the second case the TA of public space, increased or decreased, is, however, in line with the characteristics of community cohesion.

This fundamental difference in dealing with the virus reflects the community orientation of El Houma and the more individualistic orientation of British neighbourhood which cannot be restrited by legislative decrees and self-certification. Whereas the case of San Francisco de Campeche, as an example of self-regulation of the city as a socio-ecological system, reinforcing theoretical models of resilience in the ecnomic dimension of the urban landscape, is evident (Stockholm Resilience Center, 20I4).

The flexibility of external private space of the houses in Southsea, San Francisco de Campeche and the streets of El Houma afforded as many opportunities as possible of colonisation of private by new forms (sometimes also old ones) of public and semipublic appropriation without compromising the multi-dimensional vocation of the three of them.

According to the observations in all three scenarios, the resulting change in the perception of proximity and distance, indoor and outdoor, has implied an expanded use of public spaces, which can turn into significant improvement of the post-pandemic cities.

What can we learn about public space use and planning for the future?

The pandemic has taught us the importance of public spaces as arenas for social interaction, whereas people spend most of their time in public spaces during the pandemic, because of working from home and suspension of indoor coffee shops, restaurant and other leisure centres. Therefore, it is important to rethink the design of public spaces, by adapting their design to allow social distancing in otder to provide a safe environment for people. The design of more public spaces in neighbourhoods is vital to ensure equal access for all residents and prevent spaces from overcrowding to reduce teransmission risk. Wider pavements and streets are also necessary, as the observations in the three case studies showed how people occupy those spaces to socialise. It is necesary to of the streets as more a public space rather just a mere infrastructure for transportation purposes. Other aspects of urban design for the future could be considered, such as the conversion of car parks into public space, designing buildings with balconies to allow consistent contact and exchange with the outside world, and ensuring natural ventilation in buildings. We need to re-think the way in which we engage with the space, utilising divergently and creatively the public spaces in our cities. 


\section{References}

Avritzer, L. (2002). Democracy and the Public Space in Latin America. Princeton University Press.

Bolio Arceo, E. (20I2). Urban Transformations and Place-Identity: The case of Merida. Oxford Brookes University.

Edwards, C. (2020, May 20). As Europe comes out of lockdown, what lessons can be learned from Sweden? The Local SE. Retrieved from https://www.thelocal.se/20200520/as-europecomes-out-of-lockdown-what-lessons-can-be-learned-from-sweden

Evans, G. W. (2003). The built environment and mental health. Journal of Urban Health: Bulletin of the New York Academy of Medicine, 80(4), 536-555. https://doi.org/ I0. I093/jurban/jtg063

GOV.UK. (2020). Speech: Prime Minister's statement on coronavirus (COVID- 19): 23 March 2020.

Graham, S., \& Aurigi, A. (1997). Virtual cities, social polarization, and the crisis in urban public space. Journal of Urban Technology, 4(I), 19-52. https://doi.org/I 0. I080/I0630739708724546

Groat, L., \& Wang, D. (20I3). Architectural research methods (Second). John Wiley \& Sons, Inc.

Holling, C. S. (1973). Resilience and Stability of Ecological Systems. Annual Review of Ecology and Systematics, 4(I), I-23.

Jackson, L. E. (2003). The relationship of urban design to human health and condition. Landscape and Urban Planning, 64(4), I9I-200. https://doi.org/I 0.10I6/S0I69-2046(02)00230-X

Kärrholm, M. (2007). The materiality of territorial production: A conceptual discussion of territoriality, materiality, and the everyday life of public space. Space and Culture, 10(4), 437453. https://doi.org//0.1/77//20633/207304356

Khemri, Y. M., \& Melis, A. (202I). Achieving community resilience through informal urban practices: the case of El Houma in Algiers. In A. Di Raimo, S. Lehmann, \& A. Melis (Eds.), Informality Now: Informal Settlements Through the Lens of Sustainability. Routledge. Taylor \& Francis Group.

Khemri, Y. M., Melis, A., \& Caputo, S. (2020). Sustaining the Liveliness of Public Spaces in El Houma through Placemaking. The Journal of Public Space, 5(I), I29-I52.

Lara-Hernandez, J. A. (20I3). Urban Revitalization. Domus Academy.

Lara-Hernandez, J. A., \& Melis, A. (20I8). Understanding the temporary appropriation in relationship to social sustainability. Sustainable Cities and Society, 39C, I-I4. https://doi.org//0.1016/j.scs.2018.03.004

Lara-Hernandez, J. A. (2020). Emerging Temporary Appropriation: Post-2020 Scenario. In L. Bravo (Ed.), 2020: A Year without Public Space under the COVID-19 Pandemic: Tactical urbanism as a crisis response and as mobiliser for systemic change. City Space Architecture. Retrieved from https://youtube.com/playlist?list=PLrcH8PpHiZgLr7nJTwoKWwcm42GRSO9tn

Lofland, L. H. (1998). The public realm: Exploring the city's quintessential social territory. Transaction Publishers.

Madanipour, A. (1998). Social Exclusion and Space. The City Reader, I58-165. https://www.dawsonera.com.ezp.sub.su.se/abstract/9780203869260

Martínez, E. (20I4). Configuracion urbana, hábitat y apropiación del espacio. Scripta Nova. Revista Electrónica de Geografia y Ciencias Sociales, 493(33), I-20.

McBride, K. (2005). Brave New Neighborhoods: The Privatization of Public Space. International Journal of Urban and Regional Research. 29(4), I00 I-1003. https://doi.org/ I 0. I I I /j. I 4682427.2005.00635_4.x

Melis, A., Lara-Hernandez, J. A., \& Foerster, B. (2020). Learning from the biology of evolution: Exaptation as a design strategy for future cities. In A. Ghaffarianhoseini, A. Ghaffarianhoseini, \& N. Naismith (Eds.), The 54th International Conference of the Architectural Science Association (Issue November, pp. 680-688). The Architectural Science Association (ANZAScA).

Melis, A., Lara-Hernandez, J. A., \& Thompson, J. (2020). Temporary Appropriation in Cities: Human Spatialisation in Public Spaces and Community Resilience. Springer Nature Limited. https://doi.org// 0.1007/978-3-030-32/20-8

Mouffe, C. (2007). Public spaces and democratic politics. LAPS. 
Murphy, K,D (200I). Review: The Invention of the Historic Monument by Françoise Choay, Lauren M. O'Connell. The Journal of the Society of Architectural Historians, 6(2), 248-249. https://doi.org// 0.2307/99/857

Redacción. (2020, July 9). Se perdieron en México más de 12 millones de empleos en dos meses. El Financiero | Bloomberg. https://www.elfinanciero.com.mx/economia/se-perdieron-enmexico-mas-de-12-millones-de-empleos-en-dos-meses-segun-datos-de-banxico

Roy, A., \& Alsayyad, N. (2004). Urban informality: Transnational perspectives from Midle East, Latin America and South Asia. Lexington Books.

Salcedo-Hansen, R. (2002). El espacio público en el debate actual: Una reflexión crítica sobre el urbanismo post-moderno. EURE (Santiago), 28(84), I-I I. https://doi.org/S0250?716I200200840000 I

Stockholm Resilience Center. (20I4). What is resilience? An introduction to social-ecologial research. Retrieved from http://www.stockholmresilience.org/download/I8.5ea7abe0 I39d0dada52 I ac/resilience_sum mary_lowX.pdf

UNISDR, \& WMO. (2012). Disaster risk and resilience. UN System Task Team on the Post-2015 UN Development Agenda. United Nations Office for Disaster Risk Reduction. World Meteorological Organization, May.

United Nations. (2020). COVID-19 in an Urban World. Policy Brief: July.

Varna, G., \& Oswell, D. (202I). Towards a stronger quality-of-place agenda in the 'new normal.' Town Planning Review, 92(I), I07-I I4. https://doi.org/I0.3828/tpr.2020.7I

Wehner, P. (2020). Future of UK Cities: Unlocking the power of public space. EGI, November II.

World Health Organisation. (2020). Naming the coronavirus disease (COVID-19) and the virus that causes it. Retrieved from https://www.who.int/emergencies/diseases/novel-coronavirus2019/technical-guidance/naming-the-coronavirus-disease-(covid-20/9)-and-the-virus-thatcauses-it

World Population Review. (2020). United Kingdom Population 2020 (Demographics, Maps, Graphs). Retrieved from https://worldpopulationreview.com/countries/united-kingdom-population/

Yamagata, Y., \& Maruyama, H. (2016). Urban Resilience: A Transformative Approach. In Y. Yamagata \& H. Maruyama (Eds.), Advanced Sciences and Technologies for Security Applications. Springer Nature Switzerland AG. https://doi.org/I0.1007/978-3-3 I9-398I2-9

Zukin, S. (1987). Gentrification: Culture And Capital In The Urban Core. Annual Review of Sociology, I3(I), I29-147. https://doi.org/I0.1 146/annurev.soc.13.I.129 


\title{
Observations on Death and Life of Public Space in Australia during the COVID- 19 Pandemic
}

\author{
Gregor H. Mews \\ Queensland University of Technology, Australia \\ Gregor.Mews@qut.edu.au \\ Milica Muminovic \\ University of Canberra, Australia \\ milica.muminovic@canberra.edu.au
}

\begin{abstract}
"Do not touch me, touch and deal with other people in the spirit of love" is stated upfront in Zizek (2020) recent reflection on the unprecedented global pandemic that has a firm grip on our societies. The quote makes two strong points that highlight the essence of this commentary. First, it implies that during the global COVIDI9 pandemic each and every one of use is forced to deal with their on human spirit embodied through the ontological state of existence and apply mindfulness and accountability for their actions in their everyday life routines. Second, public life in cities is different. Quickly the 'new normal' dictates our everyday life routines while systemic spatial issues being amplified, while social distancing measures are in place and restriction on social encounter being enforced. We present an argument that is based on direct observations of lockdown conditions during the first wave in 2020 in the Australian context. Careful framing around the concepts of 'urban loveability' and public space allows us to critically examine the synergy between aspects of the human spirit that celebrate and unite us. Whether the 'new normal' embraces death or life is evident if we pay attention to detailed traces of dynamic and intangible elements in public spaces. They remind us what makes us human and holding the possibility to realise a new ontological state of existence.
\end{abstract}

Keywords: public space, COVIDI9 pandemic, new normal, urban loveability, Australia

To cite this article:

Mews, G., Muminovic, M. (2020). Observations on Death and Life of Public Space in Australia during the COVID-19 Pandemic, The Journal of Public Space, 5(3), I73-182, DOI

I0.3289I/jps.v5i3.1366

This article has been double blind peer reviewed and accepted for publication in The Journal of Public Space. (C) This work is licensed under a Creative Commons Attribution - Non Commercial 4.0 International License https://creativecommons.org/licenses/by-nc/4.0/ 
The degree, speed and level of impact of the COVID-I9 is vast and affects all pores of people's everyday life across the world, such that soon it became the 'new normal'. We argue that it is important to capture those associated changes, thus with this article we seek to report on traces of everyday life that can be detected in public space as a result of the looser stages of social distancing (also referred to as physical distancing) under lockdown conditions early 2020. Those observations are providing room for a discourse that allows us to negotiate ways into a different public space culture that celebrates public life in cities and enables a renegotiation of new boundary conditions of social production of spaces.

Mumford's classic account from 1937 on what cities ought to be- namely a conscious work of art embedded within a communal framework in which personalised forms of art are manifested and celebrated with others can serve as a practical orientation (Mumford, 2016). Recent academic discussions on public spaces and their roles in the cities have reported the need to redefine the public space and its role in public life (Amin, 2008; Madanipour, 2019). In addition, the value of capturing people's everyday life experiences in neighbourhoods as a mean to enable transformational change has been realised since the pioneering work by Jacobs (196I). This concept is further developed within the approach of 'urban loveability' (Ottosen and Mews, 2019; Mews, 2020) that imbues public spaces with new life and allows us to observe the birth of positive meaning through co-produced spaces that truly appreciate and celebrate the value of public life in cities. Consequently, this contribution observes how those traces of everyday life generate new manifestations of connection between the individual and public space under conditions of social distancing. By applying the diary method (Gehl et al., 2013) and direct observation during the first wave in April to March 2020, we report on the changes observed since the introduction of social distancing during regular visits to public spaces in two Australian cities, countries (Ngunnawal Country where Canberra is situated and Jagera and Turrabal country where Brisbane now stands on).

\section{A critical remark on the 'before' and the 'new normal'}

The phrase 'new normal' and its associated human conditions are considered as a baseline in immediate response to the lasting impacts of the COVID-I 9 pandemic globally. Since the start of the initial lockdown waves people across all ages utilise social media to communicate personal stories and individualised perspectives on how this "new normal' impacts their everyday life and how to celebrate breaks of the habitus that dominates human behaviour under lockdown conditions. An observable commonality is that the reporting contains a description of 'everyday life' and in most cases how that relates to the appreciation of public life in cities. When interrogating public space data framed around concepts such as commodification, value, and different forms of spatial practices associated with alienation and separation then, we argue that everyday life during the 'new normal' before the rollout of the vaccine allows us to engage in a discourse that overrides the dominant Keynesian and neoliberal paradigm in various forms and shapes. Noticeably these paradigms gave rise to the private sector enabling conditions in which spaces for public everyday life are produced that focus on the targeted distribution of resources and intervention in favour of capital accumulation (Butler, 2012, Lefebvre, 199I, Harvey, 1985). Australian capital cities demonstrate a plethora of different case studies that are a testimony of such conditions (Farrelly, 
202I). Privatisation of public spaces and programming in pursuit of unbalanced capital accumulation became an inescapable means to connect to other people (Madanipour, 2019) as privately managed public spaces are often the only places available and can afford public liability insurances that allow for the programmed celebration of public space for certain user groups. For example, from a place-making perspective, most public administrations across Australia operate within a 'risk averse' operation paradigm that in consequence discourages, suppresses, and in fact inhibits dynamic ad-hoc initiative and space appropriation that overrides capital accumulation by embracing diversity and possibility that imbue public space with social life.

The idea of welcoming uncertainty through a sense of discovery and adventure by consciously escaping or even breaking the prevalent paradigm is not yet new. The Situationist International created a movement framed around The Spectacle (Debord, 1983, Debord, 1957). The Spectacle reveals itself within the manifestation of news, advertisement, entertainment and of course through consumption and capital accumulation. Everyday life in relation to public space in its broadest sense defines how we interact with the city. There are two important aspects of this everyday life, firstly it takes most of our time thus represents an important part of our lives and secondly, this everydayness disappears in the repetition, the normal, the mundane and thus the insignificance of a routine (Lefebvre, 1991). The way we can become aware of this 'normal' is in the creation of new situations distancing us from these repetitive and ordinary activities (Perec, 2008, p. 210). Thus, the 'new normal' created with the current condition of pandemic represents an opportunity to review the everyday life and the role of public space. Arguably, applying such a conceptual window to data related to everyday life in contemporary Australia, is highly relevant today as it allows us to understand the impact of spatial practices that override neoliberal conditions under lockdown conditions. The new normal offers a new 'situation' and opportunity to discuss the new view on the ordinary public spaces, often considered underutilised and emerging traces of the public life in such spaces.

Therefore, this commentary examines and reports on public space conditions to better understand and conceive the city as a piece of art in which the hope to overcome fecklessness through co-production of spaces that celebrate everyday life beyond alienation and separation ought to be obtainable. Based on this critical remark and the abrupt death of public everyday life as we know it, we pay attention to what currently unfolds across many local neighbourhoods across Australia. Observations of everyday life in public spaces in Brisbane and Canberra illustrate the break from the conditioning before the COVID-19 pandemic during the first wave of government restrictions in 2020. The Australian Government adopted a number of restrictions that came into effect from the $20^{\text {th }}$ March (Australian Government). Most people were forced to work from home and only allowed to appropriate public space for essential trips and errands, locally within their respected neighbourhood. Residents were able to engage in public space only to service everyday life necessities, namely food consumption, domestic materials and utilities and recreation. A stark rise in unemployment, reported cases of anxiety, stress and gender-based violence are some of the consequences. The rule of social distancing a minimum of 1.5 metres and limited access to markets is strictly enforced. Public institutions, pubs and restaurants remained closed or were only allowed to operate with home delivery options. Mail services were disrupted while international and interstate travel is still not possible. With respect to facilities in public 
Observations on Death and Life of Public Space in Australia during the COVID-19 Pandemic

spaces such as national parks, campgrounds, playgrounds, dog parks, beaches, exercise stations and BBQ areas remained closed during the lockdown (Figure I and 2).

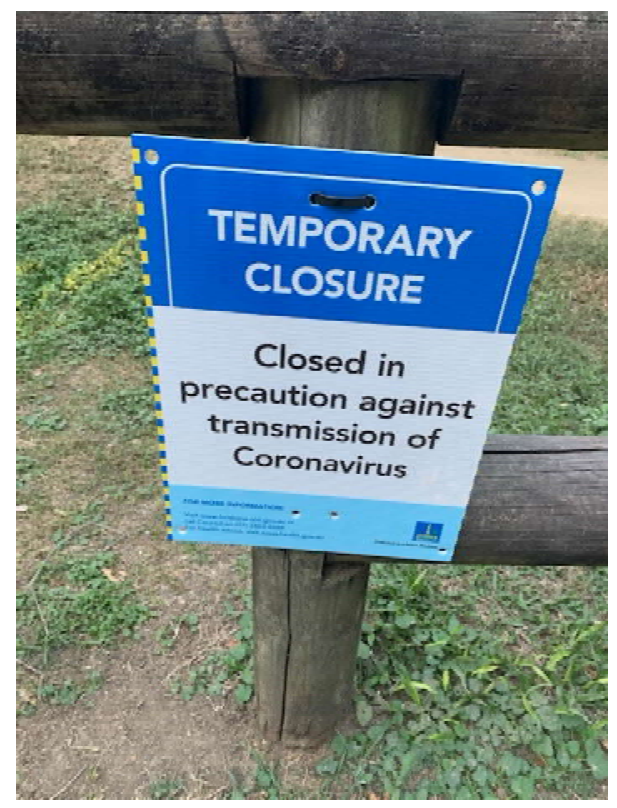

Figure I. Public space closure sign by Brisbane City Council (Source: Gregor Mews)

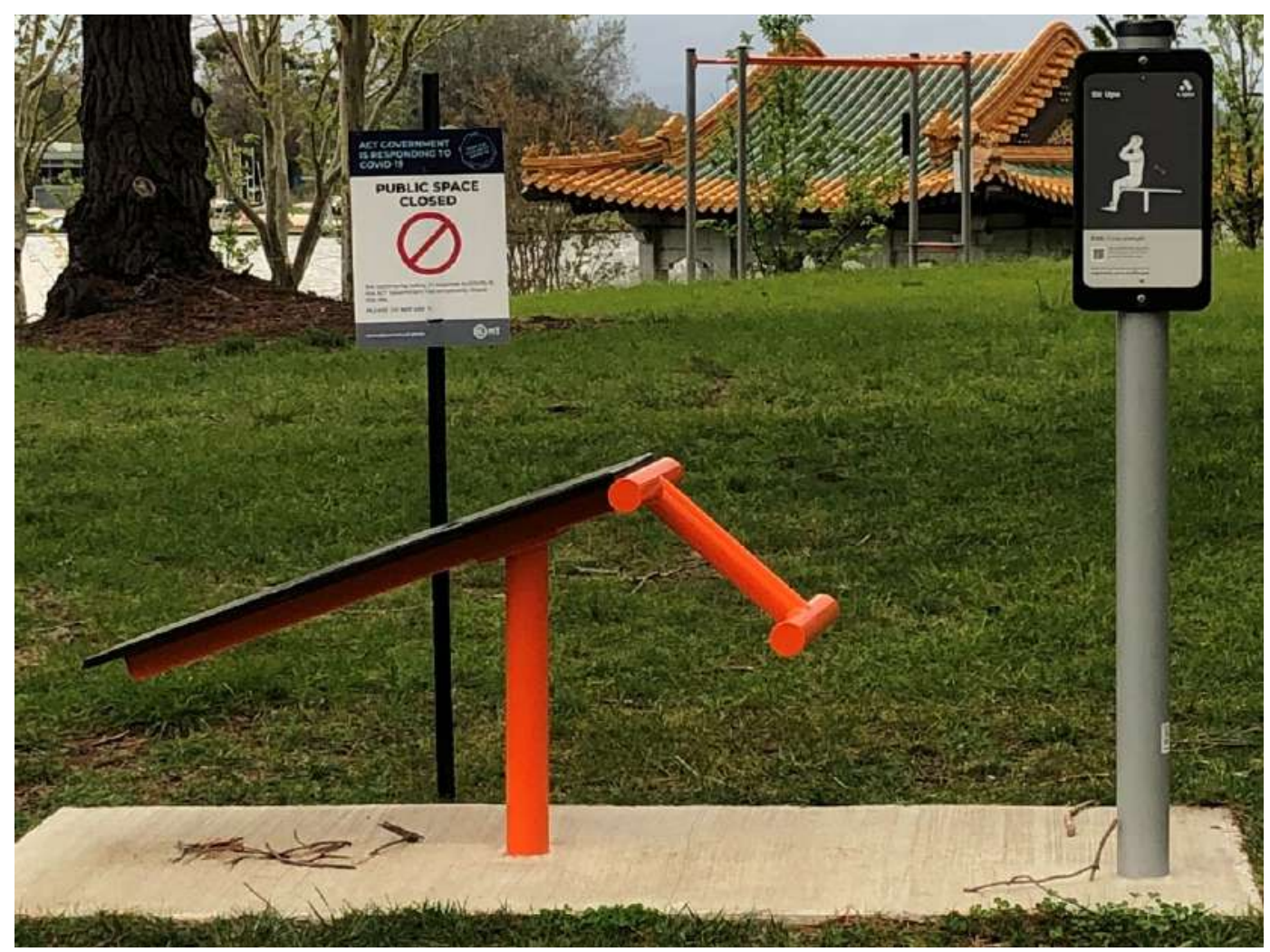

Figure 2. Public space closure sign by ACT Government (Source: Milica Muminovic) 
The new environmental conditions enabled people to co-produce spaces in a hyperlocalised sense and outside of their previously commodified state of existence. 'Hyper' due to the physical distancing policies, and 'localised' caused by the spatial movement restrictions, people start to rediscover their neighbourhood. Meanwhile, Australia wide data confirmed that mobility (walking and cycling) rates have increased on average up to 17- 34 percent compared to previous levels across the neighbourhoods (Google, 2020). At the same time retail visits have decreased by 24-33 percent (Google, 2020).

\section{Observations from Jagera and Turrabal country/ Brisbane}

Jagera and Turrabal country where Brisbane is situated is now the third most populated state capital city in Australia and one of the oldest cities on the continent that has been in the making on the homeland of the Turrabal and Jagera people. Currently around 2.4 million people call subtropical Brisbane their home and imbue life to public spaces in various ways (Population Australia, 2020).

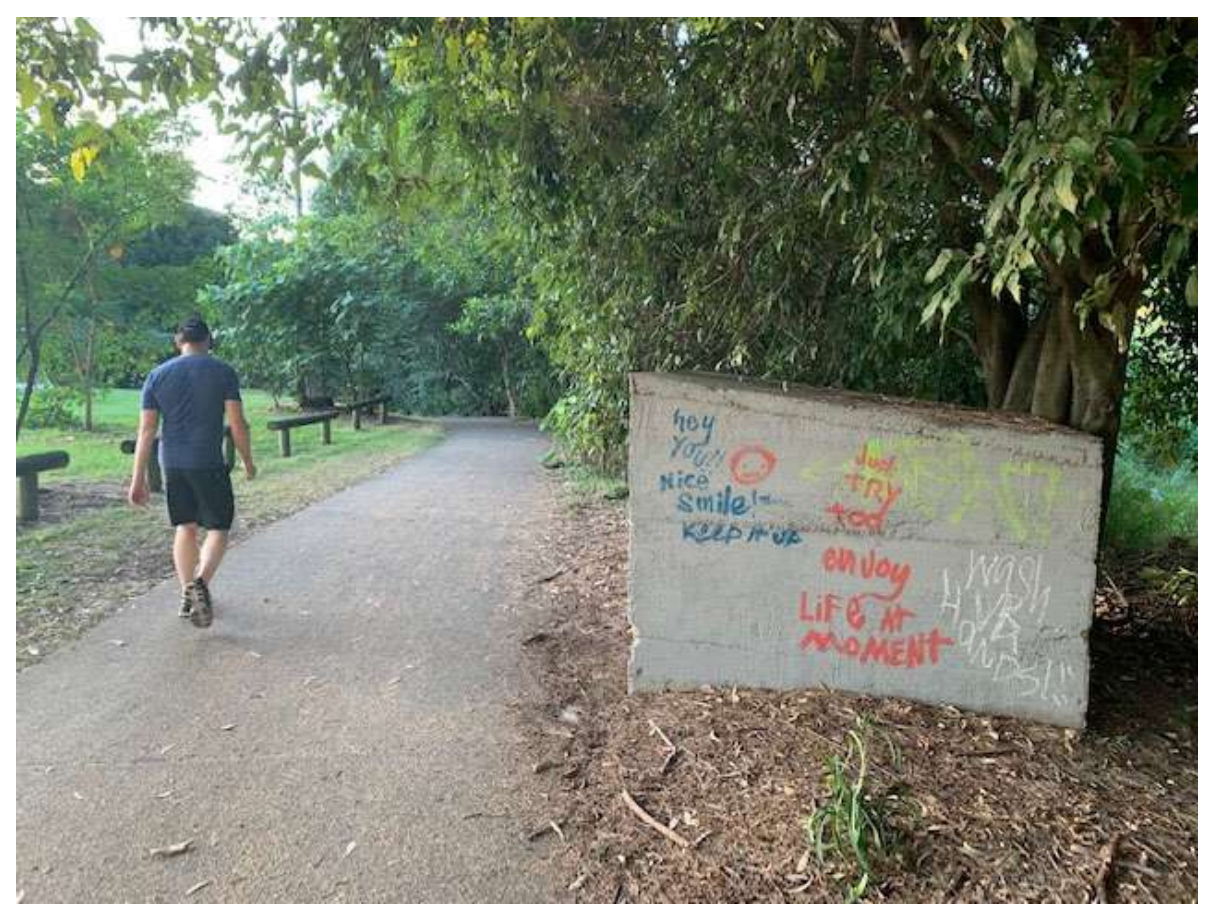

Figure 3. Images with positive messages (Source: Gregor Mews)

Apart from the Central Business District, most people spend their everyday life in suburban neighbourhoods in this subtropical environment and the enforced social distancing policies, or preferred physical distancing, shapes public life in several ways. For example, across the neighbourhoods of Paddington and Red Hill, the following direct observations in public spaces have collected through the diary method in close vicinity of the researcher's residence made during the month of April. A significant increase in the number of people appropriating public open space within walking and cycling distance. This occurred at sports fields, shared path networks, nature strips, 
Observations on Death and Life of Public Space in Australia during the COVID-19 Pandemic

bush lands, local streets and footpaths. While parents teach their children how to ride bikes, others choose to play football, soccer, basketball or cricket in the middle of the streets.

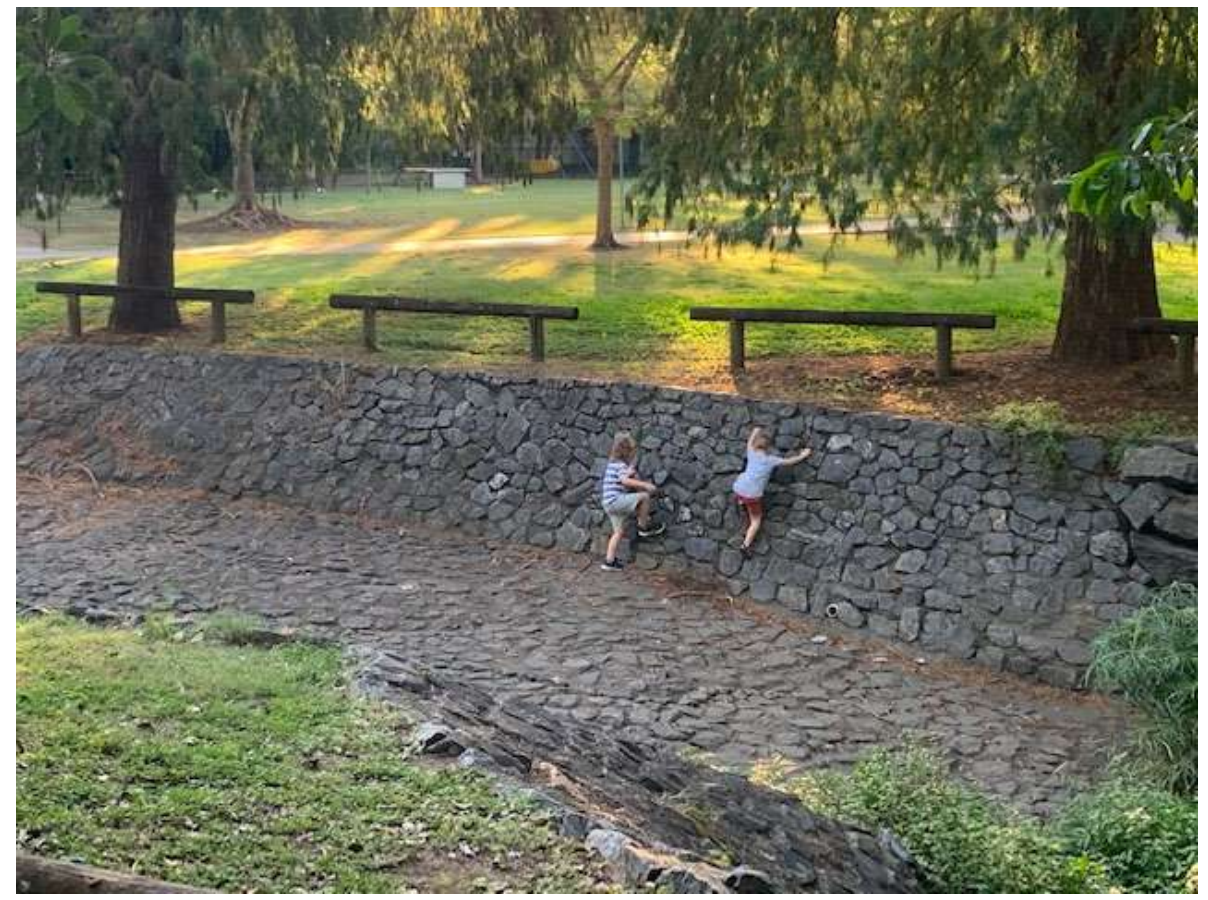

Figure 4. Rock climbing action of children in local open space (Source: Gregor Mews)

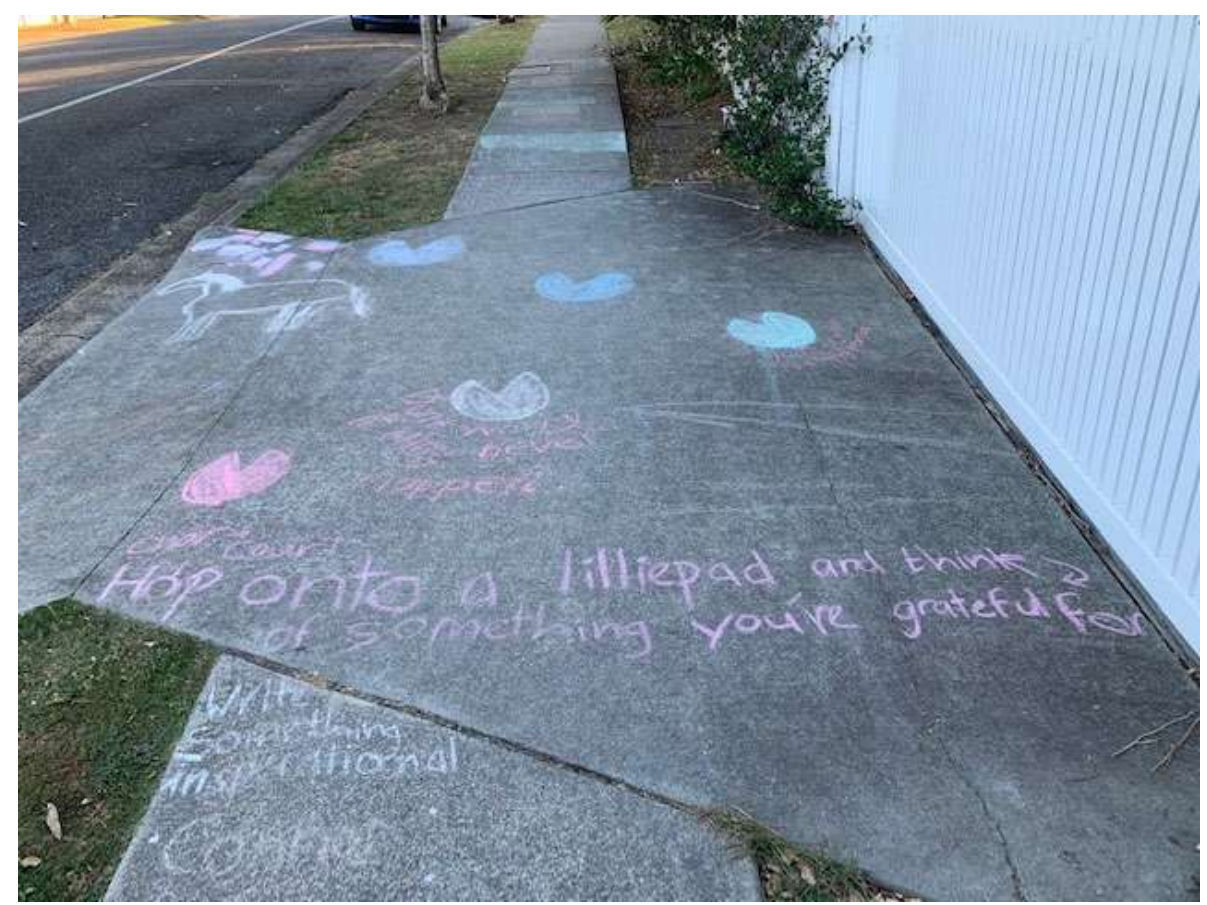

Figure 5. Invented street game during COVID-19 Lockdown (Source: Gregor Mews) 
Many walk their pets and enjoy sitting on benches, logs and fences while observing others passing by. Noticeably many more people sit consciously in their front yards or having dinner or picnic in their driveway in order to experience some sort of social cohesion. Physical props such as chairs, benches or stuffed animals decorate the yards as symbolic representation and celebration of solidarity with others. In addition, graffiti with positive messages are created by children or youth (Figure 3).

Especially children invent games to deal with the 'new normal' in creative ways. Games such as rock climbing (Figure 4) or Lillypad jumping (Figure 5) emerging as a form of grassroots 'tactical' urbanism.

\section{Observations from Ngunnawal Countryl Canberra}

Ngunnawal country also commonly known as Canberra is a place of a designed city build on the land of the Ngunnawal and Ngambri people. It is the capital of Australia with only 420000 inhabitants and considered a young city in its development (Australian Bureau of Statistics). Designed on the basis of garden city and city beautiful concepts, Canberra is considered the "Bush Capital" with endless suburbs as satellite centres and low-density living (Reid, 2002). Canberra has an abundance of open green spaces, the highest of all cities in Australia, with approximately 353 square meters of green space per capita (Australian Bureau of Statistics, 2017).

Direct observations in March and April during the social distancing measures are showing an increase in usage of local public spaces, for exercise, walking, biking, etc. The areas traditionally used for exercise such as for example the lake Burley Griffin have seen an increase also. We can observe intensification in the use of local public space. The traces of this trend can be seen in the children's graffiti messages on the pavement, or book reading exchange practices around the neighbourhood (Figure 6) as well as suburban bear hunt activities for children, and 'driveway project'.

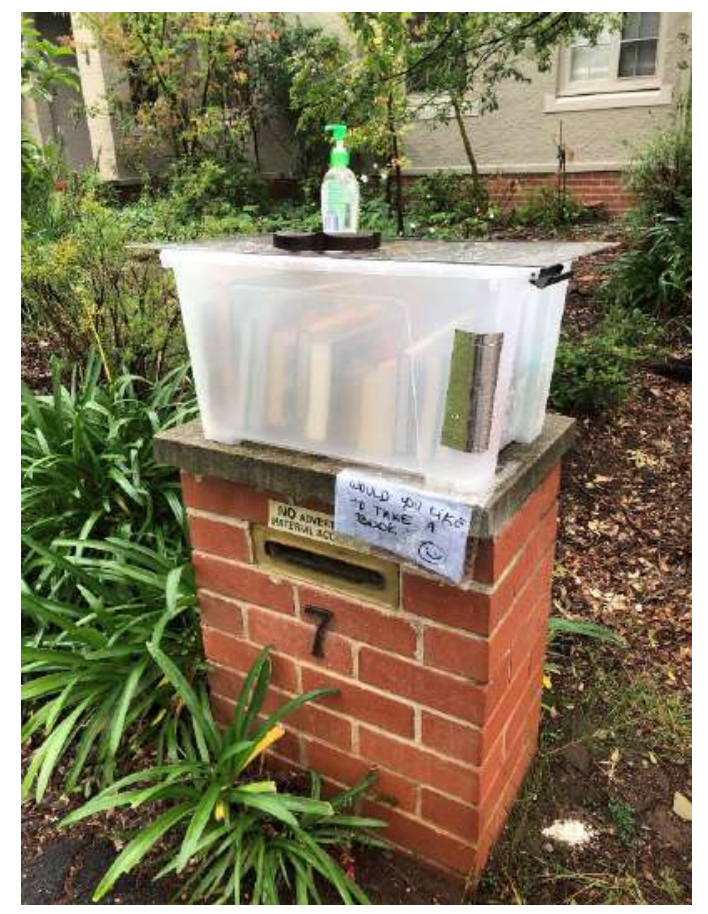

Figure 6. A neighbourhood book sharing initiative (Source: Milica Muminovic) 
Utilising social media to promote the neighbourhood, reinforce solidarity and a sense of community and activate the public space there are examples of individual leadership. For example, the bear hunting included people participating leaving a bear toy on the window for the children to go on 'hunt' for as many as they can spot. Generating a sense of community and solidarity. One other interesting example of the message sharing is located on the apartment building, where during the night the slide show is projected on the facade with different slides sharing the messages to the local community. The messages have been changing every week, for example there was a special message for Anzac Day and on ordinary days reflections related to everyday life (as in the example of Figure 7) all positive support to the community.
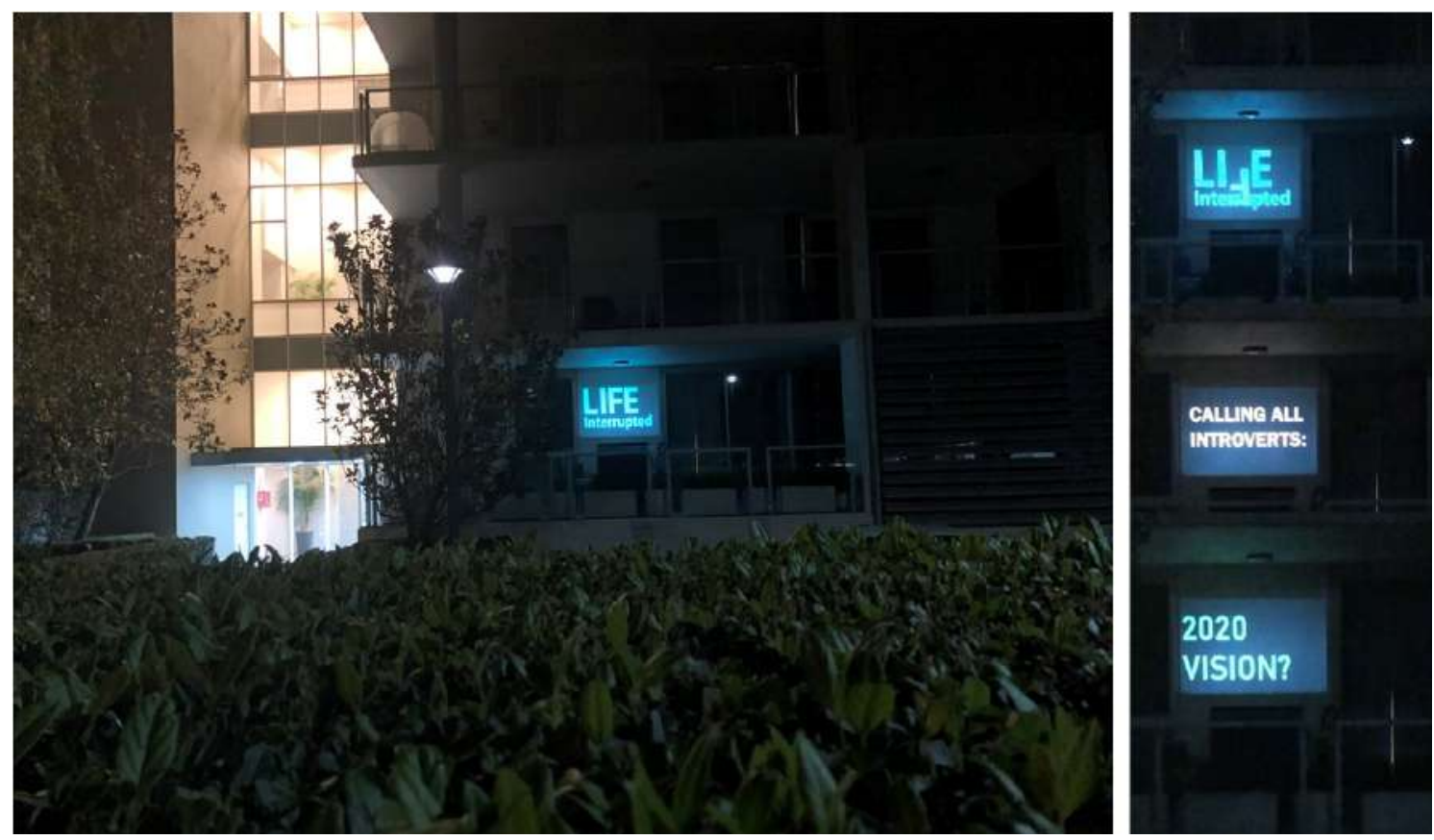

Figure 7. A neighbourhood screening on the façade with messages as short videos (Source: Milica Muminovic)

\section{Urban loveability and public space culture post-COVID I9}

Both case studies highlighted that many people are rediscovering and imbue their local neighbourhoods with public life. On the one hand, it might be too early to tell how COVID-19 is impacting everyday life beyond the novelty of re-experiencing the local. On the other hand, this extreme situation offers the opportunity to see the everyday life and the local suburban neighbourhoods in a different light. The spaces people were producing are not based on the pursuit of capital accumulation (Harvey, 2006). Could this situation offer a glimpse of a new way of interaction? Large community events are simply not possible under current restrictions and therefore it is too early to tell what type and how many new grassroots place-making activities might occur post lockdown. Furthermore, focusing on the very small details related to activities in public space might hold answers to questions related to what type of new spaces are being co-produced, 
how they contribute to a sense of community and function as mean to celebrate public life. All these are bringing us to question again small, local, ad-hoc, bottom-up ways of expressing the 'urban loveability' that can contribute to different ways of socialising, health and well-being, as well as belonging.

For example, the case of the invented street game, where people are encouraged to jump lily pads. Firstly, the preconditions were right. Parents were near-by and felt it is safe for their children to play on the street. Local vehicle traffic is currently exceptionally low, while many neighbours are also at home contributing to some sort of passive surveillance. Further, the creative process of producing drawings and patterns on flat surfaces meets the definition of 'urban loveability' as a voluntary, positive and intrinsic feeling to create something that is good for the maker as well as others. Once this space was socially produced, others were voluntarily engaged in the spirit of sharing or just observing, laughing and giggling. Arguably, human existence becomes meaningful with a sense of immediacy. Other examples, including the making of graffiti with positive messages or climbing on the walls follow the same process and outcome.

The optimism of Jane Jacobs can be shared, we as a design community have the right tools and know-how to help shape a 'new normal' in which the city as a conscious work of art can indeed emerge out of a collaborative and communal framework. This 'new normal' can be filled and enriched with many personalised forms of art as Mumford described it, and that transcends commodification in the service of capital accumulation and overcomes separation or alienation.

Unlike so many other societies, Australia experienced rather fortunate circumstances including low transmission rates that resulted in conditions that enable travel bubbles and a 'new normal' where most people regain confidence in the pre-COVID paradigm. In fact, in pursuit the compensation for the temporary losses that occurred during 2020, the society accelerated its efforts to reinforce a 'normal' that is again far away from what we observed during the lockdown. However, hope is what remains as it presents an opportunity for all to become conscious and accountable for our own actions and the impact of individual actions on others around us.

Ultimately, it is now up to each and every one of us to be brave, proactive in realising this shared potential. A realisation that a new ontological state of existence is obtainable. We should start by paying attention to the very small acts and deeds of everyday life in public spaces and nurture conditions that enable the possibility to bring out the very best in us. Only then we will be able to truly celebrate, share and lastingly value public spaces for all.

\section{References}

Amin, A. (2008). Collective culture and urban public space, City, I2 (I) 5- 24. DOI: 10.1080/I36048I0801933495.

Australian Bureau Of Statistics (2017). 2016 Census Community Profile [Online], Available: https://quickstats.censusdata.abs.gov.au/census_services/getproduct/census/2016/commu nityprofile/8ACTE?opendocument [Accessed I May 2020].

Australian Government (2020). Corona virus updates [Online], Available: https://www.australia.gov.au/coronavirus-updates [Accessed I May 2020]. 
Butler, C. (2012). Henri Lefebvre: Spatial Politics, everyday life and the right to the city, New York, NY, Oxon, OX, Routledge.

Debord, G. (1957). Report on the Construction of Situations and on the International Situationist Tendency's Conditions of Organization and Action., Paris, Bureau of Public Secrets.

Debord, G. (1983). The Society of the Spectacle, Cambridge, MA, London, UK, MIT Press.

Farrelly, E. (202I). Killing Sydney: The Fight for a City's Soul, Pan Macmillan Australia.

Gehl, J., Svarre, B. \& Steenhard, K. A. (2013). How to study public life, Washington, DC, Island Press.

Google (2020). Google COVID-1 9 Community Mobility Report [Online]. Google Available: https://www.google.com/covid 19/mobility/ [Accessed 23 April 2020].

Harvey, D. (1985). Consciousness and the urban experience: Studies in the history and theory of capitalist urbanization, Johns Hopkins University Press.

Harvey, D. (2006). The Political Economy of Public Space. In: LOW, S. \& SMITH, N. (eds.) The Politics of Public Space. London, UK: Routledge.

Jacobs, J. (I96I). The death and life of great American cities, New York, NY, Random House.

Lefebvre, H. (199I). Critique of everyday life, London, UK, New York, United States, Verso.

Mews, G. (2020). Urban loveability in a post-COVID-I9 world World Urban Campaign [Online]. Available from: https://www.worldurbancampaign.org/urban-synergies-group-urbanloveability-post-covid-19-world [Accessed 06/05/2020 2020].

Mumford, L. (20I6). The culture of cities, Open Road Media.

Ottosen, N. \& Mews, G. (2019). Exploring new horizons for youth wellbeing and Public Space in Sierra Leone. ISOCARP Review I5-Planning for Metropolitan area:, 332-349.

Population Australia (2020). Brisbane Population 2020 [Online]. Population Australia. Available: http://www.population.net.au/brisbane-population/ [Accessed 28 April 2020].

Zizek, S. (2020). Pandemic!: COVID-1 9 shakes the world, John Wiley \& Sons.

REID, P. 2002. Canberra following Griffin, A design history of Australia's National Capital. National Archives of Australia. 


\title{
Porch Placemaking. How In-between Spaces Work During and After the COVID-I 9 Pandemic
}

\author{
Koichiro Tamura \\ Sotonoba, Japan \\ tamurakoichiro@gmail.com
}

\begin{abstract}
This article illustrates the concept of "porch placemaking" emerging in various neighbourhoods in the world during the COVID-19 pandemic. While people face difficulty going to and staying in public spaces, they invent micro-intervention to socialize with others at their front porch, balcony, or window with a lighter, quicker, cheaper approach. These spaces are in-between spaces interfacing private and public realms. Porch placemaking can positively influence socially, culturally, and mentally in neighbourhoods, but it seems conditioned to apply by physical, natural, and social settings.

Porch placemaking is a quick and improvisational reaction to the pandemic. However, it could be an effective way to enhance a sense of neighbourhood even after the pandemic. This article discusses ways to sustain and expand the practice.
\end{abstract}

Keywords: porch placemaking, in-between space, soft edge, transitional space, community resilience

To cite this article:

Tamura, K. (2020). Porch Placemaking. How In-between Spaces work During and After the COVID-I9 Pandemic, The Journal of Public Space, 5(3), I83-I90, DOI I0.3289I/jps.v5i3.I376

This article has been double blind peer reviewed and accepted for publication in The Journal of Public Space.

(c) (7) $\$$ This work is licensed under a Creative Commons Attribution - Non Commercial 4.0 International License https://creativecommons.org/licenses/by-nc/4.0/ 


\section{Introduction}

The global pandemic of COVID-19 has changed daily lives in cities; many cities have restricted going out from home or recommended staying there for a few months as of May 2019. Consequently, city dwellers avoid mingling and staying long in public spaces and lost chances of refreshing themselves and socializing with others. This situation is stressful for people, and they have desired a space to escape from their indoor private space and substitute parks and open spaces for social wellbeing.

This article documents and analyses how people react to the current situation under stay-home order and physical distancing, based on observation of the author's neighbourhoods, collecting international cases on online media, and forum discussion with participants worldwide.

\section{Active use of porches and around across the world}

As a reaction to the situation, many people in the world use their porch, front yard, balcony, or windows to entertain themselves and others, share a positive mood, and feel connected to each other.

For instance, residents in the Oakwood neighbourhood, Raleigh, NC, came out to their porch to sing, make music, make noise, and connect from a distance (Govan, 2020). In doing so, some of them placed messages such as "howdy" and "thank you" there to communicate with others. Another example appeared on a balcony, porches, front yards, and sidewalks in Buffalo, NY. Residents there gathered across a street had a "social distancing dance party" every evening. Even though the state was one of the most severe pandemic epicentres, the party amused all ages' neighbours (Wright, 2020).

The use of the front door space happened even without the presence of people. A resident in New Jersey found a message saying, "we're all in this together," with a rainbow painting on a front door in their neighbourhood. She appreciated the message and wrote that she would follow the neighbour and put the same sign on her door (Fullilove, 2020). Similar ways of using spaces in-between private and public spaces also happen in other cities in Europe, Australia, and other regions. An opera singer sang in a balcony in Milan, a resident in Melbourne placed a board with a cheering message on a sidewalk, and so forth.

\section{Outlining "porch placemaking"}

These similar cases emerged spontaneously in different cities and countries without any design guides or campaigns in a very early stage (i.e., March and April of 2020) because these actions were rooted in fundamental human needs. Schneider and Alderfer (1973) developed an existence, relatedness, and growth (ERG) model based on Maslow's hierarchy of needs. The model explains that many city dwellers now demand the existence need that contains a physiological need safety need in terms of the physical environment. At the same time, people have got aware that they are losing chances to satisfy the relatedness need that comes after the existence need. The above actions come out from this need to feel interpersonal connection and belongingness. This article labels these actions to fill the relatedness need in front of one's home as "porch placemaking." These actions have several key features of placemaking - a 
collaborative process in which people come together to create vital public spaces that bring health, happiness, and social connection to their communities (Project for Public Spaces, 2018).

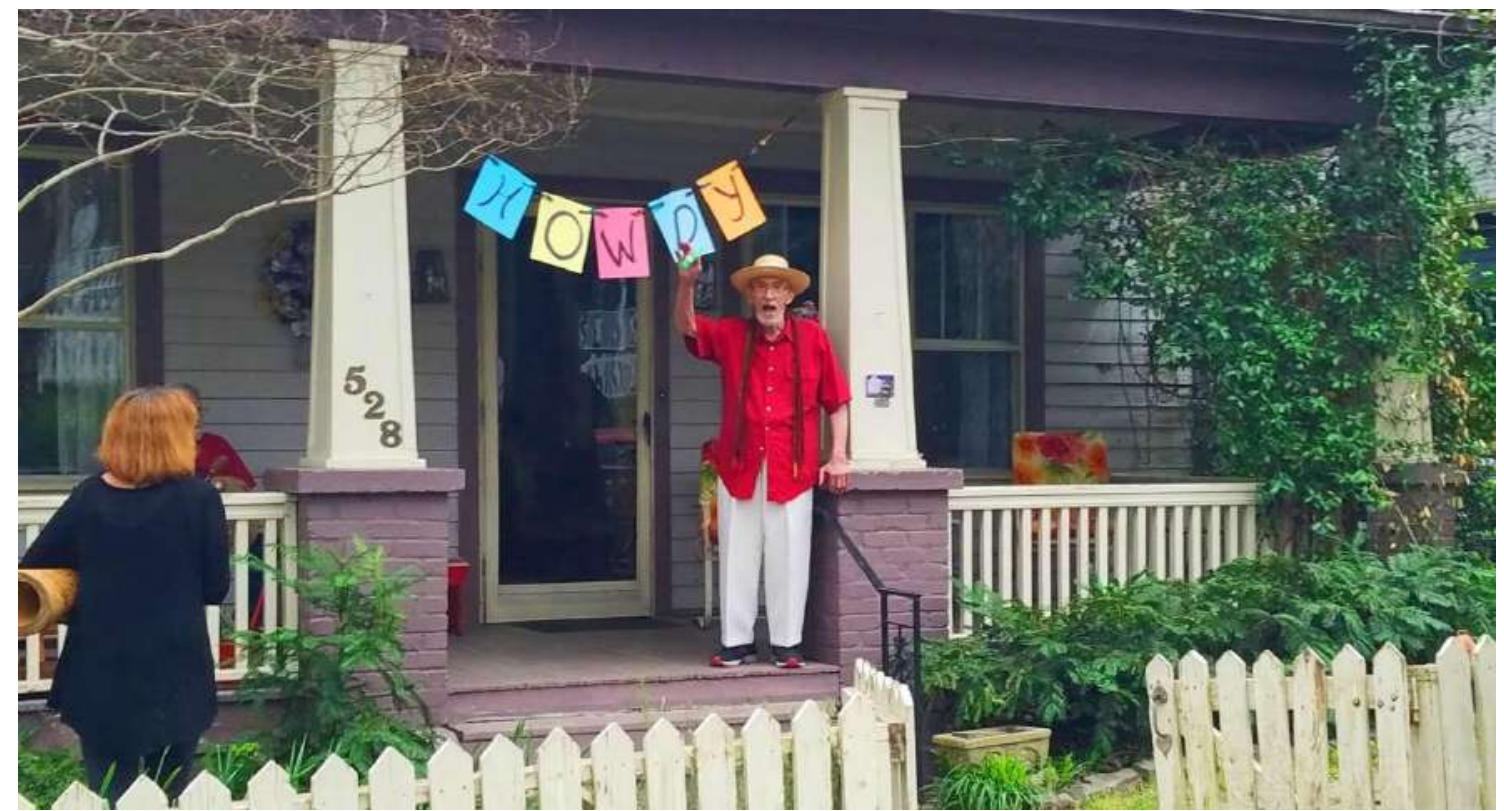

Figure I. People are singing and making musing in the Oakwood neighbourhood, Raleigh, NC. Photo: Tina Govan Architect, 2020.

More specifically, porch placemaking has the following characteristics.

- Creating social connection: porch placemaking practices have an intention to communicate with others, unlike purely personal use of the space. Moreover, they often induce neighbours to join the action.

- Quickly done on a micro-scale: "lighter, quicker, cheaper (LQC)" is one of the approaches characterizing placemaking, and porch placemaking is an extreme form of the manner. Porch placemaking usually happens with stuff available in one's home, and there is no thorough plan or preparation. This approach fits the circumstance when it is challenging to go shopping for new materials.

- Led by individuals and supported by communities: in other words, porch placemaking is not planned, advised, or financed by authorities or professionals. It is a spontaneous and self-motivated action for an implementor's common goods and his/her neighbours'.

There are three types of porch placemaking by how people are involved. The first one is a solo porch placemaking that randomly takes place by an individual or group. This type is not planned but spontaneously attracts the attention of passers-by and opens interactions. The second is a planned type like the case of the social distancing dance party. This type is more like an event and actively engaging neighbours. The third type does not need the presence or live-action of people in the space. Instead, they show a meaningful message and/or sign to communicate with others. 


\section{Spatial characteristics of porch placemaking}

Although this article calls "porch" placemaking, this concept intends to include actions happening in porch-like spaces such as balconies, windows, stoops, and front yards. The porch is not a universal format of architecture, but other cultures also have equivalent spaces. For instance, traditional Japanese houses have a space called "engawa", a wooden deck attached on the house's face just about a meter. The "fuzzy space" often functions as an interface of social communication with neighbours (Fujii, 20I5). In a blog post on porches, Architect Tina Govan points out that in-between spaces of public and private realms can be a porch:

"Whether it's balconies, porches, or stoops, these in-between spaces are essential and too often are omitted. I've never felt comfortable in buildings that don't offer this kind of transitional space, where there is an abrupt division between in and out, a black or white choice with no grey in-between. Porches offer us the freedom to choose where we want to be on the spectrum between inside and out, social or not. They create a soft edge, a kind of flexible connective tissue, that mediates between individual and community, and in these times, a safe way to maintain our social, mental and physical health."

(Govan, 2020)

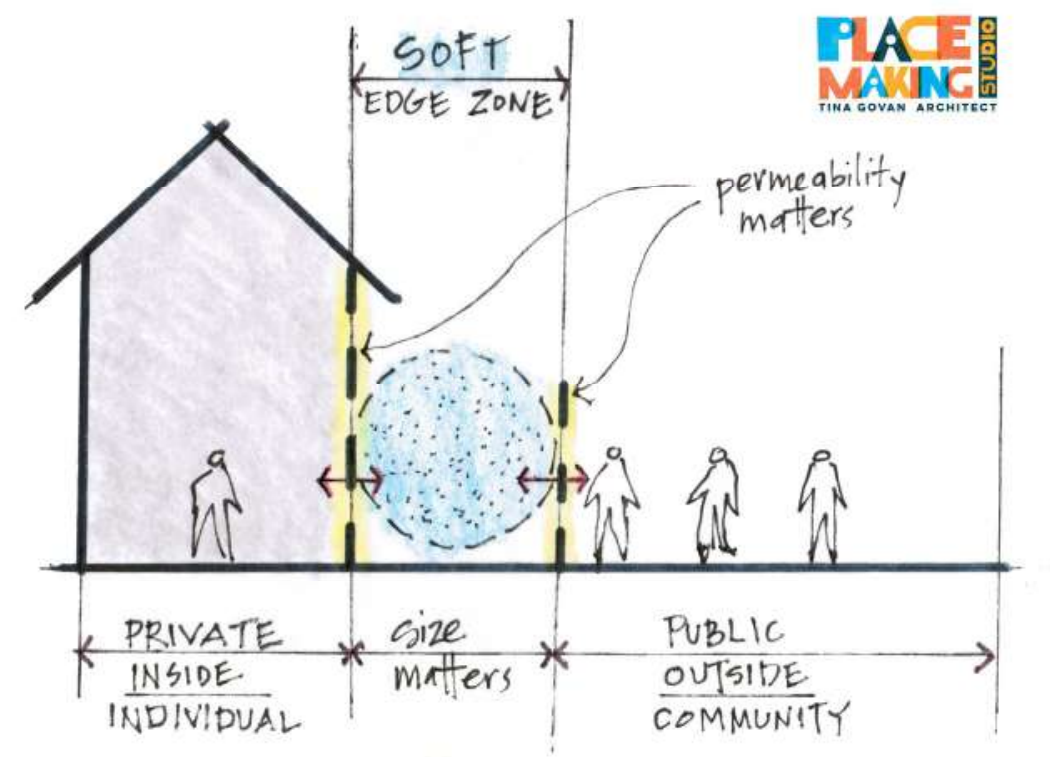

Figure 2. Soft edge at a porch between private and public spaces. Image: Tina Govan Architect.

Porches usually belong to a private property where residents can control and implement small interventions while they are visible from a street. This feature enables people to express their creativity in an LQC manner and spill it into the public realm. 


\section{Conditions for porch placemaking}

By collecting international cases of porch placemaking, authors find that it is active in some areas and not in others. It means that several conditions help porch placemaking. One is building and neighbourhood design. When there is no porch space or equivalent, it is not easy to take action. For instance, such spaces are not available in suburban neighbourhoods developed decades ago where a hard edge surrounds individual houses. Those bed town neighbourhoods follow the modern development idea prioritizing home security, single-use, and auto transport over walking. Traditional engawa spaces die out or hide behind a wall that distinctly divides private and public realms.

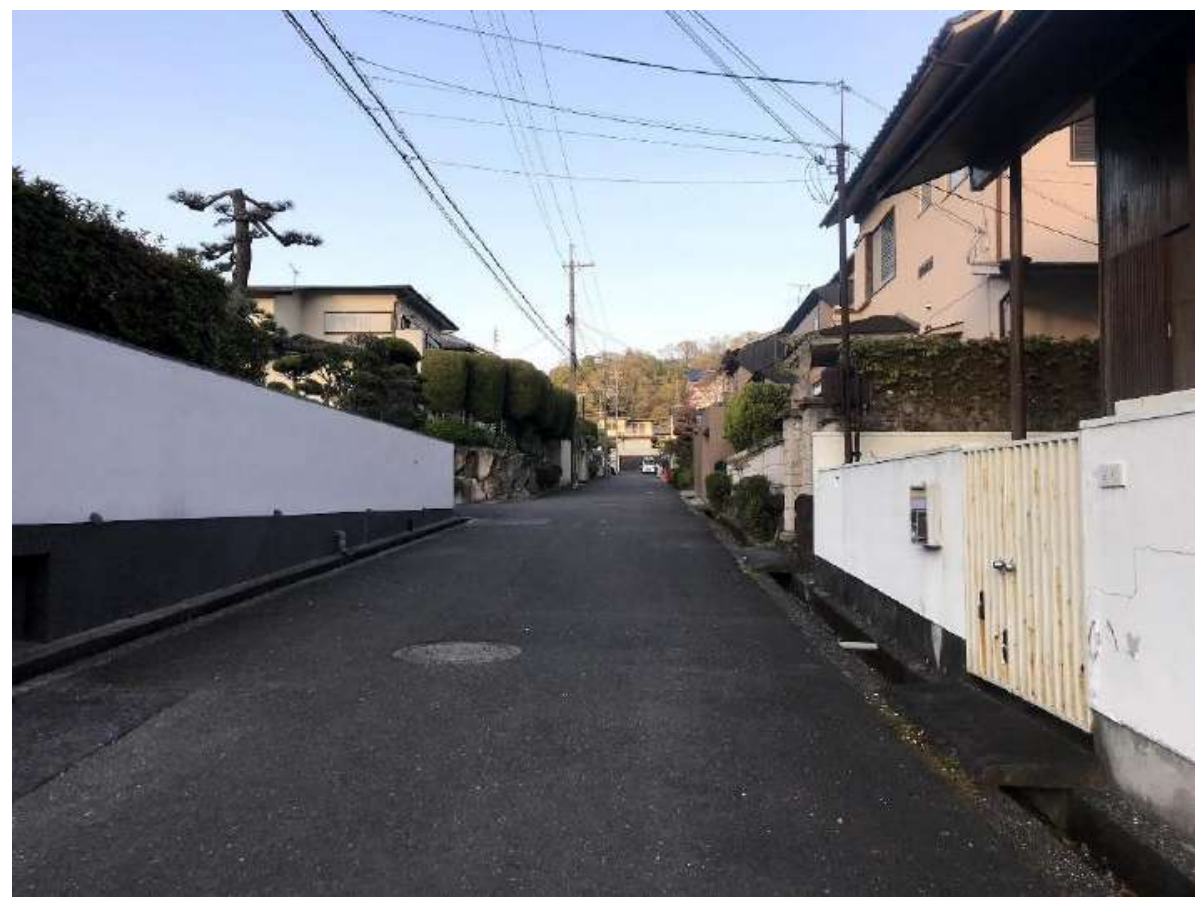

Figure 3. Hard edges in a bed town suburb in Japan. Photo: author.

Poon (2020) points out that a balcony, patio, deck, or porch is accessible by $62 \%$ of renters across the top 15 most populated metro areas in the United States. According to her analysis of the housing survey, wealthier renters tend to access the space. Another condition is the density and building scale of the neighbourhood. Porch placemaking usually happens in an urban or suburban area with a certain level of density, and it is deemed not as active in a less dense rural area. On the other hand, it is also difficult for residents in a high riser in a dense area to communicate with people on the ground level from their balcony.

Additionally, there is a non-physical condition. People are likely to take a porch placemaking action when they share the same level of difficulty staying home at the same time of a day. This condition is not a case in Japanese cities because the government does not have the legislative power to enforce staying home but only to request it. Due to this loose movement restriction, a certain number of workers kept commuting and did not spend time around home.

Thus, grounds for porch placemaking are visibility or communicability between private and public spaces, extent of freedom to use such in-between spaces (i.e., porches), 
presence of a certain number of people in proximity in same time of a day and sharing desire to socialize.

\section{Porch placemaking week - a global movement to amplify the impact}

An Australian placemaking group, Codesign Studio, organized the initiative of "porch placemaking week" from May $30^{\text {th }}$ to June $5^{\text {th }}$ of 2020 to share global practices on an online platform. This campaign aimed to deepen the discussion and help communities to keep benefitting from micro-scale placemaking. This movement was formed with over 200 porch placemaking projects across 23 countries from every continent in the world. Participants posted their interventions on a Facebook group during the week and shared their thoughts in a series of online forums.

There was no rigid criteria or requirement for registering a project as porch placemaking. Instead of defining the concept distinctly, this campaign explored various ways to apply porch placemaking by cultural and design contexts of different countries and neighbourhoods through crowdsourced actions. Eventually, registered interventions varied in scale, location, purpose, groups involved, and type of activities.

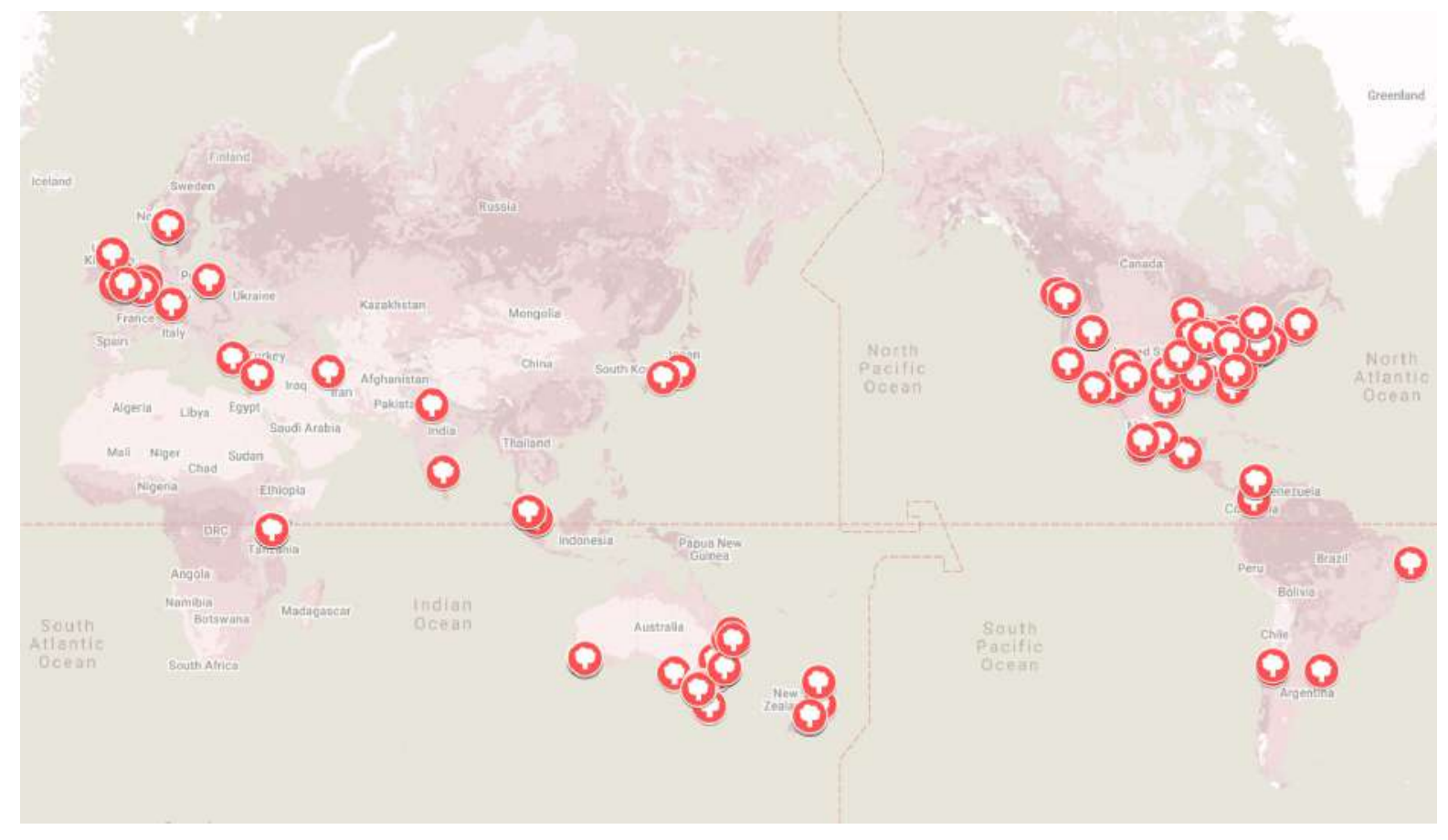

Figure 4. Projects registered in the porch placemaking week 2020. Image: web site of porch placemaking week 2020.

One notable finding in this global action is that porch placemaking is not only for residents of a house with a porch in wealthy countries but for those who live in informal settlements or densely populated cities. For instance, in Nairobi, Kenya, local artists joined the movement by painting visual messages that encourage infection control behaviours on housing walls in a slum. 


\section{Effectiveness of porch placemaking - during and after the pandemic}

Although there is no rigorous survey or data of influences brought by porch placemaking, images of actions usually come with positive statements about increased social interaction and mental refreshment during a hard time. Some report that they had more chances to communicate and know their neighbours than ever by using their porch.

O'Sullivan (2020) collected actions happening in-between spaces in the article titled "Alone Together, in Community Resilience." According to the article, "cohesive communities where neighbours check in on neighbours" is part of urban resilience. Porch placemaking contributes to enhancing community cohesion.

Porch placemaking possibly has short-term impacts during the pandemic and indirect impacts in the long run. Practices of porch placemaking may shift their behaviour and social life in the outdoor space by making them aware of possible ways to use spaces, their desire for social wellbeing, and the people around them. Moreover, it may affect an approach of architectural and neighbourhood design.

\section{Way forward to expand and sustain actions}

Since porch placemaking is an emerging concept, further case studies and examinations are necessary to take insights for design, planning, and policy to respond to urban issues and maintain community resilience in the future.

There is a possibility to support and expand small-scale individual actions at a porch by a campaign like the porch placemaking week. Another interesting case is the "Uchi Hana" project initiated by Ikoma city, Japan. The project is to distribute nursery flowers to households to place the flowers in front of their house. The city tied the project with the concept of porch placemaking to encourage citizens to make streets active.

\section{Acknowledgment}

This article received tremendous inspiration and contribution from Tina Govan and a forum discussion with her and international participants at the second online Placemaking Forum. An online visual presentation and discussion of these ideas by her and the author is viewable on the Placemaking Forum's Facebook page.

Also, the initiators and collaborators of the porch placemaking week played a vital role in testing and developing the emerging concept, which brought rich sources and insights. 
Porch Placemaking

\section{References}

Fujii, M. (2015) Urban Engawa / Veranda -Making Interactive Spaces for Tokyo Urbanites in the Fuzzy Spaces between Inside and Outside-. Thesis. Available at: https://digital.lib.washington.edu:443/researchworks/handle/I773/33987 (Accessed: 18 March 202I).

Fullilove, M. T. (2020) 'Coronavirus: This new togetherness', Countdown to Main Street, April. Available at: https://mainstreetnj.blogspot.com/2020/04/this-new-togetherness.html (Accessed: I 4 May 2020).

Govan, T. (2020) In Praise of Porches During Covid-19, PLACEMAKING STUDIO. Available at: http://tinagovan.com/lifeofplaces/2020/3/3I/in-praise-of-porches-during-covid-19 (Accessed: 13 May 2020).

O'Sullivan, F. (2020) Alone Together, in Community Resilience, CityLab. Available at: https://www.citylab.com/life/2020/03/coronavirus-alone-together-community-resilienceneighbors/608374/ (Accessed: I 3 May 2020).

Poon, L. (2020) A Lesson from Social Distancing: Build Better Balconies, CityLab. Available at: https://www.citylab.com/life/2020/04/apartment-design-balcony-private-outdoor-spacezoning-laws/610162/ (Accessed: 13 May 2020).

Project for Public Spaces (2018) How to Turn a Place Around: A Placemaking Handbook. 2nd edition. Project for Public Spaces.

Schneider, B. and Alderfer, C. P. (1973) 'Three Studies of Measures of Need Satisfaction in Organizations', Administrative Science Quarterly, I8(4), pp. 489-505.

Wright, M. (2020) New York residents throw a 'social distancing dance party', Mail Online. Available at: https://www.dailymail.co.uk/news/article-8167949/New-York-residents-throw-socialdistancing-dance-party-bust-Rolling-Stones.html (Accessed: I 4 May 2020). 


\title{
Exploring the Impact of COVID-I 9 Lockdown on Public Spaces through a Systems Modelling Approach
}

\author{
Nicholas Stevens \\ University of the Sunshine Coast, Australia \\ nstevens@usc.edu.au \\ Silvia Tavares \\ University of the Sunshine Coast, Australia \\ stavares@usc.edu.au
}

\begin{abstract}
This paper offers a Human Factors and Ergonomic \& Sociotechnical Systems (HFE \& STS) methodology to assist in the exploration and description of COVID- 19 lockdown impacts on public spaces in Queensland, Australia. The approach utilises an existing before COVID - systems model of an archetype public space to identify activities that were restricted in public space, and how such restrictions affect system performance. First an overview of the HFE \& STS system modelling approach, Cognitive Work Analysis, is provided and we present the systems model of an archetype public space. Next, the range of lockdown restrictions on public space activity are identified in the model and the system's implications on community and individual wellbeing are explored. In conclusion, the necessity for new activities and functions of public space, post COVID-19, are reflected upon and considered from a systems standpoint.
\end{abstract}

Keywords: human factors and ergonomics, sociotechnical systems, urban design, COVID-19, public space

To cite this article:

Stevens, N., Tavares, S. (2020). Exploring the Impact of COVID-19 Lockdown on Public Spaces through a Systems Modelling Approach, The Journal of Public Space, 5(3), I9I-206, DOI

10.3289|/jps.v5i3.1377

This article has been double blind peer reviewed and accepted for publication in The Journal of Public Space. (c) (1) (5) This work is licensed under a Creative Commons Attribution - Non Commercial 4.0 International License https://creativecommons.org/licenses/by-nc/4.0/ 


\section{New approaches to exploring urban complexity}

The dynamics of urban spaces are complex, and disasters exacerbate this complexity. Previous research has demonstrated the change in the nature of urban public spaces in post-disaster situations, when key desirable urban design outcomes - such as urbanity and vibrancy - become a source of fear. Urbanity is manifested through the combination of density and diversity, or the combination of the most diverse social things in the smallest space allowing for incidental interaction (Lévy, 1997). In the case of a disaster where density is an issue, urbanity is consequently compromised, and in these cases the design of urban spaces has to consider aspects of built form not previously favoured (Tavares et al., 2019). An example is the consideration of variations of levels of urbanity (Lees, 2010; Van Diepen \& Musterd, 2009), allowing for different levels of interaction through the design of urban social spaces and urban retreat spaces. To explore such possibilities for the design of novel and new urban spaces it is useful to extend current thinking and perhaps look to disciplines with a legacy of human interaction and safety critical research.

The use of Human Factors and Ergonomics \& Sociotechnical Systems (HFE \& STS) approaches in the design and development of urban form is an emerging paradigm (e.g. Patorniti et al., 2018; Stevens, 2016), demonstrating the recognition that HFE \& STS viewpoints are aligned to those of urbanism and urban development. Both sets of disciplines are concerned with the human condition and the interface between people and their environments. HFE \& STS approaches seek to jointly optimise the socio (of people and society) and technical (non-human) aspects of our environments (Walker et al., 2008). They are used extensively in a range of complex and safety critical domains, for example computer science (e.g. Bisantz et al., 2003); road safety (e.g. Cornelissen et al., 20I3); disaster management (e.g. Jenkins et al., 20l0); and aviation (e.g. Salmon, Walker, et al., 2016). While new to urbanism, they have much to offer in the exploration of the inherent complexity of our cities. Such approaches permit a systems examination of the range of interdependent activities and competing demands of our urban world view (Stevens et al., 2018).

This paper details the use of an existing (pre-COVID) HFE \& STS model of 'ideal public space' (Stevens \& Salmon, 20I5) to explore the implications of COVID- 9 lockdown on community and individual health and wellbeing. The model was created to represent universal design template of public spaces which supports and promotes a healthy and happy community; an inclusive and connected community; and a healthy and active individual. This model is employed as an archetype baseline, and the 2020 Queensland (Australia) lockdown limitations are then imposed on the public space activities presented within it. The implications of limiting those activities are then revealed in the overall system performance. The Queensland Level 3 lockdown limitations represent work and study from home orders, travel distance restrictions, the closure of all non-essential service industries, food and beverage businesses and hotels only offer takeaway service, grocery stores remain open with capacity limits (Queensland Government, 2020). During Level 3 restrictions people are permitted to move freely within their neighbourhoods and evidence suggests the use of local parks and public spaces increased (ABC, 2020). Whilst public spaces are in demand and largely accessible (physical distancing of 2 metres applies) authorities limited access to the recreational and public amenity infrastructure within them. Despite this curtailed capacity, the important functions and contributions of public space to social wellbeing and physical and mental health have never been in more demand. This study aims to better understand the impact of these 
restrictions on the use of public spaces and its urbanity. Any limits to access of parks and green spaces are already anticipated to be detrimental for the community (Freeman \& Eykelbosh 2020), as well as the reduced social connections provided by urban encounters, which is a consequence of urbanity itself (Montgomery, 1998).

A detailed overview of the systems approach, model development and methods is provided next; followed by the consideration and implications of Queensland Level 3 restrictions on the model. In the discussion section the consequences for public space design and use are explored; as well as the efficacy of HFE \& STS systems approaches for investigating the inherent complexities of public space.

\section{Methods - Cognitive Work Analysis (CWA) \& Work Domain Analysis (WDA)}

Cognitive Work Analysis (CWA) is a well-established HFE approach and was originally developed at the Risø National Laboratory in Denmark (Rasmussen et al., 1994). A key strength of CWA is its formative nature which provides a description of what could happen in the design of a complex system, rather than the more common normative analyses of what should happen (Vicente, 1999).

CWA and its first phase Work Domain Analysis (WDA) have been increasingly applied to examine a range of complex urban systems. These include, for example, transport land use integration (Salmon, Read, et al., 2016); active transport corridors (Stevens et al., 2018); and smart cities (Stevens et al., 2019). The sociotechnical and formative nature of the approach has allowed for the identification and optimisation of the emergent human behaviours and actions that occur (purposefully and accidently) within urban settings by virtue of the quality of their design. It offers new insights for urban design which present the possibilities for change, rather than the characteristic approach of limiting choice and enforcing controls on action.

CWA consists of five phases (Table. I), with a gradual transition from describing system elements to cognitive considerations - working from the environment and layout, to goals and context, to human behaviors (Jenkins et al., 2009; Vicente, 1999). WDA is often used as an independent method to provide detailed descriptions and analyses of complex sociotechnical systems (see Jenkins et al., (2009).

Table I. Five phases of Cognitive Work Analysis (adapted from Vincente, 1999).

\begin{tabular}{l|l} 
Phase & Tools used \\
\hline $\begin{array}{l}\text { I. Work Domain Analysis (WDA) } \\
\text { Identifies the constraints on behavior that are imposed by the physical context } \\
\text { and defines the environment that activity is conducted in (What, How, Why) }\end{array}$ & $\begin{array}{l}\text { Abstraction } \\
\text { Hierarchy } \\
\text { (AH) }\end{array}$ \\
\hline $\begin{array}{l}\text { 2. Control Tasks Analysis (ConTA) } \\
\text { Addresses constraints on activity imposed by events (How, By Whom) }\end{array}$ & $\begin{array}{l}\text { Decision } \\
\text { Ladder }\end{array}$ \\
\hline $\begin{array}{l}\text { 3. Strategies Analysis } \\
\text { Addresses various ways of approaching the same activity and the way } \\
\text { constraints influence the activity (How) }\end{array}$ & $\begin{array}{l}\text { Information } \\
\text { Flow Map }\end{array}$ \\
\hline $\begin{array}{l}\text { 4. Social \& Organization Cooperation Analysis (SOCA) } \\
\text { Addresses constraints imposed by roles and structures in place and different } \\
\text { factors may work together (How) }\end{array}$ & $\begin{array}{l}\text { All of the } \\
\text { Above }\end{array}$ \\
\hline $\begin{array}{l}\text { 5. Worker Competencies Analysis (WCA) } \\
\text { Addresses constraints by user behavior within the environment and what is } \\
\text { required (What) }\end{array}$ & $\begin{array}{l}\text { Skills Rules } \\
\text { Knowledge }\end{array}$
\end{tabular}


Of interest specifically for this paper was the development, in 2015 , of a systems representation of urban public space utilising WDA (Stevens \& Salmon, 20I5). That study involved the development of a systems model of an archetype or 'ideal' public space that sought to achieve the 'inclusive public space for all' concept, regardless of an individual's cognitive or physical ability. The aim was twofold: first, to showcase the utility of using HFE systems analysis methods such as WDA in urban design applications. Second, to provide a public space design model that made explicit the complex interactions afforded when seeking to incorporate subjective and objective outcomes, such as inclusiveness, health, safety, engineering, and sensory design.

The model was developed to be representative of a range of suburban park and inner urban public space typologies. Specifically, those public spaces developed in the tradition of post $19^{\text {th }}-20^{\text {th }}$ Century anglo-colonial urban form, represented strongly, for example, in the cities of Australia, New Zealand and the United States. Figure I. For this study, we have operationalised the existing 2015 model as a pre-COVID baseline for the review of the lockdown implications on public space in Queensland, Australia.
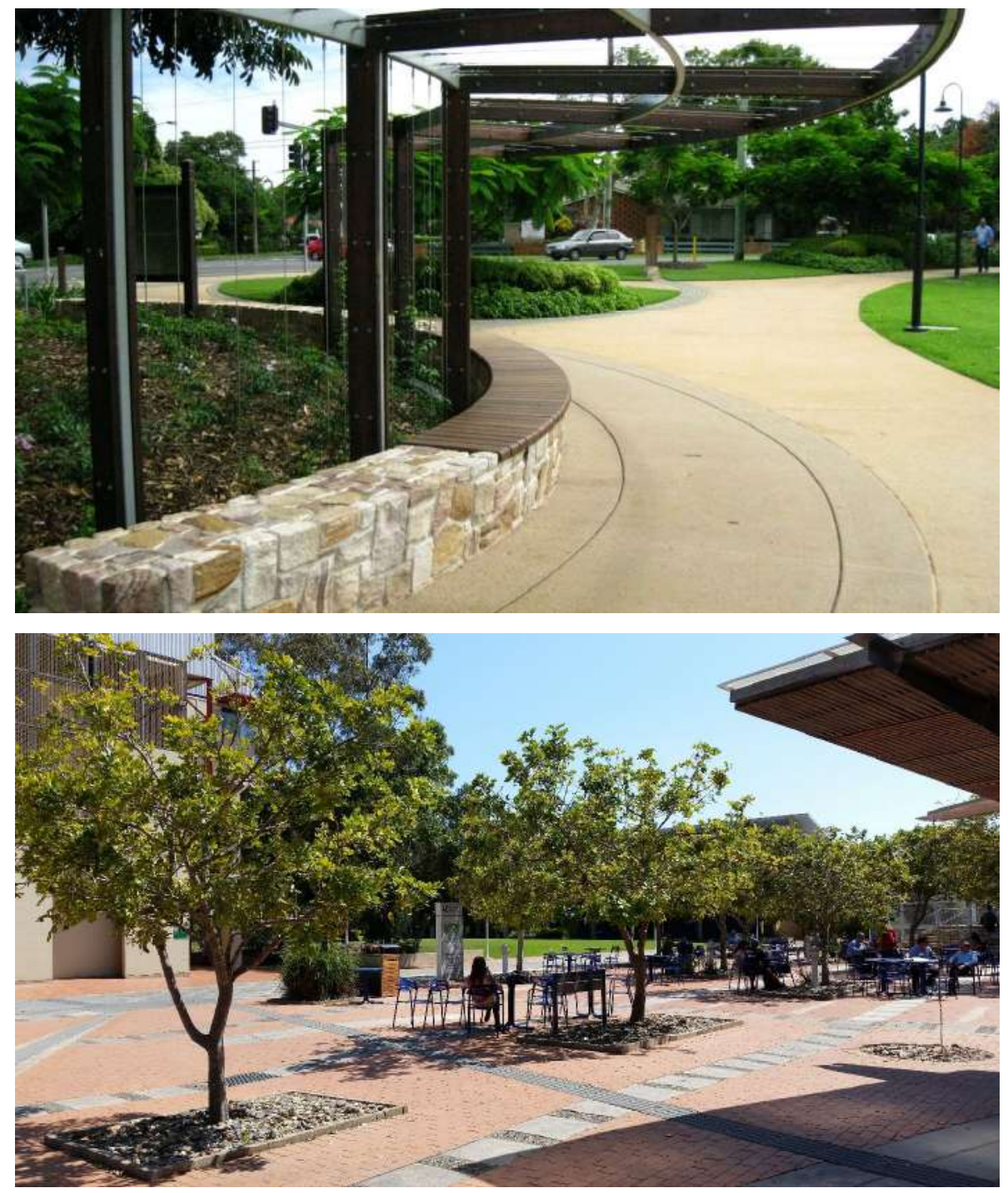

Figure I. Typical suburban park and inner urban public spaces (Source: Authors). 


\section{Work Domain Analysis (WDA)}

WDA can be used to model complex (urban) sociotechnical systems by describing them from their overall intended purposes, the activities that are undertaken within them, to the range of resources available to the system. The method involves constructing an Abstraction Hierarchy $(\mathrm{AH})$ of the system in question which provides an event and actor independent description of it. That is, a WDA is not concerned with contextual issues - e.g. night and day, seasonality or weather - it is simply describing and defining the domain, in this instance public space. This does not make WDA any less useful, as it allows for a comprehensive and complete description of the system (work) in addition to the environment within which this occurs (domain) (Naikar, 20I3).

The WDA models the system across five (5) levels of abstraction; here to describe an archetype urban public space. The levels include:

I. Functional purpose - The overall purpose(s) of the system. E.g. an inclusive and connected community.

2. Values and priority measures - The criteria the system uses for measuring progress towards its functional purpose. E.g. maximise safety.

3. Purpose related functions - The general functions or activities within the system required for it to achieve its functional purpose. E.g. allow social Interaction.

4. Object related processes - The processes associated with the physical objects within the system. E.g. surfaces for sitting.

5. Physical objects - The physical objects and resources within the system that afford the required processes. E.g. seating.

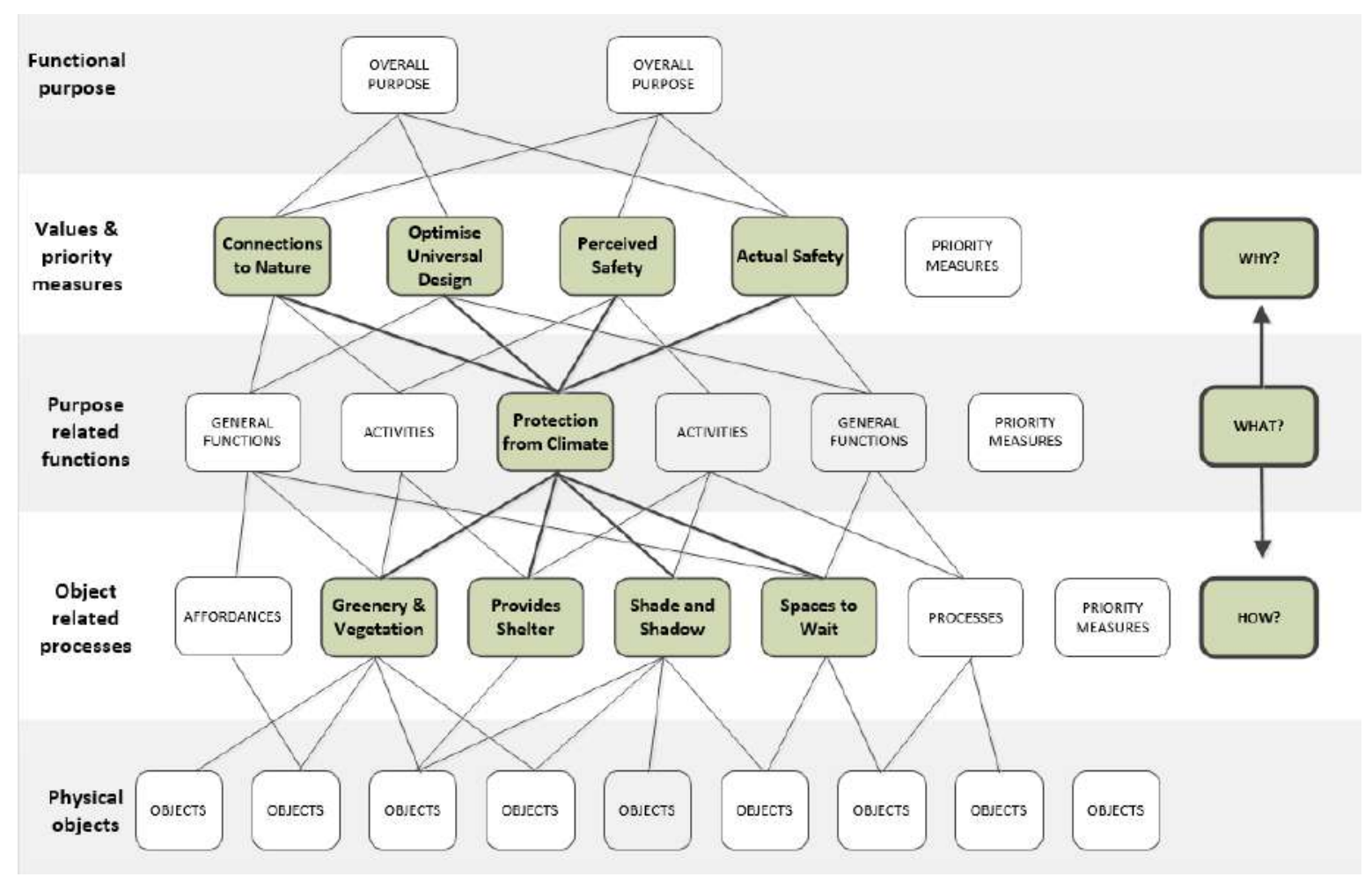

Figure 2. Work Domain Analysis levels of abstraction \& means-ends relationships (Source: Authors)

The output provides a model of what activities can be performed within a system, but also how and why they are performed and with what. Through a series of 'means-ends' 
links it is possible to model the what, why and how interactions of the system components and the influence this has on overall system performance. That is if a single node is explored in the model, the links it has to the level above identify why this node is necessary, and the links below represent how it is achieved (Figure 2). These links are not weighted but simply represent a relationship between the nodes at each level. They indicate that the operation of the system will follow these pathways and have these interactions and interdependencies in its operation.

The following is a condensed eight-step approach for the development and establishment of a WDA. The following overview provides both a general description of the method, and detail on the approach taken to establish the public space model used in this study (Stevens \& Salmon, 2015).

Step one: define the system and establish aims

Clearly define the system under analysis and establish the aim of the project. Consult with end users and subject matter experts (SMEs) to discuss the aims and expectations of a project.

The public space WDA aimed to establish an archetype which drew together current literature and leading practice approaches to build an indepth and integrated understanding of accessible, engaging and inclusive public space.

Step two: anticipate project constraints

Consider any logistical and financial constraints which may impact the scope of the WDA. Overcoming schedule and funding-based constraints necessitates a well-defined and realistic project timeline, budget and careful management.

Step three: define the system boundary

The analytical boundary of the system under analysis must be defined. It should be broad enough to capture the system in detail yet narrow enough to remain manageable. Whilst acknowledgeing that no system operates in isolation, it is important to be able to imagine the focus of analyses as discrete. For example, published case studies of urban systems using WDA have included footpaths (Stevens \& Salmon, 2015); playgrounds (Missen et al., 20I7); and main streets (Patorniti et al., 20l8).

Step four: locate data sources Identifying and utilizing a range of data sources to develop the model is necesarry (Naikar et al., 2016). They may typically include document review (e.g. standards, guidelines or technical manuals), academic literature review and analyses, case study observation, and interviews or focus groups with SMEs.

The public space WDA model presented has considered and included, where appropriate, the academic literature on walkablity (Ewing \& Handy, 2009; Gray et al., 20I2); inclusive public space and urban design (Low et al., 2009; Burton et al., 2006); and sensory urban design (Abedi et al. 20II; Degen \& Rose, 2012). Further it reviewed the 7Senses design framework (http://www.7senses.org.au/); drew upon the resources of Project for Public Spaces (https://www.pps.org/); and considered guidelines for public space design from government (Australian Government, 20I2; Victorian Government, 20I4). The WDA was developed and refined by five SMEs from the disciplinary fields of landscape architecture, urban design, public health, community development and human factors. Two of the analysts had previously developed WDA models in urban design 
contexts, whilst another has extensive experience of developing systems models across a range of domains including defence, road and rail transport.

Step five: construct the WDA

The WDA is systematically developed by the analysts through the inclusion of keyword 'nodes' at each level. There is a software tool available for the development of the WDA, and for CWA more broadly (Jenkins et al., 2009). It is often appropriate to document a 'data dictionary' as a table of terms to allow for the more detailed description and attribution of the included nodes. Once the functional purposes and values and priority measures are described, it is generally easier to include the types of physical objects and purpose-related functions required. Table 2 provides a series of prompts for inclusions at each of the WDA hierarchy levels.

Table 2. Example WDA prompts (see also Naikar et al., 2016)

\begin{tabular}{lll}
\hline WDA hierarchy & Prompts & Key words \\
\hline Functional Purpose & $\begin{array}{l}\text { For what reasons does the } \\
\text { system exist? }\end{array}$ & $\begin{array}{l}\text {-purpose, goals, aims, objectives, } \\
\text { rationale. }\end{array}$ \\
\hline Values and Priority Measures & $\begin{array}{l}\text { What criteria establish if the } \\
\text { work domain is achieving its } \\
\text { purposes? }\end{array}$ & $\begin{array}{l}\text {-measures, results, targets, laws } \\
\text { and regulations, standards, criteria. }\end{array}$ \\
& $\begin{array}{l}\text { What functions are required } \\
\text { to achieve the purposes of } \\
\text { the work domain? }\end{array}$ & $\begin{array}{l}\text {-function, roles and responsibilities, } \\
\text { maintenance, tasks, activities. }\end{array}$ \\
& $\begin{array}{l}\text { What processes are the } \\
\text { physical objects in the work } \\
\text { domain used for? }\end{array}$ & $\begin{array}{l}\text {-uses, components, processes, } \\
\text { limitations, capacity, }\end{array}$ \\
\hline Object-Related Processes & $\begin{array}{l}\text { What are the physical objects } \\
\text { or resources - both human- } \\
\text { made and natural? }\end{array}$ & $\begin{array}{l}\text {-tools, equipment, infrastructure, } \\
\text { fittings, facilities, layout, buildings, } \\
\end{array}$ \\
\hline ahssets.
\end{tabular}

Step six: refine the analysis

To refine the analysis and establish the links between nodes across each level the 'means-ends' approach is used. The means-ends links are informed by a series of 'howwhat-why' relations (Figure 2). This is an iterative process and not only helps establish links between nodes but assists in establishing if nodes are correctly located at a particular level of the WDA model.

Step seven: review and validation of the WDA

Draft WDA models is reviewed by appropriate SMEs. Often in a workshop, SMEs are asked to focus on each node within the model. SMEs may be first asked if nodes are appropriate, and second to identify any missing nodes. Third, SMEs may review the links between the nodes via means-ends enquiries of what, why and how. Naikar (2016) 
highlights that this review by SMEs is also an appropriate strategy for validating the work domain model.

A draft of the public space model was constructed by the urban design and public health practitioners, which was reviewed by all experts at an analyst workshop. Any disagreements about the inclusions or the linkages between levels of model were resolved through discussion until consensus was met.

Step eight: detailed domain analyses

Following the completion of the WDA model, depending on the aim and purpose of the project, it is often useful to use the analyses for either the assessment of existing systems, or to inform the design of proposed systems. The 'before COVID' baseline public space.

\section{The 'before COVID' baseline public space}

The establishment of this systems model of public space was a cooperative research project undertaken in South-east Queensland, Australia in 2015. The result was a WDA which modelled and described inclusive public space whose overall purposes were focused on community and individual wellbeing. Purposes which we would argue underpin the design and establishment of all public space. An overview of each of the levels of the 'before COVID' baseline public spaces model are presented, beginning at the top of the abstraction hierarchy. Following this, the approach undertaken to review the Level 3 lockdown restrictions on the model are detailed.

\section{The functional purpose}

The overall 'functional purposes' of public space were identified as 'a healthy and happy community'; 'an inclusive and connected community'; and 'a healthy and active individual' (Figure 3). It is important to note that, despite often being considered as the 'purpose' of public space, it is not at this level of the model where activities such as 'places to meet' are identified. The WDA permits a higher system understanding of such spaces, and when reflecting on their emergent influence with urban settings it is the community and individual purposes of health and wellbeing that are paramount.

Values and priority measures

The 'values and priority measures' support the ways in which the system achieves its purposes, and these are often quantifiable. For example, for all fourteen (I4) measures identified in this model (Figure 3), it is possible to establish data to support their progress. From the inclusion of 'engaging design elements', through to 'community connections and values' and 'actual safety' metrics are feasible. This is often assisted by reviewing the purpose-related functions, or activities, on the level below - remembering that the connected elements below always tell us how a specific node above is achieved. 


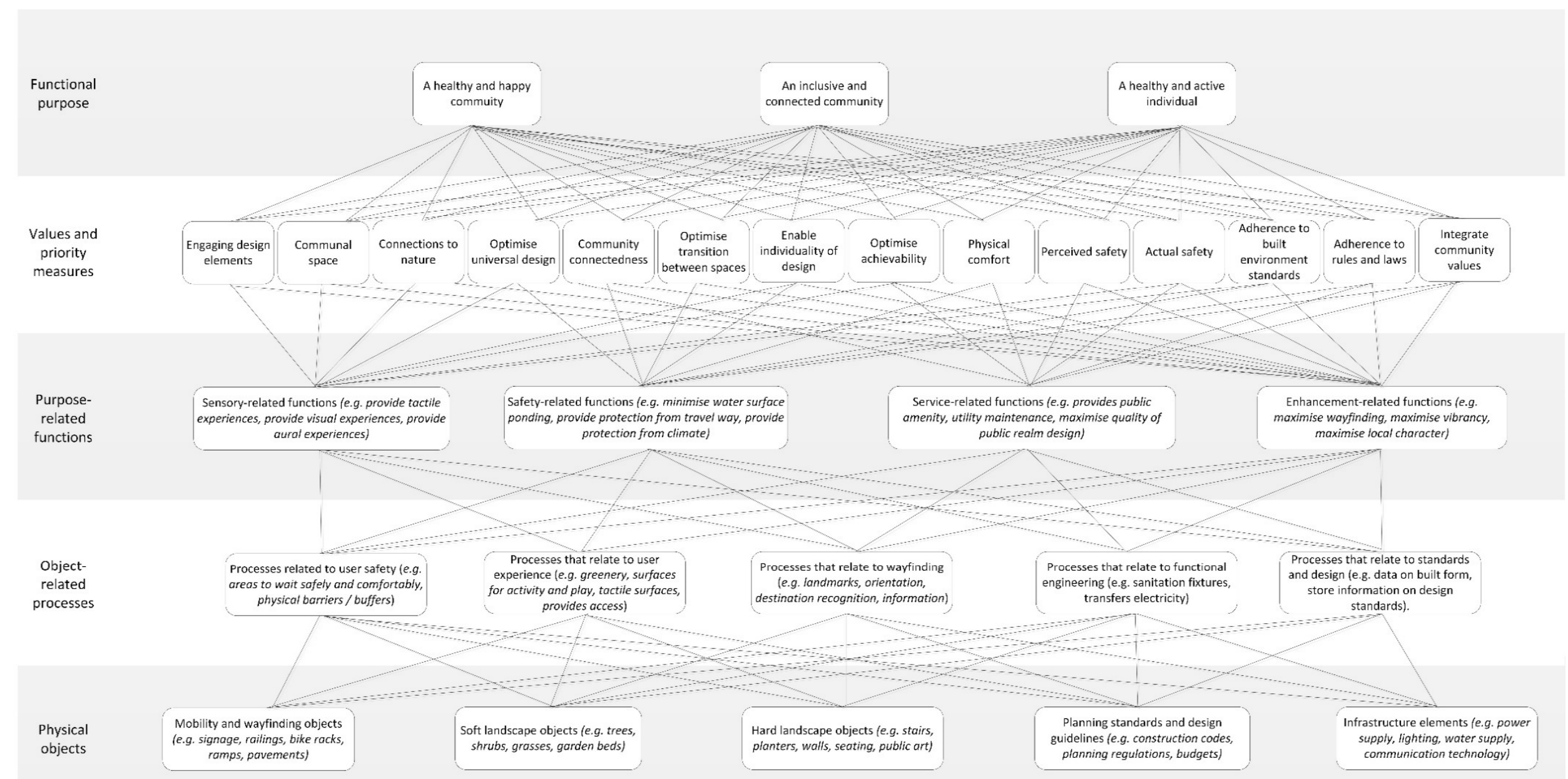

Figure 3. WDA model of archetype public space (Source: Authors

The Journal of Public Space, 5(3), 2020 | ISSN 2206-9658 | 199

City Space Architecture / UN-Habitat 
Exploring the impact of COVID-19 lockdown on public spaces through a systems modelling approach

\section{Purpose Related Functions}

Public spaces are complex places and this model has established that there are 25 different purpose-related functions (functions) that are necessary for the system to achieve its values and purposes above (Figure 3 ). In this project it was possible, and useful to aggregate or summarize the primary categories. These included sensory-related functions (e.g. provide tactile experiences, provide visual experiences, provide aural experiences); safety-related functions (e.g. minimise water surface ponding, provide protection from travel way, provide protection from climate); service quality related functions (e.g. provides public amenity, utility maintenance, maximise quality of public realm design); and user enhancement-related functions (e.g. maximise wayfinding, maximise vibrancy and urbanity, maximise local character) (Stevens \& Salmon, 20I5).

This level of the WDA is perhaps the most significant in that these functions (or activities) within the system link the more strategic, goal-oriented levels above it; with the physical resources and processes on the levels below. Any restriction upon the activities at this level have direct implications for the attainment (and diminished levels) of community and individual wellbeing at top of the system.

\section{Object Related Processes}

Individually in the model these nodes represent the 'object related processes' afforded by the physical resource in the level below. For example, 'provide shade and shadow', is a process which may be afforded by shelters, trees, or adjacent built form. Or, 'provides surface for objects' is an affordance of, pavement surface, fences, lawn, tables, and seating. This notion that a process can be acquired from multiple resources is important for resilience and flexibility in the design of public space. For efficiency in presentation the forty-seven (47) object-related processes have been aggregated (Figure 3). Those that relate to user safety (e.g. areas to wait safely and comfortably, physical barriers / buffers); user experience (e.g. greenery, surfaces for activity and play, tactile surfaces, provides access); wayfinding (e.g. landmarks, orientation, destination recognition, information); functional engineering (e.g. sanitation fixtures, transfers electricity,) and; standards and design (e.g. data on built form and land use, store information on design standards).

\section{Physical Objects}

The identification of the 'physical objects' and resources within the system is intended to be comprehensive. So, while it will include all elements that may be anticipated within public spaces - soft landscape (e.g. trees, shrubs, grasses, garden beds), hard landscape (e.g. stairs, seating, pavements) - it will also include those resources that are critical to operation but exist away from the space itself. For example, planning and engineering standards, design guidelines, maintenance budgets, rules and laws; all of these resources have intrinsic influence on public space, and it cannot effectively achieve its functional purposes without them. Important to acknowledge for exploring complexity and for optimising design is that a single resource can also afford multiple processes. A tree, for example, provides greenery, fruit and flower, shelter, shade and shadow, it is a landmark, and if endemic to the area offers both habitat and cultural knowledge. The fifty-five (55) physical objects included within the model of archetype public space have also been broadly categorised (Figure 3 ). 
Identifying the lockdown impacts on activity

To assist in determining the lockdown impacts, the authors reviewed each of the twentyfive (25) purpose related functions (public space activities) at the middle level of the WDA. They considered, first the requirements of the Level 3 lockdown, and then individually made a determination if this would effect each activity in turn. It was agreed that for this exploratory analyses that the lockdown measure either did, or did not, impact the activity. There was no partial determination. The authors then met to compare their results, and any variation between them was discussed until consensus was met. In addition, local case studies of park and public space settings were observed for a clearer determination of the lockdown restrictions (Figure 4).
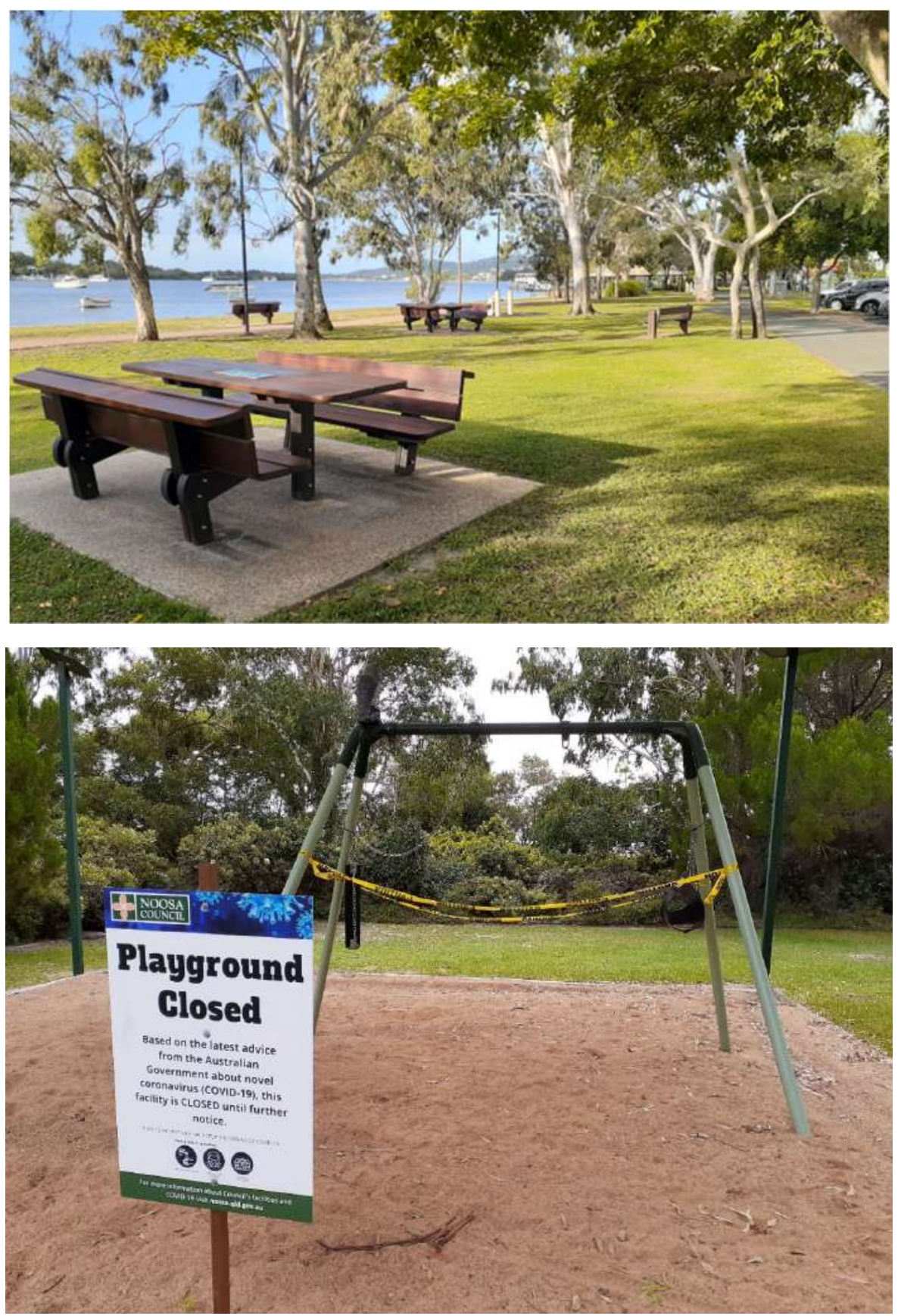

Figure 4 Public spaces under lockdown in Queensland (Source: Authors) 


\section{What does the model tell us about COVID lockdown?}

This pre-COVID baseline model of inclusive public space reveals that the overall functional purposes are principally related to community and individual wellbeing. That is, at the highest level, the purpose of public space is to contribute to: a healthy and happy community; an inclusive and connected community; and a healthy and active individual. The model also identifies that there are fourteen (14) measures which support and allow for the achievement of those purposes. Perhaps most importantly it identifies that there are twenty-five (25) purpose related functions, or activities, that are necessary for optimal system performance and attainment of the overall purposes. From a systems viewpoint of interdependence it follows that if any of these elements are diminished or missing, there is deterioration across the entire system.

In Australia, and nearly every country, COVID- 19 lockdown restrictions limited activity in public spaces. The use of this WDA model allows new insights into the knock-on effect of those restrictions for individuals and the broader community. This analysis will focus on the top three levels of the model as a way to demonstrate the efficacy of the systems approach. These levels provide the ability to succinctly explore the higher order implications of the COVID-I 9 lockdowns on public space. When undertaking analyses using WDA it is also possible, and useful, to consider the impacts from the physical objects level at the bottom. These types of design reviews consider the system implications of absent physical objects within a setting. Interestingly for this case study, even under lockdown many of the objects remain largely unchanged - it is the access to them via activities which has degraded the system. As such this analysis begins at the purpose related functions level, where these activities are first identified. Then by tracing the connections up the model it is possible to identify the links which are broken and therein how the loss of the public space activity undermines the values and therein, how the three overall purposes are also impacted.

Table I, represents the relationships between all twenty-five (25) purpose related functions (functions) on the $x$ axis; and all fourteen (I4) 'values and priority measures' on the $y$ axis. It identifies the established connections from the archetype WDA, and indicates via shading the fifteen (I5) functions that ceased under Level 3 COVID-19 lockdown in Queensland, Australia.

Which public space functions were impacted in lockdown

The function of providing 'public amenity', in the context of sanitation facilities, was no longer available, however also largely not required. It was however reported in some instances the closure of these facilities did have adverse outcomes for the homeless, and still diminished the measure of physical comfort and the capacity for communal space. Each of the five (5) functions associated with access to sensory experiences within public spaces were also unavailable to the community. These functions are recognised as underpinning some of the core values in public space including community connectedness, physical comfort and connections to nature. The four (4) prominent functions of public space which offer the individual and community access to 'local character', 'vibrancy', 'diversity', and 'fun \& adventure' also ceased. Further it was identified that the capacity for meaningful 'local ownership \& agency' generated via quality public space also ceased under lockdown. Perhaps most significantly, the activities associated with people interacting with each other were limited and often 
prevented - 'places to meet and wait'; 'active \& passive social interaction'; and 'community \& civic functions'.

The implications of removing these functions from public space may be explored in a systems sense by considering the dependencies between them and the measures they support. Of importance to note is that each function is connected to multiple measures, supporting different ways of how that measure is achieved. For example, the model establishes that the measure of perceived safety is supported and achieved via the functions of 'minimise traffic speeds', 'acknowledge seasonal changes', 'maximising vibrancy and urbanity', 'provide places to meet and wait', 'protection for the travel way', 'optimise the use of obstacles', 'optimise walkability and mobility', and 'optimise way finding'. In this example only the 'maximise vibrancy and urbanity' and 'provide places to meet and wait' functions have been lost via lockdown. The other functions remain in the system as they still support the public space even without the human interface. To take a functions perspective, on average, each removed function connects to and supports six (6) measures, with 'provides public amenity' the least linked function with four (4) connections, and 'active and passive social interaction' the most connected supporting eight (8) of the fourteen (14) measures.

Table 3. Values \& priority measure and purpose related functions relationships, and COVID-19 impacts

\begin{tabular}{|c|c|c|c|c|c|c|c|c|c|c|c|c|c|c|c|c|c|c|c|c|c|c|c|c|c|}
\hline $\begin{array}{l}\text { O shows a relationship between elements } \\
\text { shading shows the relationship is lost }\end{array}$ & 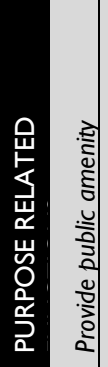 & 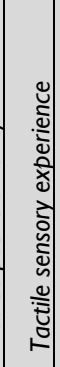 & 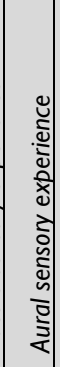 & 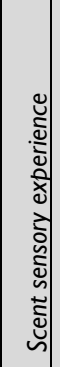 & 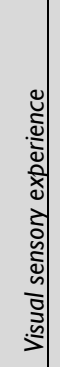 & 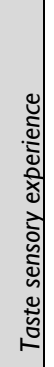 & 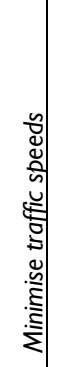 & $\begin{array}{l}0 \\
0 \\
0 \\
0 \\
0 \\
0 \\
0 \\
0 \\
0 \\
0 \\
0 \\
0 \\
0 \\
0 \\
\frac{0}{3} \\
0 \\
0 \\
\frac{5}{y}\end{array}$ & 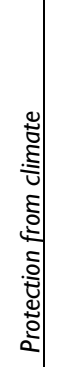 & 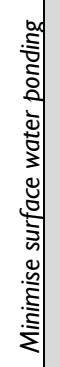 & 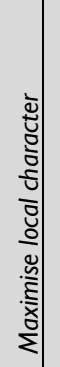 & 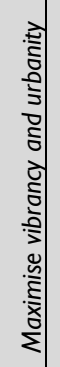 & 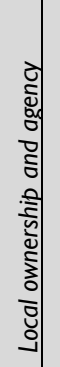 & 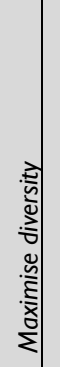 & 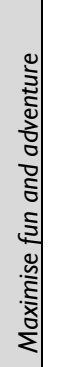 & 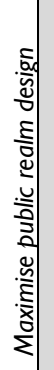 & 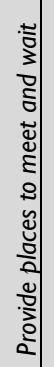 & 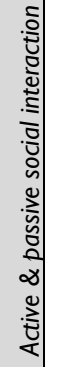 & 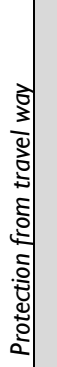 & 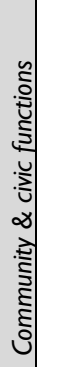 & 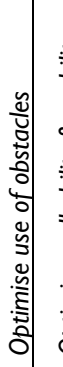 & 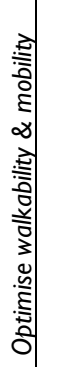 & 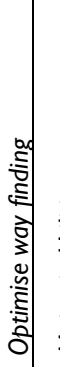 & 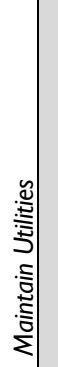 & 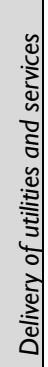 \\
\hline \multicolumn{26}{|l|}{ VALUES \& PRIORITY MEASURES } \\
\hline Engaging design elements & $\mathrm{O}$ & O & 0 & $\mathrm{O}$ & $\mathrm{O}$ & O & & & & & & $\mathrm{O}$ & O & & 0 & & & $\mathrm{O}$ & & O & $\mathrm{O}$ & & $\mathrm{O}$ & & \\
\hline Communal space & o & & & & & & & & & & 0 & $\mathrm{O}$ & $\mathrm{O}$ & 0 & 0 & & 0 & 0 & & 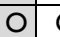 & $\mathrm{O}$ & & $\mathrm{O}$ & $\mathrm{O}$ & 0 \\
\hline Connections to nature & & 0 & 0 & $\mathrm{O}$ & $\mathrm{O}$ & O & & $\mathrm{O}$ & 0 & & $\mathrm{O}$ & & & $\mathrm{O}$ & 0 & & & 0 & & & \begin{tabular}{l|l}
$\mathrm{O}$ & $\mathrm{c}$ \\
\end{tabular} & $\mathrm{O}$ & & & \\
\hline Community connectedness & & 0 & 0 & $\mathrm{O}$ & $\mathrm{O}$ & O & & & & & 0 & $\mathrm{O}$ & 0 & 0 & 0 & & $\mathrm{O}$ & $\mathrm{O}$ & & O & & \begin{tabular}{l|l}
0 & ( \\
\end{tabular} & $\mathrm{O}$ & 0 & 0 \\
\hline Optimise transition between spaces & & 0 & 0 & $\mathrm{O}$ & $\mathrm{O}$ & o & 0 & $\mathrm{O}$ & & $\mathrm{O}$ & 0 & & 0 & & 0 & $\mathrm{O}$ & & & $\mathrm{O}$ & & \begin{tabular}{l|l}
$\mathrm{O}$ & $\mathrm{C}$ \\
$\mathrm{c}$
\end{tabular} & \begin{tabular}{l|l}
$\mathrm{O}$ & $\mathrm{c}$ \\
\end{tabular} & $\mathrm{O}$ & & \\
\hline Enable individuality of design & & 0 & 0 & 0 & $\mathrm{O}$ & 0 & & 0 & & & 0 & 0 & 0 & 0 & 0 & & & 0 & & O & & 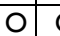 & $\mathrm{O}$ & & \\
\hline Optimise achievability & & & & & & & & $\mathrm{O}$ & & & 0 & & 0 & & & $\mathrm{O}$ & & & & & & & & $\mathrm{O}$ & 0 \\
\hline Physical comfort & O & O & O & $\mathrm{O}$ & $\mathrm{O}$ & $\mathrm{O}$ & $\mathrm{O}$ & & $\mathrm{O}$ & & & & & & & & $\mathrm{O}$ & & $\mathrm{O}$ & & \begin{tabular}{l|l}
0 & $c$ \\
\end{tabular} & \begin{tabular}{l|l}
$O$ & $c$ \\
\end{tabular} & $\mathrm{O}$ & & O \\
\hline Perceived safety & & & & & & & 0 & $\mathrm{O}$ & & & & 0 & & & & & 0 & & $\mathrm{O}$ & & \begin{tabular}{l|l}
$\mathrm{O}$ & $\mathrm{s}$ \\
\end{tabular} & \begin{tabular}{l|l}
$\mathrm{O}$ & $\mathrm{s}$ \\
\end{tabular} & $\mathrm{O}$ & & \\
\hline Actual safety & & & & & & & $\mathrm{O}$ & & $\mathrm{O}$ & 0 & & & & & & 0 & & & 0 & & 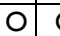 & O & & & 0 \\
\hline Optimise universal design & 0 & & & & & & & & $\mathrm{O}$ & & & & & 0 & & 0 & & 0 & & & 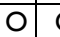 & 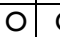 & 0 & & 0 \\
\hline Adherence to built environment standards & & & & & & & & & 0 & & & & & & & 0 & & & & & & & & 0 & 0 \\
\hline Adherence to rules and laws & & & & & & & 0 & & & & & & & & & & & 0 & & 0 & & & 0 & 0 & \\
\hline Integrate community values & & & & & & & & & & & 0 & 0 & 0 & 0 & 0 & 0 & 0 & 0 & & O & & & & & \\
\hline
\end{tabular}

In considering the linkages from the perspective of the priority measures many of these are significantly supported by the twenty-five (25) functions. For example, the priority measure for 'community connectedness' is achieved via seventeen (17) functions.

Significantly fourteen (14) of those activities ceased under lockdown, vastly diminishing the capacity of this measure to support all three (3) top level purposes it is connected 
to - a healthy and happy community; an inclusive and connected community; and a healthy and active individual.

In a similar way the priority measure of engaging design elements relies on thirteen (I3) functions, of which eleven (II) were unavailable in COVID-19 lockdown. The following priority measures also lost more than $70 \%$ of their supporting functions - connections to nature; individuality of design; communal space and integrate community values. While the measures of optimise transition between spaces; optimise achievability; and physical comfort also lost more than $50 \%$ of their supporting functions. The results highlight a significant deterioration of the capacity for these measures to support and achieve the higher order purposes of the public space system.

Conversely the model reveals some measures were largely unaffected by lockdown including adherence to built environment standards; and actual safety, each only losing one (I) function. This reveals that these measures are supported by functions that are largely built into the public space and remain regardless of lockdown restrictions, e.g. 'minimise surface water ponding'; 'protection from the travel way'

\section{Limitations}

Limitations of this study are related to its exploratory nature and application within the singular context of Queensland, Australia. Further insights would be gained from additional public spaces case studies from other countries and cultural contexts. In addition, only the first phase of CWA has been applied, and as an actor and event independent approach, there would be much to gain by exploring the implications of different public space users, times of day, and seasonal conditions.

\section{The impacts on design}

The WDA assists in establishing the cumulative impact of the removal of multiple supporting functions, in the capacity of the priority measures to then support the overall purposes. In many ways we already knew this to be true; individuals and communities craved the activities that public space afforded them which were suddenly no longer possible. However, what the systems model reveals is how the limits of those activities resulted in us feeling individually and collectively less happy and healthy, and without these important urban spaces to share and dwell within, often less connected as a community.

This analysis was exploratory in nature, and sought to offer new perspectives on the emerging challenges facing the design and usability of public space. It is offered to assist in investigating the increasing complexity of our urban environments. This paper has outlined some of the contributory factors associated with the individual and community impacts of lockdown on existing public space.

Going forward, the intention is that a systems viewpoint may also assist in exploring the possibilities to reinstate some of those functions and conceive opportunities for new functions even under lockdown. If we move from the intention and values of public space, at the top of WDA, to the design and deployment of objects and resources, at the bottom, it is possible to consider new design outcomes. Some of the functions lost in the COVID-19 lockdown could be brought back into the urban realm in a safe way as a consequence of different design approaches and prioritising variations in the intensity of human interaction in urban public spaces. For instance, the recovery of community wellbeing would benefit from a revision of levels of urbanity, as different types of space 
can promote a sense of being together while phisically apart, allowing community members in the same place in a safe way while supporting functions such as local businesses and community cohesion. In this regard, the design and establishment of both social and retreat spaces can provide evidence of how urban spaces can function based on different configurations (street-based and landscape-based spaces and physical objects) consequently affording and enabling urbanity through different types of human interaction (Tavares et al., 2019; Tavares \& Swaffield, 2017). The implementation of social and retreat spaces which offer different 'object related processes' and 'physical objects' may enable 'safe behaviour' and 'offer diversity in spaces', as necessary functions in post COVID- 19 public spaces.

\section{References}

Abedi, M., Mofidi, M., \& Behzadfar, M. (20II). Investigation role of sensory stimulus in perception of urban spaces. International Journal of Academic Research, 3(2), 20I-205.

Australian Broadcasting Corporation (ABC). (2020). Massive boost to outdoor exercise in Sydney's green spaces during coronavirus, survey finds. Retrieved from: https://www.abc.net.au/news/2020-06-28/sydneys-green-space-use-booms-duringcovid-

$19 / 12400104$ ? utm_source=abc_news\&utm_medium=content_shared\&utm_content=mail\&ut $\mathrm{m}$ campaign $=\mathrm{abc}$ news

Australian Government (20II). Creating Places for People — an urban design protocol for Australian cities. Infrastructure Australia. Retrieved from https://www.infrastructureaustralia.gov.au/publications/creating-places-people-urban-designprotocol-australian-cities

Bisantz, A. M., Roth, E., Brickman, B., Gosbee, L. L., Hettinger, L., \& McKinney, J. (2003). Integrating cognitive analyses in a large-scale system design process. International Journal of Human-Computer Studies, 58, I77-206.

Burton, E., Mitchell, L., \& Lynne Mitchell, M. E. S. (2006). Inclusive urban design: Streets for life. Elsevier.

Cornelissen, M., Salmon, P. M., \& Young, K. L. (20I3). Same but Different? Understanding Road User Behaviour at Intersections Using Cognitive Work Analysis. Theoretical Issues in Ergonomics Science, 14(6), 592-615.

Degen, M. M., \& Rose, G. (2012). The sensory experiencing of urban design: the role of walking and perceptual memory. Urban studies, 49(I5), 327I-3287.

Freeman, S., \& Eykelbosh, A. (2020). COVID-19 and outdoor safety: Considerations for use of outdoor recreational spaces. National Collaborating Centre for Environmental Health. Public Health Agency of Canada.

Grahn, P., \& Stigsdotter, U. K. (2010). The relation between perceived sensory dimensions of urban green space and stress restoration. Landscape and urban planning, 94(3-4), 264-275.

Jenkins, D. P., Salmon, P. M., Stanton, N. A., \& Walker, G. H. (2010). A New Approach for Designing Cognitive Artefacts to Support Disaster Management. Ergonomics, 53(3), 617-635.

Jenkins, D. P., Stanton, N. A., Salmon, P. M., \& Walker, G. H. (2009). Cognitive Work Analysis: Coping with Complexity. Ashgate Publishing Limited.

Lees, L. (2010). Planning urbanity? Environment and Pla nning A, 42(I0), 2302-2308.

Low, S., Taplin, D., \& Scheld, S. (2009). Rethinking urban parks: Public space and cultural diversity. University of Texas Press. 
Exploring the impact of COVID-19 lockdown on public spaces through a systems modelling approach

Lévy J (1997) La mesure de l'urbanité. Urbanisme, 296, 58-6I.

Missen, L., Stevens, N. J., \& Salmon, P. M. (2017). A Sociotechnical Systems Analysis Approach to Playground Design. Proceedings from Contemporary Ergonomics \& Human Factors, 35-42.

Montgomery J (1998) Making a city: Urbanity, vitality and urban design. Journal of Urban Design 3(I). 93-I |6. DOI: 10.1080//35748098087244I8.

Naikar, N. (2013). Work Domain Analysis: Concepts, Guidelines, and Cases. CRC Press.

Patorniti, N. P., Stevens, N. J., \& Salmon, P. M. (20I7). A Systems Approach to City Design: Exploring the Compatibility of Sociotechnical Systems. Habitat International, 66, 42-48.

Patorniti, N. P., Stevens, N. J., \& Salmon, P. M. (2018). A Sociotechnical Systems Approach to Understand Complex Urban Systems: A Global Transdisciplinary Perspective. Human Factors and Ergonomics in Manufacturing \& Service Industries, 28(6), 28I-296.

Queensland Health (2020). Queensland Government Health Department, Restrictions in Queensland. Brisbane, Australia. Retrieved from: https://www.qld.gov.au/health/conditions/health-alerts/coronavirus-covid-19/currentstatus/public-health-directions

Rasmussen, J., Pejtersen, A. M., \& Goodstein, L. P. (1994). Cognitive systems engineering. Wiley.

Salmon, P. M., Read, G. J., \& Stevens, N. J. (2016). Who is in Control of Road Safety? A STAMP Control Structure Analysis of the Road Transport System in Queensland, Australia. Accident Analysis \& Prevention, 96, 140-151.

Salmon, P. M., Walker, G. H., \& Stanton, N. A. (2016). Pilot Error Versus Sociotechnical Systems Failure: A Distributed Situation Awareness Analysis of Air France 447. Theoretical Issues in Ergonomics Science, I 7(1), 64-79.

Stevens, N. J. (2016). Sociotechnical Urbanism: New Systems Ergonomics perspectives on Land Use Planning and Urban Design. Theoretical Issues in Ergonomics Science, I 7(4), 443-45I.

Stevens, N. J., \& Salmon, P. M. (20I4). Safe Places for Pedestrians: Using Cognitive Work Analysis to Consider the Relationships between the Engineering and Urban Design of Footpaths. Accident Analysis \& Prevention, 72, 257-266.

Stevens, N. J., \& Salmon, P. M. (2015). New Knowledge for Built Environments: Exploring Urban Design from Socio-technical System Perspectives. International Conference on Engineering Psychology and Cognitive Ergonomics, 200-2II.

Stevens, N. J., Salmon, P. M., Walker, G. H., \& Stanton, N. A. (2018). Human Factors in Land Use Planning and Urban Design: Methods, Practical Guidance, and Applications. CRC Press.

Tavares, S. G., \& Swaffield, S. (2017). Urban Comfort in a Future Compact City: Analysis of Open space Qualities in the Rebuilt Christchurch Central City. Landscape Review, I7(2), 523. https://journals.lincoln.ac.nz/index.php//r/article/view/I 035

Tavares, S. G., Swaffield, S., \& Stewart, E. J. (2019). A case-based methodology for investigating urban comfort through interpretive research and microclimate analysis in post-earthquake Christchurch, New Zealand. Environment and Planning B: Urban Analytics and City Science, 46(4), 73I-750. https://doi.org/I0.1 I77/23998083 I77253/8

Van Diepen AML and Musterd S (2009) Lifestyles and the city: connecting daily life to urbanity. Journal of Housing and the Built Environment 24: 33I-345.

Vicente, K. J. (1999). Cognitive Work Analysis: Toward Safe, Productive, and Healthy Computer-Based Work. Lawrence Erlbaum Associates.

Walker, G. H., Stanton, N. A., Salmon, P. M., \& Jenkins, D. P. (2008). A Review of Sociotechnical Systems Theory: A Classic Concept for new Command and Control Paradigms. Theoretical Issues in Ergonomics Science, 9(6), 479-499. 


\title{
Affirmatively Reading Post-consumerism. Distributed Participatory Creativity and Creative Destruction of the Malled Metropolitan Centres of Auckland, New Zealand, during COVID-19 Lockdown
}

\author{
Manfredo Manfredini \\ The University of Auckland, Urban Relational Informatics Lab, School of Architecture and \\ Planning, New Zealand
}

\begin{abstract}
The impact of the progressive spatial financialisation of contemporary on the centres of public life has involved the privatisation of a relevant portion of their social, cultural, political and economic nodes and their polarisation into the private precincts of integrated shopping and entertainment enclosures. This dispossession and dislocation have increased spatial inequality and atomised the networks of local communities. A recent occurrence of creative destruction presided by the inexorable logics of capital reproduction has hit the paradigm that informed these enclosures. The production of the ultimate model of these centres, here defined as ultra-modern centres with totalising superlative simulated civicness, has intimately combined consumption with production in what Ritzer calls prosumption. I submit that the novel prosumer has become a primary actor of dynamic choral practices of semi-complicit participatory consumption that originate counterspatial associative assemblages by articulating three novel digitally augmented phenomena: networked translocalisation, multiassociative-metastable transduction, and desiring-resistant transgression. To validate this hypothesis I set out an observational analysis of grassroots social networks of digital spatialities emplaced in the malled urban centres of Auckland, New Zealand during COVID-19 lockdown, a period of outright access negation to the physical centres of public relational life. Empirical findings not only provided evidence of the formation, high resilience and independence of the novel emplaced translocal networks, but also documented their explicit redistribution of orders of ownership and belonging, and their assertive reappropriation and reassociation of commoning spatialities. The found effectiveness of these assemblages in breaching of the fundamental rule of non-response of dominant powers controlling the places of superlative abstract civicness, deconstructing the dominant spatial logics of the simulative infrastructure that inhibit the elaboration of sign values that affirm the right to identification, and supplementing the postconsumerist use-exchange value amalgamation that sustains the commodity fetishism mechanism of these civic simulacra underpins my critical affirmative interpretation of the post-consumerist condition.
\end{abstract}

Keywords: public space and COVID-19, shopping centres, spatial data analysis, Instagram, Auckland, New Zealand

To cite this article:

Manfredini, M. (2020). Affirmatively Reading Post-consumerism. Distributed Participatory Creativity and Creative Destruction of the Malled Metropolitan Centres of Auckland, New Zealand, during COVID-19 Lockdown, The Journal of Public Space, 5(3), 207-226, DOI 10.3289I/jps.v5i3.I392

This article has been double blind peer reviewed and accepted for publication in The Journal of Public Space. 


\section{Structures and issues in emergent urban centralities}

The process of universal alienation (Harvey, 2018), which includes the progressive spatial financialisation (French et al., 20I I) and obliteration of the commons (Hardt \& Negri, 2009, p. 137) led by dominant class and corporate power with the support of neoliberal governance, has instituted an urbanisation mode of enclavic segmentation (Shane, 2005) that reifies geographically the unbalances in power and wealth of the contemporary strong and rigid social hierarchy. The spiralling spatial inequity of such a molar fragmentation of the urban geography has particularly concerned the centres of public life. A relevant portion of the social, cultural, political and economic nodes have moved into the private precincts of integrated commercial enclosures, such as shopping and entertainment centres. With this migration, public spaces have lost centrality to private quasi-public realms and, with it, reified the influential role of transnational financial organisations of the current financialised mode of urban governance. This dislocating privatisation within the relationally adverse conditions of such commercial environments and the consequent atomisation of emplaced local networks are integral part of the overall spatial restructuring that reflects the increase of vertical social segregation (Harvey, 2006).

In the last decades, the enclosures of consumption have undergone a major systemic reset: a process of creative destruction dictated by the inexorable logics of capital reproduction (Harvey, 2007, 2012; Ritzer \& Lair, 2007). Disruptive digital technologies drive this severe unfolding that has even given rise to the prevision of an imminent outright disappearance of the shopping centre model (Ritzer \& Degli Espositi, 2020). The retail and entertainment sector, the engine of this model, has unrelentingly moved towards online services, intensifying the restructuring imperative which emerged a few years ago with the advent of the experience economy (Pine \& Gilmore, 20I I). The experiential transformation of these centres into "creative" places of eventful consumption (Manfredini \& Jenner, 2015; Voyce, 2006) was inadequate to halt the disruption. Shopping mall corporations have promptly responded with the conception of a radical "spatial fix" (Harvey, 20I2) that lures back customers and revitalises the fading consumption flows in their spaces.

The ultimate model quickly eventuated through the development of an ultra-modern centre with totalising superlative simulated civicness (Manfredini, 2019b). Different from the latest version of the modern shopping and entertainment centre of magic spectacle (Goss, 1993), where the consumer is an upgraded Debordian passive character of a finely tuned and microscripted spectacular eventfulness, the new centre has implemented an intimate combination of distributed consumption and production. The customer has become a primary actor of dynamic choral performances of participatory consumption (Hoyer et al., 2020). Curated coalescences of production and consumption encourage the omnicapable prosumers to proactively engage with and excessively consume the alienated products of their commodified labour (Ritzer, 2014; Ritzer \& Jurgenson, 2010). Enchantment is produced by creating pseudo cities "more real than reality" - cities that break down "the wall of the second dimension, creating not an ... illusion, but a total theatre ... with human beings" (Eco, 1986, p. 45). A theatre where the hyperreal social finds "a sort of effectively realized utopia in which the real emplacements, all the other real emplacements that can be found within culture, are simultaneously represented, contested and inverted" (Foucault, 2008, p. 17). This concrete utopia is Foucauldian heterotopic diapositive that combines illusory and compensatory functions (Foucault, 
2008, pp. 2I-22). Illusions and compensations reinstitute the dispossessed civic self, deploying spatial, social and symbolic simulation means. The simulation subsumes and conflates elements of experientially rich pseudo-urbanity that transcend the real, to produce the hyperreal: a "hallucinatory resemblance of the real to itself" (Baudrillard, 1994, p. 23). Multifarious civic simulacra, the quintessence of Baudrillardian copies without actual reference, stage mise-en-scènes of fascinating fetishes of relationality material, social and cultural - which provide abundant materials for territorial associations and stabilisation of (pseudo)communities of prosumers (Manfredini, 2017). As illusory emplacements, these civic heterotopias institute ideal paradigms of urban space associated to them. Their embodiments expose "all real space, all the emplacements in the interior of which human life is enclosed and partitioned, as even more illusory" (Foucault, 2008, p. 2I). Their materialisation affirms normative discourses on what is desirable or permissible, excluding what is not. The reformist "precession" of these simulacra (Baudrillard, 1994, Pp. I-42) is reinforced by their compensatory function. Concrete ideals are introduced in the everyday practice as instances of perfected mundane reality, constituting other places of meticulously constructed reality showing how "ours is disorderly, ill construed and sketchy" (p. 2I). Embracing participatory consumption, these malls fully accomplish the task of commodifying the civic, promote ultra-consumption, take possession of collaborative creativity and exploit free labour (Ritzer \& Degli Espositi, 2020). However, within this process initiated by the modern mall, by replacing and vigorously activating the entire social, communal, cultural and recreational infrastructures and practices of the city, there is more than assimilation and complicity with the hegemonic logics (Miles, 20I2). Everyday practices in the spatialities of the ultra-modern enclosure exceed the realm of exchange value of commodities. Pleasure and, most importantly, desire are basic materials for the elaboration of sign values that foster transgressive reidentification processes that disband the commodity fetishism mechanism making sign-value a "supplement or super-signifier of use-exchange value" (Miklitsch, 1998, p. 4). Pleasure and desire liberate the relationality elicited by the "space of appearance" (Arendt, 1958) from the controlled interfaces between the quasi-private and the quasi-public.

(Antagonist surrogate or simulated facilities include also those of private domestic practices, particularly effective in the sectors of wellness, conviviality and children care; Manfredini, 2019a).

The prosumer of the ultra-modern simulacra of superlative civicness experiences a new form of engagement. Their post-consumerist behaviour combines three pervasive phenomena of the digital age that foster reproduction of socio-spatial relationships: networked translocalisation, as relational mobilisation of emplaced assemblages; multiassociative-metastable transduction, as recombinant mobilisation of networked presences; and desiring-resistant transgression, as positive dissociative of coded systems. Networked translocalisation is the constant revolution of territorialisation patterns due to an increasing mobilisation of people and things variously related in productive concatenations. While the constant process of transfer and occupation across expanse spaces and on all spatial scales, from the local to the global, challenges both spatial and temporal stability of these concatenations (Deleuze \& Guattari, I987, pp. 35I-423; Kazig et al., 2016), digital technologies have enhanced cohesion and interaction of translocal networks, especially those of the "have-less," who chiefly depend on "an informational dimension - the commingling of critical information across time and space 
- which almost always contextualises and conditions the movement of people, goods, and services" (Cartier et al., 2005, p. 14). A typical example of the new mall's outpacing environment to networked translocalisation is the capacity of their material and symbolic patterns to constitute workable conditions for the emplacement of mobilised actants.

Multiassociative-metastable transduction involves the establishment of assemblages through transmutative relations that operate simultaneously on representation and production realms (Guattari, 2006, p. 258). Iterative systems of relations bring together distributed and heterogeneous elements in disjunctive relationships of concatenations that restructure local conditions and contexts. Since the realms produced by these concatenations instituted by iterative relational systems are determined by their status the transformative effect is metastable, as it persists only when the systems are activated. The inborn capacity of virtual, augmented and mixed realities to bring together heterogeneous elements across different domains with progressive speed and efficiency makes contemporary transduction instances increasingly immersive and evenemential (MacKenzie, 2006). A typical example of the new mall's outpacing relational spatialities is the growth of nodes of social networks that progressively gain centrality due to the combination of the metastable relations between their translocalised members and the reterritorialising (i.e., pseudo-associative and hyperidentifying) properties of their simulacra.

Desiring-resistant transgression is a widely diffused agent of translocalised urbanites who deploy "shared symbols, subversive recodings, and semiotic inversions of the existing order" (Ferrell, 20I I, p. 56I) to deconstruct and challenge existing structures. "Agonistic" (Mouffe, 1999) counterspaces are produced informally or illicitly at the margins of society to favour autonomy and spontaneous forms of self-organisation to resist or oppose apparatuses of domination (Figure I). Particularly active in the digitally enhanced world of Mediapolis (de Jong \& Schuilenburg, 2006), this dissociation of coded systems is the key to set off or strengthen forms of becoming that produce the vision, creation and presentation of alternative systems of identification, meaning and representation (Ferrell, 20I3). A typical example of the new mall's outpacing agential capacity is the resistance to congregation bans implemented with explicit codes of conduct that prosumer communities enact with intense activity on emplaced social media networking.

These three phenomena have critically contributed to create conditions that can oppose the fragmenting agency of the quasi-public space of the mall. The realityvirtuality continuum (Milgram et al., 1995) that they have implemented forms a highly performative interconnected hybrid realm that can counter the segregational power of the enclosures. The combined forms of digitally enhanced translocalisation, transduction and transgression can operate to reinstate their space of flow in the political sphere. Locative mobile social media applications (e.g., Twitter, Instagram and Sina Weibo) enable the simultaneous presence and action of local and remote actors, including the translocal, the marginalised and the antagonist. These platforms build relational capacity of the individual and collective prosumers to independently reappropriate and reassociate the abstracted territories of their daily life (Manfredini, n.d., 2017). 


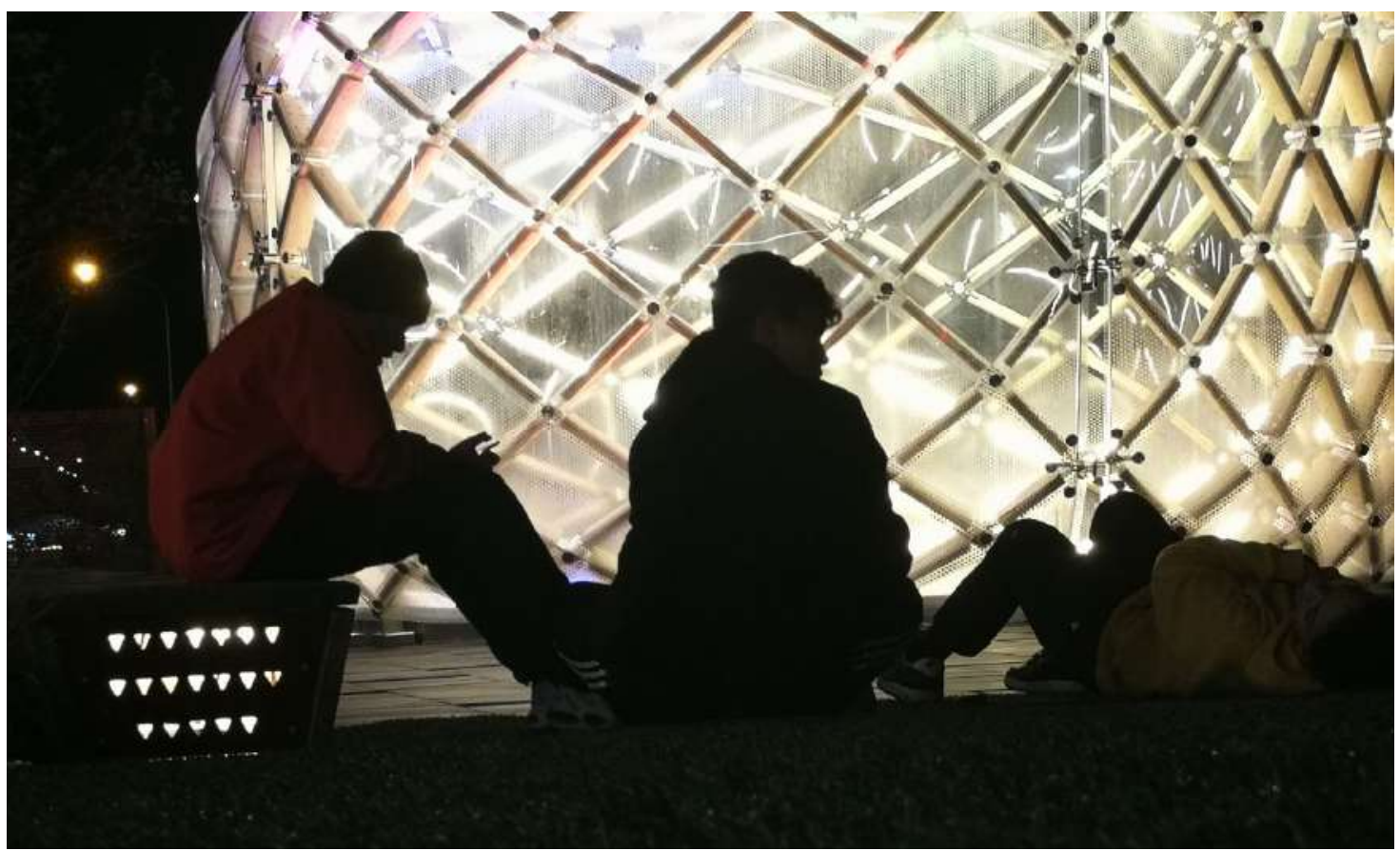

Figure I. Irregular spatial practices: "non-compliant" appropriation of consumers in the theatron in the luxuriant open theatre of the "Grove," the new lifestyle dining district of Auckland's Sylvia Park Shopping Centre (M. Manfredini, 2020)

COVID-19's mobility and gathering restrictions have caused major social, political, and economic deprivations. The height of both cultural and material disciplinary regimes deployed by the state to negate access to urban space has shown the enormous hardship of urbanites dispossessed of the emplacements of their relational spheres. Surrogate digital spatialities have partially compensated for the loss, but have dramatically expanded the existing inequalities. Exacerbations have included the disruption of the public space-dependent informal economic sector caused by the failure of economic governance to mitigate the asymmetrical systems of social protection (OECD, 2020), and the increase of social exclusion caused by the inefficacy of governing bodies in moderating the effects of the divide in the digital "pulsing field of tension" on the morbid multidimensional isolation of individuals (Sloane, 2020).

In the new simulated commons, the effects of this crisis have been even higher.

Proactively confirming the capacity of their simulacra to precede and preempt those of the rest of city beyond their boundaries, the malls instantly responded with a total and politically unchallenged interdiction of their quasi-public spaces. Fencings were promptly erected and invigilators to reinforce the panoptical control with 24 hour CCTV surveillance introduced (Figure $I$ and 2). Communication reaffirming the normativity of the new normal with imposing billboards elaborating deferential "public wellbeing" narrative followed suit (Figure 3 ) The disruption deformedly mirrored by the total space of the mall not only occluded their mediated space, richly supporting transduced social networks by shutting down the metastability of their social spatialities, but also completely obliterated the informality of its externalities, such as the translocal and multicultural bottom-up daily and nightly impermanent markets grown at their margins (Tan, 2020). 

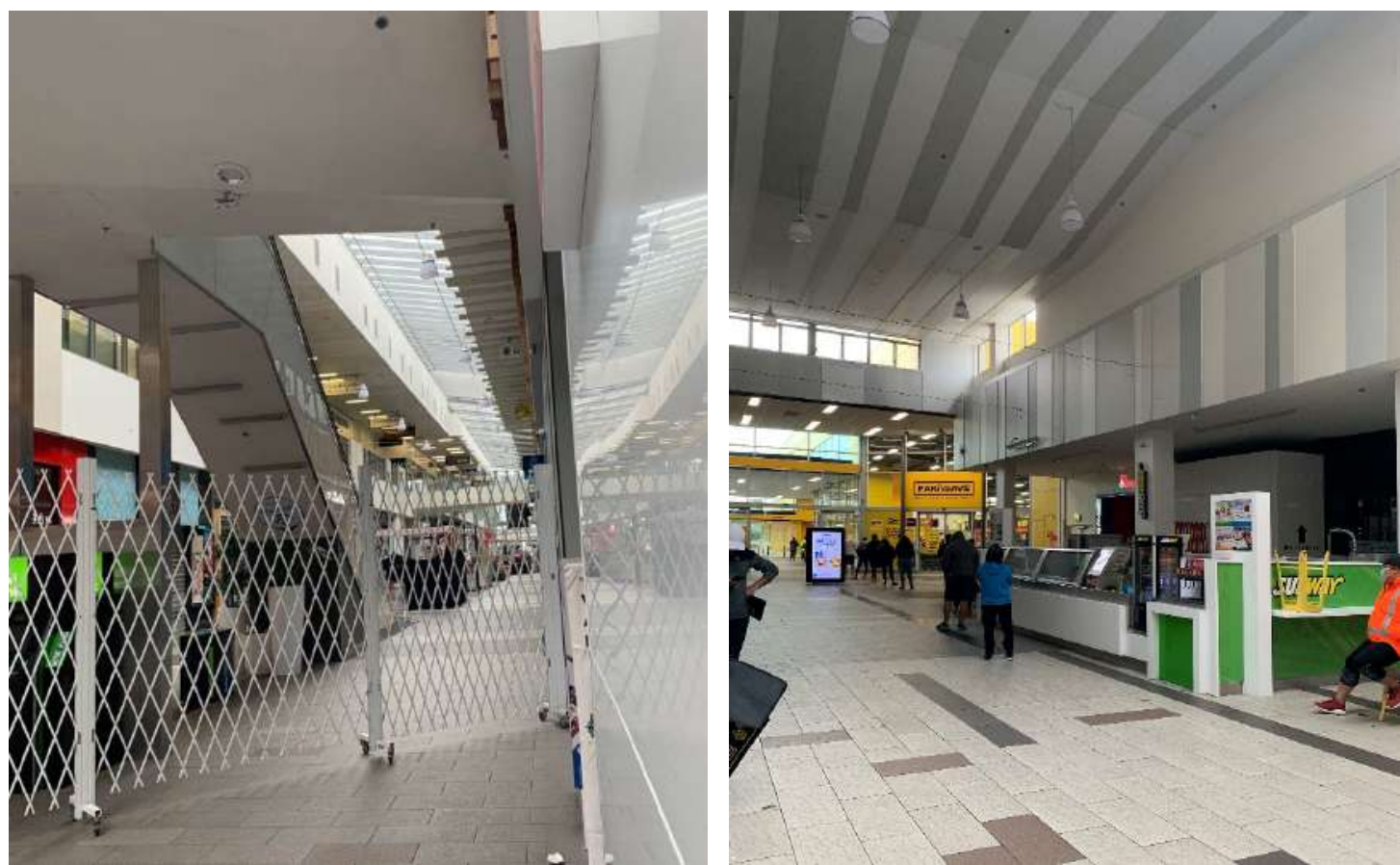

Figure 2. The securitised Sylvia Park Shopping Centre, Auckland's premiere ultra-modern mall, during the strict lockdown of Alert Level 4 - Eliminate: Instant fencing off of the main arcade (left), (J. Rong 2020), and invigilated distanced queues to the supermarket, the only large facility open during lockdown

(J. J. Rong, 2020)
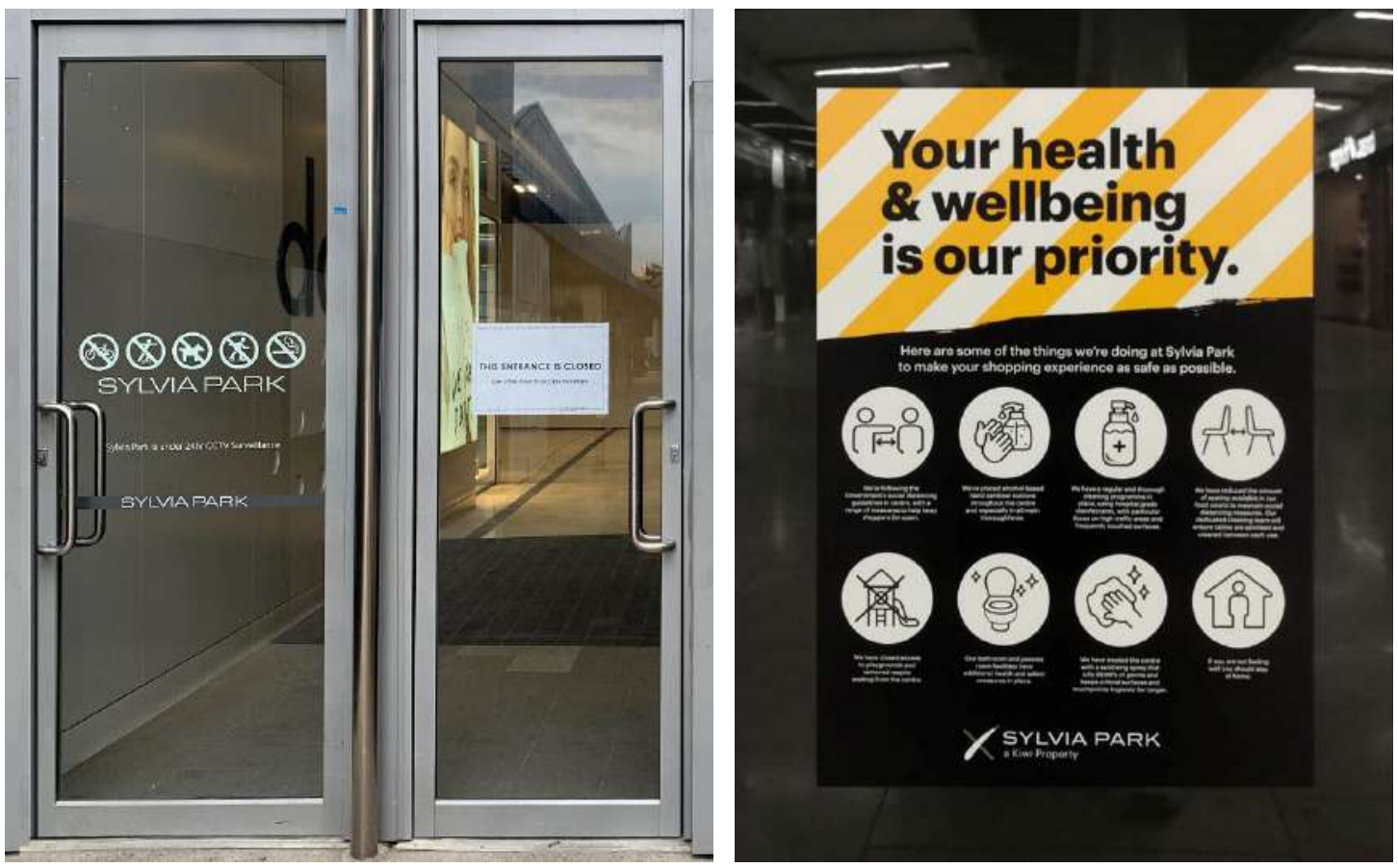

Figure 3. The securitised Sylvia Park Shopping Centre: access interdiction to a corridor connecting to the local surface public transport stop (centre), and customer information billboard during Alert Level 2 Reduce (M. Manfredini, 2020). 


\section{Auckland's malled urbanism under COVID- 19}

The New Zealand response to the pandemic has been internationally recognised for its early success in "crushing the curve" of coronavirus's infection (WHO, 2020).

Restrictive measures, based on a four-tier alert system framework whose highest level, "Eliminate," introduced a strict lockdown at a very early stage, resulted in a swift regression of the transmission rate (Ministry of Health Manatū Hauora, 2020a, 2020c) (Figure 4).
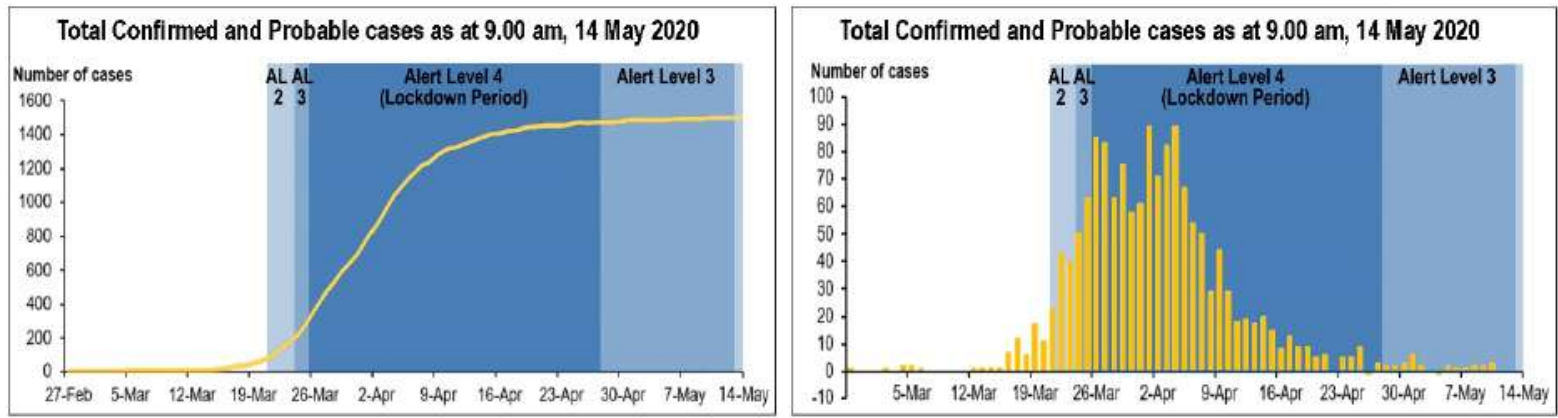

Figure 4. New Zealand coronavirus epidemic curve (Ministry of Health Manatū Hauora, 2020a)

The suppressed transmission prevented a crisis of the health system, contained the number of fatalities and led to the loosening of the restrictions and the adverse social, psychophysical and economic impact of prolonged isolation (Ministry of Health Manatū Hauora, 2020b). The high compliance of the public was buttressed by policies that involved substantial investments - larger than in most of the other advanced international free-market economies, when compared to GDP (The Treasury Te Tai Ōhanga, 2020) - prioritising people's welfare, wages, income.

This early action undertaken against the pandemic eventuated in a peculiar distribution of the infection. Substantially inverting the New Zealand's structural socio-economic inequalities in health (Wilson et al., 2018), the most affected by the virus were the privileged, belonging to the ethnic group with the highest income, which outnumbered by far all other groups combined (Ministry of Health Manatū Hauora, 2020a; Stats NZ Tatauranga Aotearoa, 2020). With regard to age, the distribution of cases was aligned with global figures, showing the highest percentage of cases, $23 \%$, among millennials in their 20s (Ministry of Health Manatū Hauora, 2020a). Geographically, the incidence of the infection has been uneven too. The largest concentration was in urban areas, headed by Auckland, the largest city in the country, accounting for $36 \%$ of the cases. The main public space where the most affected by the pandemic gravitated is located in the major urban centres. Most of these centres are interspersed throughout urban Auckland: an area home to one-third of New Zealand's population with low and distributed density with limited efficiency of urban and social infrastructural systems and an increasing geographical polarisation of socioeconomic inequalities (Terruhn, 2020). Decades of neoliberal regimes have weakened the civic role of the older centres and their commons, enabling their dislocation and financialisation within new locally disconnected urban malled sub-centres, which are dominated by large enclosures for shopping and entertainment, and incorporate a large part of the local social infrastructures (Manfredini \& Jenner, 20I5). 


\section{The digital spatialities of the apparatuses of totalising superlative simulated civicness during lockdown}

To shed light on the contemporary Auckland's public space condition during COVID-19 lockdown, an impromptu exploratory study set out to study the emerging relations between novel spatial structures and daily practices. It focused on the transformation of the emplaced public sphere during the contemporary paradigm change in the mall sector. The penetration of the novel sociospatial civic simulacrum model into the local environment has already resulted in the redevelopment of its main malls. A confirmation of this is offered by Kiwi Propert Group, the owner and manager of the main centre of the city. In the opening statement of the dedicated corporate webpage, it explicitly declares that "developed ... between 2006 and 2007 [the mall] and has since grown from New Zealand's largest shopping centre to a thriving mixed-use community" (Group, n.d.). The outright negation of public, material, emplaced relational spatialites during the early New Zealand COVID- 19 lockdown offered the opportunity to study the effects of an exacerbation of the public space deprivation progressively brought about by the universal alienation process (Harvey, 2018). The lockdown restrictions aggravated the already reduced accessibility of the local communities to the displaced malled centres - a distinctive element of the progressive sociospatial fragmentation and financialisation of everything that obliterates commoning in public space (Figure 2, 3, and 5).
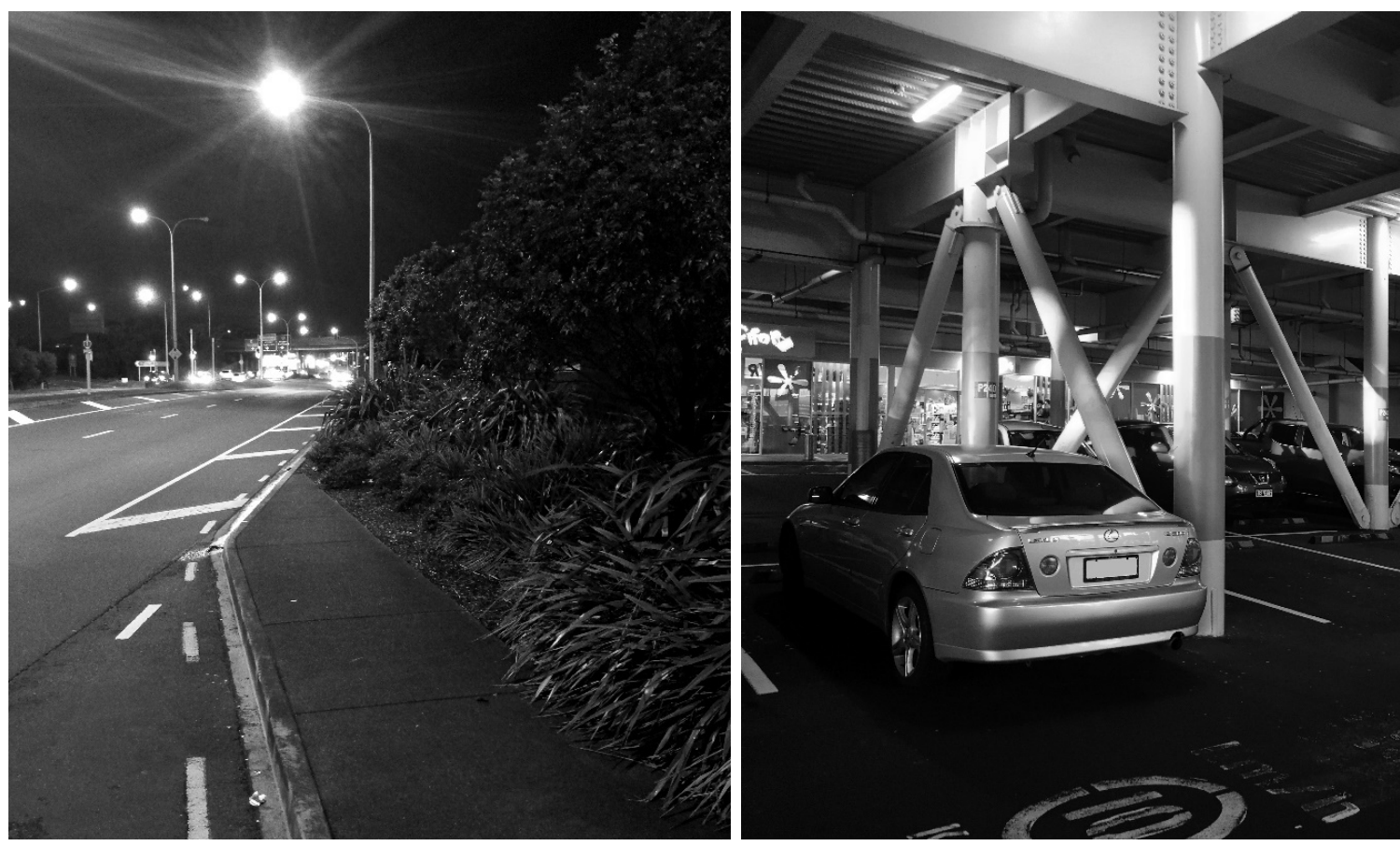

Figure 5. Pedestrian aversions of Auckland's fully malled centres: A sidewalk to "Erewhon, or, Over the Range" (Butler, 1872) in a central section of the movement network in Sylvia Park's Metropolitan Centre (left; M. Manfredini, 2020), and one of the main entrances of shopping centre in St Lukes Town Centre (right, M. Manfredini, 2020).

The study utilised the comparative research methods developed at the Urban Relational Informatics Lab of the University of Auckland (URIL, n.d.) for the Give Us Space research project. This set of methods unveil the effects of networked translocalisation, multiassociative-metastable transduction and desiring-resistant transgression (Manfredini 
et al., 2019) on network formation and spatial perception in hybrid actual-virtual spatialities using crowdsourced data from Instagram, the most popular geolocated visual-based social media (Statcounter, 2020).

The analysis was conducted on two centres of contemporary Auckland's malled urbanism model: the Metropolitan Centre of Sylvia Park (hereafter Sylvia Park) and Westfield St Lukes Shopping Centre (hereafter St Lukes). These cases are the best representation of statutory designated fully malled urban centres - respectively a metropolitan Centre and a Town Centre (Figure 6 and 7).

Sylvia Park is the premier example of integrated ultra-modern mall of superlative simulated civicness. The mall, a Regional Centre with gross lettable area of $86,427 \mathrm{sqm}$, was opened in 2006 and constantly upgraded and expanded (the recent additions include also one open-air lifestyle precinct with green and cultural spaces). Its owner and operator, Kiwi Property Group owner has a portfolio including 6 shopping centres (FigureFigure 7 7). Westfield St Lukes Shopping Centre (hereafter St Lukes) is a good example of the modern mall. This mall, a Sub-Regional Centre with a gross lettable area of 39,479 sqm, was built in 197I, converted into a Town Centre with a Plan change in 2010 , and has currently a major redevelopment project in the pipeline (FigureFigure 7 7).

The study had the following operating question and subquestions:

- Has the temporary outright negation of public, material, emplaced relational spatialites during the early New Zealand COVID-19 lockdown revealed the formation of digitally emplaced relational practices that oppose the modern progressive obliteration of the urban commons, which is epitomised by ultra-modern mall - the ultimate apparatus of totalising superlative simulated civicness?

○ Have the networks of the digital public sphere emplaced in the ultra-modern centres during the early New Zealand COVID-I 9 lockdown showed a distinctive behaviour that indicates forms of emancipation of spontaneous social networks from the total control of the apparatuses of the socially adverse civic simulacra that have colonised them?

- Have the communicative acts of the digital public sphere emplaced in the ultramodern centres during the early New Zealand COVID- 19 lockdown showed instances of territorial appropriation and association that indicate the emersion of antagonist deterritorialising practices of socialisation, civic cohesion, community connectedness and commoning?

Data analysis and interpretation concentrated on the detection of relationships between different forms of interaction by dissecting their networks to identify their socio-spatial reproduction capacity.

The selected centres best represent the comprehensive spatial sublation of the COVID19 lockdown. Their fenced-off squares, lanes, atria and corridors deserted, with the exception of supermarkets and pharmacies, the only large facilities open during lockdown (Figure 2). Their (dis)location makes them particularly relevant to this study as the profile of their primary users include both those most affected by the pandemic the privileged, the young adults and the urbanites - and the most avid users of digital media services - those who massively turned to social media to maintain their networks when their face-to-face interaction was drastically interrupted (Statcounter, 2020). 


\section{Affirmatively Reading Post-consumerism}

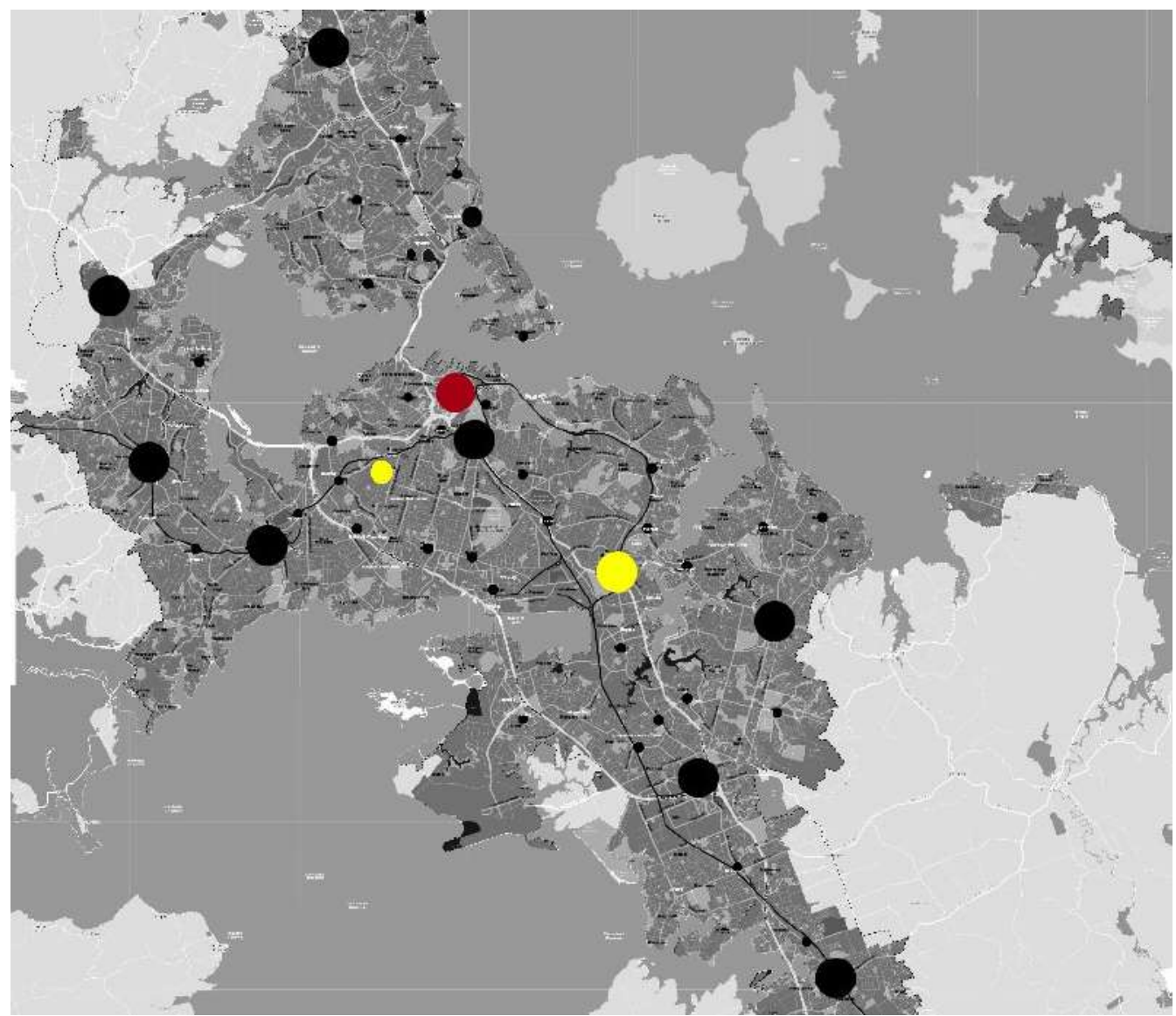

Figure 6. Auckland Plan 2050: Development Strategy. Map showing the City Centre (red circle) and the nine Metropolitan Centres (large black circles with Sylvia Park in yellow) and the town centres (small circles with St Lukes in yellow), (Auckland Council, 2012; adapted by the author).
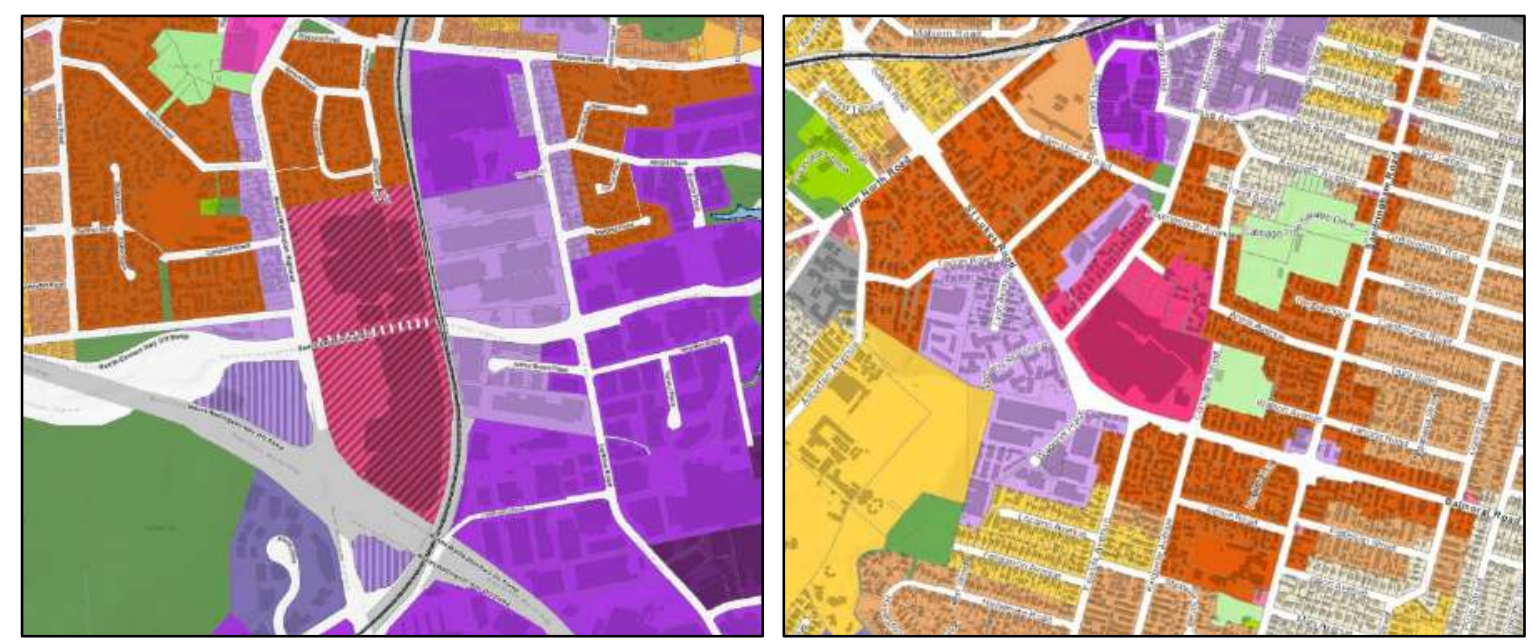

\begin{tabular}{|c|c|c|c|}
\hline Residential & & Business & \\
\hline Residentia - Large Lot Zone & Residental - Mxed Housing Suburban Zone & Business - City Centre Zone & Business - Local Centre Zone \\
\hline Residential - Rural and Coastal Settement Zone & Residental - Mixed Housing Urban Zone & Business - Metropolitan Centre Zone & Business - Neighbourhood Centre Zone \\
\hline
\end{tabular}

Figure 7. Zoning the mall as urban centre: Auckland's Sylvia Park's Metropolitan Centre (left) and St Lukes Town Centre (right) in the Auckland Unitary Plan (Auckland Council, 2020; adapted by the author).

216 | The Journal of Public Space, 5(3), 2020 | ISSN 2206-9658

City Space Architecture / UN-Habitat 
Data collection and processing

Crowdsourced data were collected from the points of interest (POI) located in the two centres. Data included metadata and content of public posts and related interactions (as with many other social media platforms, Instagram engages the user in three modes: author, commenter and liker). Data of the posts was categorised and systematised, as in the previous research (Bueno et al., 2019; Manfredini et al., 2019), including ID data (post URL, date and author's username), media content (images and videos), captions (content of text and hashtag/s), comments (number and username of commenters and text of the comment), and likes (number and username of likers). Data were collected in two periods of equal length, the 33 days of the lockdown period (26th March to 27th April included) and the preceding 33 days (22th February to 25th March included). The URLs were included to enable quick access to posts at any stage during the analysis, as well as providing a base for further information retrieval.

POls were selected through a preliminary analysis of their activity. Each centre included multiple POls with very different usage frequency, most with very low or moderate activity. In each case study, one POI had users greatly outnumbering all the users of the other POls combined. Most of the latter had one single main user, who was usually associated with a local business and shared content polarised around it. Overall, this confirmed the findings of previous longitudinal research conducted on the same malls (Bueno et al., 2019; Manfredini et al., 2019), showing a positive correlation between location tags' popularity and three variables: descriptive efficiency, frequency and diversity of commercial activation. Descriptive efficiency refers to the degree of comprehensiveness and unambiguity of the hashtag name, which favours retrievability and recognition of the place amongst the public. The frequency and diversity of commercial activation of their domains refers to the intensity and variety of the spectrums of promoted products and services, recurring activities and special events, which sustain public interest and engagement. The analysis also showed that the proportion of commercial activity in the most popular tags is rather small. Given these findings, the analysis concentrated on the most popular location tag of each case study: "Sylvia Park Shopping Centre" for Sylvia Park and "Westfield St Lukes" for St Lukes. The quantity of their interaction guaranteed their representativeness. The prevailing presence of non-commercial activity in their domains reduced the risk of inaccurate evaluation of the independent activity.

Data-cleaning minimised non-autonomous, redundant and irregular interaction instances in posts, comments and likes. Items of a commercial origin were recognised and coded manually by triangulating information from different sources (username, visual content and caption often explicitly reveal their origin) and evaluating posting intensity and frequency (commercial activity tends to be greater in quantity and regularity). Findings were validated by accessing previous activity of the Instagram account of the authors (accounts established for marketing purposes consistently pursue their commercial scope). Redundant instances were detected as multiple, superfluous or vain data in protracted comment trails. This was also addressed in the network analysis by using the number of commenters instead of that of comments. Irregularities in posts, likes and comments, such as duplications (reposting of visual content), were also identified and excluded. Abnormal posting, commenting and liking were not considered valid grounds for exclusion (this was the case of one post uploaded during the lockdown which received an exceptionally high number of likes but an average number of comments). 


\section{Findings}

The overall engagement analysis focused on non-commercial data. Findings showed relevant differences of intensity and distribution of interaction instances between the two case studies in the comparison of both the total activity and its variation between the two analysed pre-lockdown and lockdown periods.

The networks emplaced in Sylvia Park maintained a sustained activity, confirming the high engagement of their digital communities (detected in a previous longitudinal study at Urban Relational Informatics Lab, URIL, n.d.). The average daily activity in the analysed period was of 137.9 instances (9102 in total). The lockdown period had only a moderate reduction (-10.5\%), with the number instances moving from I45.5 (4,804 in total) during pre-lockdown to 130.2 (4,298 in total) during lockdown. The variation resulted from a decrease of instances that was sharp in the primary (-75.7\% posts) at and secondary textual (-43.39\% comments), and minor in secondary appreciative $(-7.4 \%$ likes). The ratio of secondary per primary instances showed a strong increase (from 32.4 to 121.8$)$ both in textual $(+124.7 \%$ comments per post) and appreciative $(+281.1 \%$ likes per post) (Figure 8).

The networks emplaced in St Lukes had a comparably lower interaction intensity, with an average daily activity of 29.8 instances (1973 in total). This activity sharply decreased from 4I.2 (I,367 in total) during pre-lockdown to I8.4 (606 in total) during lockdown. The sharp decrease in total interactions $(-55.7 \%)$ resulted from a sharp decrease across all instances (primary $-66.7 \%$, textual secondary $-79.5 \%$ and secondary appreciative 52.3\%) (Figure 8).

The structure of the digital network was explored by addressing the relations between users. This analysis concentrated on Sylvia Park, as the limited quantity of data available for St Lukes undermined analytical reliability and validity. The role of individuals in the networks was investigated by analysing the relationship between them (i.e., the interaction links via comments or likes). The centrality of each user was estimated by assessing the intensity of interactions and the reach of their links. A visualisation of these patterns was obtained by plotting graphs that use nodes and edges as in previous research (Bueno et al., 2019). A node represents an Instagram user who is either an uploader, a commenter or a liker. An edge is the link connecting two nodes and indicating the relationship between them. Subsets for nodes and edges were formed. The node sets included categories for ID number, label (username) and type (poster, commenter or liker). The edge sets included directions, with source and target associated with ID numbers. Sources are poster nodes, targets are either commenters or likers who have interacted with the post nodes. Different graphs displaying the total size of the networks were produced for the pre-lockdown and lockdown periods. In this bimodal network built upon nodes and edges, indication of centrality is determined by the number of immediate connections that associate the nodes. As the data collection captured Instagram users receiving and giving out comments and likes, the immediate links of a node could point towards or away from it. In this analysis, the centrality degree is measured in two different ways: indegree and outdegree centrality. The former represents the amount of connections directed to each node, while the latter corresponds to the number of connections departing from each of them. The graph uses size variations to represent change in the centrality value of each node (change in value is proportional to the change in size), adopts different colours to distinguish poster-nodes and liker/commenter-nodes, and displays the direction of 
connections using arrows. Findings show a strong difference between the pre-lockdown and lockdown structures and centrality patterns of the networks. As is visible in the graphs, the distribution of edges is relatively even in the former and strongly polarised in the latter. The strong polarisation in the lockdown map is determined by the limited number of sources which, consequently, have a much higher level of indegree centrality (Figure 9).

Commercially driven interaction, though not central to this study, provided relevant side information. Analysis showed significant differences between the two case studies. In Sylvia Park this kind of activity was minimal during the pre-lockdown and almost disappeared during lockdown (it moved from $4.2 \%$ to $0.3 \%$ of the total). No evidence was found of commercial activity generated by the central mall management. In St Lukes it had high intensity during the sublation pre-lockdown ( $24.8 \%$ of the total interaction) but it substantially dropped during lockdown (3.8\%). This prominence of commercial posts is sustained by the intense activity of the mall management, which included the best part of the 474 commercially driven interactions generated over both periods. Comparatively, the difference between the two malls may be ascribed to the larger marketing capacity of the management of Scentre Group over that of Kiwi Property Group.

The content analysis on visual data of representational space was concentrated on Sylvia Park, for the same reasons informing the centrality analysis. It primarily considered the lockdown period, to shed light on the nature of the spatial referentiality of the inaccessible spaces of the centre. Based on previously utilised methods (Manfredini et al., 2017), the data were used to detect representations of spatial instances that identify meaningful places of the centre. This involved triangulating information from different sources: images and videos, captions, comments, hashtags and, when necessary, previous activity on the Instagram account of the users. Spatially relevant posts were coded as such and further analysed to determine the most relevant characteristics of placeness based on their capacity to represent identifiable and meaningful material: social and cognitive spatialities of the site in its everyday becoming. The comparison of findings with previous research (Manfredini et al., 2019), showed an unusually high prevalence of spatially relevant posts (83\%) over the usually predominant generic content focused on goods and services provided by the centre, such as food, garments and personal care. Further analysis of the spatially relevant posts revealed another atypical characteristic: the outnumbering proportion (44\%) of visual content originated from personal experiences of the centre produced before the lockdown rather than those produced during the lockdown (39\%) (Figure 8). Most of this content not only deliberately represented locally situated events, but moments of strong personal involvement with the context, when the centre had normal operations (Figure 10). The remaining spatially relevant content was chiefly composed of images, probably concurrently created and posted, representing highly identifiable spaces of the centre in the peculiar lockdown situation (the most common case being long queues of distanced people waiting to enter the only major open amenity, the supermarket, in the extensive corridors and sidewalks under both in-person and remote security surveillance). 


\section{Affirmatively Reading Post-consumerism}

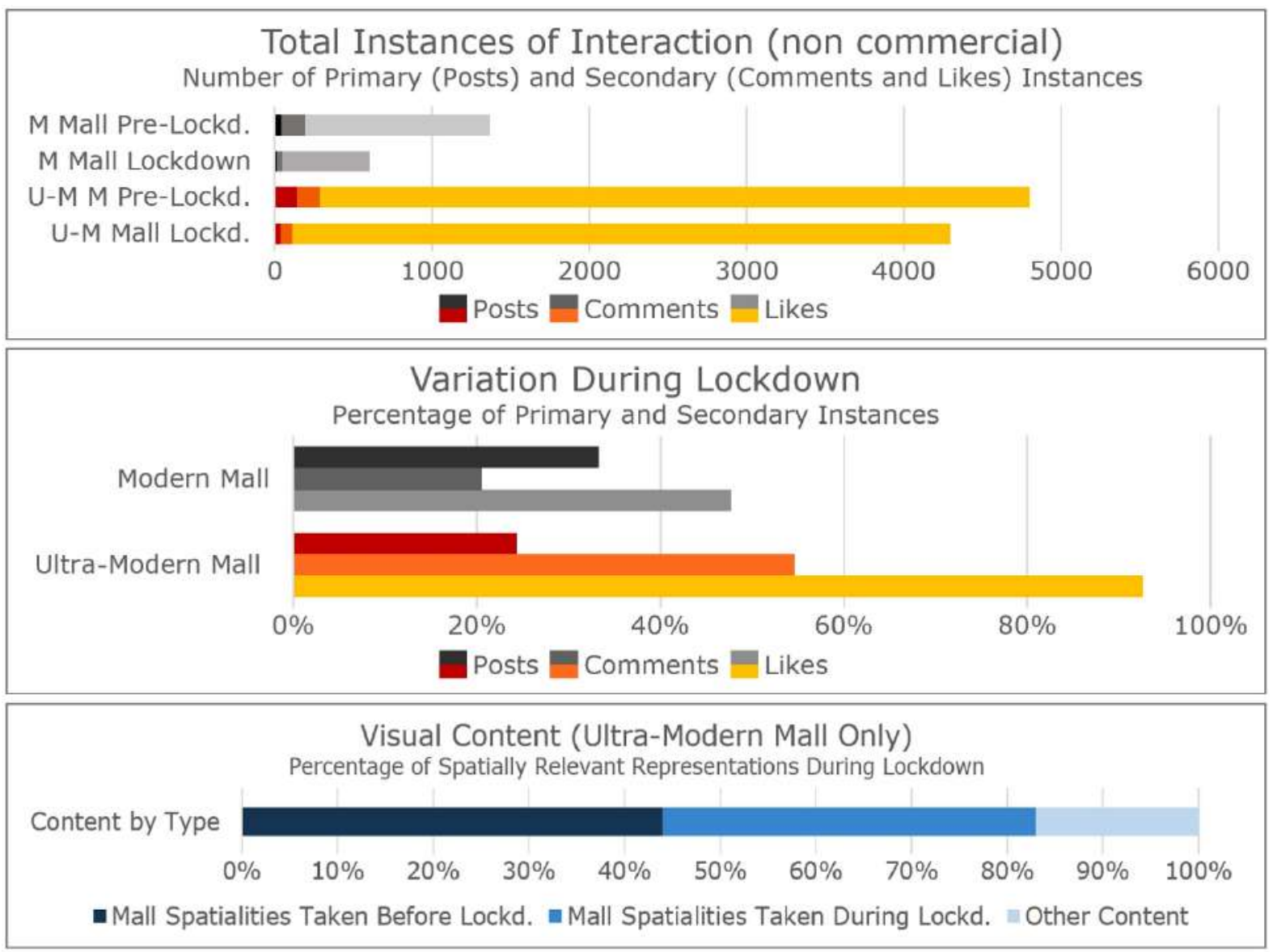

Figure 8. Emplaced digital activity (Instagram data): user interaction instances during pre-lockdown and lockdown (top) and their variations (middle); visual content by type

(J. J. Rong, J. Y. Ye and M. Manfredini, 2020)
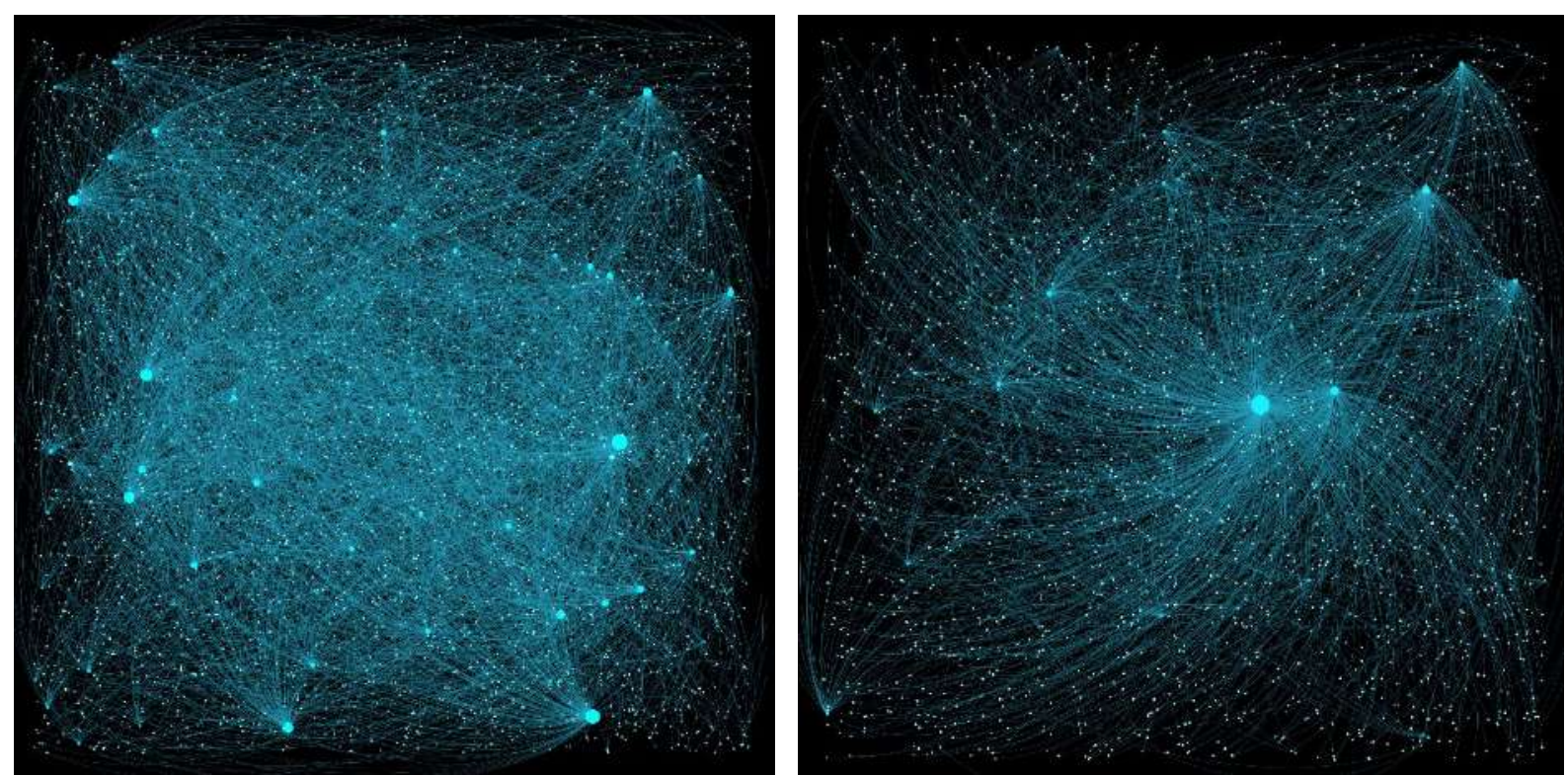

Figure 9. Network centrality: diagrams visualising the variation in network centrality between pre-lockdown (left) and lockdown (right) (J. J. Rong, J. Y. Ye and M. Manfredini, 2020) 

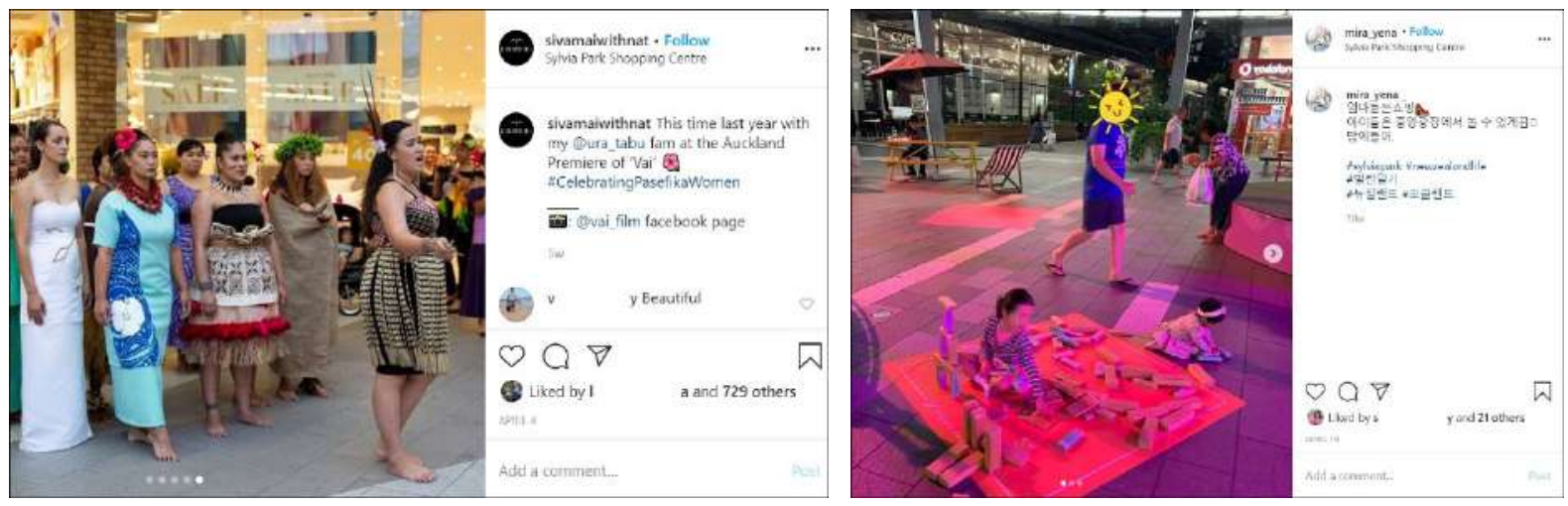

Figure 10. Territorial association: sample of posts (with multiple images) representing strongly associative moments with spatialities of the centre documented before the lockdown (sivamaiwithnat, 2020, left, and mira_yena, 2020, right).

\section{Interpreting the emerging spatialities}

This study was conducted on the digital public space of the best representative case of ultimate apparatus of totalising superlative simulated civicness in the malled urban centres of Auckland, the Ultra-modern Sylvia Park mall. It provided evidence of the formation of novel digitally emplaced relational practices. The documented presence of active emplaced, translocal social networks during the early New Zealand COVID-19 lockdown - an outright negation of public, material, emplaced relational spatialites prompts an affirmative answer to the main research question on the validity of such a study.

Findings on the networks of the digitally enhanced autonomous communities showed minor effects on the continuity and stabilisation during the lockdown period. The sustained commoning activity indicates the outstanding resilience of these networks in effectively negotiating, adapting to, and managing the disruption caused by the lockdown to their relationality.

The comparative network analysis of data provided an affirmative answer also to the first sub-question. Data of the two periods in the ultra-modern mall provided evidence on the actual establishment of the theoretically formulated associative assemblages. They showed that these are able to elude the total control of the apparatuses of the socially adverse civic simulacra that have colonised their commons. The robustness of their translocal operativity documented the maintained intensity of the digitally transductive relationality of their mobilised actors, resources (both tangible and intangible) and relation systems. The comparison between the activities during prelockdown and the lockdown periods showed the vitality of the grassroots networks, which offset the sharp decrease in primary communicative acts (i.e., the lowered number of posts consequent to the interrupted visitation) with a very steep increase in their response ratios in both secondary levels of engagement. This demonstrated efficacy of their mobilisation successfully mitigated the threats of the abrupt transfer of all their operations to the digital component of their spatial emplacements (where the pre-lockdown data are consistent with those a longitudinal research conducted on the same case study).

The comparison of case studies' data showed a notable difference of the activities of the grassroots digital relational networks situated in the modern and ultra-modern centres. 
While under the exacerbated fragmentation agency of the lockdown the networks of the modern centre abated, the meta-stable spatialities of the ultra-modern mall revealed the presence and resilience of collectively produced counterspaces with sustained acts of territorial appropriation and association. Such a difference underlines the sharp transition associated with the creative destruction in the mall sector between the social space of the modern transactional (i.e., shopping-based) centre and the ultra-modern post-consumerist (i.e., pseudo-civic) paradigms. The findings on the role of commercial activity confirm this, showing that the variation in the proportions of this kind of activity in the two types of malls has a limited impact on the activity of grassroots networks. Findings on network analysis were relevant because they not only indicate that the lower number of primary instances had a minor impact on the overall engagement (i.e., ascribed to it the polarisation), but also emphasise the relevance of the social content of posts and comments to foster independent communicative action.

Consistent with the other findings, the content analysis of the representational space in the ultra-modern centre provided evidence to affirmatively answer the second subquestion. The emerging practices in the representational space of the mall showed that the discourses, narratives and practices are efficacious constitutive agents for the reassembling of the mall's destitute commons. These are essential to the institution of the emplaced digital concatenations established by translocal and transductive concrete elements and relation systems.

The locally situated representations (which vastly exceeds the proportion found in the previous longitudinal study on the same area) affirm the composite dimension of social space, articulating the associative capacity of desire through an explicit expression of redistributive orders of ownership and belonging. Portraying recombinant moments of spontaneous appreciation and pleasure, these representations assert the effectiveness of these agents in deconstructing the dominant spatial logics of the simulative infrastructure, elaborating sign values that affirm the right to identification. By supplementing the post-consumerist use-exchange value amalgamation and disbanding the commodity fetishism mechanism of these civic simulacra, these expressions indicate the emerging force of counterterritorial association toward an emancipatory agency of "the pro-active complicity of the citizen consumer" (Miles, 20I2).

Final disclaimer: the COVID 19 lockdown provided evidence of the concurrent implementation and breach of the fundamental rule of non-response of emplacements of superlative abstract civicness designed to manipulate people's practices and actions. This impromptu study on the relational behaviours in the lockdown's exacerbated spatial abstraction supports the theoretically posited critical affirmative interpretation of the emerging post-consumerist urban condition. However, given its multiple limitations, its conclusion should be posited in the form of an opening question in the Foucauldian genealogical tradition: to which extent can the autonomous production of antagonist socio-spatial relational assemblages of the ultra-modern mall avoid to falling prey to the universal alienating normativity that marginalises and displaces antagonist and misaligned groups (Hubbard, 2004), while unrestrainedly dispossess the public and private local entities of their asset's ownership and control (Harvey, 2019)? 


\section{Acknowledgments}

This work was developed as part of the projects "Analysing the Role of Urban Forms in Making Sustainable, Healthy Cities" funded by WUN-World University Network; and "Give Us Space", funded by the National Science Challenge Building Better Homes Towns and Cities of the Ministry of Business, Innovation \& Employment.

\section{References}

Arendt, H. (1958). The human condition. University of Chicago.

Baudrillard, J. (1994). Simulacra and simulation. University of Michigan.

Bueno, A., Chalermtip, T., \& Manfredini, M. (2019). Digital space analysis. https://cpb-apse2.wpmucdn.com/blogs.auckland.ac.nz/dist/b/596/files/2019/08/I .3.I-Digital-SpaceAnalysis-Sylvia-Park-Instagram-SMALL-IMGs.pdf

Butler, S. (1872). Erewhon, or, Over the range. Trübner and Ballantyne.

Cartier, C., Castells, M., \& Qiu, J. L. (2005). The information have-less: Inequality, mobility, and translocal networks in Chinese cities. Studies in Comparative International Development, 40(2), 9-34. https://doi.org//0.I007/BF02686292

de Jong, A., \& Schuilenburg, M. (2006). Mediapolis: Popular Culture and the City. 010 Publishers.

Deleuze, G., \& Guattari, F. (1987). A thousand plateaus: Capitalism and schizophrenia. University of Minnesota Press.

Eco, U. (1986). Travels in hyperreality. Harcourt Brace Jovanovich.

Ferrell, J. (20I I). For a ruthless cultural criticism of everything existing. In J. Ferrell \& K. Hayward (Eds.), Cultural Criminology: Theories of Crime (pp. 558-567). Routledge.

Ferrell, J. (20I3). Cultural Criminology and the Politics of Meaning. Critical Criminology, 2 I(3), 257-27I. https://doi.org/I0.1007/s I06I2-0I3-9I86-3

Foucault, M. (2008). Of other spaces. In M. Dehaene \& L. DE Cauter (Eds.), Heterotopia and the city: Public space in a postcivil society (pp. 13-30). Routledge.

French, S., Leyshon, A., \& Wainwright, T. (201 I). Financializing space, spacing financialization. Progress in Human Geography, 35(6), 798-819.

Goss, J. (1993). The "Magic of the Mall": An Analysis of Form, Function, and Meaning in the Contemporary Retail Built Environment. Annals of the Association of American Geographers, 83(I), 18-47.

Group, K. (n.d.). Sylvia PArk. Retrieved October 8, 2020, from https://www.kiwiproperty.com/corporate/property/sylvia-park/

Guattari, F. (2006). The Anti-Oedipus Papers. In Interpretation A Journal Of Bible And Theology. Semiotext(e).

Harvey, D. (2006). Paris: capital of modernity. Routledge.

Harvey, D. (2007). Neoliberalism as creative destruction. Annals of the American Academy of Political and Social Science, 610(I), 21-44.

https://doi.org/I0.I I77/00027/6206296780 
Hardt, M., \& Negri, A. (2009). Commonwealth. Harvard University Press.

Harvey, D. (20I2). Spaces of capital: Towards a critical geography. Taylor and Francis.

Harvey, D. (2018). Universal alienation. Journal for Cultural Research, 22(2), I37-150. https://doi.org/10.1080//4797585.2018.146/350

Harvey, D. (2019). Rebel cities: from the right to the city to the urban revolution. Verso.

Hoyer, W. D., Kroschke, M., Schmitt, B., Kraume, K., \& Shankar, V. (2020).

Transforming the Customer Experience Through New Technologies. Journal of Interactive Marketing, 5 I, 57-7I. https://doi.org/I0.1016/j.intmar.2020.04.00 I

Hubbard, P. (2004). Revenge and injustice in the neoliberal city: Uncovering masculinist agendas. Antipode, 36(4), 665-689.

Kazig, R., Masson, D., \& Thomas, R. (2016). Atmospheres and mobility. Mobile Culture Studies - The Journal, 3, 7-20.

MacKenzie, A. (2006). Transductions: Bodies and machines at speed. Continuum.

Manfredini, M. (n.d.). Envisioning urban commons as civic assemblages in the digitally augmented city. A critical urbanism exploration of Counterhegemonic Individuation in the Age of Networked translocalism, multiassociative transduction and recombinant transculturalism (A. Taufen \& Y. Yang (eds.)). Routledge.

Manfredini, M. (20I7). The augmented meta-public space: Interpreting emerging transductive territories in enhanced centres of consumption. The Journal of Public Space, 2(3), III-I 28.

Manfredini, M. (2019a). Envisioning atmospheres of spectacle and activism. Utopia and critical urbanism instruments for the reclamation of the fragmented territories of the WALL and the MALL. The Journal of Public Space, 4(4), 83-108.

Manfredini, M. (2019b). Simulation, control and desire: Urban commons and semi-public space resilience in the age of augmented transductive territorial production. The Journal of Public Space, 4(2), I79-198.

Manfredini, M., \& Jenner, R. (20I5). The Virtual Public Thing: de-re-territorialisations of public space through shopping in Auckland's urban space. Interstices: Journal of Architecture and Related Arts, 16, 70-82. https://doi.org// 0.24I35/ijara.v0i0.493

Manfredini, M., Reeves, D., \& Kiddle, R. (2019). Give Us Space: Improving community wellbeing by enhancing performance and communication of semi-public space in the evolving public realm. https://www.drh.nz/labs/urban-relational-informatics/

Manfredini, M., Tian, X., \& Jenner, R. (20I7). "Transductive urbanism" A method for the analysis of the relational infrastructure of malled metropolitan centres in Auckland, New Zealand. Athens Journal of Architecture, 3(4), 4I I-440. 
Miklitsch, R. (1998). From Hegel to Madonna: Towards a general economy of commodity fetishism. State University of New York Press.

Miles, S. (2012). The neoliberal city and the pro-active complicity of the citizen consumer. Journal of Consumer Culture, I2(2), 216-230.

Milgram, P., Takemura, H., Utsumi, A., \& Kishino, F. (1995). Augmented reality: A class of displays on the reality-virtuality continuum. Telemanipulator and Telepresence Technologies. https://doi.org/10.1117/12.197321

Ministry of Health Manatū Hauora. (2020a). Covid-1 9 - Current cases. https://www.health.govt.nz/our-work/diseases-and-conditions/covid-19-novelcoronavirus/covid-19-current-situation/covid-19-current-cases\#probable

Ministry of Health Manatū Hauora. (2020b). COVID- 9 (novel coronavirus). https://www.health.govt.nz/our-work/diseases-and-conditions/covid-I9-novelcoronavirus

Ministry of Health Manatū Hauora. (2020c). Section 70(I)(f) Health Act Order (COVID-19 Alert Level 4) 24/03/2020. https://covid I 9.govt.nz/assets/resources/legislation-andkey-documents/COVID-I9-Section-70If-Notice-to-all-persons-in-New-Zealand-3April-2020.PDF

Mouffe, C. (1999). Deliberative democracy or agonistic pluralism? Social Research, 6(3), 745-758.

OECD. (2020). Organisation for Economic Co-operation and Development: Informality and social protection in the time of COVID-19. Governing Board Thematic Session on COVID19 \& social resilience. http://www.oecd.org/dev/HLM-Thematic-note-Informalitysocial-protection-post-COVID-19.pdf

Pine, B. J., \& Gilmore, J. H. (20I I). The experience economy. Harvard Business Review Press.

Ritzer, G. (20I4). Prosumption: Evolution, revolution, or eternal return of the same? Journal of Consumer Culture, I4(I), 3-24.

Ritzer, G., \& Degli Espositi, P. (2020). Creative destruction and cultural lag in the digital age. Sociology Between the Gaps: Forgotten and Neglected Topics, 5. https://digitalcommons.providence.edu/sbg/vol5/iss I/5

Ritzer, G., \& Jurgenson, N. (20I0). Production, consumption, prosumption. Journal of Consumer Culture, 10(1), I3-36. 
Ritzer, G., \& Lair, C. (2007). Outsourcing: Globalization and Beyond. In G. Ritzer (Ed.), The Blackwell Companion to Globalization (pp. 307-329). Blackwell.

Shane, G. (2005). Recombinant urbanism: Conceptual modeling in architecture, urban design, and city theory. Wiley.

Sloane, M. (2020). Inequality in the digital pandemic. Social Science Research Council, Insights Form the Social Sciences. https://items.ssrc.org/covid-19-and-the-socialsciences/society-after-pandemic/inequality-in-the-digital-pandemic/

Statcounter, G. S. (2020). Social media stats New Zealand. https://gs.statcounter.com/social-media-stats/all/new-zealand

Stats NZ Tatauranga Aotearoa. (2020). Earnings for people in paid employment by region, sex, age groups and ethnic groups. http://nzdotstat.stats.govt.nz/wbos/Index.aspx?DataSetCode=TABLECODE747 I\#

Tan, L. (2020). Covid 19 coronavirus: Auckland Night Markets to start delivery operations at level 3. https://www.nzherald.co.nz/nz/covid-19-coronavirus-auckland-nightmarkets-to-start-delivery-operations-at-level3/YMDUO6L2XYX6ENP7IVVY6SDJFE/

Terruhn, J. (2020). Urban diversity and inequality in Auckland. In R. Simon-Kumar, F. Collins, \& W. Friesen (Eds.), Intersections of Inequality, Migration and Diversification. Mobility \& Politics (pp. |3|-|5|). Palgrave Pivot.

The Treasury Te Tai Ōhanga. (2020). The Treasury Te Tai Ōhanga. https://treasury.govt.nz/sites/default/files/2020-05/covid-19-econ-dashboard29may2020.pdf

URIL. (n.d.). Urban Relational Informatics Lab. Retrieved October 8, 2020, from https:/www.drh.nz/labs/urban-relational-informatics/

Voyce, M. (2006). Shopping malls in Australia: The end of public space and the rise of “consumerist citizenship"? Journal of Sociology, 42(3), 269-286.

https://doi.org/ I0. I I77//440783306066727

WHO. (2020). New Zealand takes early and hard action to tackle COVID-19. World Health Organisatoin - Western Pacific. https://www.who.int/westernpacific/news/featurestories/detail/new-zealand-takes-early-and-hard-action-to-tackle-covid-19

Wilson, N., Boyd, M., Teng, A., \& Blakely, T. (2018). A century of health inequalities in NZ—New data. https://blogs.otago.ac.nz/pubhealthexpert/2018/03/26/a-century-ofhealth-inequalities-in-nz-new-data/ 


\title{
Public Spaces as an Invaluable Resource for Delivering Healthy and More Equitable Cities and Communities
}

\author{
Jose Chong, Sohel Rana, Mark Ojal \\ UN-Habitat, Kenya \\ jose.chong@un.org | sohel.rana@un.org | mark.ojal@un.org
}

\begin{abstract}
The state of our cities and towns is a significant determining factor of the health and wellbeing of most of the world's population in the twenty-first century. Cities and towns have become the epicentre of the COVID-19 pandemic. The pandemic has put to test the current urban development model including mobility, urban form, urban food systems and local economy. Cumulative social, economic and environmental inequalities reinforced by chronic spatial injustice have shaped exposure, vulnerability and ultimately, the risk and outcome of non-communicable, and infectious diseases. In the same context, green and public spaces have emerged as an infrastructure of opportunity to build back better, especially in low income and minority communities. This article looks at the impacts, responses and pathways for future-proofing cities and human settlements through green, and public spaces.
\end{abstract}

Keywords: healthy cites, equitable cities, COVID-19, green public spaces

To cite this article:

Chong, J., Rana, S., Ojal, M. (2020). Public Spaces as an Invaluable Resource for Delivering Healthy and More Equitable Cities and Communities, The Journal of Public Space, 5(3), 227-232, DOI I0.3289I/jps.v5i3.I4I5

This article has been double blind peer reviewed and accepted for publication in The Journal of Public Space. (c) (1) (5) This work is licensed under a Creative Commons Attribution - Non Commercial 4.0 International License https://creativecommons.org/licenses/by-nc/4.0/ 


\section{Introduction}

Urban health and wellbeing are becoming increasingly dominant urban problems in both developed and developing countries (Perdue, Stone, \& Gostine, 2003). The state of our cities and towns is a significant determining factor of the health and wellbeing of most of the world's population in the twenty-first century. 54 percent lives in urban areas, and this is projected to rise to six out of every 10 people by 2030 (UNDESA, 2014). Today, rates of non-communicable diseases (NCDs), infectious diseases, and mental illness are higher in cities compared to rural areas. The global economic impact of the five leading NCDs cardiovascular disease, chronic respiratory disease, cancer, diabetes and mental illness could total US $\$ 47$ trillion over the next 20 years (RTPI, 20I4). Moreover, cities and towns have become the epicentre of the COVID-19 pandemic, accounting for over 90 percent of the confirmed cases (United Nations, 2020; UN-HABITAT, UNCDF, UCLG-Africa, UNECA, 2020).

The pandemic found many cities and countries unprepared despite many warnings and recent epidemics such as Ebola and Severe Acute Respiratory Syndrome (SARS) (UNHabitat; UNDRR, 2020). It has challenged the current urban development model including mobility, urban form, urban food systems and local economy. Cumulative social, economic and environmental inequalities reinforced by chronic spatial injustice have shaped exposure, vulnerability and ultimately, the risk and outcome of non-communicable, and infectious diseases. The pandemic has exposed stark inequalities in accessibility to risk-reducing infrastructure and services, shining light on disparities in accessibility, quality and distribution of green and public spaces across the urban divide. In the same context, green and public spaces have emerged as basic risk-reducing infrastructure, an essential urban service, an infrastructure of opportunity to build back better, especially in low income and minority communities, an important 'third place' (Oldenburg R. , 1989; Oldenburg \& Brissett, 1982), especially in times of crisis.

The quest for healthier cities and towns is therefore an urgent development agenda. Urban development decision makers, the built environment and the scientific communities, the private sector and the civil society must look for ways to develop cities as instruments of health and wellbeing. The COVID- 19 pandemic provides an opportunity to build back better, rethinking the city from the group-up, integrating spatial and environmental justice in urban regeneration endeavours including mobility and accessibility of green, and public spaces. This article looks at the impacts, practices and pathways for future-proofing cities and human settlements through green, and public spaces.

\section{Public spaces in the face of unprecedented crises}

Well designed and well managed public spaces such as parks and gardens, urban forests, nature reserves, playgrounds, greenways, markets and streets make direct contributions to urban health and wellbeing, ensuring healthy living and longer life. When provided in adequate quantity across the urban divide, high quality of green, and public spaces support ecosystem services such as clean water, purifying air, enhancing and protecting biodiversity, cooling our cities, storing carbon, and protecting the earth natural features and processes (Prospero, 20I0). They are a critical risk-reducing infrastructure, and provide storm-water attenuation, contributing to flood management. They also provide opportunities for active and passive recreation, active mobility including cycling and walking, a natural relief from the 
hustle and bustle of the city, and social interaction, consequently promoting better health outcomes.

The counter-pandemic measures like lockdowns, isolation, physical distancing and 'stay home' advisory are also leading to some unintended consequences like increasing genderbased violence, violence against children and loneliness (UN Women, 2020). The pandemic has challenged the uses, roles of and perceptions towards public space; roles and capacity of urban development actors; the place of public, and non-motorised transport; planning of green, and public spaces; regulations for use of public spaces; and the $21^{\text {st }}$ century urban model (Honey-Rosés, et al., 2020). Similarly, it has also helped city leaders realize the extended and alternative uses of public spaces to respond to urban risks, highlighting the need for short, medium and long-term strategies. Streets and public open spaces have been adapted as alternative medical facilities, public markets, community gardens and places for walking and cycling.

Globally, cities are reclaiming green, and public spaces, including parks and streets, and transforming them into people places. In Nairobi, the pandemic has sparked a green renaissance, leading to reclamation and revitalization of green, and public spaces. The influx of people into parks and urban forests in the city is a manifestation of the demand for these spaces and is also a wake-up call to improve the accessibility and distribution across the urban divide, providing public spaces such as parks, forests and playgrounds within neighborhoods. In Kibera, an informal settlement in Kenya, there are very few public spaces and lack of clean water and sanitation. During this time of the pandemic, public spaces have doubled up as hand-washing stations and as places to get information on COVID-19

prevention. They have also become places where vulnerable groups gather to receive relief support.

Besides recreational and ecological benefits, public spaces are also places where livelihoods thrive, women vend their produce and young people sell their art. Cities and local governments need to support these livelihoods, especially in rapidly urbanizing and resource poor cities where a large part of the population works in the informal sector earning a daily wage. In Kalaw, a small tourist town in Myanmar, officials have closed off some streets and converted them into vegetable markets to promote safe vending and grocery shopping. In Banjul, the Gambia, the city council is working on a public market decongestion plan to reduce the number of vendors and visitors using the city's main public market. In Kisumu, Kenya, the county government in collaboration with local youth has converted public open spaces into temporary open-air markets, decongesting the city's public markets to achieve physical distancing and adequate aeration. In Nairobi's Korogocho slums, local youth are integrating vertical gardens in public spaces, providing them with food and they sell excess produce.

These innovations and practices can help urban development decision-makers and practitioners to prepare for and adapt to a multiplicity of everyday risks and disasters. Creating a well-connected and integrated system of public open spaces and streets makes more liveable, lovable and resilient cities and neighbourhoods. This results into multiple cobenefits including better air quality, which also impacts general health and well-being in cities and human settlements. A holistic approach to planning should consider combining grey, green and blue infrastructure at different levels to support healthier cities and communities. 


\section{United Nations Development System and COVID-I 9 response and recovery}

The 2030 Agenda for Sustainable Development places premium on health and wellbeing and recognizes the role of good urban design in delivering better health outcomes. Goal 3 specifically calls for ensuring healthy lives for all and promoting wellbeing for all at all ages. This is further reinforced by target II.7 which recognizes creating safe, inclusive and accessible green, and public spaces as a lever for achieving sustainable cities and communities. Health and wellbeing of cities and communities has also been recognized as the pulse of the New Urban Agenda, underscoring the link between the quality of urban environment on one hand, and physical and mental health and wellbeing in cities and communities on the other (WHO and UN-Habitat, 2020).

The pandemic in the urban world presents a classic example of a tangled 'mess of thread' where it is difficult to determine which one to pull first. Overcrowding, concentrated poverty, inadequate water and sanitation, and solid waste management, poorly distributed risk-reducing infrastructure all make cities soft spots for diseases and disease-causing pathogens to thrive (Mukherjee \& Sen, 2020). In the wake of the devastation and disruption of lives and livelihoods in cities and communities, the United Nations released a five-point policy brief to guide governments, and development and humanitarian partners across all levels on how to reduce the impact of the pandemic on lives, livelihoods, and protect the most vulnerable. These include: ensuring that essential health services are available and health systems are protected; helping people cope with adversity, through social protection and basic services; protecting jobs, supporting small and medium-sized enterprises, and informal sector workers through economic response and recovery programmes; guiding the necessary surge in fiscal and financial stimulus to make macroeconomic policies work for the most vulnerable and strengthening multilateral and regional responses; and lastly, promoting social cohesion and investing in community-led resilience and response systems. Collectively, this set of policies attempt to 'untangle' the mess of thread by offering targeted entry-points. The policy brief recognizes the need to accelerate building resilient cities and communities.

Globally, the COVID-19 pandemic has exposed the fragility of our urban systems (UNHabitat, 2020). Structural intra-urban inequalities have been exacerbated by the pandemic and vulnerable populations including the low income and the urban poor have found it difficult to cope with the prevailing situation and adhere to the COVID- 19 control guidelines. It is for this reason that UN-Habitat is concentrating its efforts to mobilize human and financial resources to support local governments and communities affected by the pandemic. Experiences and innovations from the COVID pandemic demonstrate that stronger partnerships are needed to build safer, resilient and inclusive cities and communities. They also underscore the need for a shared policy agenda across the built environment community of practice, the scientific community, the business community and the civil society to work towards future-proofing cities and communities (UN-Habitat, 2020).

\section{Key recommendations on planning public spaces for healthy communities}

Based on the experience of the UN-Habitat's Global Public Space Programme and partners, there are inspiring practices from around the world, find below some key recommendations proposed to that link public space and health agendas (UN-Habitat, 2020). 
$\checkmark$ Design public spaces as flexible, multifunctional and adaptable.

They can provide space for emergency response during the pandemic (temporary health care facilities, medical supplies and food distribution). During the crisis, open spaces can also facilitate movements through non-motorized mobility alternatives, provide opportunities for physical outdoor activities and support livehood of economic vulnerable populations.

$\checkmark$ Design public spaces so that they can provide emergency services for the vulnerable and marginalized.

Well-planned and designed public space can provide the necessary public sanitation facilities during the crisis (bathrooms, water points, washing facilities). The availability of these public facilities is particular important and it is vital in informal settlements to keep daily hygiene practices.

$\checkmark$ Establish a well-connected, integrated and equitable system of public spaces.

Streets and open spaces system with enough space and greening which promotes cycling and walking. A well-designed and maintained public space network can contribute with the reduction of $\mathrm{CO} 2$ emissions and better air quality improving people's health and wellbeing.

$\checkmark$ Plan for the self-sufficient and compact neighbourhoods.

Allow that the residents can have all their needs met (work, school, shopping, health, leisure or culture) within 15 minutes from their own doorstep by foot, bike and/or public transport.

\section{Conclusions and way forward}

The common reference to green public spaces such as parks and gardens, urban forests, greenways and nature reserves among others with the physiological metaphor 'the lungs of the city' connotes the intricate relationship between urban planning and design, and health and wellbeing in cities. The COVID-19 pandemic has put the importance of access to green, and public spaces on the limelight. It has highlighted disparities in the supply and distribution of green, and public spaces across the urban divide, reinforcing existing structural inequalities regarding access.

Urban development decision makers and actors need to ensure that the planning system delivers a comprehensive network of green, and public spaces in cities and towns as an urgent global urban (re)development agenda. In addition, national and local governments need to step up action on disaster risk governance, and disaster risk-informed urban planning and development in order to prepare for, adapt to and build back better from urban risks such as pandemics. Importantly, governments and urban development actors need better granular data including new metrics for green, and public spaces, and health and wellbeing to inform better urban planning and design.

\section{References}

Honey-Rosés, J., Anguelovski, I., Chireh, V., Daher, C., Van den Bosch, C., Litt, J., Nieuwenhuijsen, M. (2020). The impact of COVID-I 9 on public space: an early review of the emerging questions - design, perceptions and inequities. Cities and Health. 
Public Spaces as an Invaluable Resource for Delivering Healthy and More Equitable Cities and Communities

Mahler, D. G., Lakner, C., Castaneda, A., \& Wu, H. (2020, June 08). World Bank Blogs. Retrieved from World Bank: https://blogs.worldbank.org/opendata/updated-estimates-impact-covid- I9global-poverty

Mukherjee, J., \& Sen, A. (2020, May 19). From SMART to sustainable cities: Is COVIDI9 an opportunity? Retrieved from Oberver Research Foundation: https://www.orfonline.org/expert-speak/fromsmart-to-sustainable-cities-is-covid I 9-an-opportunity-66363/

OECD. (2020, July 23). Cities Policy Responses . Retrieved from OECD Website: https://www.oecd.org/coronavirus/policy-responses/cities-policy-responses-fd I 053ff/

Oldenburg, R. (1989). The great good place. New York: Marlowe.

Oldenburg, R., \& Brissett, D. (1982). The third place . Qual Sociol, 265-284.

Perdue, W., Stone, L., \& Gostine, L. (2003). The Built Environment and Its Relationship to the Public's Health: The Legal Framework. Am J Public Health, 1390-1394.

Prospero, F. (2010). Healthy Open Spaces: A summary of the impact of open spaces on health and wellbeing. Lower Hutt: Regional Public Health .

RTPI. (2014, October). Promoting Healthy Cities. Retrieved from Royal Town Planning Institute: https://www.rtpi.org.uk/media/ I470/promoting-healthy-cities-full-report-20I4.pdf

Sandford, A. (2020, April 3). Coronavirus: Half of humanity now on lockdown as 90 countries call for confinement. Retrieved from Euronews: https://www.euronews.com/2020/04/02/coronavirus-ineurope-spain-s-death-toll-hits-10-000-after-record-950-new-deaths-in-24-hou

UN Women. (2020). Covid-I 9 and ensuring safe cities and safe public spaces for Women and Girls. Retrieved from UN Women: https://www.unwomen.org//media/headquarters/attachments/sections/library/publications/2020/brief-covid-19-andensuring-safe-cities-and-safe-public-spaces-for-women-and-girls-en.pdf?la=en\&vs $=632$

UNDESA (2014, July 10). World's population increasingly urban with more than half living in urban areas, Retrieved from United Nations:

http://www.un.org/en/development/desa/news/population/world-urbanization-prospects20l4.html

UN-Habitat. (2020). COVID-I 9 Response, Report of Activities. Nairobi: UN-Habitat.

UN-Habitat. (2020). UN-Habitat COVID-I 9 Response Plan. Nairobi: UN-Habitat.

UN-Habitat. (2020, June). UN-Habitat Guidance on COVID-1 9 and Public Space. Retrieved from UNHabitat: https://unhabitat.org/sites/default/files/2020/06/un-habitat_guidance_on_covid19_and_public_space.pdf

UN-HABITAT, UNCDF, UCLG-Africa, UNECA. (2020). COVID-I 9 IN AFRICAN CITIES: Impacts, Responses and Policies. Retrieved from United Nations Economic Comission for Africa: https://www.uneca.org/sites/default/files/PublicationFiles/covid19 in_african_cities_impacts_responses_and_policies2.pdf

UN-Habitat; UNDRR. (2020, June 15). Covid 19 demonstrates urgent need for cities to prepare for pandemics. Retrieved from United Nations Human Settlements Programme: https://unhabitat.org/opinion-covid-19-demonstrates-urgent-need-for-cities-to-prepare-forpandemics

United Nations. (2020). A UN framework for the immediate socioeconomic response to COVID-19. New York: United Nations.

United Nations. (2020, July no date). Policy Brief on COVID-19 in the Urban World. Retrieved from United Nations:

https://www.un.org/sites/un2.un.org/files/sg_policy_brief_covid_urban_world_july_2020.pdf

United Nations. (2020). United Nations Comprehensive Response to COVID-19. Saving Lives, Protecting societies, Recovering Better. New Work: United Nations.

WHO and UN-Habitat. (2020). Integrating health in urban and territorial planning: A sourcebook . Geneva: WHO. 


\title{
VIEWPOINT
}

\section{Urban Questions in the Times of Coronavirus. Responding to the Crisis of Public Space}

Darko Radović (Keio University, co+re), Davisi Boontharm (Meiji University, co+re) radovic@keio.jp | nout.davisi@gmail.com

Antonella Bruzzese (Politecnico di Milano), Stephen Cairns (ETH Future Cities Laboratory, Singapore), Alenka Fikfak (University of Ljubljana), Pieter Klomp (City of Amsterdam), Kengo Kuma (KKAA, University of Tokyo), Beatriz Maturana Cossio (Universidad de Chile), Ana Medina (Universidad des las Américas), Eiji Oguma (Keio University, Tokyo) David Sim (Gehl, Copenhagen), Sidh Sintusingha (University of Melbourne), Saline Verhoeven (s-coop, Amsterdam)

\begin{abstract}
This paper is co-edited on the basis of an intensive round-table discussions within a relatively small group of colleagues interested and involved in thinking, making and working towards quality of public space, to discuss, problematise and evaluate what is going on and to speculate on actions suitable for these times, and the times that follow. The title of the round table emphasises questions, deliberately pointing at the enigmas posed by current situation. We see it as an opportunity to get and think together in a structured brain-storming session that encourages brave and risky discussion. The "task" for all of the participants is to reflect upon practices/experiences that we are individually familiar with, those that we are witnessing these days, and - to suggest what would be the key questions /issues that need to be (re)thought and addressed in the weeks, months, perhaps years to come. The roundtable discussions were held online on Ist May 2020 - then recorded, transcribed, edited and published as a joint piece.
\end{abstract}

Keywords: public space, COVID-19, immediate response, cross-cultural perspectives

To cite this article:

Radović, D., Boontharm, D., Bruzzese, A. Cairns, S., Fikfak, A., Klomp, P., Kuma, K., Cossio, B. M., Medina, A., Oguma, E., Sim, D., Sintusingha, S., Verhoeven, S. (2020). Urban Questions in the Times of Coronavirus. Responding to the Crisis of Public Space. The Journal of Public Space, 5(2), 233-248, DOI 10.3289I/jps.v5i3.I362

This article has been double blind peer reviewed and accepted for publication in The Journal of Public Space. 


\section{Introduction}

The outbreak of Coronavirus provided us all with a surprise, a sort of shock and a sense of the need to react. But, not knowing much about the threat is not an easy place to begin. I remember initial distrust into reports, denial and rejection of "overreaction", mingling with completely opposite feelings of dismay, unease and the outright fear. Personal coincidences matter. Caught traveling we were first-hand experiencing the diversity of responses to the same cause. Our journey was never to be easy. It led us from Tokyo to Bangkok, then Belgrade, Zagreb to Ljubljana. Just before continuing to Milano, the borders started to close and we have (in hindsight - luckily) found ourselves in Split. Our flights back started to be rescheduled and postponed; the lock-down begun. There was a plenty of time to observe and reflect, firmly landed while, perhaps, globally connected more than ever.

For the first time in more than fifty years of knowing the city of Split, the magnificent Diocletian Palace and the fine-grained fabric of its public spaces were empty. The photos in the media and, even more dramatically, those coming from the people we knew were placing the sense of distress where our professional, academic and personal histories intersect - our love of the urban. Riva, the buzzing seafront of Split - empty. Diocletian's Peristyle - empty. Is an empty piazza still a piazza? Can we exercise our innate right to the city under the condition of the lock-down, in fear? This place, and some other places dear to me have experienced terrible natural and man-made disasters before. But, how to live this one, how to address its ills, how and what to do to reduce both the tragedy of the moment and help avoid similar tragedies in the future? Questions, questions, questions.

Staying in touch with dear ones, friends and colleagues included discussions of pressing questions: how to react, what to expect, how to do something about it. That is where the creative instincts and our background in disciplines related to the production of space kicked in. Planning and design are always about making a better world.

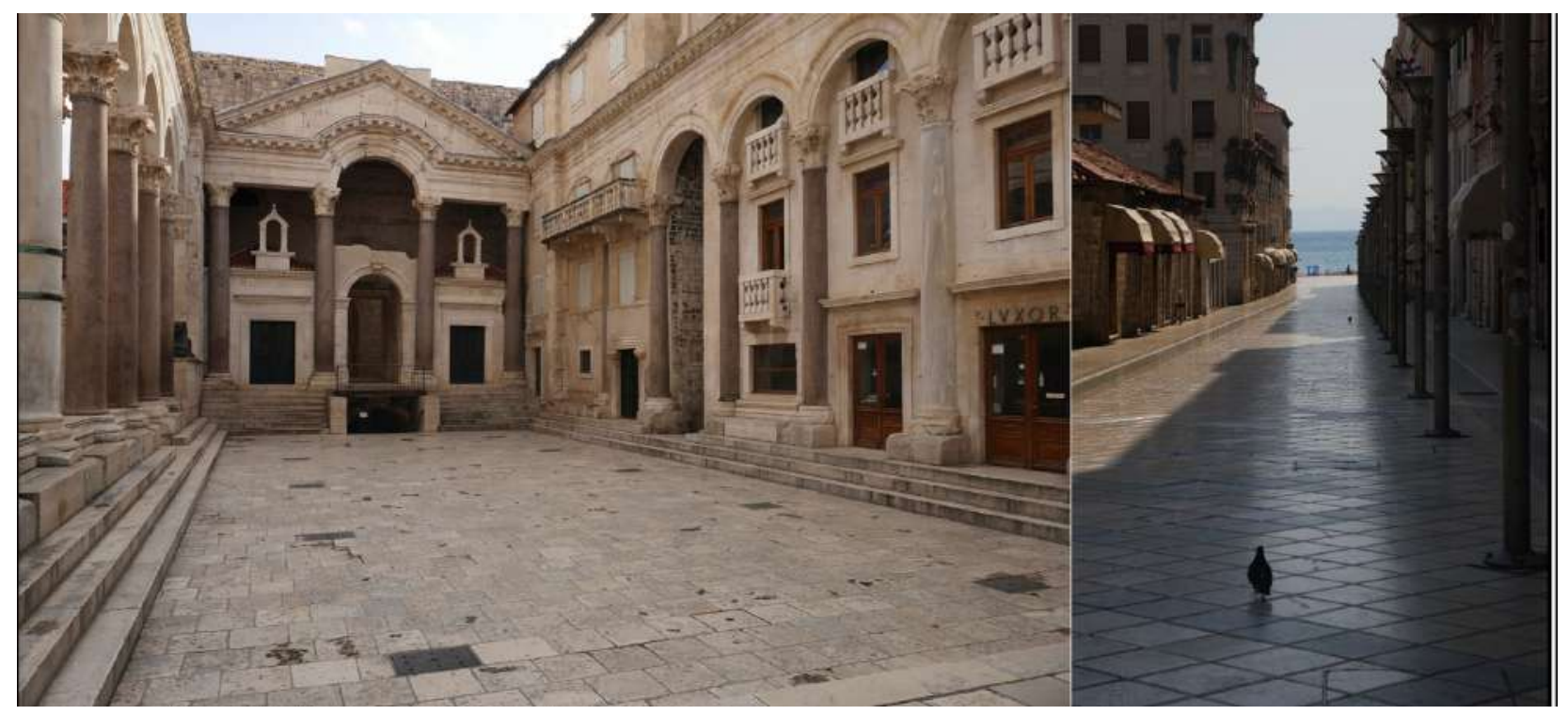

Figure I. Empty public spaces in Split, left: the Peristyle, right: Marmontova Street 


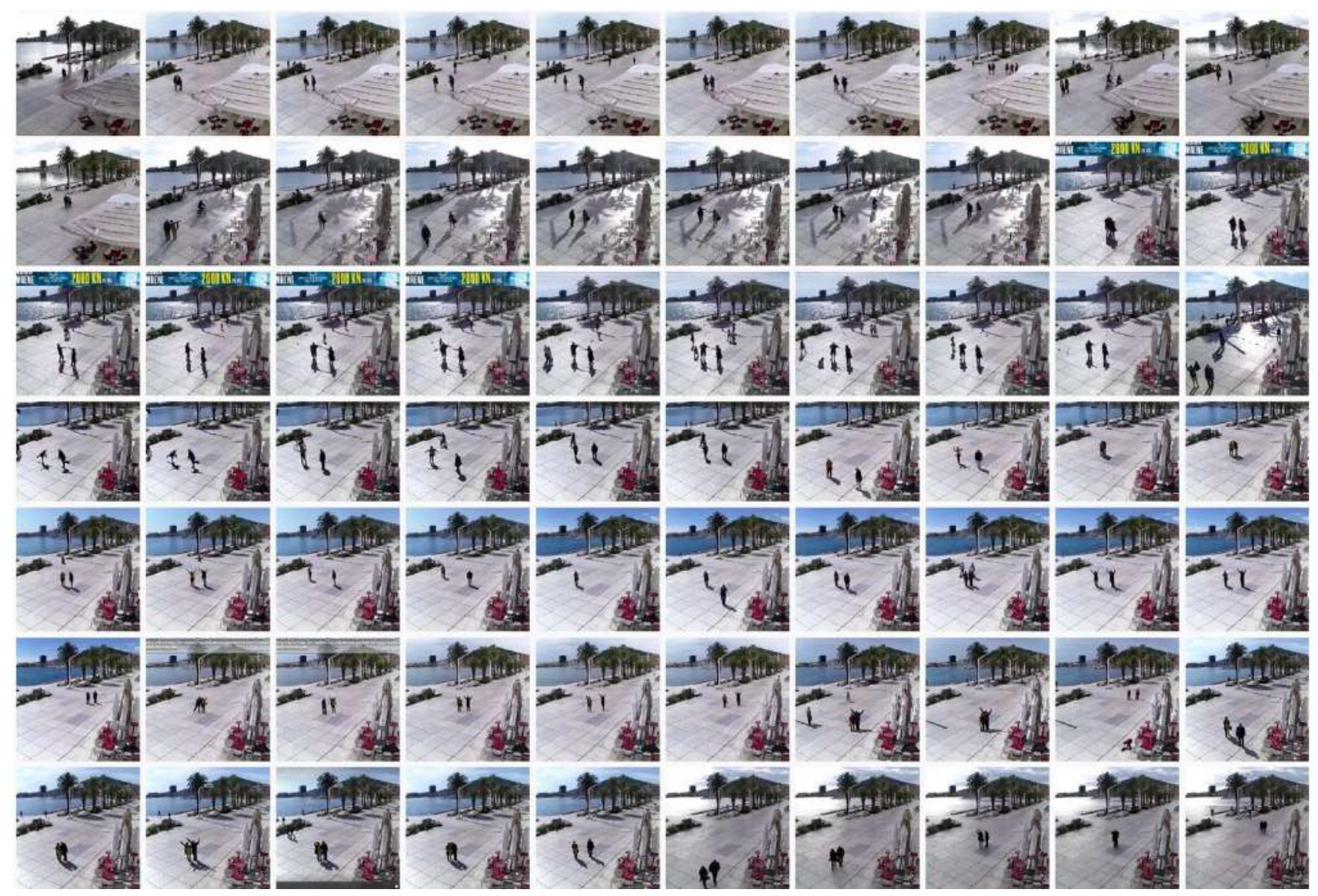

Figure 2. The compilation of snapshots taken from Split's Webcam on Riva during the lockdown

Darko as Senior co-Chair on the Advisory Board of Public Space Experts and Davisi as a Member of the Council Board, we have responded to the City Space Architecture "2020: A Year without Public Space under the COVID-I9 Pandemic" initiative by proposing a concrete action. Our emphasis was on the imperative to pause and formulate relevant questions. From day one of the pandemic the common rush for "solutions" has started, but we have found overarching, "simple" questions - such as solutions to what?! - sorely missing. Our times made us prone to almost religious belief in never-easier tech and financial fix to - everything. Many, at least in the (over)developed world, increasingly believe that, as Morozov has cynically, brilliantly put it, when things go wrong we simply can, "in order to save everything, click here". Unfortunately, the Coronavirus pandemic cannot be reversed by new app, or pressing the almighty Ctrl. $Z$ command. Serious situations demand serious thinking, measures which can reach beyond cheap (albeit usually financially expensive) fix. We have agreed that the Coronavirus pandemic invites humility. It points at our limitations and the need for different kind of thinking and action - with an acute sense of emergency.

On 15 April 2020, at City, Space, Architecture meeting we have agreed to place our proposal within the network of other worthy initiatives. On 17 April we invited a remarkable group of friends and colleagues across four continents, asking them to participate in discussion "Urban questions in the times of Coronavirus". All of them responded positively. On 25 April I only needed to explain the format. We would organise an intensive round-table discussion. The expectation from the strong panel 
interested and involved in thinking, making and working towards quality of public space, was to discuss, problematise and evaluate what was going on, and to speculate on actions suitable for these times, and the times that follow.

The title of the round table emphasised questions, pointing at the dilemmas and enigmas posed by the current situation. I saw it as an opportunity to think together in a structured brain-storming session that encourages brave and risky discussion. Each of the participants provided an opening, 250-500 words long input, with key observations, personal position, thoughts, questions and provocations that would move us faster. On I May we co-chaired two round tables

This unusual, co-produced, collective essay, which is aimed to open rather than close discussions, is the result of that initiative.

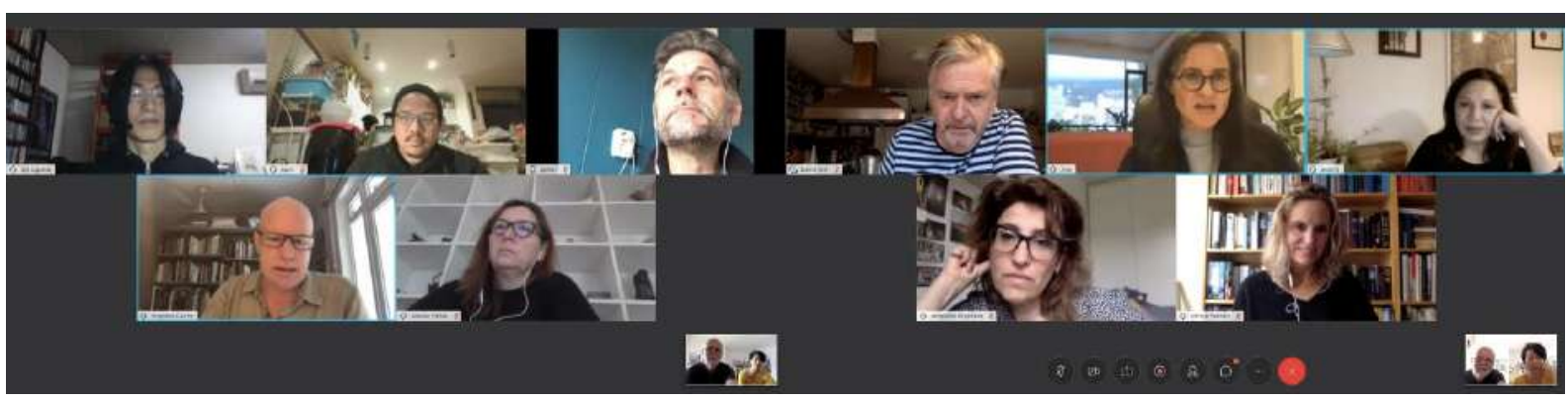

Figure 3. The participants of the two round tables (screenshots of the Webex meetings)

Roundtable session I, I May 2020

Davisi Boontharm DB, Stephen Cairns SC, Eiji Oguma EO, Alenka Fikfak AF, Pieter Klomp PK,

Kengo Kuma KK (inputs only), Sidh Sintusingha SS, Darko Radović DR, chair

\section{INPUTS}

KK: The theme I want to introduce could be called - the departure from the box. In the 20th century, we were trapped in boxes, boxes as workplaces and transportation machines. The city became filled up with boxes and in between were only the gaps to move. The century was called the "Century of Freedom", but being trapped in boxes seems very far from that ideal. Work in boxes enforced many sacrifices, especially on women. The Coronavirus crisis came in suddenly. The governments requested us to stay away from those boxes, except when expressly needed. The technology has proven that it was possible to work efficiently without such, inhuman confinement.

Breaking out of the box is also breaking out of the room. These days I walk a lot. By walking, my physical condition improved and, while walking, I have thought and sketched various things. I was able to choose distance from other people, which was not the case in steel, transportation boxes. Walking allows us to choose, to be alone and free. Being stuck in boxes became fully possible only with the advent of devilish air-conditioning machines. But the parks are not air-conditioned.

On the famous Giambattista Nolli's map of Rome (1748) all spaces accessible to anyone were white, regardless if external or interior; the publicly inaccessible spaces, such as private residences, were black. With invention of air-conditioners, the interiors became 
hermetically sealed, and the outside temperature has increased. The cars made the outdoors even more uncomfortable. The streets, supposed to be white on Nolli's map, become increasingly black and dirty. I felt that there was almost no white space in Tokyo. We need more white space and more human interaction.

In Hidden Dimension, Edward T. Hall points out the importance of cultural difference in perception of distances. Japanese gardens, with their steppingstones and narrow spaces, stimulate full use of muscles. Hall praises differentiation of places and distances. When exploring spaces by walking, one develops a fine sense of own body. Walking requires muscles to participate in the space. In the National Stadium, which I was involved in designing, we did not want to seal the roof off. We have proposed an open-air stadium that breathes together with the Gaien's Forest. The eaves were made of four layers allowing a wooden, airy stadium to be linked to the forest by garden design methods. Wood was not one of the building materials, but plants also cover the middle eaves. After the pandemic, I would like to keep on walking between the boxes and working while walking. With more of us walking, the gaps between the boxes will get transformed from empty voids into fully open, white places and ventilated gardens of human interaction.

SC: Epidemiologists have argued that urban density is one of the mediums that spread COVID. On the other side of the agenda, agencies interested in urban development from planning authorities to the World Bank - have been trying to show that the relationship between density and the COVID spread is not determining. Some indicators show the correlation, while others do not. In Singapore density is a nationally significant issue. Singapore has a deep commitment to the values of urban density. And, the citystate has been doing well in managing Covid-19 until it spread into the migrant dormitories and compounds. Suddenly, it seemed, two densities were revealed in the city: the density of a well-planned city and the density of migrant workers. This has quickly become an important topic of debate and will likely bring about policy and design reforms on managing density.

While there is so much ambiguity around the issue of density and COVID-19, we can venture a number of early practical trajectories. (I) we have to consider density in relation with all other aspects of cities; density can never just be a stand-alone quantitative indicator; (2) as COVID cases were mostly contracted indoors, we need to focus at making a well aerated city that makes good use of outdoors. A lot of interesting local examples already exist in Singapore, such as hawker centres (3) it is important to diversify mobility, with autonomous vehicles and electric vehicles breaking up a monolithic mass transportation system, particularly busses and their rigid schedules; and (4) designing a cyber-physical city in which we make better use of augmented and virtual realities in everyday spaces.

AF: I am coming from Slovenia, a small country with very low density of population, from the town of Vrhnika, which is situated $20 \mathrm{~km}$ from Ljubljana and has just 8,000 inhabitants. In these times the municipality borders were closed, there is no public transport, no possibility to go to Ljubljana. In terms of Coronavirus cases, with only 91 deaths, in Ljubljana region we did not have serious problems. In other municipalities the outbreaks were mainly in the homes for elderly. Municipalities bordering with Italy have no cases. That is because "stay at home" campaign starter early, on I 3 March. The 
streets were emptied, social distancing imposed, with only food stores and pharmacies open. The only public spaces used were urban gardens.

I wonder if these two months caused enough suffering to keep these rules seriously applied. The main questions which this outbreak leaves are cultural and social. As we are part of the Balkans, we tend to hug each other. That might have to change.

PK: In the Netherlands the picture is quite different. Schools, universities and restaurants are closed, but the rest is left up to common sense, so to speak. That works relatively well, although parts of the country have been seriously hit. Ours is a very densely populated, small country with 17 million inhabitants, which at the same time is the second largest exporter of agricultural products worldwide. Corona-casualties, also in absolute numbers, have been much higher in parts of the countryside then in the larger cities. Perhaps not coincidentally, because of bio-industry there has been much less of a Corona "air quality-bonus"in these parts.

In my city Amsterdam, growing numbers of inhabitants, commuters and visitors haven been posing a huge challenge on mobility within limited space, even though the bicycle has attained inner city predominance already. Adding density while coping with relatively limited rush hour peaks has been determining spatial and financial decisions. It is interesting to see how suddenly this peak has gone, now that temporarily teleworking from home has been widely adopted. I am interested to see if there are lessons to be learnt here. Not to measure density in square meters, but density of use. Will we have a different view on density when we are able to continue to flatten the peaks and use our buildings and public space more "decompressed" and effectively, not just cut up and designed for single use?

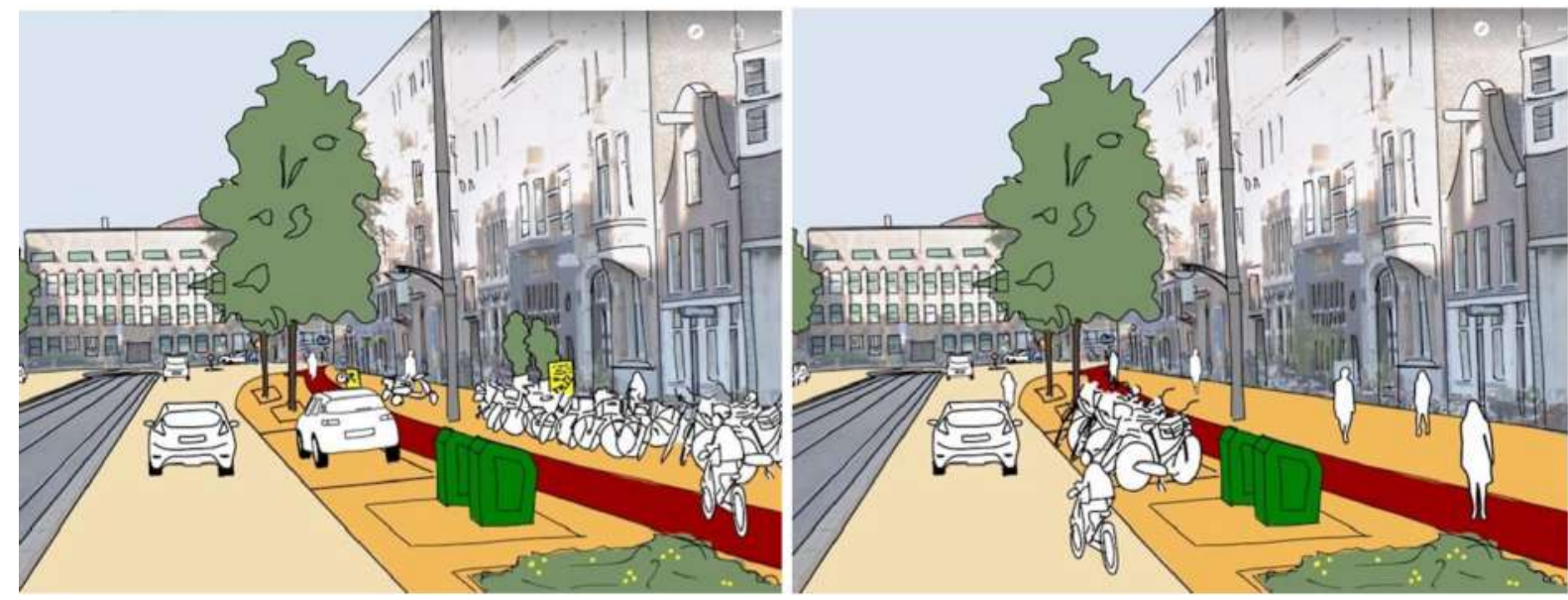

Figure 4. Amsterdam, the temporary measures of public space - undiving public space for social distancing conditions

EO: I would like to point out the importance of agencies and activities in public space. If there are no agencies and activities, no theatres, protests and activists, even welldesigned public spaces are vacant. Tokyo and Kyoto are full of small restaurant, shops and theatres. The image of Japan abroad is that of a super developed, high-tech country while in reality there operate three million small, private companies. Only I\% of companies are exceptionally big. Most of Japanese cultural spaces, such as movie and 
performance theatres, publishers, bookstores and entertainment industries are carried by medium- and small-sized companies.

The Japanese government has decided to introduce the Coronavirus lockdown at the end of March. One month later, in the end of April they decided to provide maximum 2,000,000 JPY (I 880 USD) subsidies for SMEs and maximum I,000,000 JPY for small business owners. Many economists predict that without such subsidies businesses such as bookstores and entertainment companies will not survive a month, or two. I think that in 3-4 months most of cultural activities in Japan might disappear. The same situation is with other urban activities, citizen groups, activists, protestors involved in demonstrations, assemblies, food supplies. During the lockdown they are running out of budgets, losing skills, knowledges and networks that mobilize members in public spaces. Without such agencies, skills and activities, discussion on space design becomes meaningless. That is the main point of the only sociologist in this group.

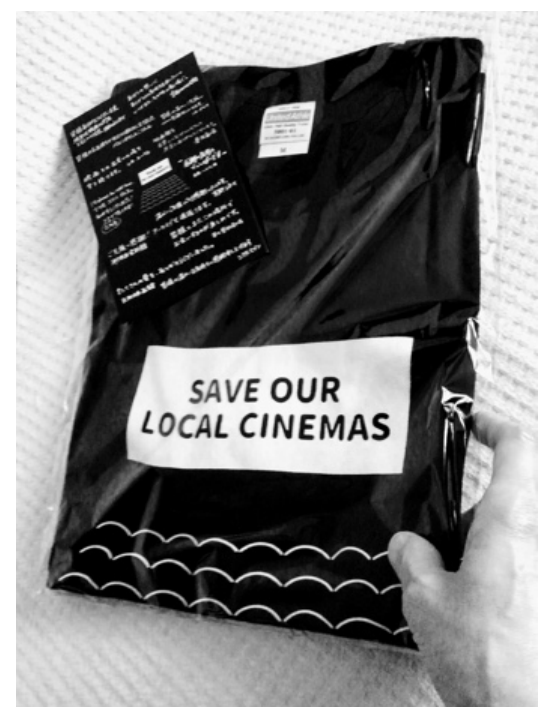

Figure 5. "SAVE OUR LOCAL CINEMAS" T-shirt has arrived. Hot messages from movie theater people. Cine Libre Kobe, Motomachi Movie Theater. Thank you. (from a tweeter feed of Kuri@torso009 on II May 2020)

DR: Exposed to a single, albeit fuzzy and even questionable threat, the World responded in an endless number of ways. That is consistent with my research into diversity of urban cultures: while Coronavirus stands "nicely" next to other globalizing forces, human responses to it were as diverse as we are.

While many talk about "return to normal", it is easy to forget that the pre-Coronavirus reality for majority on this planet was below humanely acceptable conditions. Shouldn't the way out of this emergency be a way forward, not a way back(wards)? That is not a rhetorical question. As in Lefebvre's right to the city, it "is like a cry and a demand. It can only be formulated as a transformed and renewed right to urban life". While questioning the return to "normality" might be dismissed as unrealistic, we do need new realism grounded in environmental and cultural sustainability, and to expose the "return" itself as unrealistic and totally irresponsible. There should be no cost-benefit analysis of health and life, including social life. To achieve that - cities need new kind of politics.

These times make us realise how hard is to formulate new, relevant questions. Those questions need to be based on the idea(I)s of humanism, democracy, urbanity, right to the city, solidarity, conviviality. The locked-down cities offer many manifestations of 
these ideals - lived, exercised, practised. From that one can learn a lot, but only after the first lesson - that we should not return to Debordean Spectacle in which "the globalization of the false was also the falsification of the globe".

SS: I've stayed indoor for more than a month, rarely leaving the house. I see that public spaces and "others" are now perceived as "diseased"; fear has revealed and intensified camouflaged biases. My observation focuses on two contestations in 'digital public space'. One is the Geopolitical contestations, the big picture of China vs. the West blame game. That is affecting the geopolitics and economic reopening that we are discussing. This urban ethno-centric contestation manifested in a video clip of a racially motivated attack on two international students in Melbourne's CBD. Attacked as "Chinese", they are Malaysian and Singaporean. The second contestation manifests itself in informal urbanism exacerbating in inequity in Thailand. The 'new' urban poor, part of the pre-Covid-19 socially mobile class, are queueing for food and money donation from mostly private benefactors. This sustains the beneficial aspect of informal urbanism, the role that streets played in providing opportunities, now providing strong social support while at the same time in the virtual media exacerbate the work-from-home, middleclass prejudice that people are crowding and spreading the disease.

My position is that, more than ever, we need micro-scaled, human face-to-face experiences of difference in public spaces. That is not a return to the "village square", but rather a 'retreat' from the antagonistic global digital public realm to city's tangible spaces.

\section{DISCUSSION}

SC: Let me begin with just one theme that I have experienced, that l'm sure others feel too: My daily life has gradually blurred morning and evening, day and night, weekend and weekday. That is related to Pieter's point about scheduling of the city. [...] It seems to me that the temporality of the city becomes super interesting and important to connect to the issue of managing density. Many studies have been done on breaking up the 9 to 5 commuter logic of the city. [...] There are all kinds of larger trends heading into that direction, such as the four-day working week, the rise of cyber-physical infrastructures, the robotisation of labour. What struck me in my own daily life, but also listening to this discussion, is that temporality, alongside the obvious spatiality of the city needs to be considered. An old theme, how spaces are occupied in time, should be reactivated in this new framework.

DR: We can speak about long rhythms, short rhythms and singular moments which highlight certain issues. Therefore - temporality of urban life in the times of Coronavirus. This moment has triggered certain sensibilities and certain possibilities.

SC: The city is getting used in different ways. Those are not necessarily new practices, but they are certainly being retrofitted with interesting technological developments. This is a practice issue that needs larger frameworks. I agree with you, we are inside a different temporality. We are being forced to experience different kinds of temporality. At the moment, we feel a larger sensitivity to the question of time, and how this might be experienced will vary radically depending on which density you occupy. 
PK: I agree with Stephen. It also struck me what Alenka said about adapted behavior in view of local culture. Kuma-san also wrote about that. Practically and technically a lot of things are still functioning, sometimes even more effectively so. Perhaps we could organize a spread-out society which functions while keeping to distance rules. But there is also a "social craving". The opening of the lock-down will not just be for economic reasons, as the very meaning of social life and face-to-face urban culture is the key issue.

AF: I would like to add another point, based on a lot of time spent on Zoom, giving online lectures, corresponding with students and urban designers, I am afraid that my students are having better results than in normal life. Everyone attends, everyone is on Zoom. They have never been so good. Someone may tell us, you have done so good, why would university not turn online. But, I really like working with students, learning by doing things together, making things, having fieldwork. How to do that in the time of distancing? We follow the rules, but we must be concerned with that does to us.

My second point is that of globalization. Knowing that we will not have trips to unknown places, experience new cultures, encounter different faces, discover other typologies and so on - do we only need to think how to stay safe?

My last point is based on an observation that, in my country, some of the business owner prefer to keep them closed not because of Coronavirus, but for economic reasons. Full compliance with the rules of distancing, cleaning, sitting, limiting numbers etc. damages their income, and they prefer to close. Those are significant cultural changes. Which types of activities are going to survive? How will the use of open spaces react to that?

EO: The social distancing might advance centralization of capital and downfall of small companies, as predicted by Karl Marx in $19^{\text {th }}$ century. Social distancing requires tools or platforms for communication, such as Amazon, Google, Facebook. That could cause centralization. For instance, in Japan bookstores flourish. About two times per capita comparing to UK, and four times to the US. Because of the lockdown there are no visitors and customers, bookstores will have to close. Only Amazon and the likes will be able to supply books and food. That could result in domination of big suppliers. Direct face-to-face communication and urban density guarantee direct communication and cultural diversity. If we let the current trend to proceed, diversity might be provided only via Netflix and Amazon. All that together would critically deprive smaller groups of people.

PK: That is an interesting point that brings us back to the question of density. One could say that a society which Oguma-san describes could be the ultimate result, the nightmare resulting from this crisis. This might be less dramatic in low-density non-urban areas. But it could be catastrophic to urban density conditions. Density should not just be measured in numbers, but as density of behavior and cultural patterns - what ultimately makes the society.

DR: In the period 20I I-I4 we had a major research project Measuring the nonMeasurable, which has dealt with dialectics between urban density and intensity, also asking - the density of what? That is in the spirit of Georg Steiner, who described that the density of discourse made Greek polis an epitome of the public. 
Up to this moment, our discussions pointed at human nature, at the need for what JeanLuc Nancy formulated as "being with". That is not Heideggerian "being", living in an isolated hut to fully be (human). We are like chemical elements; we need another human being to create a "molecule". That is our precious, defining social capacity and need. As Pieter has put it, social craving. Prisoners get additionally punished by isolation, by solitary confinement. These days we are all becoming Zoombies. Zoom and Webex cannot replace, they only reduce reality. From citizens, we have already been reduced to consumers; now, we all became users. SC mentioned the example of Singapore, where Coronavirus dented the famed efficiency and cleanness by exposing hidden reality, the existence of an invisible underclass.

SC: That reflects what Sidh mentioned. The issue of class gets revealed in the time of crisis.

I am also interested in Alenka's report about studio teaching. I am fond of the same kind of things. I also love bookshops, cafés, markets, but I am skeptical about nostalgia that we might attach to that kind of sociality. I would rather be in Tokyo talking together in a nice restaurant, but this - this virtual, zoom-enabled - kind of sociality is only possible at this moment because of the particular condition and technological mediation. Perhaps there is a new kind of sociality taking shape. I agree with Darko this is a "being with", the relational issue. Density is always quantitative and qualitative. This is a technologically enabled social meeting. This interface diminishes it in some way, but enhances in another way. I do take the point about the dark under side of the cause. There has to be some way in which the digital media becomes a commons. Where is the governance system that would allow the commons of the web to emerge? I agree with you, but I am skeptical about nostalgia for old forms of sociality.

DR: It is not either-or, it is both. There was never a city without technology, of course. This idea about governance is of critical, strategic importance, getting it straight across scales. Only, to me, the idea of global governance and government is always dangerous.

SS: Continuing on Stephen's point about social media as public space, or commons. This is one of major challenges as this type of commons seems to be making things worse, not better when we return to real space. I also want to raise the question of 'privilege', the position we are in when discussing and talking about all of this, whether it is compromising, devaluing the real space if this becomes the 'new normal'. I am sure that tech companies have plans in place to make these tools function better, taking us further away from real physical spaces, tangible social interactions, especially with people who are different from us.

In Singapore, where the story of the First World was, in a month, followed by the story of the Third World situation. Those two worlds seem to be totally segregated, with no links between them. Global audiences became aware through this new interfacing. SC: They were physically separated, in tangible physical spaces. Digital media, such as Tiktok, allowed us a glimpse into those realities.

DB: Environmental issues have not been mentioned yet. We are looking at this Coronavirus issue from an anthropocentric perspective, how all this affects human health and human well-being. But the lockdown, stopping of many human activities 
(gatherings, traffics, travels) has significantly reduced our environmental impact. For instance, Bangkok "normally" has a tremendous problem with air pollution, but during the lockdown people can breath clean air again. To me, the question is what will happen when the lockdown gets eased and human activities resume? Should we allow ourselves to return to that unacceptable "normal", or seek ways for not going to the same place?

EO: I don't intend to stick to nostalgia, but I want to make a point related to the character of interaction in communication with social distancing and in digital media. Being out in, for example, Central Park will cause coincidental interactions. If we visit the Park, we will meet come across unexpected persons, people of different social class. If we were to interact in digital media, our communication is limited to the same class, same level of education. That causes the decline of diversity, and polarization.

Researchers of social media claim that they follow the Biblical Law of Mathew, with rich becoming richer, and poor staying poor. [...]Marshall McLuhan, pointed out that printed media enhance only one single sense of vision. In this Webex meeting, we can see and listen, but we cannot smell each other. Of our five senses, digital media engage only two. I think McLuhan suggested that such kind of limitation in communication contributes to the raise of nationalism, homogeneity and centralization.

DR: Referring back to the Nancean "being with" and reduction to only two senses, all of us here as well as our students in their "cells" get reduced, flattened to only one task at the time. While such reductionism might increase "useful" execution of certain tasks, it does diminish our humanity.

\section{Roundtable session 2, I May 2020}

Antonella Bruzzesse AB, Beatriz Maturana Cossio BMS, Ana Medina AM, Darko Radović DR

David Sim DS, Saline Verhoeven SV, Davisi Boontharm DB, Chair

\section{INPUTS}

DB: I am privileged to be locked down in a beautiful city, but that beauty is now reduced to that of space, to pleasure for eyes. That beauty cannot compensate for an awareness that people suffer, with no income, no spaces that feel safe.

“Think Globally act locally". The pandemic has stopped global movement and activities. It limited us to basic needs, depriving us of social life. The lockdown also heightens everybody's responsibility towards others. One of direct consequences is the collateral dramatic reduction of emissions. In congested and polluted cities like Bangkok the lockdown has brought back the sidewalks, clean air, smooth traffic. However, the most vulnerable people whose lives depend on streets are paying huge price. It shows that something is wrong in the system we are living in.

What if we don't stay limited to anthropocentric perspective. I ask: is it possible to "restart" towards genuine triple bottom line? The release of the lockdown is coming, but we shouldn't go back to "business as usual". We should learn from this crisis. Can elements of the lockdown become new "normal", giving priority to environmental quality, social equity and different economy? 
AB: I Live Milan. Lombardy is one of the regions worse hit by Coronavirus. The mantra "stay at home" opens the question "what is home?". Studying public housing in Milan, I investigated what l've called "sequences of domestic spaces". Not only the apartment but a series of different spaces are part of our experience of inhabiting our idea of home: public and collective spaces that somehow makes the city. Otherwise, we have gated communities with well-equipped and introverted houses unable to create spaces of exchange and urbanity or, at the opposite, a series of small apartments unable to fully respond to the needs of the people. The opposite of a livable city. This crisis has reduced the idea of home to private, familiar spaces. This concerns our understanding of living space, creating an opposition where interior, home is private and safe, and outdoor, public is dangerous. A kind of mistrust in public space has emerged, while the infections actually happen mostly in closed and private homes. In order to make public spaces work again, we have to dismantle such mistrust and rebuild the meaning of public space, to bring it back into our understanding of home, inhabitation and good living. We are not facing an easy future. On one side there is a strong push to go back, as if forgetting COVID was possible; on the other side is the push towards privatization, gated houses as supposedly safer. In the middle is a challenge of new normality, new ordinary, public spaces with distanced people, different scales of intervention, even in time. We need to go back to public space, with stronger attention and different proxemics. For Ugo La Pietra "living is feeling at home everywhere". In order to build the new ordinary, we need to feel safe both at home and in public space.

BCM: In Chile, before the pandemic, five months of a politically motivated crisis was played out in public space. On October 18, 2019, unprecedented citizen violence exploded with widespread looting, arson and vandalism destroying public buildings, urban facilities and infrastructure. Formerly a good example of integrated living, by March 2020 the centre was destroyed by this protest and renamed Ground Zero. Public pride was transformed into public fear and residents fled. The self-induced recession that followed was suspended on March 18 by COVID 19. It sounds terrible, but the pandemic saved the city. The destruction is being repaired and the threat to citizens is in quarantine. We can hear the birds not the riots, smell the air not the arson.

I am interested in ethics of public space, as much as in its physical changes in any crisis. How a functioning and economically growing capital city (carbon neutral by 2040) can evolve into a public disorder of "protest" that can destroy the infrastructure and trust of its public spaces that can only be stopped by a public health crisis.

AM: People make cities and public space is about time. We are confined indoors (those who are lucky to have a house) while the city is being attacked by an invisible monster. Now, we only see empty public spaces. Changes considered impossible became real: from cultural buildings transformed into hospitals to anti-riot water-cannons disinfecting streets. Social distancing makes me think of three themes: (I) surveillance was with us for years, but now it inside us; (2) informal local activism gets redefined; (3) how public space will be in informal cities, which is the normality for millions?

DS: Urban life is defined by time and place. Paradoxically as the world has slowed down, we seem to have more time, we have become time rich. The world gets smaller and we more mindful. Simple experiences have gained more significance: eating, going for a walk, a 
bit of sunshine on your face, wind on your skin. Sensory moments became more significant, as we have time to notice them.

I am concerned about human scale. Things like a window suddenly become more significant. A balcony. A front garden. Would you like to negotiate space with others in an elevator, or take staircase so that you can manage the contact? In this crisis, different urban forms make our lives easier, or more difficult. The buffer spaces (windows, doors, balconies, front gardens), which seem like boundaries, are connecting us, allowing us to be together. Like a mask that allows us to be closer, yet separate. We can still socialize, while keeping physical distance. The softness of architecture lets people connect to the world.

SV: In Amsterdam we have "intelligent lockdown". People are advised (not forced) to stay at home as much as possible. In discussions about limited public space, infrastructure, cars, economy, money-related issues usually win from adding green space. But in the times of Coronavirus green spaces are amongst the basic needs. For me, healthy cities are those that combine ecological, physical and mental health.

People walk. Walking eases stress. Walking is a nice way to uplift your spirits and to reflect. Dispersed accessibility of enough green space helps. In the Netherlands, people were heading to popular nature parks and regions in such numbers that they had to be closed, to avoid overcrowding.

Space can be found. Trying to work from home, we don't commute; we do not need to travel much. Travel is commonly considered as essential. How to turn such thinking around? Can we rethink car-oriented mobility? Giving space to humans. Healthy economy needs healthy population.

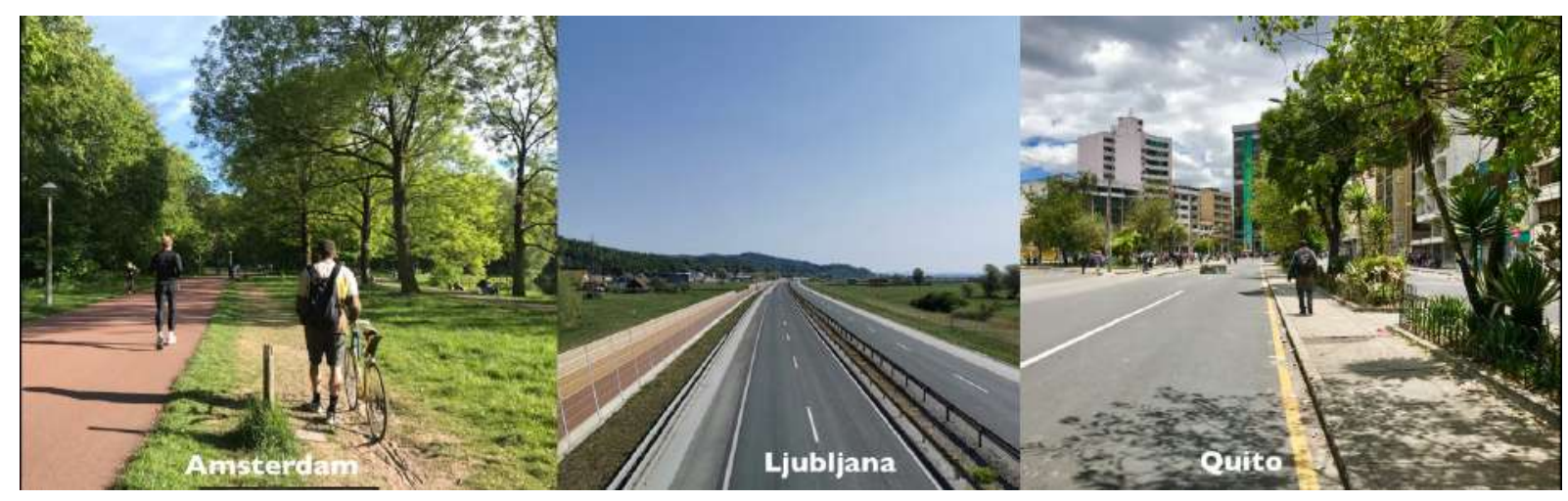

Figure 6. Adding room to walk in a park in Amsterdam, the empty highway in Ljubljana and clam street in Quito

\section{DISCUSSION}

DR: Many discussions address normality. If we agree that in these times of crisis, which is not going to end abruptly or fast, the dominant, so-called "free" market economy doesn't work, a question to ask is - what kind of economy can work? The return to economy which does not work makes no sense.

I also want to highlight the importance of politics. Involvement of medical experts in dealing with pandemic provides the sense of confidence. I believe them. But now, economists are getting back as key advisors to politicians, and - I do not believe these advocates of a particular school of economy. Cities need generalist experts, capable to 
deal with the totality of the city. Of course, that is complex. Balcony makes full sense only when there is somebody, hopefully someone significant to you, down in the street.

DS: In Sweden the crisis is non-political. This situation is totally run by the experts. The Prime Minister stood back. The schools remained open, as closing them was an emotional question. Across the EU the trust in government varies. Should we talk about the software, governance, trust and control, or about something physical, the fabric of the city?

DR: For me, in Lefebvrian way, each city is spatial projection of a concrete society. When talking about society we already speak about "hardware". Every city looks precisely like the society producing it.

DS: But suburban Netherlands looks like suburban America. Detached houses and cars seem safe, but they are separate from everything else. In urban environments we are better connected, we survive because we know our neighbours, we are closer to things, we can better organise our lives on foot. We don't have to have a car. Which environment performs best in the time of crisis?

DR: To that, I would only add - "where?".

BCM: Globalization is one of my themes. The virus is shared globally, but response varies according to the social, economic and political conditions of each country. Chile has an enviable record in its approach to COVID 19. The pandemic has revealed the question of self-reliance and the government's ability to coordinate and commandeer the goods, services and resources of the public, private and civil society sectors. The world's dependence on China for primary materials, technology and products, including medical, has shifted thinking in many countries.

DS: In Japan you do not wear the mask to protect yourself, but to protect others. It may be uncomfortable for me, but it protects you.

SV: I want to discuss that in terms broader than masks. City space can generate or stimulate care for others. In Amsterdam I notice that, when spaces get crowded, people give room to others. Providing room for everybody is an issue for urban design.

DR: Wearing the mask, or keeping distance are expressions of urbanity. I disagree with politicians stepping back. They should represent us, as an executive arm of our will. They should listen to experts, make us informed, take and let us take responsibility.

Responsibility distinguishes citizens from consumers.

AB: I live in the region where more than 12,000 have died (now I5.000!). Every local situation is different and differently influences our questions and issues. What can be in common is that as our space of living has been reduced (home), our attention increased, for example I became more aware of the people I meet and the places I lived in; our understanding of needs towards public spaces somehow changed: I need green spaces but for a dispersed use to keep safe distances; we need to go back to a more complete idea of public spaces including our bodies, or the unexpected: digital media (as this one) it is not enough. So what to do? What the public administrator have to do? 
DS: There is a question of responsibility. It is not about giving up responsibility, it is about leaving it is up to the individuals to use their common sense instead of applying blanket rules. It is about decentralizing the decision making, applying common sense to allow society to work, to be able to live even 2-3 years in the situation of lockdown.

AM: Following Antonella point, Ecuador doesn't have a government capable to deal with disasters. Everything is down to the local governments. The two biggest cities, Quito and Guayaquil, are very different. Guayaquil is hot and humid, highly dense. People depend on air-conditioning. Spending precious time outdoors became impossible. Quito depends on daily informal economy. Neither public spaces are democratic, but time is.

BMC: Continuing with what Ana and Darko said about capitalist neoliberal politics, I agree, the city is political and economic. For forty years neoliberal politics led Chile to a different place from where it was before. However, this government has dealt with Coronavirus in a very technical way, which works. Chile is 4000 kilometers long and highly centralized which appears to be a problem. Santiago has one third of the country's population. In our COVID 19 response, centralization has provided a coordination of the public health services, infrastructure and equipment that are planned and delivered in this circumstance. Country without economy will starve people to death. ... Politics, economics and the city are never straightforward.

DB: In the previous session, SS mentioned another type of conflicts, the search for scapegoats. In some countries politicians want to sue the Chinese government. Xenophobia gets expressed in public. In Melbourne, two Chinese-looking students were attacked. So, yes, we are aware of each other in public space, but let's not forget that those spaces are conflictual.

DR: Globalisation is an elephant in the room. It is not only that difference exists; we are entitled to our differences. In the times of crises, the likely scapegoats are precisely those who don't look like me, like majority. The loss of diversity and cultural difference to this crisis would be terrible. Protecting the right to be different is a civilisation imperative.

DS: We have different politics in the background, which is natural. We became aware that we need people of lower skills more than ever before. The crisis made us see them and appreciate their contribution. I want to bring the conversation back towards physical.

SV: People and circumstances are different. As Antonella stressed, the city is our home, so we should be aware that everybody needs good life. Spaces have to be flexible to accommodate others. Public space is part of our homes, that is important.

AB: Our discussion is becoming clear. It not only about space, but about interdependences and relationships between people. My possibility and way to stay in public depends also on the behavior of others. We are enlightening a banal but important issue - the significance of interdependence. 
AM: Using public space only "when needed" is a frightening issue. It takes long to democratize space, which now gets subjected to increased control. What would be the ways other than government surveillance of public space? Some kind of resilience, dissidence, resistance? Bottom-up provision for the needs of people, local dynamic, extra small scale?

DR: Availability of public space at all time is needed, to which Kuma-san referred by invoking Giambattista Nolli's Map. That is part of the right to the city. When I say politics, I mean even that of the shared corridor, which Antonella mentioned earlier. As soon as we encounter other people, we are negotiating space. All relationships are political, the Nancean "being with". Public spaces provide opportunities to meet even those whom we dislike. It makes us aware of each other, form positions about each other, about difference itself. Thinking about politics is not primarily about politicians, but about being human.

BMC: The quarantine helps us reflect upon consumer society. I was lucky to live in a cultural precinct with art galleries, shopping, theaters, cafés, music, restaurants with tables on the footpaths, where going out and using public space to "see and be seen"which also meant consuming - was essential. The pandemic has made many realize that we do not need much to live well and I wonder whether there is a level of fetishism about intense "café culture" and public space.

\section{OUTPUTS or - INSTEAD OF CONCLUSIONS}

The following words and phrases kept on reappearing and stayed lingering on, after the discussions were over.

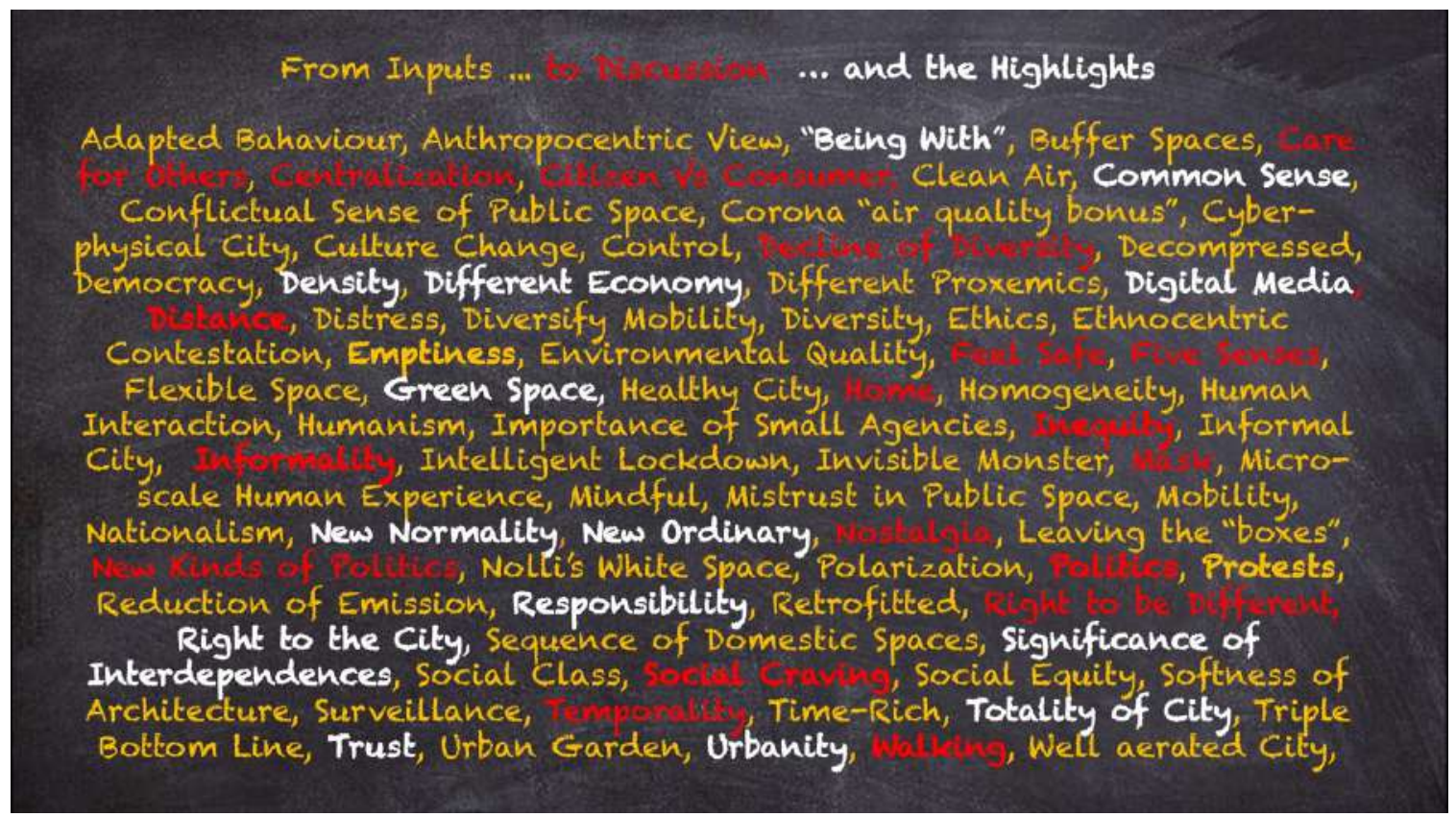

Figure 7. Blackboard of keywords raised from the two sessions of round tables in alphabetic order (curated by Davisi Boontharm) 


\title{
VIEWPOINT
}

\section{Thoughts on Public Space and Flourishing during COVID- I 9}

\author{
Setha Low \\ City University of New York (CUNY), The Graduate Center, United States of America \\ slow@gc.cuny.edu
}

\begin{abstract}
Public space offers the places, circuits and networks used for contact with the diverse people and different activities that make up our social and psychological world. There is 35 years of ethnographic research evidence that public space is a major contributor to a flourishing society by promoting social justice and democratic practices, informal work and social capital, play and recreation, cultural continuity and social cohesion, as well as health and well-being. During this COVID-19 pandemic, however, we are experiencing a shrinking sense of this world and the resulting isolation tears at the fabric of our lives and exposes how dependent we are on one another for well-being and happiness. At the same time the pandemic highlights the socioeconomic basis of disease vulnerability and exposure risk. Expanding the use of streets, parks and open spaces can help to reinstitute the kinds of connections and relationships that underpin a flourishing society but only if a social justice agenda is kept in mind.*
\end{abstract}

Keywords: public space, covid-19, flourishing, positive psychology, inequality

* This article includes data updated to March 2021.

To cite this article:

Low, S. (2020). Thoughts on Public Space and Flourishing during COVID-19, The Journal of Public Space, 5(3), 249-254, DOI 10.3289I/jps.v5i3.I365

This article has been double blind peer reviewed and accepted for publication in The Journal of Public Space. 


\section{Introduction}

Public space offers the places, circuits and networks used for contact with the diverse people and different activities that make up our social and psychological world. During this COVID-I9 pandemic with the closing of public spaces and restrictions on public interaction, though, we are experiencing a shrinking sense of this sociality. Instead we are focusing on our families and home places as we translate the numbers of cases, hospitalizations and increasing numbers of deaths into risks faced individually. The resulting isolation tears at the fabric of our lives and exposes how dependent we are on one another for well-being and happiness.

Most of my friends are suffering from isolation and loneliness because they can't go to their neighbourhood gym to workout, meet in their local café or bar to talk at the end of the day or attend services at their church, mosque or synagogue. The number of calls I make to my family and friends has increased and I treasure my online courses and meetings with students for the sense of connection they provide. I expect that the ties to friends, third spaces such as churches and cafés and local community will remain intact regardless of how long this persists as we are actively "missing them" in a palpable and visible way. But what about other spaces, including public spaces, where we meet people we do not know and create new ties and relationships?

The pandemic is also revealing the socioeconomic inequality and racism that structures the built environment particularly in terms of housing and household density, adequate health services and safe public transportation as well as the amount of public space available for being outside safely. The coronavirus hotspots in most cities are in the poorest neighbourhoods, often populated by Black and Latino residents who are also essential workers without adequate health insurance, job security or the ability to shelter-in-place as public health officials advocate. Not only is the pandemic socially and psychologically painful for low-income residents, it is also economically and physically devastating.

\section{Fear of public space}

I am concerned about the use and meaning of public spaces that are now deemed dangerous because of the possibility of coming into contact with those who might be infected. Similar to people who live in a gated community, each time a person walks outside they are reminded to wash hands, exercise physical distancing, wear a mask and avoid groups and indoor spaces. While this is certainly prudent advice, we need to ask what the long-term impact will be on the fragile ties that weave together a complex society together.

Just the daily separation of us and them (or "people like us" and "others") can become a pattern that reinforces segregation and with it less tolerance, more fear and greater prejudice.' What will be the consequence of fearing that others may be contagious and unknowingly cause us harm? I expect that social distancing could be a new norm, recruited for other purposes and feed into already festering class and racial anxiety, now in a "medicalized" form. And what about the xenophobia of calling it a "Chinese

\footnotetext{
' Low, Setha (2003). Behind the Gates. New York: Routledge.

Low, Setha (2017). Spatializing Culture. London and New York: Routledge.
} 
virus" and recent attacks on Asian Americans simply because the previous US President associated a nation with the initial infection. Where does this kind of thinking and daily practice lead? A "booster shot" to the already increasing xenophobic, racist hate crimes and police beatings of Black men that predate the viral threat?

There are already more announcements about who should be allowed into a state or city based on whether they might be a carrier of disease. People living in Sweden can not enter Norway or Denmark because of differences in their COVID statistics and degree of openness. For a period of time in the U.S., Rhode Island and Florida police stopped and questioned New York City drivers before being allowed to enter. A few months later, Florida is the hot spot and their residents are not welcome elsewhere. Hong Kong requires a I4-day quarantine upon entering for everyone and visitors must where bracelets that record their date of arrival. There is now talk about creating "vaccinated" passports for those who were able to get the vaccine (only 9.3\% in the US on March 8, 2021) leaving those who were unable or unwilling to be vaccinated excluded from a return to any kind of spatial normalcy.

All this is to say that not only is our physical, mental and economic health being challenged, but also social health that depends on ongoing interaction with people who are different in a multiplicity of ways. It is more important than ever to think about the various obstacles faced, and to not retreat into separate "clean" and "safe" places for some and "dirty" ones for others. Instead I suggest that we consider public spaces the basis for a flourishing society and address the new lessons learned from the risks and consequences of the restricted use of public space during COVID-19.

\section{Public space contributes to a flourishing society}

Public space contributes to the flourishing of individuals, communities, cities and societies. "Flourishing" refers to what are considered the essential psychological components for humans to thrive from a positive psychology perspective, although this individual-focused paradigm can be extended to include social and group well-being. Ideas about flourishing also draw upon research on universal human needs and values for a healthy and productive life.

Flourishing offers a normative perspective in much that same way that Susan Fainstein employs Martha Nussbaum's set of human capabilities necessary for the full development of the person in her formulation of the just city. ${ }^{2}$ Flourishing goes beyond the usual standards for what urban planners and designers mean by a well-designed space, but depicts aspects of what it means to be human and an agent in one's own life. Applying these psychological attributes as a guide for design and planning public space provides a different way of imagining the built environment and its social infrastructure. Positive psychology is a school of applied psychology that studies the strengths and characteristics that enable individuals and communities to thrive. The best-known proponent of this theory, Martin Seligman, suggests that psychologists need to focus more on what allows people to flourish rather than on measures of poor mental

\footnotetext{
${ }^{2}$ Fainstein, Susan (2005). Planning theory and the City. Journal of Planning Education and Research 25: I2I-I30.
} 
health. ${ }^{3}$ Incorporating Mihaly Csikszentmihalyi's work on flow, Seligman and Csikszentmihalyi define positive psychology as "... the scientific study of positive human functioning and flourishing on multiple levels that include the biological, personal, relational, institutional, cultural, and global dimensions of life." ${ }^{4}$ Their research provides evidence that flourishing can be attributed to what they call "PERMA" that is composed of encouraging positive emotions, engagement through activities, relationships with other people, meaning and purpose, and accomplishments. Another contributor to this discussion, Tyler VanderWeele adds physical health to this list and also considers the role of character and virtue. ${ }^{5}$

John Kinyon and Ike Lasater offer another way to characterize optimum human functioning based on three sets of universal human needs and values: I) well-being, 2) connection and 3) self-expression. ${ }^{6}$ Their model includes sustenance/health, safety/security and beauty/peace/play as part of well-being; love/caring, empathy/understanding and community/belonging as components of the need for connection, and autonomy/freedom, authenticity and meaning/contribution as subcategories of self-expression. These additional human requirements expand the original PERMA criteria.

Combined these psychological theories offer a useful framework for thinking about the importance of public space at multiple levels. I have added social justice to the list, which at the individual level is sense of fairness, but at the community and societal level is composed of other positive values such as social inclusion and belonging, representation, recognition of difference, and an ethic of caring. These dimensions extend Seligman's PERMA and Kinyon's and Lasater's human needs and values and are reconfigured to include social and cultural goals that enhance human life.

Based on thirty-five years of ethnographic research there is empirical evidence that public space contributes to this expanded definition of a flourishing society through promoting I) social justice and democratic practices, 2) informal work and social capital, 3 ) play and recreation, 4) cultural continuity and social cohesion, 5) health and wellbeing, and 6) sustainability and urban infrastructure both in the US and Latin America. Social justice includes social inclusion and belonging, representation, recognition of difference, ethic of care and contestation and resistance. Health and well-being include physical health, mental health, safety and accessibility, a sense of security, and resilience and community pride. Play and recreation includes the socialization of children, sports and team building, relaxation, retreat and religion in everyday life, and creativity.

\footnotetext{
${ }^{3}$ Seligman, Martin (20II). Flourish: A Visionary New Understanding of Happiness and Well-Being. New York: Simon and Schuster.

${ }^{4}$ Seligman, Martin and Mihaly Csikszentmihalyi (2000). Positive psychology: An introduction. American Psychologist 55(1): 5-14, page 5.

${ }^{5}$ VanderWeele, Tyler J. (2017). On the promotion of human flourishing. Proceedings of the National Academy of Science, USA I I4(3I):8I48-8I 56.

${ }^{6}$ Kinyon, John and Ike Lasater (20I5). From Conflict to Connection. El Sobrante, CA: Global Reach Books.
} 
Culture and social cohesion include cultural identity, cultural continuity, collective memory and place attachment. Informal economy and social capital include flexible workplaces, innovative forms of work, poverty reduction and social integration of immigrants. Environmental sustainability includes biophilia, disaster recovery, urban climate control, and reduced environmental injustice and toxic pollution. Public space plays a role in each as the Public Space Research Group has been able to demonstrate. These positive outcomes are based on empirical research and ethnographic findings on the presence and use of public space at neighbourhood, region and city levels. They are substantiated by a variety of methods, from quantitative surveys to large-scale park ethnographies and micro-sociological studies of social interaction on streets and sidewalks. When viewed together they offer a powerful argument that public space needs to be protected during periods when its use and availability might be questioned because of fears of crowds and people being too close together. And yet, even when protests for Black Lives Matter filled the streets of cities throughout the world it did not accelerate new outbreaks, and instead pointed to the deep discrepancies in the treatment-including the incidence and death rate during COVID-19-of Blacks and Latinos. Public space in fact offered the streets, parks, plazas, beaches and sidewalks where people could be together safely, and provided a forum to address the underlying problems of inequality that COVID-19 uncovered.

\section{Conclusion}

Public space is the major site of social interaction, contact and connection in our society. Failing to appreciate its importance and its promise as we practice social distancing and relocate our social lives to a virtual realm puts us at risk in multiple ways - mentally, physically and politically. Without public space it would be easy to overlook the inequality and lack of resources that plague cities and instead provides the parks and streets for the struggle against racism. Public space allows for some of the safest ways for people to be with each other, whether on a leisurely walk or a swim in a lake or ocean. I suggest that we remember and continue to celebrate what we are temporarily losing to restrictions and closures and appreciate its ability to improve our lives. 
Thoughts on Public Space and Flourishing during COVID-19

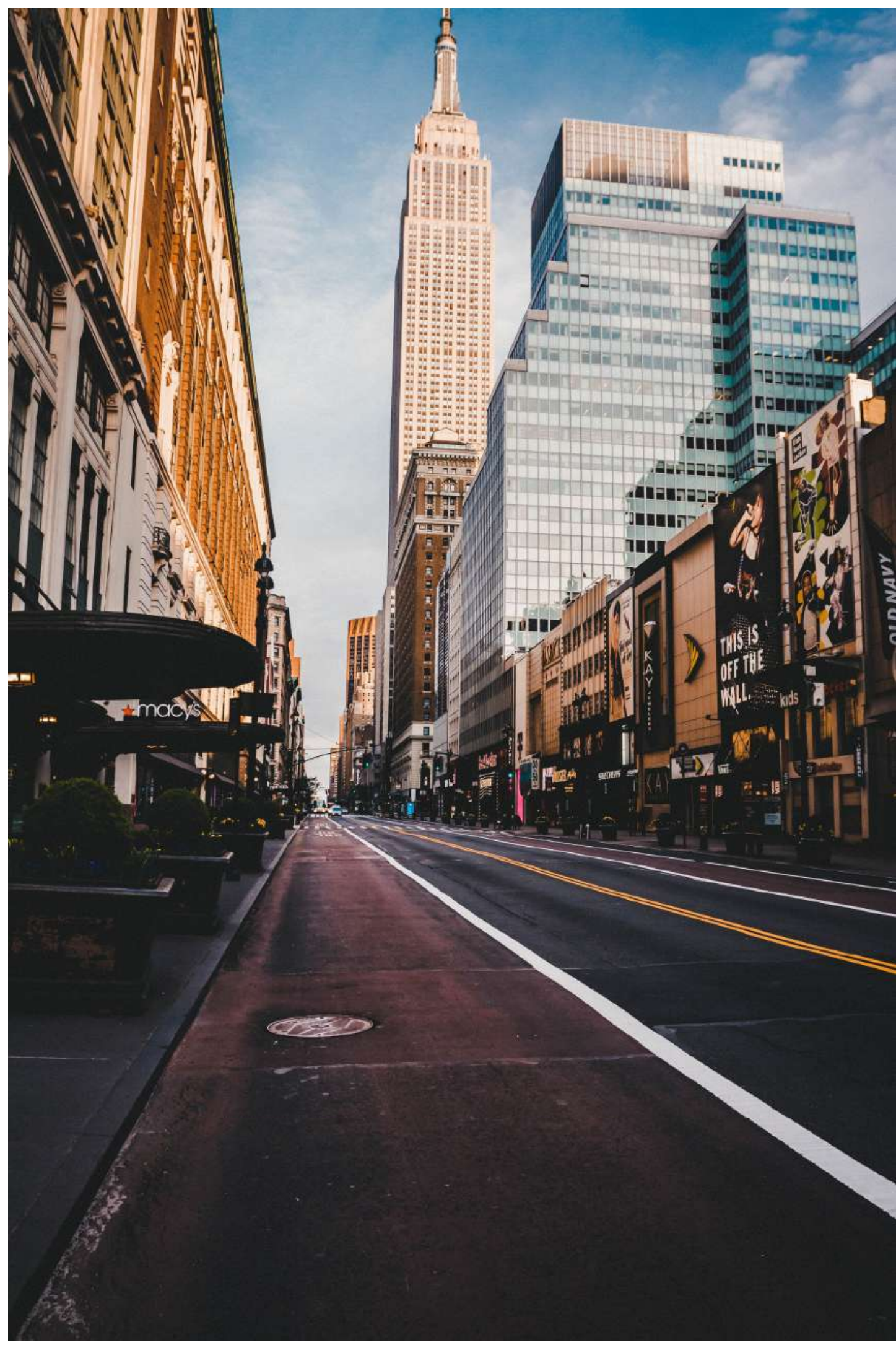

Figure I. A deserted 5th Ave. during the coronavirus lockdown in New York City, USA. Photo by Paulo Silva on Unsplash

254 | The Journal of Public Space, 5(3), 2020 | ISSN 2206-9658

City Space Architecture / UN-Habitat 


\title{
VIEWPOINT
}

\section{Artists in the Streets. Seattle Murals in the Time of COVID-19}

Catherine Anstett

Seattle, United States of America

dcasea2@hotmail.com

\begin{abstract}
Seattle has become known in recent years as the city with the most construction cranes in the nation. But in March 2020, the city grew quiet. The Seattle area was one of the first in the United States to be hit with the coronavirus and on March 16 Governor Jay Inslee closed restaurant dining rooms state-wide. On March 23, he issued a stay-athome order. Stores and restaurants closed; streets and sidewalks became empty. Property crime went down in residential areas because people were at home, but businesses and storefronts became targets. In some areas, windows were covered with plywood as a security measure.

Artists began to paint the shuttered storefronts and then one after other businesses requested the murals. Business groups in several communities sponsored murals and offered stipends to artists, prioritizing artists from the local neighbourhood. These neighbourhood streets became outdoor museums. By early May, there were nearly 200 murals.

A virtual community formed as artists, photographers and friends shared videos and photos on social media. AP and Reuters photographers posted images that reached as far as Mumbai. The Seattle Office for Arts and Culture said, "Throughout this crisis, we have seen community come together and hold each other up like never before. We have watched organic movements take hold that are devoted to supporting those in need financially, emotionally, spiritually, and creatively." The murals were an important part of this effort, for the artists, businesses, and the larger community. A book documenting the murals was published.

As Seattle artist B Line Dot said, "Art marks moments... this is a moment."
\end{abstract}

Keywords: murals, COVID-19, Seattle, Capitol Hill

To cite this article:

Anstett, C. (2020). Artists in the Streets. Seattle Murals in the Time of COVID-19, The Journal of Public Space, 5(3), 255-266, DOI 10.3289I/jps.v5i3.14I4

This article has been double blind peer reviewed and accepted for publication in The Journal of Public Space. (c) This work is licensed under a Creative Commons Attribution - Non Commercial 4.0 International License https://creativecommons.org/licenses/by-nc/4.0/ 


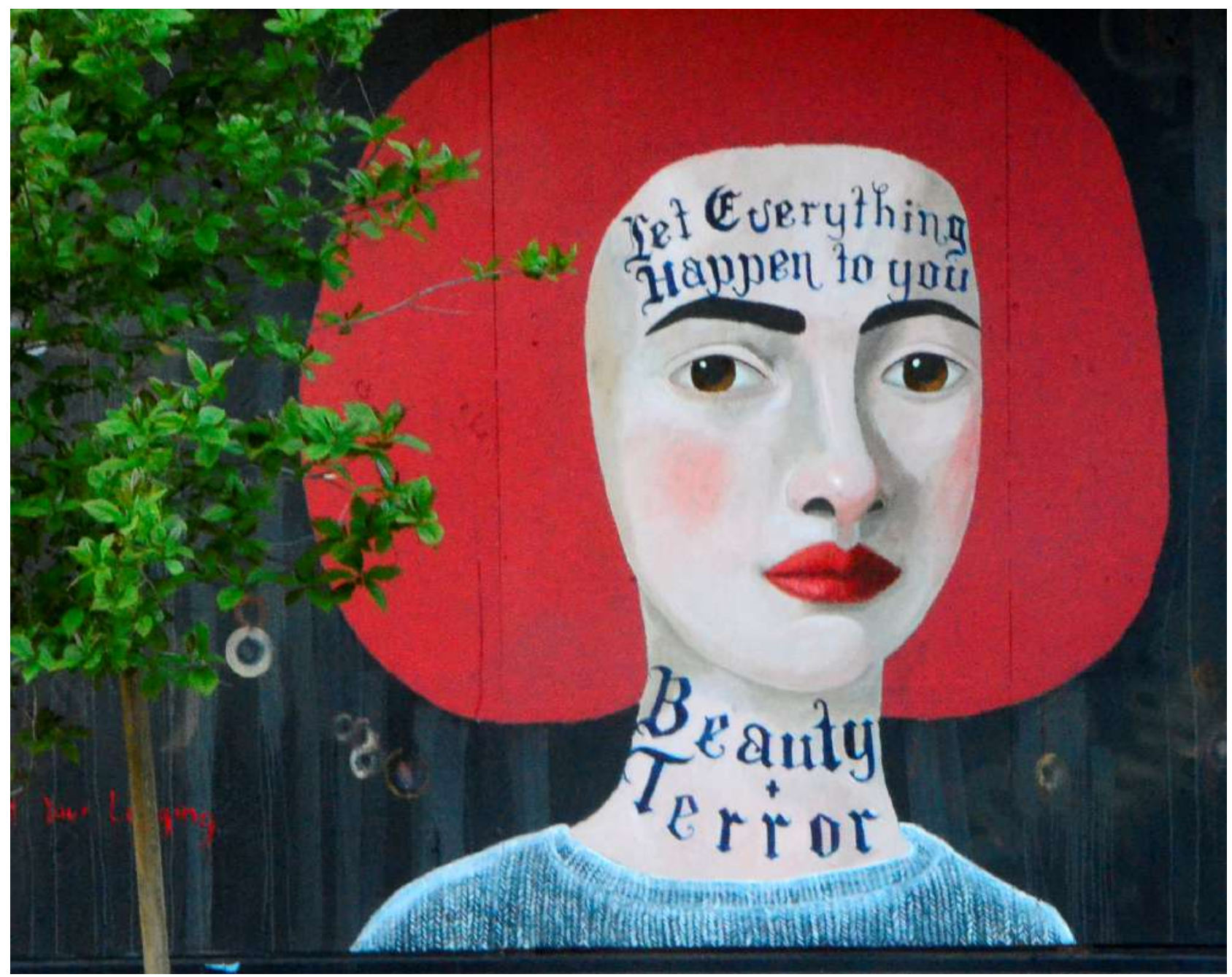

Figure I. A mural by Anne Siems, titled 'Beauty + Terror', on a boarded building in Seattle's Capitol Hill neighbourhood. The (red) quote on the left says: 'Go to the Limits of your Longing' poem by Ranier Maria Rilke. Picture by Catherine Anstett (2020).

Seattle has become known in recent years as the city with the most construction cranes in the nation.' But in March 2020, the city grew quiet. The Seattle area was one of the first in the United States to be hit with the coronavirus and on March 16 Governor Jay Inslee closed restaurant dining rooms statewide. On March 23, he issued a stay-at-home order. Stores and restaurants closed; streets and sidewalks became empty. Property crime went down in residential areas because people were at home, but businesses and storefronts became targets. In some areas, windows were covered with plywood as a security measure. (Figures a,b)

In March, the Jade Garden Restaurant in Seattle's Chinatown/International District was broken into, and the restaurant boarded its windows with plywood. It was never certain whether this was a hate crime related to the virus. The community responded, as local photograph Keiko Silvano sought artists to paint the plywood, in part to attract customers since the restaurant was still open for takeout and delivery. Five Latino artists volunteered and painted murals to reflect the spirit of the restaurant (Figures c,d,e). 

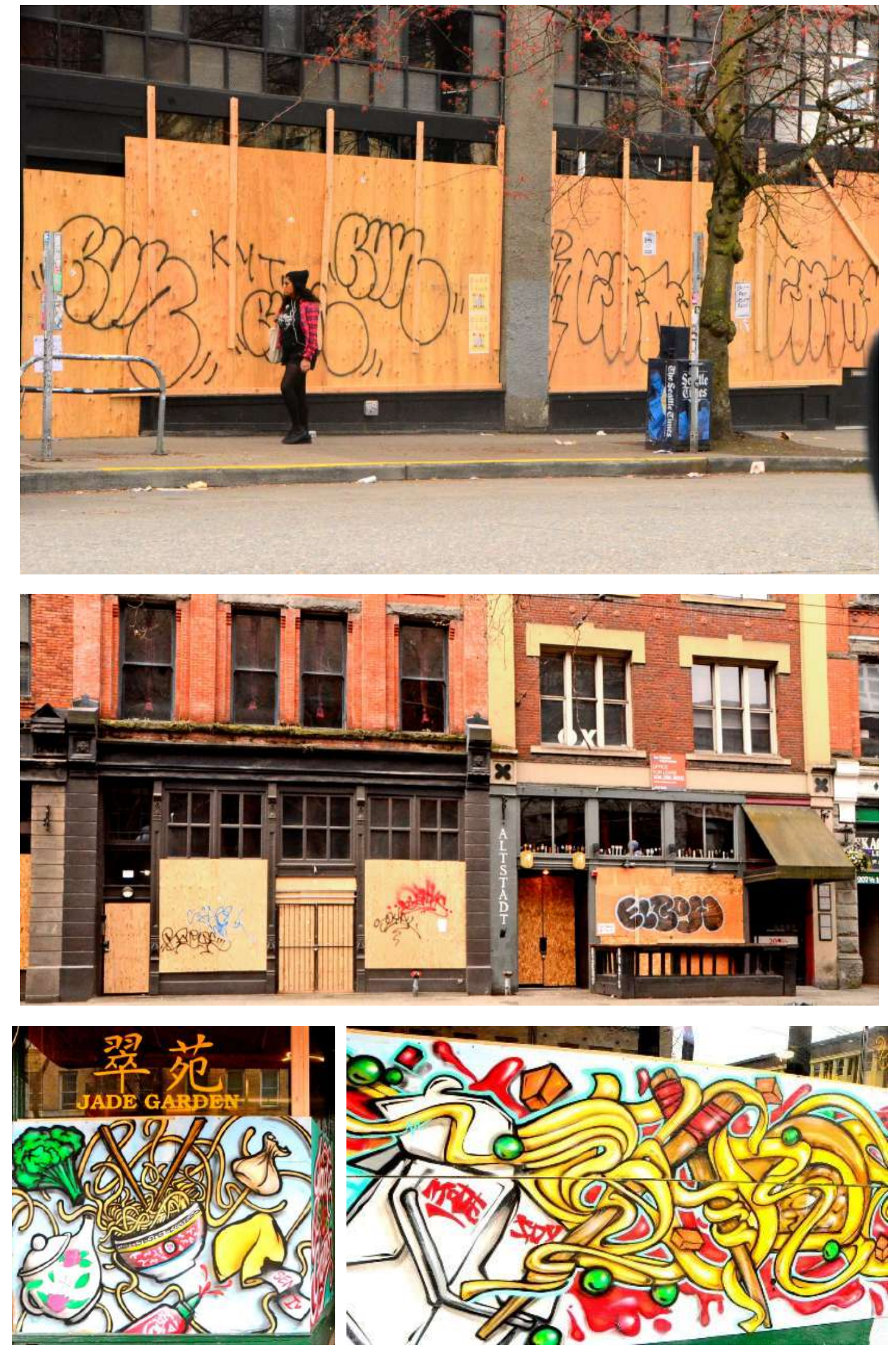

Figure a, b, c, d, by Catherine Anstett (2020). 

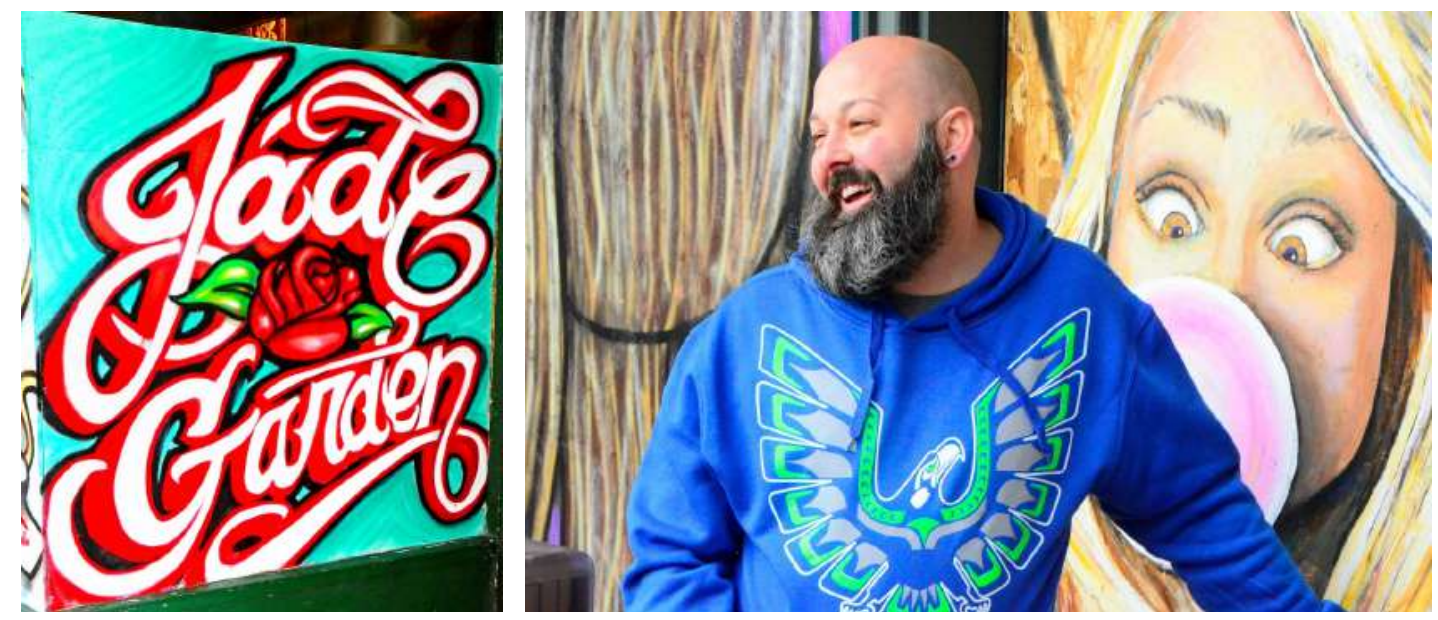

Figure e (left), Figure $f$ (right), background murals are by Henry and by Debora Spencer. Picture e and f by Catherine Anstett (2020).

In a nearby neighbourhood, Belltown Pizza was vandalized and owner Brian Lee put out a call on Facebook to artists. Within hours he had more than 200 responses and became the point person for murals not just on his restaurant but in the Belltown neighbourhood (Figures f,g,h). Some Capitol Hill bars had their windows broken by an axe wielding vandal. Artists began to paint the shuttered storefronts and then one after other businesses requested the murals (Figures i,j).

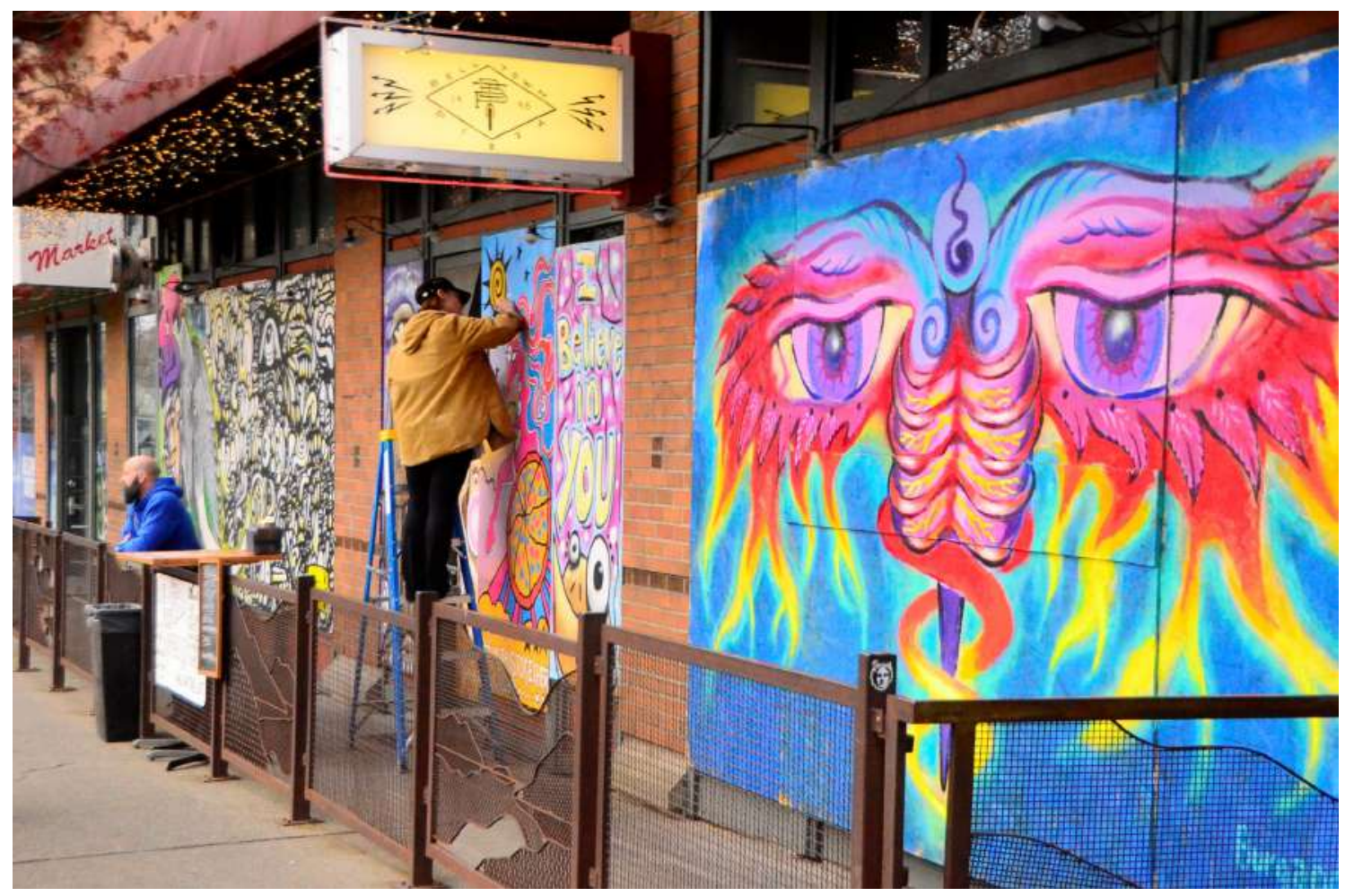

Figure g. Artist Tara Velan and Burgandy Viscosi. Picture by Catherine Anstett (2020). 
Artists in the Streets. Seattle Murals in the Time of COVID-19

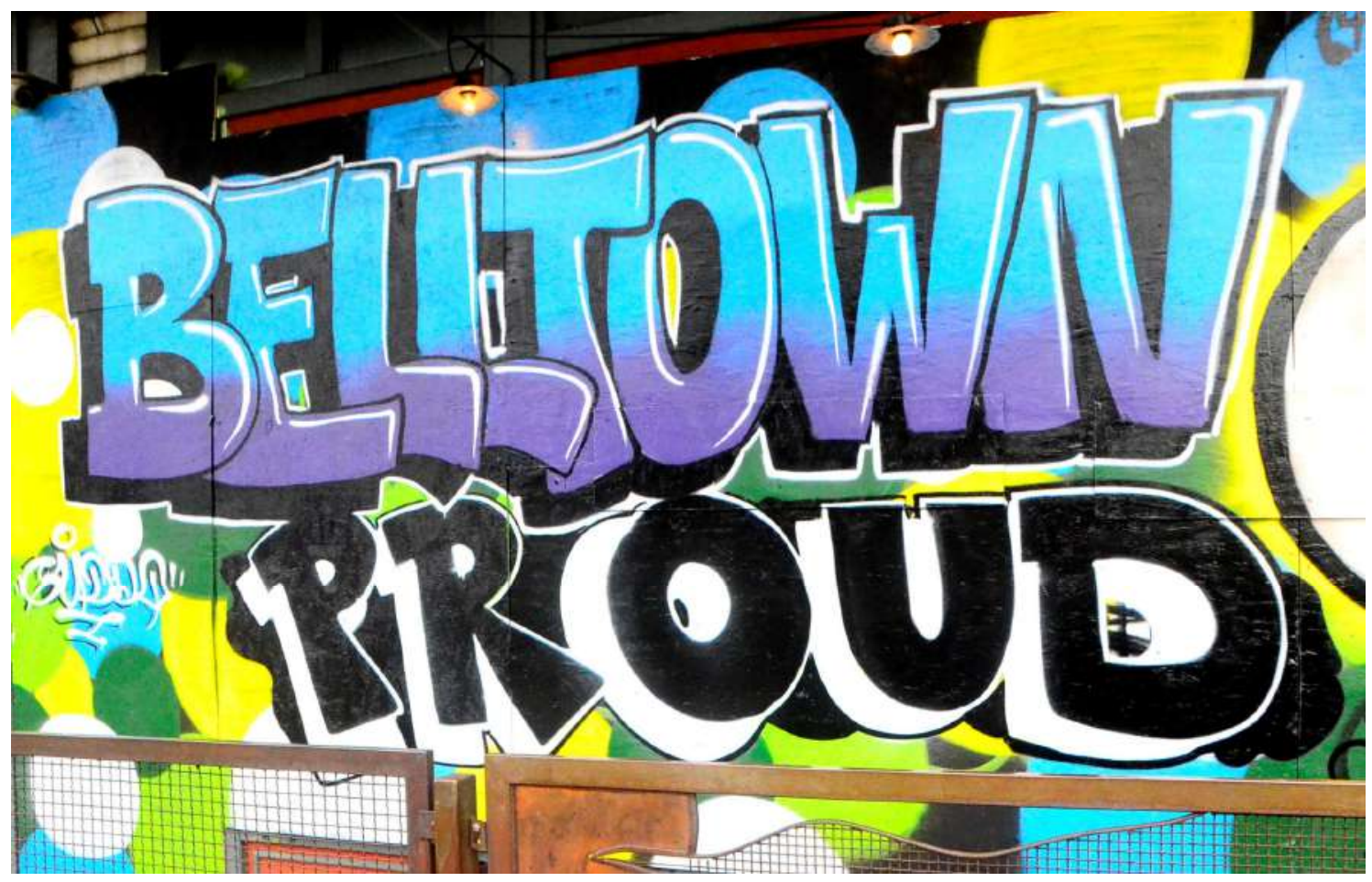

Figure h. Artist Antonio Varchetta. Picture by Catherine Anstett (2020).

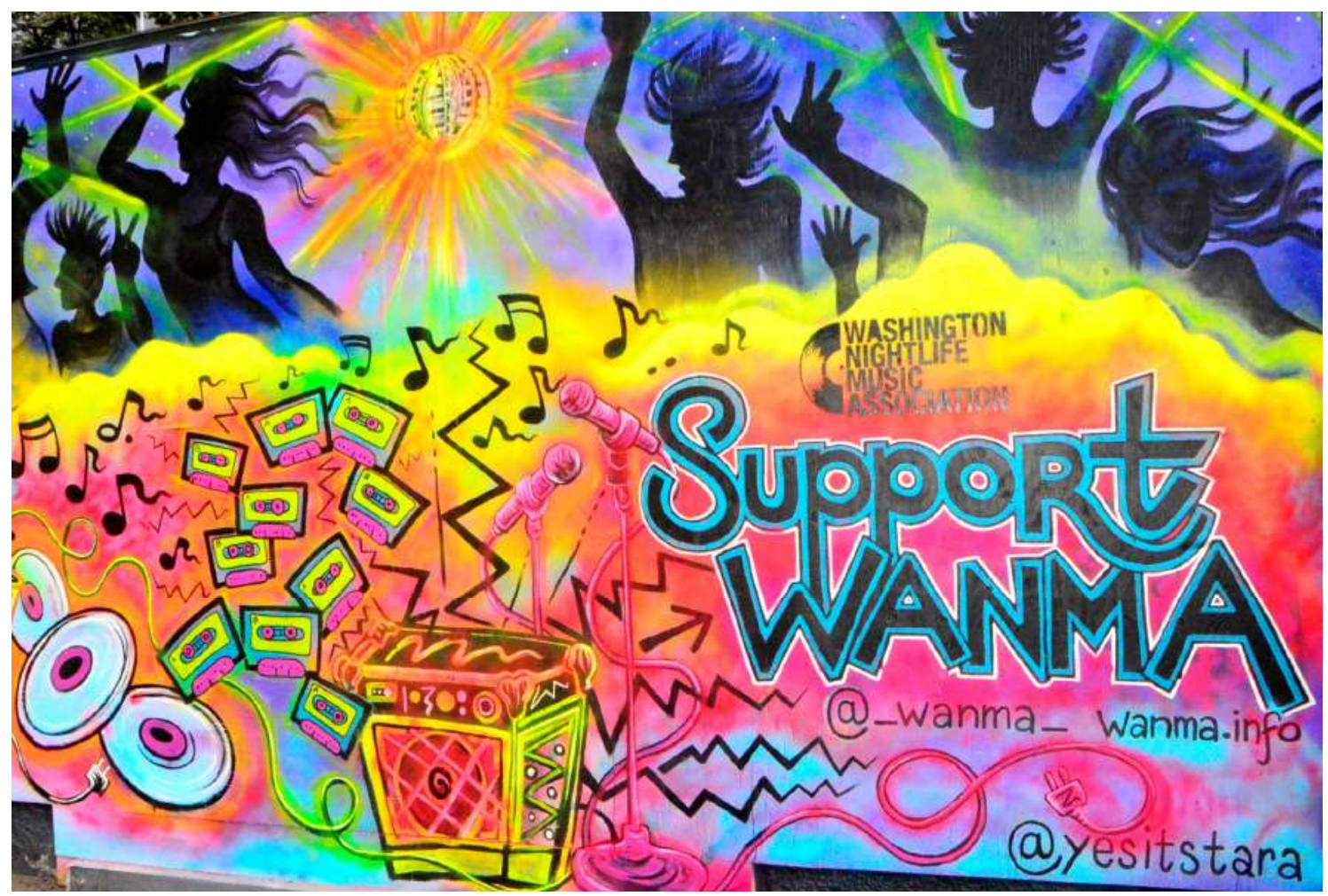

Figure i. Artist Tara Velan. Picture by Catherine Anstett (2020). 


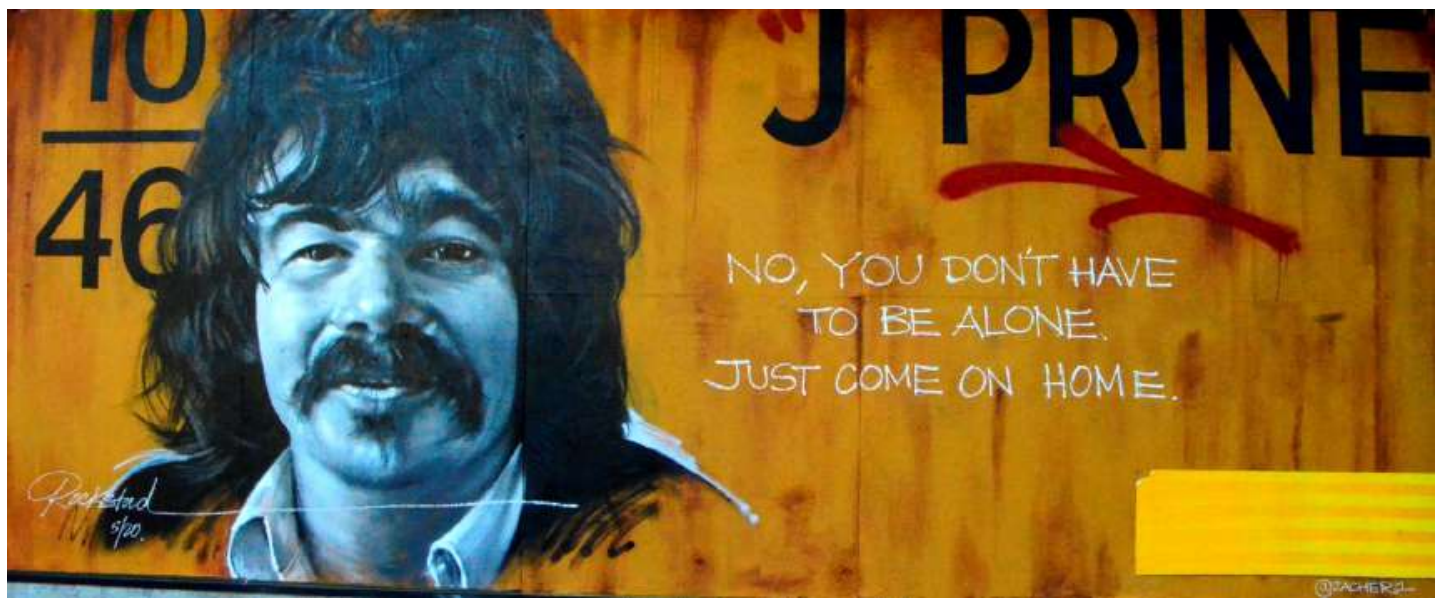

Figure j. Artist Zach Rockstad. Picture by Catherine Anstett (2020).

Business groups in several communities sponsored murals and offered stipends to artists, prioritizing artists from the local neighbourhood. Some of the murals coordinated through the Ballard Alliance reflect that community's Scandinavian heritage. The Alliance for Pioneer Square initiated a mural program, and there are now more than 40 murals in this historic neighbourhood. The Alliance has created an interactive map detailing the murals. (Figures $k, l, m, n$ )

These neighbourhood streets became outdoor museums. By early May, there were nearly 200 murals. You could watch the artists as they created their works and talk to them as they painted. In some cases it was practically performance art. The unpredictability of where the next mural would appear made it even more entertaining. (Figures o,p,q)
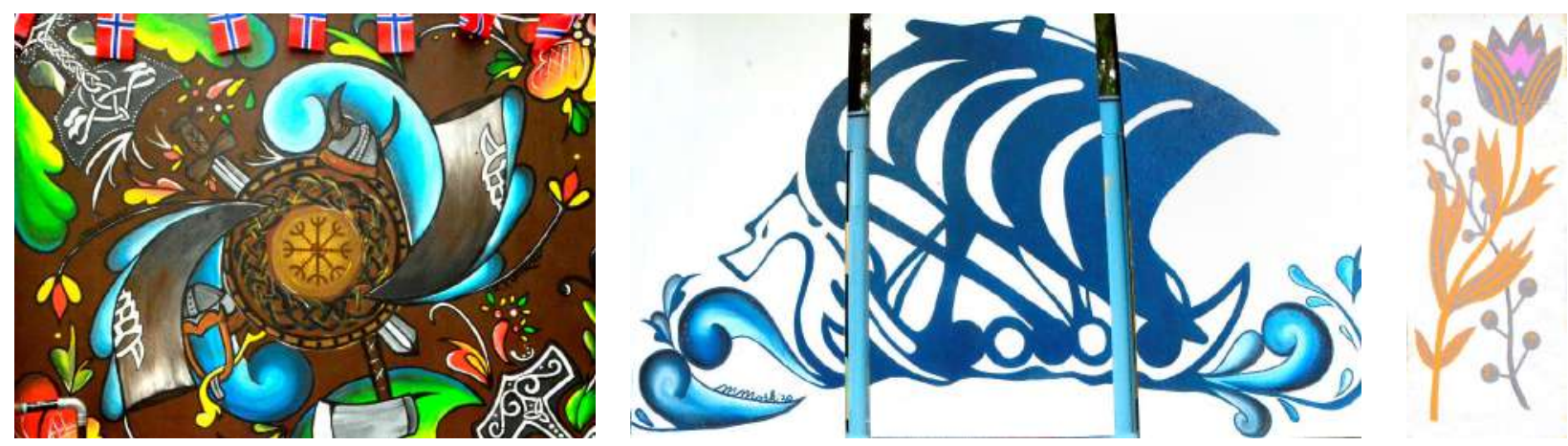

(Left to right) Figure k. Marit Helena Mork.

Figure I. Artist Marit Helena Mork. Figure m. Artist Tori Shao.

Pictures by Catherine Anstett (2020).

The artists ranged from street artists, who did not want their names or faces to be shown. to studio artists who had never done a large-scale painting. There were impressionist freehand artists and meticulous sign painters. Many of the artists had admired each other's work, but never met before. Jay Mason posted: "It has been so rad and inspiring to be working next to amazing artists such as Joseph Nix on the left and Japhee on the right. It has been amazing to watch and learn from two masters of our time." 2 


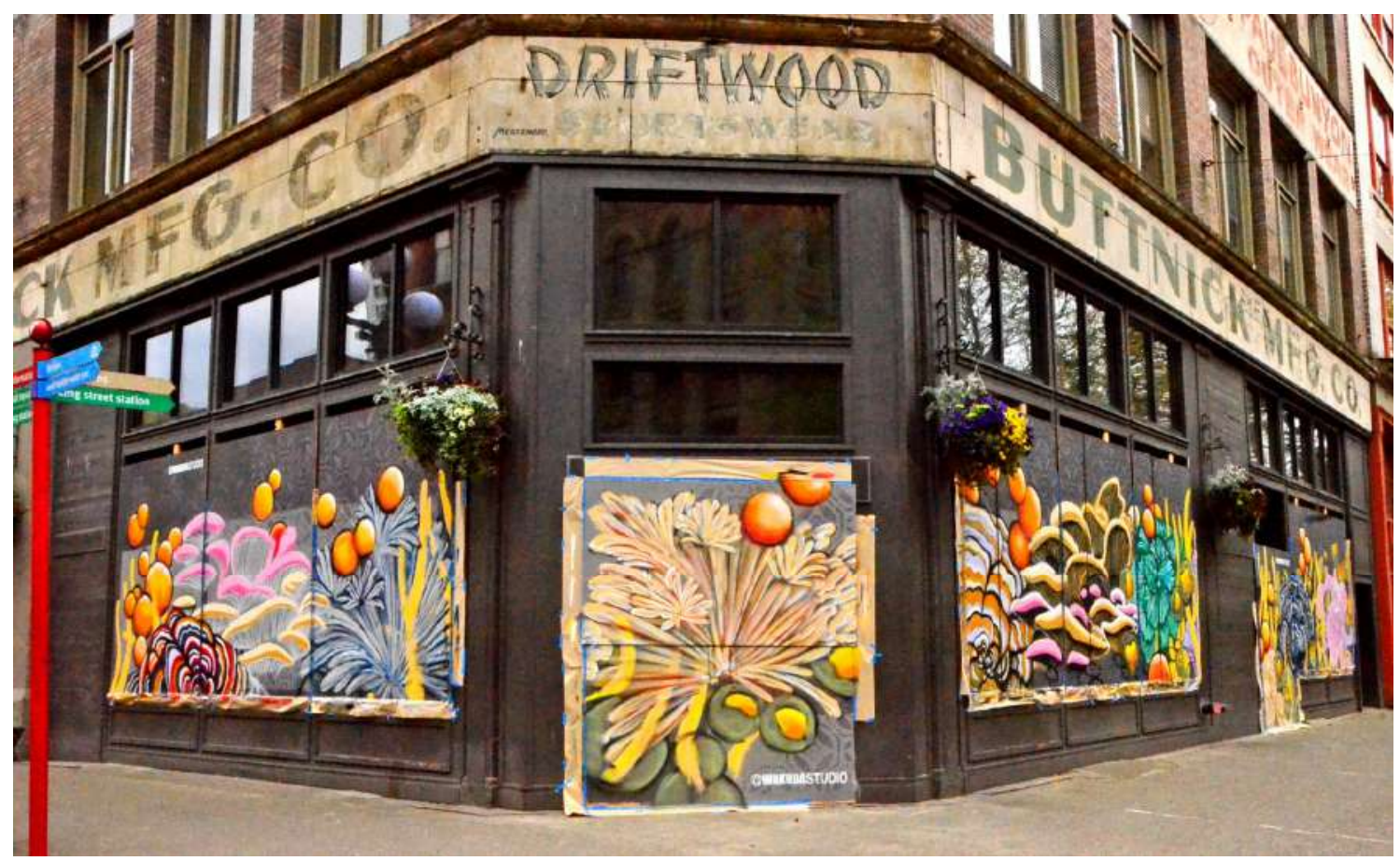

Figure n. Artists Jonathan Fischer and Wakuda Studio. Picture by Catherine Anstett (2020).

The muralists often worked as teams, while safe-distancing. The Overall Creative team inventoried the supplies they had on hand and could share with each other. With those materials and a bucket of black paint they did ten initial murals in the Capitol Hill neighbourhood (Figures r,s,t).
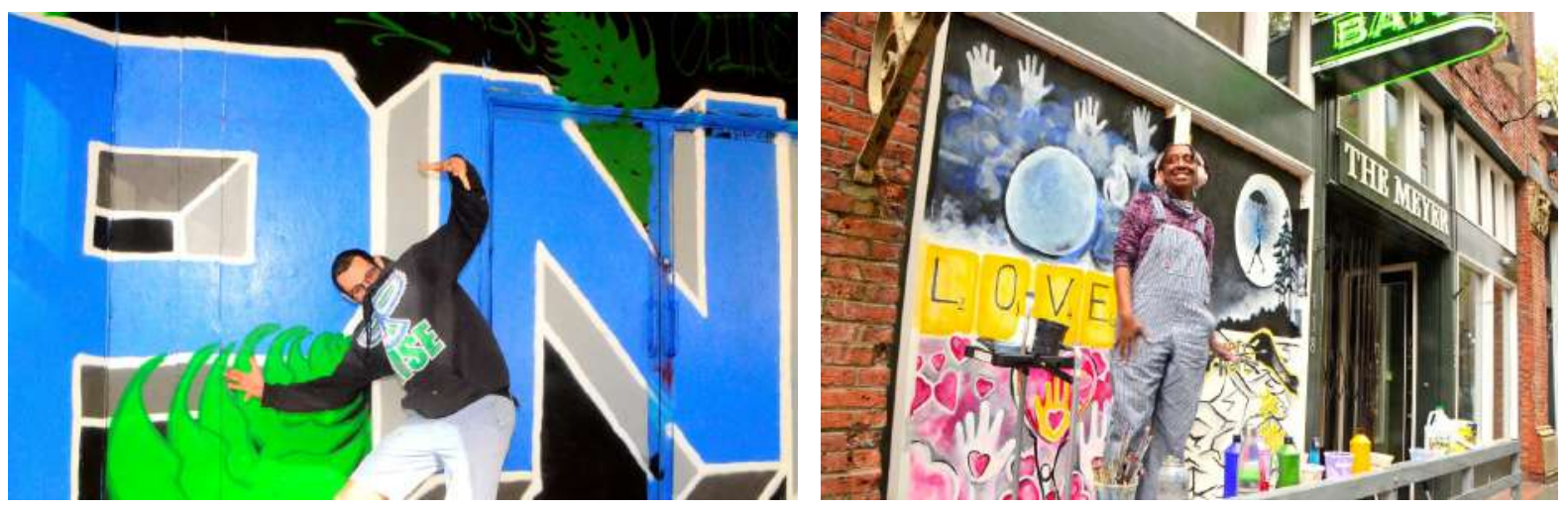

(left to right) Figure o. Artist Antonio Varchetta. Figure p. Artist Carol Rashawnna Williams. Pictures by Catherine Anstett (2020).

A virtual community also formed as artists, photographers and friends shared videos and photos on social media. AP and Reuters photographers posted images that reached as far as Mumbai.

The murals ranged from frivolous and fun to political and inspirational (Figures $u, v, w, x, y, z$ ). B Line Dot described his “Keep Dreaming” mural: "This message to keep dreaming is for all of us who feel stagnant and stifled by the current events... it is unprecedented and historic but what we do with it and beyond it will define us... so please keep dreaming, 
keep hoping and above all else keep loving... we need each other more now than ever."3 (Figure za)

A recurring theme was astronauts. Sam Trout said of his mural "I'LL SEE YOU...WHEN WE LAND," that it "stems from the idea that we're all astronauts in training right now. Lots of isolation, communication through video screens, a little space madness, and we'll land on a planet much different from the one we left." ${ }^{4}$ (Figure zb,zc)
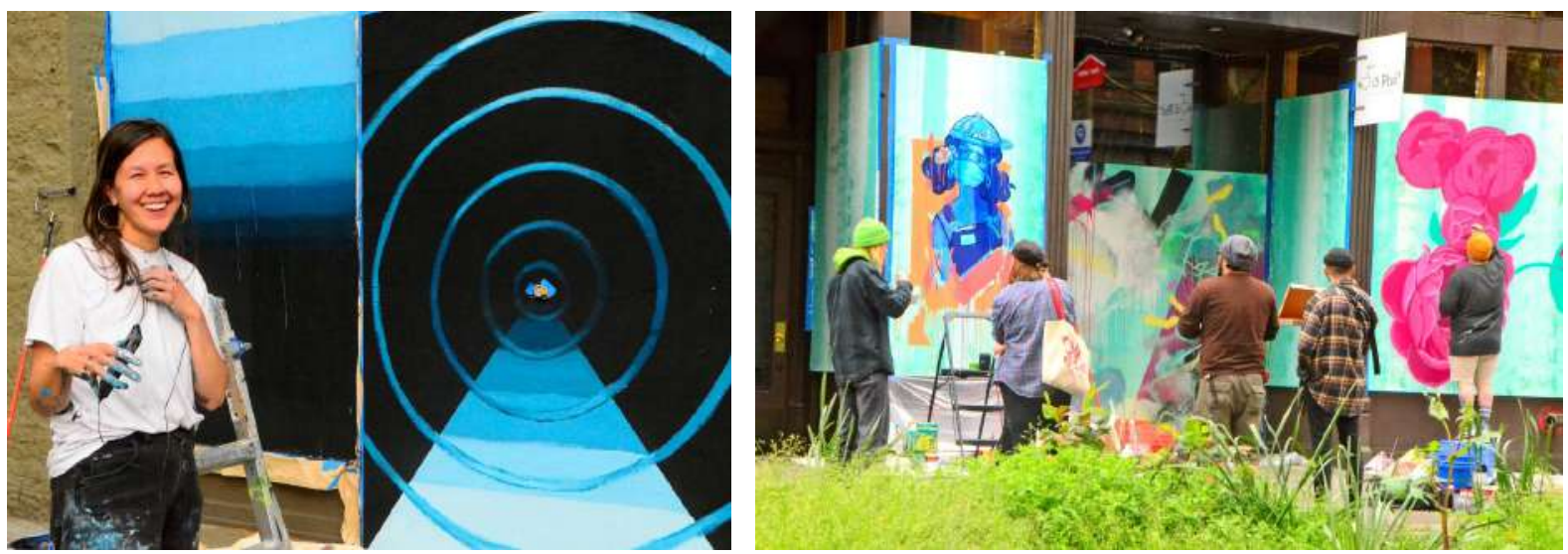

(left to right) Figure q. Artist Mari Shibuya. Figure r. Artists Madeline Owen and Jay Michael B Line Dot. Pictures by Catherine Anstett (2020).
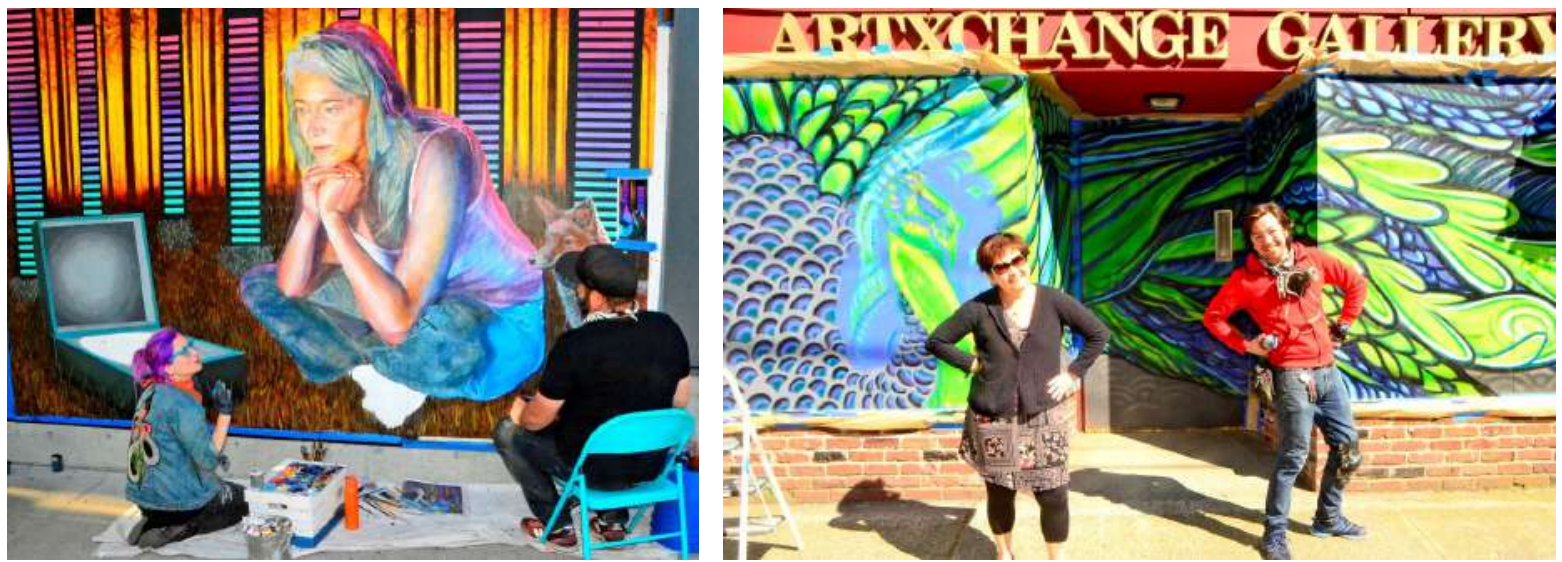

(left to right) Figure s. Artists Crystal Barbre, Casey Weldon and Zach Takasawa. Figure t. Artists Jonathan Fischer and Wakuda Studio.

Pictures by Catherine Anstett (2020).

The street scene largely consisted of artists doing their work, a few photographers and others watching them work. In Pioneer Square, there was a third group on the street those who had no other place to go.

Artist Sydney Pertl wrote: "When I was painting these, the outpouring of love and support was incredible! I made friends with many passers-by - photographers, dog walkers, and many currently experiencing homelessness. A special shout out to my new friend 'Papa,' who made me smile every time he passed me to and from the shelter. The coolest thing that happened were the two surprising thank yous I received on the same day - one from a USPS mailman hand delivering packages and the other from an ambulance driver who stopped in the middle of the street to yell thank you out of his window. 
Artists in the Streets. Seattle Murals in the Time of COVID-19
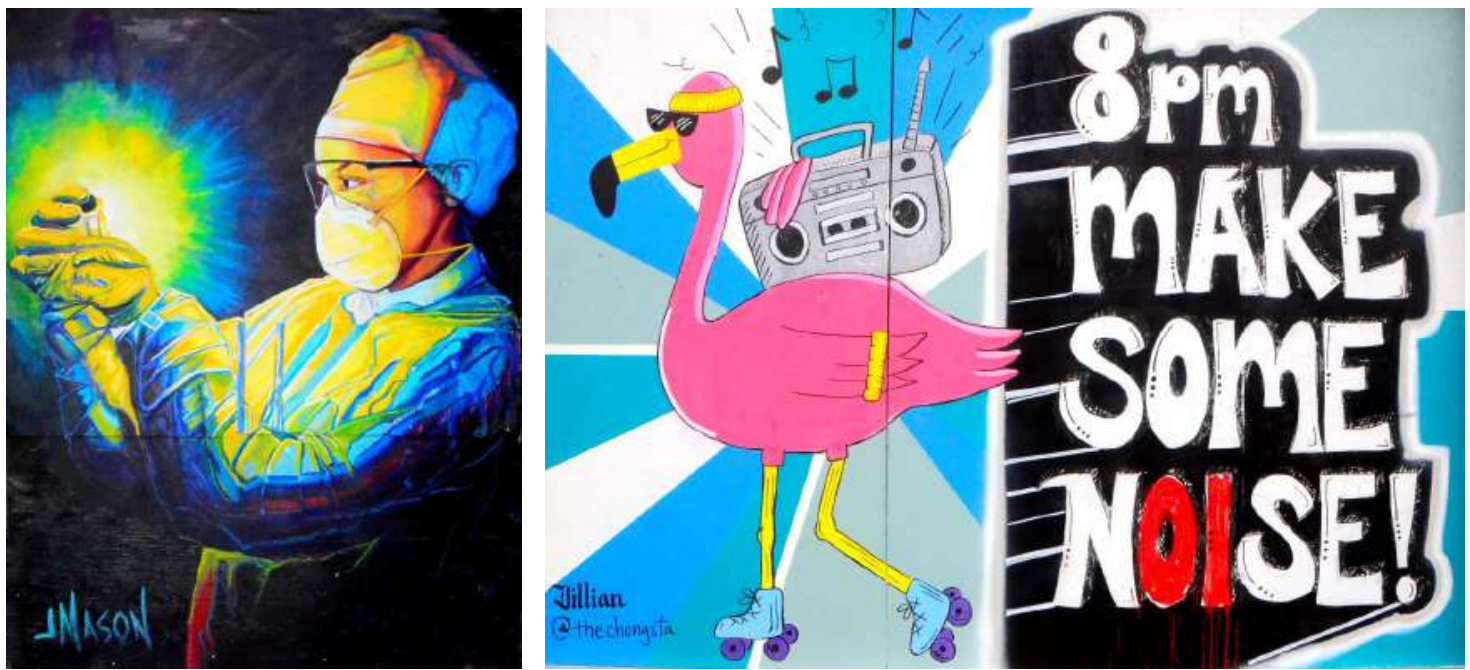

(left to right) Figure u. Artist Jay Mason. Figure v. Artist Jillian Chong. Pictures by Catherine Anstett (2020)

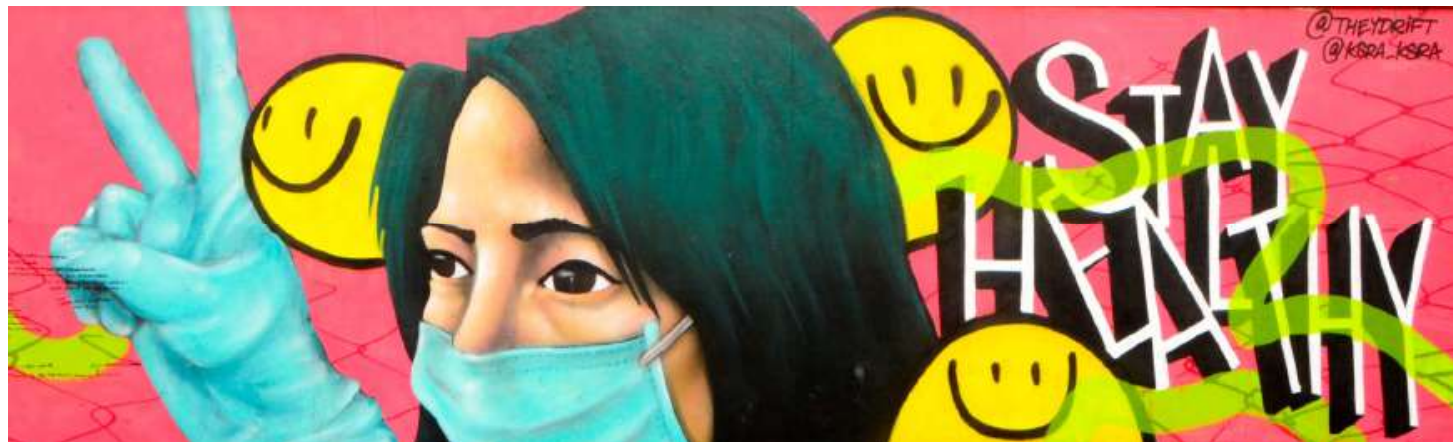

Figure w. Artist They Drift and Ksra. Picture by Catherine Anstett (2020).

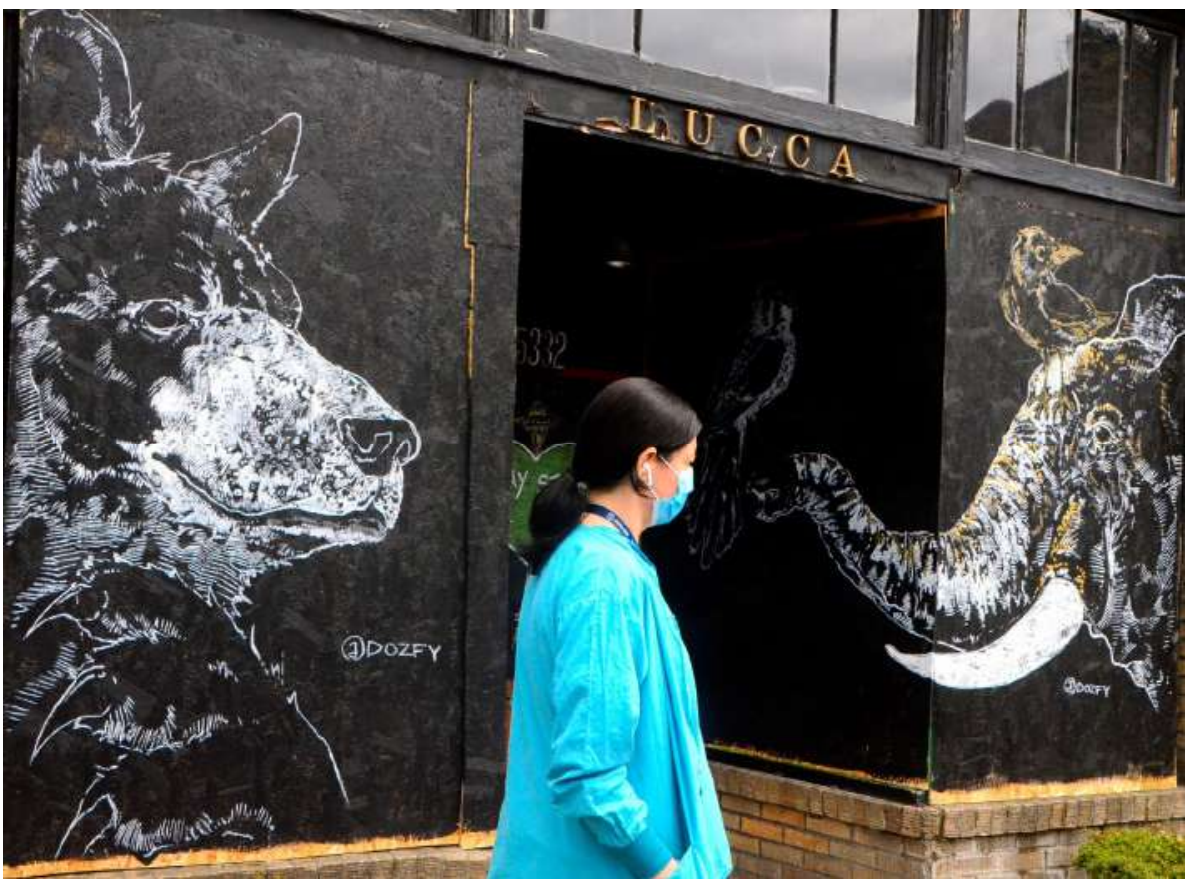

Figure w. Artist They Drift and Ksra. Picture by Catherine Anstett (2020).

The Journal of Public Space, 5(3), 2020 | ISSN 2206-9658 | 263 City Space Architecture / UN-Habitat 
"The most eye-opening thing I learned while painting in the same place every day was just how much Pearl Jam and Eddie Vedder have been doing for the homeless community here in Pioneer Square (my home). I heard so many stories about Eddie Vedder - signing Real Change newspapers, paying a man who was washing storefront windows to try to make a few dollars, pulling guitar picks out of his pocket to give to a man playing on the corner, and even tossing a football with a man in the middle of South Washington street (where my mural is located). It was inspiring how every single action I heard about became a monument to genuine humanity.
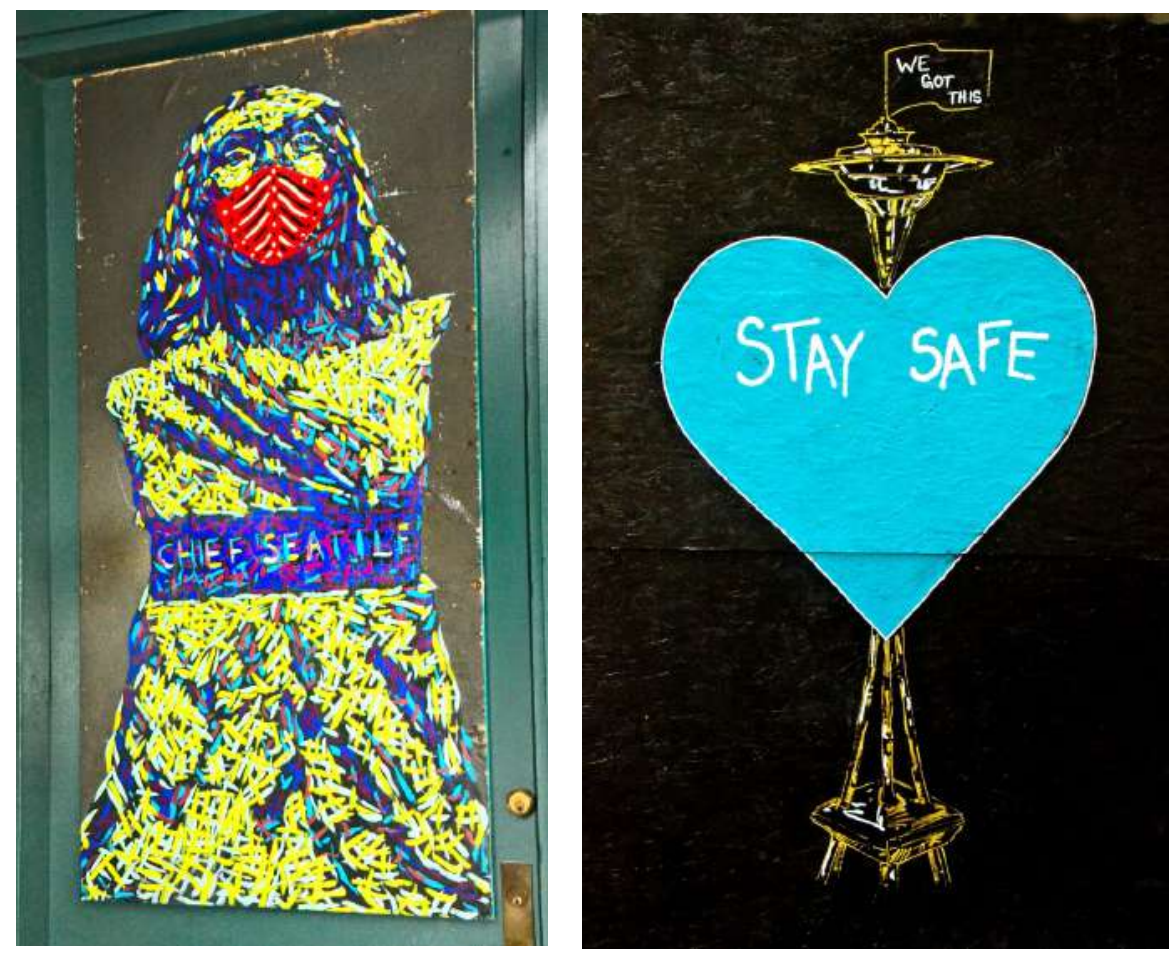

(left to right) Figure y. Artist Baso Fibonacci. Figure z. Artist Dozfy. Pictures by Catherine Anstett (2020).

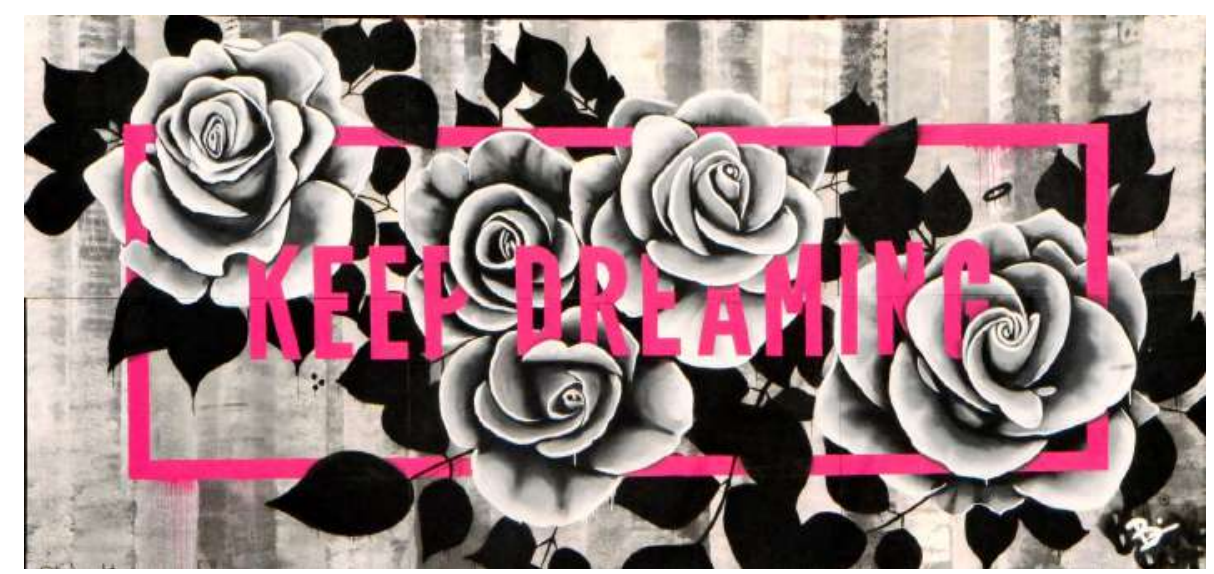

Figure za. Artist B Line Dot. Picture by Catherine Anstett (2020). 
"I hope my murals gave even a fraction of that much hope and inspiration, but it turns out that just hanging out with people (yes, six feet apart for now) means so much more." 5 (Figure zd)

The Seattle Office for Arts and Culture said, "Throughout this crisis, we have seen community come together and hold each other up like never before. We have watched organic movements take hold that are devoted to supporting those in need financially, emotionally, spiritually, and creatively. We have come together to feed one another, protect one another, entertain one another, and sustain one another through this dark and uncertain time." 6

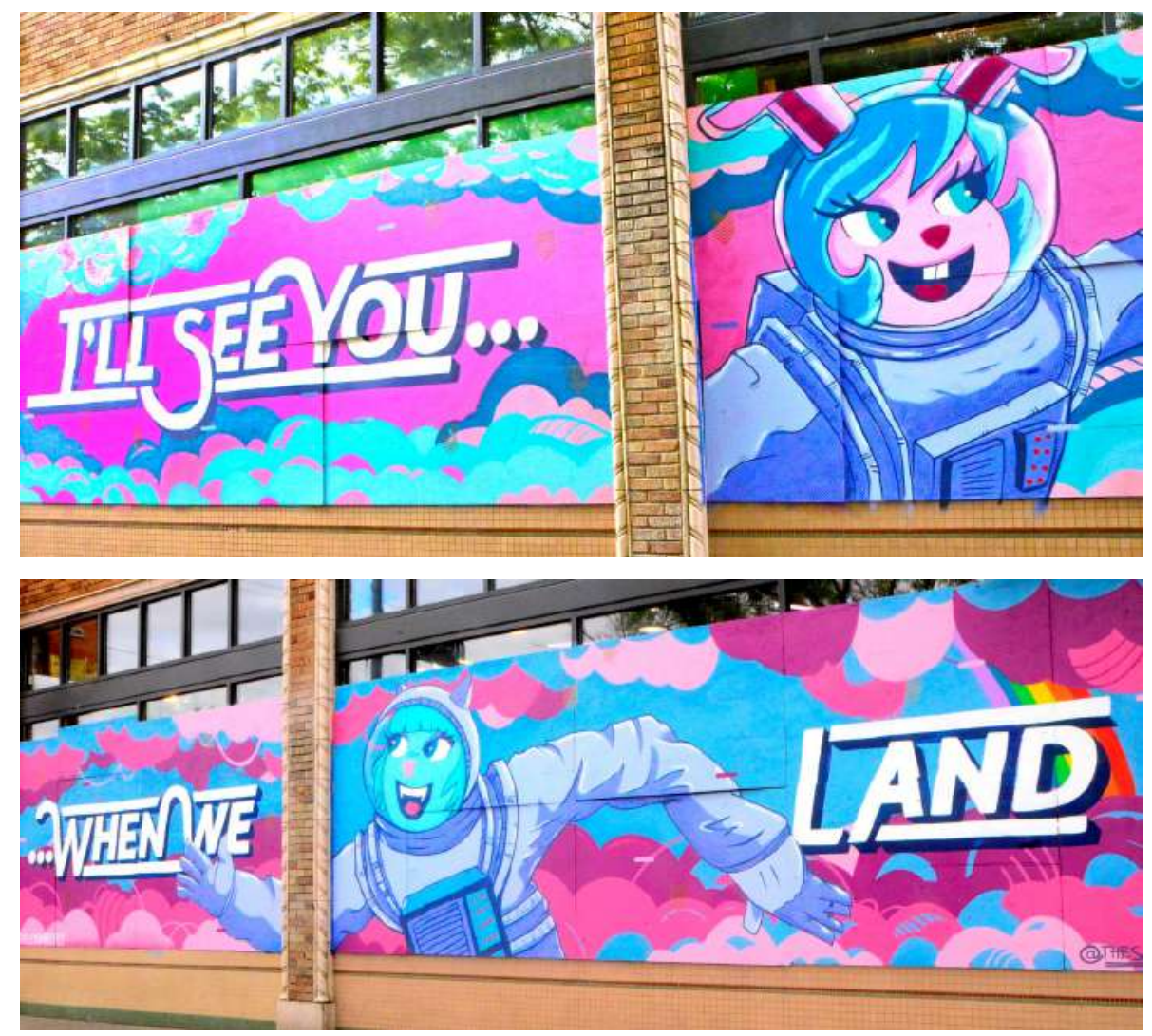

(top to down) Figure zb. Artist Sam Trout, text: Kimberly Tieu. Figure zc. Artist Sam Trout, text: Kimberly Tieu

Pictures by Catherine Anstett (2020).

The murals were an important part of this effort, for the artists, businesses, and the larger community. It has been a once-in-a-lifetime experience. So far. It's not clear if the stores and restaurants will need to close again if there is a second wave of the virus later this year. It's not clear when the plywood murals will come down, though in late May that was already happening in some areas.

A book documenting the murals is in the works, with expected publication in June. Historical societies are collecting photos and stories. The murals may be exhibited or auctioned. Some will be displayed in the stores and restaurants that hosted them. At least one documentary is underway. But the actual experience of this living art gallery in the streets, throughout the city, will be hard to replicate. And no one wants a repeat of the COVID- 19 health risk that occasioned it. 
As the artist B Line Dot said, "Art marks moments... this is a moment." 7

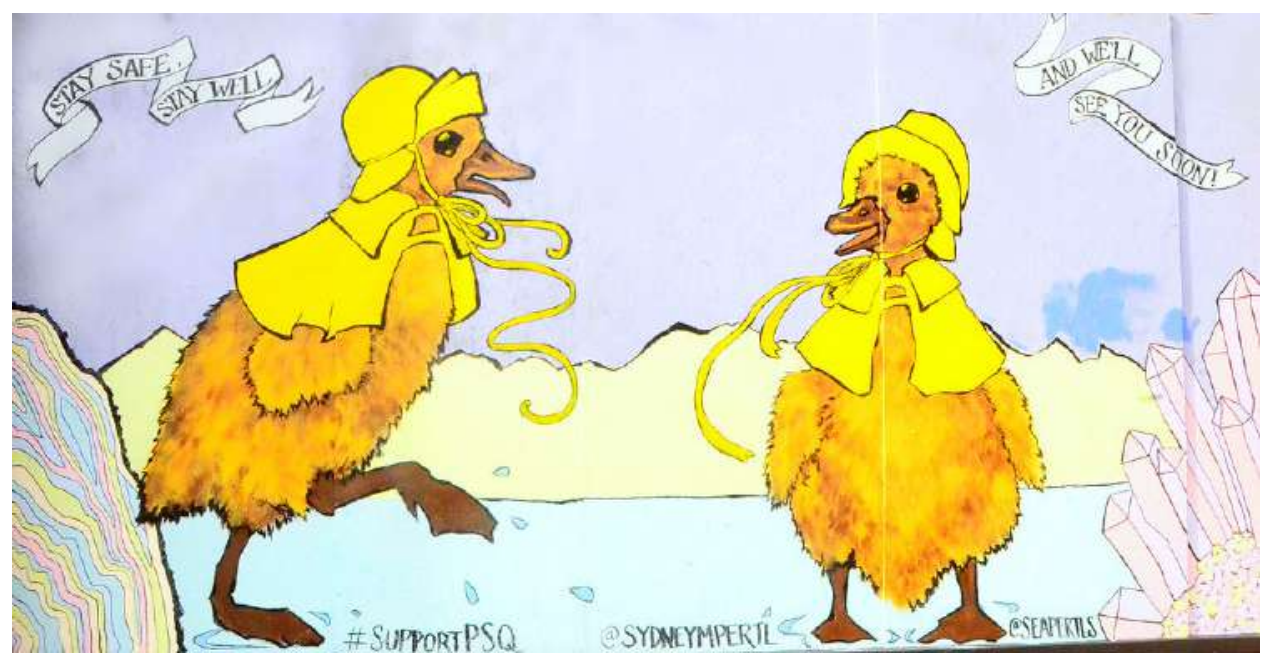

Figure w. Artist Sydney Pertl. Picture by Catherine Anstett (2020).

\section{References}

Art Beat Blog, Seattle Office of Arts and Culture, Erika Lindsay, April 9, 2020 / https://artbeat.seattle.gov/2020/04/09/seattletogether-shines-a-light-on-communityconnections/

Artist B Line Dot, Facebook, May I, 2020 / https://www.facebook.com/blinedot B Line Dot, Facebook, May 4, 2020 / https://www.facebook.com/blinedot Jay Mason, Facebook, April 30, 2020 / https://www.facebook.com/JayMasonArt KING 5 NEWS, January 2019 / https://www.king5.com/article/news/seattle-still-the-cranecapital-of-the-us/281-7f6d9c57-e6dd-4eef-986f-25af5361952a

Sam Trout, Facebook, April 25, 2020 / https://www.facebook.com/sam.trout Sydney Pertl, Facebook, April 23, 2020 / https://www.facebook.com/sydneympertl 
Thank you for reading!

The Journal of Public Space

ISSN 2206-9658

Editor in Chief Luisa Bravo

City Space Architecture Italy

https://www.journalpublicspace.org 